\title{
Effect of Initial Water Content and Stress History on \\ Water-Retention Behaviour of Mine Tailings \\ by
}

\section{Parviz Heidarian}

A thesis submitted to the Faculty of Graduate Studies and and Post-Doctoral Affairs in partial fulfillment of the requirements for the degree of

\section{Master of Applied Science}

Ottawa- Carleton Institute of Civil and Environmental Engineering

Carleton University

Ottawa, Ontario, Canada

December, 2012

(C) Copyright

2012, Parviz Heidarian 
Library and Archives

Canada

Published Heritage

Branch

395 Wellington Street

Ottawa ON K1A ON4

Canada
Bibliothèque et

Archives Canada

Direction du

Patrimoine de l'édition

395 , rue Wellington

Ottawa ON K1A ON4

Canada
Your file Votre référence

ISBN: 978-0-494-94645-9

Our file Notre référence

ISBN: $978-0-494-94645-9$
NOTICE:

The author has granted a nonexclusive license allowing Library and Archives Canada to reproduce, publish, archive, preserve, conserve, communicate to the public by telecommunication or on the Internet, loan, distrbute and sell theses worldwide, for commercial or noncommercial purposes, in microform, paper, electronic and/or any other formats.

The author retains copyright ownership and moral rights in this thesis. Neither the thesis nor substantial extracts from it may be printed or otherwise reproduced without the author's permission.
AVIS:

L'auteur a accordé une licence non exclusive permettant à la Bibliothèque et Archives Canada de reproduire, publier, archiver, sauvegarder, conserver, transmettre au public par télécommunication ou par l'Internet, prêter, distribuer et vendre des thèses partout dans le monde, à des fins commerciales ou autres, sur support microforme, papier, électronique et/ou autres formats.

L'auteur conserve la propriété du droit d'auteur et des droits moraux qui protege cette thèse. $\mathrm{Ni}$ la thèse ni des extraits substantiels de celle-ci ne doivent être imprimés ou autrement reproduits sans son autorisation.
In compliance with the Canadian Privacy Act some supporting forms may have been removed from this thesis.

While these forms may be included in the document page count, their removal does not represent any loss of content from the thesis.
Conformément à la loi canadienne sur la protection de la vie privée, quelques formulaires secondaires ont été enlevés de cette thèse.

Bien que ces formulaires aient inclus dans la pagination, il n'y aura aucun contenu manquant. 


\section{Abstract}

Every day 100's of thousands of tonne of mine tailings are conventionally discharged to tailing storage facilities.

The soil-water characteristic curve (herein referred to as the tailings-water characteristic curve) is an important parameter for understanding the dewatering behaviour of mine tailings, which has important consequences for the geotechnical and geo-environmental performance of tailings stacks deposited at relatively high initial densities and / or dry climate conditions. In this thesis, the tailings water characteristic curve (TWCC) of two different kinds of tailings has been investigated: tailings from a gold mine and mature fine tailings from an oil sands operation. The sensitivity of the TWCC to the initial state of tailings at the start of the TWCC test is investigated. This initial state comprises initial water content, settling time, initial loading or compaction, use of a polymer in sample preparation, and thickness of the sample.

Experimental tests on two different kinds of mine tailings showed:

1. Varying the thickness of the sample between 10 and $30 \mathrm{~mm}$ did not affect the SWCC. Thickness influenced only the equilibrium time.

2. The use of an anionic polymer significantly decreased the air-entry value of the oil sands tailings.

3. Increasing the initial water content of gold tailings results generally lower water content and lower saturation at a given matric suction, and a consistent but relatively small influence on the shrinkage limit.

4. In the gold tailings, while the influence of constant 1-D loading up to $150 \mathrm{kPa}$. did not substantially change the shape of the SWCC. 
5. Consolidation curves at a constant level of suction, did show a significant decrease of void ratio at lower levels of loading, compared to the consolidation curve with no matric suction applied. 


\section{Acknowledgements}

I would like to fully acknowledge the following:

- First and foremost my supervisor Professor Paul Simms, for his constant help, professional advice, his direction during my thesis and providing his comments and suggestions. Professor Paul Simms's friendship made a great difference in my entire program.

- My family, my wife and my son, for their support, help and encouragement during my program.

- The other people such as Stan Conley and Marie Tudoret who contributed in various ways to this research. 


\section{Table of contents}

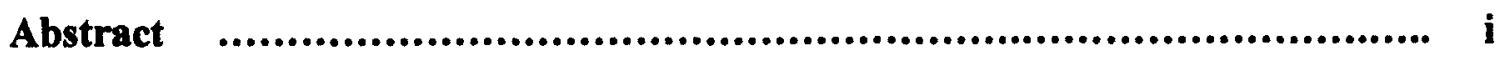

Acknowledgments $\quad$.............................................................. iii

Table of Contents $\quad$.................................................................... iv

List of Tables $\quad$........................................................................ ix

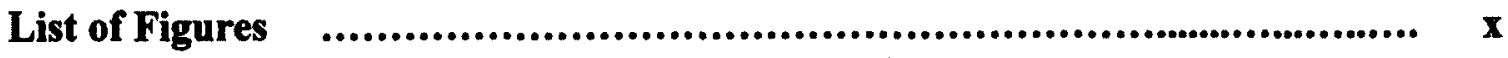

List of Appendices $\quad$.............................................................. xxii

List of Symbols $\quad$................................................................... $\quad$ xxiii

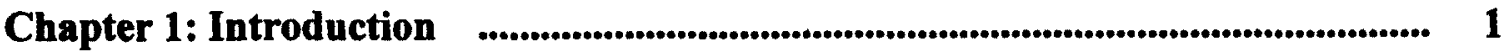

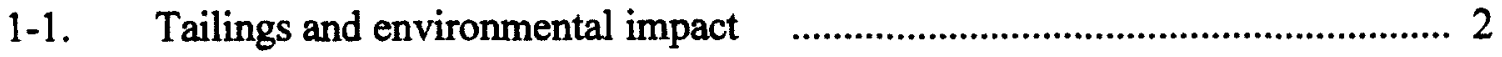

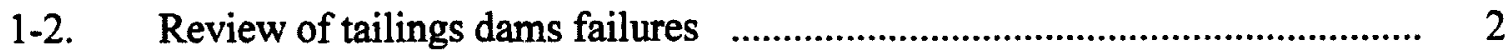

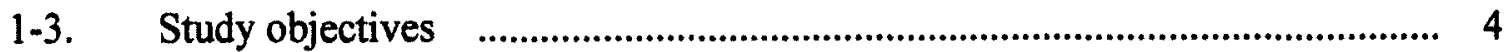

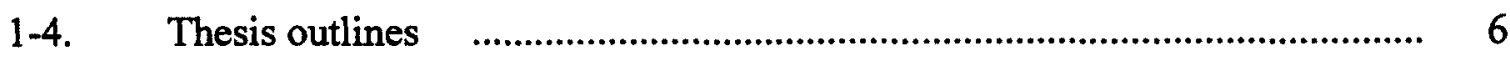

Chapter 2: Literature Review $\quad$......................................................... 8

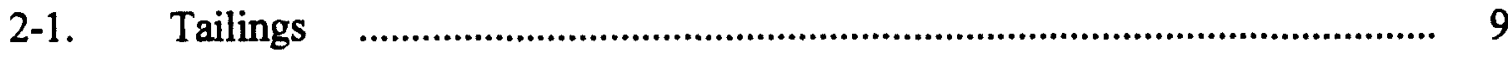

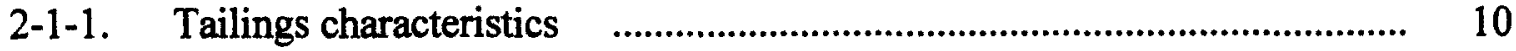

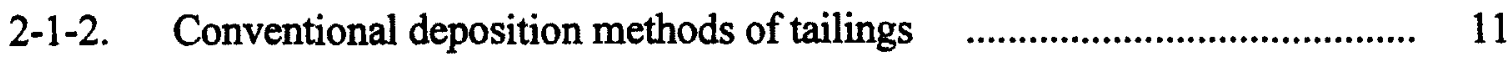

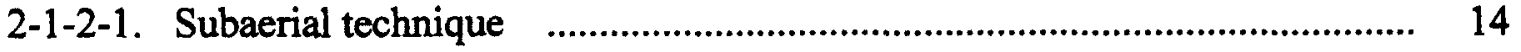

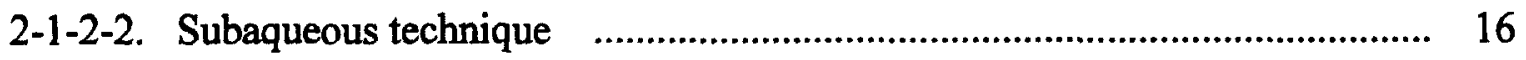

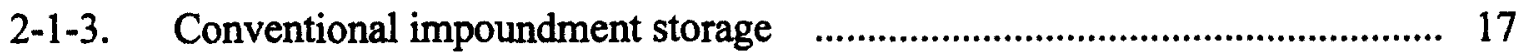

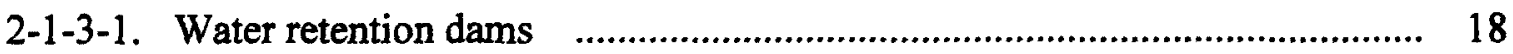

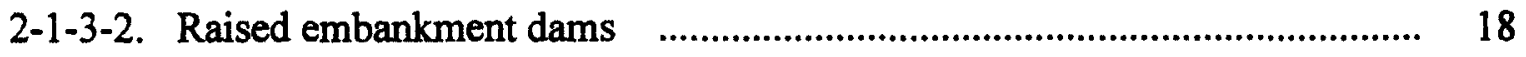

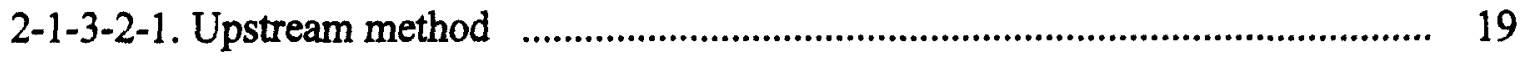


2-1-3-2-3. Centerline method

2-1-4. Thickened tailings disposal _................................................................ 23

2-2. Soil - Water Characteristic Curve (SWCC) ......................................... 24

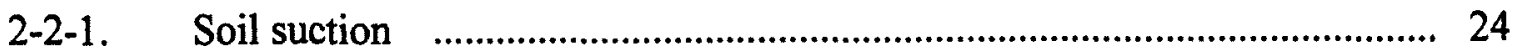

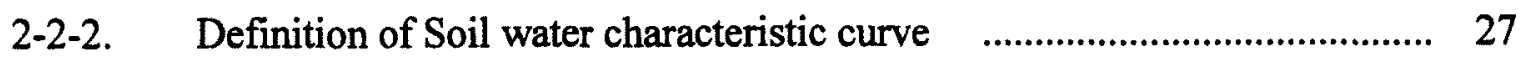

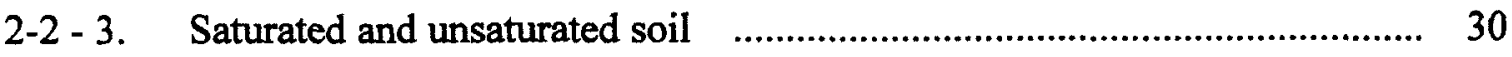

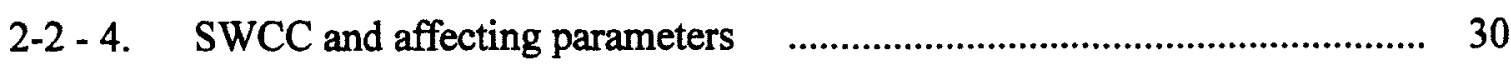

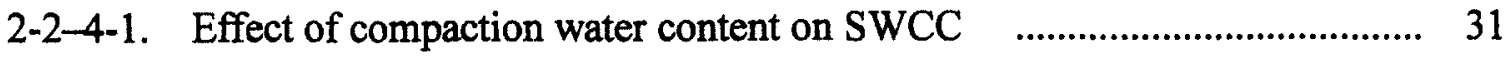

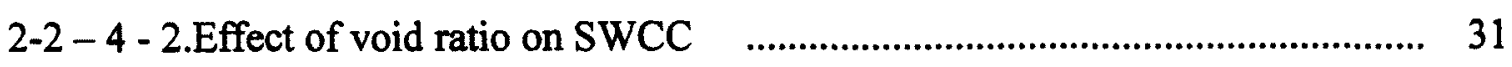

2-2 - 4 - 3.Effect of initial dry density on SWCC

2-2 - 4 - 4.Effect of 1-D consolidation pressure on SWCC $\quad$.................................... 35

Chapter 3: Description of tailings disposal at the from Bulyanhulu and

Muskeg River mines $\quad$............................................................ 37

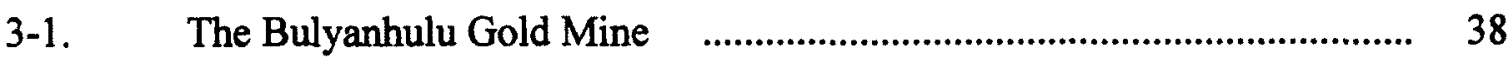

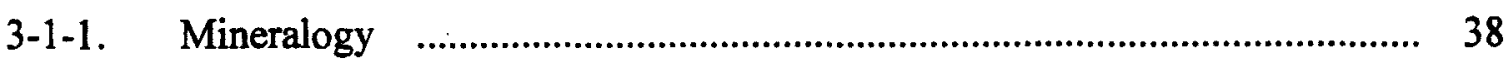

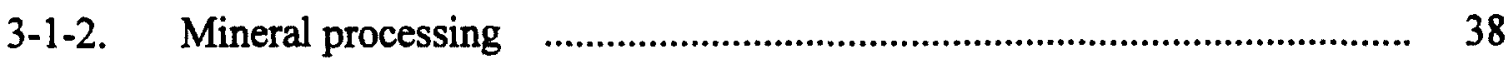

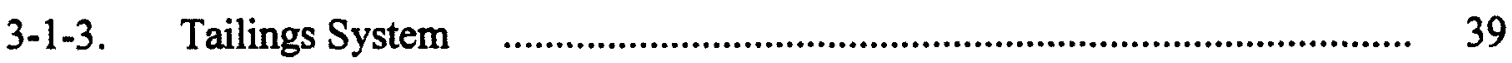

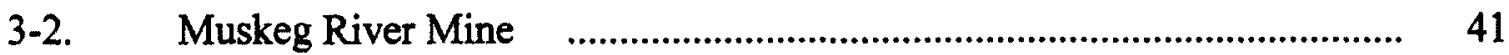

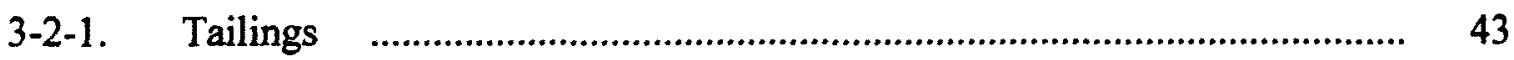

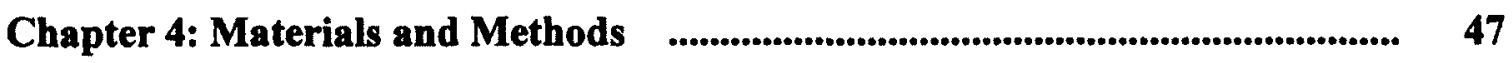

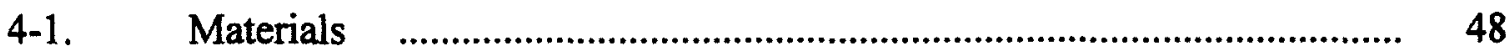

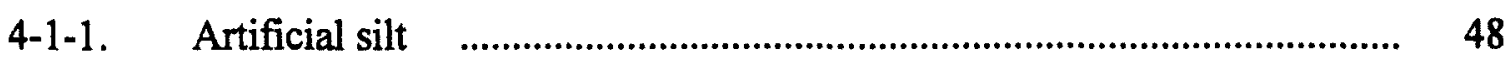




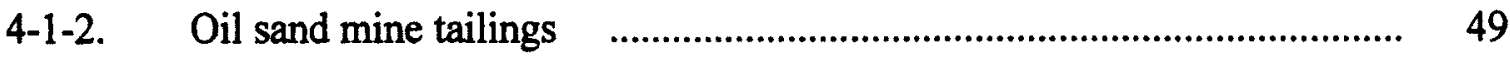

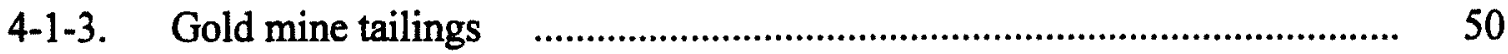

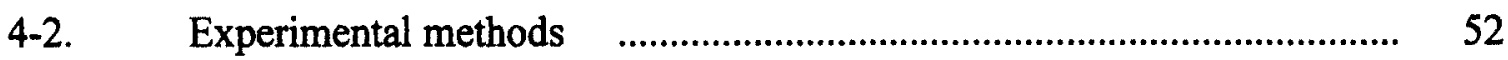

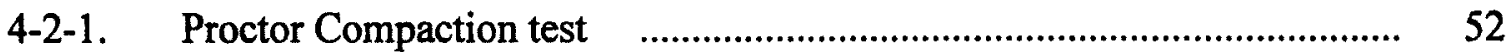

4-2-2. Shrinkage curve test (ASTMD4943) _..................................................... 53

4-2-3. Soil Water Characteristive Curve by axis-translation $\quad$............................... 54

4-2-3-1. TWCC/SWCC under 1-D loading $\quad$ …………........................................ 55

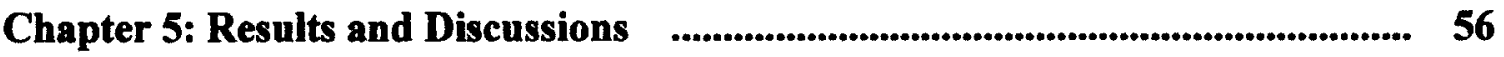

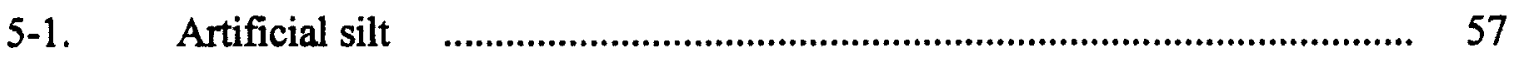

5-1-1. Proctor Compaction Test (P.C.T) _............................................................... 57

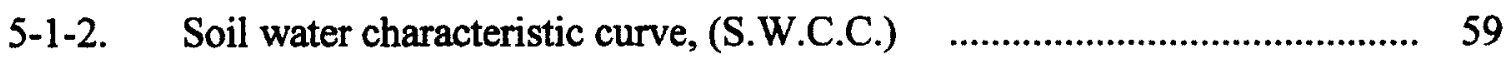

5-1-2-1. SWCC of silt before settling, axis-translation started less than 1 hour after sample preparation $\quad$........................................................................ 59

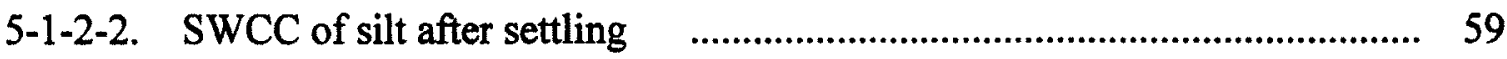

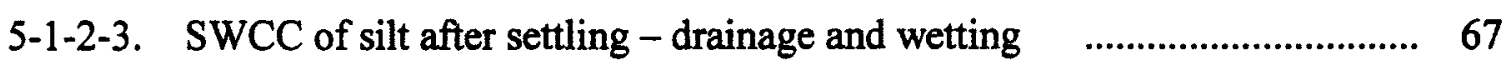

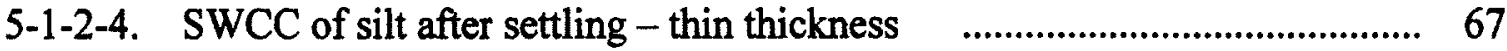

5-2. Oil sand mine tailings ( MFT) _....................................................... 73

5-2-1. Effect of initial water content on TWCC in Oil sand mine tailings (MFT) ... 74

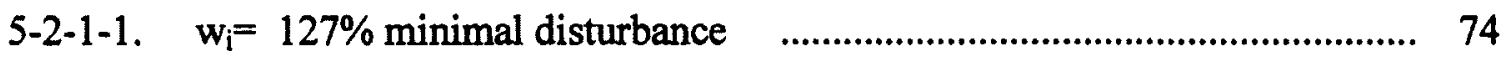

5-2-1-2. $\quad w_{i}=131 \%$ (small amount of water added with hand mixing)

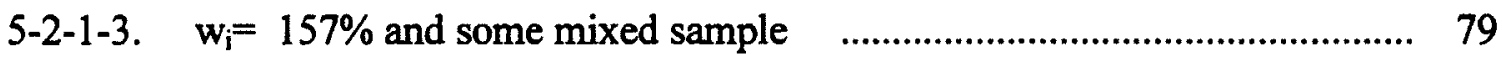

5-2-1-4. Comparison of initial water content effect on TWCC for

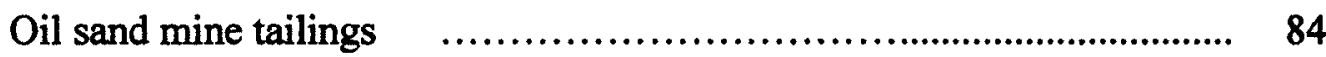


5-2-2. Effect of mixing on TWCC in oil sand mine tailings (MFT) _............... 88

5-2-3. Effect of polymer on TWCC in oil sand mine tailings (MFT) .................. 91

5-2-4. Effect of preparation method on TWCC of polymer amended MFT .......... 97

5-3. Gold mine tailings ( GMT) _............................................................ 100

5-3-1. Shrinkage limit test, (wax method) $\quad$........................................................ 101

5-3-2. Effect of initial water content (IWC) on gold mine tailings behaviour .... 104

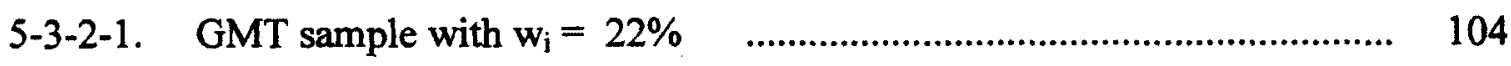

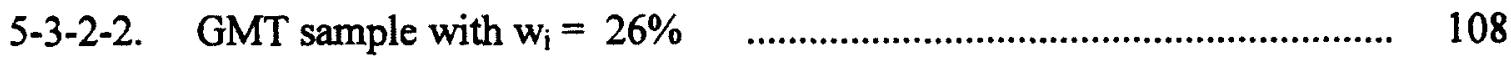

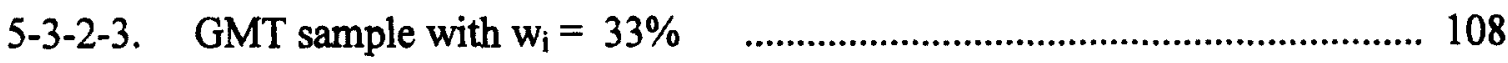

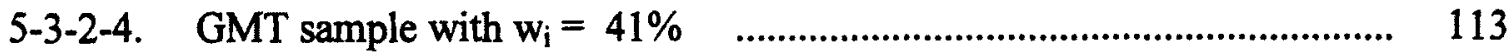

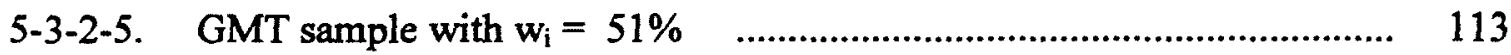

5-3-2-6. Comparison of initial water content effect on TWCC for

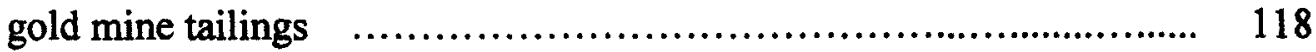

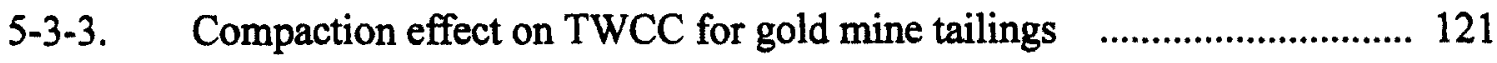

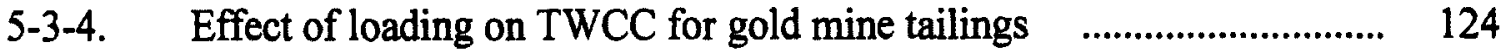

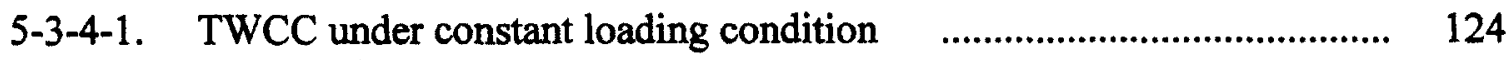

5-3-4-1-1. Initial water content of $24 \%$ and loading of $50 \mathrm{kPa} \quad \ldots \ldots \ldots \ldots \ldots \ldots \ldots \ldots . . . . . . . . . . .124$

5-3-4-1-2. Initial water content of $31 \%$ and loading of $50 \mathrm{kPa} \quad \ldots \ldots \ldots \ldots \ldots \ldots \ldots \ldots \ldots . . . . . . . . . .128$

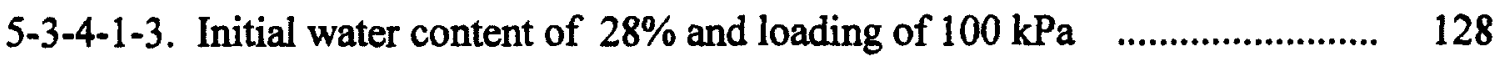

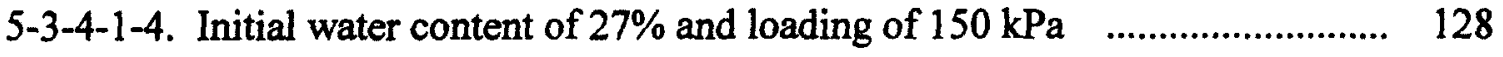

5-3-4-1-5. Comparison of TWCC under different constant loading condition .......... 133

5-3-4-2. TWCC under constant suction and variation of loading condition $\quad \ldots . . . . \quad 140$

5-3-4-2-1.Suction $50 \mathrm{kPa}$, Initial water content of $39 \%$, loading up to $200 \mathrm{kPa}$.. 140 
5-3-4-2-2.Suction $150 \mathrm{kPa}$, Initial water content of $43 \%$, loading up to $200 \mathrm{kPa} \ldots .144$

5-3-4-3. Behaviour of TWCC under no suction just loading condition $\quad . . . \ldots \ldots \ldots . . . . . . . \quad 147$

5-3-5. Comparison of dewatering behaviour of gold tailings under different combinations of 1-D loading and matric suction. ........................................ 150

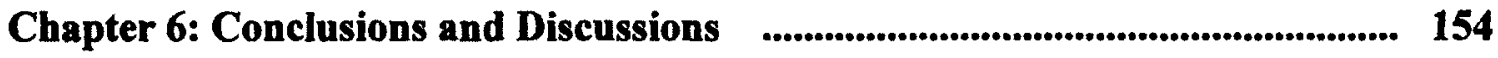

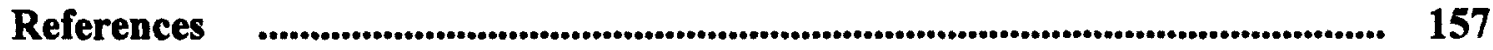




\section{LIST OF TABLES}

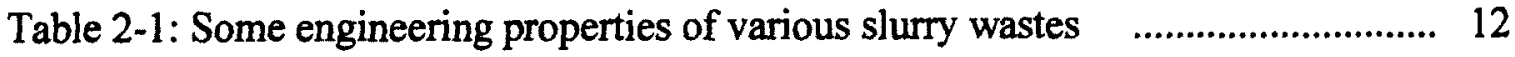

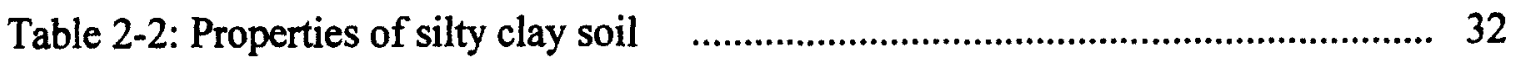

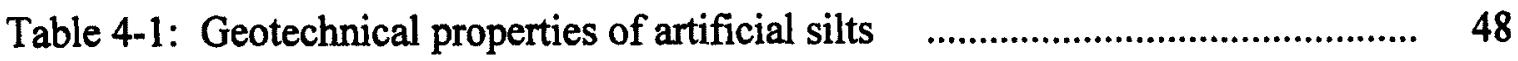

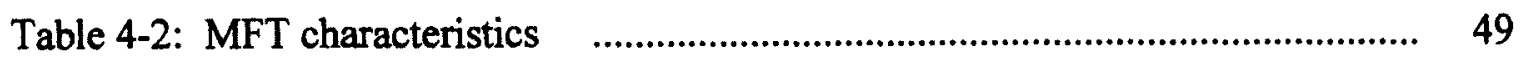

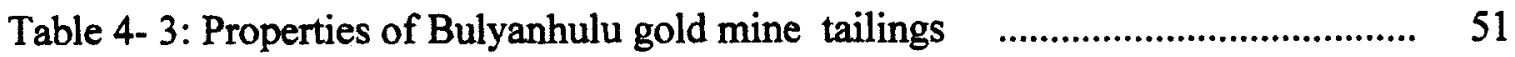

Table 5-1: Effect of suction on water content of artificial silt,

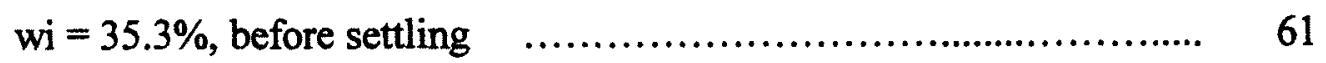

Table 5-2: Effect of suction on water content of artificial silt

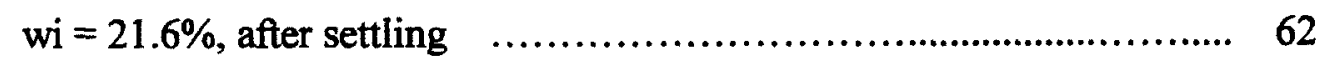

Table 5-3: Effect of suction on water content of artificial silt

$$
w i=26.1 \% \text {, after settling }
$$

Table 5-4: Effect of suction on water content of artificial silt

$$
\text { wi }=24.7 \% \text {, after settling }
$$

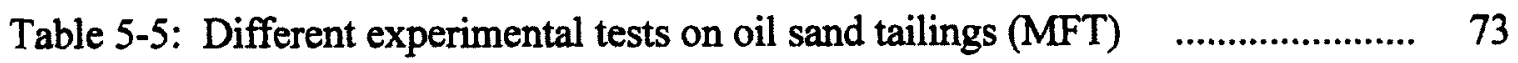

Table 5-6: Effect of initial water content on oil sand mine tailings behaviour $\quad$............ 85

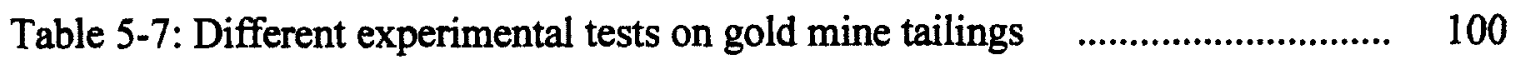

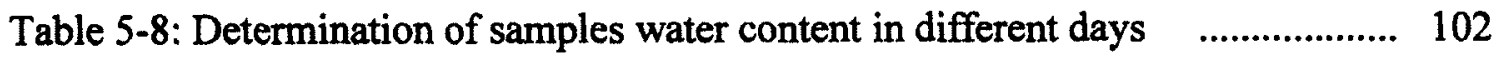

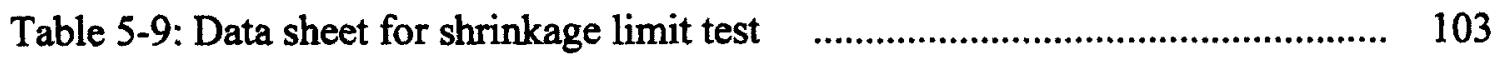

Table 5-10: Effect of suction on water content of gold mine tailings, wi $=22.1 \% \ldots . .105$

Table 5-11: Effect of suction on saturation of gold mine tailings, wi=22.1\% $\quad \ldots . . . . .105$ 


\section{LIST OF FIGURES}

Figure 1-1: Tailing dam failure in Los Frailes mine, Spain, $1998 \quad \ldots \ldots \ldots \ldots \ldots \ldots \ldots \ldots \ldots \ldots \ldots . . . \quad 3$

Figure 1-2: Effect of tailings dam failure in Romania, 2000

Figure 2-1: Tailings delivery and return water lines (left) and drop Boxes (right) $\quad \ldots . .10$ at Kennecott Copper, UT, USA

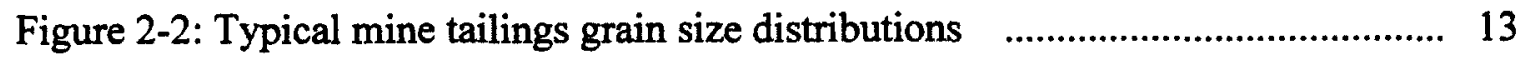

Figure 2-3: Hydro cyclone separator (USNRC, 1994) ............................................ 13

Figure 2-4: Subaerial tailings discharge (left) and shallow low velocity braided

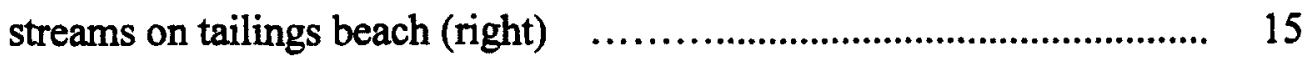

Figure 2-5: Multiple spigot discharge at the Jundee Gold Mine, NT, Australia ......... 15

Figure 2-6: Particle size sorting versus distance from deposition point $\quad \ldots . . . . . . . . . . . . . . . . . . \quad 16$

Figure 2-7: Subaqueous deposition within conventional tailings impoundment $\ldots . . . . .17$ (Courtesy Anglo American)

Figure 2-9: Stages of upstream method of raised embankment construction $\quad \ldots . . . . . . . . .20$

Figure 2-10: Stages of downstream method of raised embankment construction ........ 21

Figure 2-11: Stages of centerline method of raised embankment construction ........... 22

Figure 2-12: Surface tension and capillary rise in pore water .................................. 25

Figure 2-13: Osmotic suction in terms of pressure difference across

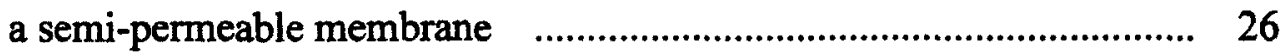

Figure 2-14: Relationship between Soil suction and relative humidity,

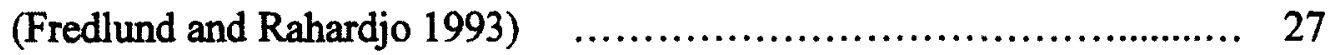

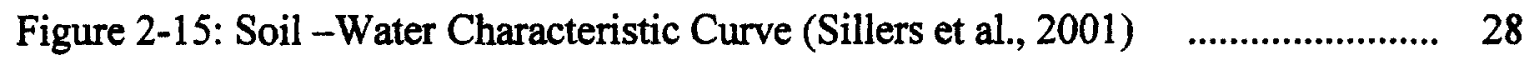


Figure 2-16: Shrinkage curve for London clay (from Croney Coleman,1954) $\quad \ldots . . . . . \quad 30$

Figure 2-17: Effect of initial water content on SWCC (Vanapalli et al. , 1999) ........ 31

Figure 2-18: Effect of void ratio on SWCC (Kawai et al., 2000) $\quad$.............................. 33

Figure 2-19: AEV versus residual water content (Kawai et al., 2000) $\quad$...................... 33

Figure 2-20: Relationship between void ratio and WEV (Kawai et al., 2000) $\quad . . . . . . .34$

Figure 2-21: Effect of initial dry density on SWCC

Figure 2-22: Effect of 1-D consolidation pressure on SWCC _.................................. 36

Figure 3-1: A part of processing plant in Bulyanhulu Gold mine $\quad$.............................. 39

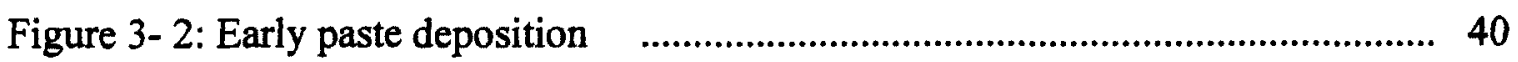

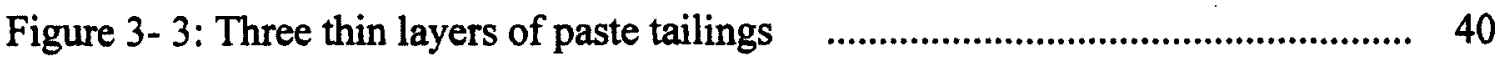

Figure 3-4: Progressive paste deposition forming a cone around a deposition tower .... 40

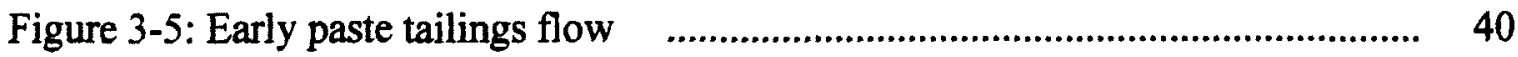

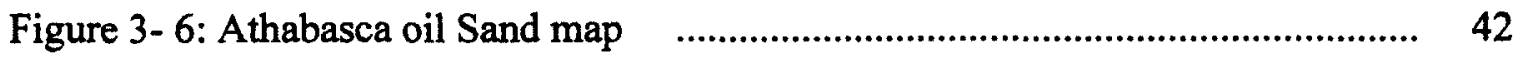

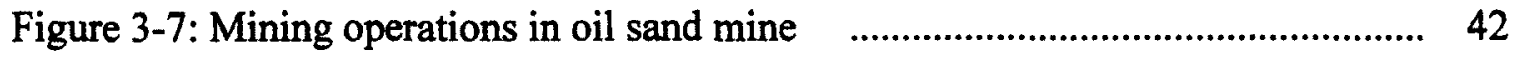

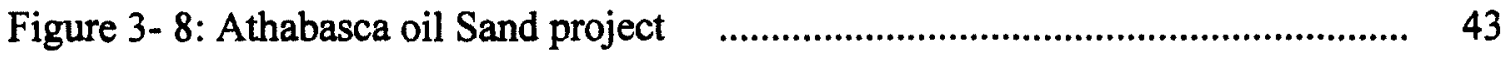

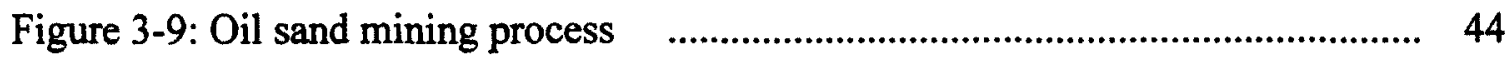

Figure 3-10: Conventional deposition of oil sands tailings deposition

in Muskeg River mine $\quad$................................................................... 46

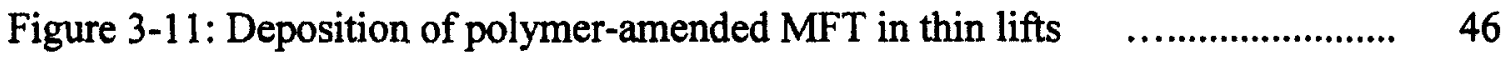

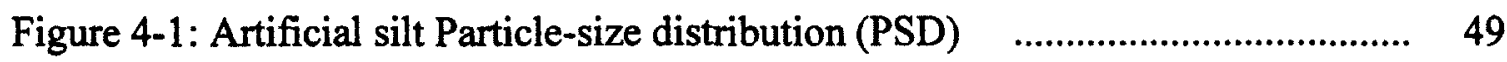

Figure 4-2: Bulyanhulu gold mine tailings particle size distribution $\quad \ldots . . . . . . . . . . . . . . . . . \quad 52$

Figure 4-3: Soil states as a function of volume and water content $\quad \ldots . . . . . . . . . . . . . . . . . . . . . \quad 53$

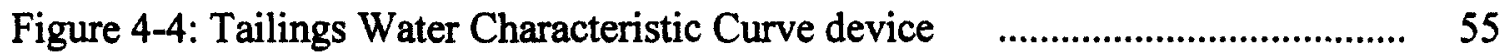


Figure 5-1: Standard proctor compaction test for artificial silt

Figure 5-2: Void ratio versus water content in Standard proctor compaction test for manufactured silt

Figure 5-3: Water content-suction curve for silt with initial water content of $35.3 \%$, before settling

Figure 5-4: Water content-suction curve for silt with initial water content of $35.3 \%$, before settling, $\log$ scale

Figure 5-5: Water content-suction curve for silt with initial water content of $21.6 \%$, after settling

Figure 5-6: Water content-suction curve for silt with initial water content of $21.6 \%$, after settling, log scale

Figure 5-7: Comparison of water content-suction curve for silt in different settling situations

Figure 5-8: Comparison of water content-suction curve for silt in different settling situations, log scale

Figure 5-9: Comparison of saturation-suction curve for silt in different settling situations 64

Figure 5-10: Comparison of saturation-suction curve for silt in different settling situations, $\log$ scale

Figure 5-11: Comparison of void ratio-suction curve for silt in different settling situations

Figure 5-12: Comparison of void ratio-suction for silt in different settling situations, log scale 
Figure 5-13: comparison of shrinkage curve for silt in different settling situations ... 66

Figure 5-14: comparison of shrinkage curve for silt in different

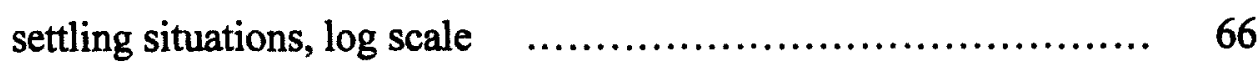

Figure 5-15: Water content versus suction for silt, wi $=26.1 \%$, after settling $\ldots . . . . .69$

Figure 5-16: Water content versus suction for silt, wi $=26.1 \%$, after settling, log scale 69

Figure 5-17: Water content versus suction for silt, $w i=24.7 \%$, after settling $\quad \ldots . . \quad 70$

Figure 5-18: Water content versus suction for silt, wi $=24.7 \%$, after settling, log scale

Figure 5-19: Comparison of Water content versus suction for silt 71

Figure 5-20: Comparison of Water content versus suction for silt, log scale $\quad \ldots . . . .71$

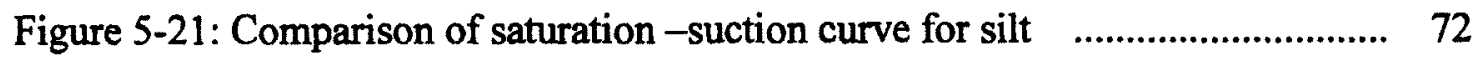

Figure 5-22: Comparison of saturation-suction curve for silt, log scale $\quad \ldots \ldots \ldots \ldots \ldots \ldots . . . . . \quad 72$

Figure 5-23: Water content versus suction for oil sand tailings, wi $=127.1 \% \quad \ldots \ldots . . .75$

Figure 5-24: Water content versus suction for oil sand tailings,

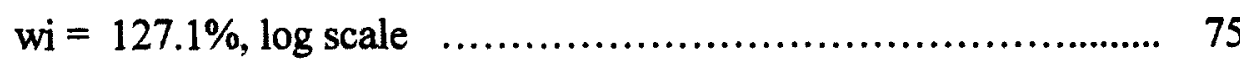

Figure 5-25: Saturation-suction curve for oil sand tailings, wi $=127.1 \% \quad \ldots . . . . . . . \quad 76$

Figure 5-26: Saturation-suction curve for oil sand tailings, wi $=127.1 \%$,

$\log$ scale 76

Figure 5-27: Void ratio versus suction for oil sand tailings, wi $=127.1 \%$

Figure 5-28: Void ratio versus suction for oil sand tailings, $w i=127.1 \%$, $\log$ scale 77

Figure 5-29: Shrinkage curve for oil sand tailings, wi $=127.1 \%$ 78 
Figure 5-30: Shrinkage curve for oil sand tailings, wi $=127.1 \%$, log scale

Figure 5-31: Water content - suction curve for oil sand tailings, wi $=131.2 \%$, log scale

Figure 5-32: Saturation-suction curve for oil sand tailings, wi= $131.2 \%$,

$\log$ scale 80

Figure 5-33: Void ratio versus suction for oil sand tailings, wi $=131.2 \%$, $\log$ scale 81

Figure 5-34: Shrinkage curve for oil sand tailings, wi $=131.2 \%, \log$ scale 81

Figure 5-35: Water content versus suction for oil sand tailings, wi $=156.6 \%$, log scale 82

Figure 5-36: Saturation-suction curve for oil sand tailings, wi $=156.6 \%$, $\log$ scale 82

Figure 5-37: Void ratio versus suction for oil sand tailings, wi $=156.6 \%$, log scale . 83

Figure 5-38: Shrinkage curve for oil sand tailings, wi=\% $156.6 \%, \log$ scale 83

Figure 5-39: Compare of water content - suction curves foroOil sand mine tailings with different initial water content - $\log$ scale

Figure 5-40: Compare of TWCC for oil sand mine tailings with different initial conditions-log scale

Figure 5-41: Comparison of void ratio-suction curve for oil sand mine tailings 87 with different initial conditions - $\log$ scale

Figure 5-42: Comparison of shrinkage curve for oil sand mine tailings with 87 different initial conditions - log scale

Figure 5-43: Mixing effect on water content - suction curve for oil sand mine tailings 
- log scale

Figure 5-44: Mixing effect on TWCC for oil sand mine tailings - log scale

Figure 5-45: Mixing effect on void ratio - suction curve for

oil sand mine tailings, log scale

Figure 5-46: Mixing effect on Shrinkage curve for oil sand mine tailings

$\log$ scale

Figure 5-47: Water content versus suction for oil sand mine tailings wi $=171.6 \%$,

with polymer, log scale

Figure 5-48: Saturation-suction curve for oil sand mine tailings, wi $=171.6 \%$, with polymer, log scale

Figure 5-49: Void ratio versus suction for oil sand mine tailings, wi $=171.6 \%$ with polymer, log scale 93

Figure 5-50: Shrinkage curve for oil sand mine tailings, wi $=171.6 \%$ with polymer $\log$ scale

Figure 5-51: Polymer effect on water content - suction curves 95

for oil sand mine tailings - -log scale

Figure 5-52: Polymer effect on saturation-suction curve in oil sand mine tailings $\log$ scale

Figure 5-53: Polymer effect on void ratio-suction curve for oil sand mine tailings

$-\log$ scale

Figure 5-54: Polymer effect on shrinkage curve for oil sand mine tailings

- log scale 96

Figure 5-55: Effect of Polymer and mixing on water content - suction curve 
for oil sand mine tailings - log scale

Figure 5-56: Effect of Polymer and mixing on saturation-suction curve for

oil Sand mine tailings log scale

Figure 5-57: Effect of Polymer and mixing on void ratio - suction curve

for oil sand mine tailings - $\log$ scale

Figure 5-58: Effect of Polymer and mixing on shrinkage curve for oil sand mine tailings

$-\log$ scale

Figure 5-59: Variation of water content versus time in air dry process

Figure 5-60: Water content versus suction for gold mine tailings, wi=22.1\%,

$\log$ scale

106

Figure 5-61: Saturation-suction curve for gold mine tailings, wi $=22.1 \%$, log scale 106

Figure 5-62: Void ratio versus suction for gold mine tailings, wi $=22.1 \%$ 107

Figure 5-63: Shrinkage curve for gold mine tailings, wi $=22.1 \%$ 107

Figure 5-64: Water content versus suction for goldmine tailings, wi $=26.1 \%, \log$ scale

Figure 5-65: Saturation-suction curve for gold mine tailings, wi $=26.1 \%, \log$ scale. .109

Figure 5-66: Void ratio versus suction for gold mine tailings, wi $=26.1 \%$ 110

Figure 5-67: Shrinkage curve for gold mine tailings, wi $=26.1 \%$ 110

Figure 5-68: Water content versus suction for ogldmine tailings, wi $=33.2 \%, \log$ scale

Figure 5-69: SWCC for gold mine tailings, wi $=33.2 \%$, log scale

Figure 5-70: Void ratio versus suction for gold mine tailings, wi $=33.2 \%$ 
Figure 5-71: Shrinkage curve for gold mine tailings, wi $=33.2 \%$

Figure 5-72: Water content versus suction for gold mine tailings,

$$
\text { wi }=40.7 \%, \log \text { scale }
$$

Figure 5-73: Saturation-suction curve for gold mine tailings, wi $=40.7 \%, \log$ scale . 114

Figure 5-74: Void ratio versus suction for gold mine tailings, wi $=40.7 \%$

Figure 5-75: Shrinkage curve for gold mine tailings, wi $=40.7 \%$

Figure 5-76: Water content versus suction for gold mine tailings, wi $=50.8 \%, \log$ scale

Figure 5-77: SWCC for gold mine tailings, wi $=50.8 \%$, log scale 116

Figure 5-78: Void ratio versus suction for gold mine tailings, wi $=50.8 \%$

Figure 5-79: Shrinkage curve for gold mine tailings, wi $=50.8 \%$

Figure 5-80: Effect of initial water content on saturation-suction curve

for gold mine tailings, log scale

Figure 5-81: Effect of initial water content on void ratio for gold mine tailings $\quad \ldots . \quad 119$

Figure 5-82: Effect of initial water content on shrinkage curve

for gold mine tailings 120

Figure 5-83: Effect of IWC on final Saturation and water content at suction of $400 \mathrm{kPa}$, for Gold mine tailings, log scale 120

Figure 5-84: Effect of compaction on water content-suction curve for gold mine tailings log scale

Figure 5-85: Effect of compaction on TWCC for gold mine tailings, log scale 122

Figure 5-86: Effect of compaction on void ratio for Gold mine tailings 123

Figure 5-87: Effect of compaction on shrinkage curve for gold mine tailings 123 
Figure 5-88: Water content - suction curve for gold mine tailings loading $=50.0 \mathrm{kpa}$

$$
\text { , wi }=23.8 \% \text {, log scale }
$$

Figure 5-89 : Tailings water Characteristive curve for gold mine tailings

$$
\text { loading }=50.0 \mathrm{kpa}, w i=23.8 \%, \log \text { scale }
$$

Figure 5-90: Void ratio curve for gold mine tailings loading $=50.0 \mathrm{kpa}, w i=23.8 \%$,

$\log$ scale

Figure 5-91: Shrinkage curve for gold mine tailings loading $=50.0 \mathrm{kpa}$,

$$
\mathrm{wi}=\mathbf{2 3 . 8 \%}
$$

Figure 5-92: Water content - suction curve for gold mine tailings loading of $50.0 \mathrm{kpa}$,

$$
\text { wi }=31.5 \% \text {, log scale }
$$

Figure 5-93: Saturation-suction curve for gold mine tailings

130

$$
\text { loading }=50.0 \mathrm{kpa}, w i=31.5 \%, \log \text { scale }
$$

Figure 5-94: Water content - suction curve for gold mine tailings

$$
\text { loading of } 100.0 \mathrm{kpa} \text {, wi }=28.3 \% \text {, log scale }
$$

Figure 5-95: Saturation-suction curve for gold mine tailings loading of $100.0 \mathrm{kpa}$, wi $=28.3 \%, \log$ scale

Figure 5-96: Water content - suction curve for gold mine tailings loading of $150.0 \mathrm{kpa}$, wi $=27.1 \%$, log scale

Figure 5-97 : Saturation-suction curve for gold mine tailings loading of $150.0 \mathrm{kpa}$, wi $=27.1 \%$, log scale

Figure 5-98: Effect of IWC and loading on water content-suction curve 135 for gold mine tailings - log scale

Figure 5-99: Effect of IWC and loading on saturation-suction curve 
for gold mine tailings - -log scale

Figure 5-100: Effect of IWC and loading on shrinkage curve

for gold mine tailings

Figure 5-101: Effect of IWC and loading on void ratio for gold mine tailings

Figure 5-102: Comparison of saturation variations in loading and unloading conditions

for gold mine tailings, log scale

138

Figure 5-103: Comparison of water content variations in loading and unloading

Conditions for gold mine tailings, log scale

Figure 5-104: Comparison of void ratio variations in loading and unloading

conditions for gold tailings

Figure 5-105: Comparison of shrinkage variations in loading and unloading conditions for gold tailings

Figure 5-106: Water conten curve for gold tailings, wi $=38.8 \%$, applied matric suction $50 \mathrm{kPa}$., $\log$ scale

Figure 5-107: Saturation curve for gold tailings, wi $=38.8 \%$, applied matric suction $50 \mathrm{kPa}$., $\log$ scale

Figure 5-108: Consolidation curve for gold tailings, wi $=38.8 \%$, applied matric suction $50 \mathrm{kPa}$.

Figure 5-109: Shrinkage curve for gold tailings, wi $=38.8 \%$, applied matric suction $50 \mathrm{kPa}$.

Figure 5-110: Water content curve for gold tailings, wi $=42.6 \%$, applied matric suction $150 \mathrm{kPa}$., log scale

Figure 5-111:Saturation curve for gold tailings, wi $=42.6 \%$, applied 
matric suction $150 \mathrm{kPa}$, log scale

Figure 5-112: Consolidation curve for gold tailings, wi $=42.6 \%$, applied

matric suction $150 \mathrm{kPa}$.

Figure 5-113: Shrinkage curve for gold tailings, wi $=42.6 \%$, applied

matric suction $150 \mathrm{kPa}$.

Figure 5-114: Effect of 1-D loading on water content curve for gold tailings,

wi $=36.3 \%$, applied matric suction $0 \mathrm{kPa}$., log scale

Figure 5-115: Effect of 1-D loading on saturation curve for gold tailings

wi $=36.3 \%$, applied matric suction $0 \mathrm{kPa}$., $\log$ scale

Figure 5-116: Effect of 1-D loading on consolidation curve for gold tailings, wi $=36.3 \%$, applied matric suction $0 \mathrm{kPa}$.

Figure 5-117: Effect of 1-D loading on shrinkage curve for gold tailings, wi=36.3\%, applied matric suction $0 \mathrm{kPa}$.

Figure 5-118: Effect of different parameters on water content curve

for gold mine tailings, log scale

Figure 5-119: Effect of different parameters on TWCC for gold mine tailings, log scale

Figure 5-120: Effect of different parameters on consolidation curve

for gold mine tailings

Figure 5-121: Effect of different parameters on shrinkage curve

for gold mine tailings

Figure 6-1: Effect of initial water content on water content-suction curve for gold mine tailings 
Figure 6-2: Effect of initial water content on shrinkage curve

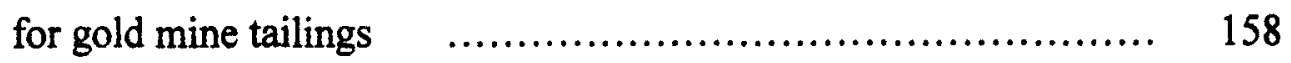

Figure 6-3: Relationship between IWC and void ratio for gold mine tailings $\ldots . .159$

Figure 6-4: Relationship between IWC and AEV for gold mine tailings $\quad \ldots \ldots \ldots . . .159$ 


\section{LIST OF APPENDIX}

APPENDIX-A: More information for experimental tests results $\quad$.............................. 170

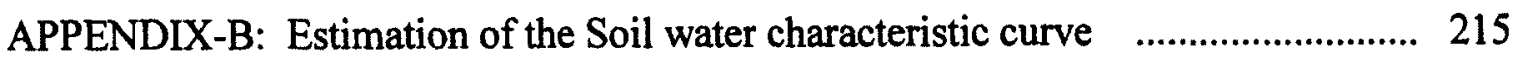

APPENDIX-C: Variations of water content and density in tailings layers $\quad \ldots \ldots . . . . . \quad 224$

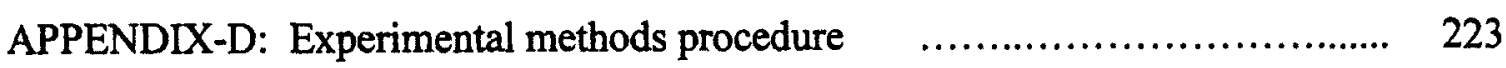




\section{LIST OF SYMBOLS}

\begin{tabular}{|c|c|}
\hline AEV & Air-entry value \\
\hline$a_{f}, n_{f}, m_{f}$ & Fitting parameters \\
\hline$d_{e}$ & Effective grain-size diameter $(\mathrm{cm})$ \\
\hline $\mathrm{g}$ & gravity acceleration $(\mathrm{m} / \mathrm{s} 2)$ \\
\hline SG & Specific gravity \\
\hline $\mathrm{h}_{\mathrm{c}}$ & Height of capillary rise $(\mathrm{cm})$ \\
\hline $\mathrm{L}_{1}$ & Liquid limit (\%) \\
\hline PI & Plasticity index \\
\hline$P_{1}$ & Plastic limit (\%) \\
\hline $\mathbf{r}$ & pore radius $(\mathrm{cm})$ \\
\hline $\mathrm{R}$ & Universal gas constant $(\mathrm{KJ} / \mathrm{mol} . \mathrm{K})$ \\
\hline RH & Relative humidity \\
\hline SWCC & Soil-water characteristic curve \\
\hline $\mathrm{T}$ & Temperature (k) \\
\hline $\mathrm{T}_{s}$ & Surface tension $(\mathrm{J} / \mathrm{m} 2)$ \\
\hline TWCC & Tailings-water characteristic curve \\
\hline $\mathrm{u}_{\mathrm{a}}$ & Pore air pressure $(\mathrm{kPa})$. \\
\hline$u_{w}$ & Pore water pressure $(\mathrm{kPa})$. \\
\hline VP & Actual vapour pressure $(\mathrm{kPa})$. \\
\hline $\mathrm{VP}_{\text {sat }}$ & Saturated vapour pressure $(\mathrm{kPa})$. \\
\hline$w$ & molecular weight of water $(\mathrm{kg} / \mathrm{mol})$ \\
\hline$w_{i}$ & Initial water content (\%) \\
\hline
\end{tabular}




$\begin{array}{ll}w_{p} & \text { Optimum water content (\%) } \\ w_{\mathrm{s}} & \text { Saturated water content (\%) } \\ a & \text { contact angle } \\ \rho_{w} & \text { Water density }(\mathrm{Kg} / \mathrm{m} 3) \\ \Psi & \text { Total suction }(\mathrm{kPa} .) \\ \Pi & \text { Osmotic suction }(\mathrm{kPa} .)\end{array}$


Chapter 1:

\section{Introduction}




\section{1-1. Tailings and Environmental impact}

Tailings are a by-product of all mining operations. Tailings include unrecoverable and uneconomic metals, minerals, chemicals, organisms and water. The maximum particle size of tailings is usually less than 100 microns due to mineral processing requirements, and sometimes can have a sizable clay fraction. Tailings are conventionally discharged as slurry and deposited in tailings storage facilities. In recent decades, due to increasing demand, it has become economical to mine large lower-grade deposits. This has greatly increased the amount of tailings and other kind of mine wastes. For larger projects, tailings embankments reach several hundred meters in height and the impoundments cover several square kilometers. The purpose of a tailings impoundment is to contain tailings in a cost-effective manner that provides for long-term stability of the impoundment and long-term protection of the environment. Water control in tailings is one of the most critical components of tailings impoundment designs and operation. Tailings dams failure are largely related to water levels and pore-water pressure buildup in the impoundment and/or the embankment. Seepage of tailings pore-water off-site and resulting environmental impacts are related to water control as well (EPA 1994).

\section{1-2. Review of tailings dams failures}

Davies (2001), stated that there are around 3500 active tailings impoundment in the world. Average major failures are 2 to 5 per year, about $0.1 \%$, and minor failures are 35 per year, i.e. 1\%. According to a review of case histories by Davies (2002), he reported that probability of tailings dams failure is between 1 in 700 and 1 in 10,000. Following are some examples of tailings dams failure and their consequences: 
1. On July 19, 1985, in Prealpi Mineraia fluorite mine at Stava, Trento, Italy, the tailings dam failure released $200,000 \mathrm{~m}^{3}$ slurry at speed up to $90 \mathrm{~km} / \mathrm{h}$, it killed 265 people, destroyed 62 buildings and covered 435 hectares (Chandler and Tosatti 1995).

2. In Los Frailes lead-zinc mine at Aznalcollar near Seville, Spain, the tailings dam failure, on April 25, 1998, released 5.5 million $\mathrm{m}^{3}$ of acidic water and 1.3 million $\mathrm{m}^{3}$ heavy metal bearing tailings into nearby Rio Agrio, a tributary to Rio Guadiamar. This slurry covered 4,600 hectares of farmland and it threatened the Donana National Park which is a UN heritage Area (Hudson-Edwards et al., 2003), (Figure 1-1).

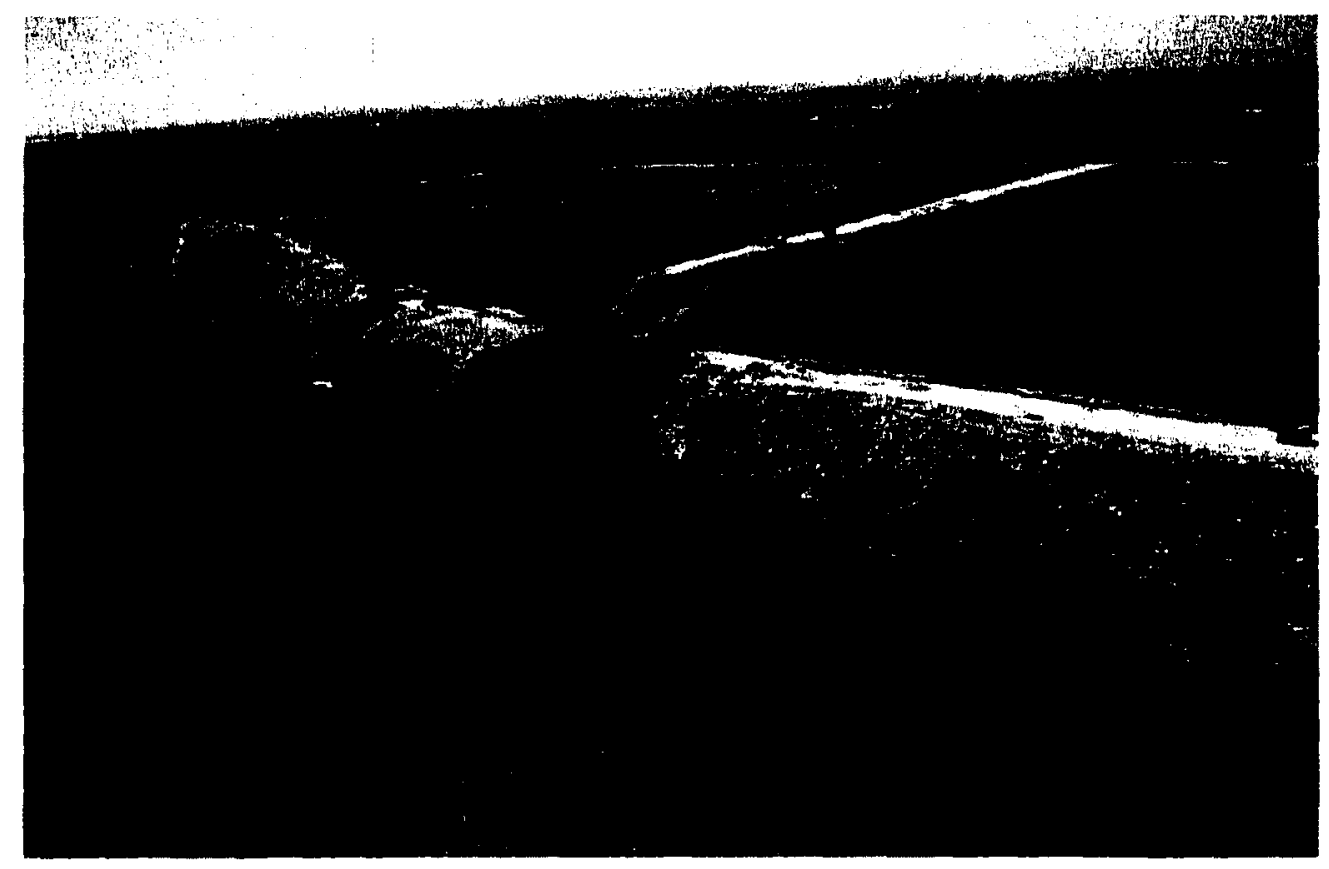

Figure 1-1: Tailing dam failure in Los Frailes mine, Spain, 1998, (UNEP 2007) 
3. Baia Mare tailings dam failure on January 30, 2000, north-west Romania, released $100,000 \mathrm{~m}^{3}$ of cyanide - rich tailings into the Some, Tisza and then into the Danube. Around 50 to 100 tonnes of cyanide and heavy metals resulted in fish kills and contaminated water ( UNEP 2007), (Figure 1-2).

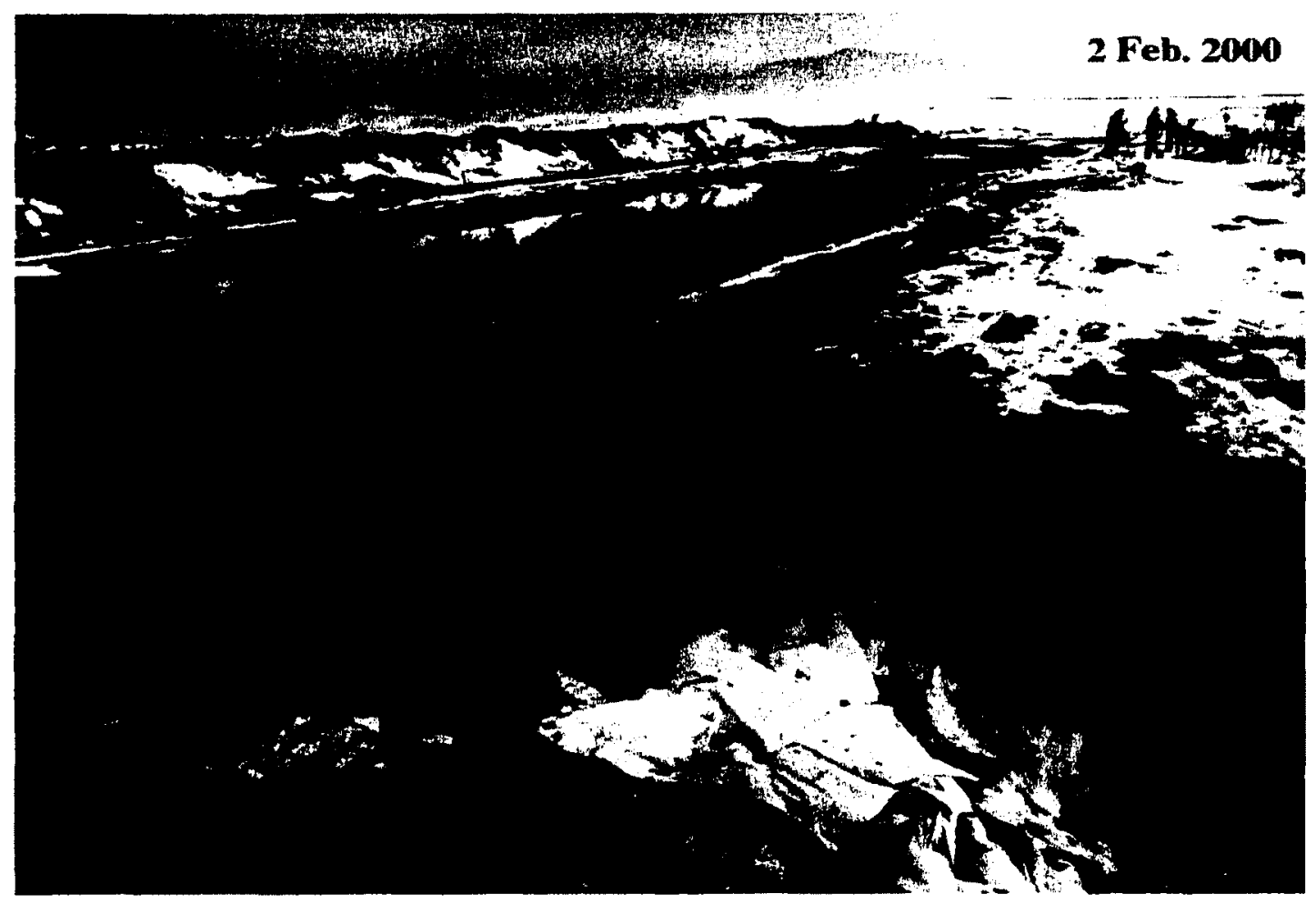

Figure 1-2: Effect of tailings dam failure in Romania, 2000, (UNEP 2007)

\section{1-3. Study Objectives}

The stability of tailings impoundments is dependent, among several factors, on both density and distribution of pore-water pressure in the tailings. Fostering dewatering of the tailings and drawdown of the phreatic surface can, therefore, improve the stability of the tailings impoundment. 
The soil-water characteristic curve (SWCC) can be used as an important tool to understand the dewatering behaviour of tailings, particularly high density tailings, or slurry tailings deposited sub-aerially in a dry climate, where unsaturated conditions might prevail during deposition or shortly thereafter. There appear to be no published studies on the influence of various parameters that may affect the SWCC. Such parameters might include the deposition water content or density, initial compaction or consolidation of the tailings prior to actual desaturation, the use of a polymer or other flocculant (which are used in different thickening operations), or even the thickness of the sample in the SWCC apparatus. Similarly, the effect of desiccation of freshly deposited consolidation characteristics of subsequently loaded tailings has not been much studied (Daliri et al. 2011).

One specific use of the SWCC is in the management of deposition layer thickness and deposition cycle time for multipoint deposition of thickened tailings (Fisseha et al. 2010) or for rate of rise in general. When the rate of rise is sufficiently slow, there is enough time for induced pore -water pressure to be dissipated, but for faster rates of rise, excess pore water pressure builds up, which is a threat for tailings dam safety. Evaporation and drainage can play a role in pore-water pressure dissipation, but depending on the characteristics of the tailings, such as the soil-water characteristic curve, the influence of desiccation and drainage may either be important, or be limited to a small region of the tailings impoundment.

The maximum rate of rise of tailings dam or stack is dependent on geotechnical characteristics of tailings, dam geometry and degree of tailings saturation (ICOLD 1995). 
The focus of this research is on the influence of initial state on water-retention and consolidation behaviour of mine tailings. For this purpose, experimental tests have been conducted on two different types of mine tailings, which are:

1. Gold mine tailings from the Bulyanhulu mine, in central-western Tanzania, East Africa. Owned and operated by Barrick Gold (Frostiak, 2003).

2. Mature fine tailings from an oil sand operation in the Athabasca oil sands in Northern Alberta.

The SWCC of these tailings was measured using the axis-translation technique for different initial states and loading conditions. The varied conditions were:

- Initial water content / density

- Effect of waiting for tailings to completely settle before starting axis-translation.

- Mixing method for sample preparation (for mature fine tailings).

- Influence of polymer.

- Degree of consolidation before axis-translation test.

Additionally, the influence of desiccation on subsequent one-dimensional consolidation was also studied.

Further, tests were also performed on an artificial silt, to examine how initial state affected the SWCC of a more ideal material, but with a particle size distribution as tailings. 


\section{1-4. Thesis outline}

- Chapter One gives a general introduction and presents the scope and objectives of the research.

- Chapter Two include a review of tailings characteristics, describes the different methods of tailings deposition, conventional impoundment storage, and includes a literature review on suction and the soil-water characteristic curve (SWCC)

- Chapter Three gives some information about the Bulyanhulu mine and the Muskeg River mine, such as geographical location, mineralogy, mineral processing, tailings system and materials.

- Chapter Four describes the tailings used in the thesis and the material characteristics and experimental protocols.

- Chapter Five presents results were obtained from thesis and discusses the results.

For the rest of thesis, when applied to tailings, TWCC will be substituted for SWCC. 


\section{Chapter 2:}

\section{Literature Review}




\section{2-1. Tailings}

Tailings are waste products of mineral processing. To be exact, extracted rocks or overburden with sufficient grade and economical value are processed to concentrate the desired mineral using physical and chemical methods such as crushing, milling and flotation. The waste of this process is called tailings, which includes unrecoverable and uneconomic metals, minerals, chemicals, organisms and water. Tailings are conventionally discharged as slurry and deposited in tailings storage facilities. Transport from the mill is done either by pumping and or gravity (through pipelines), or in open flumes (Figure 2-1). The density of most kind of tailings increases due to settling. For example for gold tailings initial void ratio of deposited tailings is around 3 with a solids concentration (mass of solids/ over total mass) of $50 \%$. The void ratio decreases to 1.5 once it is settled with a solids concentration of $65 \%$ (Simms 2007).

With improved technologies ore with lower grade is extracted that results in more production and more tailings. In the 1960 's production of tailings at typical mines was 10 's of thousands of metric tonnes every day which has been increased to 100's of thousands every day. This has increased the need for larger tailings impoundments. 

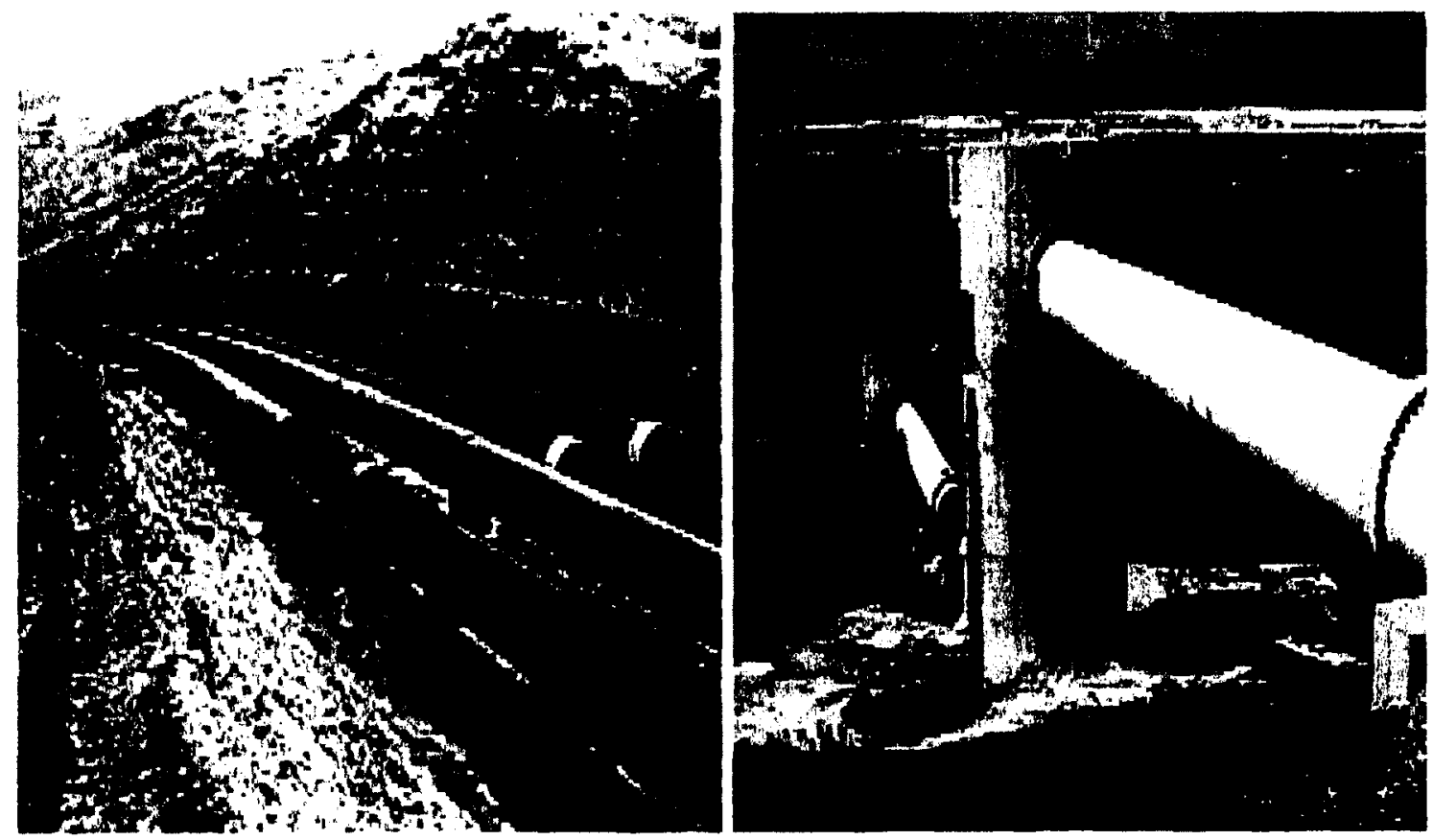

Figure 2-1: Tailings delivery and return water lines (left) and drop Boxes (right) at Kennecott Copper, UT, USA (Tailings.info)

\section{2-1-1. Tailings characteristics}

Tailings are a mixture of fine solid particles and water. Due to requirements of mineral extraction, rock is usually ground to particles less than 100 microns, and for most tailings created from rock, most of the grains are between 100 and 10 microns in diameter. Tailings created from mining of overburden (soil), such as bauxite or oil sands surface mining, contain finer particles originating from native clays.

In mining parlance particles coarser than $74 \mu \mathrm{m}$ are called sand and the fine tailings called slime. Table 2-1 shows some engineering properties of different kinds of tailings. Figure 2-2 shows typical grain size distributions. 


\section{2-1-2. Conventional Deposition methods of tailings}

Tailings emerging from the extraction process are typically at low solids concentration by mass $(<50 \%)$ and by volume $(<25 \%)$, and high water content $(>100 \%)$, such they can be transported from the mill to the impoundment as non-sedimenting slurry in the turbulent range. There are three techniques for tailings storage. Subaerial technique, (tailings are deposited on existing ground), subaqueous technique (tailings are deposited underwater) and as backfill in mined out voids underground.

For surface deposition, tailings may segregate by grain size, coarse particles settling out closer to deposition points. Degree of segregation depends on 2 parameters (Vick 1990):

- $\quad$ particle size distribution in tailings

- $\quad$ pulp density of slurry

Sometimes the coarse fraction of the tailings is used in the foundation of the embankment. A hydro-cyclone is used to separate coarse particles (sand) from fine particles (slime) (Figure 2-3). 
Table 2-1: Some engineering properties of various slurry tailings

\begin{tabular}{|l|l|l|l|l|l|}
\hline Slime type & $\begin{array}{l}\text { Specific } \\
\text { gravity }\end{array}$ & PI (\%) & $\begin{array}{l}\text { Sedimentation rate } \\
(\mathrm{ft} / \mathrm{hr})\end{array}$ & $\begin{array}{l}\text { Permeability } \\
(\mathrm{cm} / \mathrm{s})\end{array}$ & Reference \\
\hline Copper & $2.6-2.7$ & $5-20$ & $0.14-0.31$ & $10^{-5}-10^{-7}$ & $\mathrm{a}, \mathrm{b}$ \\
\hline Uranium slimes & $2.8-2.85$ & $8-50$ & $\mathrm{~N} / \mathrm{A}$ & $10^{-5}-10^{-8}$ & $\mathrm{~b}, \mathrm{c}$ \\
\hline Phosphatic clays & 2.8 & $60-200$ & 0.17 & $10^{-4}-10^{-9}$ & $\mathrm{a}, \mathrm{b}$ \\
\hline Copper-zinc & $2.9-4.0$ & 0 & $0.38-0.54$ & & $\mathrm{a}$ \\
\hline Marine sediments & & 97 & 0.54 & & $\mathrm{~b}$ \\
\hline Trona slimes & & $20-40$ & & $10^{-7}-10^{-9}$ & $\mathrm{~b}$ \\
\hline Oil sands sludge & & $24-45$ & & $10^{-4}-10^{-7}$ & $\mathrm{~b}$ \\
\hline Alumina red mud & & $5-15$ & & & $\mathrm{a}$ \\
\hline Potash slimes & & $10-38$ & & $10^{-4}-10^{-9}$ & $\mathrm{~d}$ \\
\hline $\begin{array}{l}\text { Sulphide-free tailings } \\
\text { (from hard rock) }\end{array}$ & $2.70-2.87$ & & & & $\mathrm{~b}$ \\
\hline Gold slimes & $2.6-2.7$ & $2-6$ & & & \\
\hline
\end{tabular}

(a-Vick, 1990, c- Santos et al. 1992, d- Aubertin et al. 1996, e- Jacobsz, 1998) 

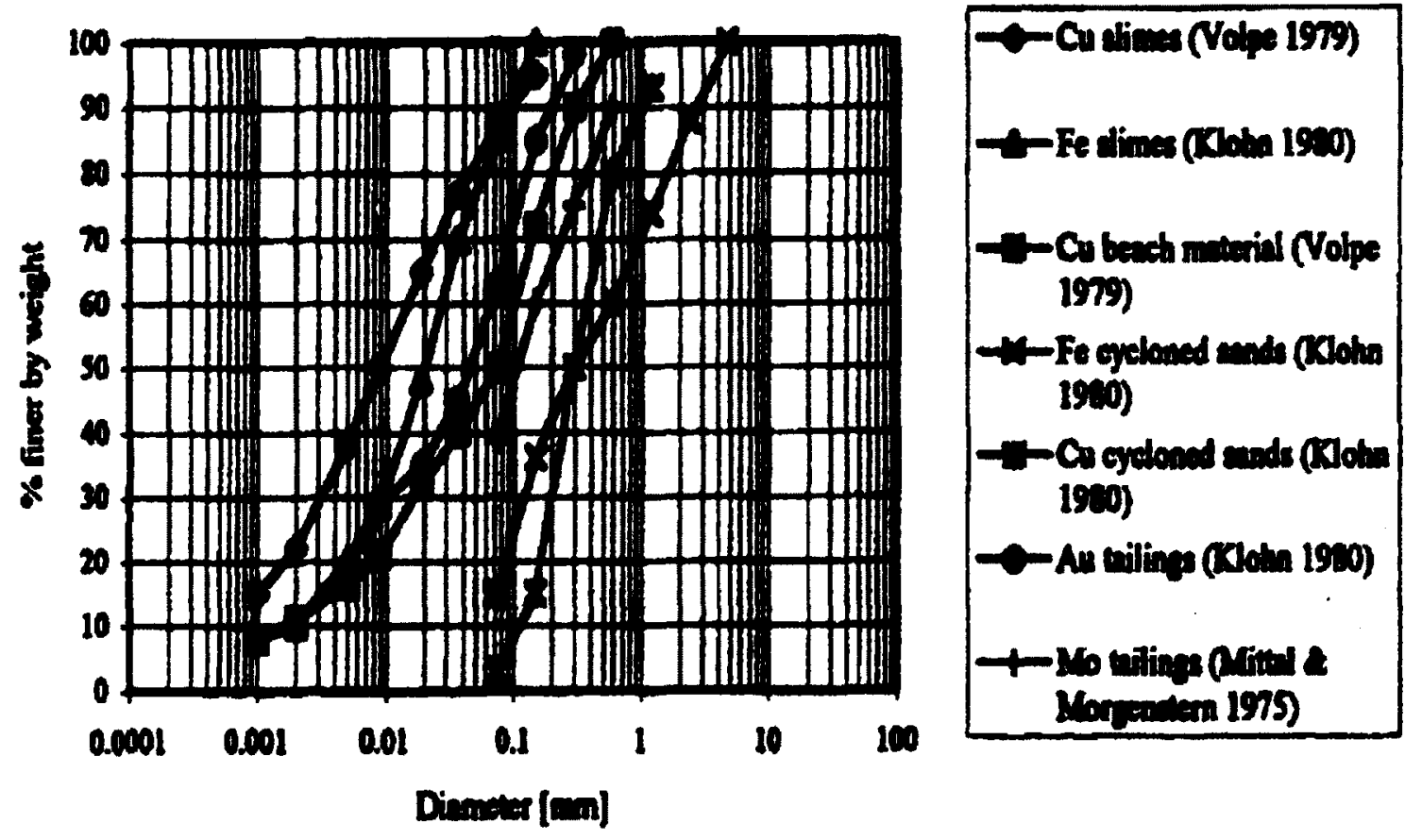

Figure 2-2: Typical mine tailings grain size distributions (Priscu 1999)

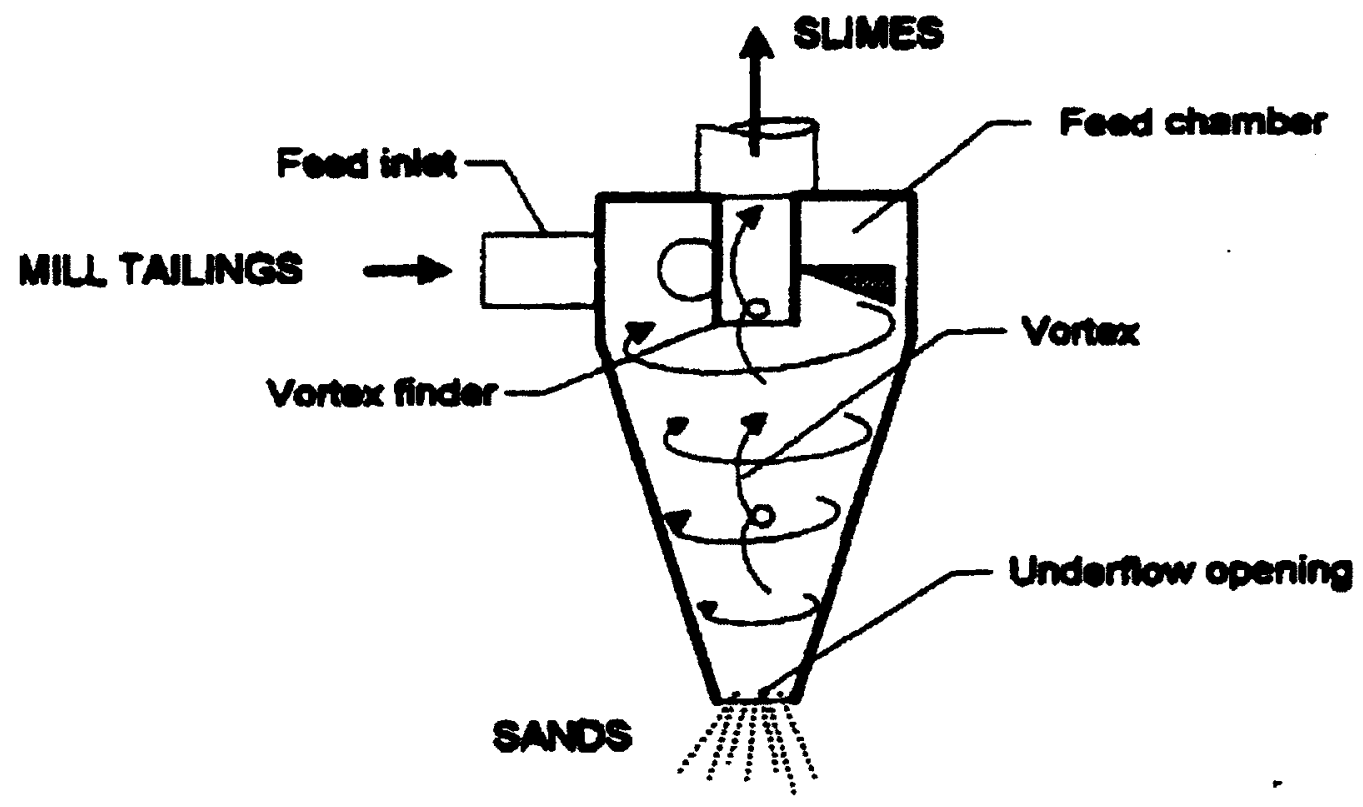

Figure 2-3: Hydrocyclone separator (USNRC, 1994). 


\section{2-1-2-1. Subaerial technique}

This method is more commonly used than subaqueous deposition. In this technique, tailings discharge from one spigot in the centre of the impoundment, or through several outfalls along the perimeter. Spigot number has a relationship with discharge velocity. With more spigots, discharge velocity is slower, local rate of rise is slower, and therefore there is more time for the tailings to discharge release water though bleeding (initial settling), drying, and consolidation (Figure 2-4, 2-5). Numbers of spigots depend on climate, tailings discharge rate, tailings dry characterises and tailings facilities shapes. In this method discharged tailings are exposed to oxygen and water. This causes oxidation. Oxidation of sulphide components will produce acid which may pose a problem through seepage of acid drainage off site into surface water and groundwater.

In subaerial deposition, the beachslope grade is between 0.5 to $2.0 \%$ for first several hundred feet. The beachslope increases towards the deposition point, and correlates with increasing pulp density and coarser particle size, as coarse particles settle closest to the discharge point and finer fraction settle further away (Vick 1990). For longer distances, the slope is less than $0.5 \%$. 

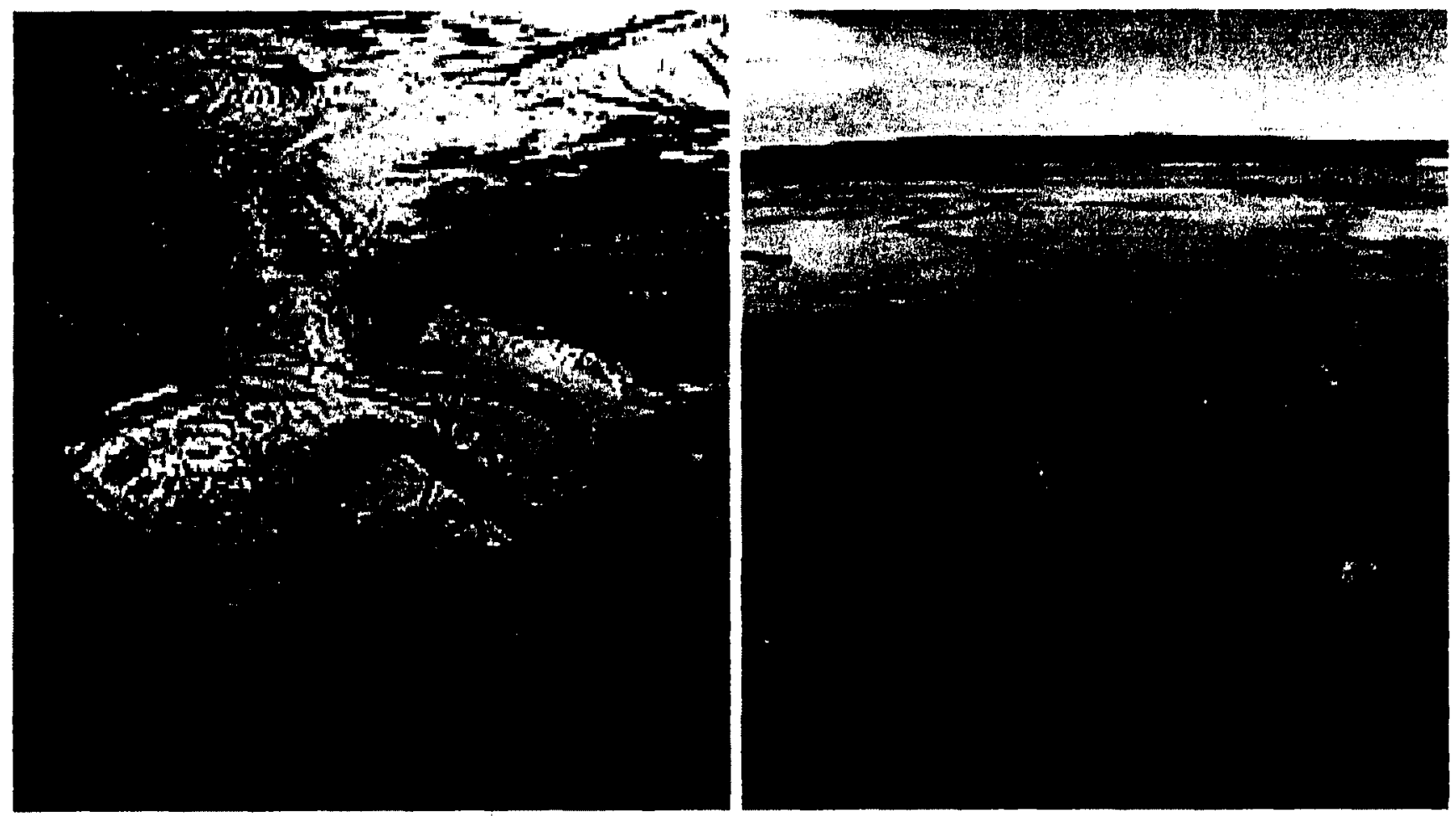

Figure 2-4: Subaerial tailings discharge (left) and shallow low velocity braided streams on a tailings beach (right) (www. Taillings.info).

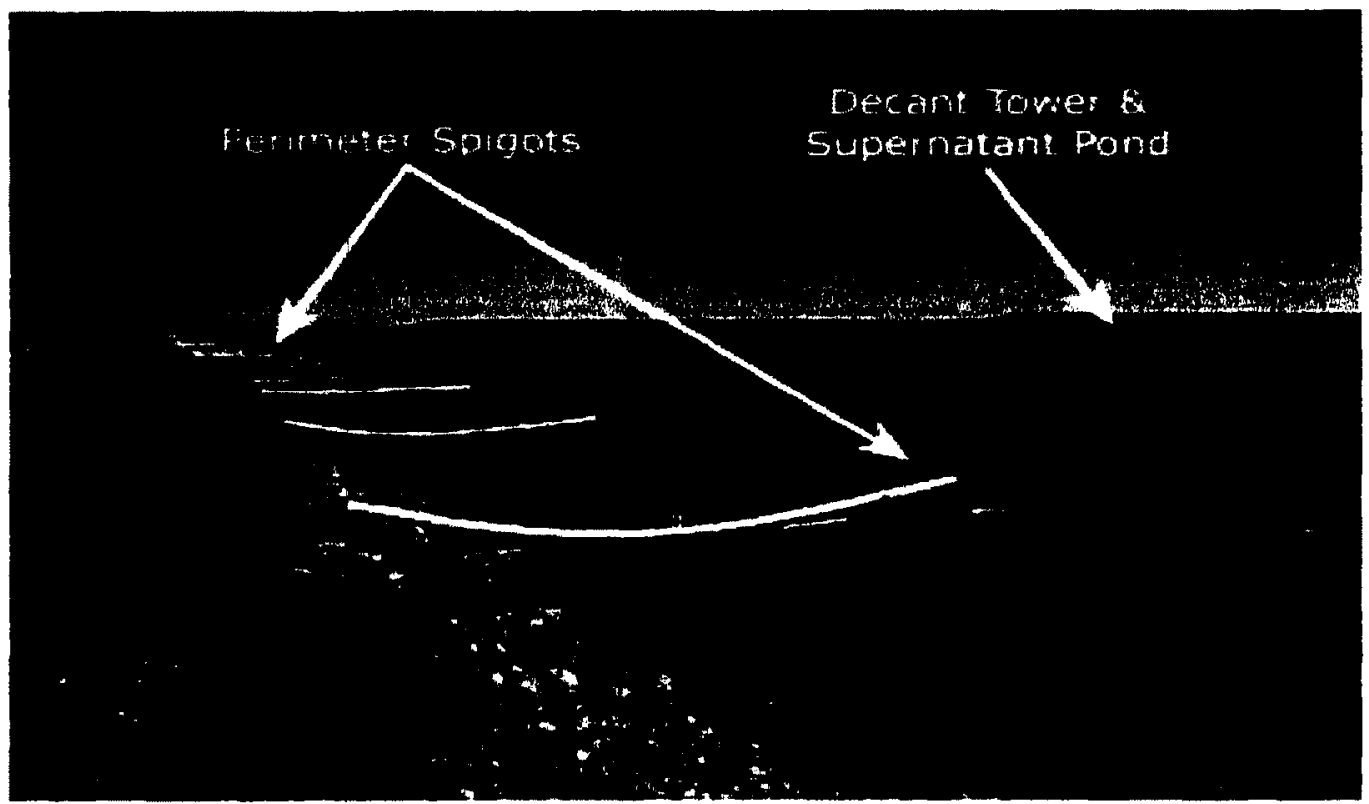

Figure 2-5: Multiple spigot discharge at the Jundee Gold Mine, NT, Australia (www.Tailings.info) 
Figure 2-6 shows relationship between particle size and distance from discharge point for diamond tailings. The inset illustrates the same relation after 12 months which $H$ represents the distance down the beach and $\mathrm{X}$ represents distance from point of deposition to the edge of the pool.

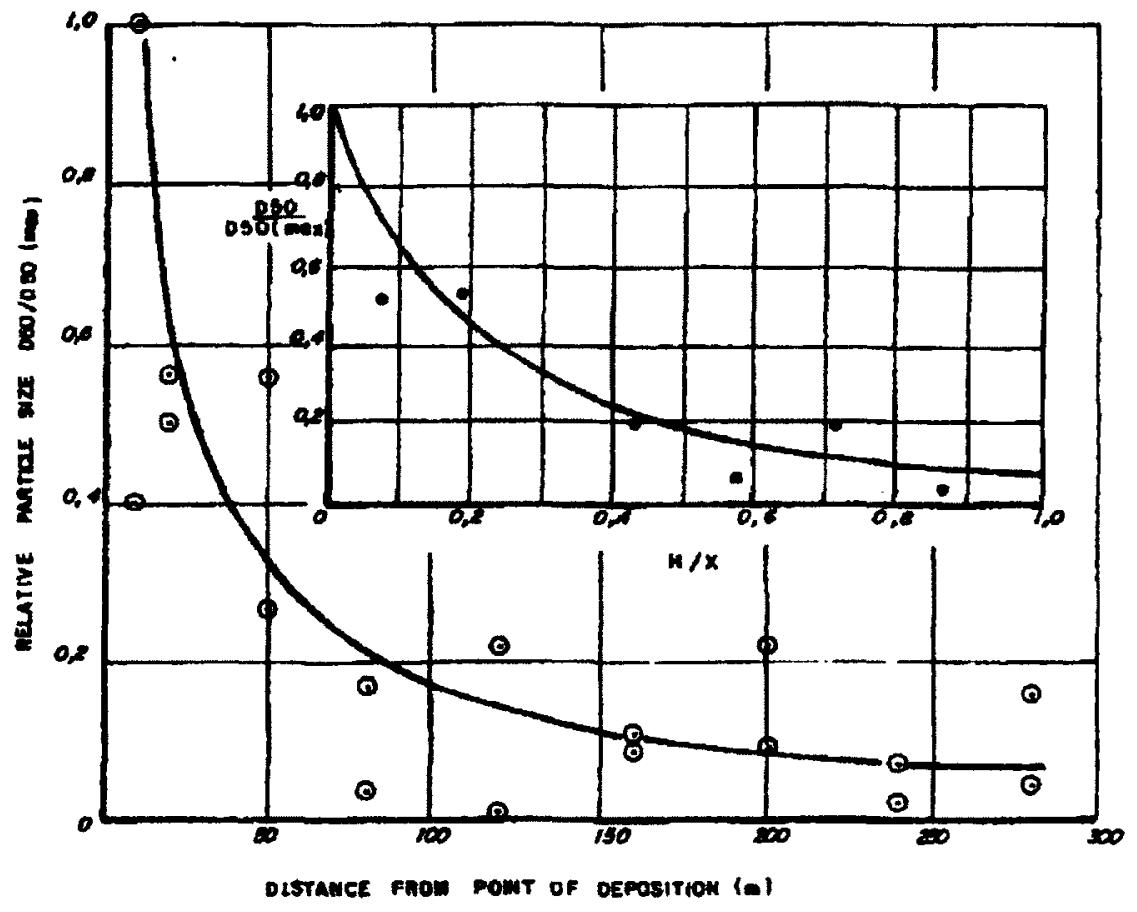

Figure 2-6: Particle size sorting versus distance from deposition point (Blight, 1983)

\section{2-1-2-2. Subaqueous technique}

In this method, tailings are discharged into natural or artificial water bodies ( Figure 27). This method is used in non-arid climate (Yanful, 2007). Tailings are disposed in a pond with enough water cover depth in order to prevent tailings resuspension and oxidation: therefore, subaqueous technique cannot be applied in a climate with a high evaporation rate. As Tremblay (1998) noted, this method is good for tailings that contain 
sulphide components and mobile metals. It prevents acid production because of low diffuse permeability of oxygen in the water. The underwater beachslope could reach more than $10 \%$ (Dillon et al. 2004).

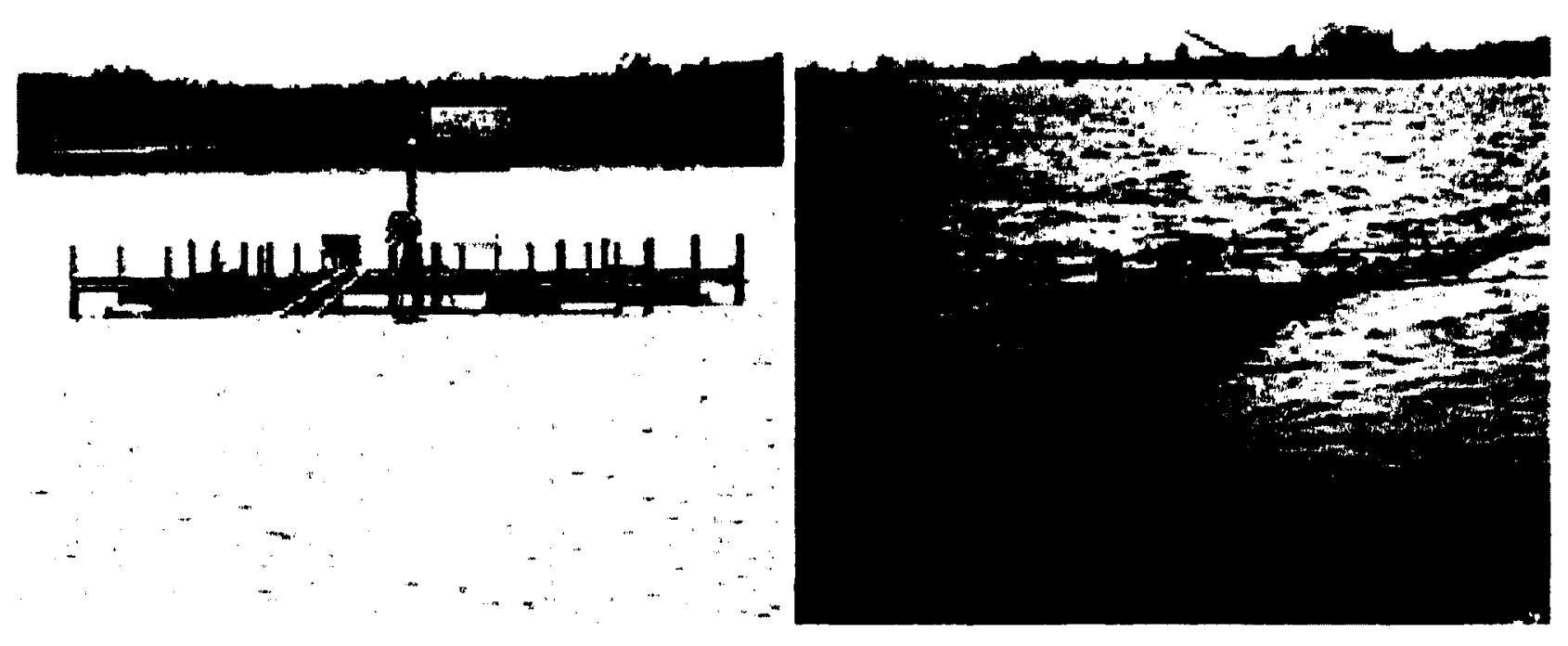

Figure 2-7: Subaqueous deposition within a conventional tailings impoundment Courtesy Anglo American, (www.Tailings.info)

\section{2-1-3. Conventional impoundment storage}

A conventional impoundment is a ground surface with a constructed embankment dam on it to store water and tailings. It can reclaim water especially for mineral processing plant. With improved technology in the future and increase material price, some of the tailings can be processed for economical material.

There are two types of conventional impoundment. One of them is water retention dams and the other one called raised embankment dams. The main different between those two is that water retention dams are constructed completely in their full designated 
shape and height before tailings discharging. But raised embankment dams are raised (constructed in stages) during discharge tailings and mining activities (EPA 1994).

\section{2-1-3-1. Water retention dams}

As mentioned above water retention dams are completely constructed in full height and shape before any tailing discharge. This is to store high volume of water to reclaim water especially for mineral processing plant (i.e. flotation) or my keep water for dry condition.

\section{2-1-3-2. Raised embankment dams}

Initial size of raised embankment is for $2-3$ years. After that with increasing volume of tailing height of embankment will be raised. These types have less initial cost (investment) than water retention dams. The construction cost is distributed over life of mine or impoundment which results in less cash flow. Another factor is to have flexibility in selecting acceptable material (i.e. waste rock, coarse fraction of tailings, natural soil) according to economical parameters (Vick 1990).

There are three types of raised embankment dams which are very common constructions to storage discharged tailings:

- Upstream raised embankment

- Centerline raised embankment

- Downstream raised embankment

The name designate direction of the embankment crest moves in regard to initial starter dyke (Vick 1990) 


\section{2-1-3-2-1. Upstream method}

In the upstream method, the initial size of the embankment is designed to provide storage for 2-3 years of production. The coarse fraction of the tailings settle closer to the starter embankment and is used as a pillar for next level of raised impoundment. Figure 2-9 shows stages of upstream raised embankment construction.

Rate of upstream embankment raising (rate of rise) is very important and must be controlled. This is to prevent excess pore-water pressure buildup and resulting loss of strength.

This method is not suitable for areas with dynamic loading potential (i.e. high risk of earthquakes). Because of the use of the coarse fraction of tailings as part of the embankment, this method has lower initial cost than other two methods. 

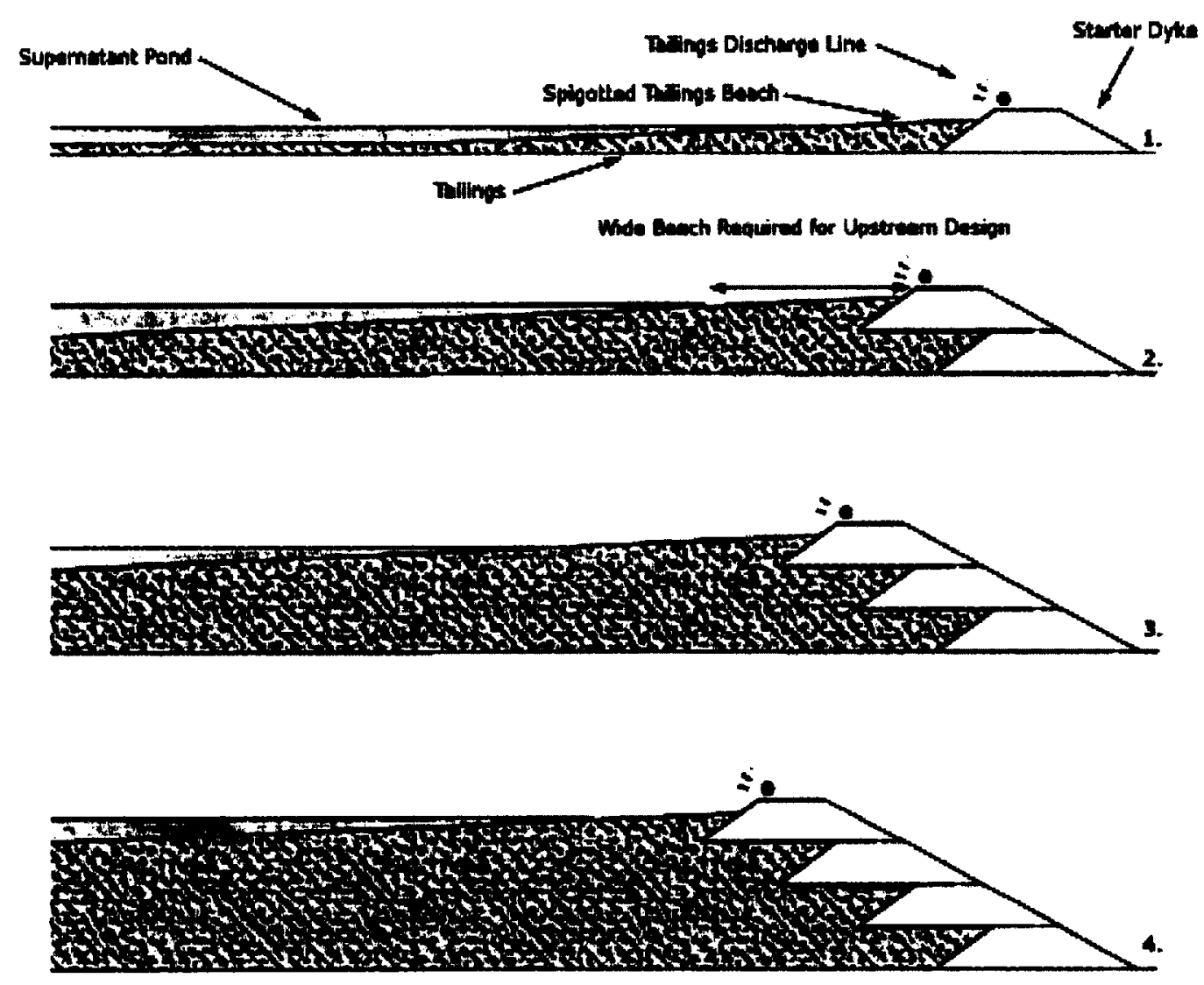

Figure 2-9: Stages of upstream method of raised embankment construction

(Vick 1990)

\section{2-1-3-2-2. Downstream method}

When tailings elevation reaches the embankment crest, the next level is constructed on the downstream slope of the pervious raise (Figure 2-10). Since downstream dam construction is independent from tailing discharge then there are no limits in height of embankment, except economic parameters. 
Downstream method reduces risk of failure especially in area with earthquake potential (dynamic loading). Significant water can be stored in downstream method and therefore it is good for some mineral processing plants which need change in production lines that results change in volume of water. Since a large volume of filling material is required to increase embankment height, this method generally costs more than other methods.
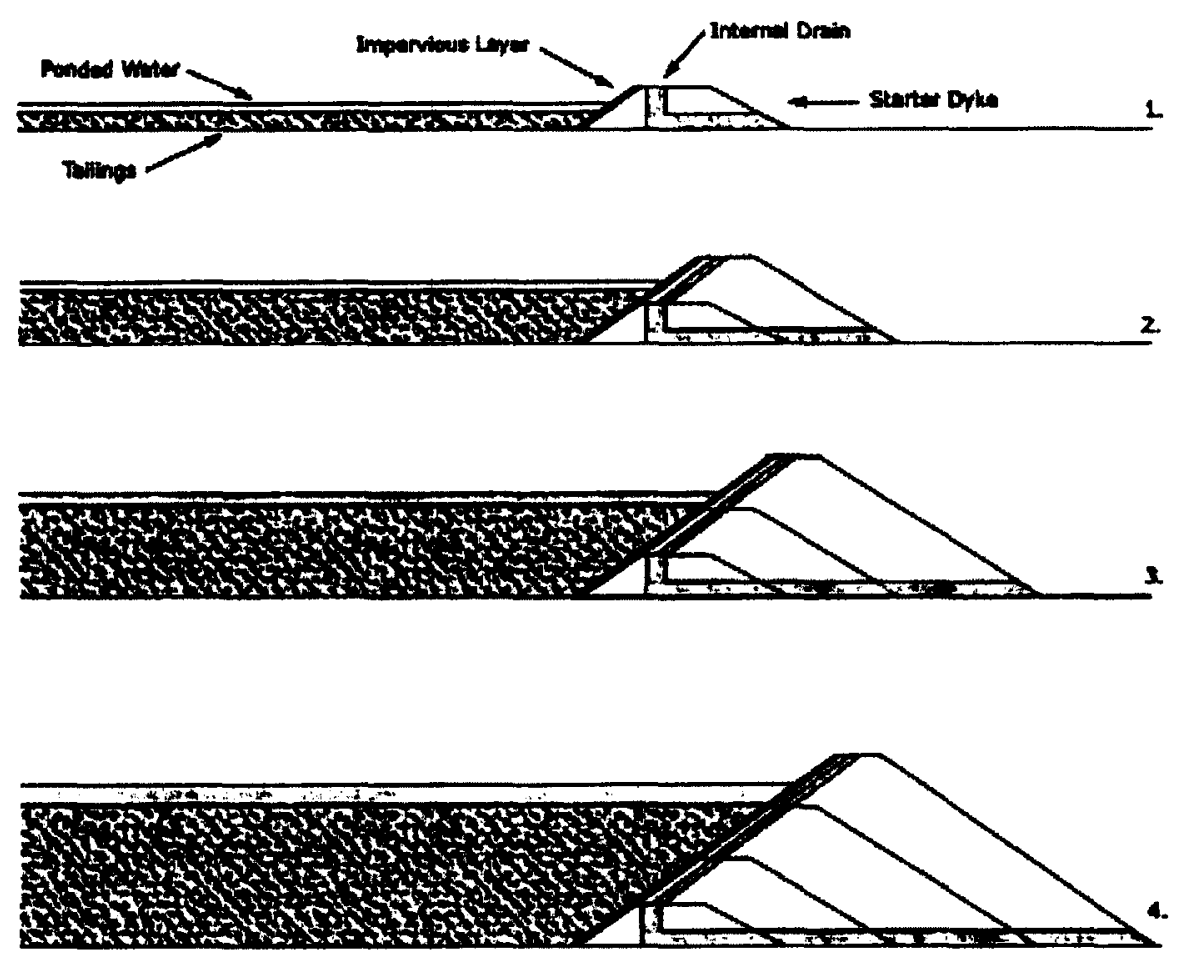

Figure 2-10: Stages of downstream method of raised embankment construction (Vick 1990)

\section{2-1-3-2-3. Centerline method}

Centerline raised embankment method is between upstream and downstream methods (Benckert and Eurenius 2001). First initial starter embankment is constructed. Once tailings reaches to crest of embankment, required material is placed on the tailings 
and the embankment. In this method the embankment raise vertically and then centerline is designed (Figure 2-11). Cost of construction is more than upstream and less than downstream dams and risk of failure due to seismic potential should be between two others methods. This method is not recommended for permanent storage of large volume of water when depth is height.
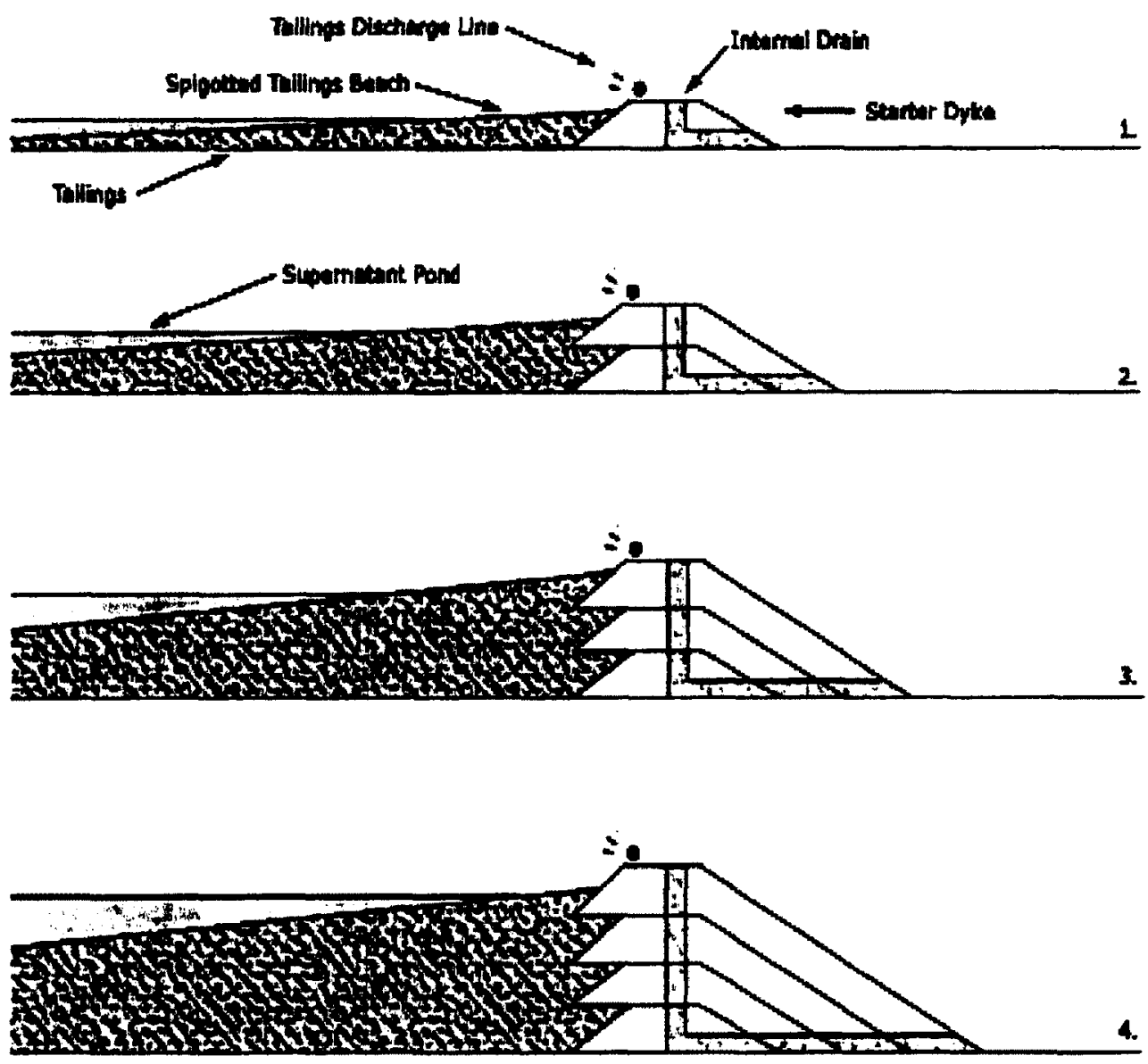

Figure 2-11: Stages of centerline method of raised embankment construction (Vick 1990) 


\section{2-1-4. Thickened tailings disposal}

Thickened tailings are created by some mechanical process of dewatering to lower the solids concentration of the slurry (Fourie 2003), which generally reaches more than $50 \%$ solids (Robinsky et al.1991). This can be achieved by using compression thickeners or a combination of thickener and filter presses. Thickened tailings are defined as homogeneous non-segregated mass after deposition (Welch 2003). No segregation results in minimal variation in moisture retention and hydraulic conductivity. Thickened tailings will flow without grain-size segregation, because of high viscosity, and eventually stops at low slope which is around $2 \%$ to $6 \%$, or $1.1^{\circ}$ to $3.4^{\circ}$ (Robinsky et al. 1991). There are some advantages of thickened tailing disposal versus conventional storage:

1. Reduces environmental problem of seepage.

2. Less capital cost by eliminating of minimizing the size of the starter dam.

3. Reduces water pumping cost to and from processing plant.

4. Little or no solid/liquid separation after deposition results in less oxygen ingress which will reduce oxidation and thus the generation of acid from sulphur bearing tailings (Welch 2003).

5. As no pond forms on top of the tailings, there is less driving head for seepage.

6. Increasing beach slopes versus conventional storage, because of lower solid concentration of tailings disposal results in more volume of tailings to be stored in the same surface footprint.

Because of their lower water content at deposition, these tailings have more likelihood of becoming unsaturated. Therefore, knowledge of the unsaturated properties of such tailings is important to this kind of tailings deposition. 


\section{2-2. Soil - Water characteristic curve (SWCC)}

The soil water characteristic curve is a relationship between soil matric suction and soil water content or degree of saturation. The SWCC is required to understand and model unsaturated flow, as it provides the storage parameter for the fundamental unsaturated flow equation. For example:

$$
m_{v} \frac{\partial \psi}{\partial t}=k \frac{\partial^{2} \psi}{\partial x^{2}}
$$

In which $m_{\nu}$ is the slope of the SWCC. Also, the SWCC itself is often used to predict the unsaturated hydraulic conductivity function (Leong and Rahardjo 1997).

Fundamentally, the soil-water characteristic is a function of the size and distribution of pores. This can be understood using the Laplace equation, that relates suction required to drain an individual ideal pore to the size of the pore:

$$
\left(u_{a}-u_{w}\right)=\left(2 T_{s} \cos \alpha\right) / r
$$

The pore-size distribution is a function of both the grain-size distribution of the soil, and the various factors that control the degree of aggregation and morphology of finer particles, which might include stress history, desiccation-rewetting history, and porewater chemistry.

\section{2-2-1- Soil suction}

Soil suction is a state of soil water that is caused by competition between forces retaining water in soils (adsorption of water to hydrophilic surfaces, cohesion between water molecules, and attraction of water to dissolved ions), and forces that remove water (evaporation, drainage). Total suction is equivalent the free energy of the liquid water 
(Fredlund and Rahardjo 1993). Total suction $(\psi)$ is contributed to by two major components: matric suction $\left(\mathrm{u}_{\mathrm{a}}-\mathrm{u}_{\mathrm{w}}\right)$ and osmotic suction (ח).

$$
\boldsymbol{\Psi}=\left(\mathbf{u}_{\mathbf{a}}-\mathbf{u}_{\mathbf{w}}\right)+\boldsymbol{n}
$$

Matric suction is equal to: pore air pressure - pore water pressure in soil. Matric suction changes with degree of saturation or moisture content in soil. It can be theoretically related to the largest saturated pores using the Laplace equation as per Figure 2-12.

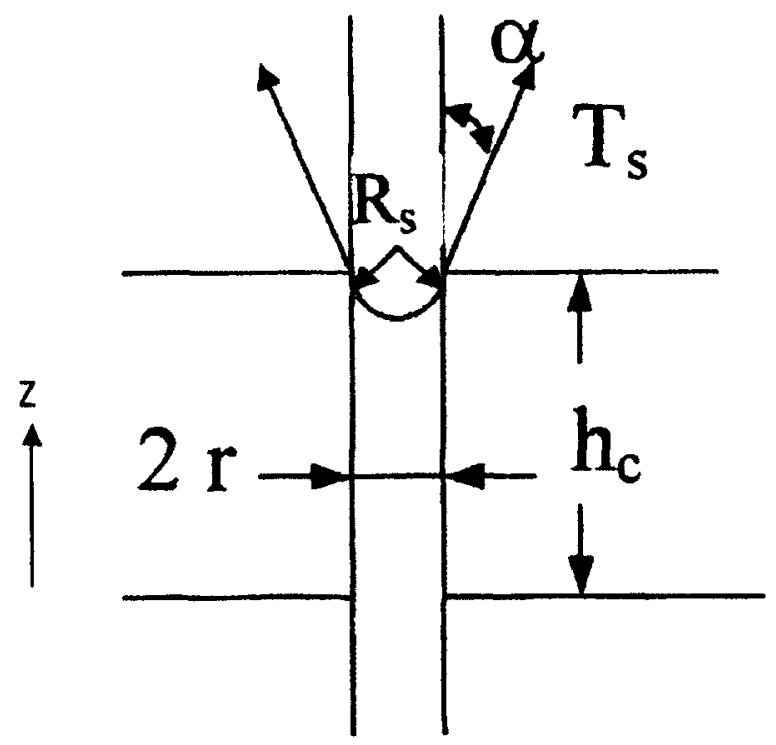

Figure 2-12: Surface tension and capillary rise in pore water

Based on Figure 2-15, the Laplace equation can be derived from force equilibrium.

$\sum F_{z}=0$ :

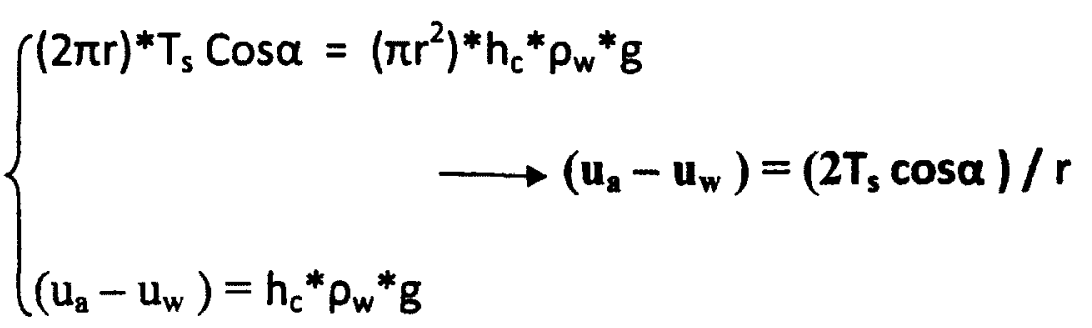


Where, $h_{c}$ is the height of capillary rise, $r$ is the pore radius, $\rho_{w}$ is the water density, $\alpha$ is the contact angle

Osmotic suction is related to the dissolved ion content in pore water. With increasing concentration osmotic suction will be increased (Fredlund and Rahardio 1993) and then total suction will be increased. Figure 2-13 illustrates how osmotic suction induces a pressure difference across a semi-permeable membrane.

Since the membrane is permeable to water, because of different ionic concentration, water flows from right hand side move to left hand side to equalize the concentration and at equilibrium, the hydrostatic pressure difference $(\mathrm{H})$ is equal to the osmotic pressure (Tindall, and Kunkel 1999).

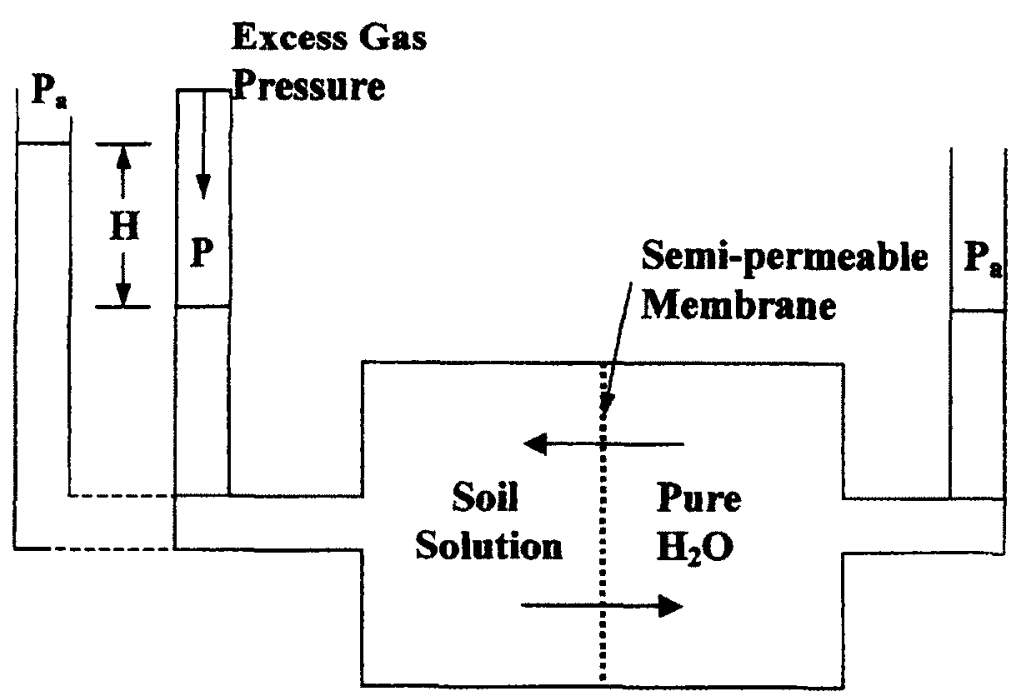

Figure 2-13: Osmotic suction in terms of pressure difference across a semi-permeable membrane

Relative humidity $(\mathrm{RH})$ of pore-air is a function of total suction at equilibrium (Fredlund and Rahardjo 1993). The equation is derived from the Kelvin equation, considering also the influence of dissolved ions. 


$$
R H=\frac{V P}{V P_{\text {sat }}}=e^{-\frac{\psi w}{R T}}
$$

Where:

$V P$ is the actual vapour pressure, $V P_{\text {sat }}=$ saturated vapour pressure, $w$ is the molecular weight of water $(\mathrm{kg} / \mathrm{mol}), R$ is the universal gas constant, and $T$ is the temperature (k).

As Figure 2-14 shows there is inverse relationship between suction and $\mathrm{RH}$ which with increasing Soil suction, $\mathrm{RH}$ exponentially decreases.

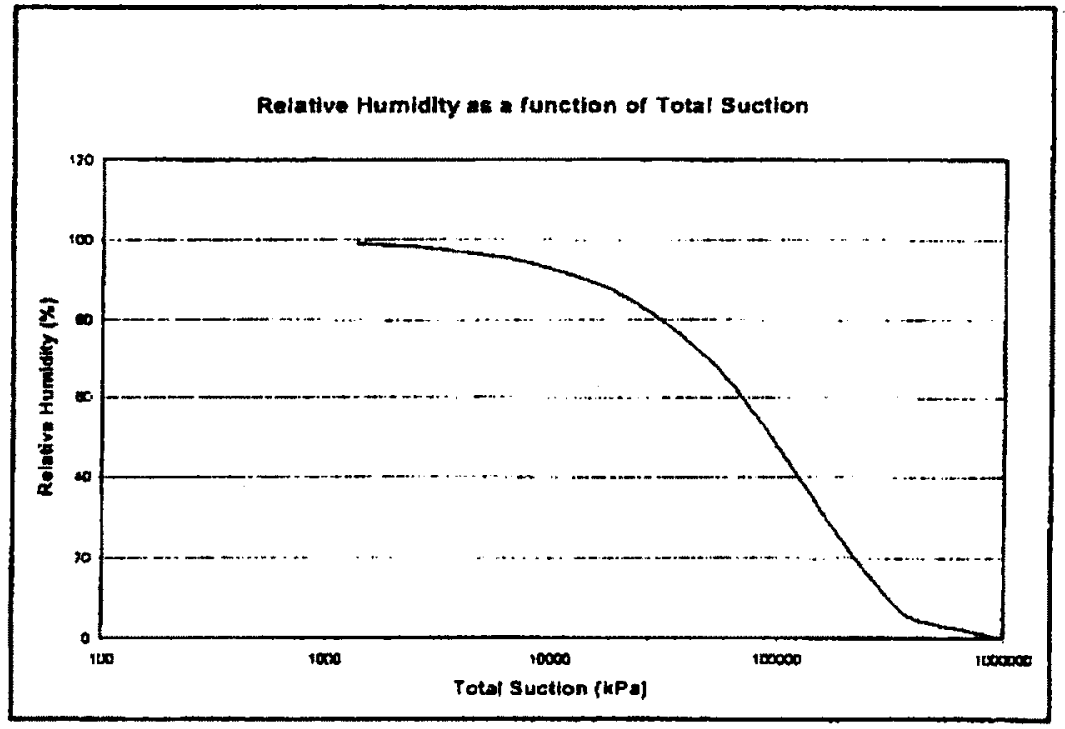

Figure 2-14: Relationship between Soil suction and relative humidity,

(modified from Gibbs, 1873)

\section{2-2-2- Definition of Soil water characteristic curve}

Soil - Water characteristic curve relates the volume or mass fraction of water retained in a soil to matric suction. This is an important relationship for unsaturated / saturated soil mechanics and many of soil properties can be obtained from SWCC such as:

- Shear strength of unsaturated soils (Fredlund 1994)

- Relative permeability (Leong and Rahardjo 1997) 
- Thermal conductivity

Figure 2-15 shows a typical soil-water characteristic curve. As seen there are three stages during desaturation which are capillary saturation zone, desaturation zone and residual saturation zone. At matric suction/soil suction less than air entry value (AEV) there is no desaturation (capillary saturation zone), though soil may change in volume and correspondingly change in water content. With increasing suction past the AEV, desaturation starts and degree of saturation decrease rapidly related to the suction(desaturation zone) after that with increasing in suction degree of saturation decrease very slowly(residual saturation zone) ( Sillers et al.,2001).

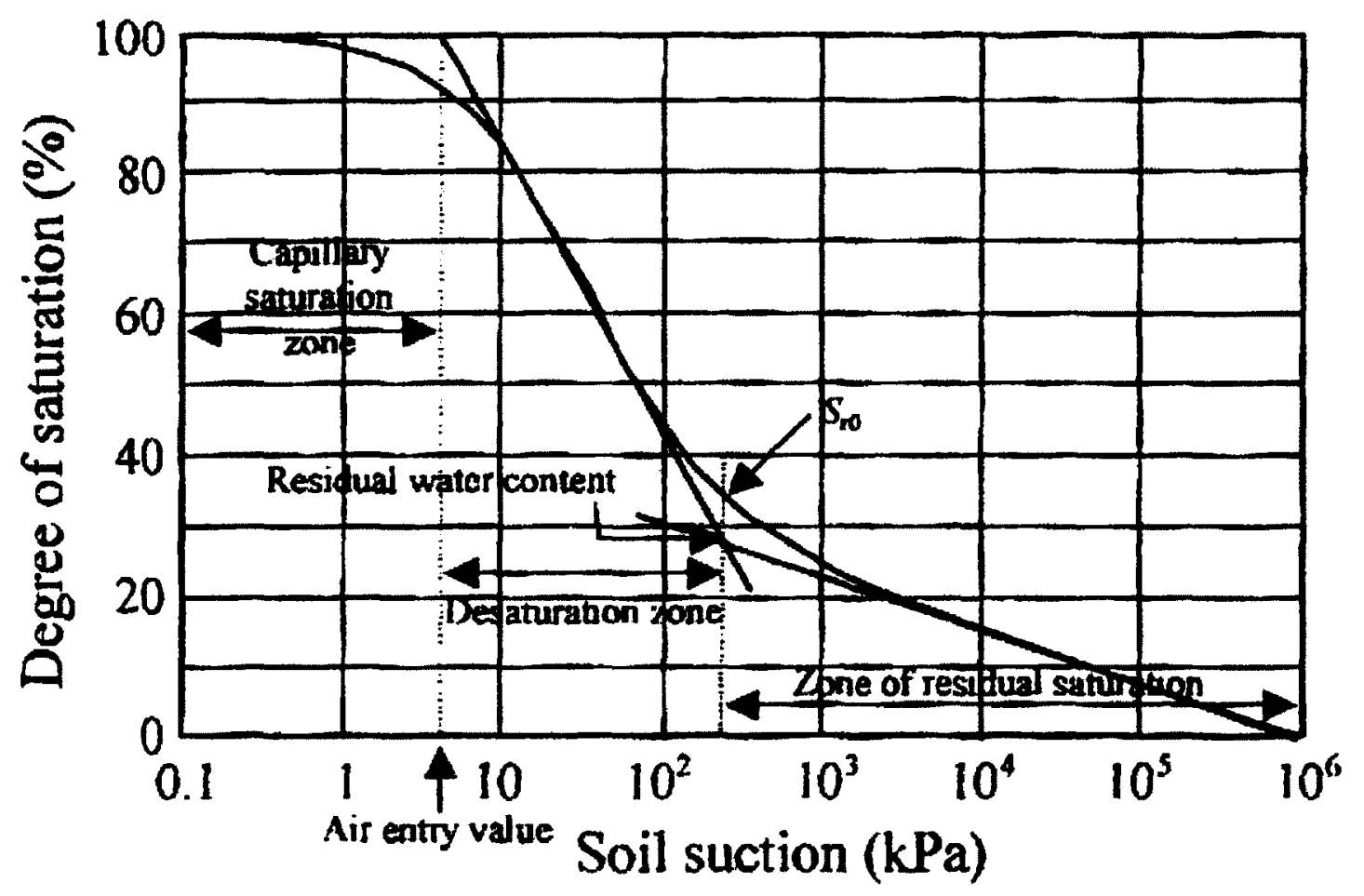

Figure 2-15: Soil - Water Characteristic Curve (Sillers et al., 2001) 
Effective stress ( $\sigma-\sigma_{\mathrm{w}}$, total normal stress - pore water pressure) is a stress state variable that is used to describe the behaviour of a saturated soil and since it is independent of the soil properties it can apply to sand, silt or clay. In saturated soil, effective stress can control two parameters which are volume change process and the shear strength characteristics. In unsaturated soil, volume change analysis must consider the influence of suction on two parameters:

- The soil structure

- The water phase

The soil structure deformation can be represented by void ratio changes or porosity changes and the water phase deformation can be represented by water content changes as well.

The relationship between void ratio and water content can be seen in the shrinkage curve. Figure 2-16 shows shrinkage curve for London clay. Using the SWCC and shrinkage curve, as a result the void ratio versus matric suction relationship can be constructed. 


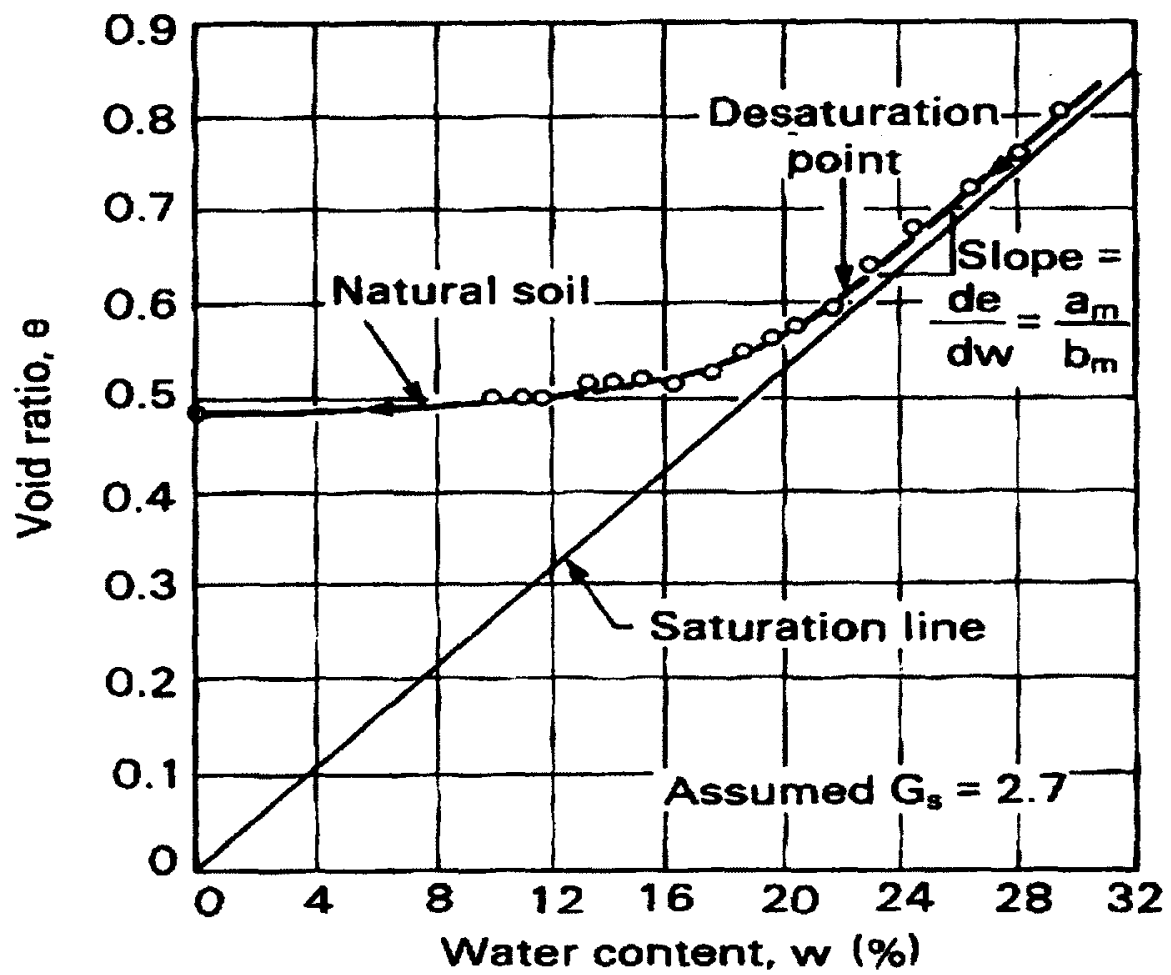

Figure 2-16: Shrinkage curve for London clay (from Croney and Coleman 1954)

\section{2-2 - 3. Saturated and unsaturated soil}

Saturated soil mechanics principles can be applied to soil with more than $85 \%$ degree of saturation so soil with less than about $85 \%$ degree of saturation is considered for unsaturated soil mechanic principles applications. In other words, at matric suction less than air entry value of the soil, soil is in near to saturation condition and behaves as saturated soil (Fredlund, and Rahardjo 1987).

\section{2- 2 - 4. SWCC and affecting parameters}

Several parameters affect the SWCC such as initial void ratio, initial water content and stress state. Each of these parameters has a different effect on the SWCC. Following is a short review of the literature on each of the above parameters. 


\section{2-2-4-1. Effect of compaction water content on SWCC}

Figure 2-17 shows the influence of compaction water content on the SWCC. Samples are sandy clay till with density of $1.80 \mathrm{~g} / \mathrm{cm}^{3}$ and specific gravity of 2.73 . As the figure shows, the compaction water content has a considerable effect on the SWCC. Higher compaction at wet of optimum results in a higher AEV. High compaction water content is related to an increase in size of the largest pores (for example, Simms and Yanful 2002). However, SWCC of the same soil but with different initial water contents tend to converge at higher matric suction values.

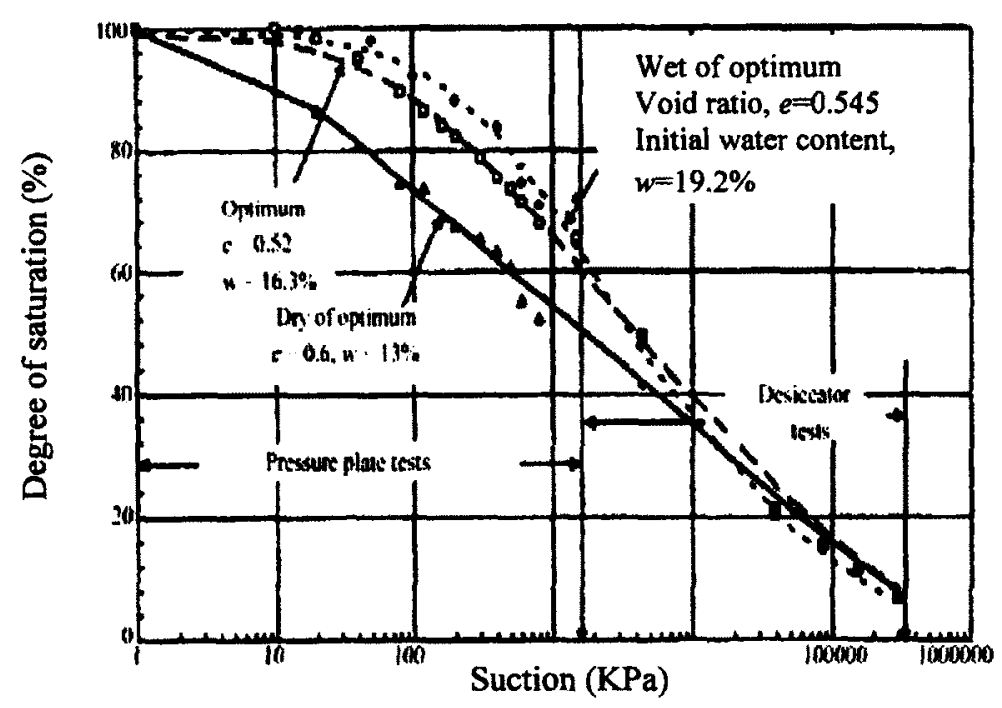

Figure 2-17: Effect of initial water content on saturation-suction curve

(Vanapalli et al. 1999)

\section{2-2 - 4-2. Effect of void ratio on SWCC}

Kawai et al (2000) investigated influence of initial void ratio on the SWCC of a moderately plastic silty clay soil with following properties (Table 2-2): 
Table 2-2: properties of silty clay soil

\begin{tabular}{|l|c|}
\hline Specific density $\left(\mathrm{G}_{\mathrm{S}}\right)$ & 2.7 \\
\hline Optimum water content $\left(\mathrm{w}_{\mathrm{p}}\right)$ & $29.6 \%$ \\
\hline Plasticity index $\left(\mathrm{I}_{\mathrm{p}}\right)$ & 13.4 \\
\hline
\end{tabular}

He found an exponential relationship between initial void ratio and AEV (Figure 218). Low void ratio (denser soil) had higher AEVs. When void ratio increases, the AEV rapidly decrease. For high void ratio (almost more than 2), AEV slowly decreases. High AEV was also correlated to higher residual water content (Figure 2-19) so the denser soil (i.e. the smaller void ratio) displayed a higher $\mathrm{AEV}$ and lower residual water content.

For wetting, a similar relationship was found between void ratio and the water entry value (WEV). A relationship between WEV and void ratio is illustrated in Figure 2-20. As it shows this relation is similar to void ratio - AEV relationship. 


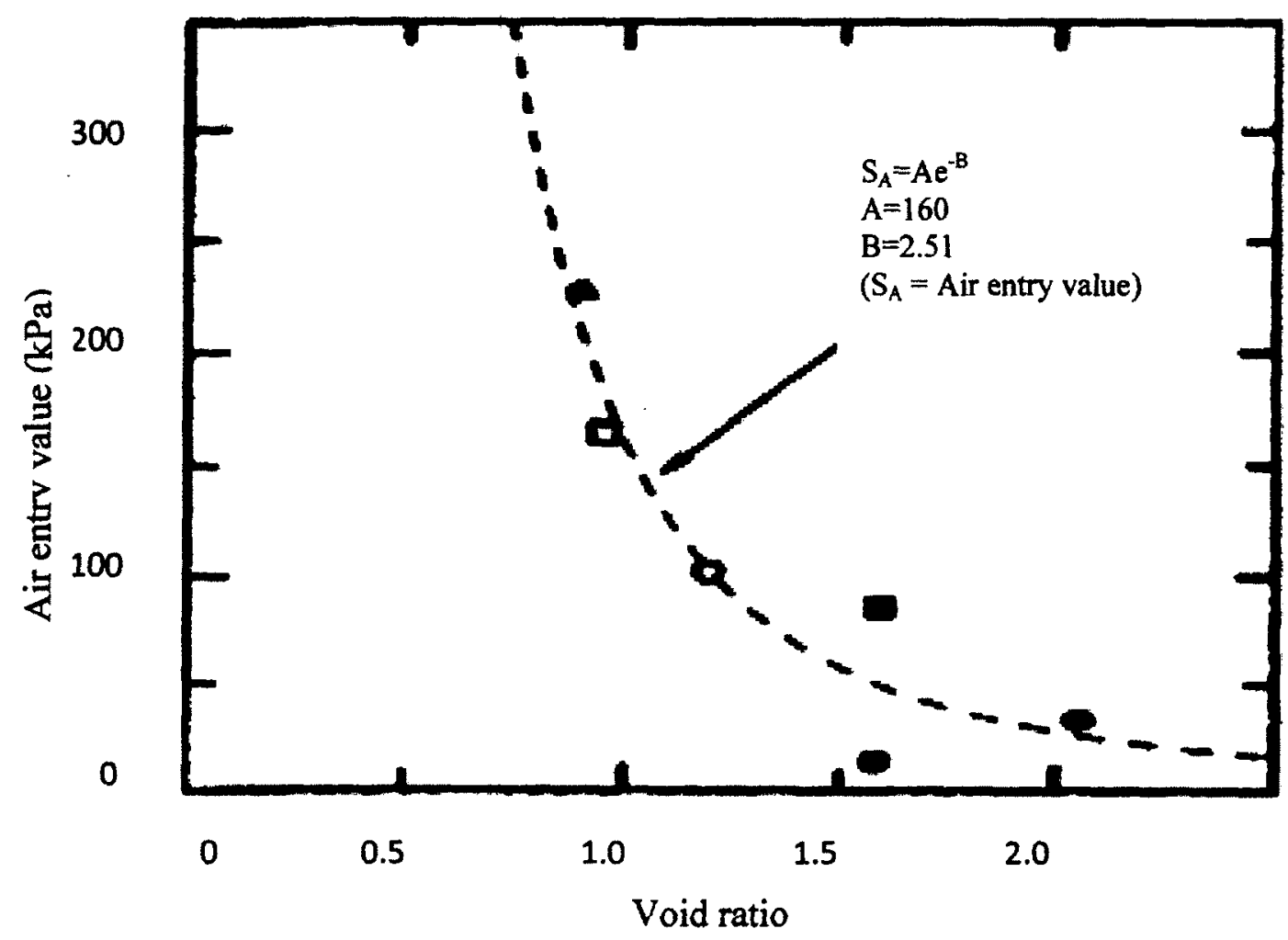

Figure 2-18: Effect of void ratio on SWCC (Kawai et al., 2000)

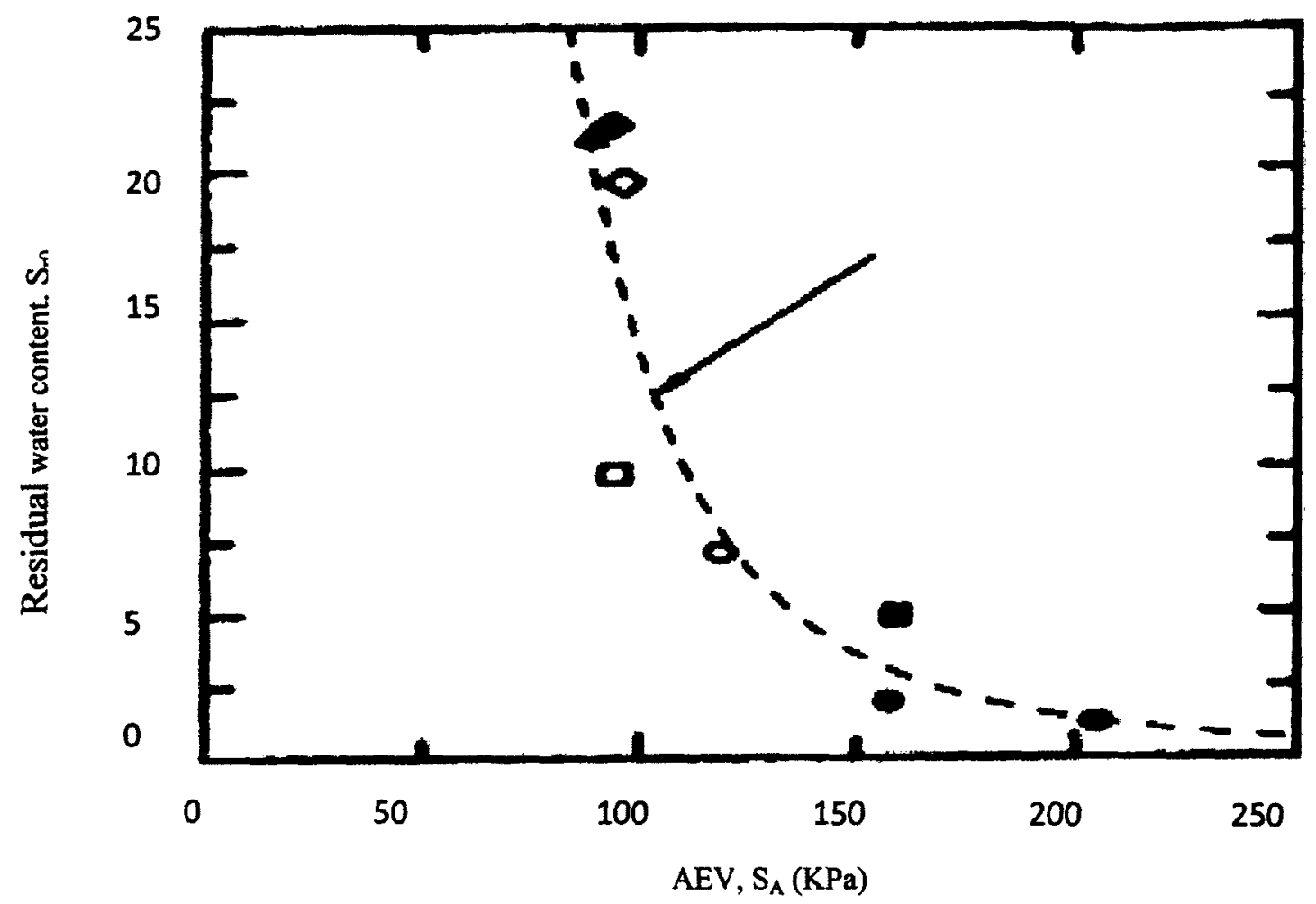

Figure 2-19: AEV versus residual water content (Kawai et al., 2000) 


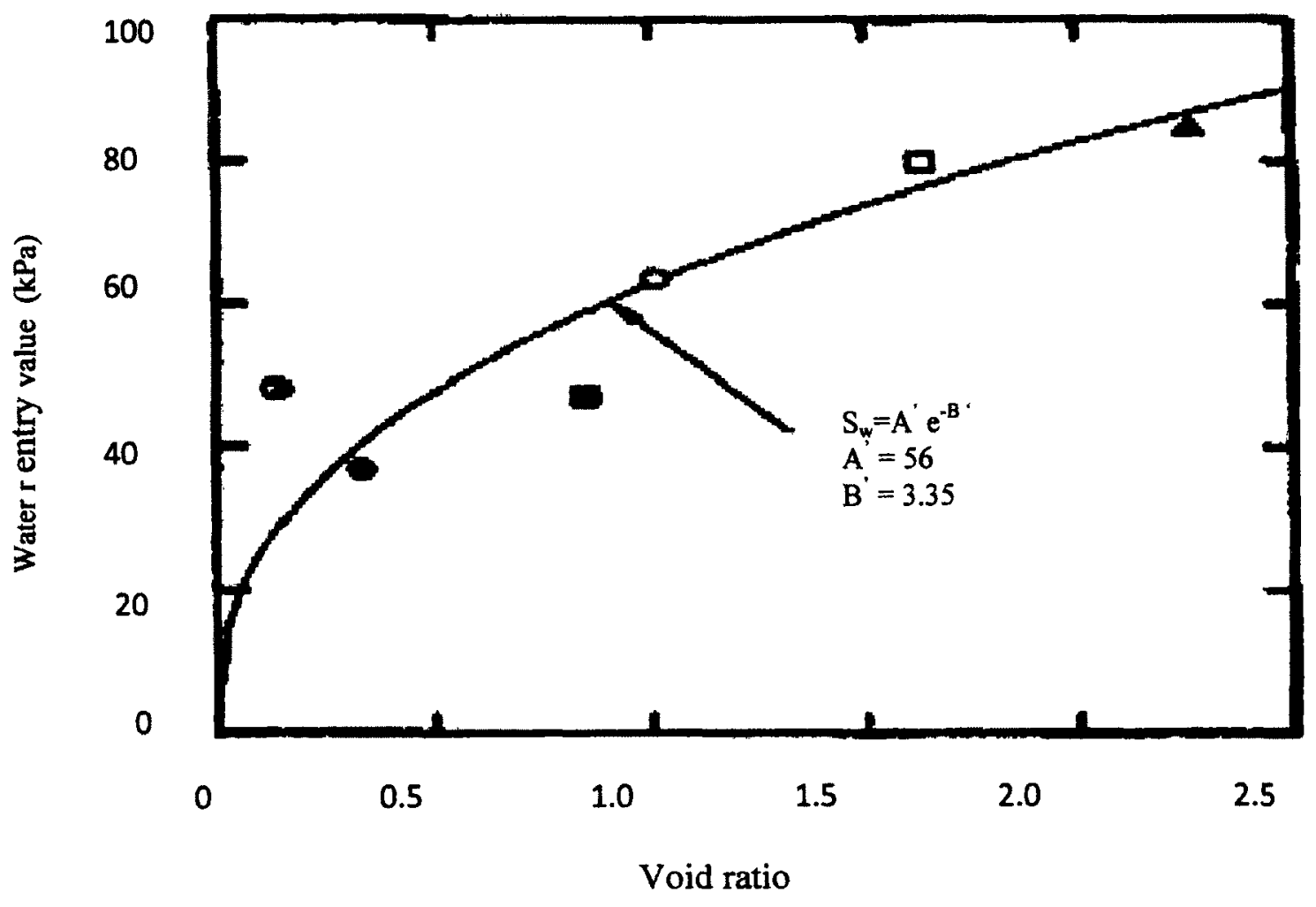

Figure 2-20: Relationship between void ratio and water entry value (Kawai et al. 2000)

\section{2-2 - 4-3. Effect of initial dry density on SWCC}

Effect of initial dry density is similar to effect of water content on SWCC. As it seen in Figure 2-21 high initial dry density (smaller pore size) has lower air entry value as low initial dry density. The rate of desaturation in soil with low initial dry density is sharper than high initial dry density. Also at matric suction less than AEV relationship between initial dry density and water content is reverse. In other words, water content in soils with low initial dry density is larger than soils with high initial dry density at matric suction beyond AEV. 


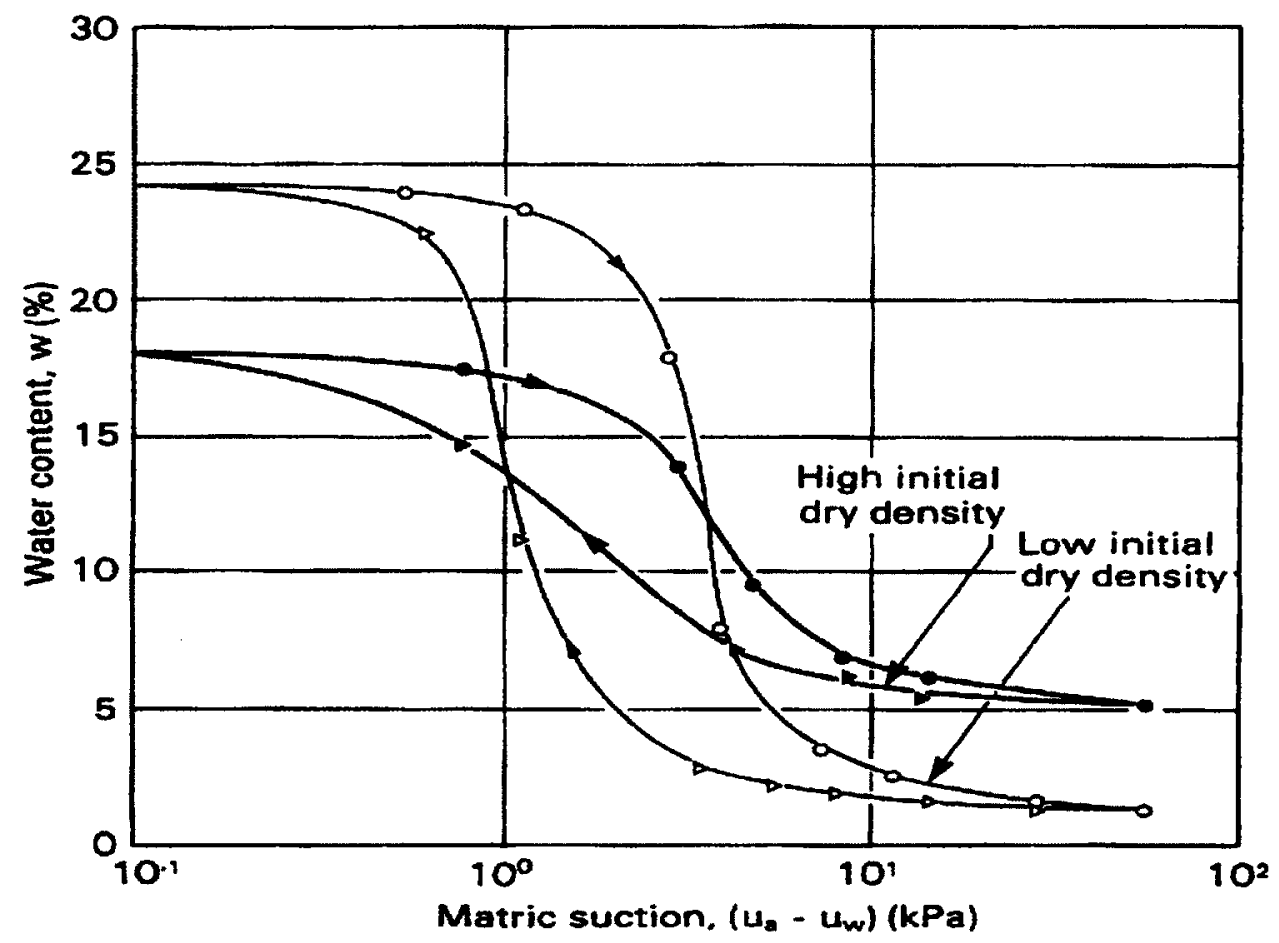

Figure 2-21: Effect of initial dry density on SWCC (Croney and Colemans, 1954)

\section{2- 2-4- 4. Effect of 1-D consolidation pressure on SWCC}

Figure 2-22 shows relationship between matric suction and volumetric water content at different stress state $(\mathrm{Ng}$ and Pang 2000). The sample was an undisturbed or natural, completely decomposed volcanic soil from Hong Kong. Three natural specimens were directly cut from the block into odometer ring. First 40 and $80 \mathrm{kPa}$ load applied on samples for 24 hours for pre-consolidation. Then suction was applied by pressure plate method. As seen specimens with higher stress (load) has lower reduction rate of volumetric water content. At which the volumetric water content starts to reduce is $\mathrm{AEV}$ point so the higher AEV related to the higher applied load. 


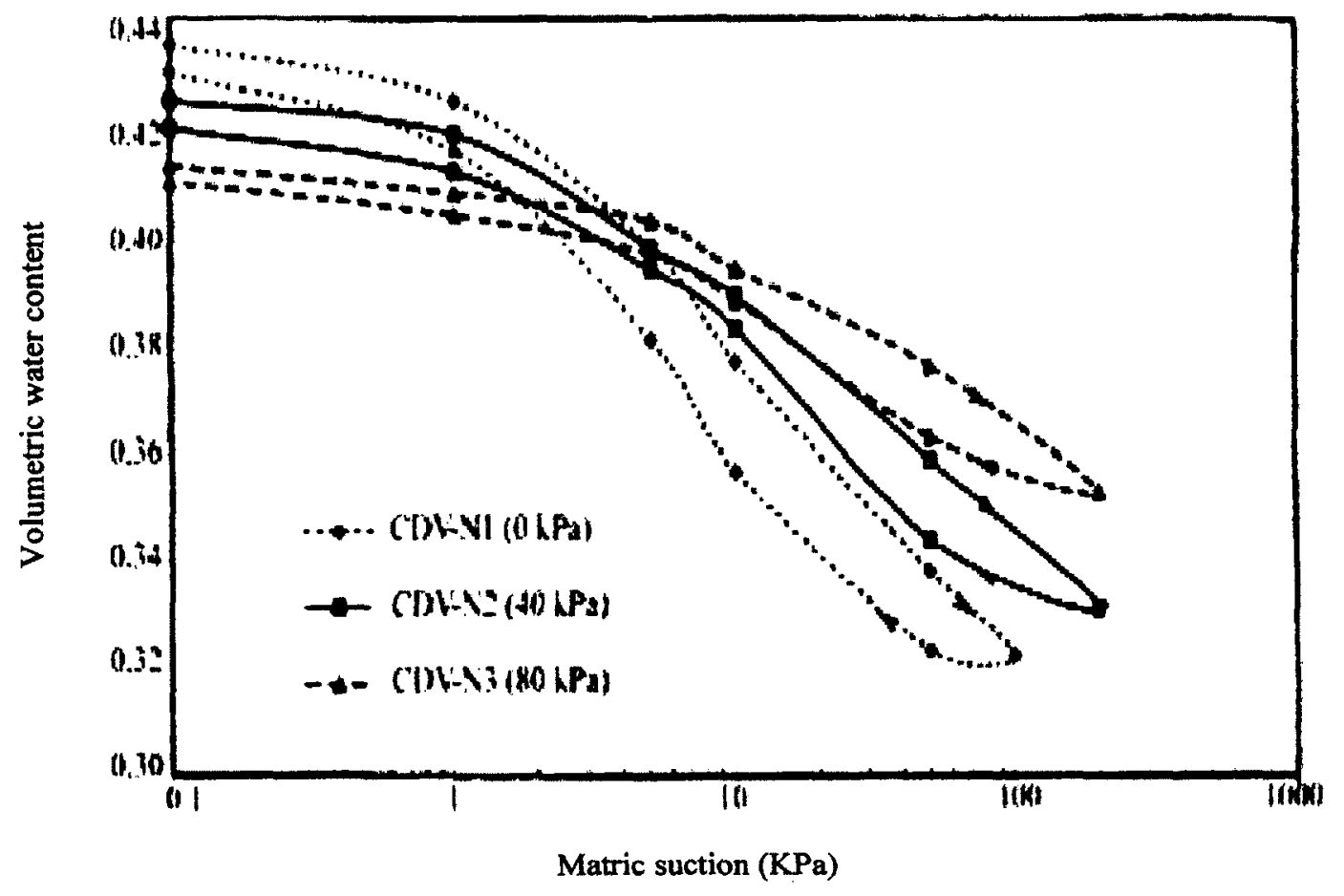

Figure 2-22: Effect of 1-D consolidation pressure on SWCC

(Ng and Pang, 2000)

To this point, changes in soil - water characteristic curve under different variable parameters has been reviewed. The goal of this thesis is to examine the dependency of the soil-water characteristic curve of two different kinds of mine tailings on initial state. Henceforth, the term TWCC (talings-water characteristic curve) will be used to denote the SWCC for tailings. 


\section{Chapter 3:}

\section{Description of tailings disposal at the}

Bulyanhulu and Muskeg River mines 


\section{Description of tailings disposal from Bulyanhulu Mine and Muskeg River mine}

In this thesis two different kinds of tailings from two different mines have been investigated which are Bulyanhulu Gold Mine tailings and Muskeg River Oil Sand Mine tailings. Following is a brief description of each mine.

\section{3-1. The Bulyanhulu Gold Mine}

The Bulyanhulu area of Kahama District in central-western Tanzania, East Africa is located approximately 850 kilometres northwest of Dar es Salaam, Tanzania's capital, and about $45 \mathrm{~km}$ south of Lake Victoria. It is the site of the Bulyanhulu Gold Mine, which started production in April 2001. Bulyanhulu is one of the largest and richest gold mines in the world. The Bulyanhulu Mine is located in northwest Tanzania, approximately 150 kilometres from the city of Mwanza. The mine is an underground mine with methods of long hole and drift-and-fill. Ore reserves are reached by a surface shaft and an internal ramp system (Frostiak, 2003)

\section{3-1-1. Mineralogy}

Sulphide mineralization includes mostly pyrite and chalcopyrite, with some minor amounts of sphalerite, galena, and pyrrhotite. There is gold with fine particle size, $<10$ micron, which is locked in pyrite-pyrite or pyrite-chalcopyrite grain boundaries. Host rocks consist of argillite, carbonaceous schist, limestone, volcanic and black siliceous rock (Frostiak, 2003).

\section{3-1-2. Mineral processing}

Processing plant consists of operations for crushing, grinding, conventional gravity, sulphide flotation, carbon in leach, cyanide destruction, filtration for dewatering, and 
paste backfill generation. Figure 3-1 shows a part of processing plant in Bulyanhulu Gold mine.

The processing plant produces copper-gold concentrate. Copper Concentrate is at 14 $18 \% \mathrm{Cu}$, and includes high grade gold $(200 \mathrm{~g} / \mathrm{t} \mathrm{Au})$ and silver $(180 \mathrm{~g} / \mathrm{t} \mathrm{Ag})$.

\section{3-1-3. Tailings System}

Almost $25 \%$ of tailings produced are transferred to the underground void spaces as a backfill (Theriault et al, 2003) and the rest are pumped as paste to the surface tailings impoundment area. In the gold mining industry this system is the first paste tailings system for hard rock mining (Frostiak 2003). "Paste" is taken to mean highly thickened tailings, of a high enough pulp density to allow for pumping as a non-seggregating mixture in the laminar range.

The paste tailings are discharged from towers and deposited in thin layers (almost 30 $\mathrm{cm}$.). Thin layers let tailings near surface desiccate to gain strength, and to allow a larger to stop flows. Figures 3-2 to 3-5 shows the tailings deposition system. The SWCC is of interest, as it controls the desiccation behaviour and therefore influences post-deposition dewatering.

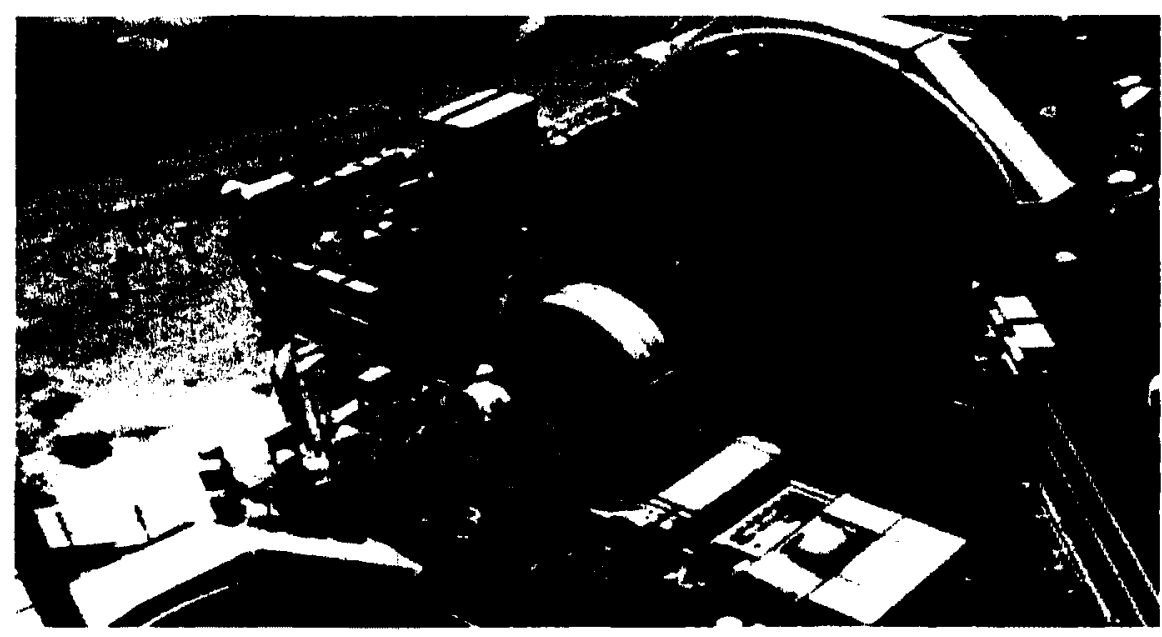

Figure 3-1: A part of processing plant in Bulyanhulu Gold mine.

(African Barrick Gold 2010) 


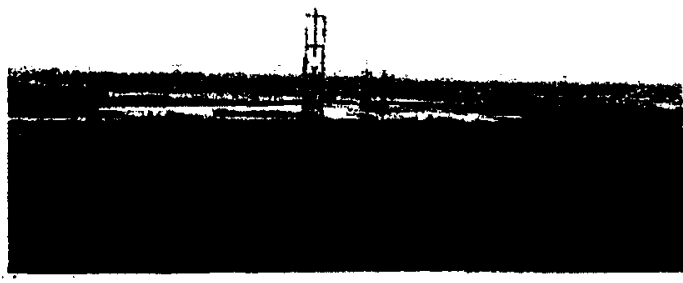

Figure 3-2: Early paste deposition

(Theriault et al. 2003)

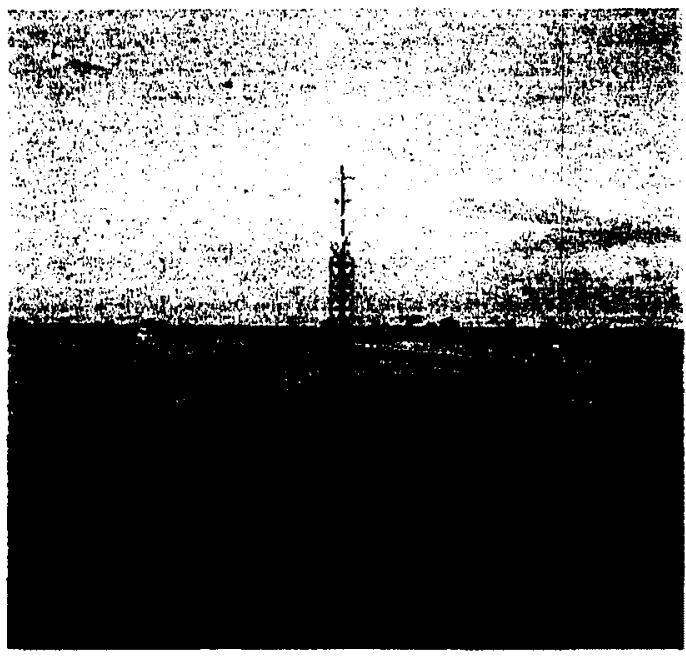

Figure 3-4: Progressive paste deposition

forming a cone around a deposition tower,

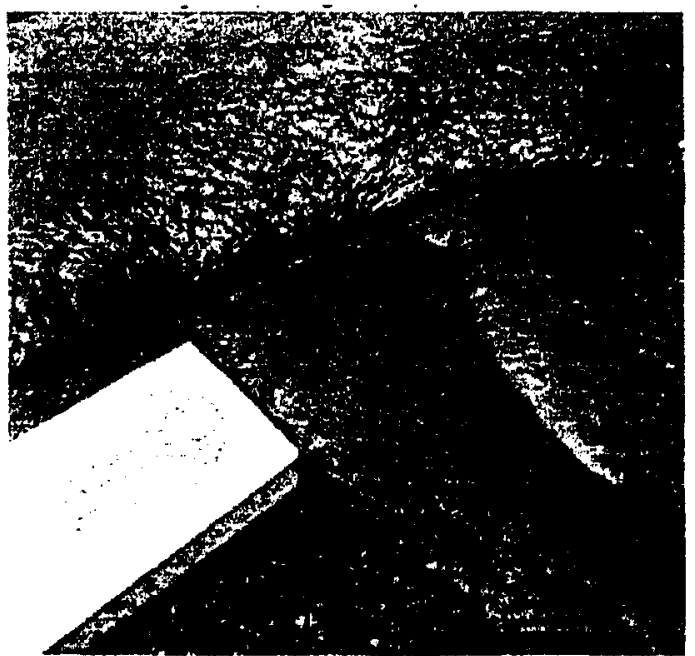

Figure 3-3: Three thin layers of paste Tailings (Theriault et al.2003)

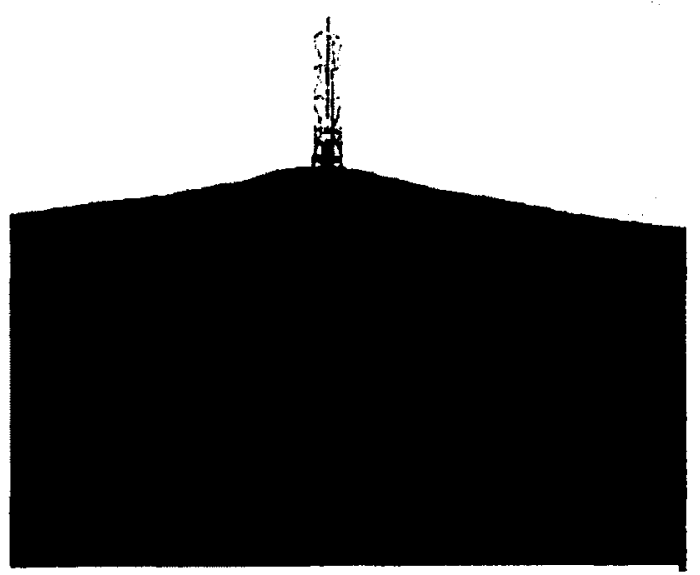

Figure 3-5: Early paste tailings flow

(Theriault et al. 2003)

(Theriault et al. 2003) 


\section{3-2. Muskeg River Mine}

The Muskeg River Mine is an oil sand mine that sits on shell's Lease 13 with more than five billion barrels of mineable bitumen ,extremely heavy crude oil, which belongs to Athabasca oil sands.

The Athabasca oil sands are large deposits of bitumen in north-eastern Alberta with 1.7 trillion barrels $\left(270 \times 10^{9} \mathrm{~m} 3\right)$ of bitumen and it is the largest reservoir in the world, (Figure 3-6). Figure3-7 shows mining activity at the Muskeg river mine.

The Muskeg River Mine is located in $75 \mathrm{~km}$ north of Fort McMurray in Alberta and $493 \mathrm{~km}$ northeast of Edmonton. The mine is located between Athabasca River in west and the Muskeg River in east. Capacity of this mine has designed for 155,000 barrels per day (bpd) of bitumen. In oil sands mining, oil sand ore consists of mixture of :

- Crud bitumen which is a semi-solid form of crude oil

- Silica sand

- Clay mineral

- Water

The Muskeg river mine has high oil concentration relatively close to the surface, so it is very suitable to be operated by surface mining methods. Mining operation is done by truck, shovel and semi-mobile crushers. The oil sand after extraction is mixed with warm water to separate oil and sand then bitumen is diluted and piped to Scotford for upgrading, Figure 3-8. To produce one barrel of oil approximately two tonnes of oil sands must be excavated and processed. The recovery rate of bitumen from sand is around $75 \%$. 


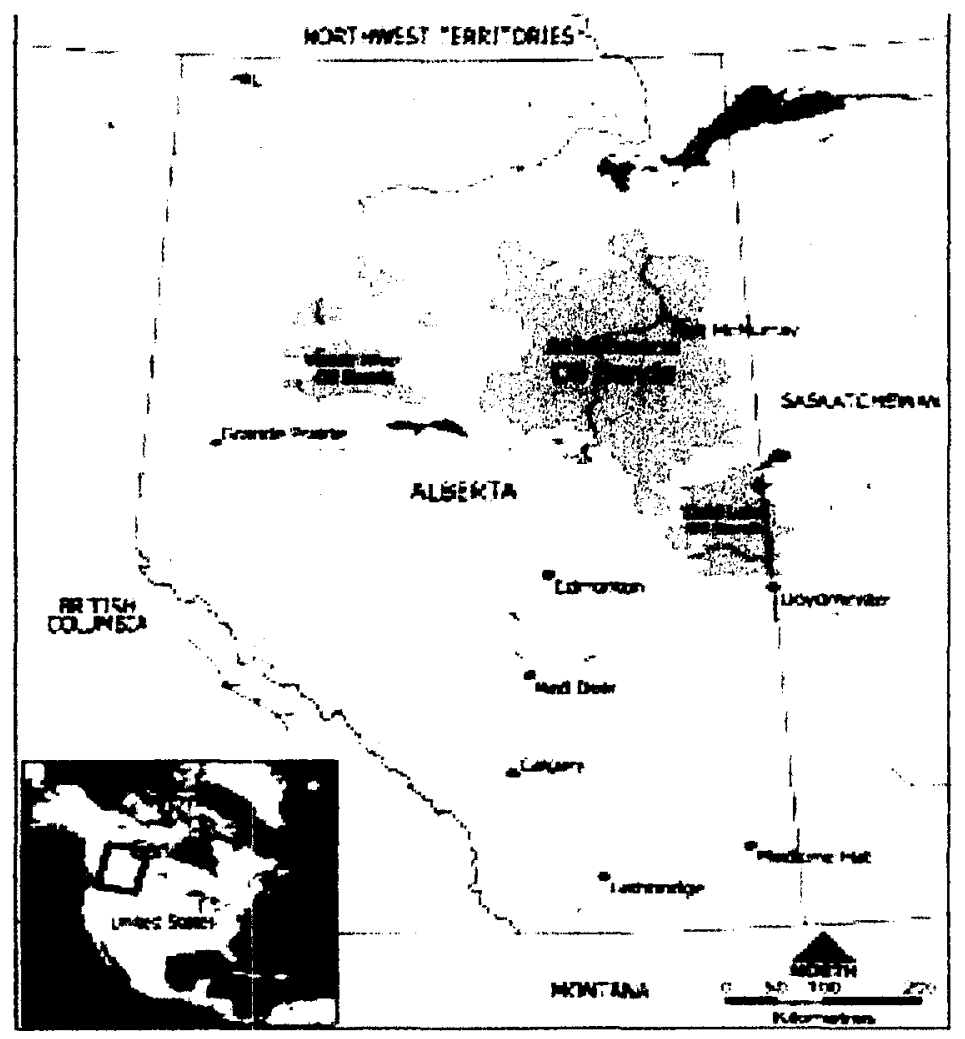

Figure 3- 6: Athabasca Oil Sand map (Athabasca Oil sand Corp.)

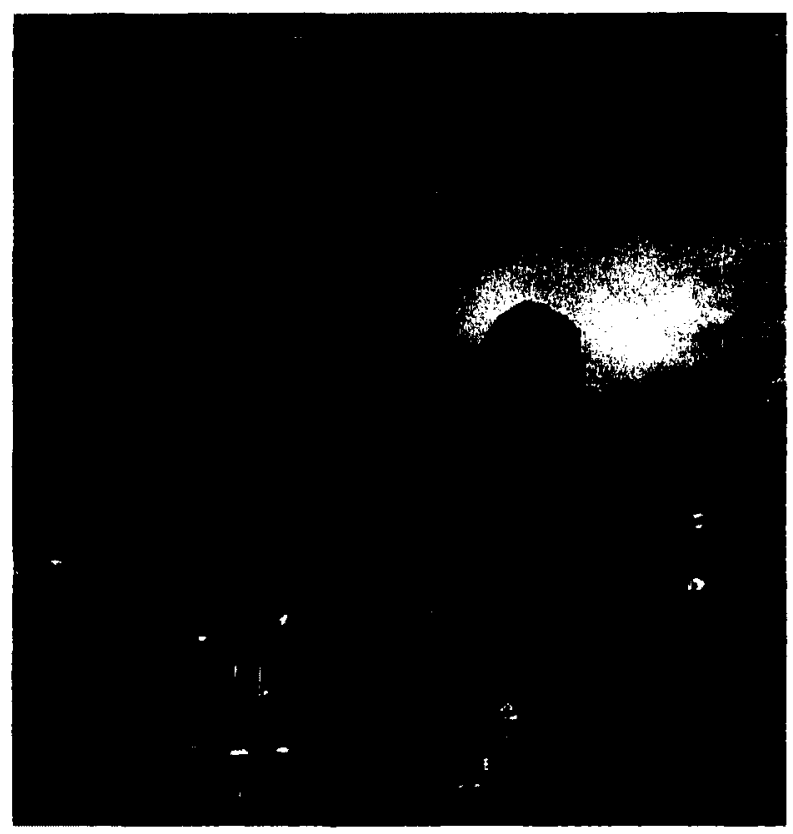

Figure 3-7: Mining operations in Oil Sand mine

(Athabasca Oil sand Corp.) 


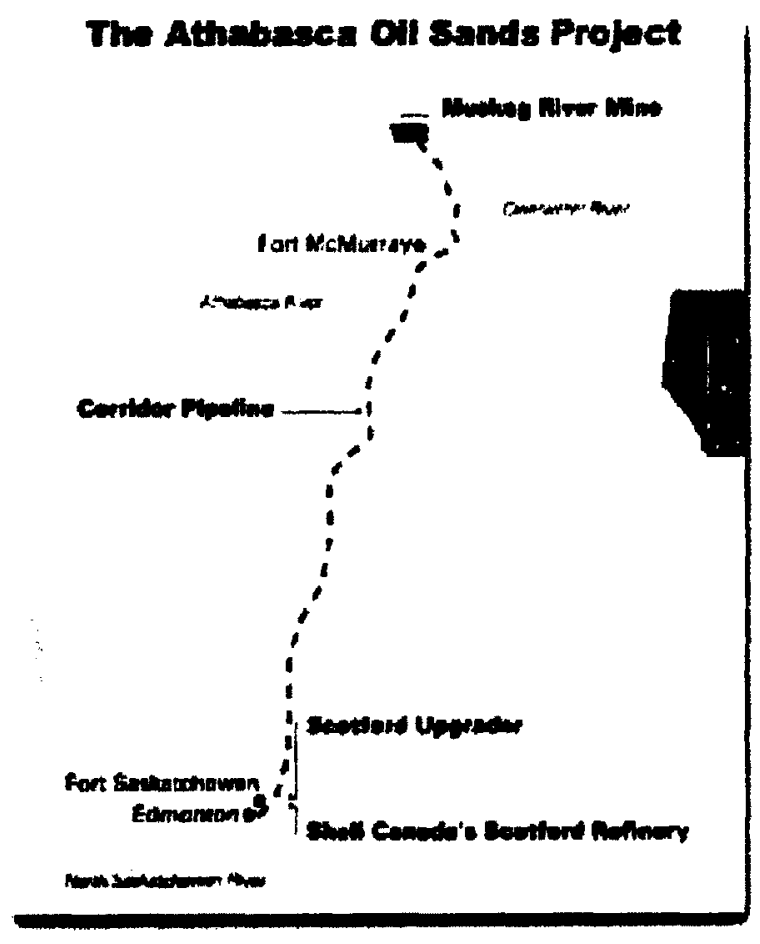

Figure 3-8: Athabasca oil sand project

(Athabasca oil sand Corp.)

\section{3-2-1. Tailings}

Figure 3-9 shows Oil Sand mining process. Tailings are hydraulically pumped to the impoundment for settling. The tailings pond is located in the south of the mine near the confluence of the Athabasca River and Muskeg River. Tailings pond is $11 \mathrm{~km}$ long by almost $200 \mathrm{~m}$ wide at the base and more than $20 \mathrm{~m}$ high.

Tailings include mix of sand, clay, fine silts, and water that contains dissolved salts and some hydrocarbons. 


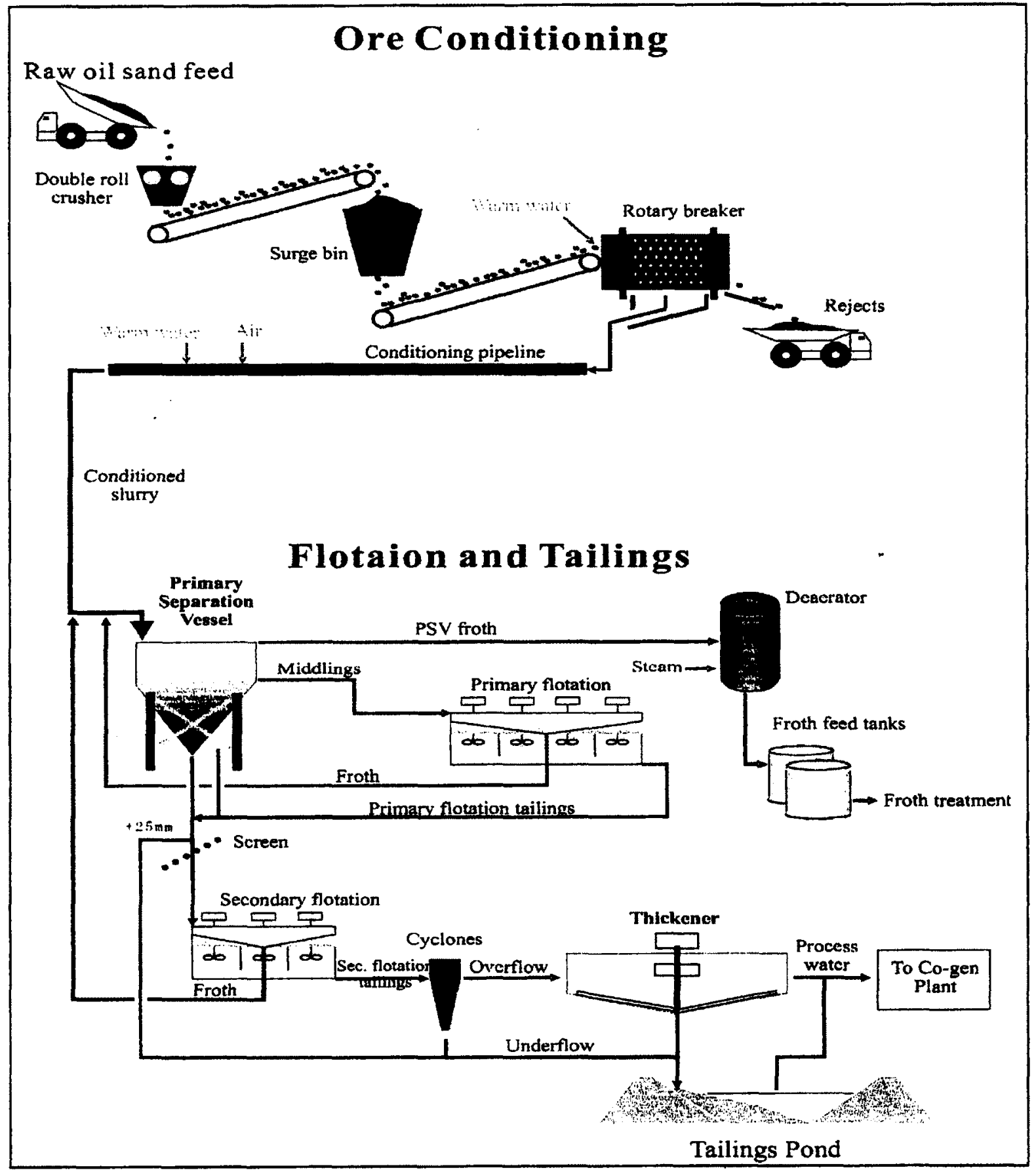

Figure 3-9: Oil sand mining process (Yasuda, 2006) 
After discharging into the pond, solids will settle and the water rises to the top is recycled and reused in mining operations. Coarse solids settle rapidly but the fine solids remain suspended in the pond. Those suspended fine solids only reach $30-40 \%$ solids concentration even after 10 years. At this point they are called mature fine tailings (MFT). MFT has no measurable strength, and does not substantially consolidate even after several decades - this is the reason that oil sands tailings ponds cannot be reclaimed (Figure 3-10).

One new method to accelerate dewatering of MFT is to treat it with a polymer, and then discharge it back into a new impoundment in thin lifts (As shown in Figure 3-11). Application of an anionic polymer results in aggregation of the fine particles, and a measure of dewatering. However, further dewatering post-deposition, either by consolidation, evaporation, or freeze-thaw, is still required for the tailings to gain sufficient strength to be trafficable, and reclaimable. Thus the influence of the polymer on the SWCC of the tailings is important, and is studied in this thesis. 


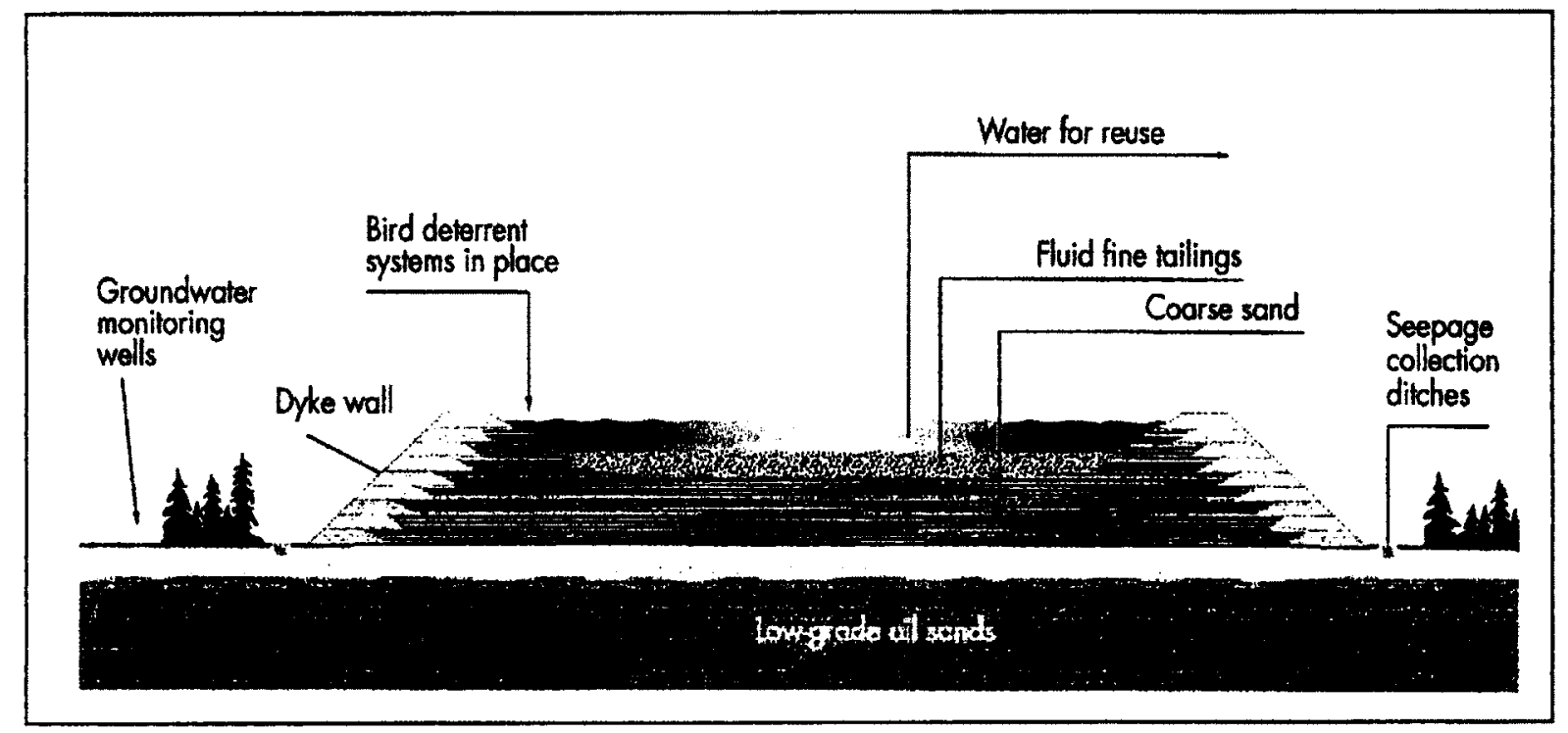

Figure 3-10: Conventional deposition of oil sands tailings deposition in Muskeg River Mine. (Shell Albian Sands)

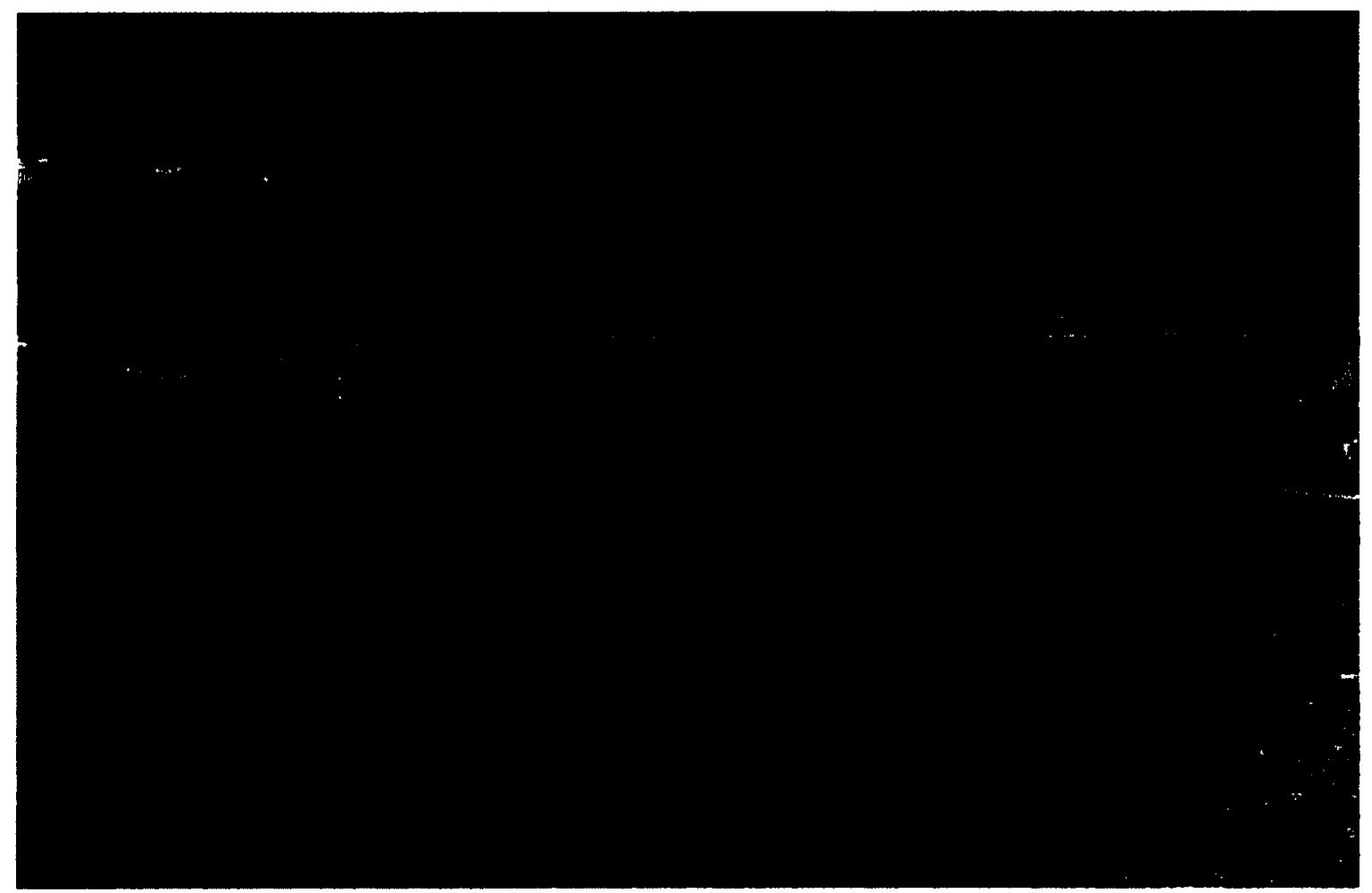

Figure 3-11: Deposition of polymer-amended MFT in thin lifts (Matthews et al. 2011). 
Chapter 4:

Materials and Methods 


\section{4-1. Materials}

Two different tailings were used: oil sand mine tailings and gold mine tailings. Some experiments were also performed using an artificial silt, in an attempt to use an ideal material of similar particle size distribution as tailings.

\section{4-1-1. Artificial silt}

The artificial silt used in this study has spherical glass micro-beads (Potter Industries Inc. LaPrairie, QC, Canada) with specific gravity of 2.48 . Other geotechnical properties are listed in Table 4-1. Figure 4-1 shows silt particle size distribution by using hydrometer method.

Table 4-1: Geotechnical properties of artificial silts.

\begin{tabular}{|l|c|c|}
\hline \multicolumn{1}{|c|}{ Property } & Unit & Amount \\
\hline Specific Gravity & - & 2.48 \\
\hline $\mathrm{D}_{10}$ & micron & 1 \\
\hline $\mathrm{D}_{50}$ & micron & 41 \\
\hline $\mathrm{D}_{60}$ & micron & 41 \\
\hline $\mathrm{Cu}\left(\mathrm{D}_{60} / \mathrm{D}_{10}\right)$ & - & 19 \\
\hline Liquid limit $\left(\mathrm{L}_{1}\right)$ & $\%$ & 13 \\
\hline Plastic limit $\left(\mathrm{P}_{1}\right)$ & $\%$ & $1.7 \times 10^{-6}$ \\
\hline $\begin{array}{l}\text { Saturated hydraulic } \\
\text { conductivity }\end{array}$ & $\mathrm{m} / \mathrm{s}$ & \\
\hline
\end{tabular}




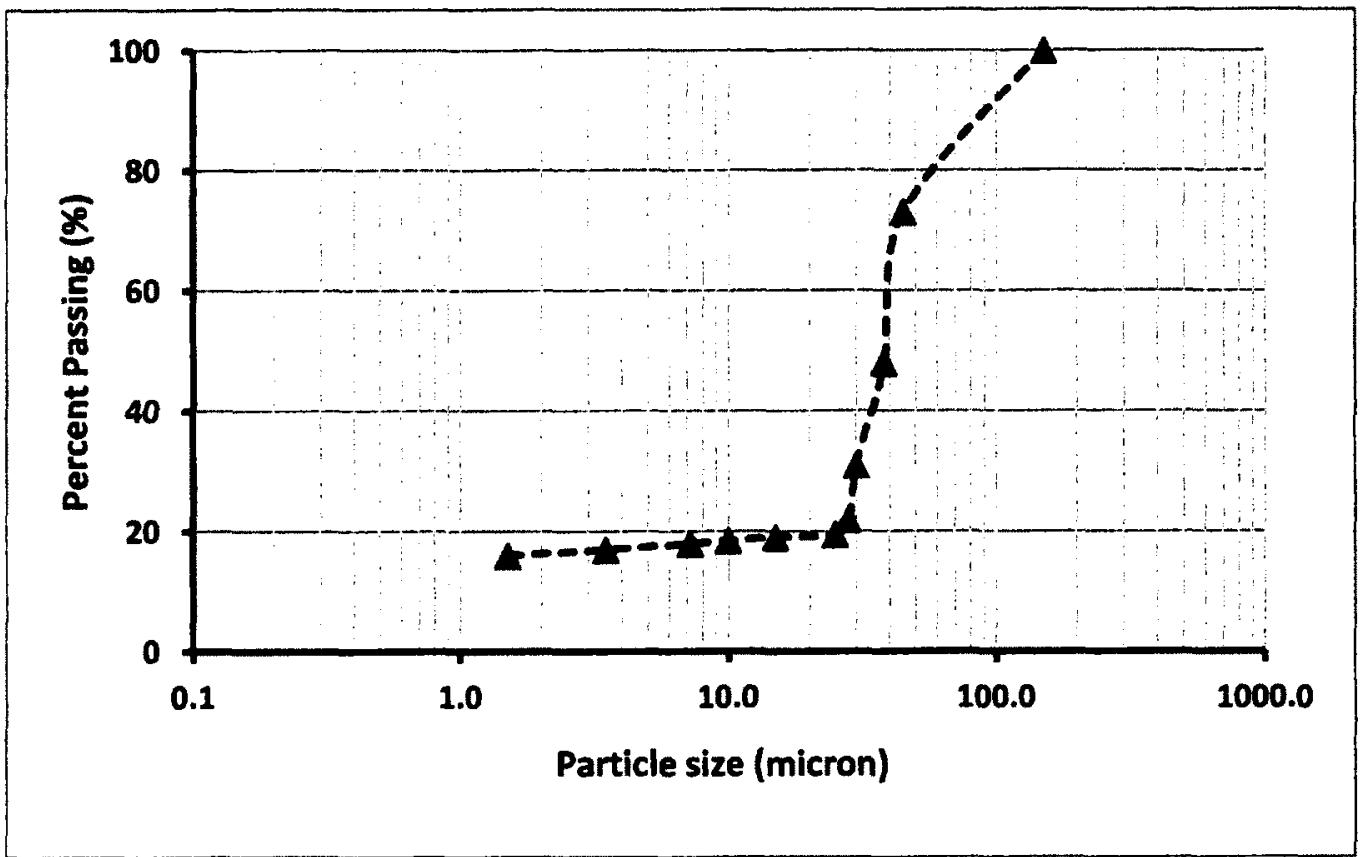

Figure 4-1: Artificial silt Particle-size distribution (PSD).

\section{4-1-2. Oil sand mine tailings}

Oil sand mine tailings include mix of sand, clay, fine silts, and water that contains dissolved salts and some hydrocarbons. Mature fine tailings (MFT) has used for experimental test. Particles size of MFT is generally less than $44 \mu \mathrm{m}$. Following are some MFT characteristics ( Matthews et al 2011):

Table 4-2: MFT characteristics ( Matthews et al 2011, Bajwa 2012)

\begin{tabular}{|l|c|}
\hline Initial solids concentration & $30 \%-35 \%$ solids \\
\hline Specific gravity & 2.55 \\
\hline Liquid limit & $70 \%$ \\
\hline Plasticity index & $37 \%$ \\
\hline $\mathrm{D}_{90}, \mathrm{D}_{60}, \mathrm{D}_{50}, \mathrm{D}_{30}$ & $40,7,4,1$ microns \\
\hline Pore - water $\mathrm{pH}$ & $8-9$ \\
\hline
\end{tabular}




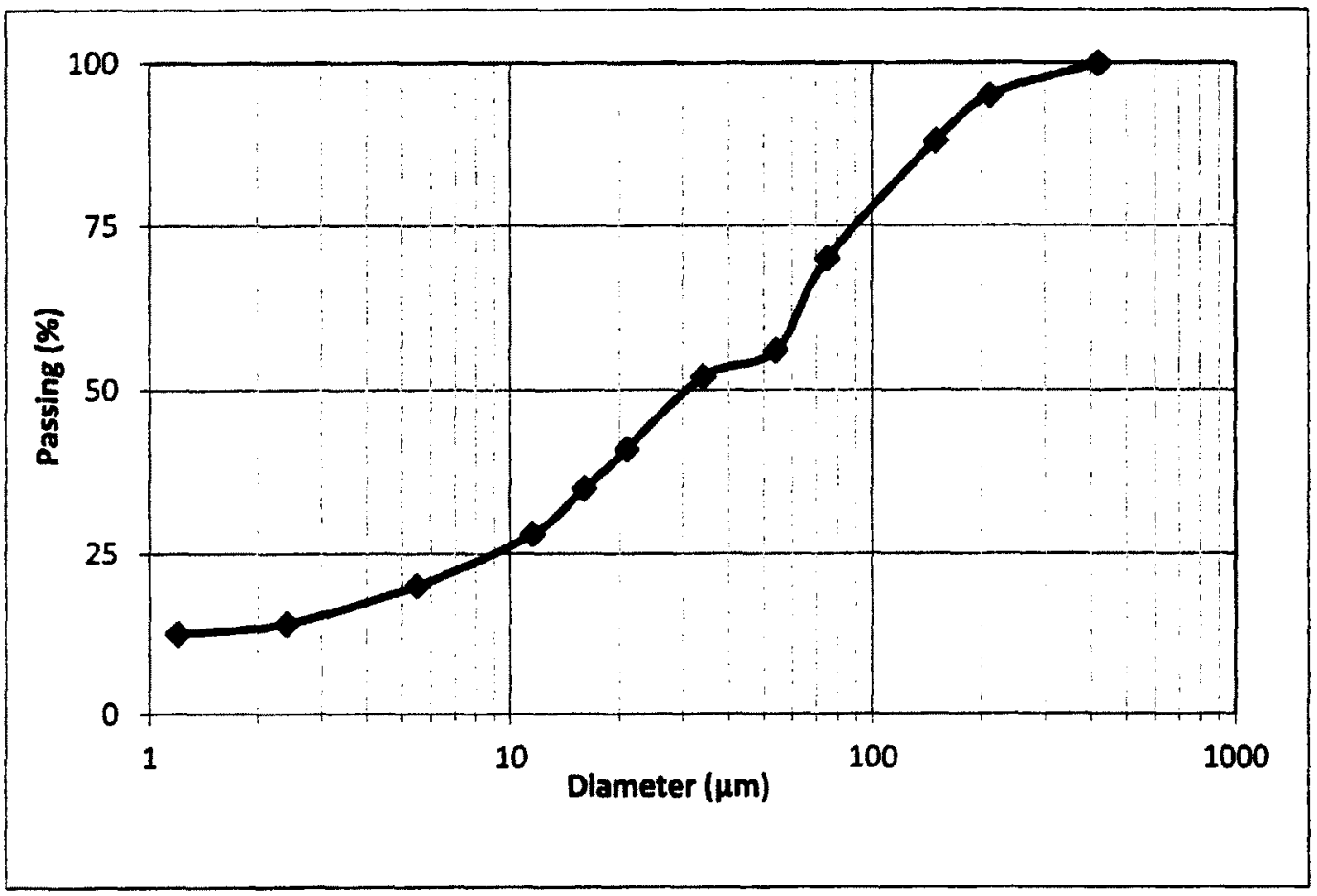

Figure 4-2: Bulyanhulu gold mine tailings particle size distribution, (Bryan 2008)

\section{4-2. Experimental methods}

These experimental methods employed in this thesis are i) Proctor Compaction test, ii) Shrinkage test, iii) Tailing (Soil) Water Characteristic test, and iv) consolidation tests using the axis-translation apparatus.

\section{4-2-1. Proctor Compaction test (ASTM D698)}

Proctor Compaction test is based on ASTM D698, to obtain maximum dry unit weight of soil at optimum water content. More information about Proctor Compaction test and its procedure was brought in the appendix. 


\section{4-2-2. .Shrinkage curve test (ASTM D4943)}

There are four states of physical and mechanical behaviour of fine grain soil:

Liquid, plastic, semisolid and solid which are related to water content. Figure 4-3 shows volume of soil versus water content. With decreasing water content, drying, soil behaviour is tending from liquid to solid.

Shrinkage limit is directly related to the water content and is just enough water to fill all the pores in soil and soil is just saturated, i.e. shrinkage limit is the maximum water content, that a reduction in water content does not cause a reduction in volume of the soil mass. (point D in Figure 4-3). Shrinkage limit test procedure which is based on ASTM D4943 was brought in the appendix.

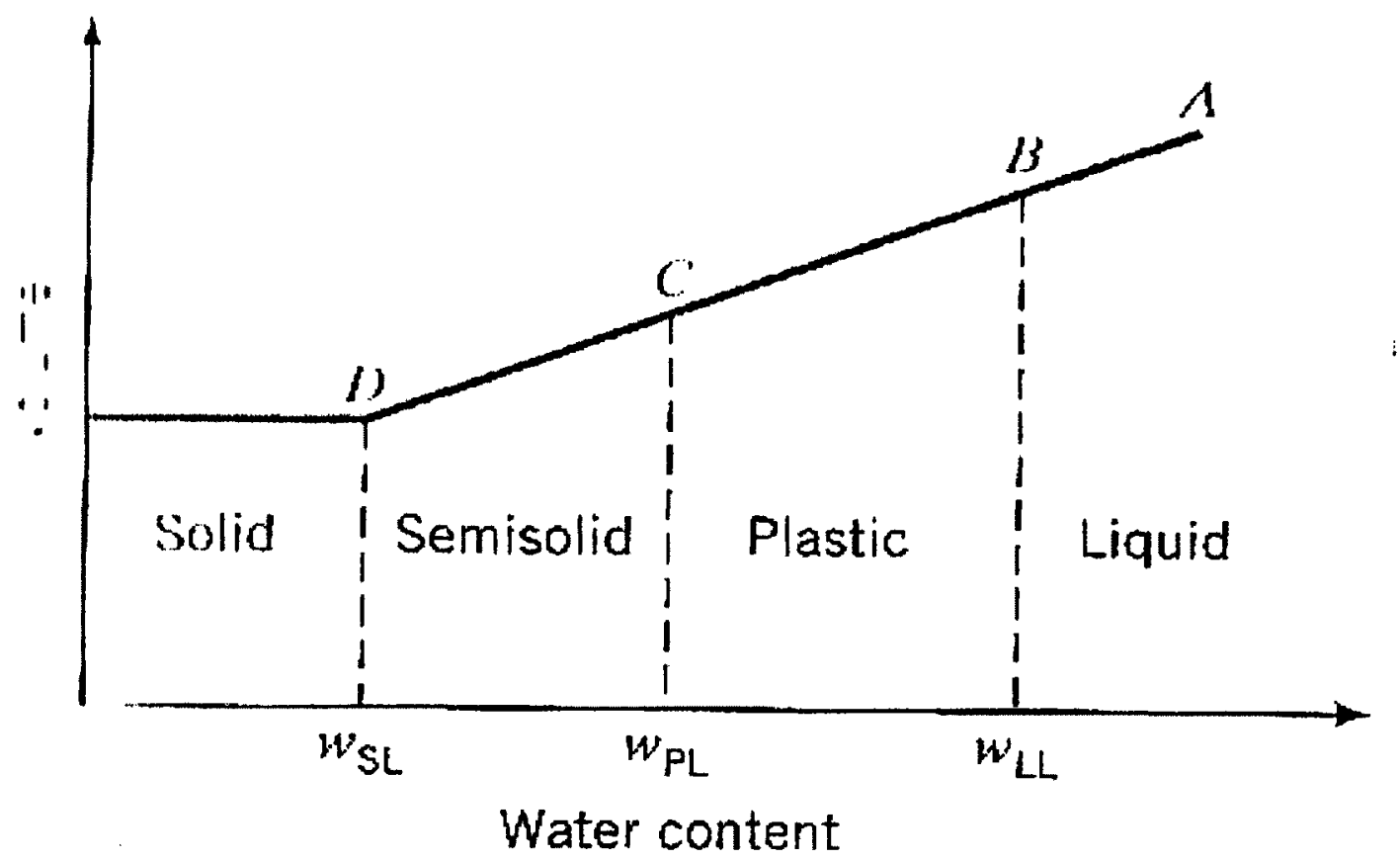

Figure 4-3: Soil states as a function of volume and water content 


\section{4-2-3. Soil Water Characteristive Curve by axis-translation}

The SWCC has been measured for different initial conditions and under different applied loads. For the silt-four different SWCC tests were done:

a) SWCC test started before full settling allowed (within 1 hour of sample preparation).

b) SWCC test after settling ( 24 hours after specimen preparation).

c) Drying and wetting SWCC test after settling

d) SWCC test with variable thickness.

Figure 4-4 shows the axis-translation device used in this research. This device can be used to obtain the complete TWCC for tailings. Matric suctions from near zero value up to $1500 \mathrm{kPa}(15 \mathrm{bar})$ can be applied, and it is also possible to apply one dimensional loading to a specimen.

Two different samples preparation methods were used: i) Hand mixing and ii) mechanical mixing. In hand mixing, the sample was mixed with a large spoon by hand for about a minute, until a homogeneous mixture was observed. In mechanical mixing the sample was mixed with a paint mixer for 20 minutes. Mechanical mixing was only used for the oil sand tailings. For the oil sand tailings, polymer amended samples were prepared in two separate ways: i) the required polymer was mixed with the required additional water to bring the tailings to a given water content, before mixing the polymer-water solution with the as-received tailings by hand mixing. ii) or added polymer directly to the asreceived tailings sample employing the mechanical mixing method. Soil Water 
Characteristic Curve or Tailings Water Characteristic curve procedure was brought in the appendix.

\section{4-2-3-1. TWCC / SWCC under 1-D loading}

The same apparatus allows for application of a vertical loading (1-D loading), during the SWCC test. A number of different tests were performed on the gold tailings, exposing the samples to different combinations of suction and load paths. Thesis includes:

a) SWCC under a constant 1-D loading

b) SWCC under a constant suction, but variable 1-D loading

c) No suction, but variable load to produce a consolidation curve.

The procedure was brought in the appendix.

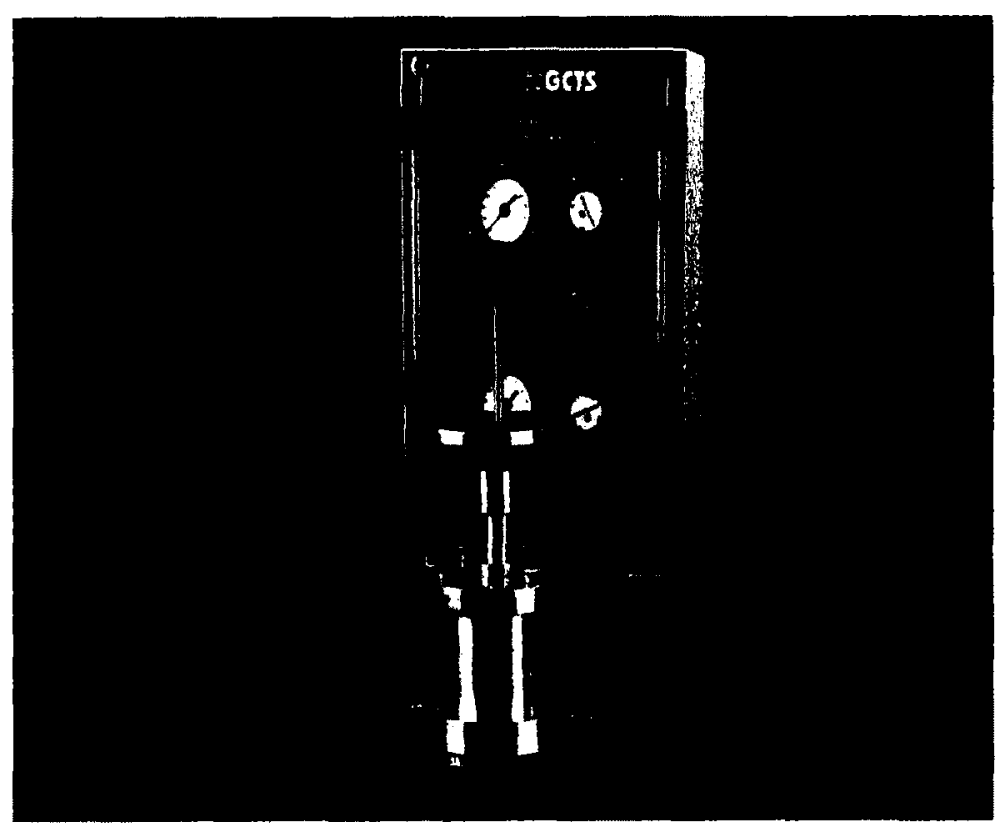

Figure 4-4: Tailings Water Characteristic Curve device.

("Fredlund Cell" model from GCTS) 
Chapter 5:

\section{Results and Discussion}




\section{Results and Discussion}

As described in the introduction, the key objective of this thesis is to explore the influence of initial state, applied stress, and desiccation history on the dewatering behaviour ( as quantified by the TWCC) and the consolidation behaviour of mine tailings.

For this purpose three different materials have been tested:

- An Artificial silt

- Mature fine tailings (MFT) from oil sand surface mining.

- Gold mine tailings

\section{5-1. Artificial silt}

For the artificial silt two different experimental tests has done which are Proctor compaction test and Soil water characteristic curve test. As explained in Chapter 4, various methods of compaction were used in attempt to reduce the void ratio of the material below its post-settling water content, in order to evaluate the effect of void ratio on the SWCC.

\section{5-1-1. Proctor Compaction Test (P.C.T)}

As shown in Figure 5-1 and in Table A5-1, this test was repeated six times with range of moisture content between $4 \%$ to $14 \%$ and reached optimum dry unit weight at $14.7 \mathrm{kN} / \mathrm{m}^{3}$ and related water content is $12 \%$. The corresponding minimum void ratio was 0.65, as shown in Figure 5-2. 


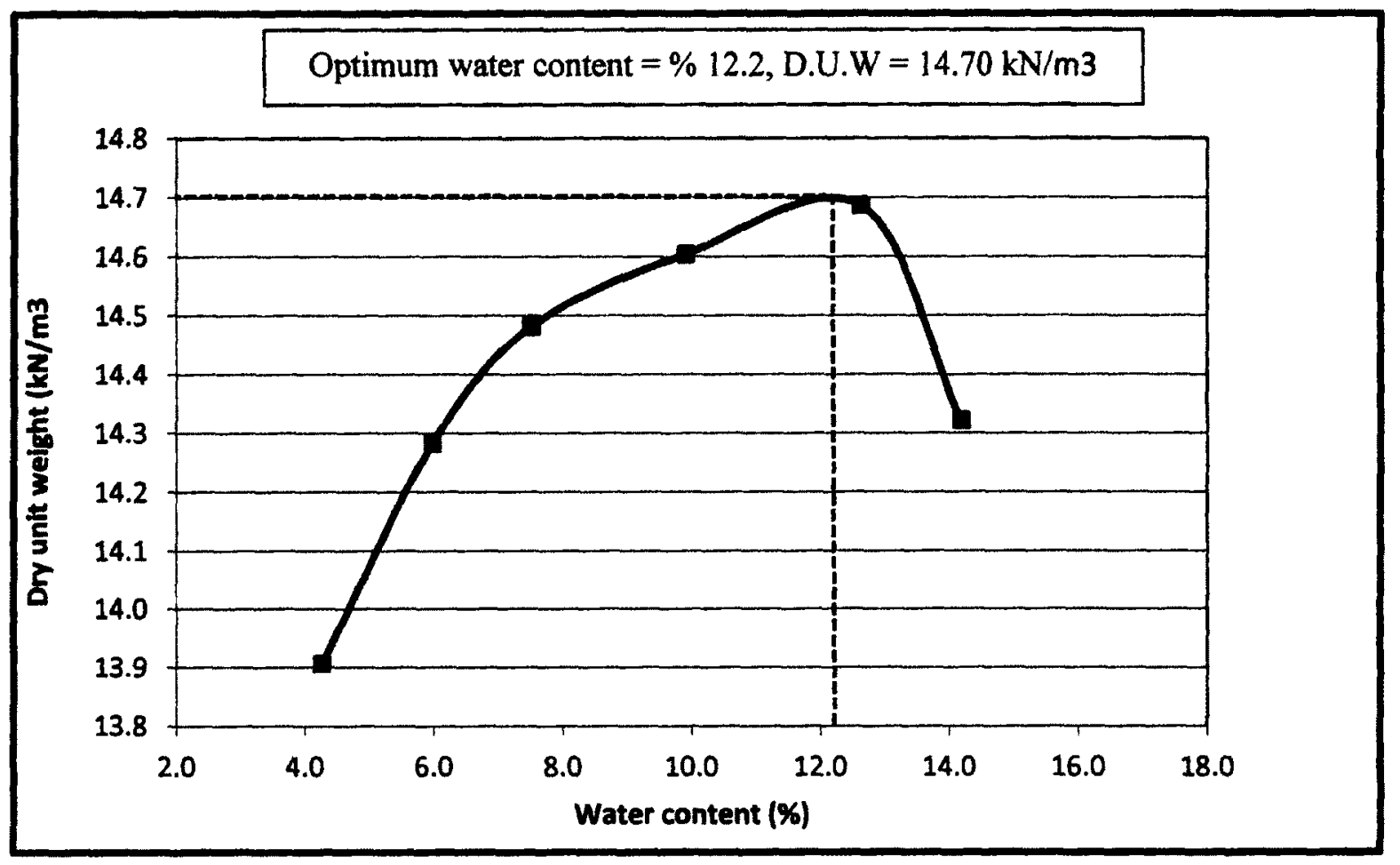

Figure 5-1: Standard proctor compaction test for artificial silt.

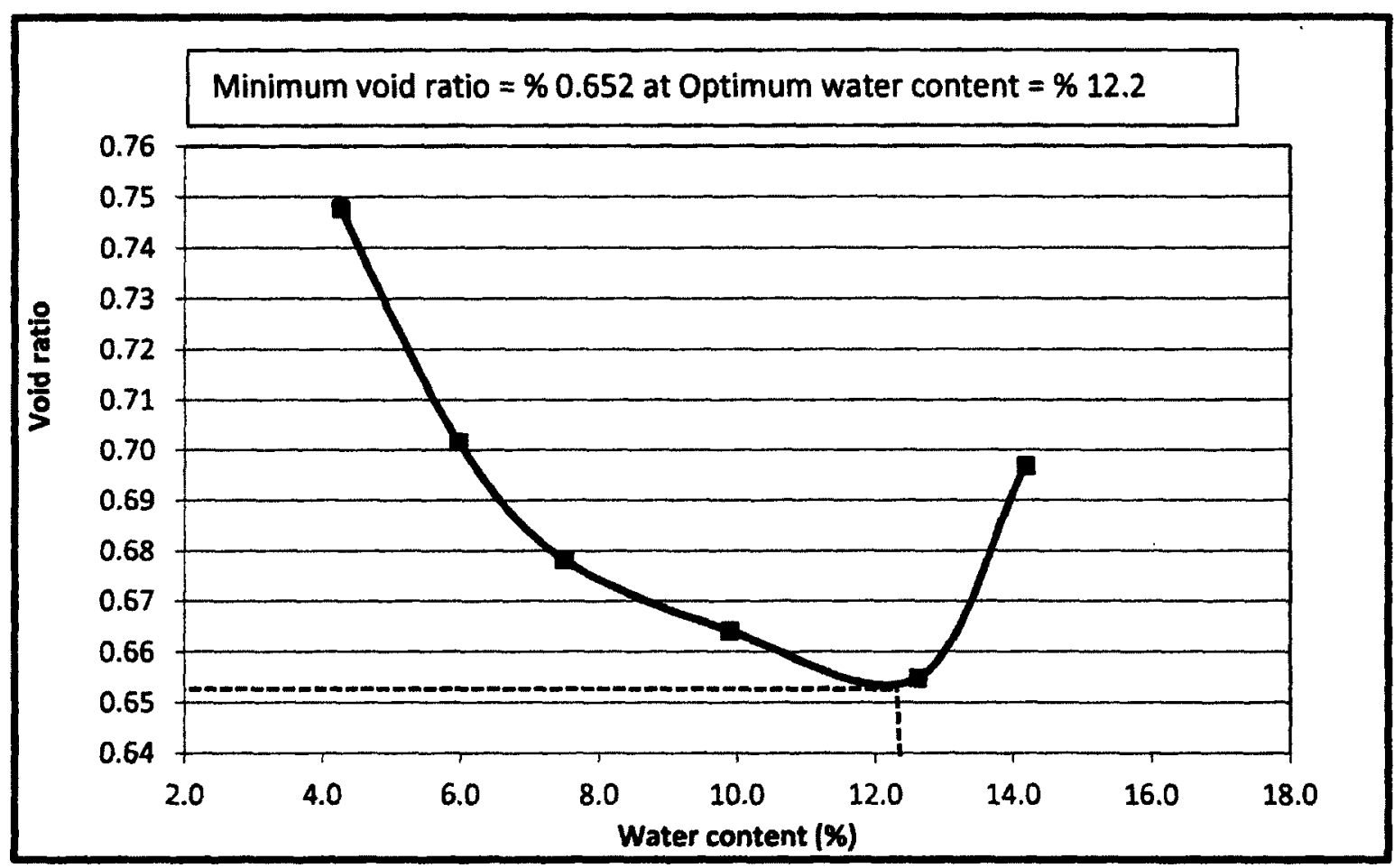

Figure 5-2: Void ratio vs. water content in Standard proctor compaction test for artificial silt 
As this "maximum density" was less than the density achieved by settling from a slurry condition, it was decided to investigate the compaction process in more detail. These investigations are reported in the Appendix. The outcome, however, was that the void ratio could not be significantly reduced below 0.65 .

\section{5-1-2. Soil water characteristic curve, (S.W.C.C.).}

\section{5-1-2-1. SWCC of silt before settling, axis-translation started less than 1 hour after sample preparation}

The sample was prepared at an initial water content of $35.3 \%$. Initial degree of saturation was $100 \%$, which decreased to $3 \%$ by a matric suction of $100 \mathrm{kPa}$ Initial void ratio of sample was 0.88 and reached to 0.56 at the end of the test. Tables 5-1 and Figures 5-3 and 5-4 show variations of silt water content during the test and different pressures. Variations of saturation, void ratio and shrinkage are shown in Tables A5-2 and Figures A5-1 to A5-6 in the appendix.

\section{5-1-2-2. SWCC of silt after settling.}

This sample was prepared at $35 \%$ water content, placed in the axis-translation cylinder, and left to settle for 24 hours. Excess water on the top of the sample was removed by syringe at this point water content of sample was $21.6 \%$. The axis-translation test was then started. Tables 5-5and Figures 5-17 and 5-18 show the variation of water content and void ratio with applied matric suction. Variations of saturation are shown in 
Table A5-3 and Figures A5-7 and A5-8 in the appendix. The void ratio did not change after settling.

In Figures 5-7 to 5-14 these variations have been compared together, final water content and final saturation of sample after settling are $2 \%$ and $9 \%$ respectively. These numbers are for the sample before settling 0.8 and $3.3 \%$. It is interesting to see that it takes several steps of axis-translation imposed suctions, over several days, to reach the same void ratio achieved by settling alone with 24 hours. Clearly, samples must be allowed to settle before the axis-translation test is started to obtain useful SWCC data. 
Table 5-1: Effect of suction on water content of artificial silt, $\mathrm{w}_{\mathrm{i}}=35.3 \%$, before settling

\begin{tabular}{|c|c|c|c|c|c|c|c|c|c|c|c|c|c|}
\hline \multirow{2}{*}{$\begin{array}{l}\text { Sution } \\
\text { (MPE) }\end{array}$} & \multirow{2}{*}{$\begin{array}{l}\text { soll } \\
\text { uegdt } \\
\text { (d) }\end{array}$} & \multirow{2}{*}{$\begin{array}{l}\text { vetre } \\
\text { veigt } \\
\text { (d) }\end{array}$} & \multirow{2}{*}{$\begin{array}{l}\text { Initid tod } \\
\text { ueidt } \\
\text { (d) }\end{array}$} & \multirow{2}{*}{$\begin{array}{l}\text { find tod } \\
\text { wedt } \\
\text { (d) }\end{array}$} & \multirow{2}{*}{$\begin{array}{l}\text { uter } \\
\text { at } \\
\text { (g) }\end{array}$} & \multirow{2}{*}{$\begin{array}{l}\text { veterin } \\
\text { theunit } \\
\text { (d) }\end{array}$} & \multirow{2}{*}{$\begin{array}{c}\text { West } \\
\text { cotet } \\
(9 / 9)\end{array}$} & \multicolumn{2}{|c|}{ inilidsots } & \multicolumn{2}{|c|}{ fratsols } & \multicolumn{2}{|c|}{ dergensots } \\
\hline & & & & & & & & $\begin{array}{l}\text { regit } \\
(\mathrm{mm})\end{array}$ & $\begin{array}{l}\text { value } \\
\text { (ant) }\end{array}$ & $\begin{array}{l}\text { heigt } \\
\text { (min) }\end{array}$ & $\begin{array}{l}\text { volue } \\
\text { (and) }\end{array}$ & $\begin{array}{l}\text { rejt } \\
\text { (mil) }\end{array}$ & $\begin{array}{c}\text { volume } \\
189\end{array}$ \\
\hline 0 & 7329 & 2886 & 48002 & 43002 & 00 & 2586 & 353 & 59 & 932 & $4 \mathbf{B 1}$ & $\mathbf{5 4 1}$ & 328 & 46 \\
\hline 20 & 7329 & 286 & 4302 & 4238 & 964 & 1522 & 21 & $4 B 1$ & 541 & 400 & 5140 & 31 & 7.2 \\
\hline 30 & 7329 & 1022 & $\triangle 028$ & 41882 & 356 & 1266 & 17.3 & 400 & 5140 & 37.0 & 4748 & 30 & 7.6 \\
\hline 40 & 7329 & 1256 & 41882 & 41314 & 588 & 698 & 95 & 37.0 & 4748 & 360 & 4617 & 10 & 28 \\
\hline 50 & 7329 & 698 & 41314 & 4054 & 260 & 488 & 60 & 360 & 4617 & 360 & 4617 & 00 & 00 \\
\hline 60 & 7329 & 488 & 41054 & 40059 & 95 & 343 & 47 & 30 & 4617 & 360 & 4617 & 00 & 00 \\
\hline ס & 7329 & 343 & 40059 & 40042 & 117 & 26 & 31 & 360 & 4617 & 300 & 4617 & 00 & 00 \\
\hline 10 & 7329 & 226 & 40042 & 4007.1 & 17.1 & 55 & 08 & 360 & 4617 & 360 & 4๓7 & 00 & $\infty$ \\
\hline
\end{tabular}

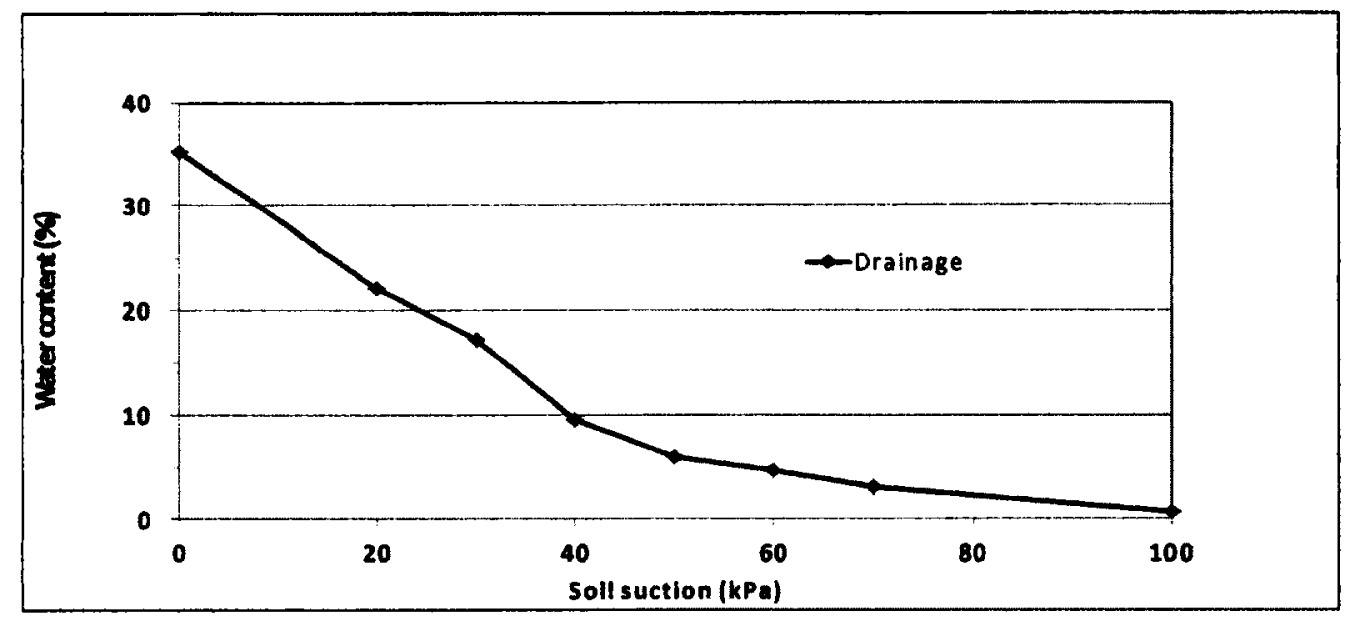

Figure 5-3: Water content-suction curve for silt with $\mathrm{w}_{\mathrm{i}}=35.3 \%$, before settling

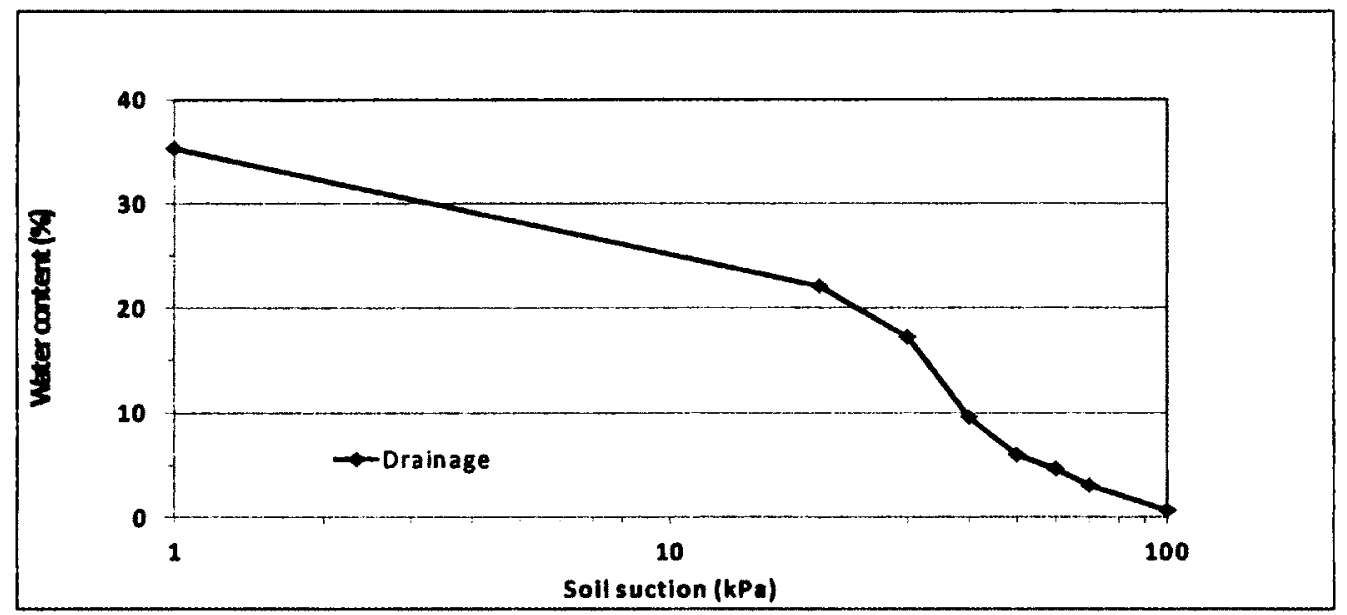

Figure 5-4: Water content-suction curve for silt with $\mathrm{w}_{\mathrm{i}}=35.3 \%$, before settling, $\log$ scale 
Table 5-2: Effect of suction on water content of artificial silt, $w_{i}=21.6 \%$, after settling

\begin{tabular}{|c|c|c|c|c|c|c|c|c|c|c|c|c|c|}
\hline \multirow{2}{*}{$\begin{array}{l}\text { Suction } \\
\text { (kPa) }\end{array}$} & \multirow{2}{*}{$\begin{array}{c}\text { soll } \\
\text { weight } \\
\text { (g) }\end{array}$} & \multirow{2}{*}{$\begin{array}{c}\text { water } \\
\text { weight } \\
\text { (R) }\end{array}$} & \multirow{2}{*}{$\begin{array}{c}\text { Initial total } \\
\text { weight } \\
\text { (g) }\end{array}$} & \multirow{2}{*}{$\begin{array}{c}\text { final total } \\
\text { weight } \\
\text { (R) }\end{array}$} & \multirow{2}{*}{$\begin{array}{l}\text { water } \\
\text { out } \\
\text { (g) }\end{array}$} & \multirow{2}{*}{$\begin{array}{c}\text { water in } \\
\text { the unit } \\
\text { (B) }\end{array}$} & \multirow{2}{*}{$\begin{array}{c}\text { Water } \\
\text { content } \\
\text { (\%) }\end{array}$} & \multicolumn{2}{|c|}{ Initial solis' } & \multicolumn{2}{|c|}{ final solis' } & \multicolumn{2}{|c|}{ change in solts' } \\
\hline & & & & & & & & $\begin{array}{l}\text { height } \\
(\mathrm{mm})\end{array}$ & $\begin{array}{c}\text { volume } \\
\text { (cm3) }\end{array}$ & $\begin{array}{l}\text { height } \\
(\mathrm{mm})\end{array}$ & $\begin{array}{c}\text { volume } \\
(\mathrm{cm} 3)\end{array}$ & $\begin{array}{l}\text { helght } \\
(\mathrm{mm})\end{array}$ & $\begin{array}{c}\text { volume } \\
(\%)\end{array}$ \\
\hline 0 & 504.9 & 109.1 & 3943.6 & 3943.6 & 0.0 & 109.1 & 21.6 & 24.6 & 312.7 & 24.6 & 312.7 & 0.0 & 0.0 \\
\hline 12 & 504.9 & 109.1 & 3943.6 & 3937.1 & 6.5 & 102.6 & 20.3 & 24.6 & 312.7 & 24.6 & 312.7 & 0.0 & 0.0 \\
\hline 20 & 504.9 & 102.6 & 3937.1 & 3919.3 & 17.8 & 84.8 & 16.8 & 24.6 & 312.7 & 24.6 & 312.7 & 0.0 & 0.0 \\
\hline 30 & 504.9 & 84.8 & 3919.3 & 3895.8 & 23.5 & 61.3 & 12.1 & 24.6 & 312.7 & 24.6 & 312.7 & 0.0 & 0.0 \\
\hline 38 & 504.9 & 61.3 & 3896.3 & 3888.0 & 8.3 & 53.0 & 10.5 & 24.6 & 312.7 & 24.6 & 312.7 & 0.0 & 0.0 \\
\hline 52 & 504.9 & 53.0 & 3888.0 & 3882.7 & 5.3 & 47.7 & 9.4 & 24.6 & 312.7 & 24.6 & 312.7 & 0.0 & 0.0 \\
\hline 60 & 504.9 & 47.7 & 3882.7 & 3878.7 & 4.0 & 43.7 & 8.7 & 24.6 & 312.7 & 24.6 & 312.7 & 0.0 & 0.0 \\
\hline 70 & 504.9 & 43.7 & 3878.7 & 3874.2 & 4.5 & 39.2 & 7.8 & 24.6 & 312.7 & 24.6 & 312.7 & 0.0 & 0.0 \\
\hline 80 & 504.9 & 39.2 & 3874.2 & 3863.4 & 10.8 & 28.4 & 5.6 & 24.6 & 312.7 & 24.6 & 312.7 & 0.0 & 0.0 \\
\hline 90 & 504.9 & 28.4 & 3863.4 & 3855.2 & 8.2 & 20.2 & 4.0 & 24.6 & 312.7 & 24.6 & 312.7 & 0.0 & 0.0 \\
\hline 100 & 504.9 & 20.2 & 3855.2 & 3844.7 & 10.5 & 9.7 & 1.9 & 24.6 & 312.7 & 24.6 & 312.7 & 0.0 & 0.0 \\
\hline
\end{tabular}

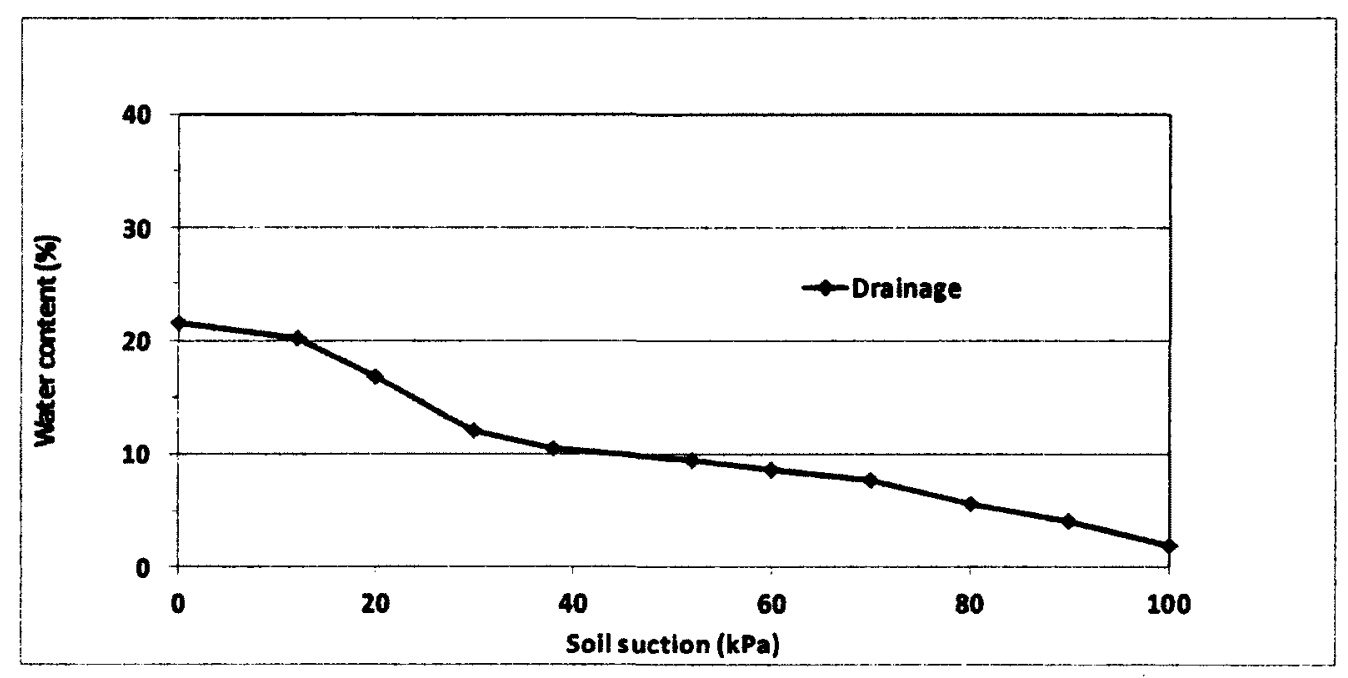

Figure 5-5: Water content-suction curve for silt with $\mathrm{w}_{\mathrm{i}}=21.6 \%$, after settling

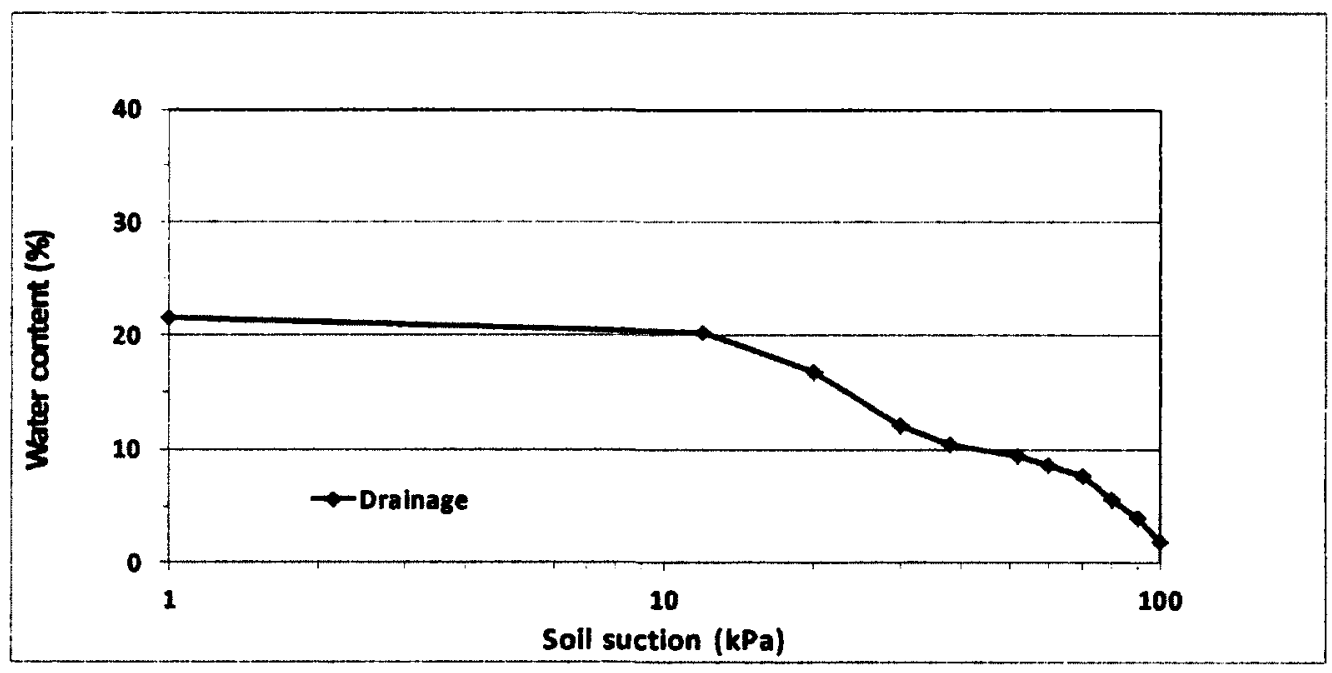

Figure 5-6: Water content-suction curve for silt with $w_{i}=21.6 \%$, after settling, log scale 


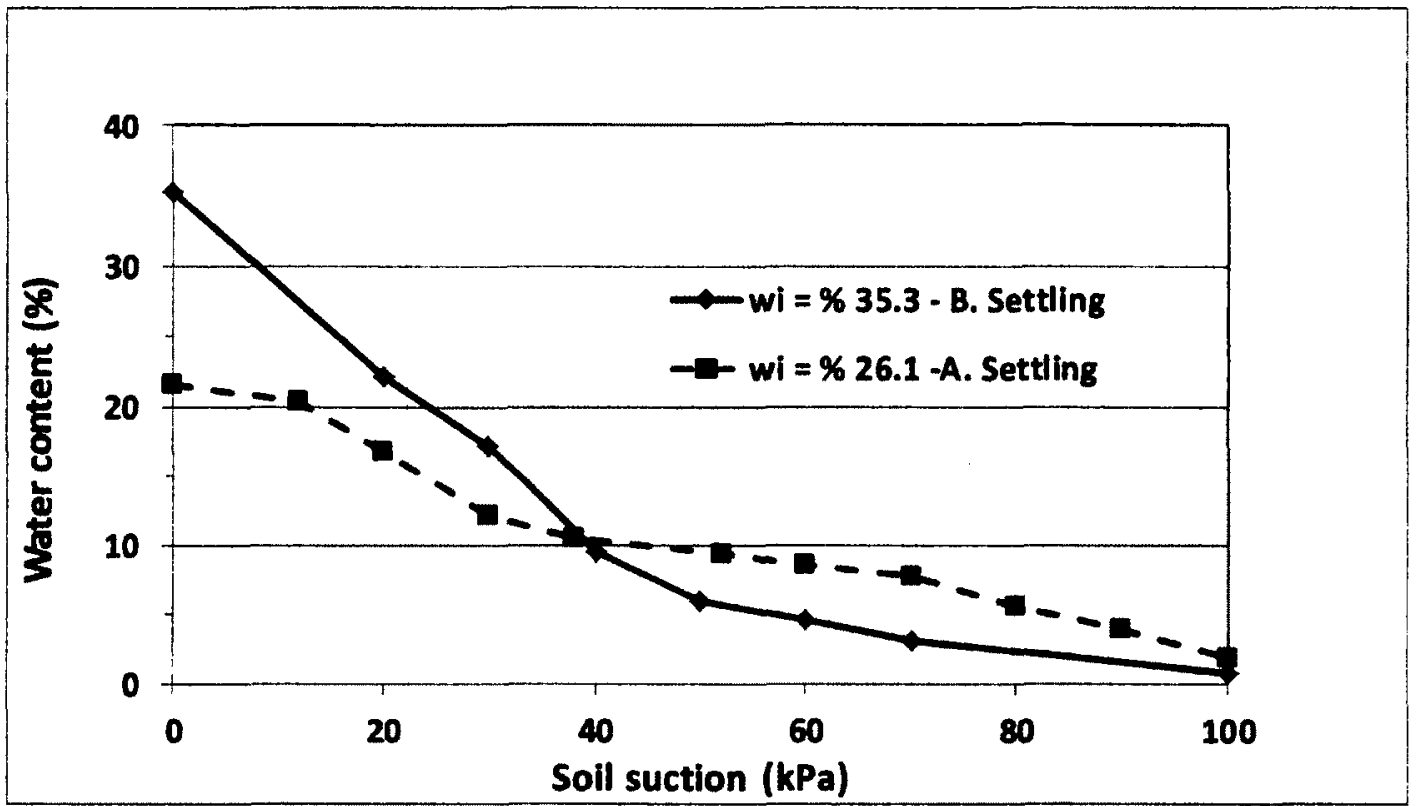

Figure 5-7: Comparison of water content -suction curve for silt in different settling situations

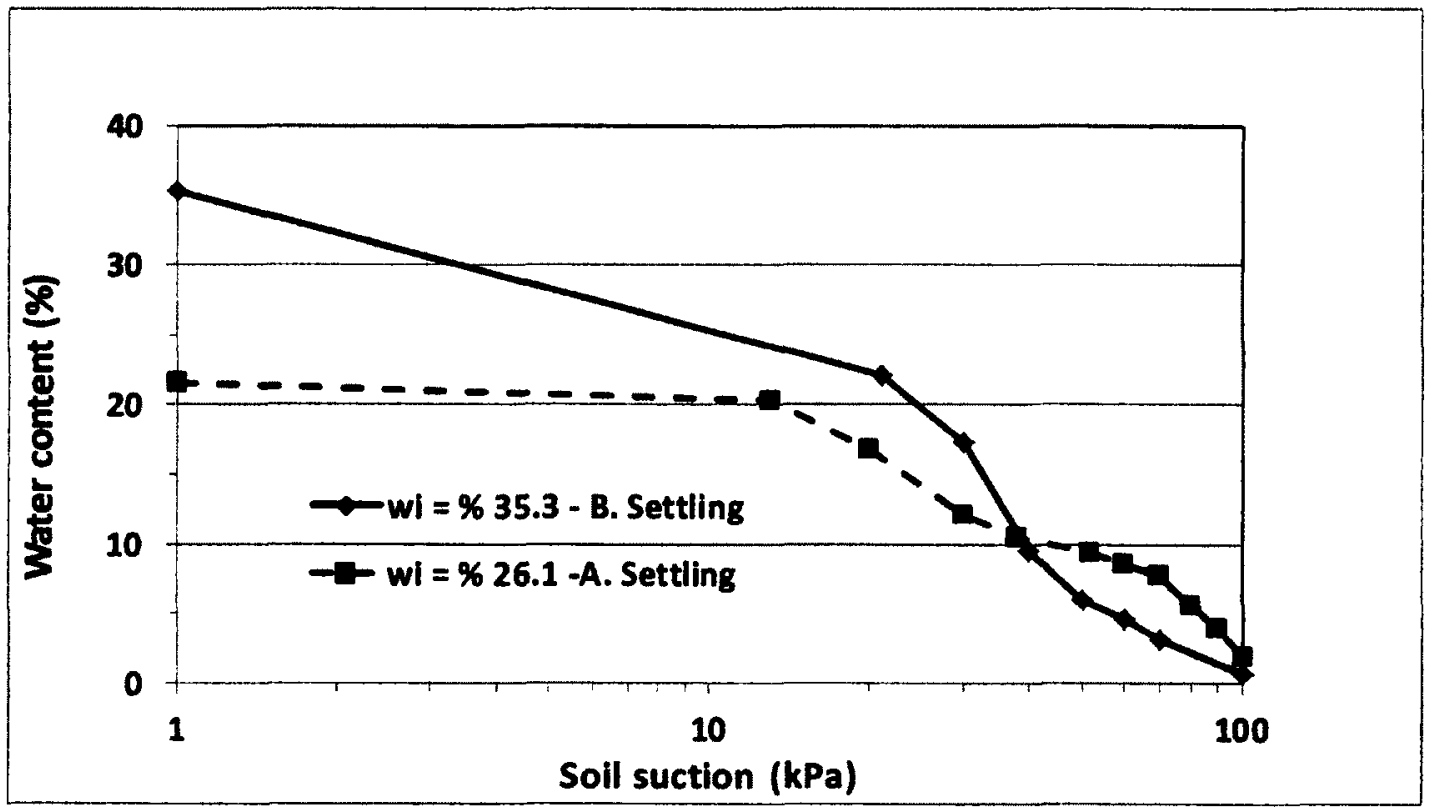

Figure 5-8: Comparison of water content -suction curve for silt in different settling situations, log scale 


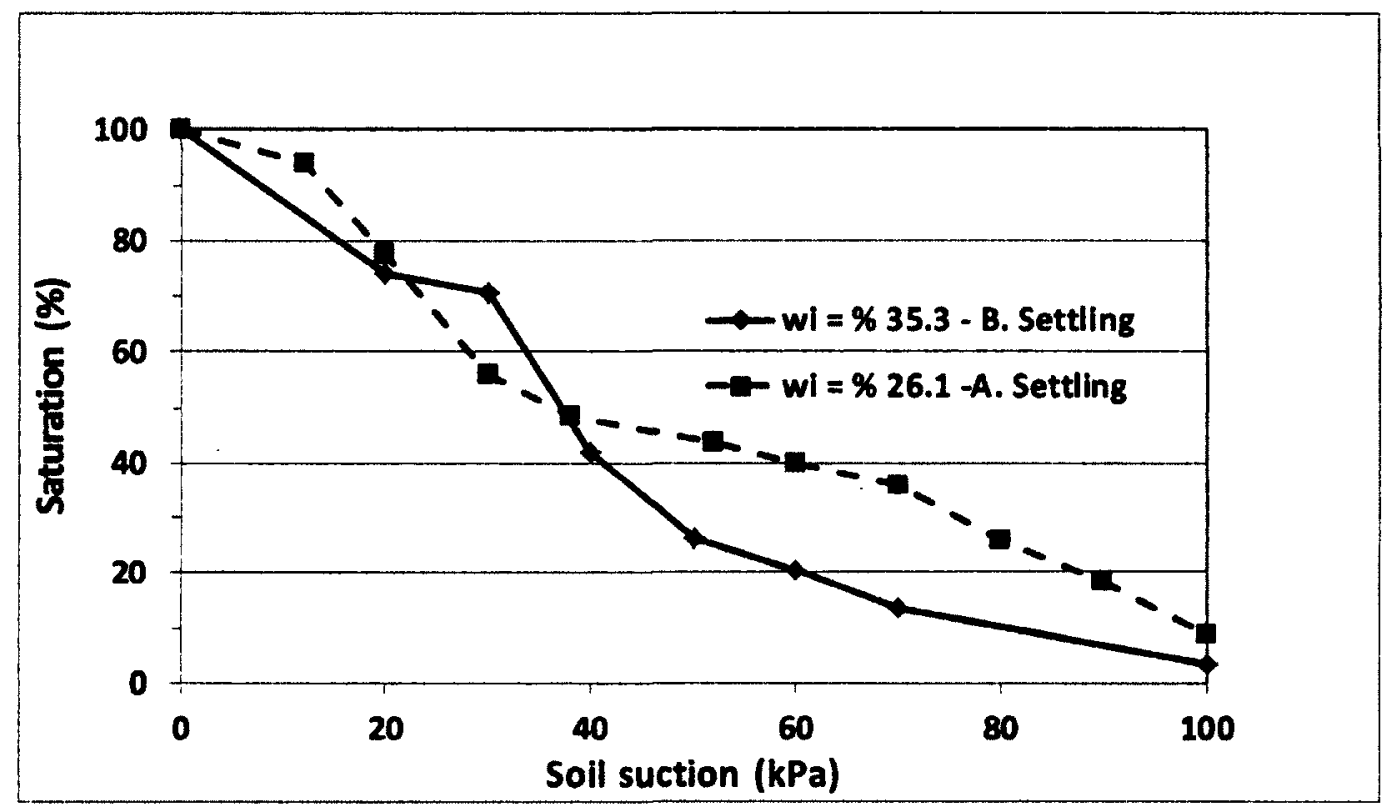

Figure 5-9: Comparison of saturation -suction curve for silt in different settling situations

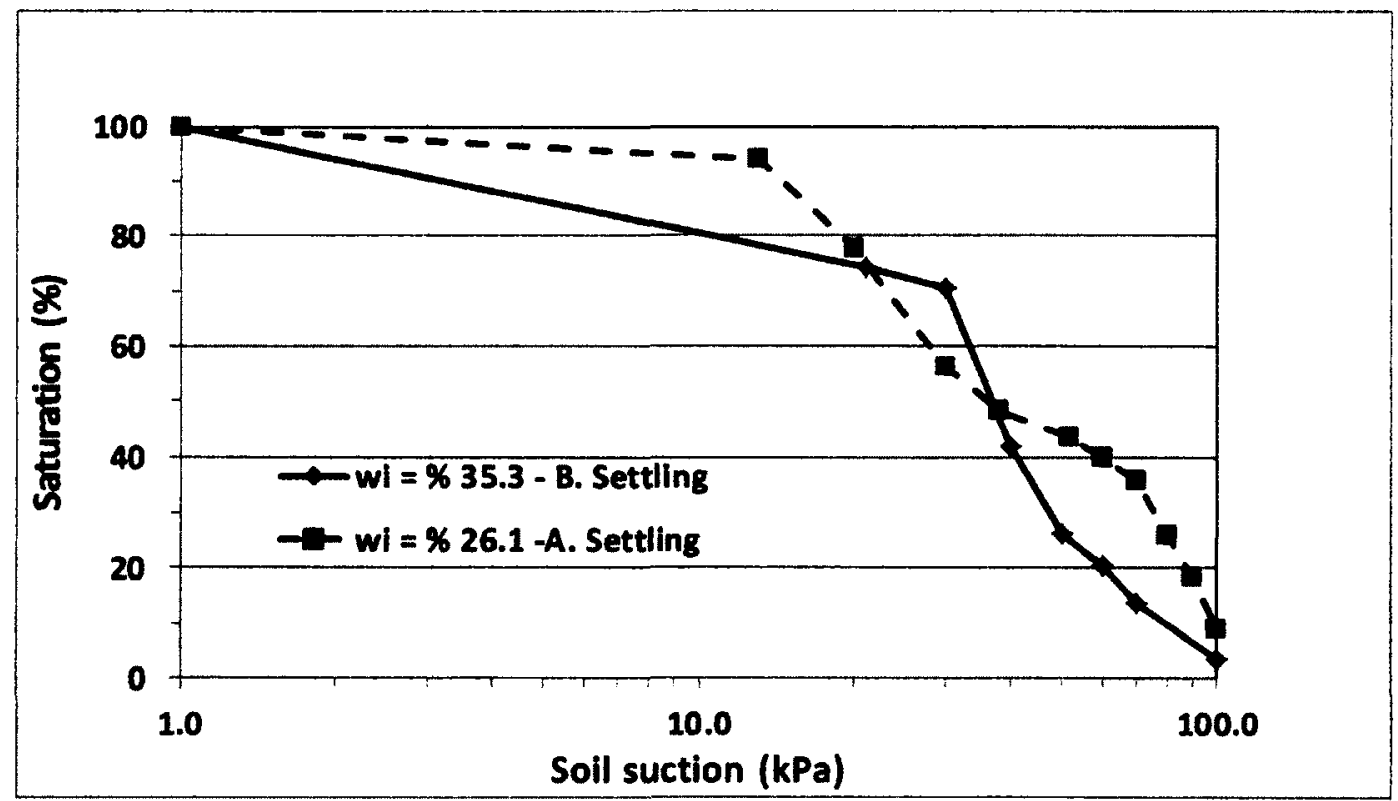

Figure 5-10: Comparison of saturation-suction curve for silt in different settling situations, log scale 


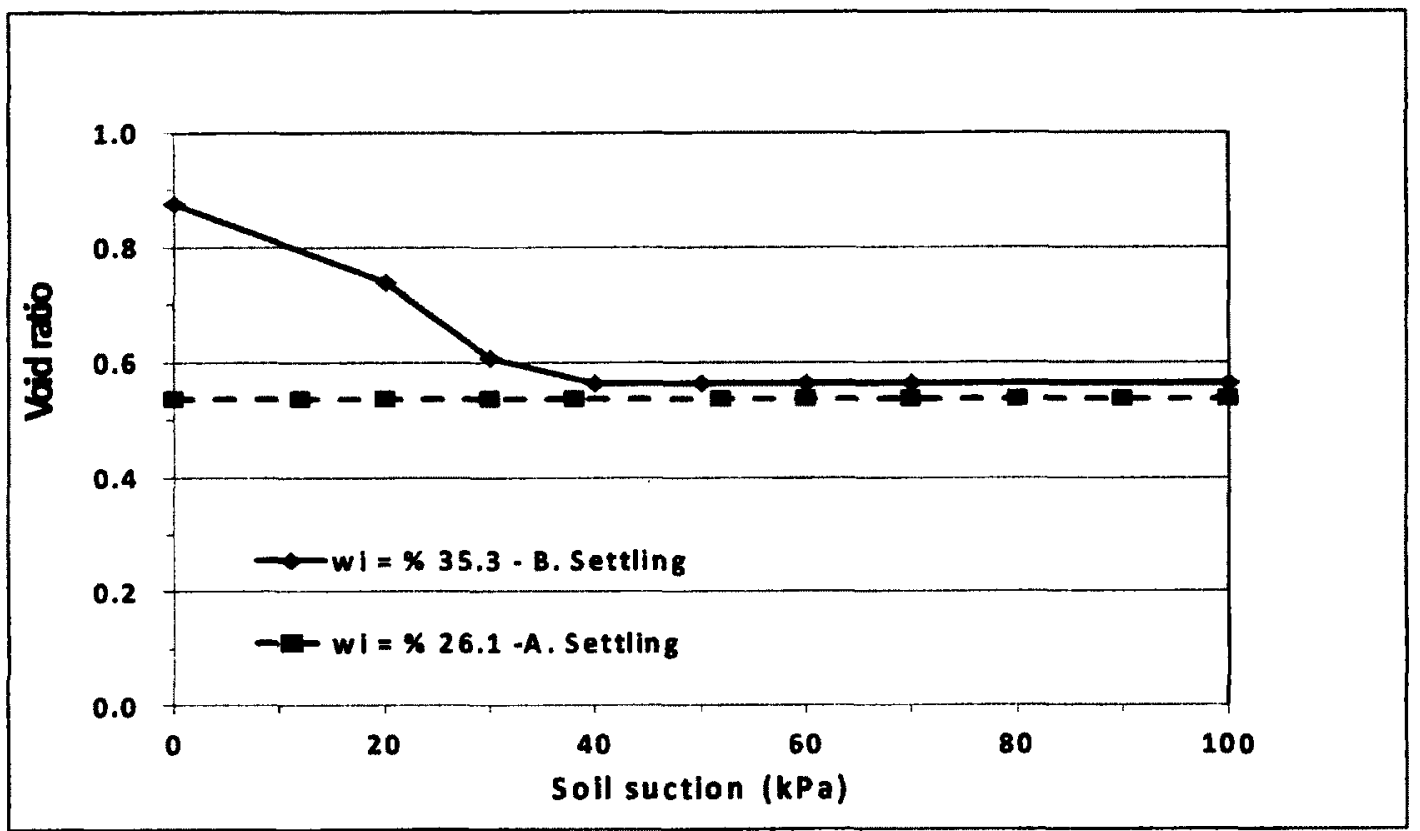

Figure 5-11: Comparison of void ratio-suction curve for silt in different settling situations

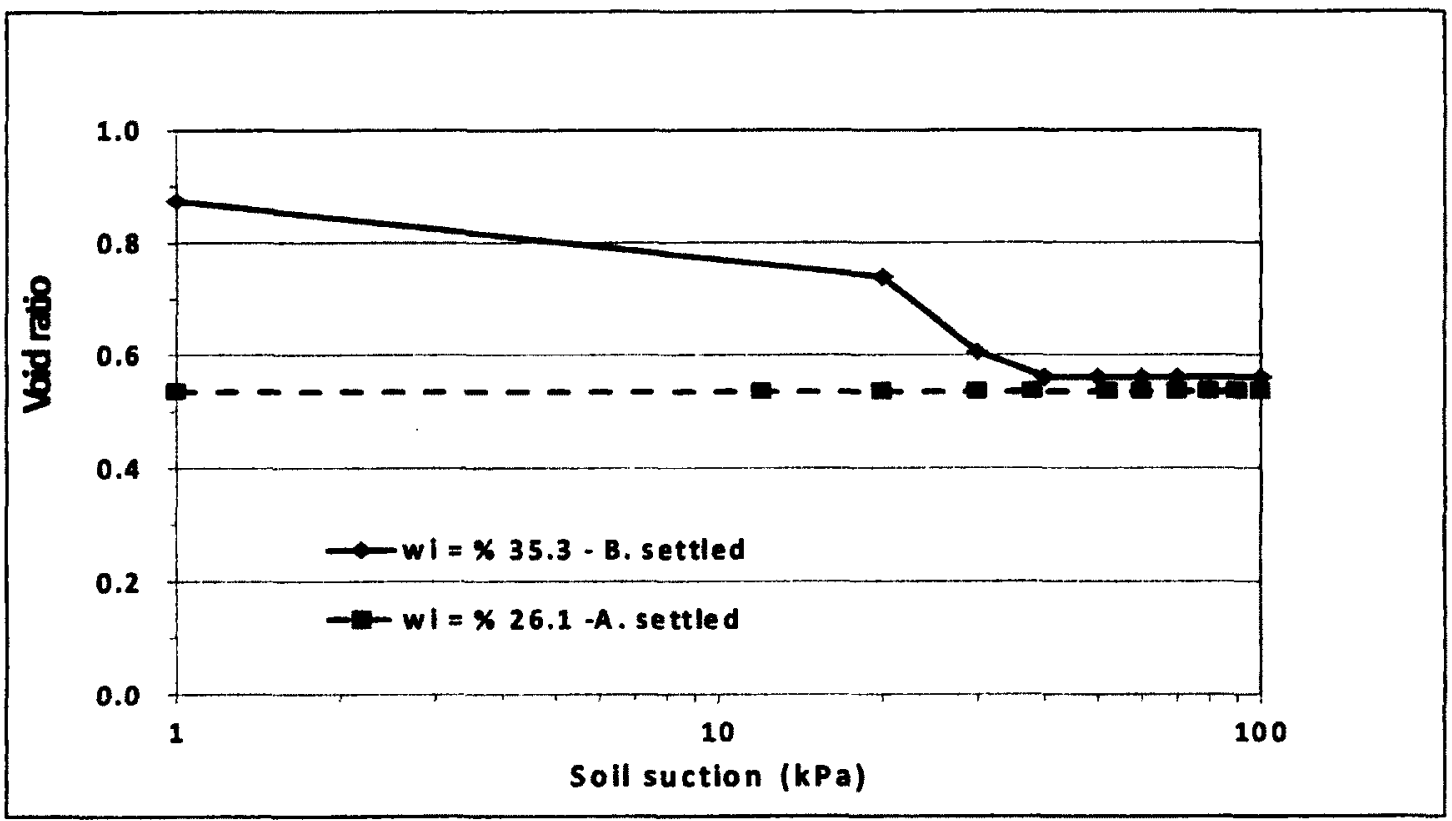

Figure 5-12: Comparison of void ratio-suction curve for silt in different settling situations, $\log$ scale 


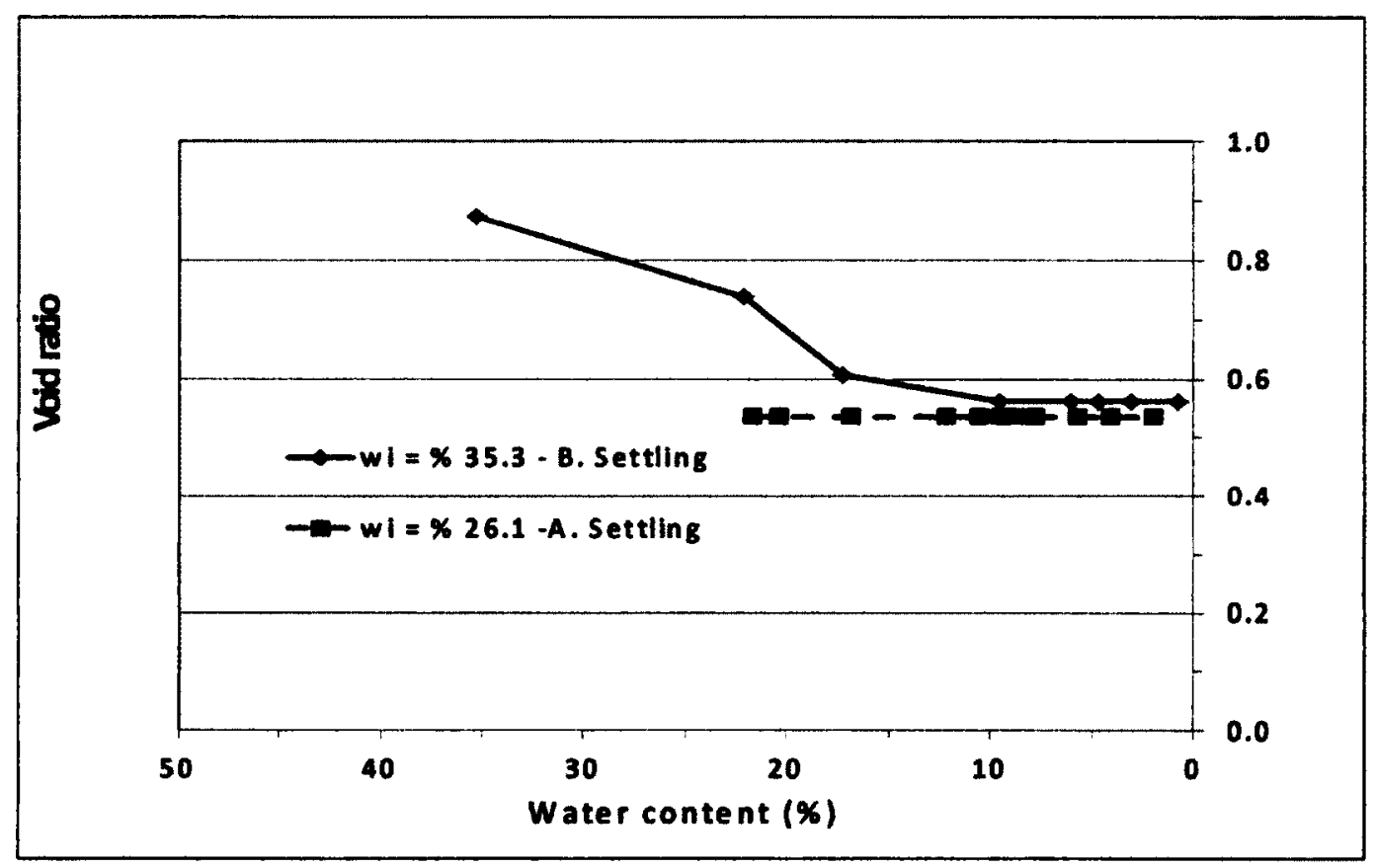

Figure 5-13: Comparison of shrinkage curve for silt in different settling situations

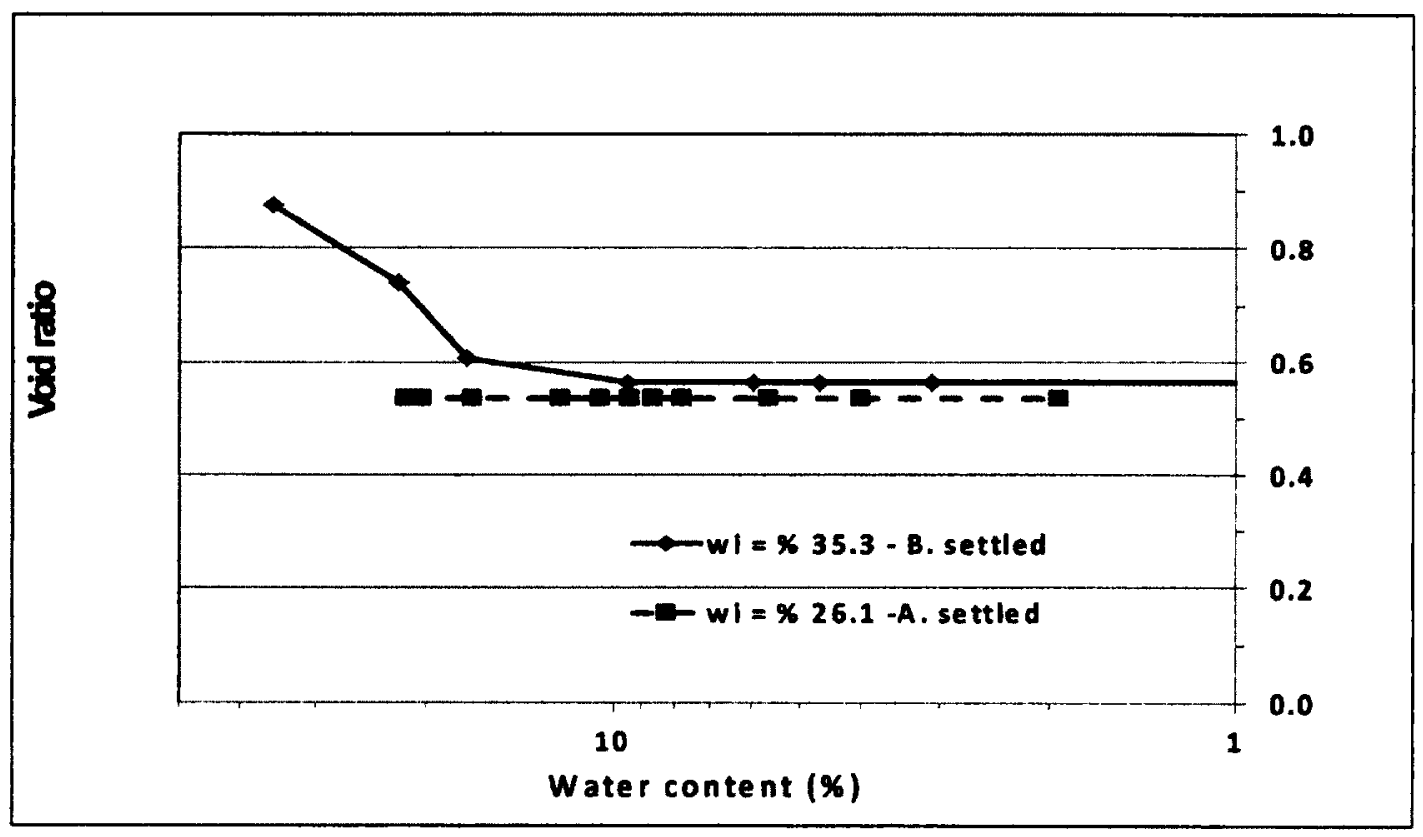

Figure 5-14: Comparison of shrinkage curve for silt in different settling situations, $\log$ scale 


\section{5-1-2-3. SWCC of silt after settling - drainage and wetting}

This sample was prepared at a water content of $35 \%$ and then put in the cylinder for 24 hours to allow for settling. After that the extra water on the top of specimen was removed by syringe - the water content after settling was $26 \%$. Tables 5-3 and Figures 515 and 5-16 show variations of water content of the specimen during drainage and wetting. Table A5-4 and Figures A5-9 and A5-10 show variations of saturation. Air entry value of sample is around $18 \mathrm{kPa}$ Minimum water content at $50 \mathrm{kPa}$ (end of drainage curve) is $4 \%$ and saturation at this point is $15 \%$. After rewetting, water content and saturation increased to $17 \%$ and $66 \%$ respectively.

\section{5-1-2-4. SWCC of silt after settling - using $10 \mathrm{~mm}$ thickness specimen}

In SWCC test the time to reach equilibrium is a function of the height of the soil and is proportional to the square of the height of the sample. To study the behaviour of SWCC in thin samples, a specimen is prepared with mix of $200 \mathrm{~g}$ silt and some water which after settling extra water is removed from the top of the sample there was a sample with $25 \%$ water content and height of $1 \mathrm{~cm}$. This specimen was tested under drainage and wetting conditions (pressure 0 to $50 \mathrm{kPa}$ for drainage and 50 to $0 \mathrm{kPa}$ for wetting). Results of this test show in Table 5-4, A5-5 and Figure 5-17, 5-18, A5-11 and A5-12.

Results of drainage and wetting of the last 2 tests are compared in Figures 5-19 to 522. These Figures show that both AEV and WEV for both are very close together: around $18 \mathrm{kPa}$ and $20 \mathrm{kPa}$ for the AEV and 20 to $22 \mathrm{kPa}$ for the WEV. However, for intermediate suctions, the water content for the $3 \mathrm{~cm}$ thick sample was substantially 
higher. This suggests that for the $3 \mathrm{~cm}$ sample, even though it took up to 7 days to reach equilibrium at a certain point, that equilibrium may still not have been completely achieved. 
Table 5-3: Effect of suction on water content of artificial silt, $w_{i}=26.1 \%$, after settling

\begin{tabular}{|c|c|c|c|c|c|c|c|c|c|c|c|c|c|}
\hline \multirow{2}{*}{$\begin{array}{l}\text { Suction } \\
\text { (kPa) }\end{array}$} & \multirow{2}{*}{$\begin{array}{c}\text { soil } \\
\text { weight } \\
\text { (g) }\end{array}$} & \multirow{2}{*}{$\begin{array}{c}\text { water } \\
\text { weight } \\
\text { (a) }\end{array}$} & \multirow{2}{*}{$\begin{array}{l}\text { Initial total } \\
\text { weight } \\
\text { (E) }\end{array}$} & \multirow{2}{*}{$\begin{array}{l}\text { finel total } \\
\text { weight } \\
\text { (a) }\end{array}$} & \multirow{2}{*}{$\begin{array}{l}\text { water } \\
\text { out } \\
\text { (8) }\end{array}$} & \multirow{2}{*}{$\begin{array}{l}\text { water in } \\
\text { the unit } \\
\text { (d) }\end{array}$} & \multirow{2}{*}{$\begin{array}{c}\text { Water } \\
\text { content } \\
\text { (\%) }\end{array}$} & \multicolumn{2}{|c|}{ Initial soils' } & \multicolumn{2}{|c|}{ final solls: } & \multicolumn{2}{|c|}{ change in solis' } \\
\hline & & & & & & & & $\begin{array}{l}\text { height } \\
\text { (mm) }\end{array}$ & $\begin{array}{l}\text { volume } \\
\text { (cm3) }\end{array}$ & $\begin{array}{l}\text { helght } \\
\text { (mm) }\end{array}$ & $\begin{array}{l}\text { volume } \\
\text { (cm3) }\end{array}$ & $\begin{array}{l}\text { heicht } \\
\text { (mm) }\end{array}$ & $\begin{array}{c}\text { volume } \\
\text { (\%) }\end{array}$ \\
\hline 0 & 590.0 & 153.7 & 4079.6 & 4079.6 & 0.0 & 153.7 & 26.1 & 30.6 & 391.6 & 30.6 & 391.6 & 0 & 0 \\
\hline 10 & 590.0 & 153.7 & 4079.6 & 4070.5 & 9.1 & 144.6 & 24.5 & 30.6 & 391.6 & 30.6 & 391.6 & 0 & 0 \\
\hline 17 & 590.0 & 144.6 & 4070.5 & 4063.7 & 6.8 & 137.8 & 23.4 & 30.6 & 391.6 & 30.6 & 391.6 & 0 & 0 \\
\hline 28 & 590.0 & 137.8 & 4063.7 & 4030.6 & 33.1 & 104.7 & 17.7 & 30.6 & 391.6 & 30.6 & 391.6 & 0 & 0 \\
\hline 38 & 590.0 & 104.7 & 4030.6 & 3971.8 & 58.8 & 45.9 & 7.8 & 30.6 & 391.6 & 30.6 & 392.6 & 0 & 0 \\
\hline 50 & 590.0 & 45.9 & 3971.8 & 3949.0 & 22.8 & 23.1 & 3.9 & 30.6 & 391.6 & 30.6 & 391.6 & 0 & 0 \\
\hline 40 & 590.0 & 23.1 & 3949.0 & 3949.0 & 0.0 & 23.1 & 3.9 & 30.6 & 391.6 & 30.6 & 391.6 & 0 & 0 \\
\hline 30 & 590.0 & 23.1 & 3949.0 & 3949.0 & 0.0 & 23.1 & 3.9 & 30.6 & 391.6 & 30.6 & 391.6 & 0 & 0 \\
\hline 12 & 590.0 & 23.1 & 3949.0 & 3956.9 & -7.9 & 31.0 & 5.3 & 30.6 & 391.6 & 30.6 & 391.59 & 0 & 0 \\
\hline 0 & 590.0 & 31.0 & 3956.9 & 4026.5 & 69.6 & 100.6 & 17.1 & 30.6 & 391.6 & 30.6 & 391.60 & 0 & 0 \\
\hline
\end{tabular}

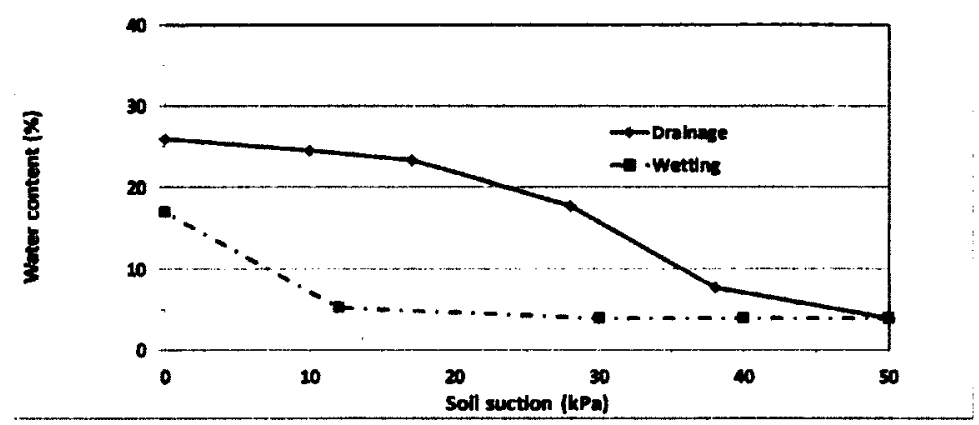

Figure 5-15: Water content-suction curve for silt, $\mathrm{w}_{\mathrm{i}}=26.1 \%$, after settling

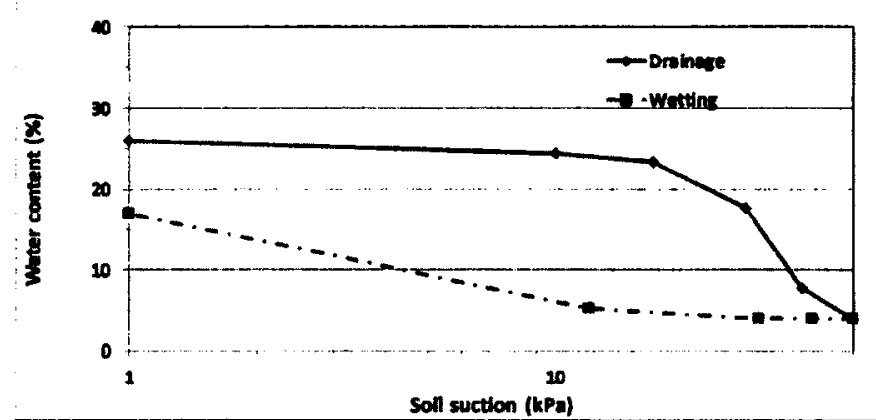

Figure 5-16: Water content-suction curve for silt, $\mathrm{w}_{\mathrm{i}}=26.1 \%$, after settling, log scale 


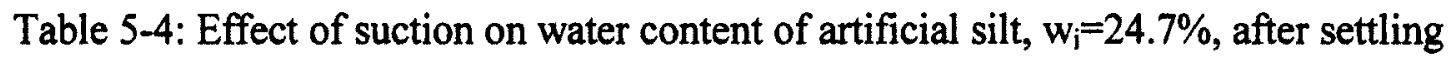

\begin{tabular}{|c|c|c|c|c|c|c|c|c|c|c|c|c|c|}
\hline \multirow{2}{*}{$\begin{array}{l}\text { Suction } \\
\text { (kPa) }\end{array}$} & \multirow{2}{*}{$\begin{array}{l}\text { soil } \\
\text { weight } \\
\text { (d) }\end{array}$} & \multirow{2}{*}{$\begin{array}{l}\text { water } \\
\text { waight } \\
\text { (g) }\end{array}$} & \multirow{2}{*}{$\begin{array}{l}\text { Initial total } \\
\text { weight } \\
\text { (e) }\end{array}$} & \multirow{2}{*}{$\begin{array}{l}\text { final total } \\
\text { weight } \\
\text { (g) }\end{array}$} & \multirow{2}{*}{$\begin{array}{l}\text { woter } \\
\text { out } \\
\text { (c) }\end{array}$} & \multirow{2}{*}{$\begin{array}{l}\text { water in } \\
\text { the unlt } \\
\text { (d) }\end{array}$} & \multirow{2}{*}{$\begin{array}{c}\text { Water } \\
\text { content } \\
(\%)\end{array}$} & \multicolumn{2}{|c|}{ Initial soils' } & \multicolumn{2}{|c|}{ final soils' } & \multicolumn{2}{|c|}{ change in solls' } \\
\hline & & & & & & & & $\begin{array}{l}\text { height } \\
\text { (mm) }\end{array}$ & $\begin{array}{l}\text { volume } \\
\text { (cm3) }\end{array}$ & $\begin{array}{l}\text { height } \\
\text { (mm) }\end{array}$ & $\begin{array}{l}\text { volume } \\
\text { (cm3) }\end{array}$ & $\begin{array}{l}\text { height } \\
\text { (mm) }\end{array}$ & $\begin{array}{c}\text { volume } \\
\text { (x) }\end{array}$ \\
\hline 0 & 200.0 & 49.4 & 3585.6 & 3585.6 & 0.0 & 49.4 & 24.7 & 10.6 & 130.0 & 10.6 & 130.0 & 0 & 0 \\
\hline 13 & 200.0 & 49.4 & 3585.6 & 3581.0 & 4.6 & 44.8 & 22.4 & 10.6 & 130.0 & 10.6 & 130.0 & 0 & 0 \\
\hline 20 & 200.0 & 44.8 & 3581.0 & 3572.9 & 8.1 & 36.7 & 18.4 & 10.6 & 130.0 & 10.6 & 130.0 & 0 & 0 \\
\hline 28 & 200.0 & 36.7 & 3572.9 & 3557.3 & 15.6 & 21.1 & 10.6 & 10.6 & 130.0 & 10.6 & 130.0 & 0 & 0 \\
\hline 36 & 200.0 & 21.1 & 3557.3 & 3542.1 & 15.2 & 5.9 & 3.0 & 10.6 & 130.0 & 10.6 & 130.0 & 0 & 0 \\
\hline so & 200.0 & 5.9 & 3542.1 & 3539.8 & 2.3 & 3.6 & 1.8 & 10.6 & 130.0 & 10.6 & 130.0 & 0 & 0 \\
\hline 38 & 200.0 & 3.6 & 3539.8 & 3539.8 & 0.0 & 3.6 & 1.8 & 10.6 & 130.0 & 10.6 & 130.0 & 0 & 0 \\
\hline 29 & 200.0 & 3.6 & 3539.8 & 3539.8 & 0.0 & 3.6 & 1.8 & 10.6 & 130.0 & 20.5 & 130.0 & 0 & 0 \\
\hline 20 & 200.0 & 3.6 & 3539.8 & 3542.2 & -2.4 & 6.0 & 3.0 & 10.6 & 130.0 & 10.6 & 130.0 & 0 & 0 \\
\hline 5 & 200.0 & 6.0 & 3542.2 & 3561.0 & -18.8 & 24.8 & 12.4 & 10.6 & 130.0 & 10.6 & 130.00 & 0 & 0 \\
\hline 0 & 200.0 & 24.8 & 3561.0 & 3577.9 & -16.9 & 41.7 & 20.9 & 10.6 & 130.0 & 10.6 & 130.00 & 0 & 0 \\
\hline
\end{tabular}

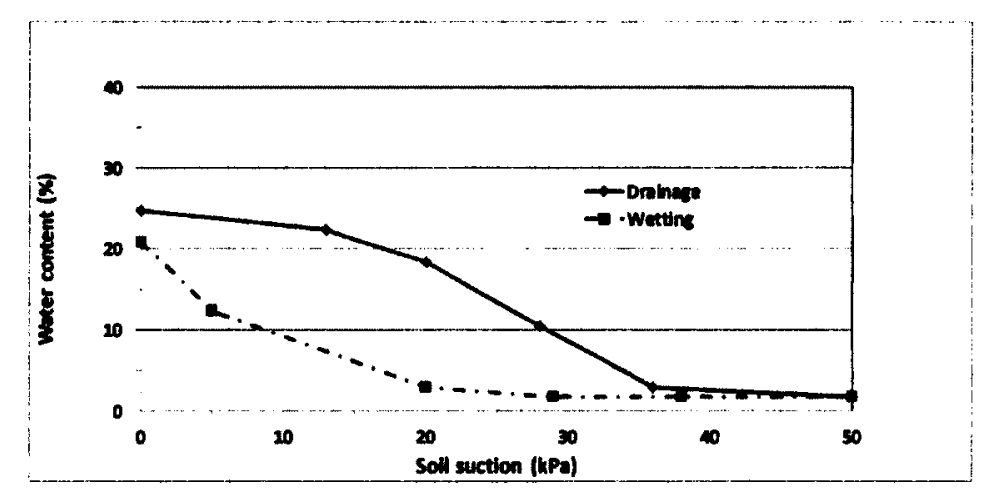

Figure 5-17: Water content-suction curve for silt, $\mathrm{w}_{\mathrm{i}}=\mathbf{2 4 . 7 \%}$, after settling

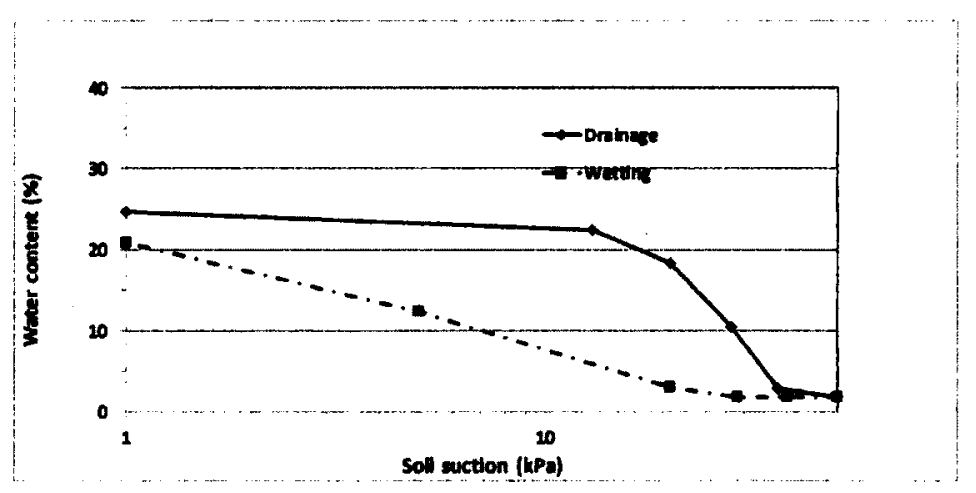

Figure 5-18: Water content-suction curve for silt, $\mathrm{w}_{\mathrm{i}}=24.7 \%$, after settling, $\log$ scale 


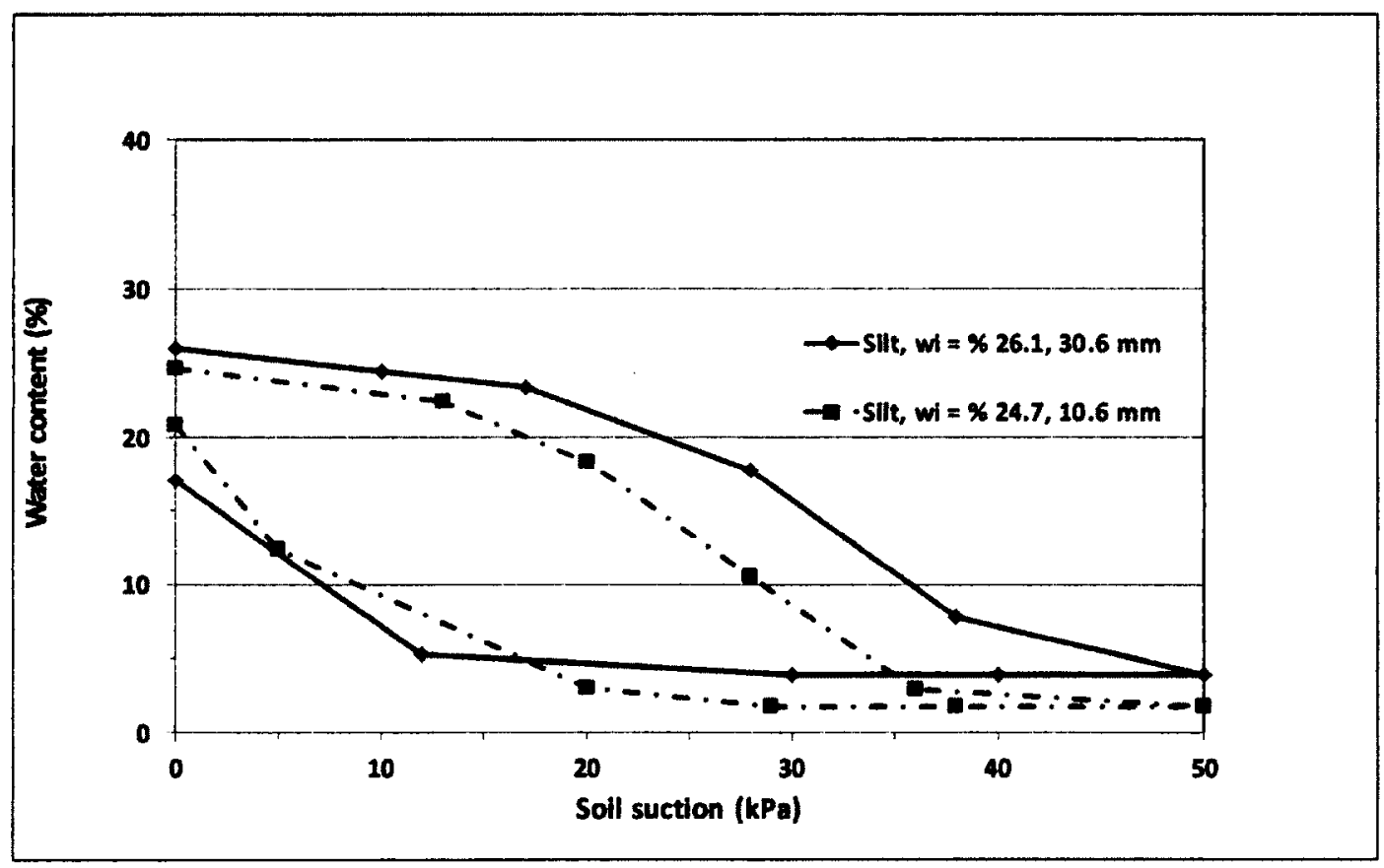

Figure 5-19: Comparison of water content-suction curve for silt with different $w_{i}$

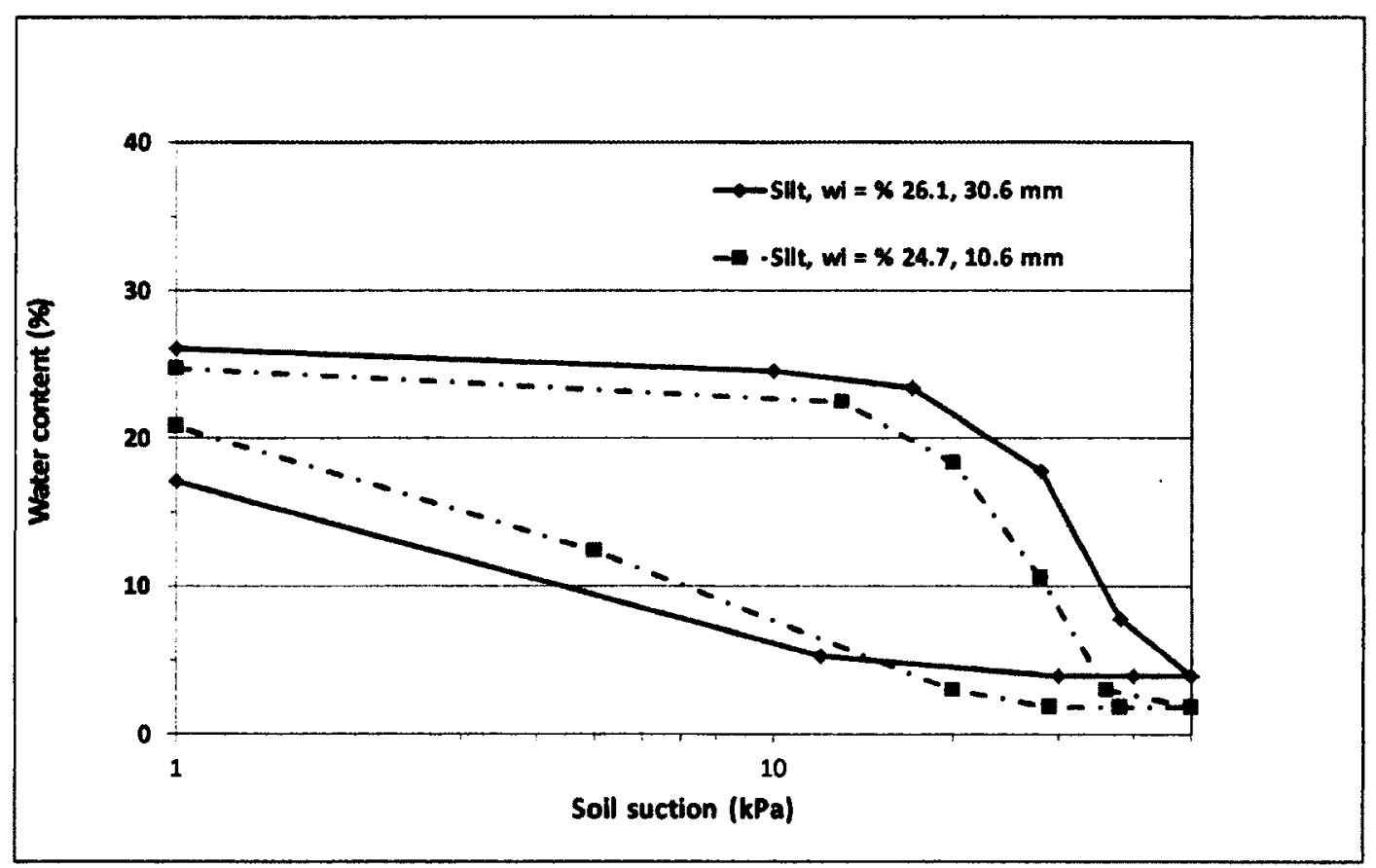

Figure 5-20: Comparison of water content-suction curve for silt with different $w_{i}$, log scale 


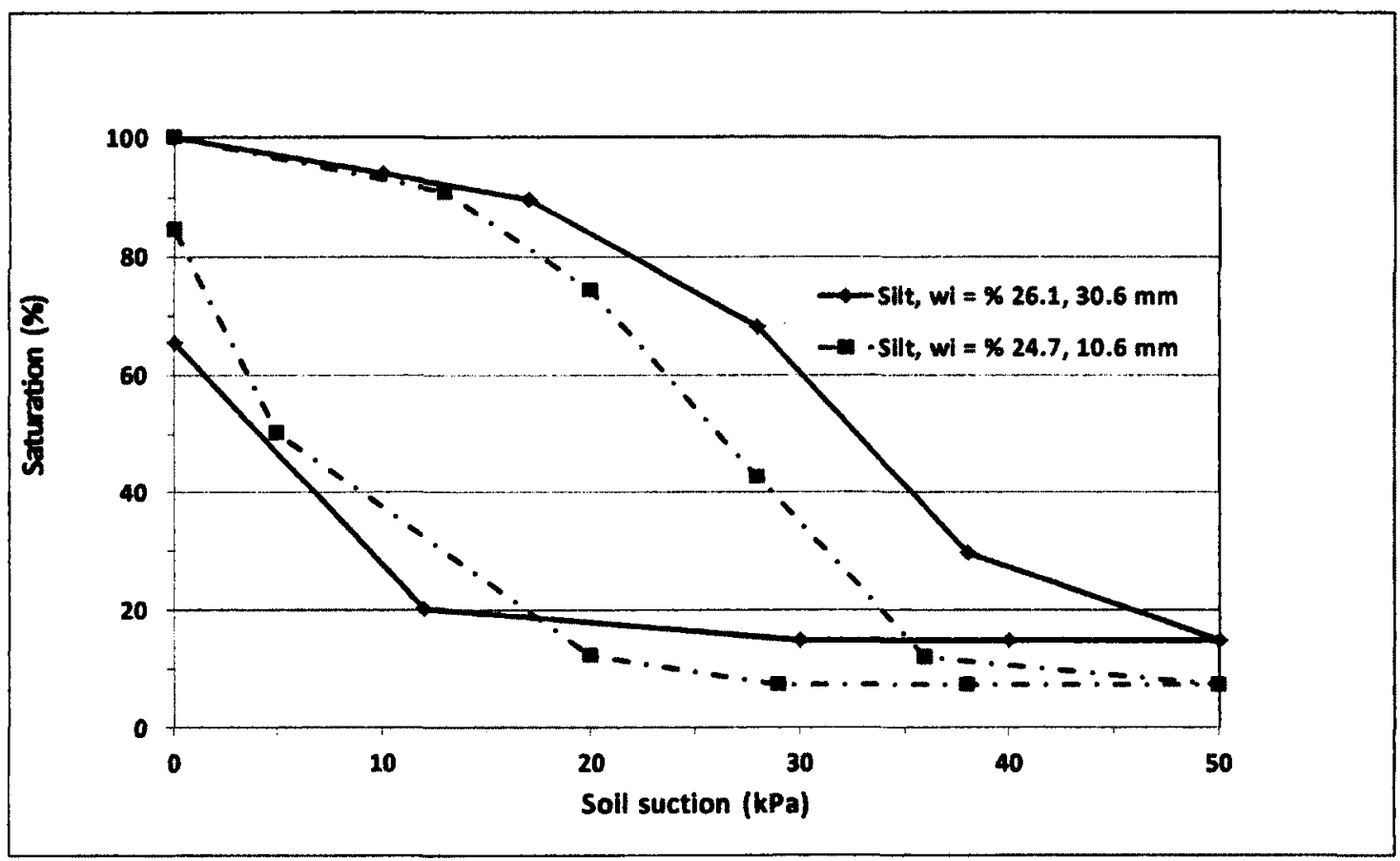

Figure 5-21: Comparison of saturation-suction curve for silt with different $w_{i}$

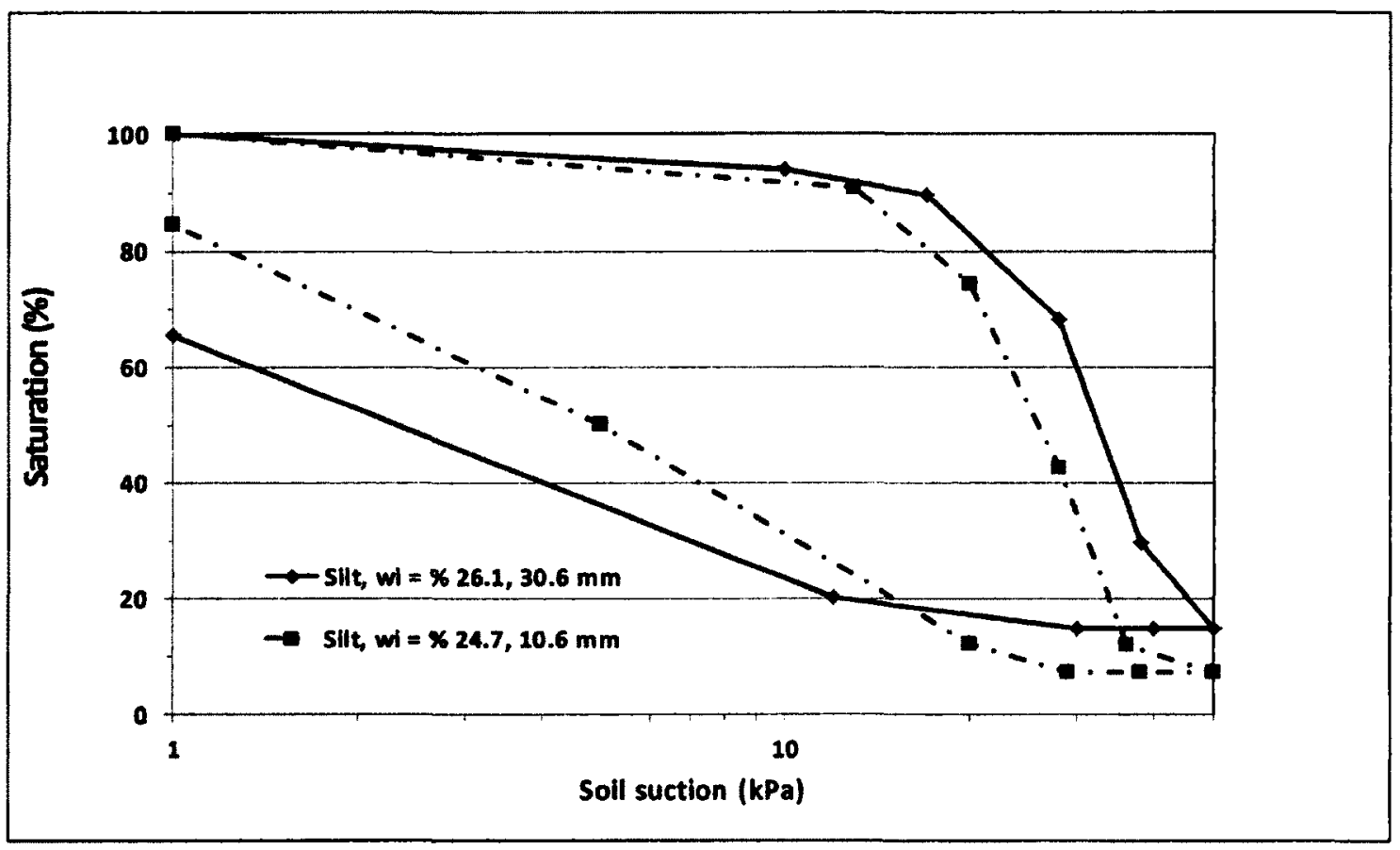

Figure 5-22: Comparison of saturation-suction curve for silt with different $w_{i}, \log$ scale 


\section{5-2. Oil sand mine tailings ( MFT)}

As described in chapter 3, fine tailings produced by discharging whole oil sand tailings in impoundments develop into mature fine tailings (MFT). Particle size of MFT is largely less than $44 \mu \mathrm{m}$. Initial water content of MFT, pumping water content, is around $120 \%$ to $130 \%$.

The behaviour of MFT under different initial water contents, different sample preparation regimens, and with and without polymer amendment have been investigated. The different treatments are summarized in Table 5-5.

Table 5-5: Different experimental tests on oil sand mine tailings (MFT)

\begin{tabular}{|l|l|}
\hline \multirow{2}{*}{ Effect of initial water content on TWCC } & $\begin{array}{l}\text { Wi=127\%, no mixing, sample taken } \\
\text { directly from shipping container. }\end{array}$ \\
\cline { 2 - 2 } & $\mathrm{Wi}=131 \%$, hand mixed sample \\
\cline { 2 - 2 } & $\mathrm{Wi}=157 \%$, hand mixed sample \\
\hline Effect of mixing on TWCC & $\mathrm{Wi}=155 \%$, mechanically mixed sample \\
\hline Effect of polymer on TWCC & $\begin{array}{l}\mathrm{Wi}=172 \%, 1 \mathrm{~g} \text { polymer to } 1000 \mathrm{~g} \text { MFT, } \\
\text { using hand mixing. }\end{array}$ \\
\hline Effect of longer mixing polymer on TWCC & Wi $=123 \%, 1 \mathrm{~g}$ polymer to $1000 \mathrm{~g}$ MFT, \\
& using mechanical mixing \\
\hline
\end{tabular}




\section{5-2-1. Effect of initial water content on TWCC in oil sand mine tailings (MFT)}

To study the effect of initial water content on TWCC in oil sand mine tailings, three experimental tests are done on this tailings with different water contents:

1. $\mathrm{w}_{\mathrm{i}}=127 \%$ minimal disturbance

2. $\mathrm{w}_{\mathrm{i}}=131 \%$, sample mixed by hand

3. $w_{i}=157 \%$ sample mixed by hand

\section{5-2-1-1. $\quad w_{1}=127 \%$ minimal disturbance}

These tailings were taken from the bucket without any mixing or disturbance. These tailings were at least one year in the bucket after it was obtained from existing tailings impoundment at Muskeg river mine. Initial water content of sample is $127 \%$ with saturation of $100 \%$. Result of this test is shown in Figures 5-23 to 5-30. Table A5-6 and A5-7 in the appendix show the details. At $800 \mathrm{kPa}$ water content decreased to $32 \%$ and saturation at this point was $55 \%$. Air entry value is around $75 \mathrm{kPa}$ With decreasing suction to $0 \mathrm{kPa}$ water content and saturation slowly increased to $37 \%$ and $64 \%$ respectively. Smaller particles have smaller pore size and bigger AEV. Void ratio of sample decreases from 3.24 to 1.48 at $800 \mathrm{kPa}$ suction and almost did not change when suction decreased. This void ratio is still well above the shrinkage limit of untreated MFT, which is about 0.6 (Koehler 2011). 


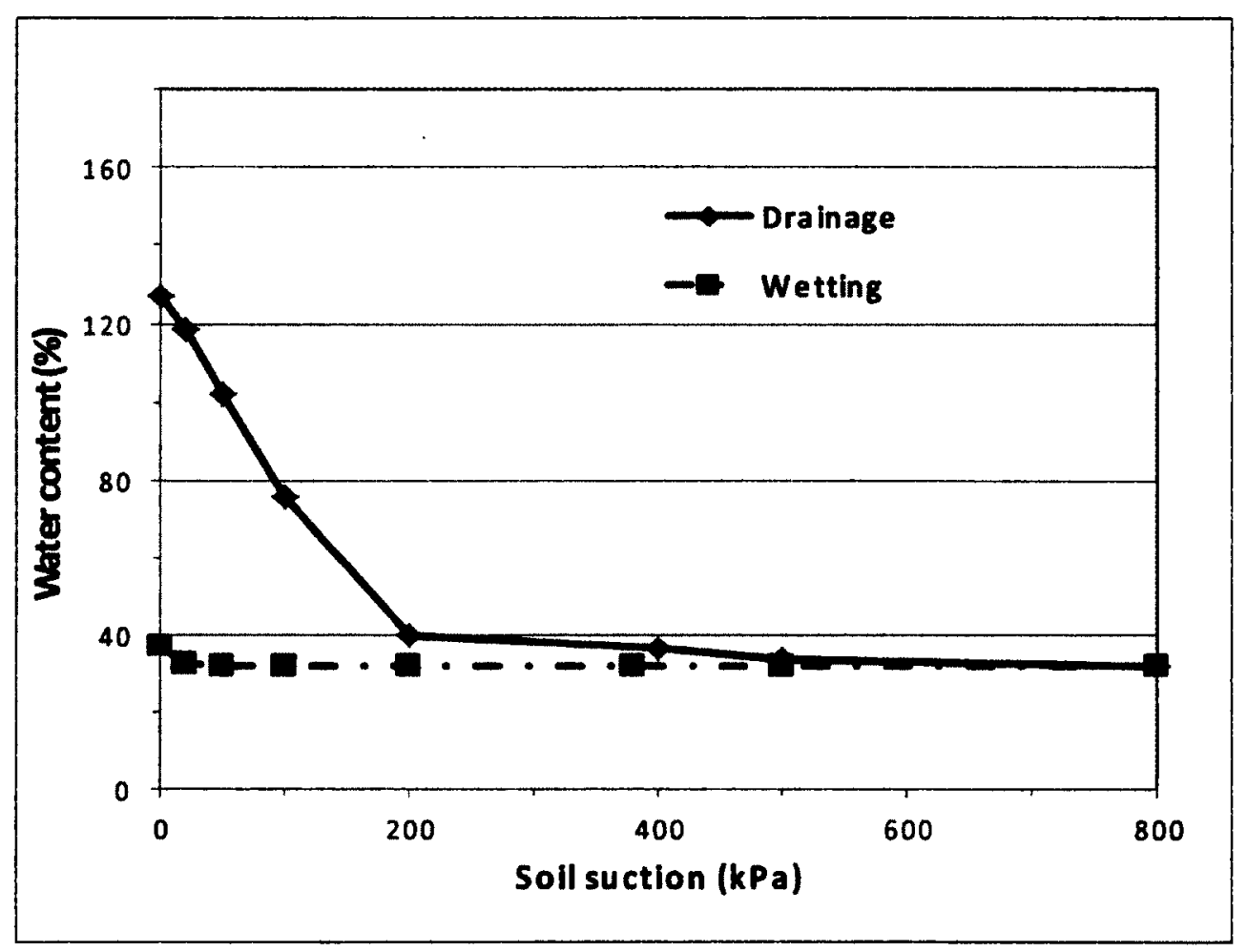

Figure 5-23: Water content-suction curve for oil sand tailings, $\mathrm{w}_{\mathrm{i}}=127.1 \%$

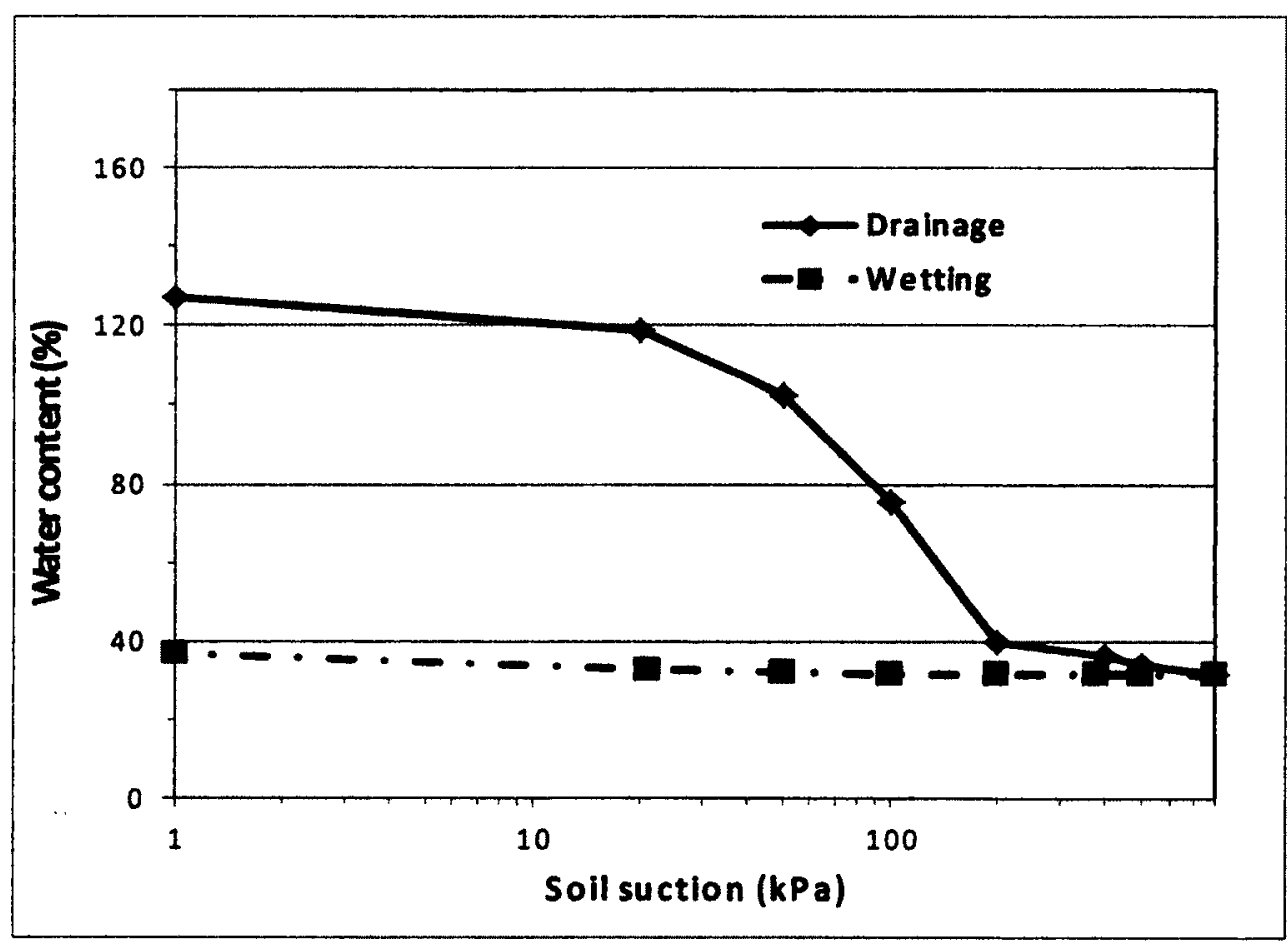

Figure 5-24: Water content-suction curve for oil sand tailings, $\mathrm{w}_{\mathrm{i}}=127.1 \%$, log scale 


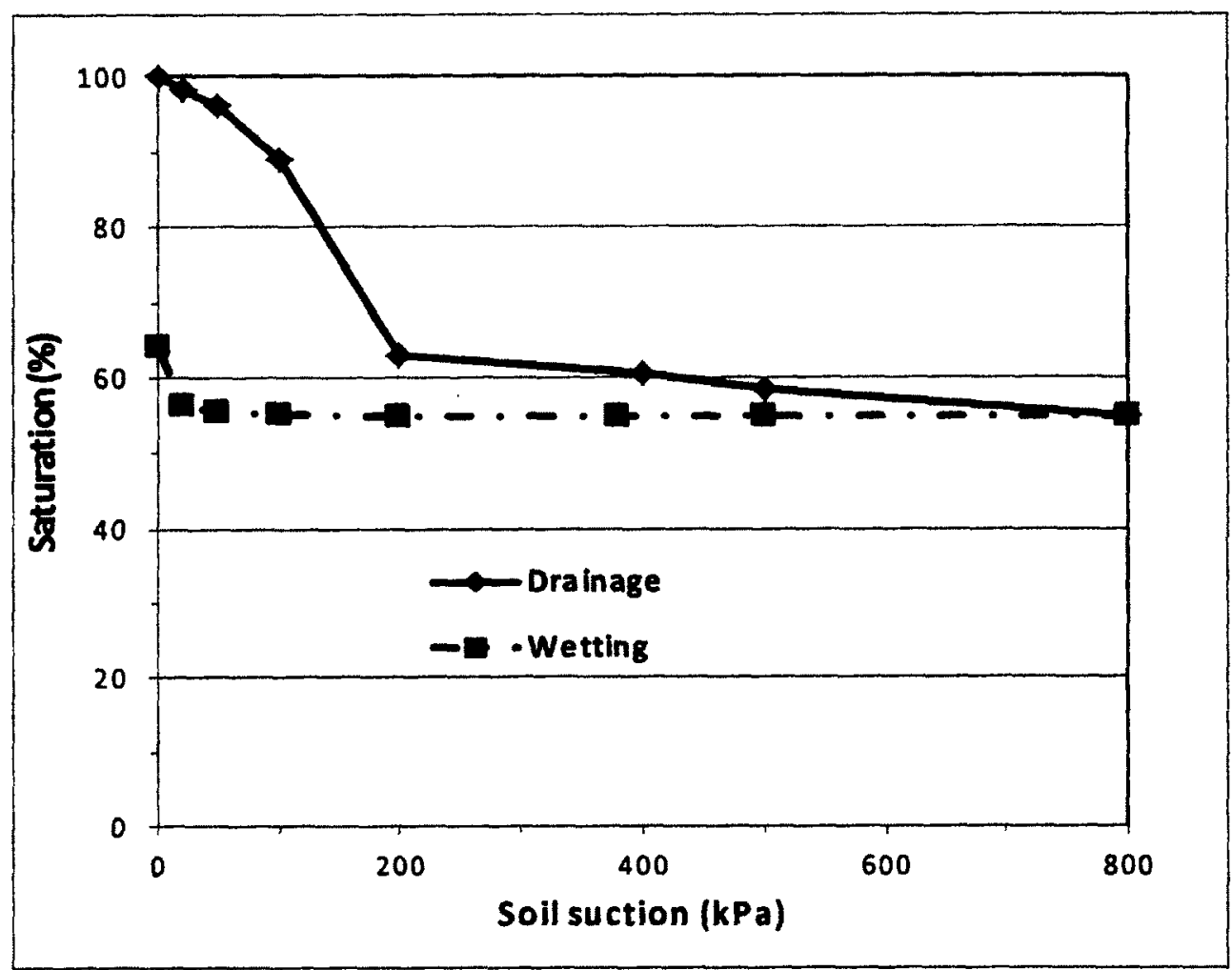

Figure 5-25: Saturation-suction curve for oil sand tailings, $w_{\mathrm{i}}=127.1 \%$,

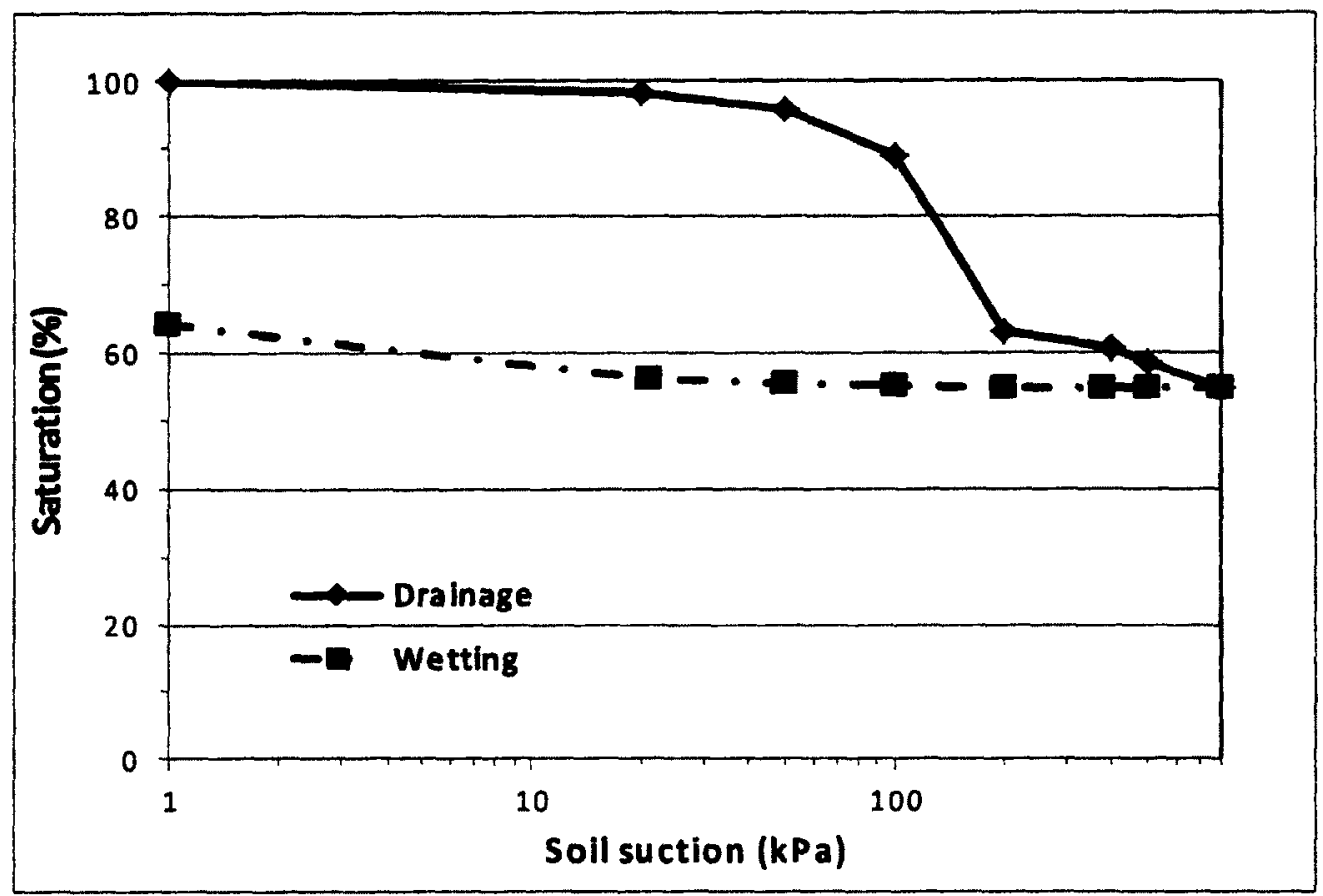

Figure 5-26: Saturation-suction curve for oil sand tailings, $w_{i}=127.1 \%$, log scale 


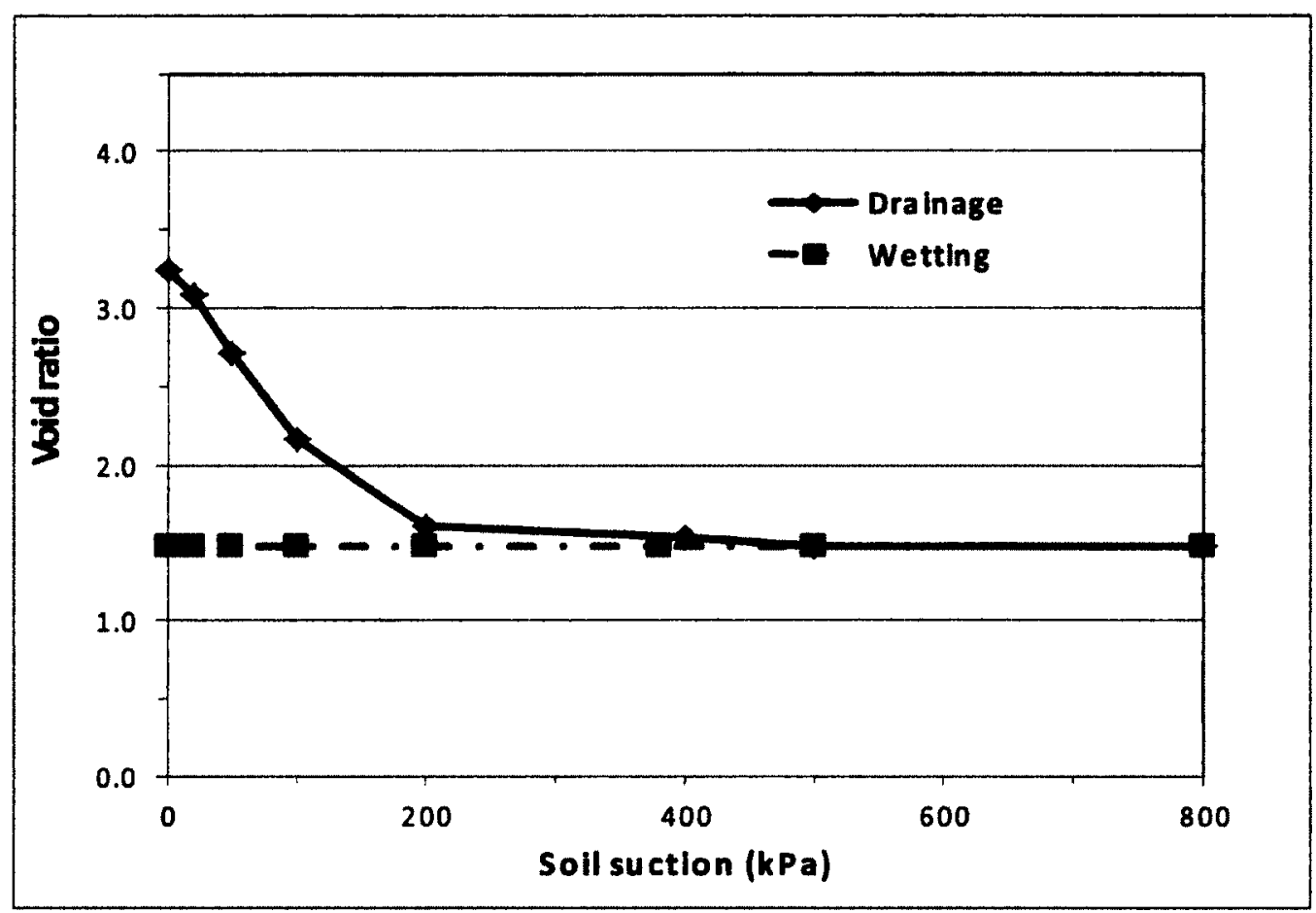

Figure 5-27: Void ratio-suction curve for oil sand tailings, $w_{i}=127.1 \%$

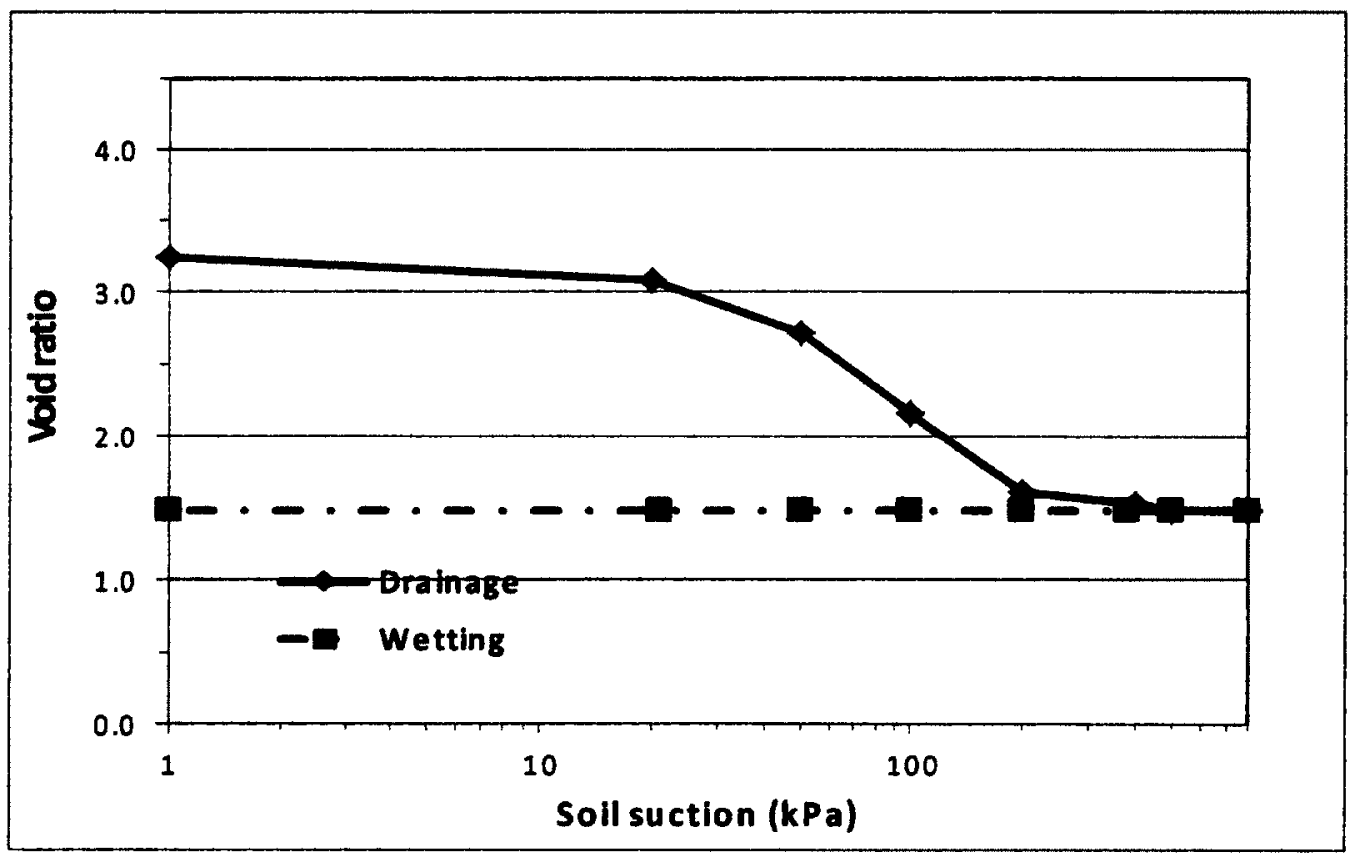

Figure 5-28: Void ratio-suction curve for oil sand tailings, $w_{i}=127.1 \%$, $\log$ scale 


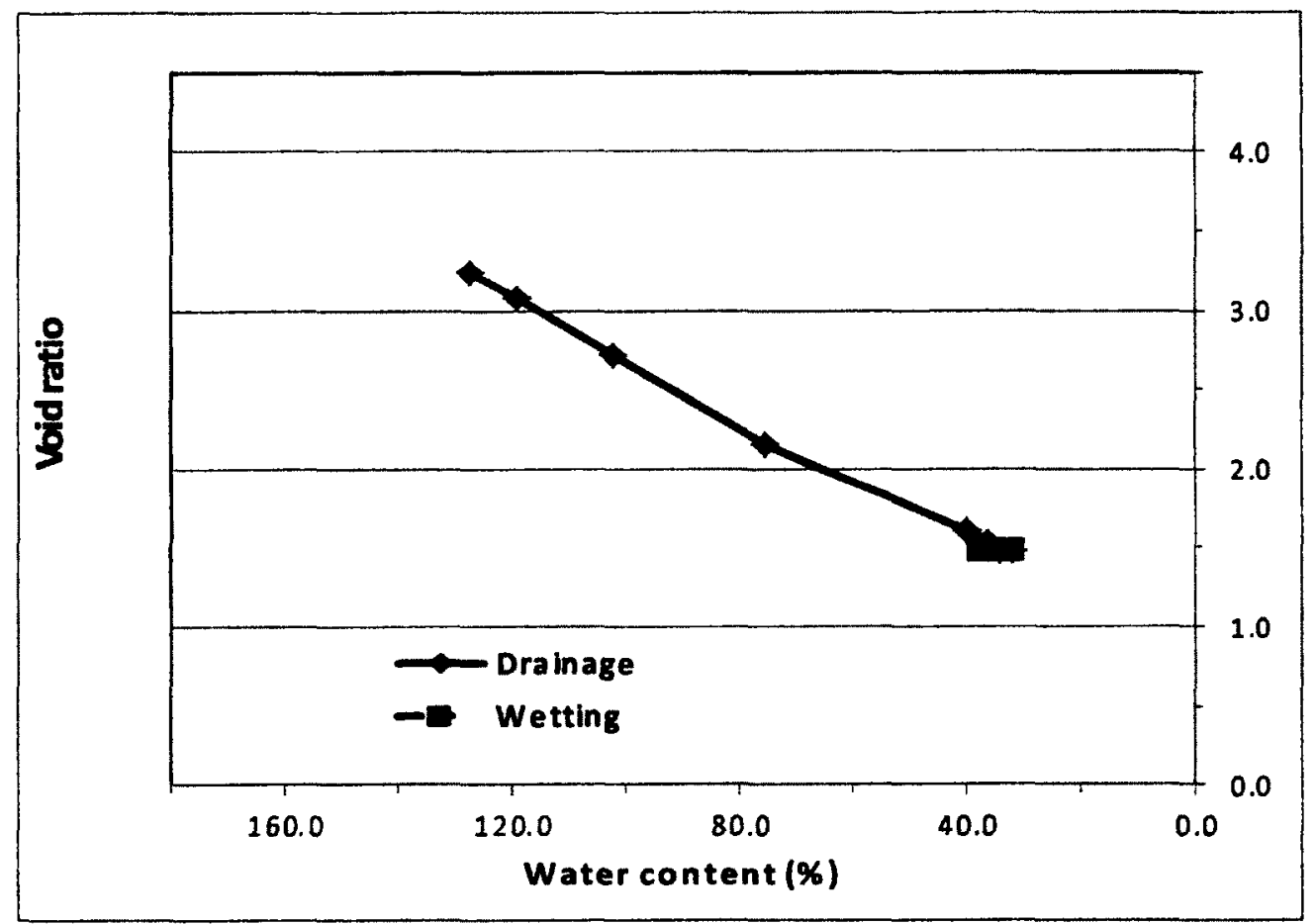

Figure 5-29: Shrinkage curve for oil sand tailings, $w_{i}=127.1 \%$

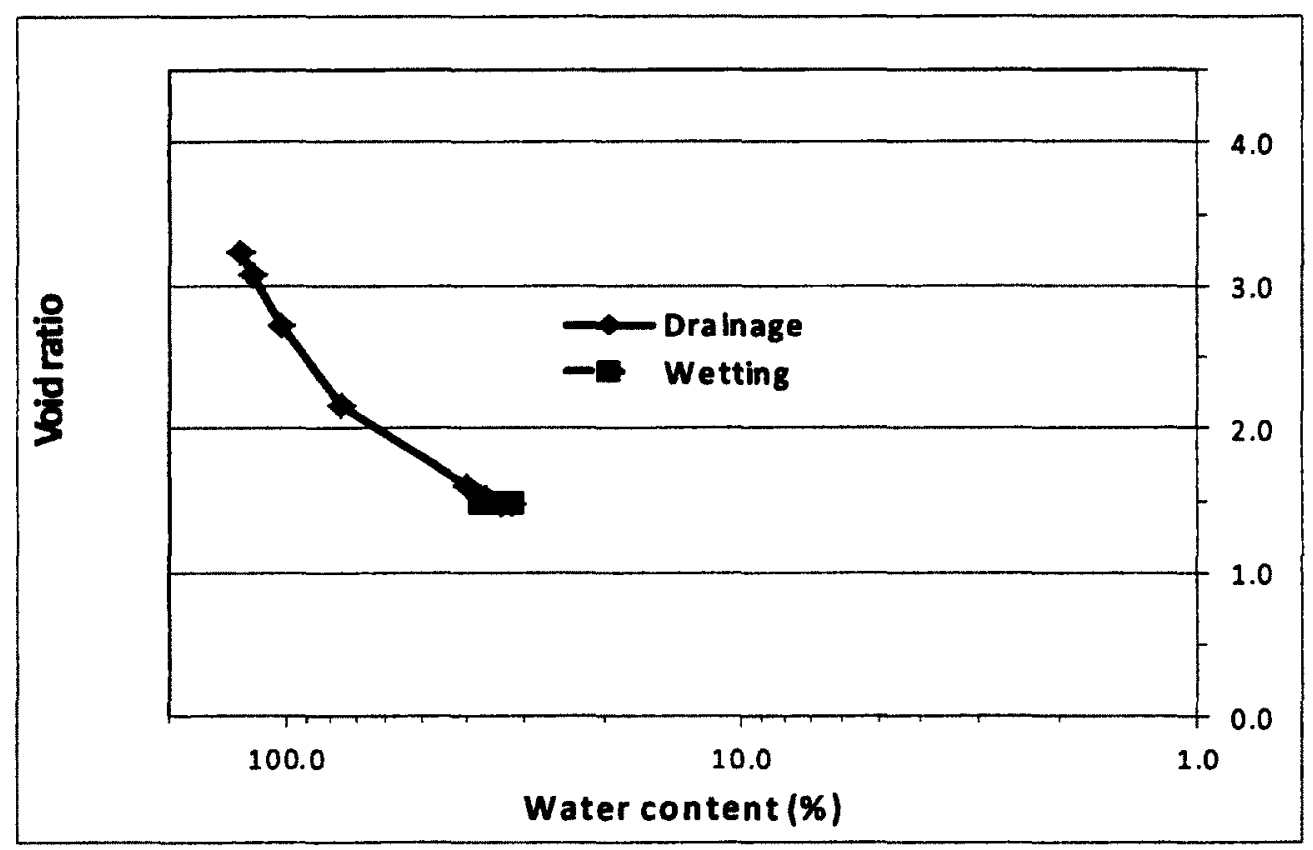

Figure 5-30: Shrinkage curve for oil sand tailings, $w_{i}=127.1 \%, \log$ scale 


\section{5-2-1-2. $\quad W_{i}=131 \%$ (small amount of water added with hand mixing)}

For this test, hand mixing and addition of small mass of water was used to increase the water content to $131 \%$, with saturation of $100 \%$ and with a void ratio of 3.34 . Sample was left for 24 hours to settle before axis-translation. After settling time $9.7 \mathrm{~g}$ water was taken out from top of the sample by syringe and void ratio of sample decreased to 3.15 .

During the TWCC test, water content and saturation of sample decreased to $31 \%$ and $50 \%$, respectively. Void ratio decreased to 1.50 . Figures $5-31$ and 5-32 show variations of water content and saturation in terms of suction in log scale. Void ratio versus suction curve and shrinkage curve can be seen in Figures 5-33 and 5-34. Tables A5-8 and A5-9 and Figures A5-13 to A5-16 in the appendix show more details.

\section{5-2-1-3. $\quad W_{1}=157 \%$ and some mixed sample}

Additional water was added by hand mixing to create a sample with $157 \%$ water content with $100 \%$ saturation and void ratio of 3.99 . After 24 hours of settling, the sample settled about $0.6 \mathrm{~mm}$ with $5.4 \mathrm{~g}$ water on the top which removed by syringe. Water content and void ratio of sample at this point were $150 \%$ and 3.89 respectively.

Suction was applied on this sample in range of $0 \mathrm{kPa}$ to $800 \mathrm{kPa}$ then decreased to 0 $\mathrm{kPa}$ Water content and saturation of sample at maximum suction were $30 \%$ and $62 \%$ with void ratio of 1.25 . AEV for this tailings sample was around $55 \mathrm{kPa}$ Figures $5-35$ to 5-38 show variations of water content, saturation and void ratio of sample in terms of suction. Also shrinkage curve can be seen in Figure 5-50. Tables A5-10 and A5-11 and Figures A5-17 to A5-20 in the appendix show more details. 


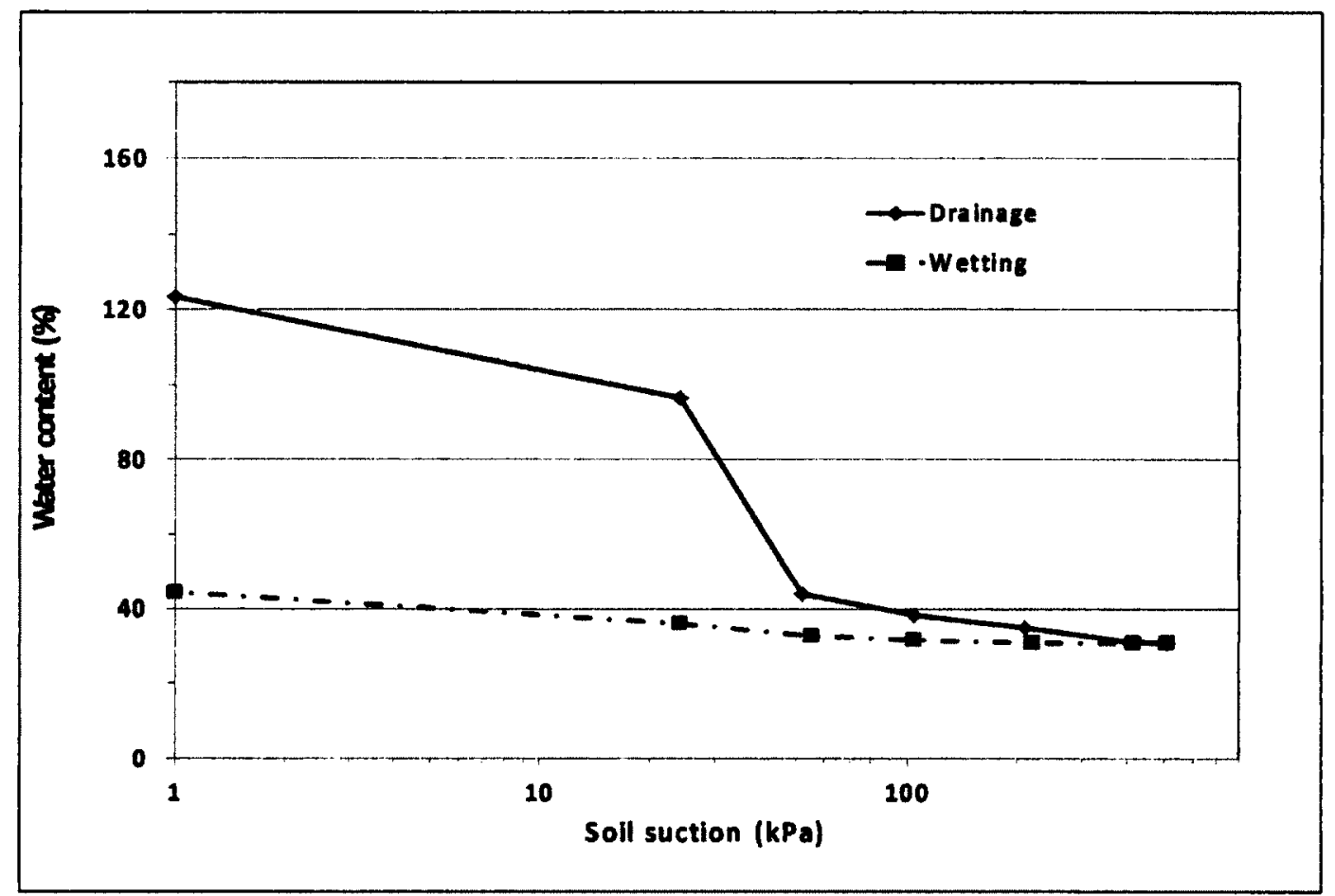

Figure 5-31: Water content-suction curve for oil sand tailings, $w_{i}=131.2 \%, \log$ scale

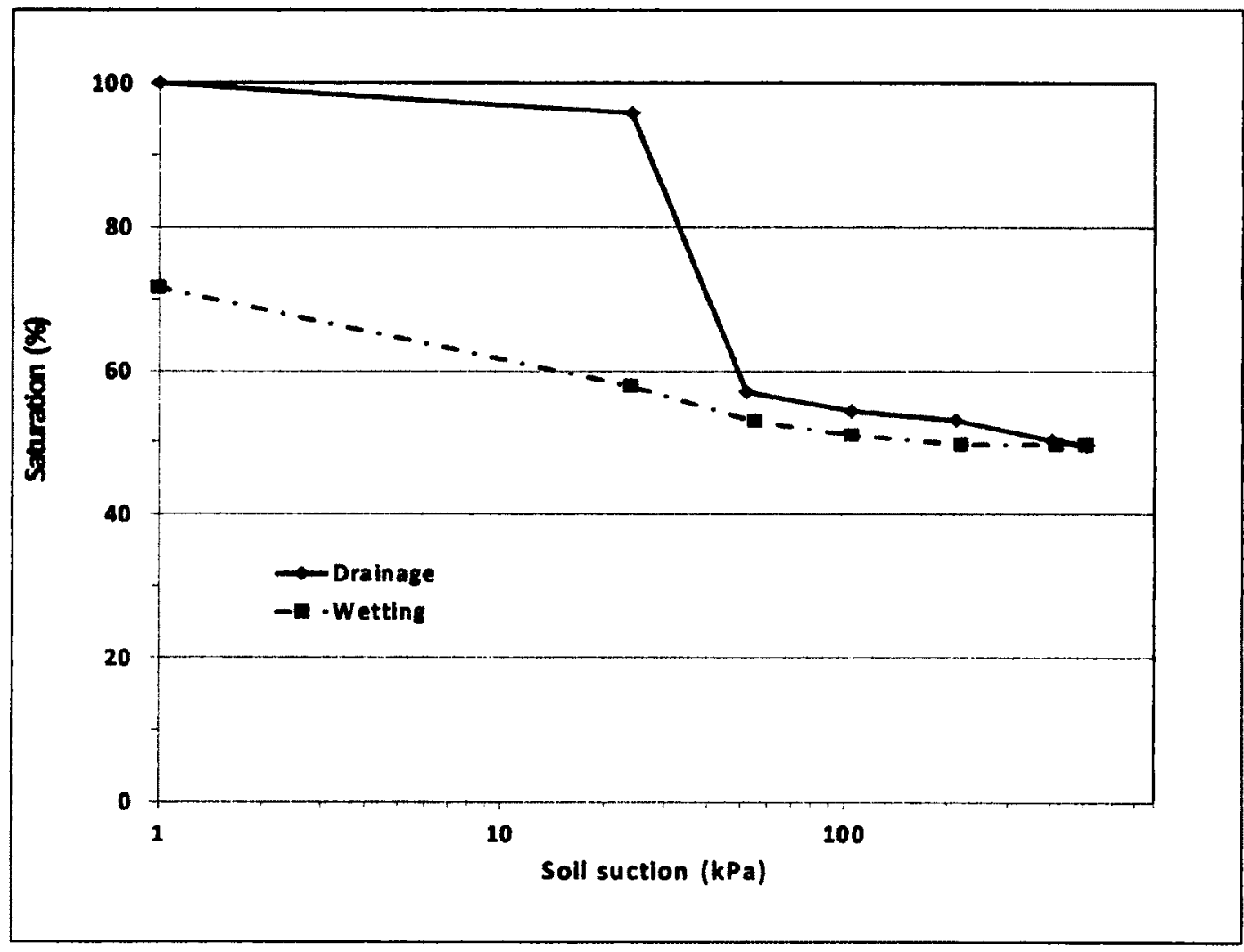

Figure 5-32: Saturation-suction curve for oil sand tailings, $w_{i}=131.2 \%$, log scale 


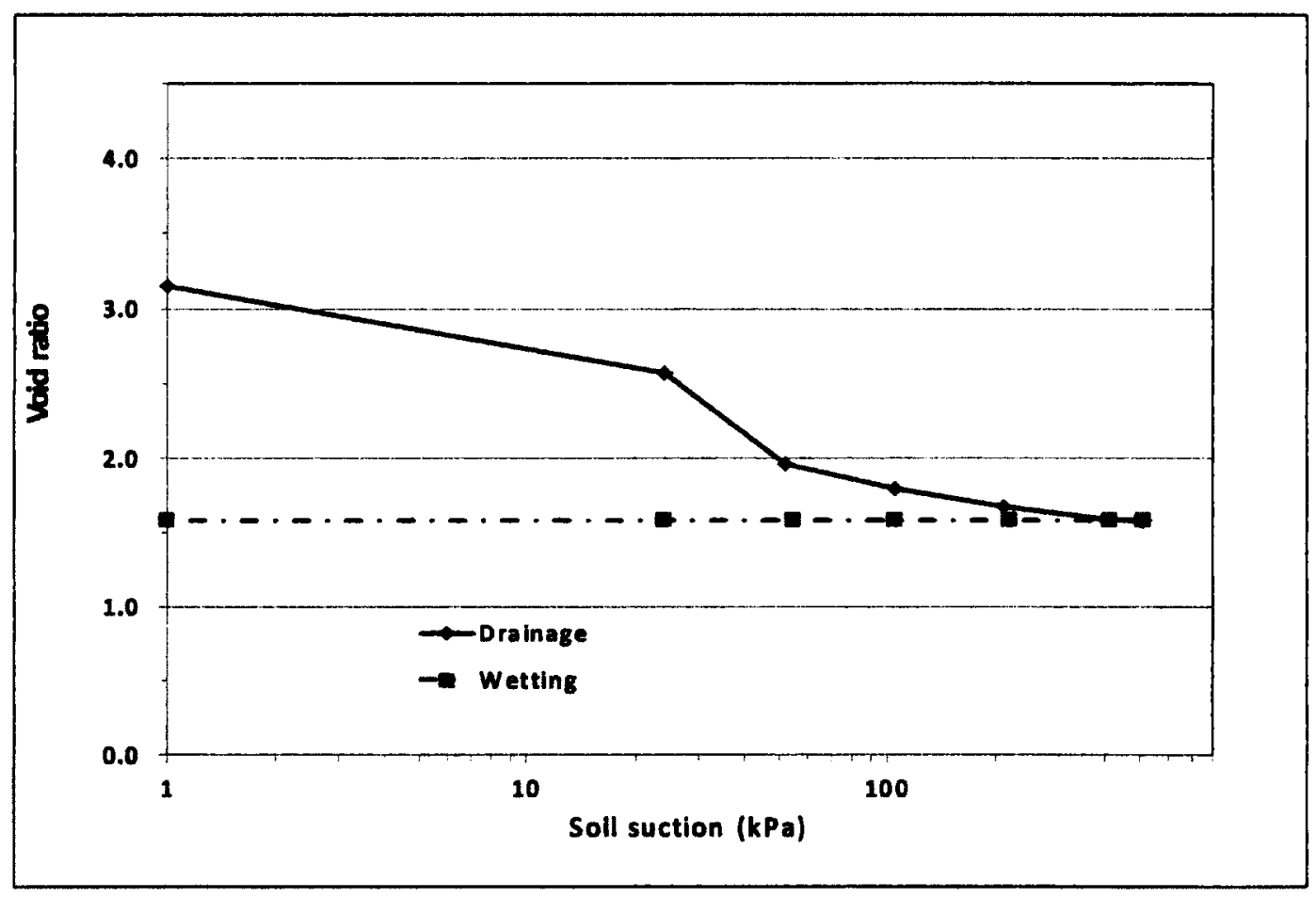

Figure 5-33: Void ratio-suction curve for oil sand tailings, $w_{i}=131.2 \%$, $\log$ scale

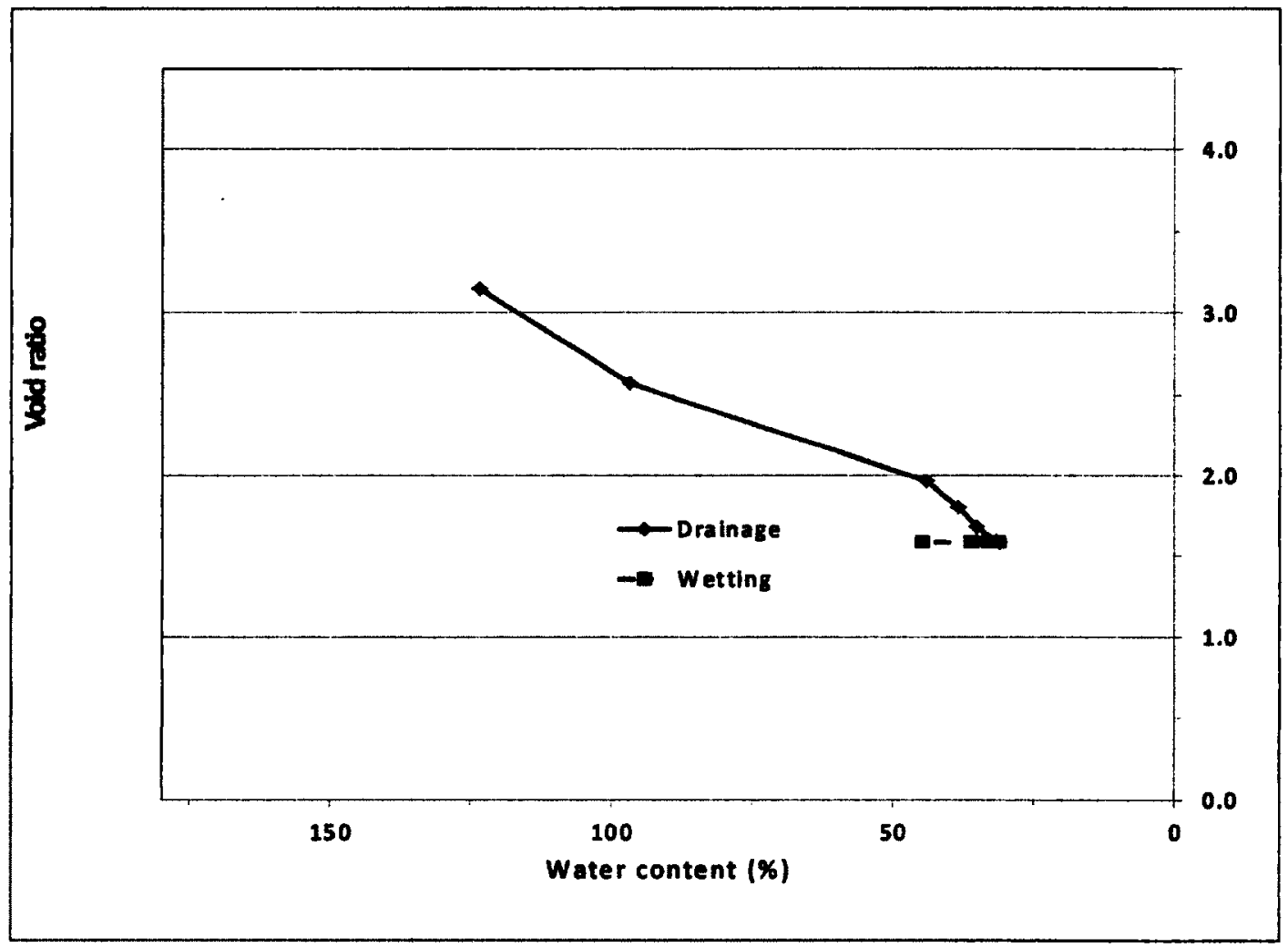

Figure 5-34: Shrinkage curve for oil sand tailings, $w_{i}=131.2 \%$ 


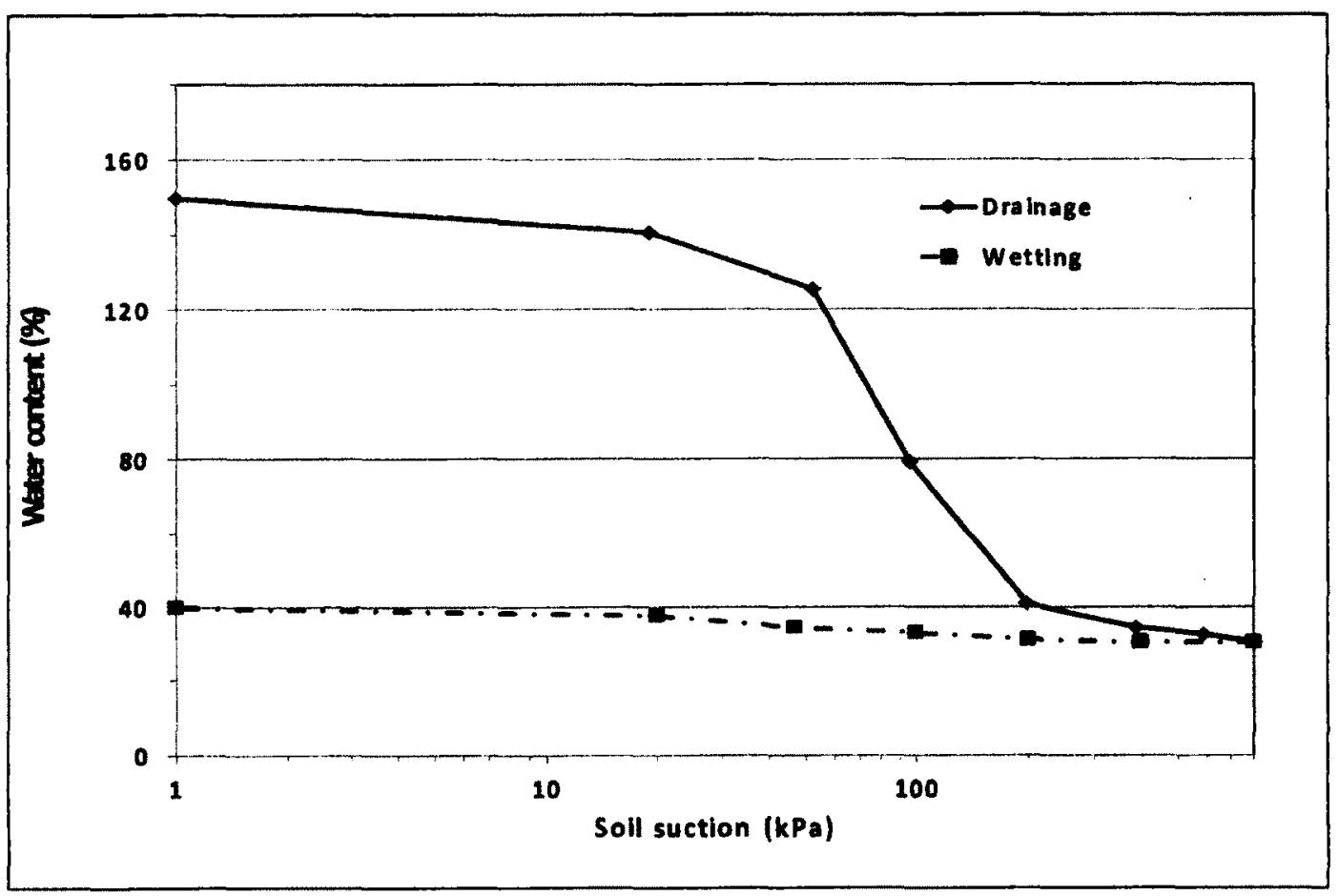

Figure 5-35: Water content-suction curve for oil sand tailings, $\mathrm{w}_{\mathrm{i}}=156.6 \%$, log scale

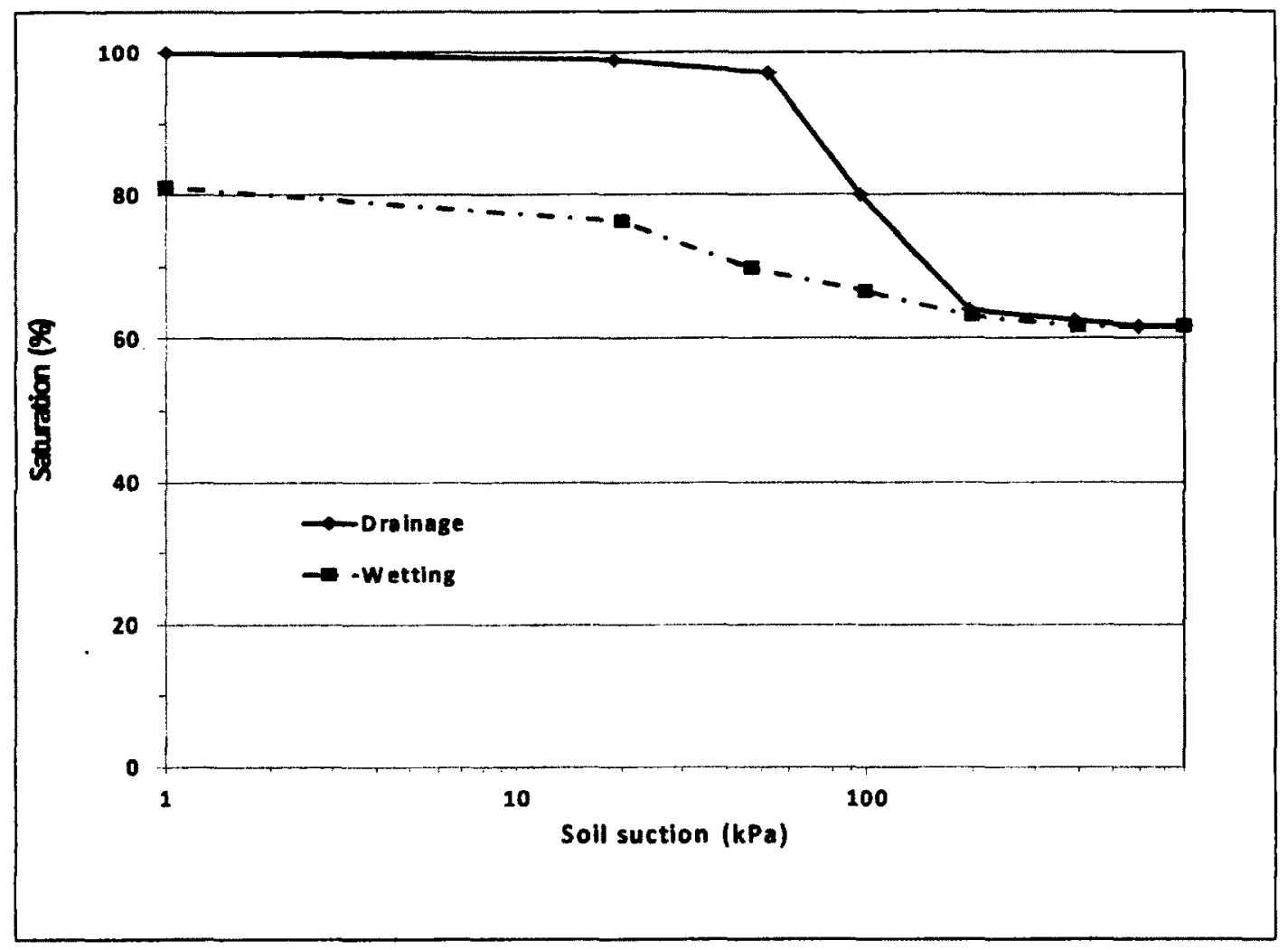

Figure 5-36: Saturation-suction curve for oil sand tailings, $\mathrm{w}_{\mathrm{i}}=156.6 \%$, log scale 


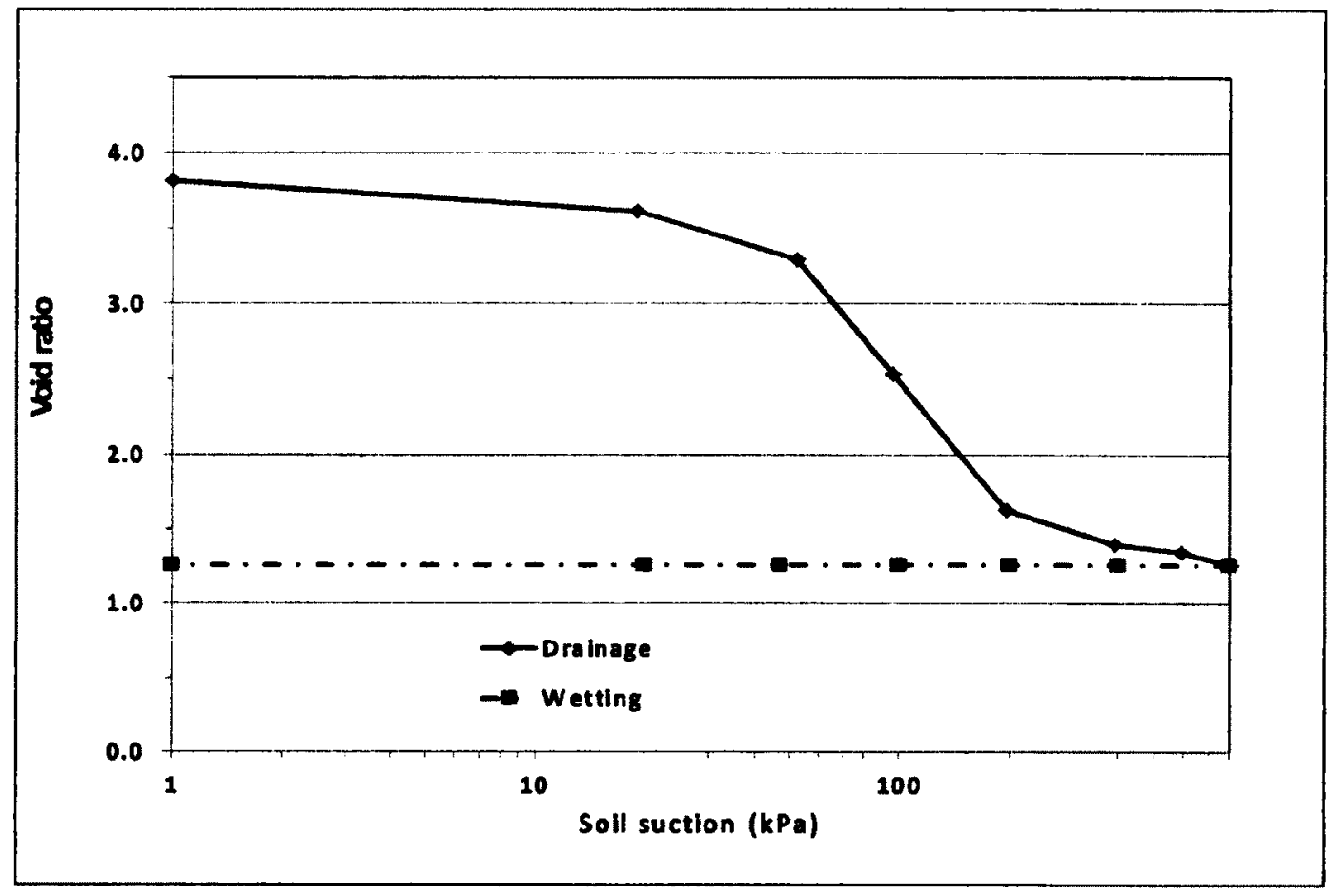

Figure 5-37: Void ratio-suction curve for oil sand tailings, $w_{i}=156.6 \%$, log scale

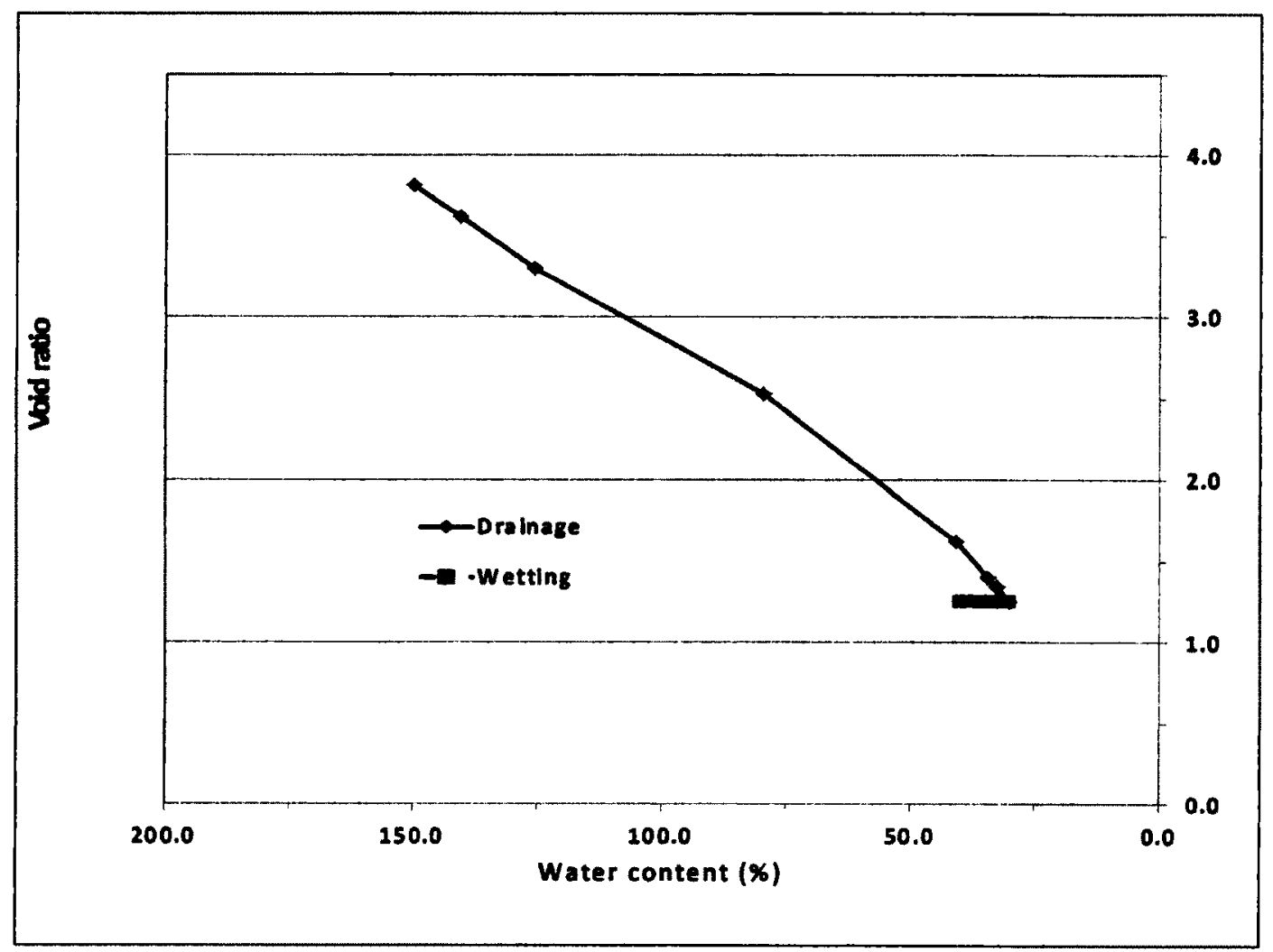

Figure 5-38: Shrinkage curve for oil sand tailings, $w_{i}=156.6 \%$ 


\section{5-2-1-4. Comparison of initial water content effect on TWCC for oil sand mine tailings}

Table 5-6 and Figures 5-39 to 5-42 shows the effects of initial water content on TWCC for oil sand mine tailings:

- Increase in initial water content by hand mixing results in an increase in the AEV.

- Initial water content does not have an effect on the residual water content. Residual water content is around $30 \%$ to $32 \%$ for all of the three samples. In other words at high suction the water content - suction curve tend to converge.

- For the wetting curves, there are similar behaviours but high initial water contents lead to higher degrees of saturation at the end of wetting curve, (suction $=0 \mathrm{kPa}$ ).

- Variation in initial water content does not have significant effect on the shrinkage curve (Figure 5-54). 
Table 5-6: Effect of initial water content on oil sand tailings behaviour

\begin{tabular}{|c|c|c|c|c|c|c|c|c|c|c|c|}
\hline \multicolumn{4}{|c|}{$w_{i}=127.1 \%$} & \multicolumn{4}{|c|}{$w_{i}=131.2 \%$} & \multicolumn{4}{|c|}{$w_{i}=156.6 \%$} \\
\hline $\begin{array}{l}\text { Sution } \\
\text { (PBa) }\end{array}$ & $\begin{array}{l}\text { Whter } \\
\text { cortert } \\
\text { (9) }\end{array}$ & $\begin{array}{c}\text { Deqeef } \\
\text { seturation } \\
\text { (\%) }\end{array}$ & Vidratio & $\begin{array}{l}\text { Suttion } \\
\text { (BPa) }\end{array}$ & $\begin{array}{c}\text { Wets cotet } \\
\text { (9A }\end{array}$ & $\begin{array}{c}\text { Degeed } \\
\text { sturation } \\
\text { (9A }\end{array}$ & Vidratio & $\begin{array}{l}\text { Suction } \\
\text { (APa) }\end{array}$ & $\begin{array}{c}\text { Weter contert } \\
(\% 9\end{array}$ & $\begin{array}{l}\text { Degeed } \\
\text { scturation } \\
\text { (9) }\end{array}$ & Voidratio \\
\hline 0 & 10.1 & mo & 3.24 & 0 & 1312 & 100 & 334 & 0 & 1566 & 100 & 399 \\
\hline 0 & 177.1 & 1000 & 3.24 & 0 & 135 & $1 \mathrm{mo}$ & 315 & 0 & 1998 & 1000 & 38 \\
\hline$D$ & 1788 & 983 & 308 & 24 & 967 & 98 & 257 & 19 & 1005 & 里 & 302 \\
\hline 50 & 1024 & 961 & 272 & 도 & 40 & 57.1 & 197 & 도 & 1256 & 97.1 & 330 \\
\hline 10 & 726 & 82 & 216 & 105 & 385 & 544 & 180 & 96 & 795 & 800 & 25 \\
\hline 20 & 299 & $\mathbf{8 1}$ & 16 & 211 & 350 & 532 & 168 & 297 & 408 & 640 & 168 \\
\hline 40 & 363 & 605 & 158 & 40 & 315 & 504 & 100 & 300 & 345 & $\underline{26}$ & 140 \\
\hline 500 & 340 & $\$ 85$ & 148 & 50 & 310 & 498 & 199 & 900 & 326 & 68 & 13 \\
\hline $\mathbf{8 0}$ & 318 & 549 & 148 & 45 & 310 & 498 & 19 & 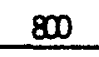 & 303 & $\mathfrak{6 7}$ & 15 \\
\hline 500 & 318 & 549 & 148 & 20 & 310 & 48 & 19 & 40 & 303 & a7 & 25 \\
\hline 300 & 318 & 549 & 148 & 106 & 317 & 511 & 19 & 20 & 311 & $\$ 2$ & 125 \\
\hline 200 & 318 & 549 & 148 & $\Phi$ & 329 & 50 & 159 & 100 & 327 & 665 & 125 \\
\hline 100 & 319 & 551 & 148 & 24 & 350 & 580 & 199 & 47 & 344 & 69 & 125 \\
\hline 50 & 322 & 555 & 148 & 0 & 445 & 716 & 15 & 20 & 375 & 763 & 15 \\
\hline 21 & 327 & 63 & 148 & & & & & 0 & 299 & 811 & 15 \\
\hline 0 & 37.2 & 640 & 148 & & & & & & & & \\
\hline
\end{tabular}




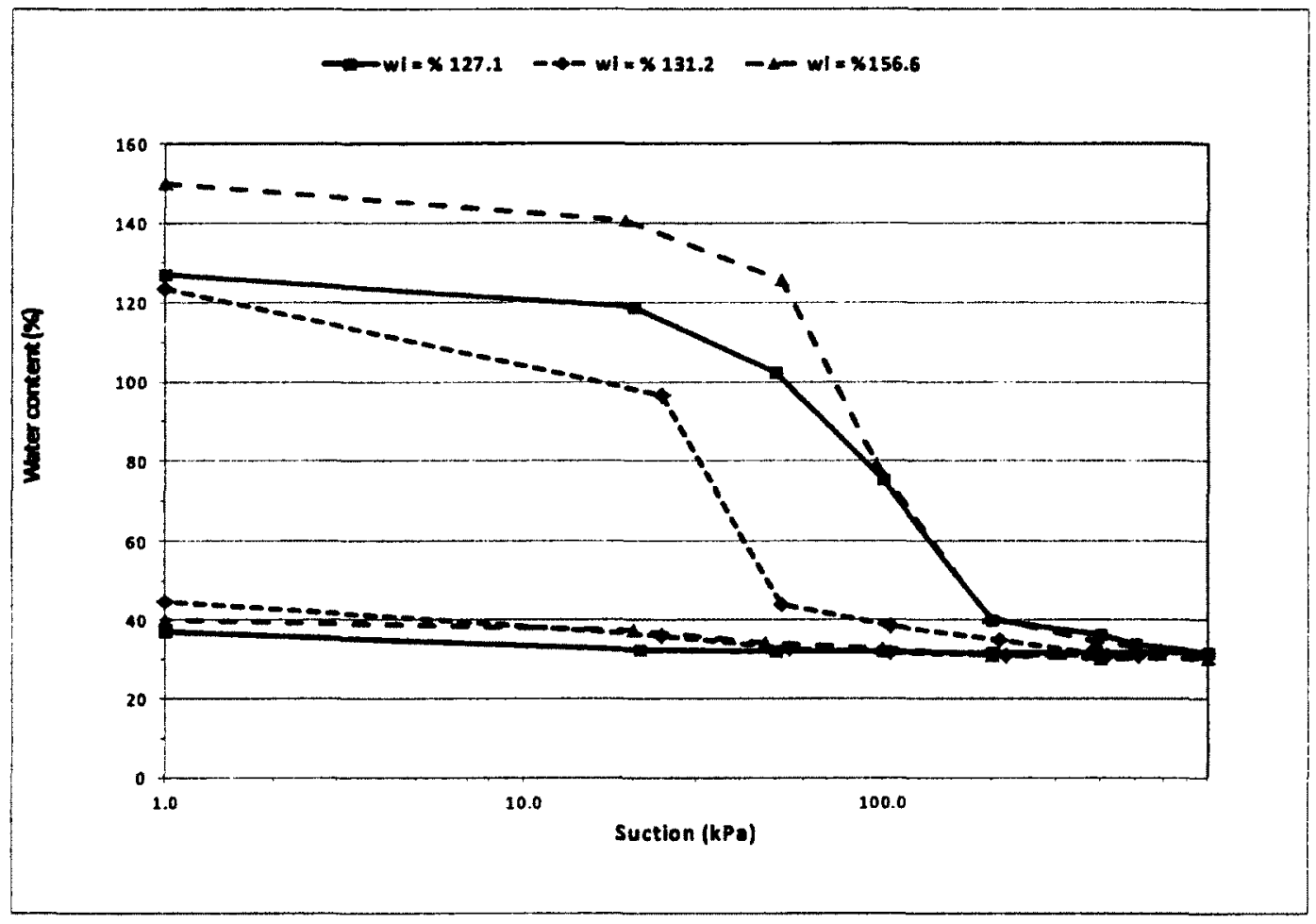

Figure 5-39: Comparison of water content-suction curve for oil sand tailings with different initial water content, log scale

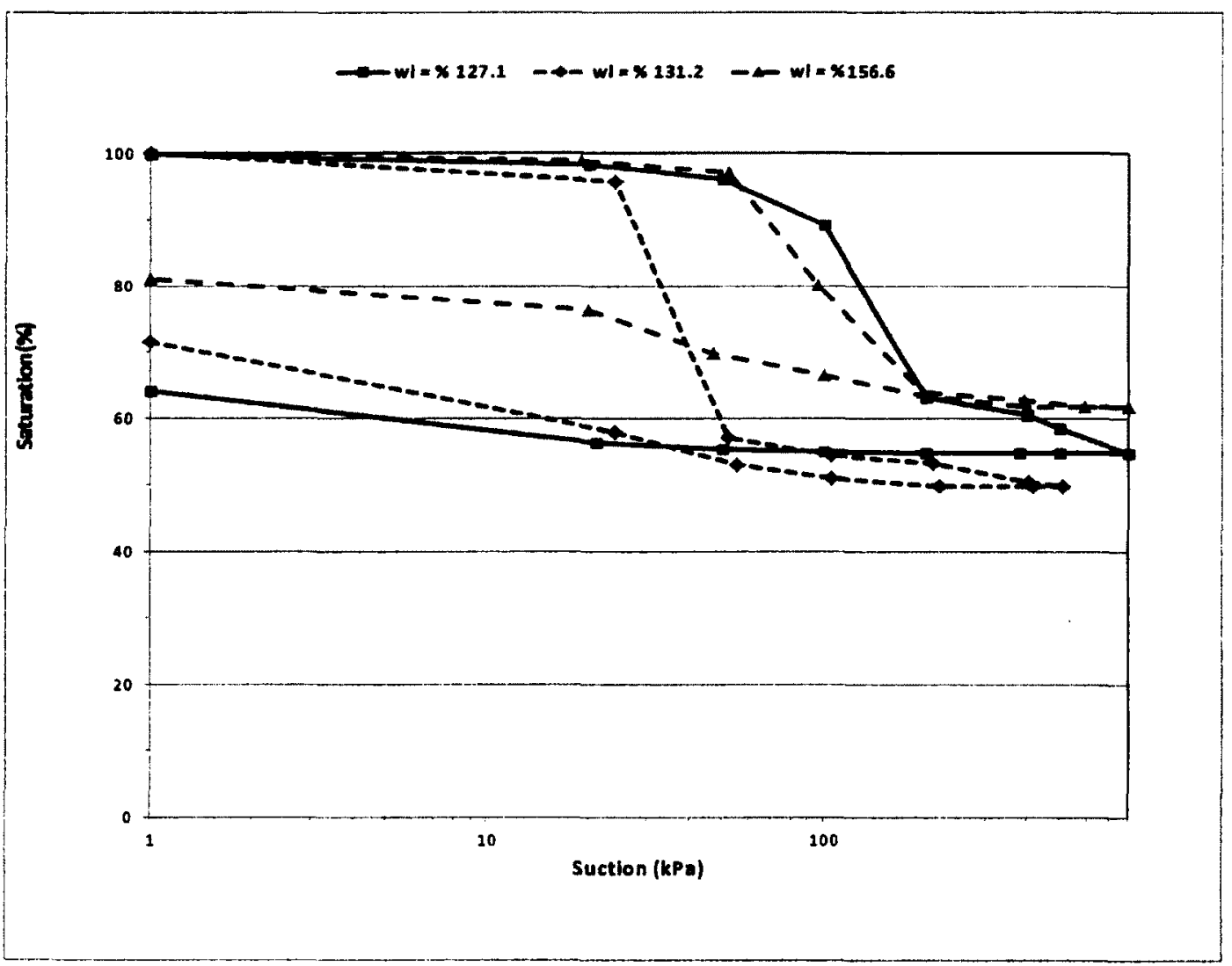

Figure 5-40: Comparison of saturation-suction curve for oil sand tailings with different initial water content, log scale 


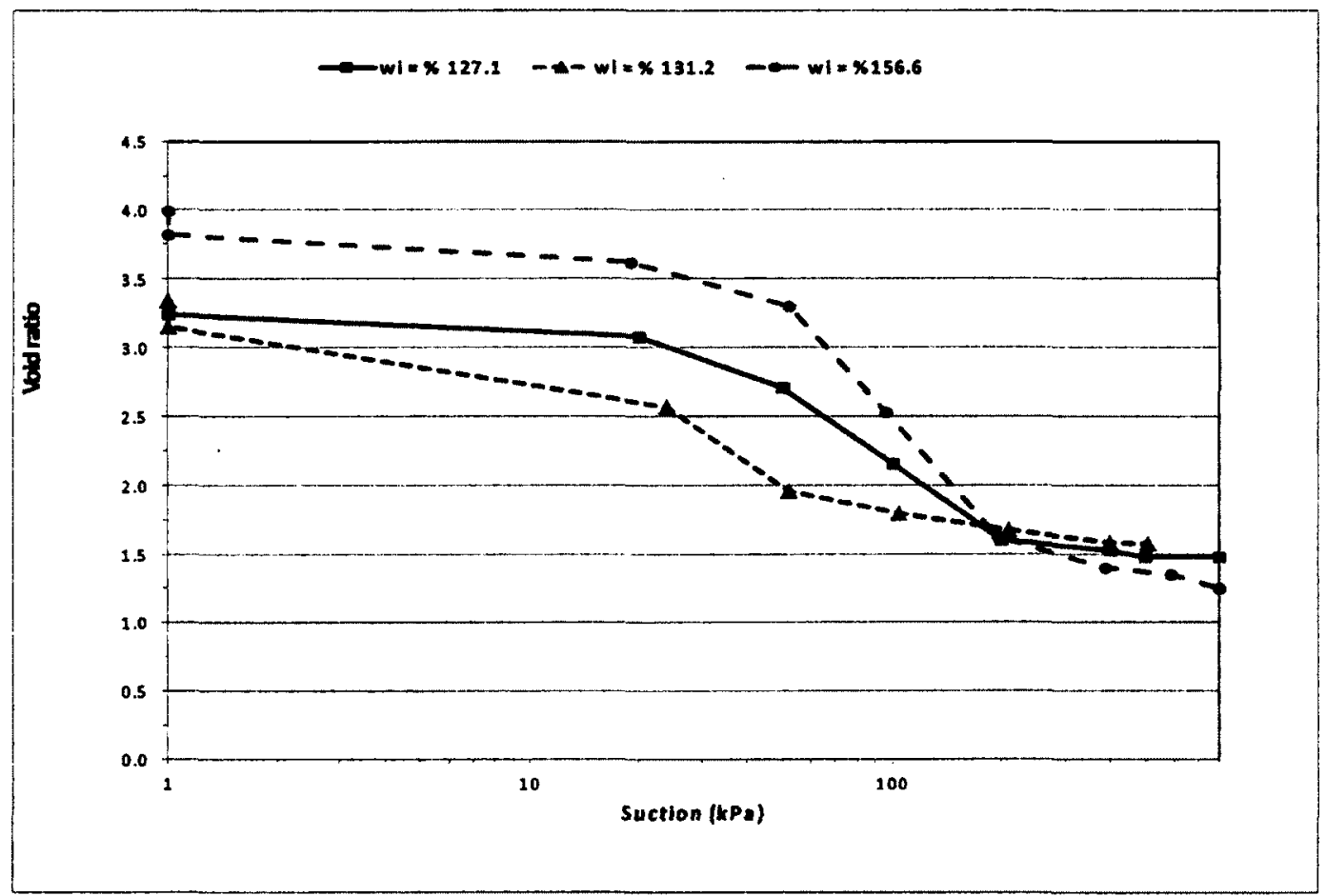

Figure 5-41: Comparison of void ratio-suction curve for oil sand mine tailings with different initial water content, log scale

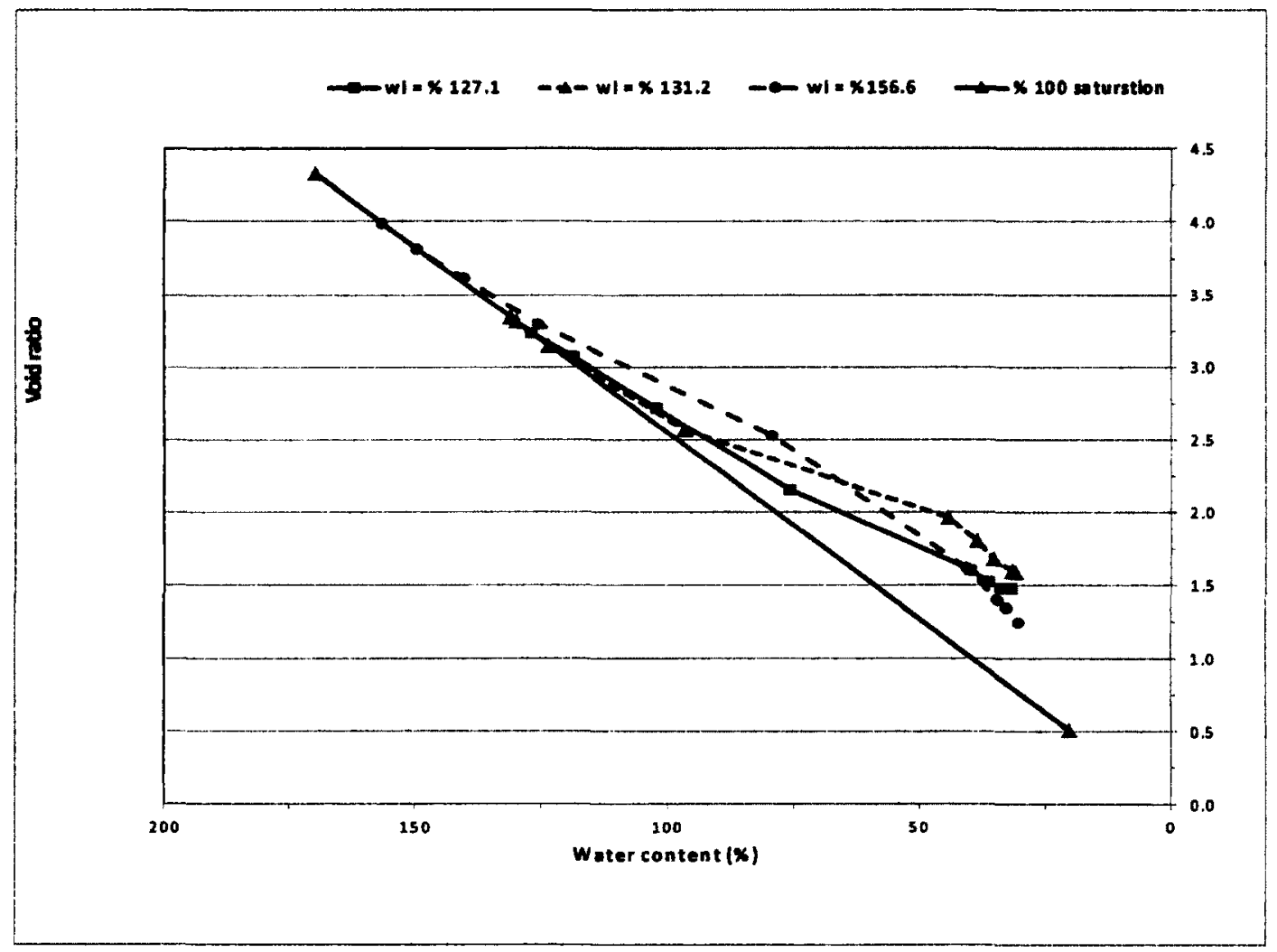

Figure 5-42: Comparison of shrinkage curve for oil sand mine tailings with different initial water content 


\section{5-2-2. Effect of mechanical mixing on the TWCC in oil sand mine tailings (MFT)}

To study the effect of mixing during samples preparation, water was added to the original tailings samples and mechanically mixed for 30 minutes. The tailings had a water content of $155 \%$, with void ratio equal to 3.94 and $100 \%$ saturation. After 24 hours of settling, $2 \mathrm{~g}$ water was removed from top of the sample. Water content and void ratio reduced to $153 \%$ and 3.90 respectively

To understand the effect of mechanical mixing on the TWCC, these results have been compared with the results presented in section 5-2-1-3. With $157 \%$ initial water content, this is close enough to be compared. Figures 5-43 to 5-46 show this comparison. Table A5-12 in the appendix shows more details.

- In the sample prepared by mechanical mixing, the drainage curve is sharper than some mixed sample and in lower suction water content reached to residual situation but residual water content for both are almost the same and around $30 \%$. In other words, at low suction, sample preparation has more influence on the TWCC than at high suction.

- At low pressure, mixing decreases the degree of saturation at a given suction, but at high pressure, saturation curves for differently mixed samples converge.

- The degree of mixing during sample preparation did not affect the shrinkage curve.

- Wetting curve was not affected by the sample preparation technique, low suction and high suction, mixing does not have significant effect on it. 


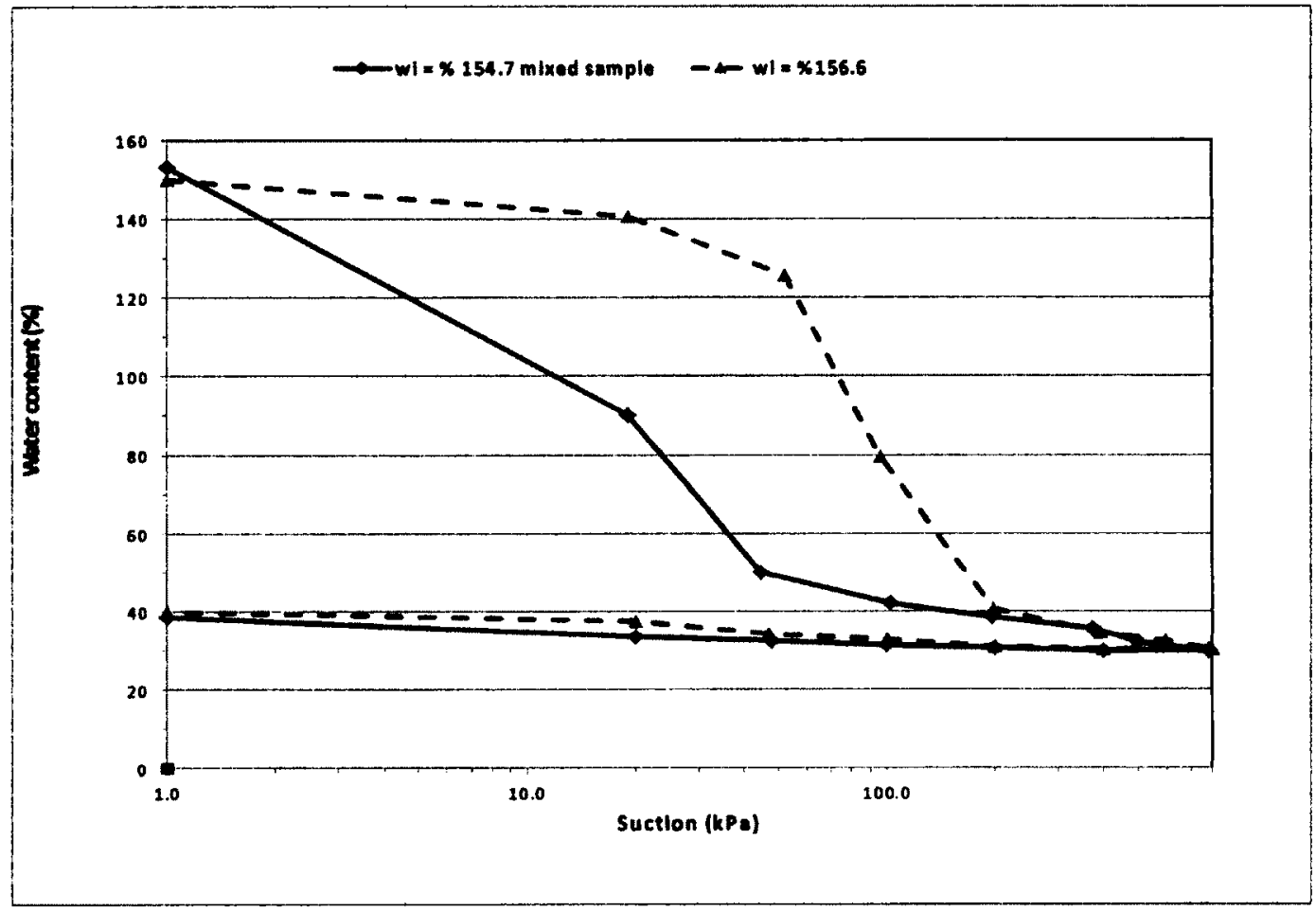

Figure 5-43: Mixing effect on water content-suction curve for oil sand mine tailings, log scale

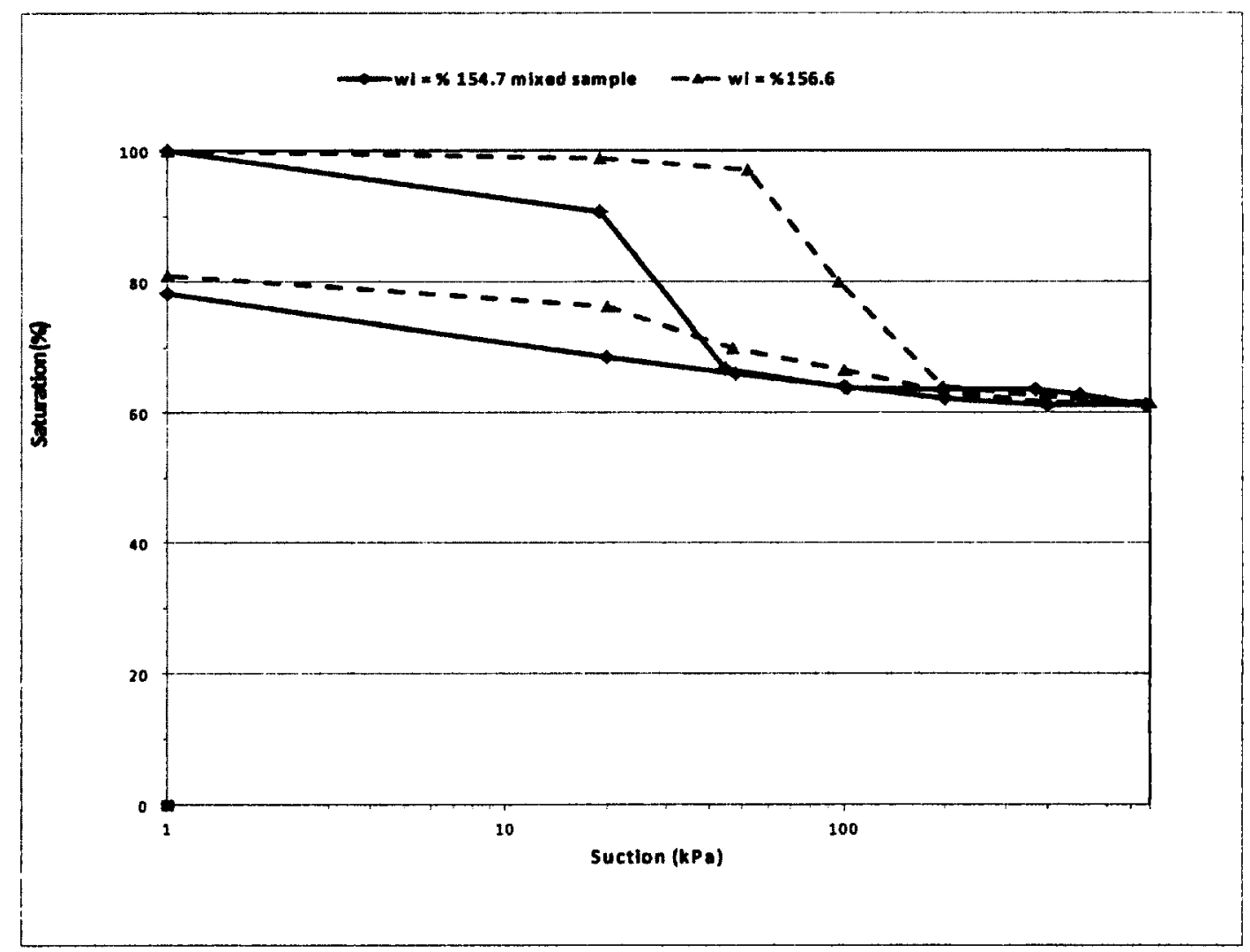

Figure 5-44: Mixing effect on saturation-suction curve for oil sand mine tailings, log scale 


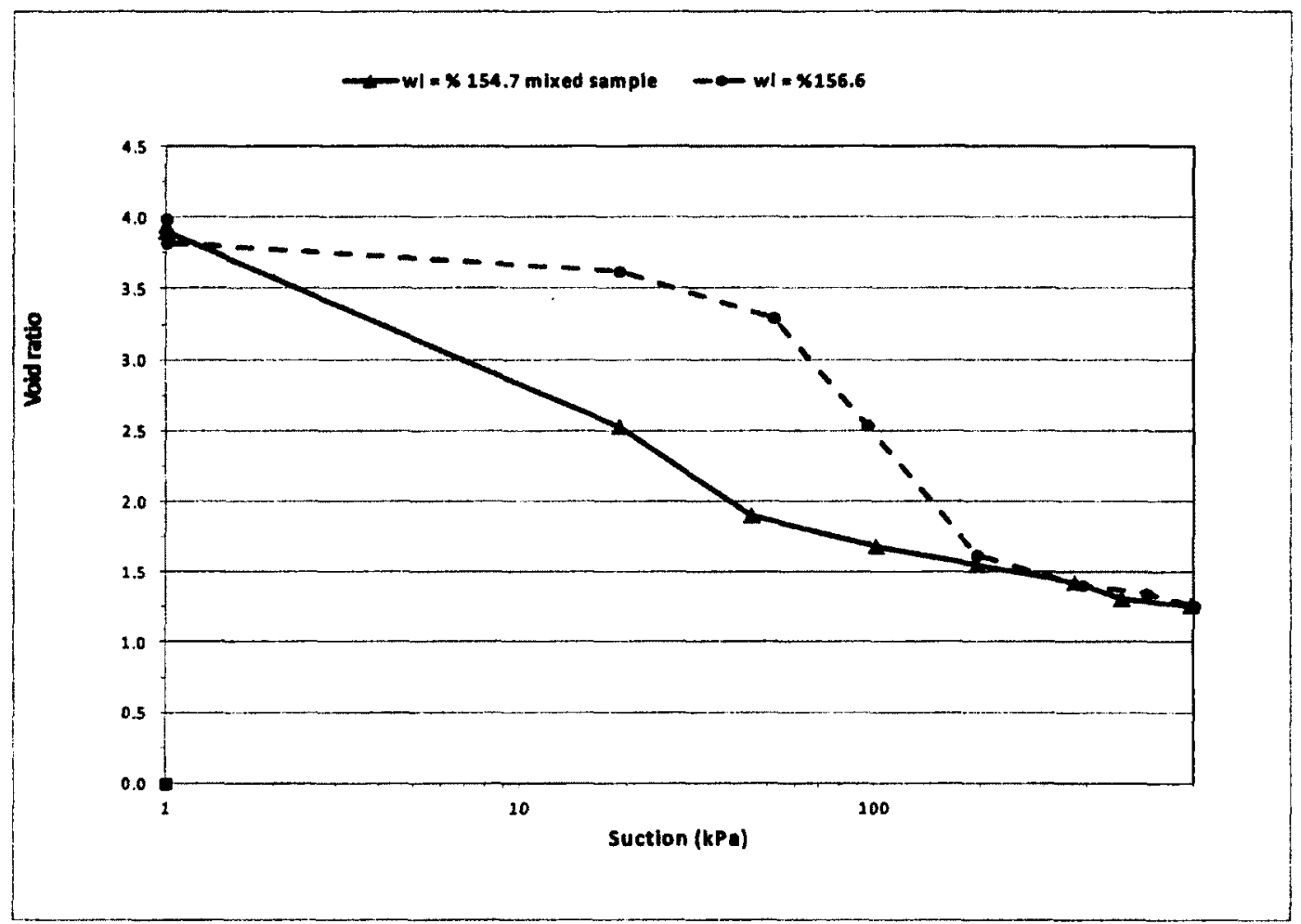

Figure 5-45: Mixing effect on void ratio-suction curve for oil sand tailings, log scale

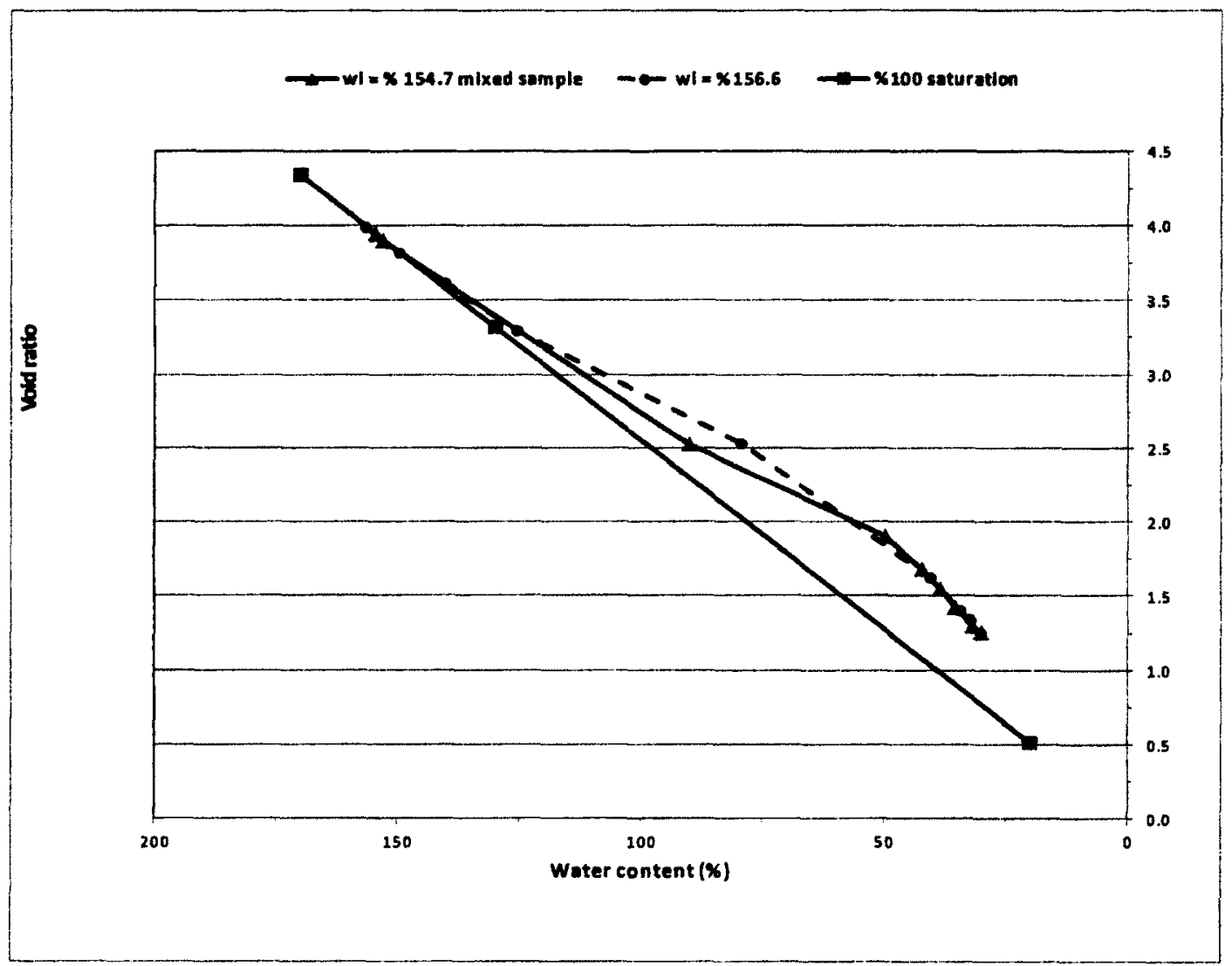

Figure 5-46: Mixing effect on shrinkage curve for oil sand tailings 


\section{5-2-3. Effect of polymer on TWCC in oil sand mine tailings (MFT)}

MFT is dosed with $1 \mathrm{~g}$ polymer to1000g MFT solids. The following tests are presented:

Initial water content of $172 \%$, polymer introduced by hand mixing of polymer-water solution (as per section 4-2-3).

After the 24 hour settling period, and removal of the bleed water, the new water content was $155 \%$. Matric suction was then applied up to $800 \mathrm{kPa}$ then decreased to 0 $\mathrm{kPa}$

Figures 5-47 to 5-50 show the results of the TWCC test, which can be summarized as:

- AEV $20 \mathrm{kPa}$

- Residual water content and saturation at $800 \mathrm{kPa}$ suction are around $27 \%$ and $42 \%$ respectively.

- Void ratio decreased from 4.37 to 1.65 . The sample apparently reaches the minimum void ratio (and its shrinkage limit).

- Volume decreased almost $50 \%$ to $130 \mathrm{~cm}^{3}$.

- Maximum water content and saturation in wetting and re-wetting situation are almost close to each other and equal to $45 \%$ and $70 \%$ respectively.

More details information is brought in Tables A5-13, A5-14 and Figures A5-21 to A5-24. 


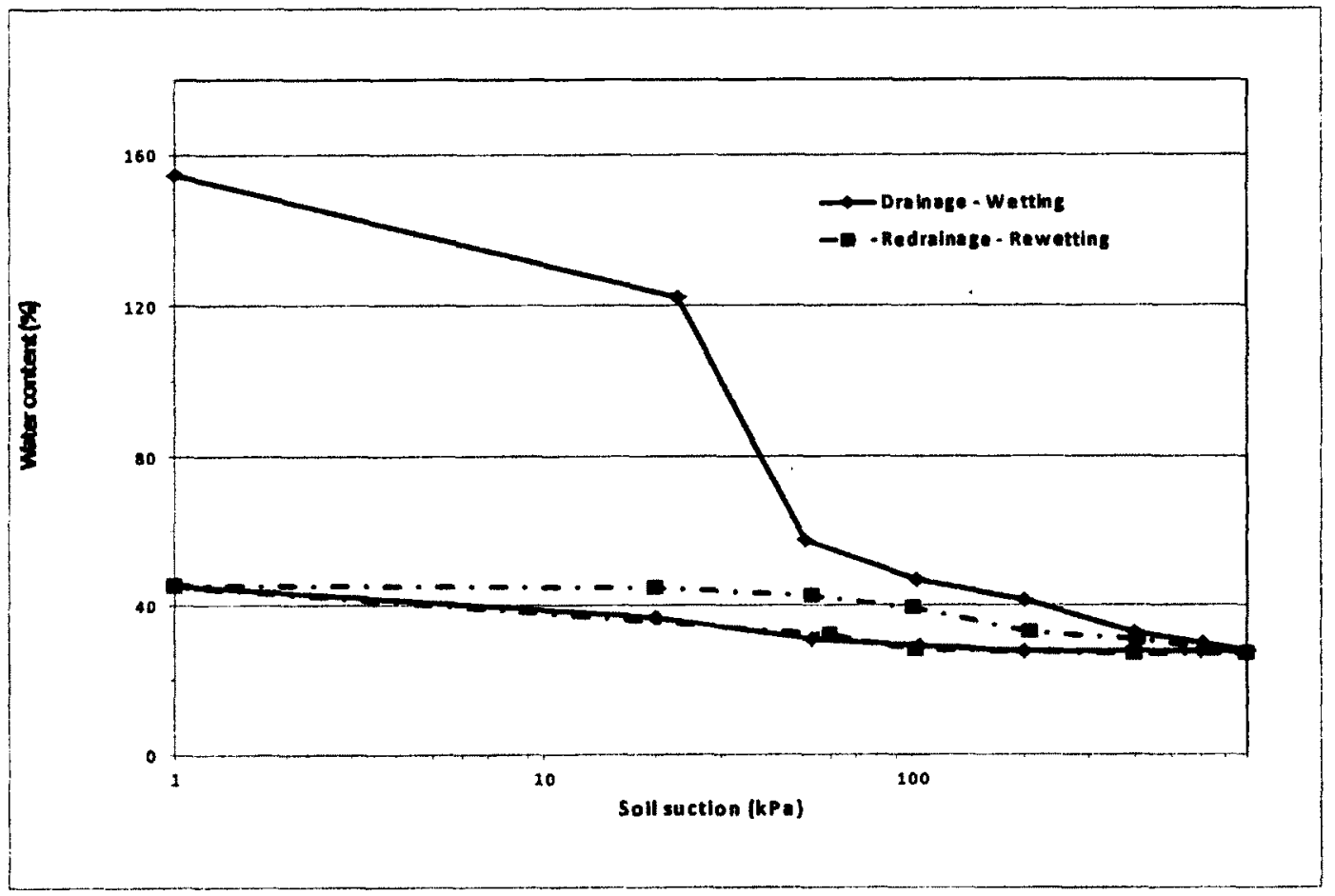

Figure 5-47: Water content-suction curve for oil sand tailings, $w_{i}=171.6 \%$, with polymer, $\log$ scale

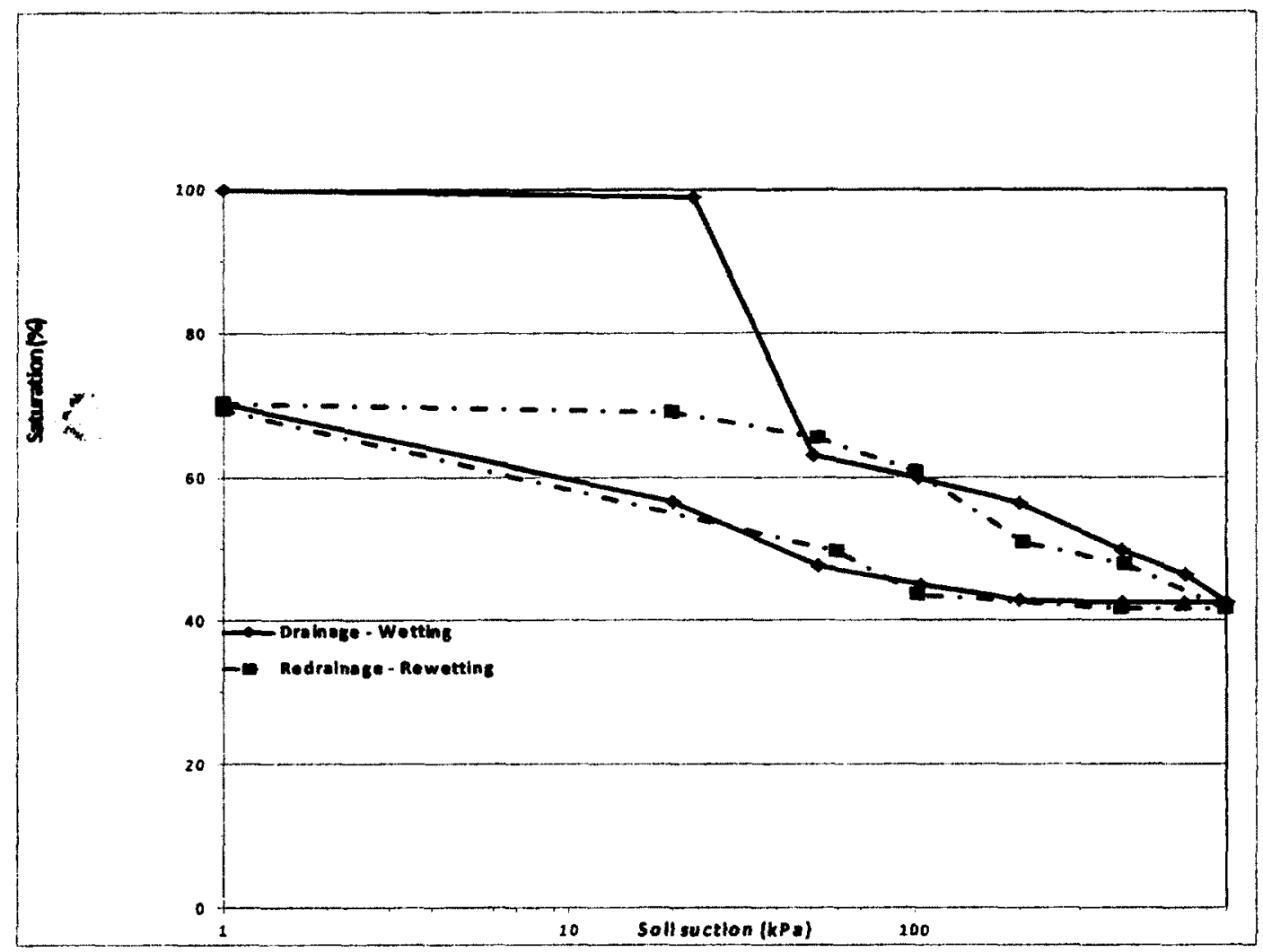

Figure 5-48: Saturation-suction curve for oil sand tailings, $\mathrm{w}_{\mathrm{i}}=171.6 \%$, with polymer, $\log$ scale 


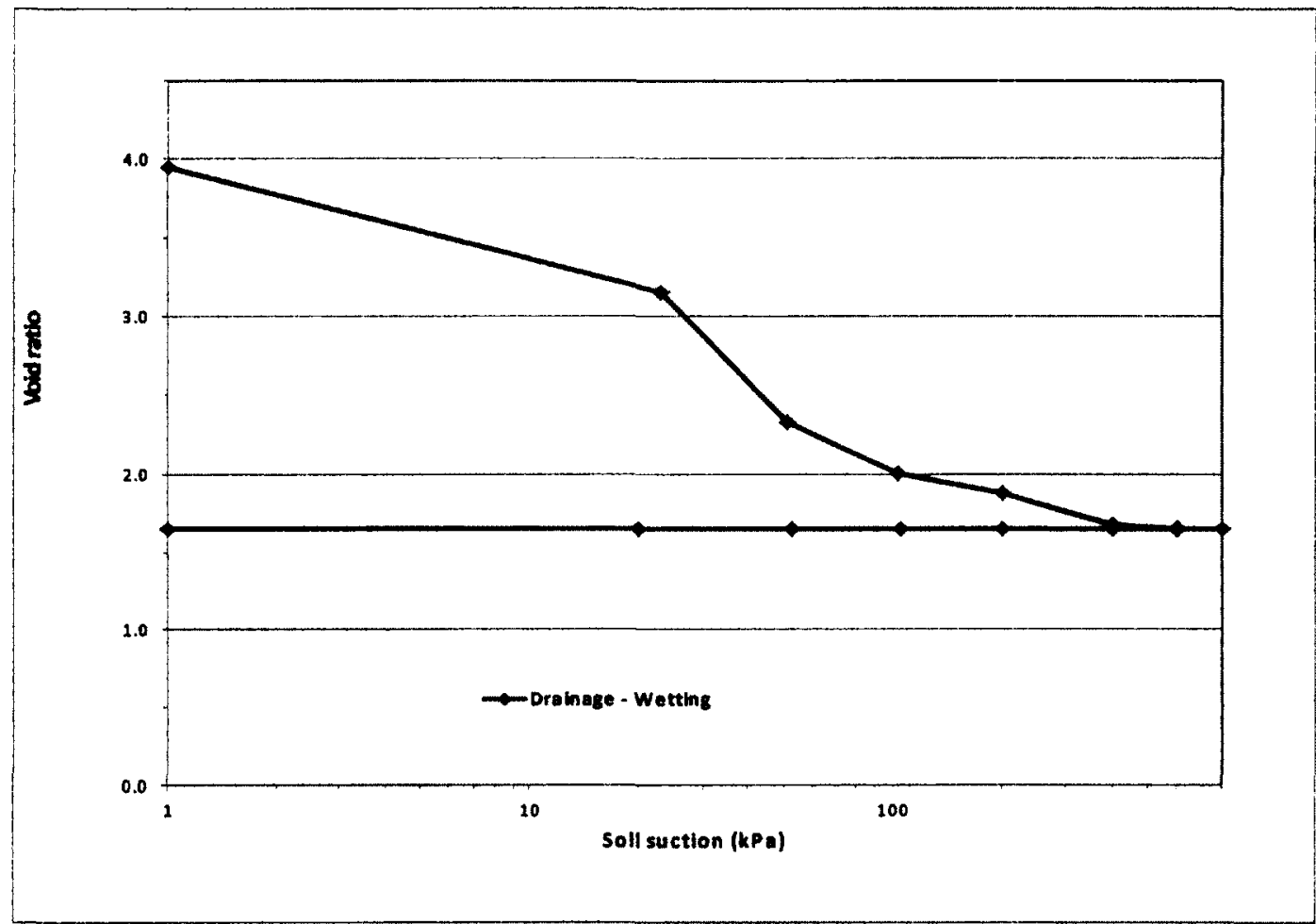

Figure 5-49: Void ratio-suction curve for oil sand tailings, $\mathrm{w}_{\mathrm{i}}=171.6 \%$, with polymer, log scale

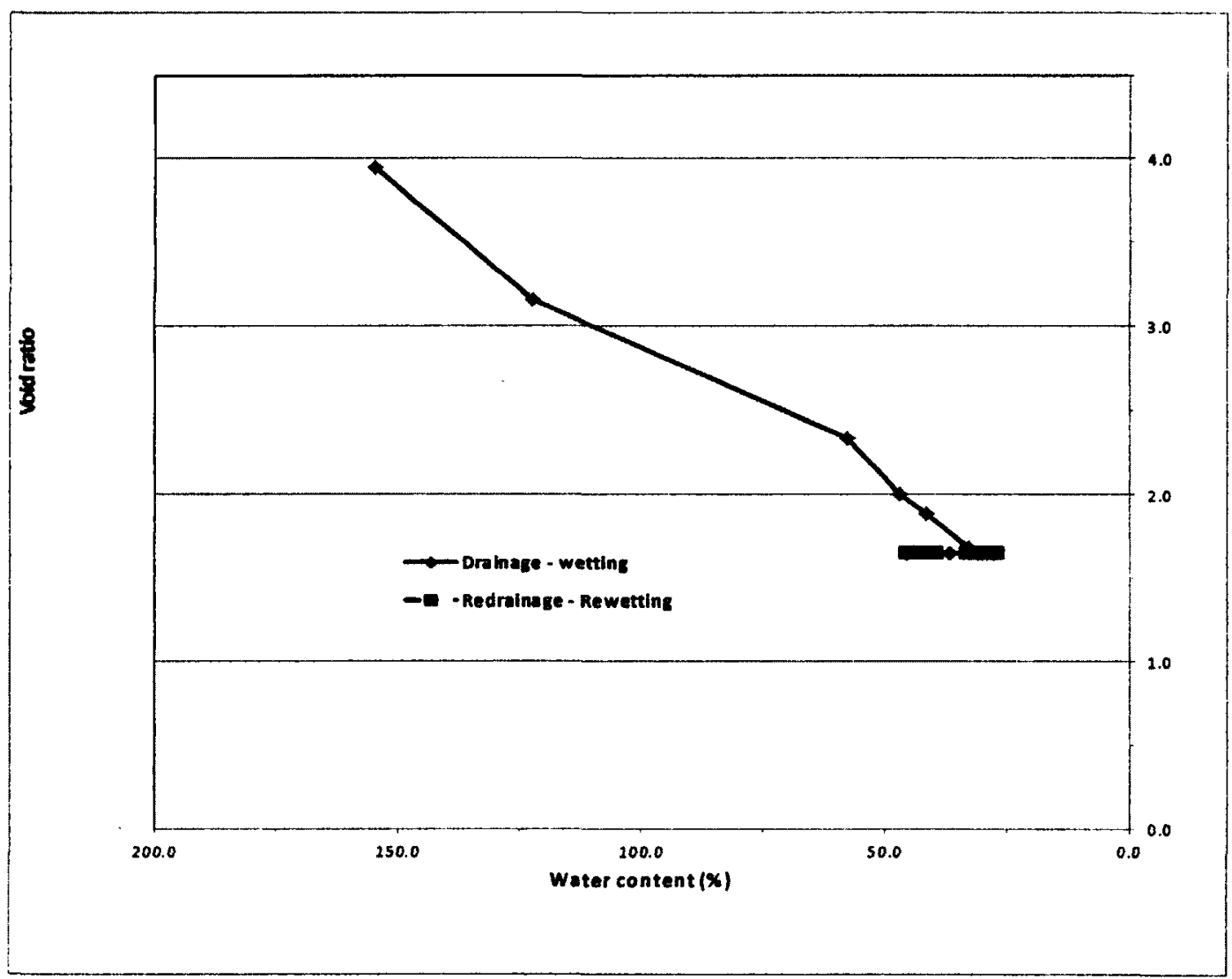

Figure 5-50: Shrinkage curve for oil sand tailings, $\mathrm{w}_{\mathrm{i}}=171.6 \%$, with polymer 
Graphs 5-51 to 5-54 are provided to show better view of polymer effect on TWCC. In those graphs and table there are comparison of TWCC of MFT for three different samples, there is more details in Table A5-15 in the appendix.

- MFT sample with initial water content equal to $131 \%$.

- MFT sample with initial water content equal to $157 \%$.

- MFT sample with initial water content equal to $172 \%$ with polymer.

According to those graphs and table following results can be taken:

- Increase in initial water content results in increasing AEV, $\left(w_{i}=131 \%\right.$ and $w_{i}=\%$ $157 \%$ ) but for the sample with polymer although has higher initial water content, $\mathrm{w}_{\mathrm{i}}=\% 172 \%$, the AEV is lower. The polymer promotes flocculation and therefore increases effective particle size, resulting in a lower AEV.

- At high suction, polymer affects saturation - suction curve more than water content - suction curve. At $800 \mathrm{kPa}$ pressure, water content for $\mathrm{w}_{\mathrm{i}}=157 \%$ and polymer is $30 \%$ and $28 \%$ respectively but for saturation is $62 \%$ and $43 \%$. So adding polymer results in lower water content and lower degree of saturation at a given value of matric suction.

- Wetting curve in water content-suction for different initial water content and polymer are almost the same. In other word, polymer dose not play any role in wetting curve.

- Increasing suction results in decrease in void ratio. At low suction this rate with polymer is sharper than without polymer.

- The sample with polymer appear to approach the shrinkage limit, as the void ratio levels off for the last few suction increments. 


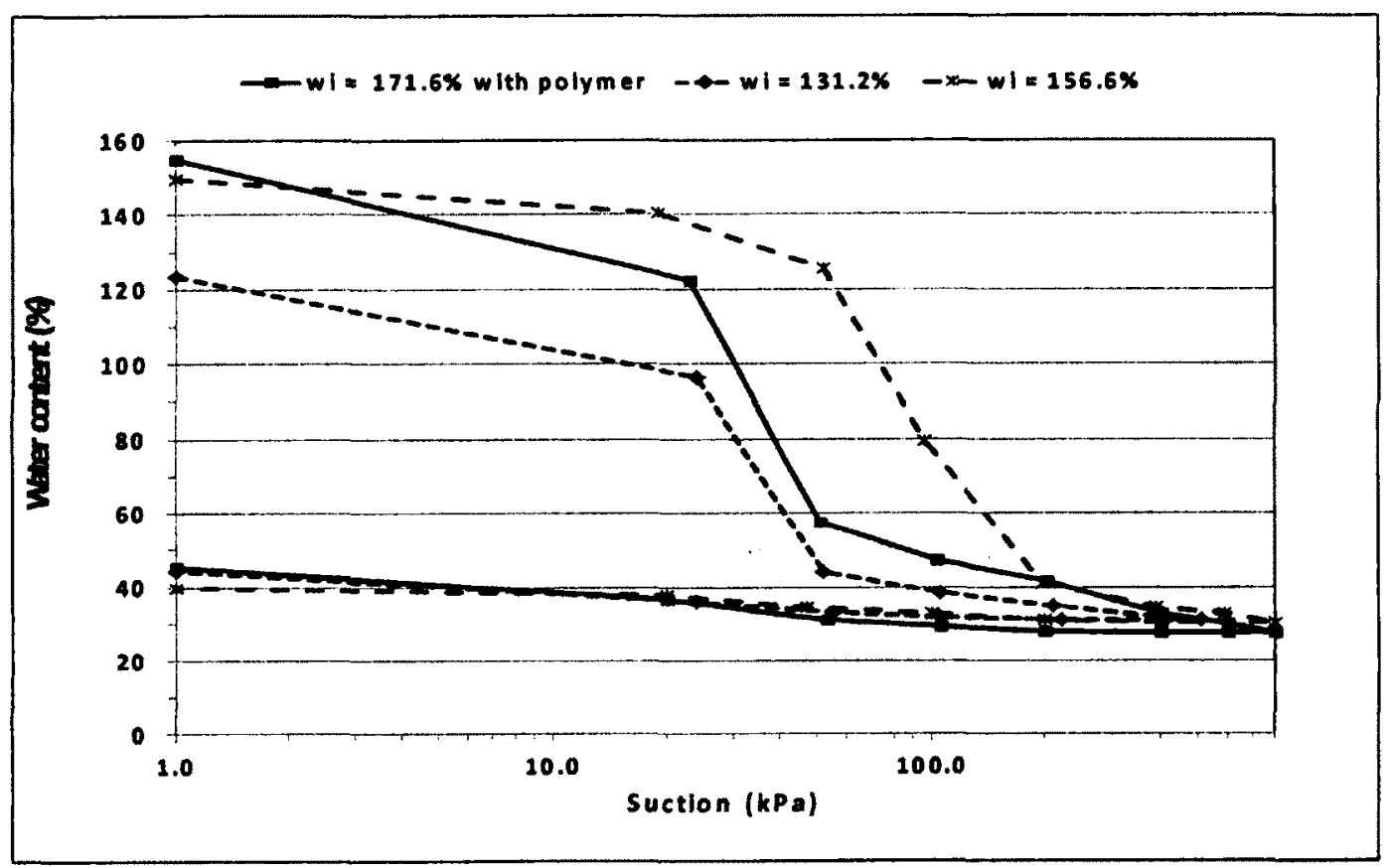

Figure 5-51: Comparison of water content-suction curve for oil sand tailings with polymer, $\log$ scale

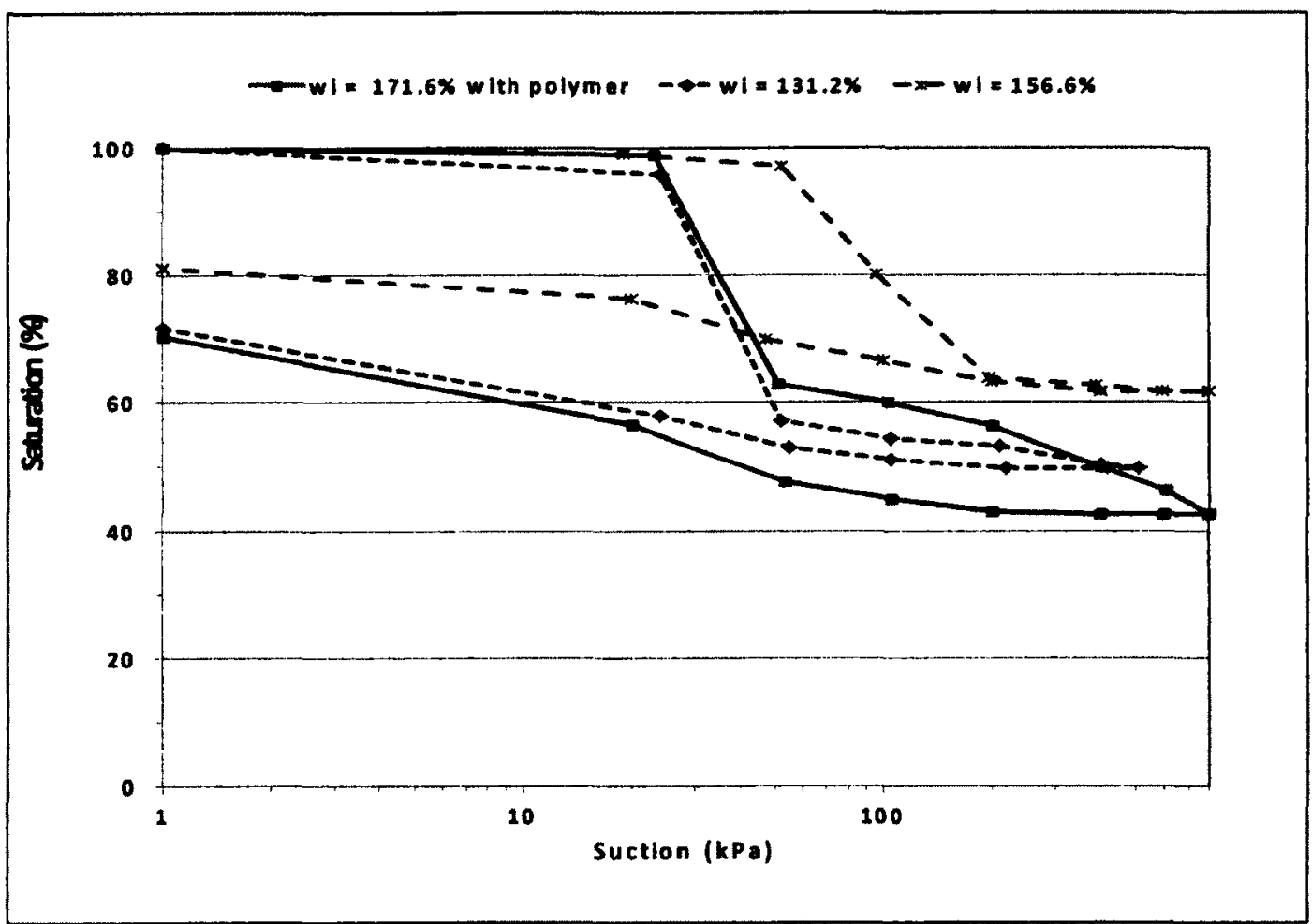

Figure 5-52: Comparison of saturation-suction curve for oil sand tailings with polymer, log scale 


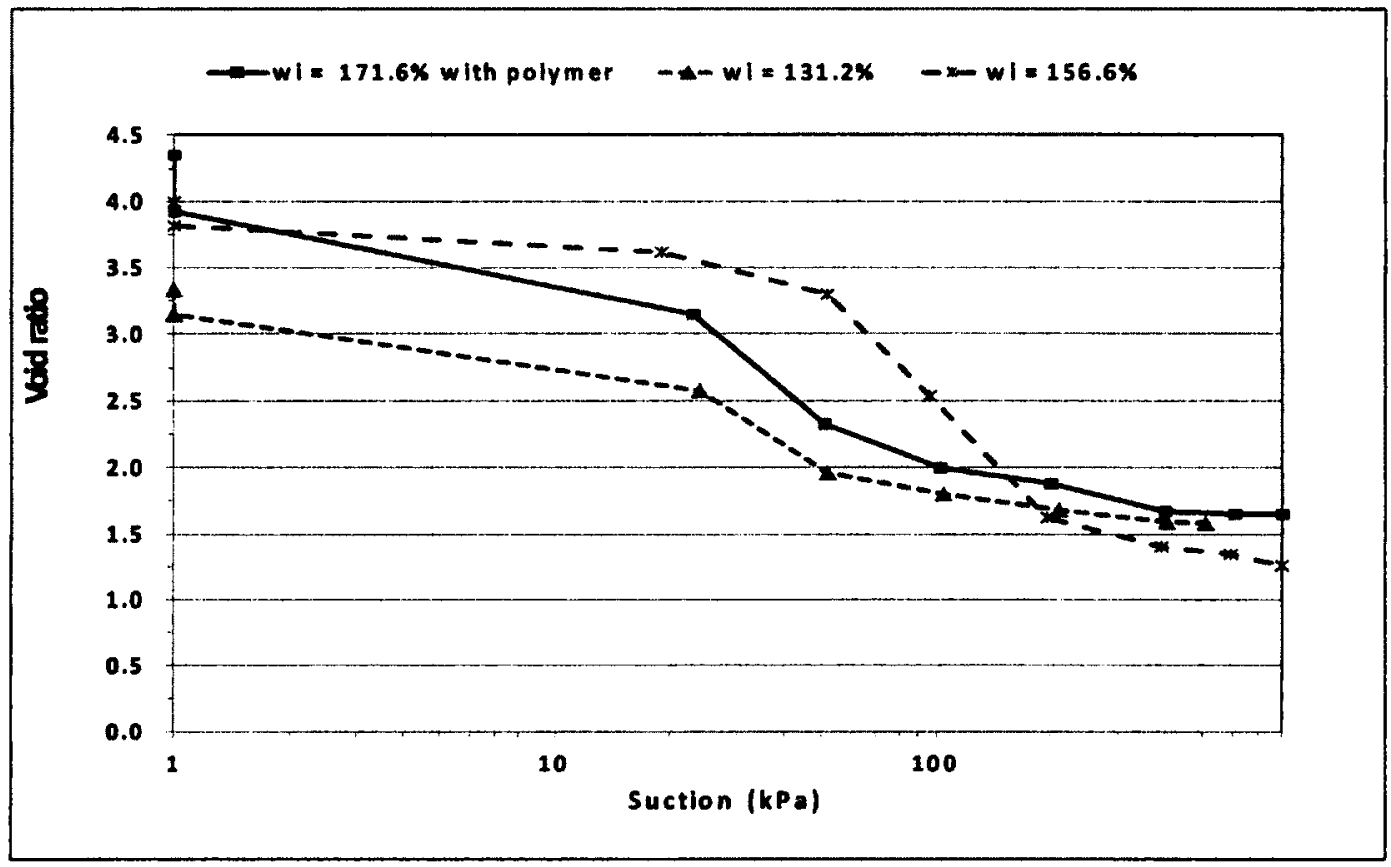

Figure 5-53: Comparison of void ratio-suction curve for oil sand tailings with polymer, log scale

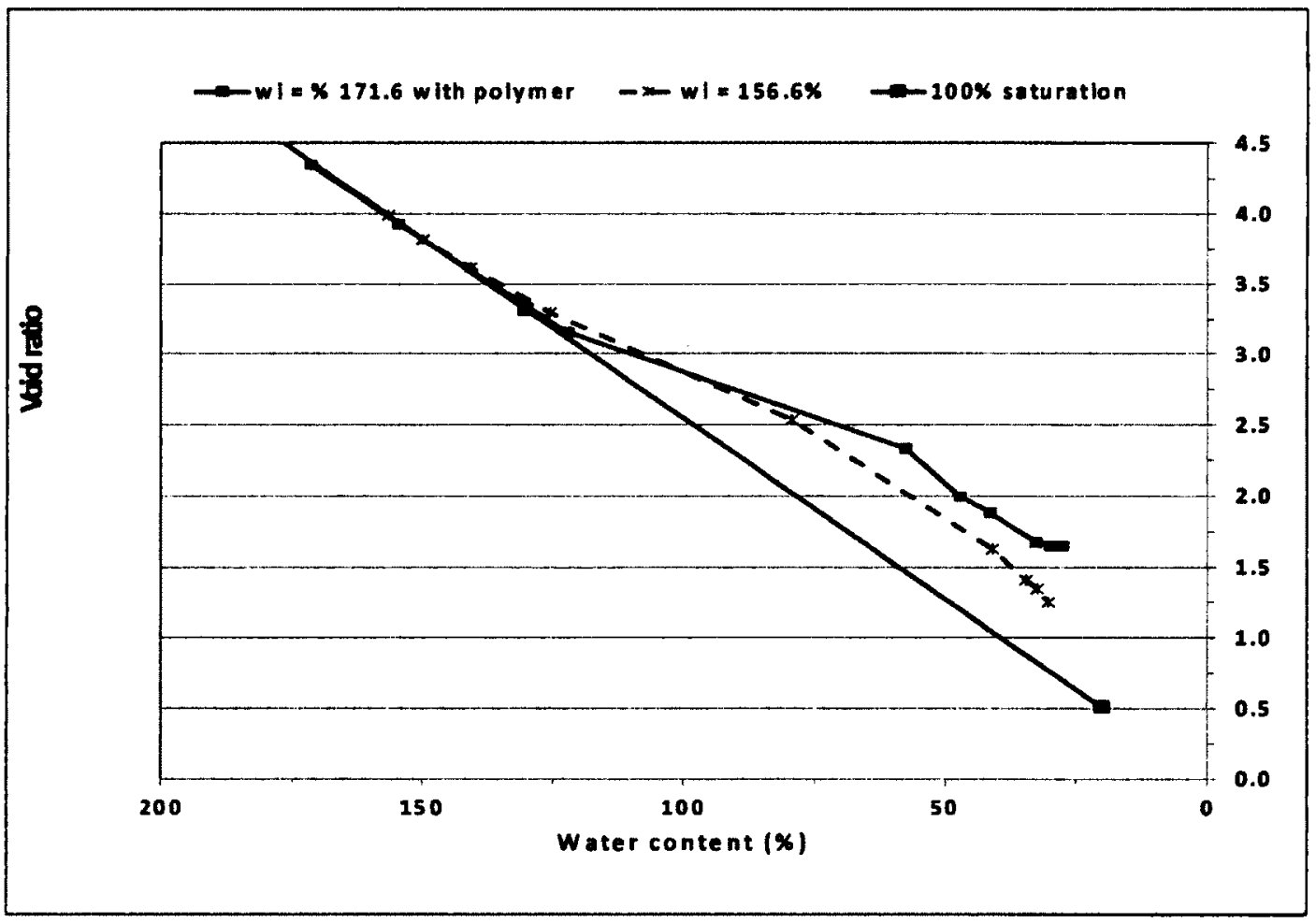

Figure 5-54: Comparison of shrinkage curve for oil sand tailings with polymer 


\section{5-2-4. Effect of preparation method on TWCC of polymer amended MFT}

To understand the effect of degree of mixing on the TWCC of polymer amended MFT, after adding $1 \mathrm{~g}$ polymer to $1000 \mathrm{~g}$ solids in tailings, tailings was mechanically mixed for 20 minutes. After 24 hours around $3.3 \mathrm{~g}$ water was removed from top of the sample. At this time sample had $123 \%$ water content with $100 \%$ saturation. At maximum suction, water content and saturation went down to $35 \%$ and $71 \%$ respectively. Also void ratio from 3.24 dropped to 1.28. More details information can be seen in Tables A5-16, A5-17 and Figures A5-25 to A5-32 in the appendix.

In Figures 5-55 to 5-58 there are a comparison between behaviour of MFT on TWCC which affected by polymer and polymer with mechanical mixing.

Mechanical mixing clearly caused an increase in AEV and a decrease in void ratio with respect to the other preparation technique (hand mixing).

Over mixing likely reduces the efficiency of the polymer, as over mixing breaks down flocs and does not enhance settling. Therefore polymer reaction is sensitive to the degree of mixing. In industry of oil sand tailings deposition, to avoid this problem and to maximize the initial water release due to settling, instead of mechanical mixing, jet injection within a static mixer is used (Matthews et al. 2011) 


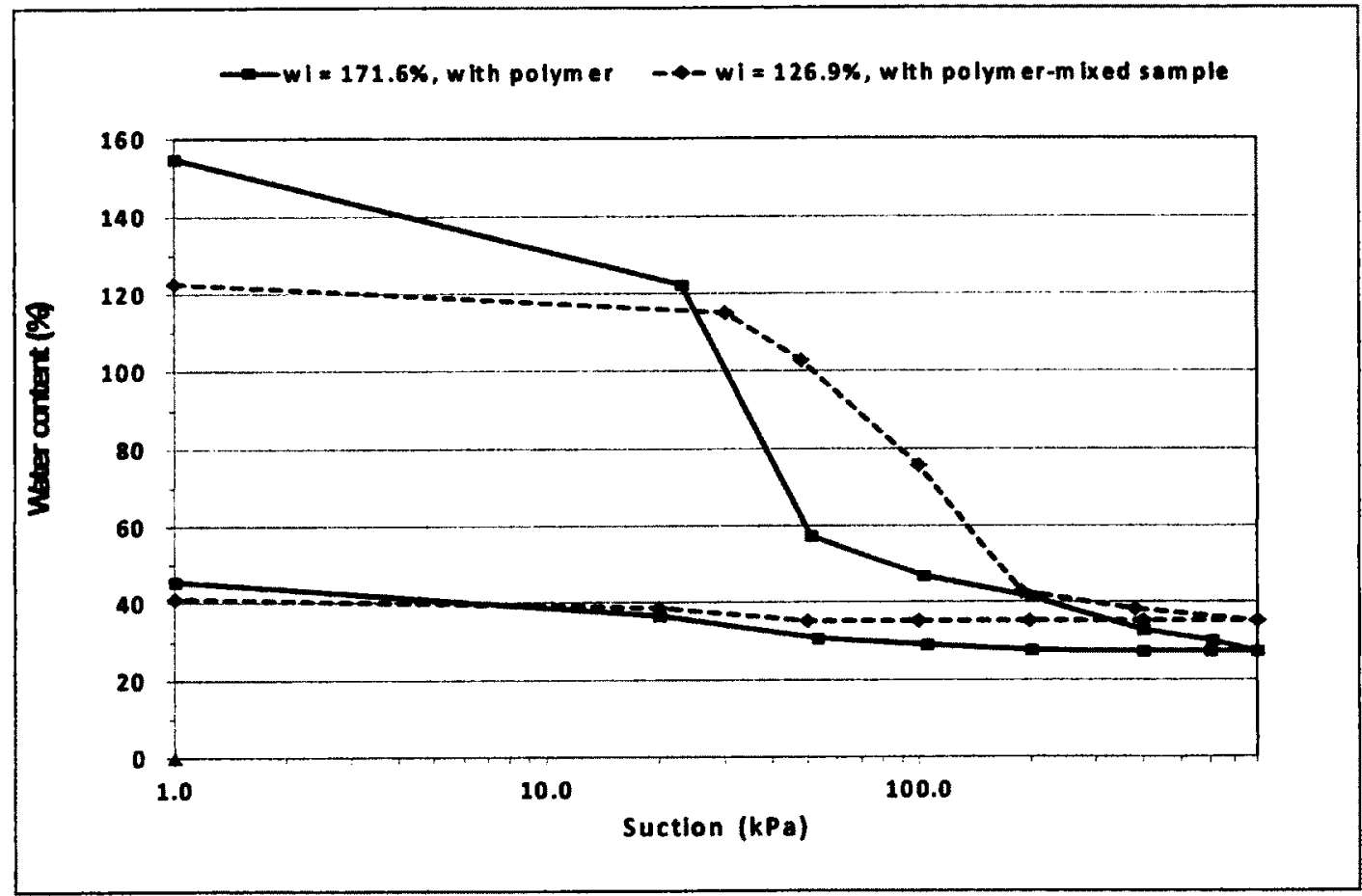

Figure 5-55: Effect of polymer and mixing on water content-suction curve for oil sand tailings, log scale

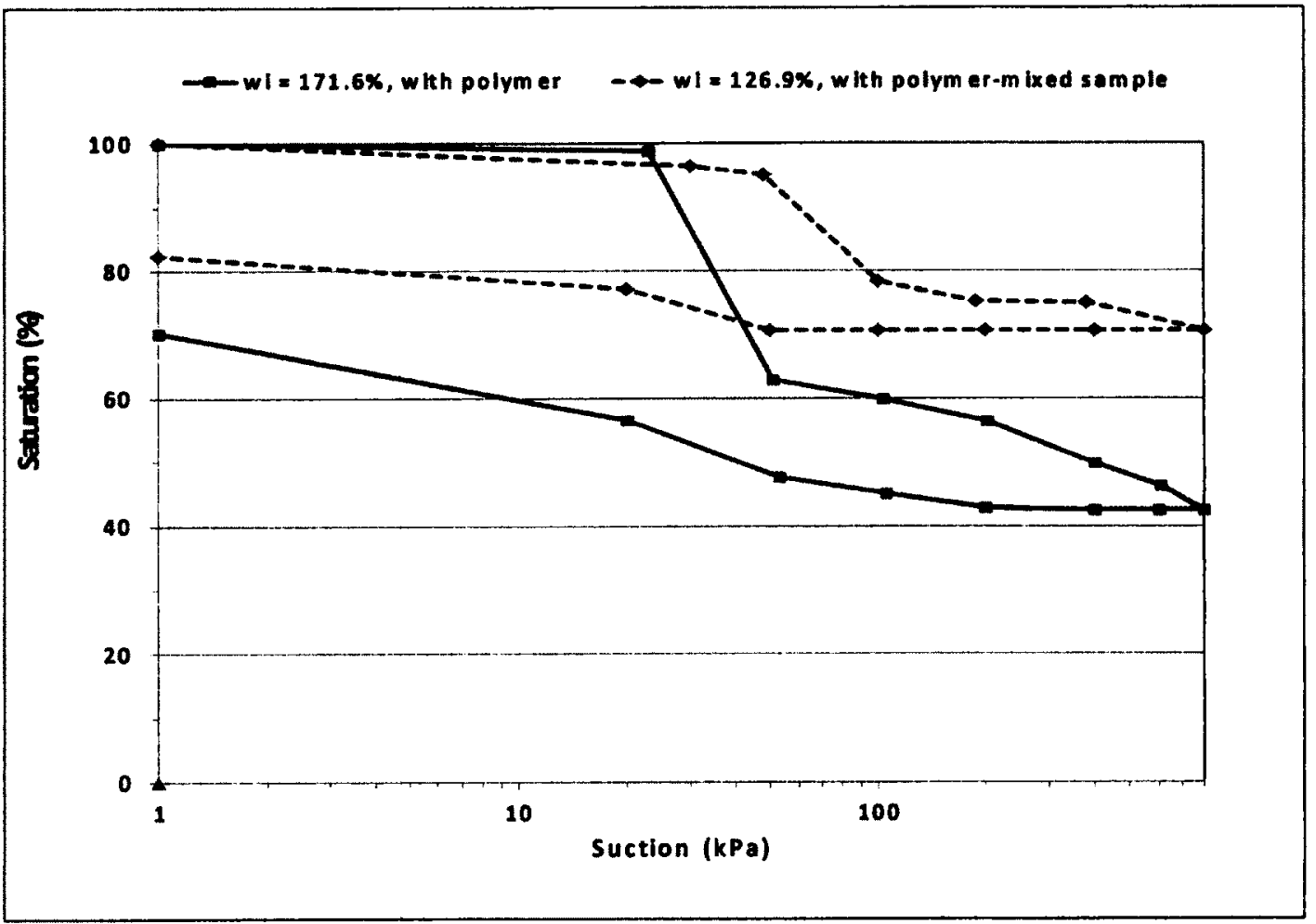

Figure 5-56: Effect of polymer and mixing on saturation-suction curve for oil sand tailings, $\log$ scale 


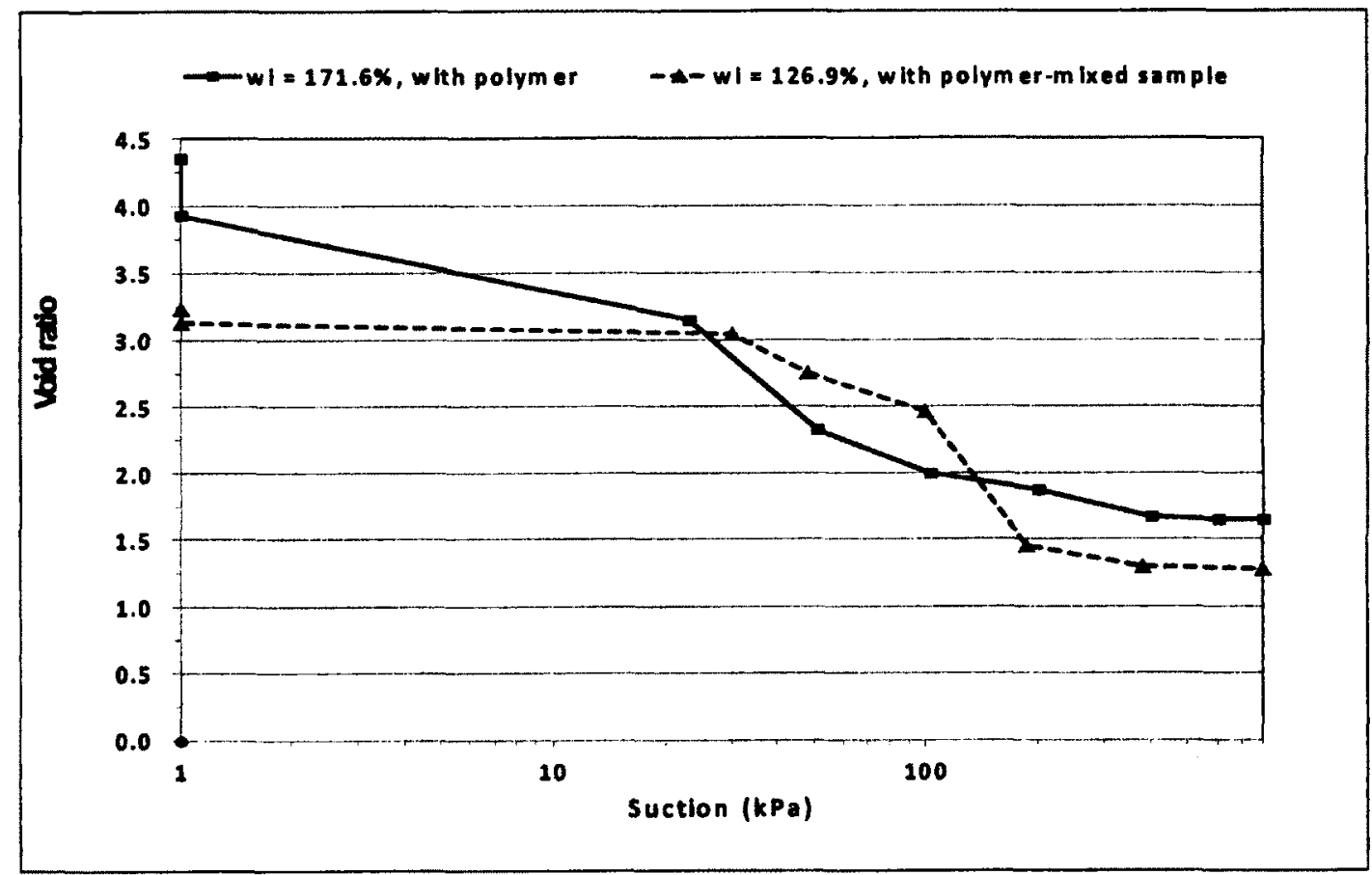

Figure 5-57: Effect of Polymer and mixing on void ratio-suction curve for oil sand tailings, log scale

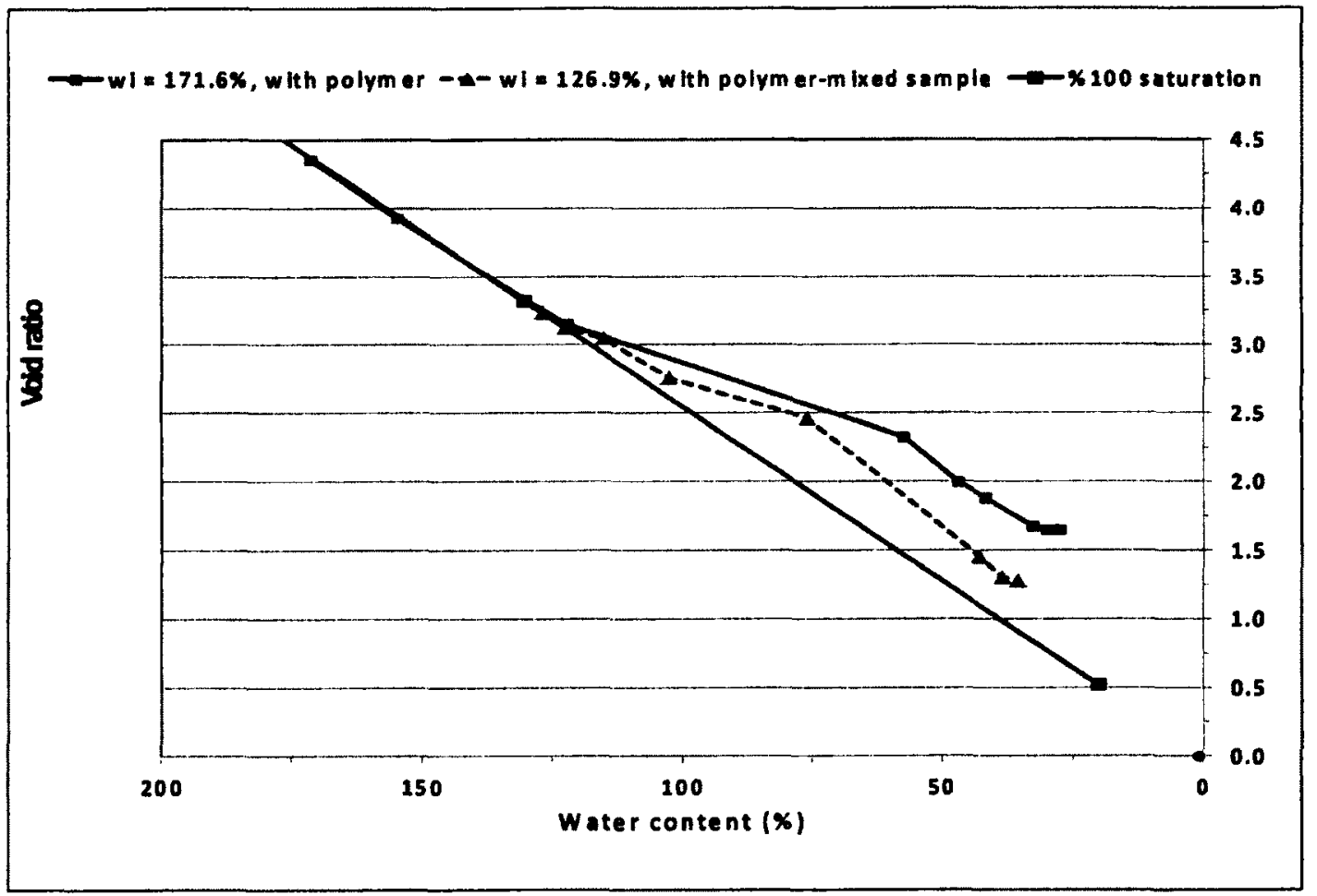

Figure 5-58: Effect of Polymer and mixing on shrinkage curve for oil sand tailings 


\section{5-3. Gold mine tailings ( GMT)}

The influence of deposition (initial) water content, $\mathrm{w}_{\mathrm{i}}$, on the TWCC is studied using four sets of experiments. The different treatments are summarized in Table 5-17.

Table 5-7: Different experimental tests on gold mine tailings

\begin{tabular}{|c|c|}
\hline Effect of initial water content on shrinkage limit & $\mathrm{Wi}=27 \%, \mathrm{Wi}=40 \%, \mathrm{Wi}=52 \%$ \\
\hline \multirow{5}{*}{ Effect of initial water content on TWCC } & $\mathrm{Wi}=22 \%$ \\
\hline & $\mathrm{Wi}=26 \%$ \\
\hline & $\mathrm{Wi}=33 \%$ \\
\hline & $\mathrm{Wi}=41 \%$ \\
\hline & $\mathrm{Wi}=51 \%$ \\
\hline Effect of compaction on TWCC & $\mathrm{Wi}=40 \%$ \\
\hline \multirow{4}{*}{ Effect of constant 1-D loading on TWCC } & $\mathrm{Wi}=24 \%, 1-\mathrm{D}$ loading $=50 \mathrm{kPa}$ \\
\hline & $\mathrm{Wi}=32 \%, 1-\mathrm{D}$ loading $=50 \mathrm{kPa}$ \\
\hline & $\mathrm{Wi}=28 \%, 1-\mathrm{D}$ loading $=100 \mathrm{kPa}$ \\
\hline & $\mathrm{Wi}=27 \%, 1-\mathrm{D}$ loading $=150 \mathrm{kPa}$ \\
\hline \multirow{2}{*}{$\begin{array}{l}\text { Effect of constant applied suction and variation of } \\
\text { 1-D loading on TWCC }\end{array}$} & $\mathrm{Wi}=39 \%$, cons. App. suction $=50 \mathrm{kPa}$ \\
\hline & $\mathrm{Wi}=43 \%$, cons. App.suction $=150 \mathrm{kPa}$ \\
\hline Effect of no suction just 1-D loading on TWCC & $\mathrm{Wi}=37 \%$ \\
\hline
\end{tabular}




\section{5-3-1. Shrinkage limit test, (wax method).}

To see the effect of initial water content (IWC) on shrinkage limit, three samples with different IWC are prepared:

- Tailings sample with $\mathrm{w}_{\mathrm{i}}=27 \%$

- Tailings sample with $w_{i}=40 \%$

- Tailings sample with $\mathrm{w}_{\mathrm{i}}=52 \%$

Table 5-8 and Figure 5-59 show variations of water content during the time (9 days). Calculations of shrinkage limit test are shown in Table 5-9. Shrinkage limit, as defined by minimum void ratio divided by specific gravity, for all three samples are around 0.22 to 0.24 , and water content when minimum void ratio is reached $20+/-1 \%$ and also shrinkage ratio is equal to 1.7. According to these numbers, initial water content does not have significant effect on shrinkage limit.

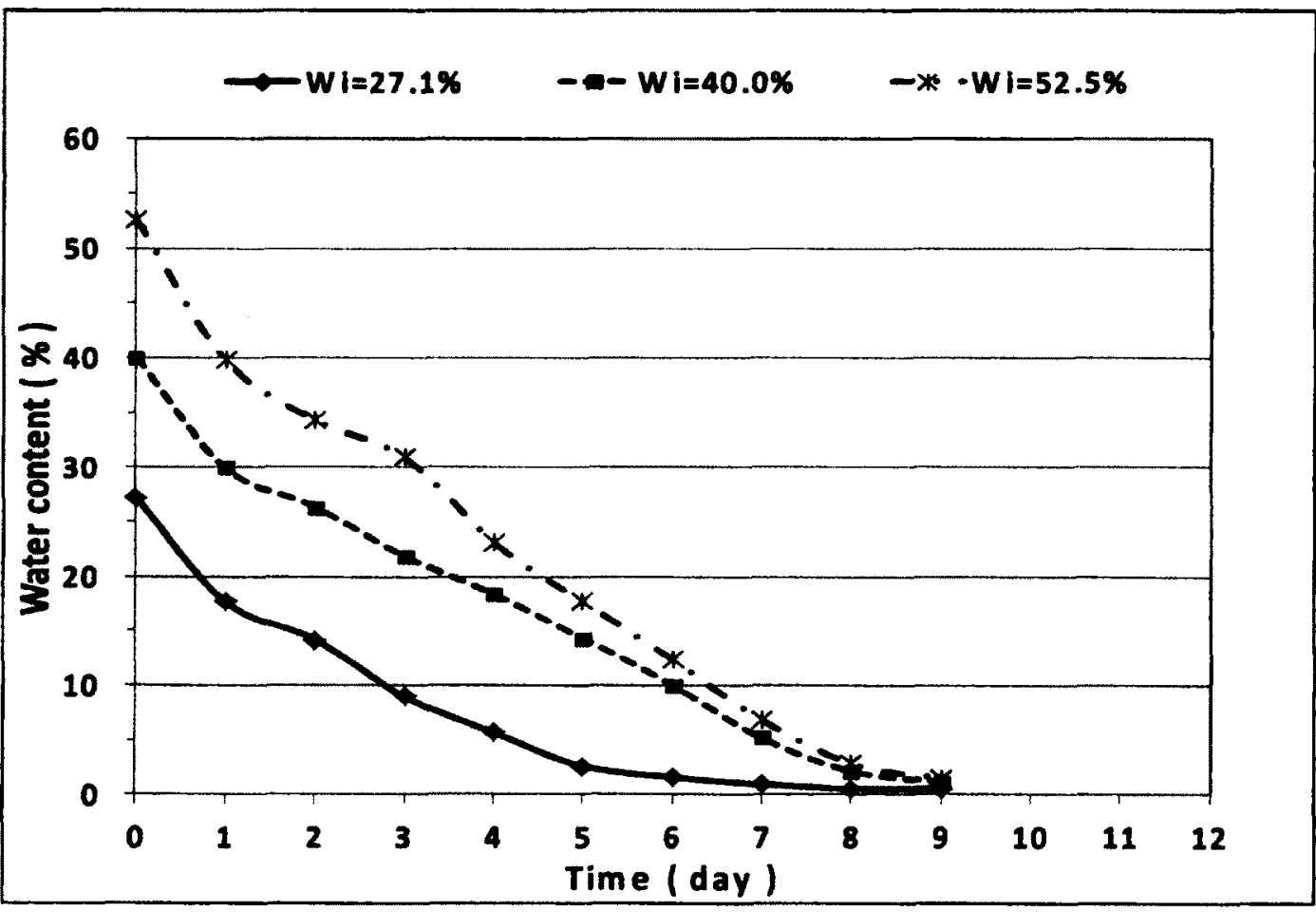

Figure 5-59: Variation of water content versus time in air dry process for gold tailings 
Table 5-8: Determination of sample's water content in different days

\begin{tabular}{|c|c|c|c|c|c|}
\hline \multirow{2}{*}{ Day } & \multirow{2}{*}{ Description } & \multirow{2}{*}{ Unit } & \multicolumn{3}{|c|}{ Sample number } \\
\hline & & & 1 & 2 & 3 \\
\hline \multirow{5}{*}{0} & Initial water content & $\%$ & 27.1 & 40.0 & 52.5 \\
\hline & Mass of wet sample + continer & g. & 1814 & 173.1 & 165.6 \\
\hline & Mss of continer & g & 19.5 & 19.4 & 19.4 \\
\hline & Mass of soil & $\mathrm{g}$ & 127.3 & 109.8 & 95.8 \\
\hline & Mass of water & $g$ & 34.6 & 43.9 & 50.4 \\
\hline \multirow{3}{*}{1} & Mass of wet sample + continer & $\mathrm{g}$ & 169.4 & 1621 & 153.4 \\
\hline & Mass of water & $\mathrm{g}$ & 22.6 & 32.9 & 38.2 \\
\hline & water content & $\mathscr{m}$ & 17.72 & 29.98 & 39.81 \\
\hline \multirow{3}{*}{2} & Mass of wet sample + continer & $\mathrm{g}$ & 164.9 & 258.1 & 148.1 \\
\hline & Mass of water & $\mathrm{g}$ & 18.1 & 28.9 & 32.9 \\
\hline & water content & $\%$ & 14.19 & 26.34 & 34.28 \\
\hline \multirow{3}{*}{3} & Mass of wet sample + continer & $\mathrm{g}$ & 158.3 & 153.2 & 144.9 \\
\hline & Mass of water & $\mathrm{B}$ & 11.5 & 24.0 & 29.7 \\
\hline & water content & $\%$ & 9.01 & 2187 & 30.94 \\
\hline \multirow{3}{*}{4} & Mass of wet sample + continer & $\mathrm{g}$ & 154.1 & 149.4 & 137.4 \\
\hline & Mass of water & g & 7.3 & 20.2 & 22.2 \\
\hline & water content & $\%$ & 5.71 & 18.41 & 23.12 \\
\hline \multirow{3}{*}{5} & Mass of wet sample + continer & $g$ & 150.2 & 144.9 & 132.2 \\
\hline & Mass of water & $\mathrm{g}$ & 3.4 & 15.7 & 17.0 \\
\hline & water content & $\%$ & 264 & 14.31 & 17.69 \\
\hline \multirow{3}{*}{6} & Mass of wet sample + continer & $\bar{g}$ & 148.9 & 140.2 & 127.1 \\
\hline & Mass of water & $\mathrm{g}$ & 2.1 & 110 & 119 \\
\hline & water content & $\%$ & 162 & 10.03 & 12.37 \\
\hline \multirow{3}{*}{7} & Mass of wet sample + continer & $\mathrm{g}$ & 148.1 & 134.9 & 1218 \\
\hline & Mass of water & $g$ & 1.3 & 5.7 & 6.6 \\
\hline & water content & $\%$ & 100 & 5.20 & 6.84 \\
\hline \multirow{3}{*}{8} & Mass of wet sample + continer & $\mathrm{g}$ & 147.6 & 1316 & 118 \\
\hline & Mass of water & $g$ & 0.8 & 2.4 & 28 \\
\hline & water content & $\%$ & 0.60 & 2.20 & 2.88 \\
\hline \multirow{3}{*}{9} & Mass of wet sample + continer & $g$ & 147.6 & 130.5 & 116.7 \\
\hline & Mass of water & $g$ & 0.8 & 13 & 15 \\
\hline & water content & $\%$ & 0.60 & 1.20 & 152 \\
\hline
\end{tabular}


Table 5-9: Data sheet for shrinkage limit test

\begin{tabular}{|c|c|c|c|c|}
\hline \multirow{2}{*}{ Description } & \multirow[t]{2}{*}{ Unit } & \multicolumn{3}{|c|}{ Sample nuber } \\
\hline & & 1 & 3 & 5 \\
\hline In'tial water content & $\%$ & 27.1 & 40.0 & 52.5 \\
\hline Mass of empty shrinkage dish & 8 & 19.5 & 19.4 & 19.4 \\
\hline Mass of strinkage dish with water equal to volume of the shrikage dish & g & 103.2 & 102.7 & 104.2 \\
\hline Mass of water in continer & $\mathrm{g}$ & 83.7 & 83.3 & 84.8 \\
\hline Volume of shrikage dish: VI & $\mathrm{cm} 3$ & 83.7 & 83.3 & 84.8 \\
\hline Mass of (shinkage dish + net sol) & g & 181.4 & 173.1 & 165.6 \\
\hline Mass of wet sol : Ml & 8 & 161.9 & 153.7 & 146.2 \\
\hline Density of wet sample & $\mathrm{g} / \mathrm{cm} 3$ & 1.93 & 1.85 & 1.72 \\
\hline Mass of sol & $\mathrm{g}$ & 127.3 & 109.8 & 95.8 \\
\hline Mass of water & $g$ & 34.57 & 43.91 & 50.36 \\
\hline Mass of (shrinkage dish + dy sol) & $\mathrm{g}$ & 147.6 & 130.5 & 116.7 \\
\hline Mass of dry soi : Ms & $g$ & 128.1 & 111.1 & 97.3 \\
\hline Mass of remined water & $\mathrm{g}$ & 0.8 & 1.3 & 1.5 \\
\hline Water content & $\%$ & 0.60 & 1.20 & 1.52 \\
\hline Mass of (dish + Wax equal to in volume of dry pail + dry soil) & $\mathrm{g}$ & 154.70 & 145.00 & 139.60 \\
\hline Mass of wax in dish & $\mathrm{g}$ & 7.1 & 14.5 & 22.9 \\
\hline Volume of wax in dish: & $\mathrm{cms}$ & 9.2 & 18.8 & 29.7 \\
\hline Volume of sol after strikage : V2 & & 74.50 & 64.52 & 55.14 \\
\hline Vohme of dry sol (solids) & & 44.17 & 38.31 & 33.55 \\
\hline Void ratio & & 0.69 & 0.68 & 0.64 \\
\hline Void ratio/S.G. & & 0.24 & 0.24 & 0.22 \\
\hline Specific gravity of soil & & 29 & 2.9 & 29 \\
\hline Shrikage lim, $\quad k_{i}=\frac{\left(U_{1}-M_{i}\right)-\left(P_{1}-r_{i}\right) P_{4}}{U_{i}} \times 100$ & $\%$ & 19.21 & 21.44 & 19.77 \\
\hline Shrikage ratio, $\quad S R=\frac{\lambda r_{s}}{T}$ & & 1.72 & 1.72 & 1.76 \\
\hline Volumetric strikage $\quad V_{s}=\frac{V_{1}-V_{2}}{V_{2}} \times 100$ & $\mathbf{c m} 3$ & 12.34 & 29.11 & 53.79 \\
\hline Wax density (pwax) & $8 / \mathrm{cm} 3$ & 0.772 & 0.772 & 0.772 \\
\hline Water density (pw) & $\mathrm{g} / \mathrm{cm}^{3}$ & 1 & 1 & 1 \\
\hline
\end{tabular}




\section{5-3-2. Effect of initial water content (IWC) on Gold mine tailings behaviour}

To investigate effect of initial water content (IWC) on Gold mine tailings behaviour, five tailings - water characteristive curve tests have been done with different IWC:

- GMT sample with $\mathrm{w}_{\mathrm{i}}=22 \% \quad$ (water content of samples as they arrived at our laboratory)

- GMT sample with $w_{i}=26 \%$

- GMT sample with $w_{i}=33 \% \quad$ (after settling water content)

- GMT sample with $\mathrm{w}_{\mathrm{i}}=41 \%$

- GMT sample with $w_{i}=51 \%$

The lowest water content is the water content at which the transported tailings arrived at the laboratory. The $51 \%$ water content corresponds to a solids concentration of $65 \%$, which would be close to the minimum solids concentration at which tailings could be expected to be non-segregating during deposition.

\section{5-3-2-1. GMT sample with $w_{1}=22 \%$}

Since no water was added and sample was not distributed, there was no settling observed after 24 hours. IWC of sample was $22 \%$ with void ratio equal 0.64 . As with all gold tailings samples, the maximum applied matric suction was $400 \mathrm{kPa}$. Water content, saturation and void ratio decreased to $10 \%, 50 \%$ and 0.57 respectively (Tables $5-10$ and 5-11). AEV was around $85 \mathrm{kPa}$ With decreasing suction, water content and saturation increased $17 \%$ and $86 \%$ respectively. But there was no significantly change in void ratio. Figures 5-60 to 5-63 show variations of GMT behaviour parameters. As Figure 5-98 shows at water content less than $20 \%$, shrinkage appears to be small. 
Table 5-10: Effect of suction on water content of gold mine tailings, $\mathrm{w}_{\mathrm{i}}=\mathbf{2 2 . 1 \%}$

\begin{tabular}{|c|c|c|c|c|c|c|c|c|c|c|c|c|c|}
\hline \multirow{2}{*}{$\begin{array}{l}\text { Sution } \\
\text { (kPa) }\end{array}$} & \multirow{2}{*}{$\begin{array}{l}\text { soi } \\
\text { neidt } \\
\text { (d) }\end{array}$} & \multirow{2}{*}{$\begin{array}{l}\text { weter } \\
\text { weight } \\
\text { (d) }\end{array}$} & \multirow{2}{*}{$\begin{array}{c}\text { Initid total } \\
\text { vegtt } \\
\text { (g) }\end{array}$} & \multirow{2}{*}{$\begin{array}{l}\text { finel total } \\
\text { weigt } \\
\text { (d) }\end{array}$} & \multirow{2}{*}{$\begin{array}{l}\text { neter } \\
\text { at } \\
\text { (d) }\end{array}$} & \multirow{2}{*}{$\begin{array}{c}\text { weterin } \\
\text { theunit } \\
\text { (g) }\end{array}$} & \multirow{2}{*}{$\begin{array}{c}\text { Water } \\
\text { cortert } \\
198\end{array}$} & \multicolumn{2}{|c|}{ initial so's" } & \multicolumn{2}{|c|}{ final so's' } & \multicolumn{2}{|c|}{ dengeinsol's' } \\
\hline & & & & & & & & $\begin{array}{l}\text { hedt } \\
\text { (min) }\end{array}$ & $\begin{array}{l}\text { volume } \\
(0 \pi B)\end{array}$ & $\begin{array}{l}\text { heigt } \\
\text { (m) }\end{array}$ & $\begin{array}{l}\text { volure } \\
\text { (omi) }\end{array}$ & $\begin{array}{l}\text { hett } \\
\text { (min) }\end{array}$ & $\begin{array}{l}\text { voture } \\
\text { (2/4) }\end{array}$ \\
\hline 0 & 24 & 3 & & & 00 & & & 153 & & 125 & & HI & 00 \\
\hline 0 & 2554 & 63 & 37050 & 37050 & 0.0 & 653 & 21 & 135 & 167.1 & 135 & 157.1 & 00 & 00 \\
\hline 25 & 2954 & $\mathbf{6} \mathbf{3}$ & 37050 & 3918 & 13.2 & 521 & 17.6 & 13.5 & 167.1 & 130 & 1605 & 0.5 & 40 \\
\hline 54 & 2954 & 521 & 30918 & 30022 & 26 & 495 & 168 & 130 & 1605 & 130 & 1605 & 0.0 & 00 \\
\hline 102 & 2554 & 49.5 & 30922 & 36061 & 3.1 & 464 & 15.7 & 130 & 1605 & 13.0 & 1603 & 0.0 & 01 \\
\hline $\mathbf{2 0 8}$ & 2954 & 464 & 3061 & 3574.1 & 120 & 344 & 116 & 130 & 1803 & 130 & 159.8 & $\mathbf{Q 0}$ & 0.3 \\
\hline 400 & 254 & 344 & $36 / 41$ & 3084 & 5.7 & 287 & 9.7 & 13.0 & 1598 & 13.0 & 159.5 & 00 & 0.2 \\
\hline 20 & 254 & 287 & 36084 & 36687 & -0.3 & 29.0 & 9.8 & 13.0 & 1595 & 13.0 & 159.5 & a. & 00 \\
\hline 100 & 2554 & 290 & 36887 & 36716 & -29 & 319 & 108 & 13.0 & 159.5 & 13.0 & 159.5 & 00 & 00 \\
\hline 50 & 295.4 & 319 & 36716 & $36 / 83$ & 67 & 386 & 13.1 & 13.0 & 1595 & 130 & 1595 & 0.0 & $\infty$ \\
\hline 17 & 295.4 & 386 & 36783 & 3051 & 68 & 45.4 & 15.4 & 13.0 & 1595 & 13.0 & 1595 & 00 & $\mathrm{aO}$ \\
\hline 0 & 2554 & 45.4 & 3051 & 3021 & -40 & 49.4 & 167 & 13.0 & 1995 & 13.0 & 1995 & 00 & Q0 \\
\hline
\end{tabular}

Table 5-11: Effect of suction on saturation of gold mine tailings, $\mathrm{w}_{\mathrm{i}}=\mathbf{2 2 . 1 \%}$

\begin{tabular}{|c|c|c|c|c|c|}
\hline $\begin{array}{l}\text { Sution } \\
\text { (MPa) }\end{array}$ & $\begin{array}{l}\text { Toted } \\
\text { volume } \\
\text { (Omb) }\end{array}$ & $\begin{array}{c}\text { volumed } \\
\text { void } \\
(\mathrm{am} B)\end{array}$ & $\begin{array}{l}\text { Void } \\
\text { ratio }\end{array}$ & $\begin{array}{c}\text { Volmeof } \\
\text { Water } \\
\text { (cmi) }\end{array}$ & $\begin{array}{l}\text { Sturation } \\
199\end{array}$ \\
\hline 0 & 167.1 & $6 \mathbf{6 3}$ & 0.64 & 63 & 1000 \\
\hline 0 & 167.1 & 653 & 064 & 653 & 1000 \\
\hline 25 & 1605 & 586 & 0.58 & 521 & 889 \\
\hline 54 & 180.5 & 586 & 058 & 49.5 & 845 \\
\hline 102 & 1603 & 584 & 057 & 464 & 794 \\
\hline 208 & 1598 & $58 C$ & 0.57 & 34.4 & 594 \\
\hline $4 \mathbb{C}$ & 1995 & $57 . \epsilon$ & 057 & 287 & 498 \\
\hline 200 & 159.5 & 57.6 & 057 & $29 . C$ & 503 \\
\hline $10 \mathrm{C}$ & 1595 & 57.6 & 0.57 & $31 \mathrm{c}$ & 55.4 \\
\hline 5 & 1995 & 57.6 & 057 & $38 E$ & $67 \mathrm{C}$ \\
\hline 17 & 1595 & 57.6 & 05 & 45.4 & 788 \\
\hline C & 1595 & 57.6 & 0.57 & 494 & 857 \\
\hline
\end{tabular}




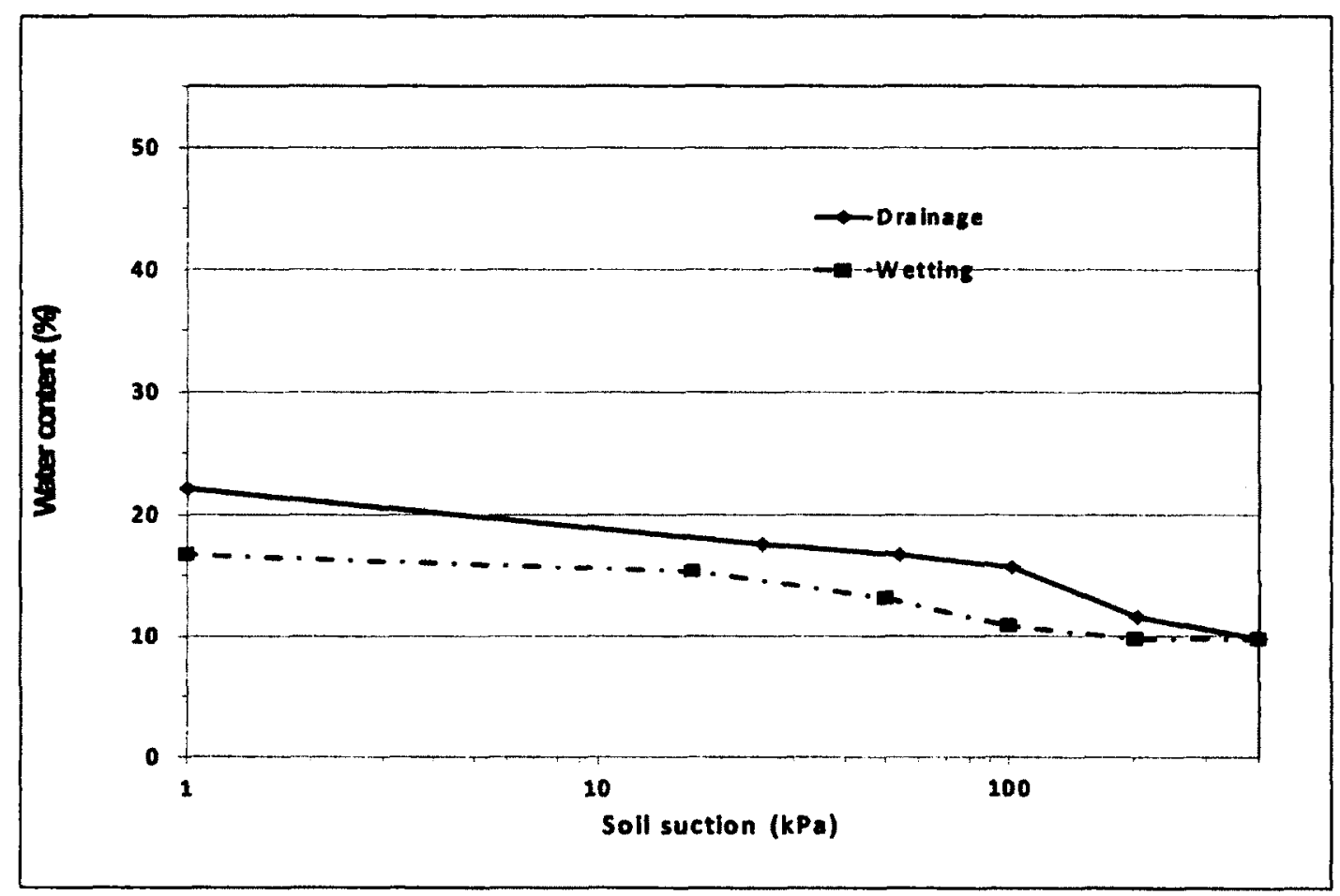

Figure 5-60: Water content-suction curve for gold tailings, $w_{i}=22.1 \%$, log scale

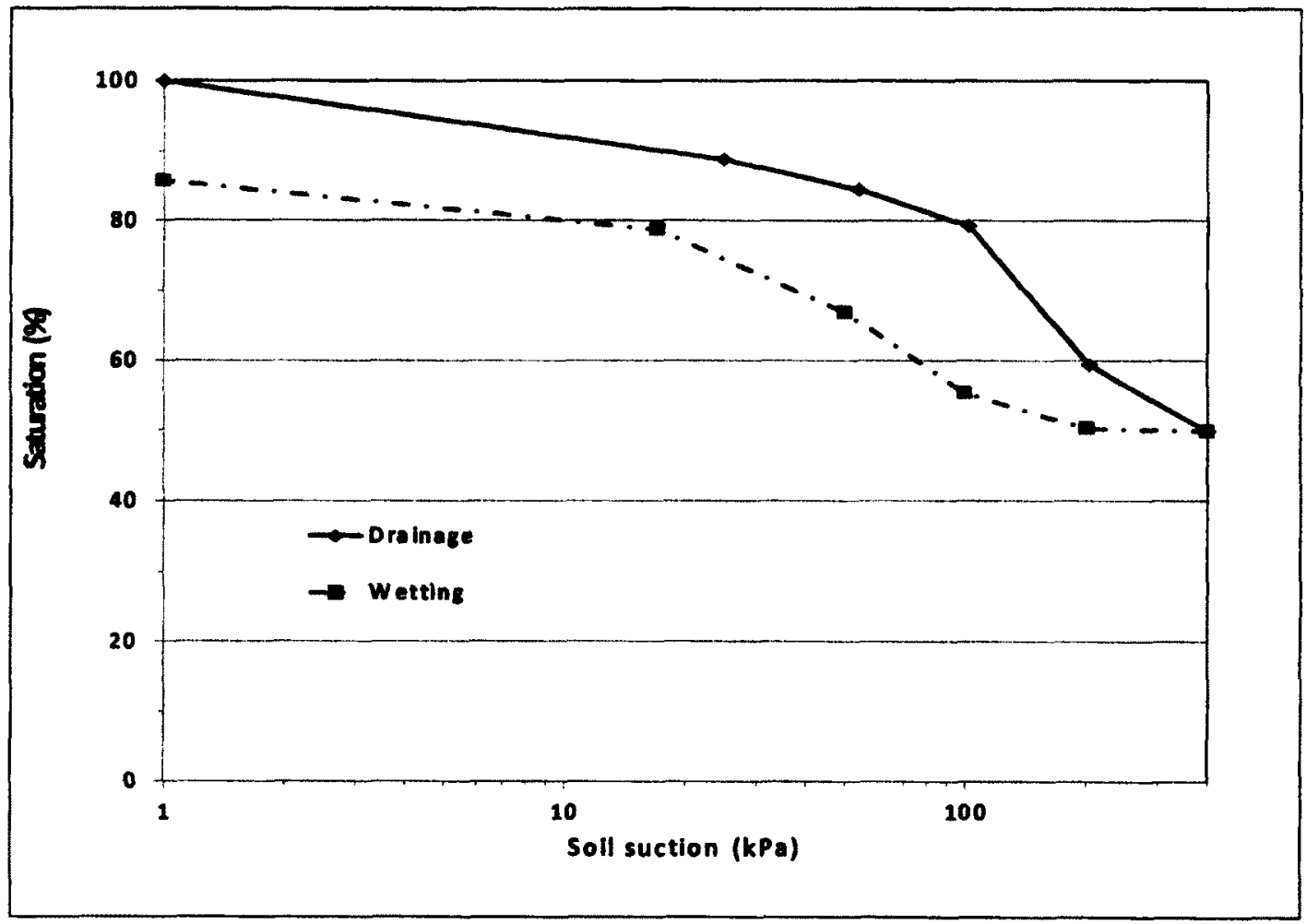

Figure 5-61: Saturation-suction curve for gold mine tailings, $w_{i}=22.1 \%, \log$ scale 


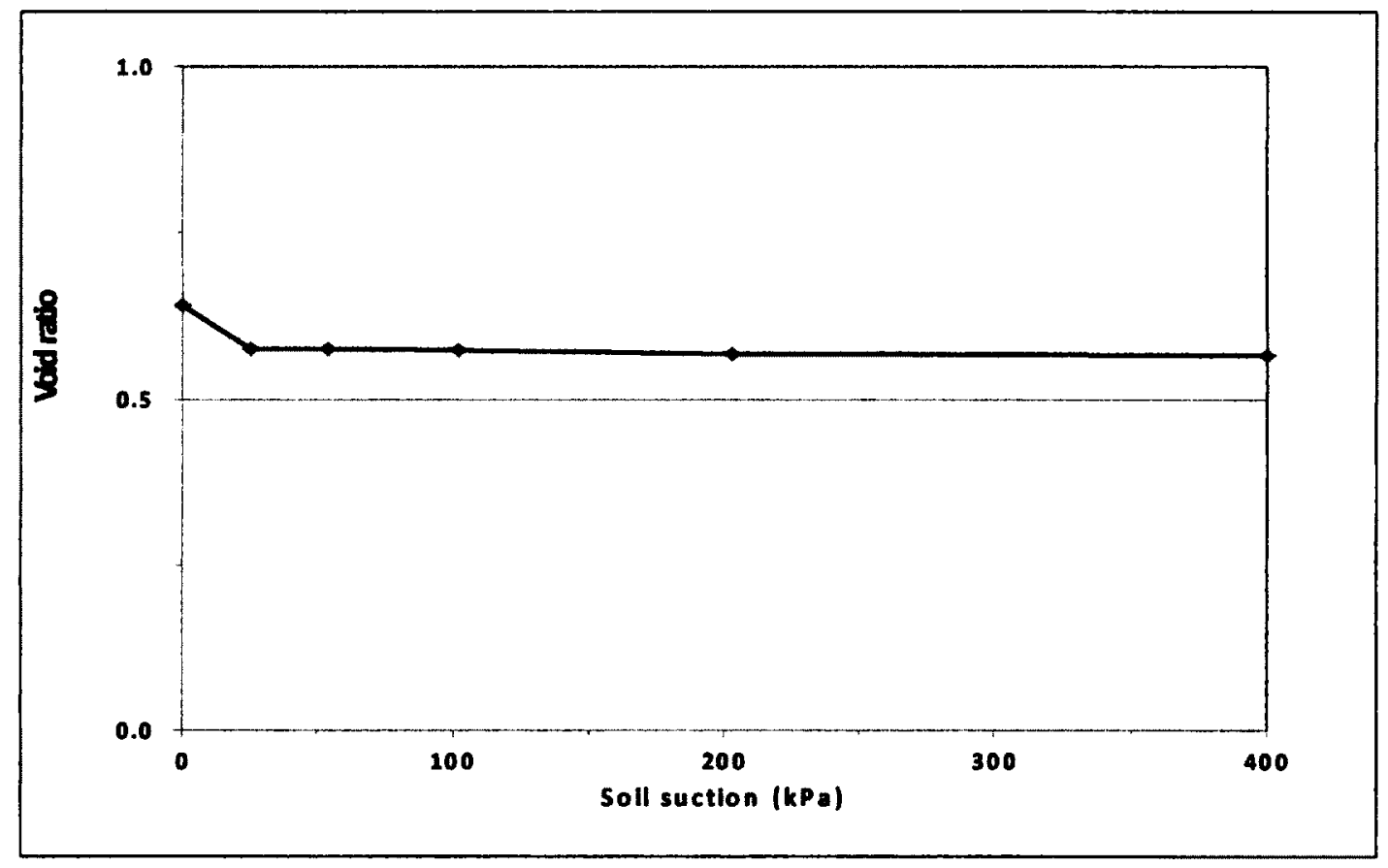

Figure 5-62: Void ratio-suction curve for gold tailings, $w_{\mathrm{i}}=22.1 \%$

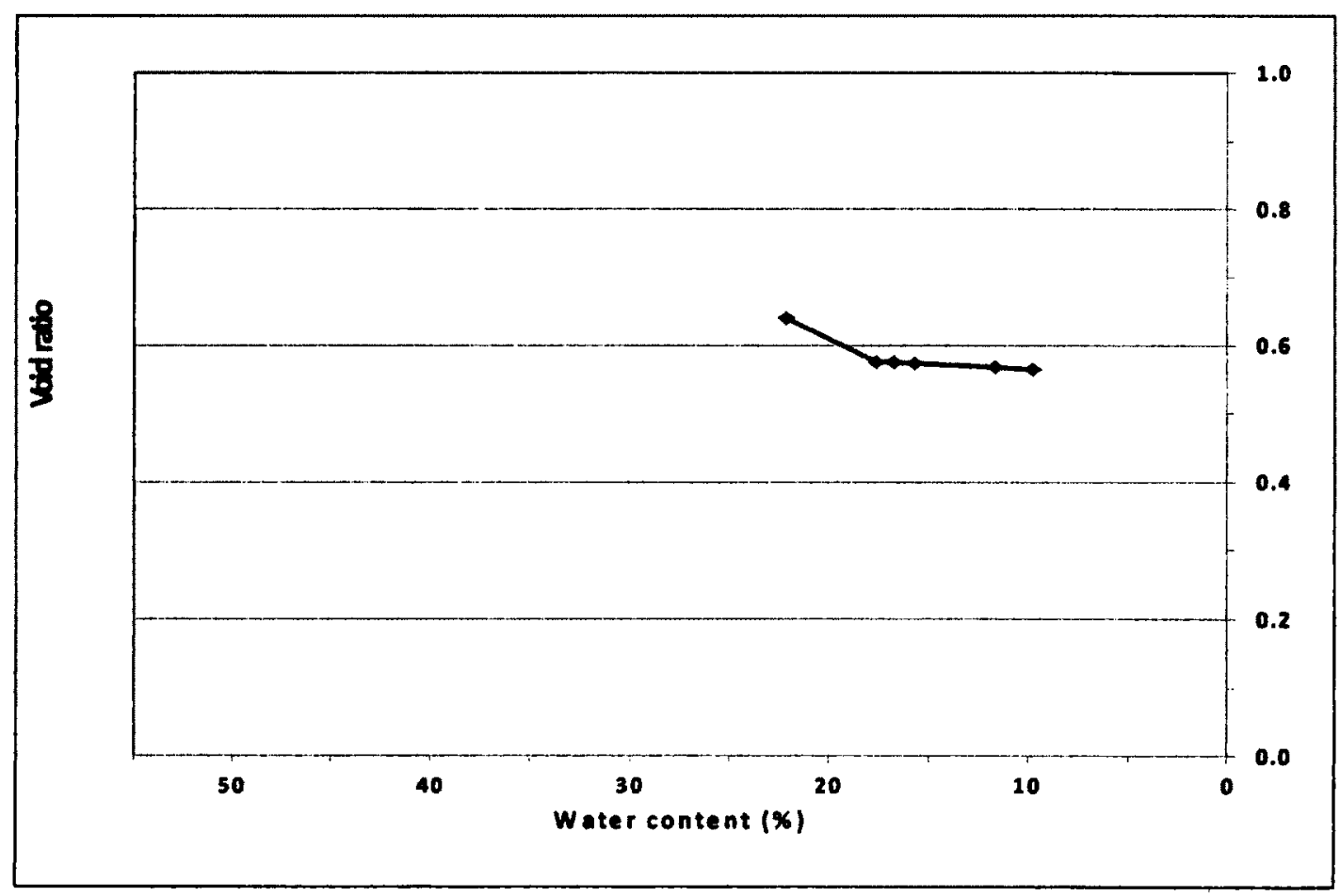

Figure 5-63: Shrinkage curve for gold tailings, $\mathrm{w}_{\mathrm{i}}=22.1 \%$ 


\section{5-3-2-2. GMT sample with $w_{i}=26 \%$}

Minimum water content and saturation at $400 \mathrm{kPa}$ matric suction, were $7 \%$ and $32 \%$. These parameters at the end of wetting increased to $18 \%$ and $86 \%$ respectively. Void ratio of sample from 0.76 reduced to 0.62 and also rate of decreasing in volume of sample was around 8\%. Tables A5-18 and A5-19 and Figures A5-33 and A5-34 in the appendix show more details. Results are plotted in Figures 5-64 to 5-67.

\section{5-3-2-3. GMT sample with $w_{i}=33 \%$}

Sample was left for 24 hours for settling, after settling time $9.1 \mathrm{~g}$ water was taken out from top of the sample by syringe and water content and void ratio of sample decreased to $30 \%$ and 0.87 respectively. At maximum suction, water content, degree of saturation, and void ratio decreased to $6 \%, 30 \%$, and 0.61 respectively. Figures 5-68 and 5-69 show variations of water content and saturation in terms of suction in log scale. Void ratio curve and shrinkage curve can be seen in Figures 5-70 and 5-71. Tables A5-20 and A-21 and Figures A5-35 and A5-36 in the appendix show more details. 


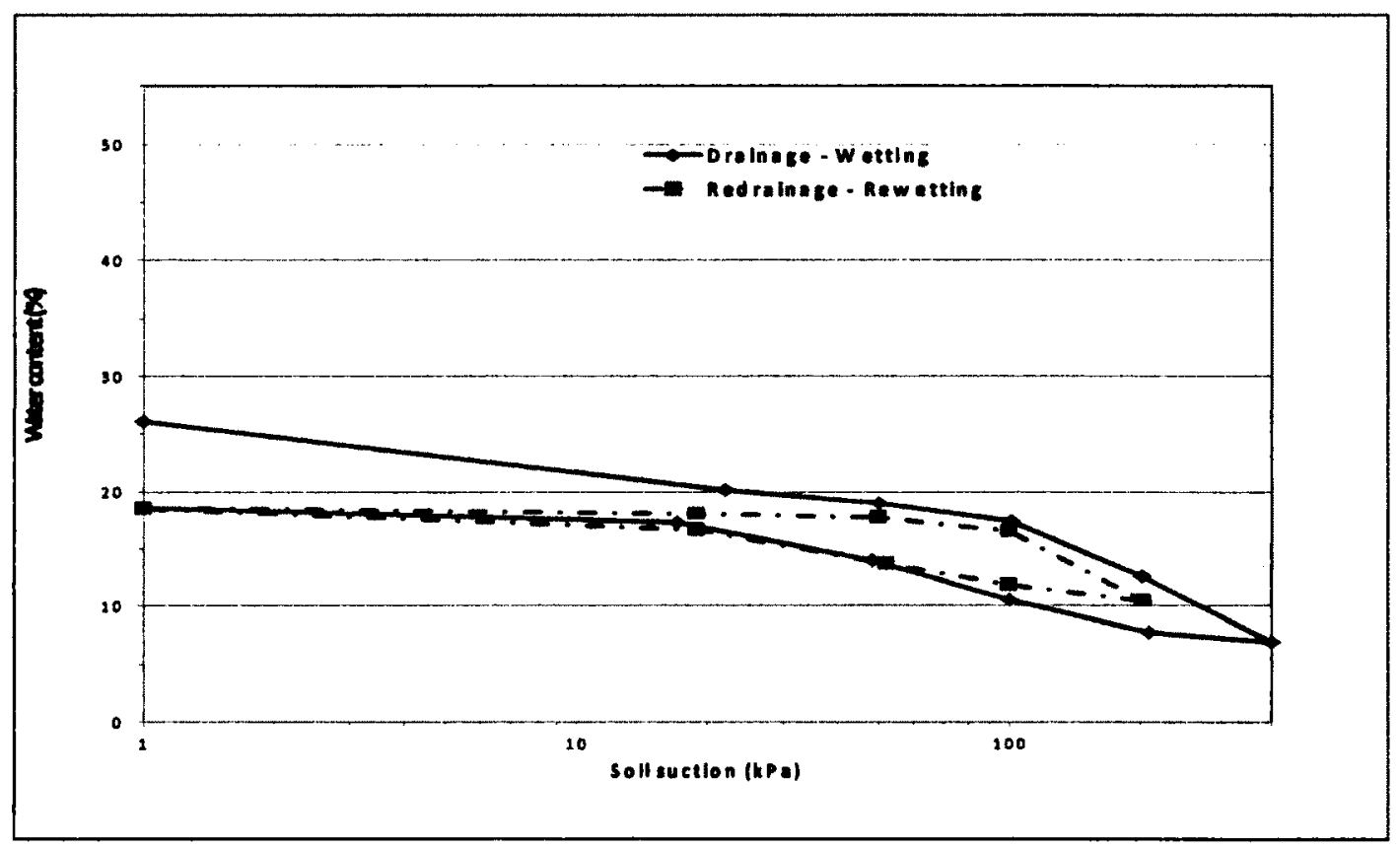

Figure 5-64: Water content -suction curve for gold mine tailings, $w_{i}=26.1 \%$, log scale

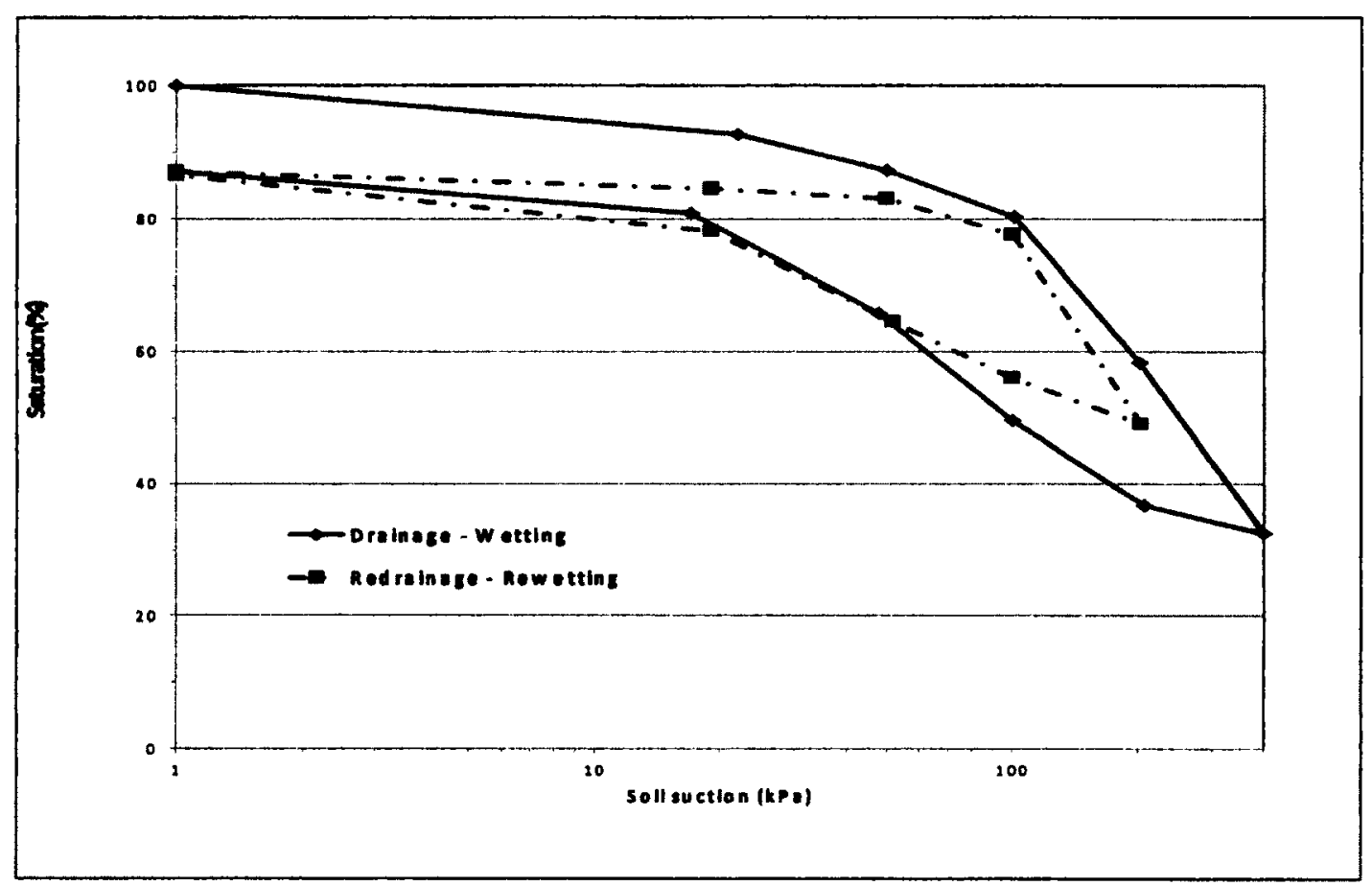

Figure 5-65: Saturation-suction curve for gold mine tailings, $w_{\mathrm{i}}=26.1 \%$, $\log$ scale 


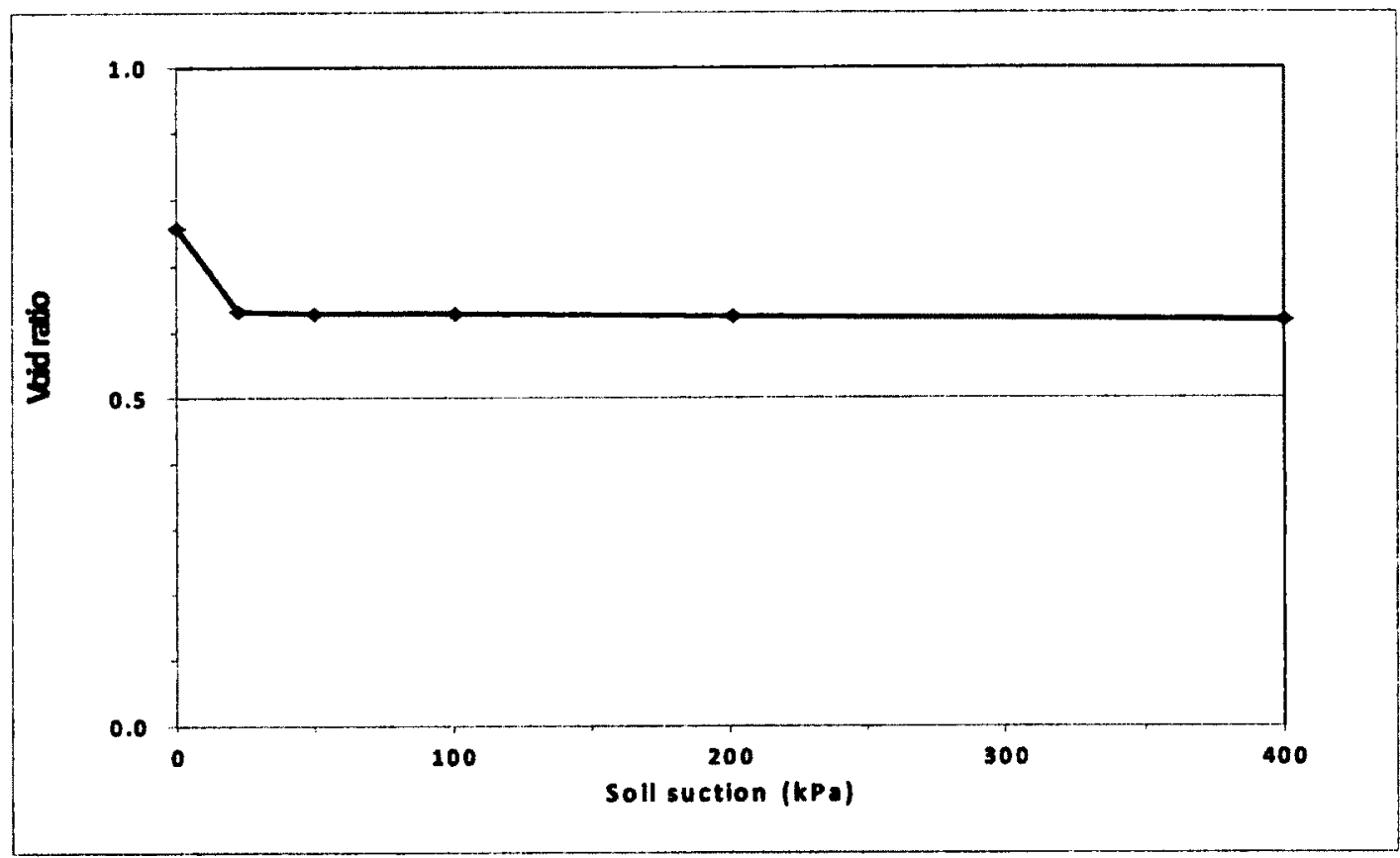

Figure 5-66: Void ratio -suction curve for gold mine tailings, $w_{i}=26.1 \%$

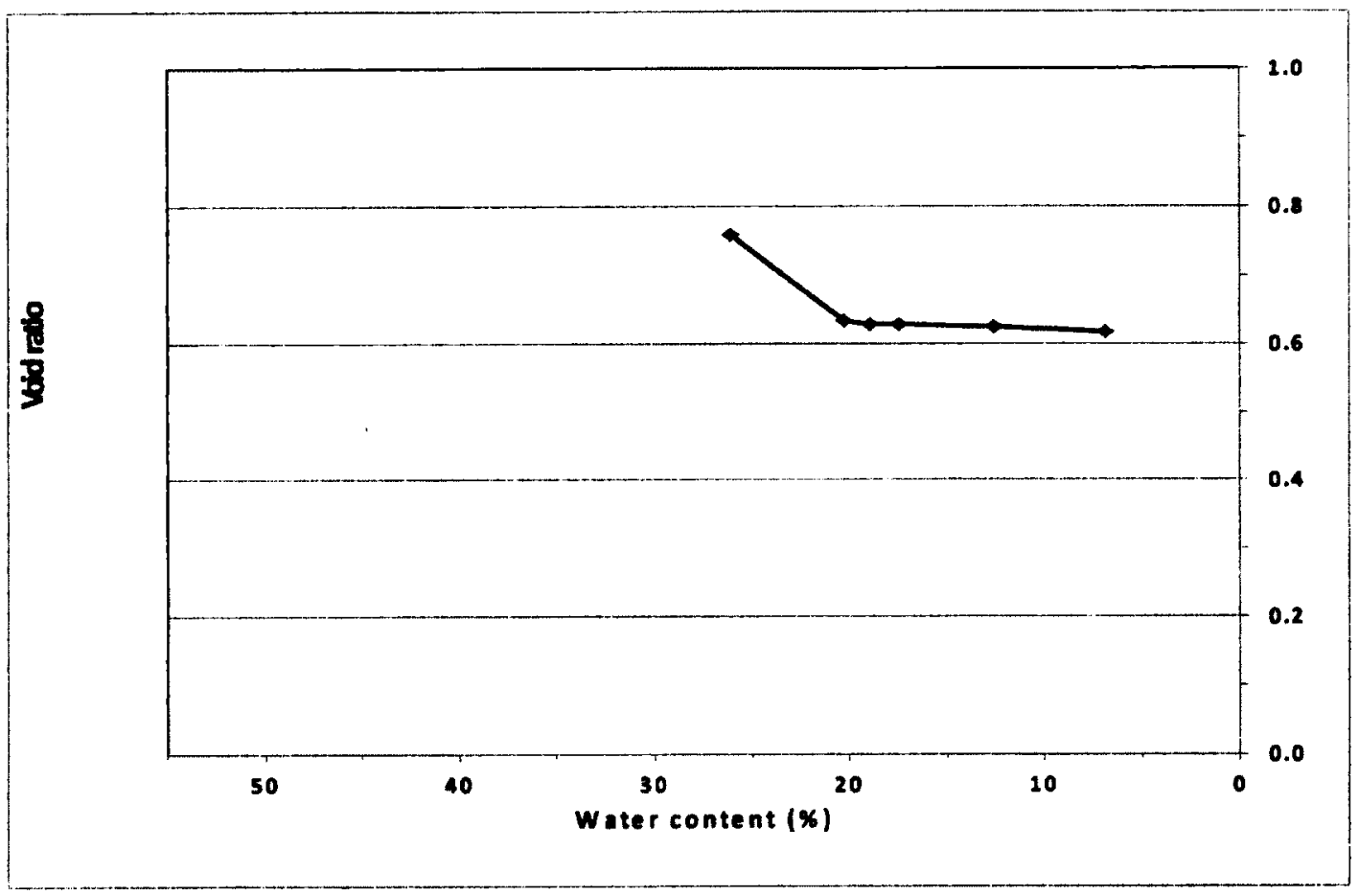

Figure 5-67: Shrinkage curve for gold mine tailings, $\mathrm{w}_{\mathrm{i}}=26.1 \%$, 


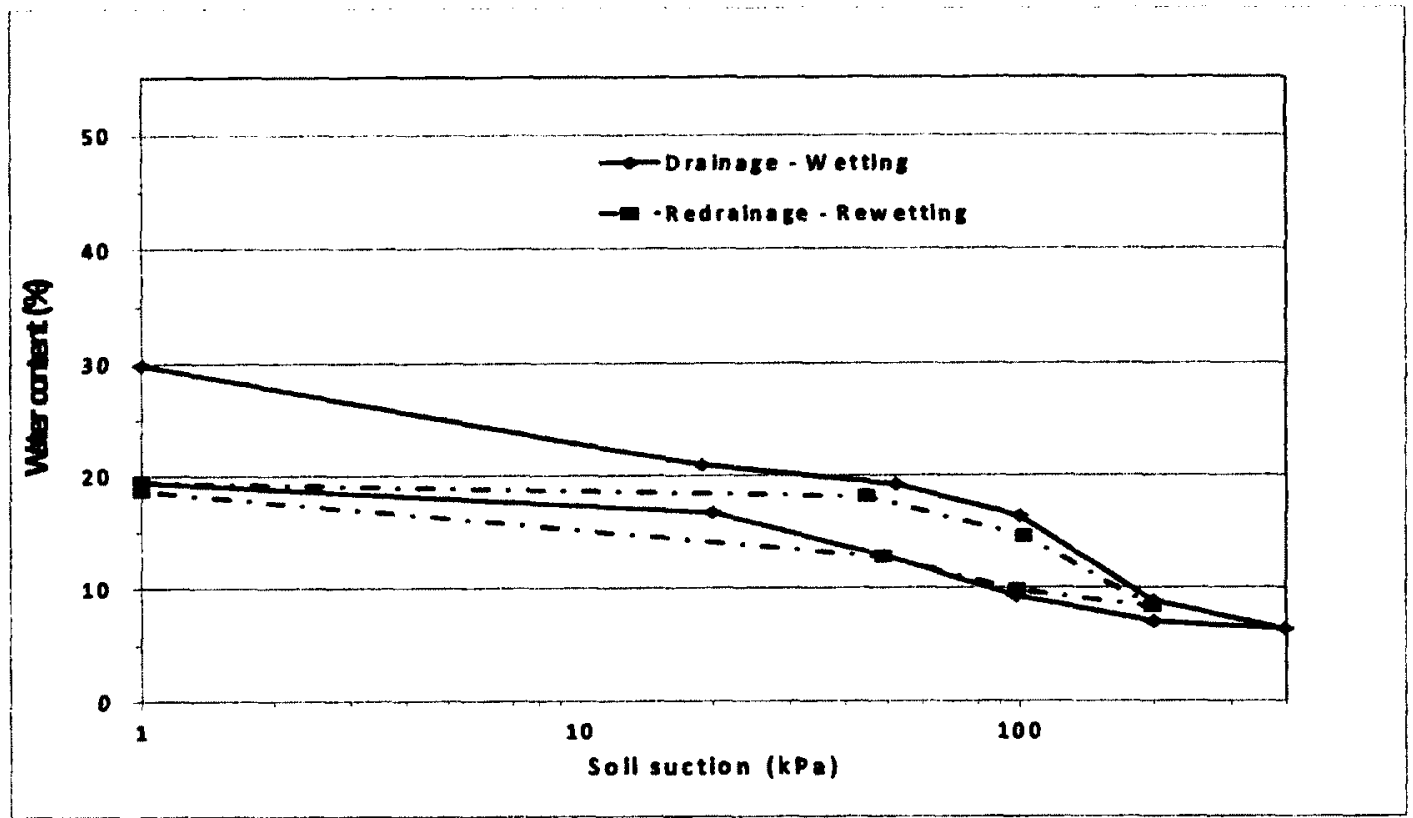

Figure 5-68: Water content -suction curve for gold mine tailings, $w_{i}=33.2 \%$, log scale

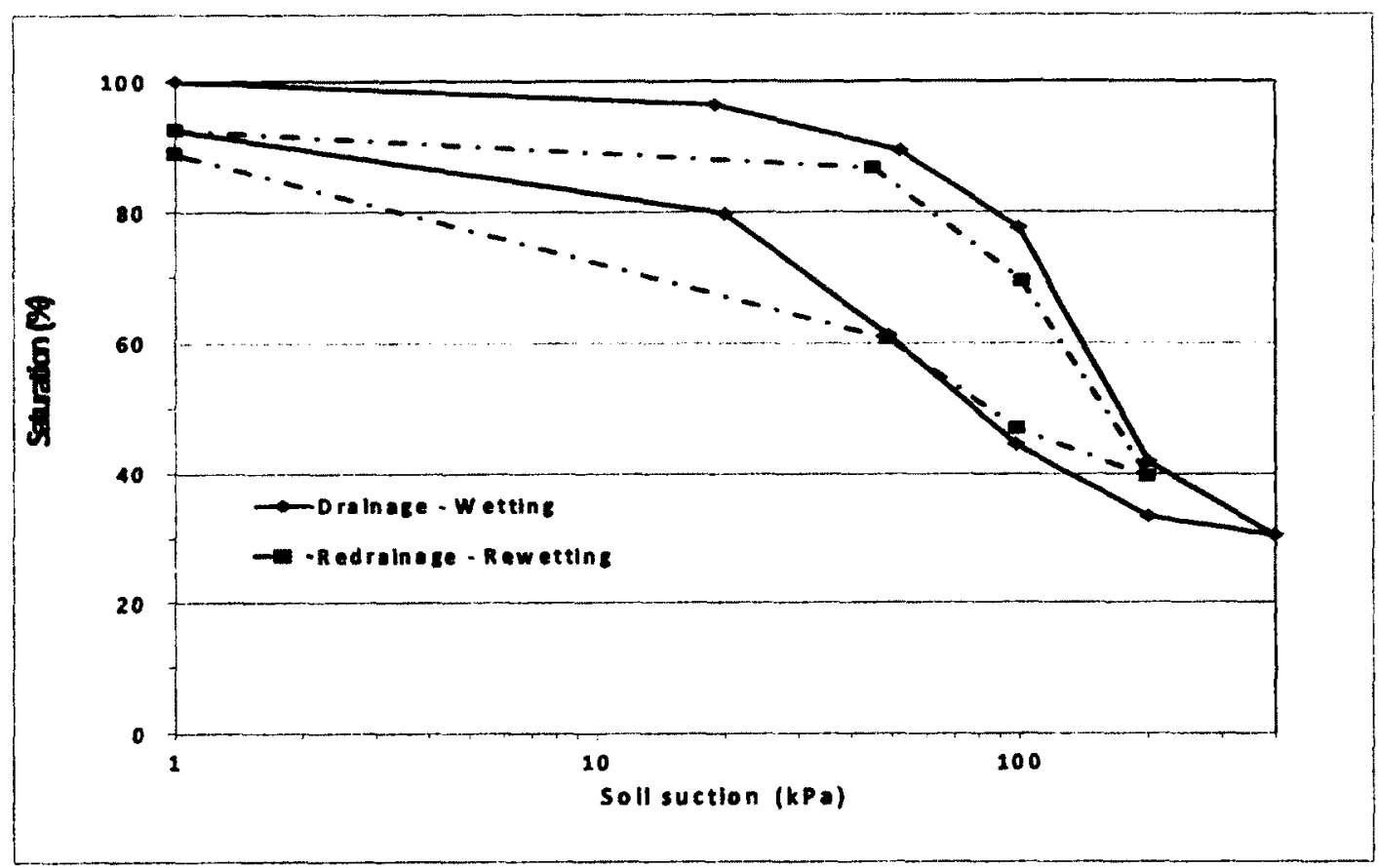

Figure 5-69: Saturation-suction curve for gold mine tailings, $\mathrm{w}_{\mathrm{i}}=33.2 \%$, $\log$ scale 


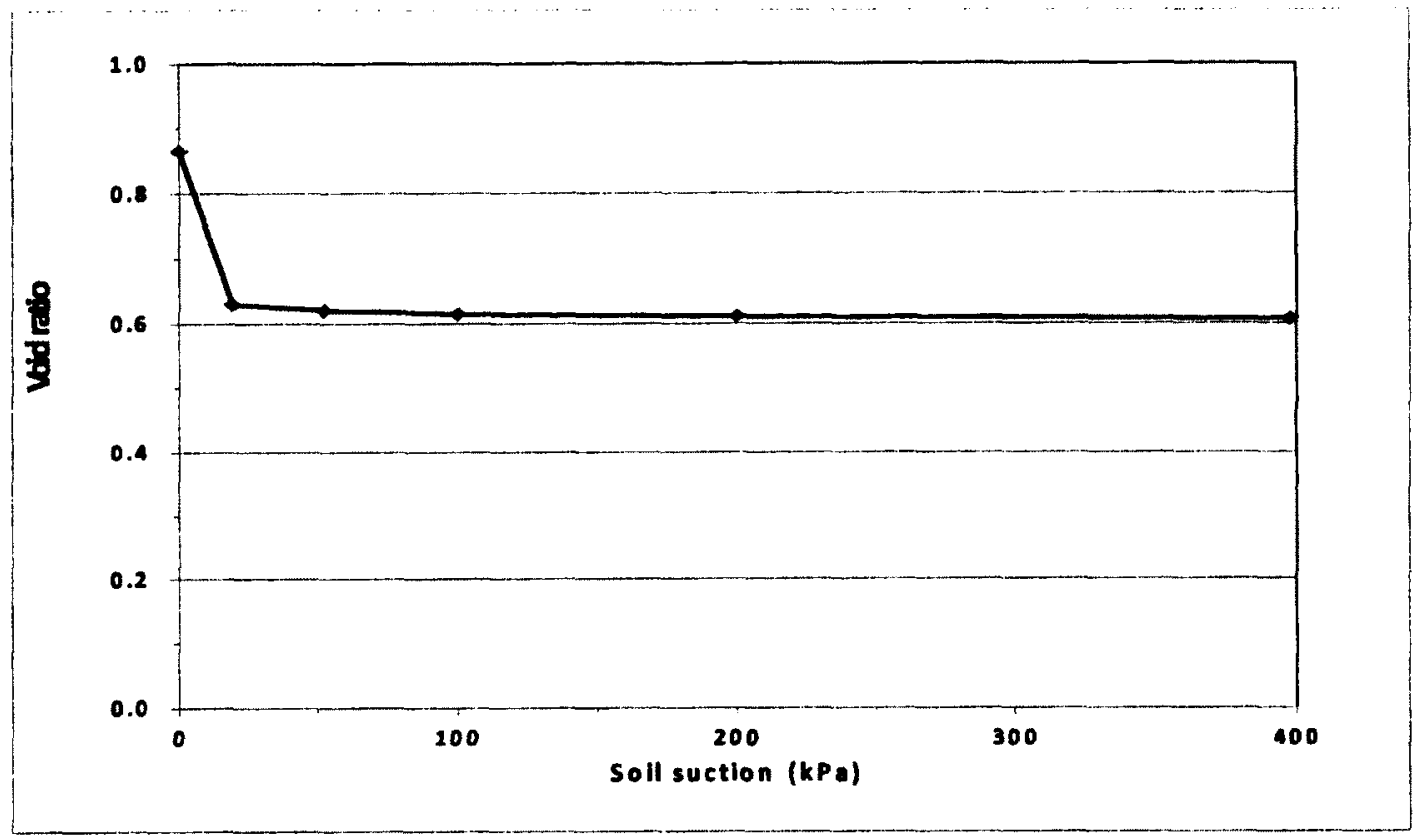

Figure 5-70: Void ratio -suction curve for gold mine tailings, $\mathrm{w}_{\mathrm{i}}=33.2 \%$

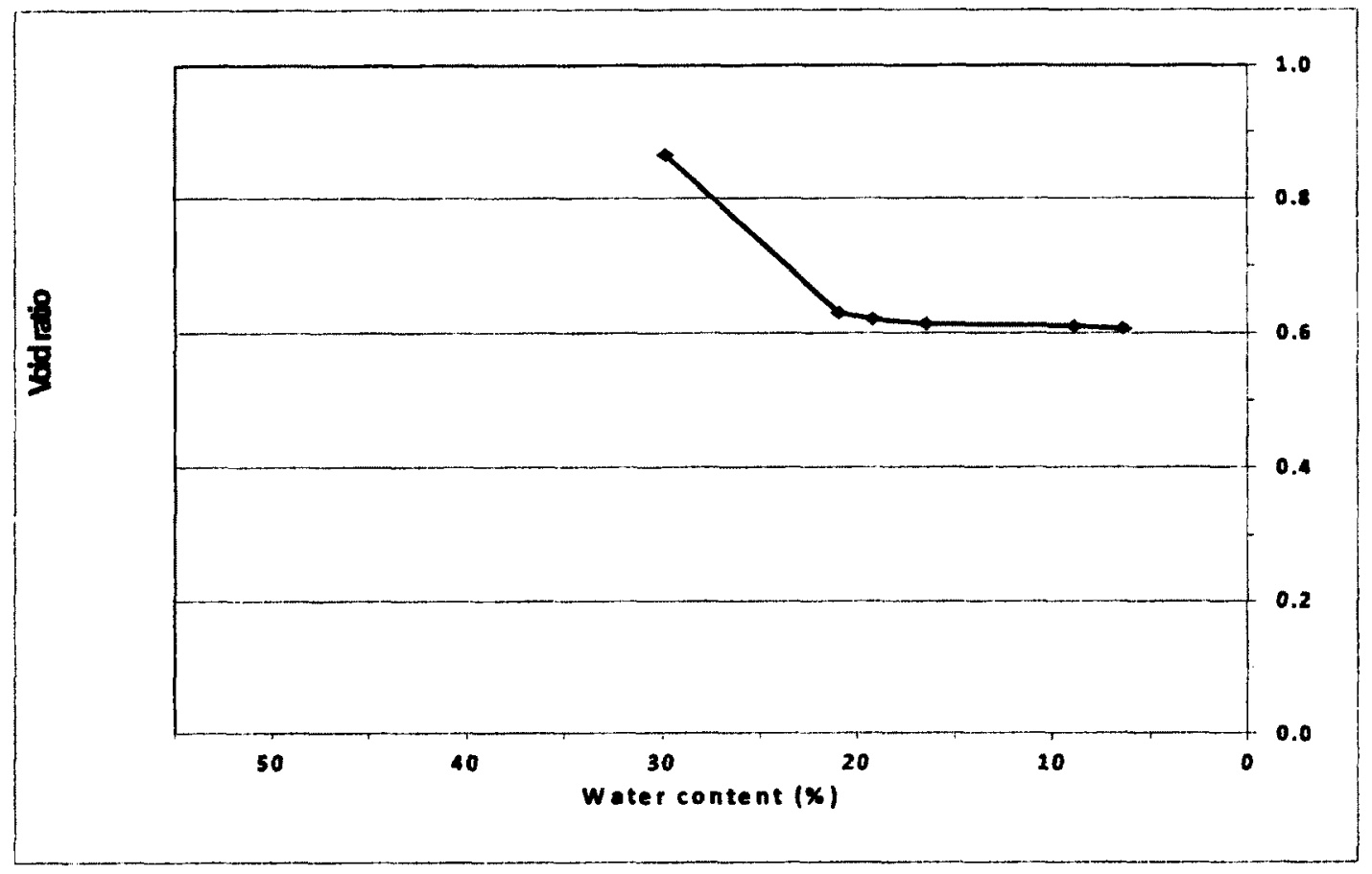

Figure 5-71: Shrinkage curve for gold mine tailings, $w_{i}=33.2 \%$ 


\section{5-3-2-4. GMT sample with $w_{i}=41 \%$}

The following test shows behaviour of Gold mine tailings with initial water content of $41 \%$. These tailings settled to $35 \%$ water content after 24 hours.:

Figures $5-72$ to $5-75$ show the results:

- $\mathrm{AEV}$ is around $50 \mathrm{kPa}$

- Water content and saturation at $400 \mathrm{kPa}$ suction are around $5 \%$ and $24 \%$ respectively.

- Void ratio dropped from 1.18 to 0.67 .

- Volume decreased almost $24 \%$ to $166 \mathrm{~cm}^{3}$.

More details information is brought in Tables A5-22, A5-23 and Figures A5-37 and A538.

\section{5-3-2-5. GMT sample with $w_{i}=51 \%$}

After 24 hours settling, sample settled about $3.6 \mathrm{~mm}$ with $47.5 \mathrm{~g}$ water on the top which removed by syringe. Water content and void ratio of sample at this point were $38 \%$ and 1.09 respectively.

Water content and saturation of sample at maximum suction were $5 \%$ and $22 \%$ with void ratio of 0.70 . AEV for this tailings sample was around $45 \mathrm{kPa}$ Figures 5-76 to 5-78 show variations of water content, saturation, and void ratio of sample in terms of suction. Also shrinkage curve can be seen in Figure 5-79. Tables A5-24 and A5-25 and Figures A5-39 and A5-40 in the appendix show more details. 


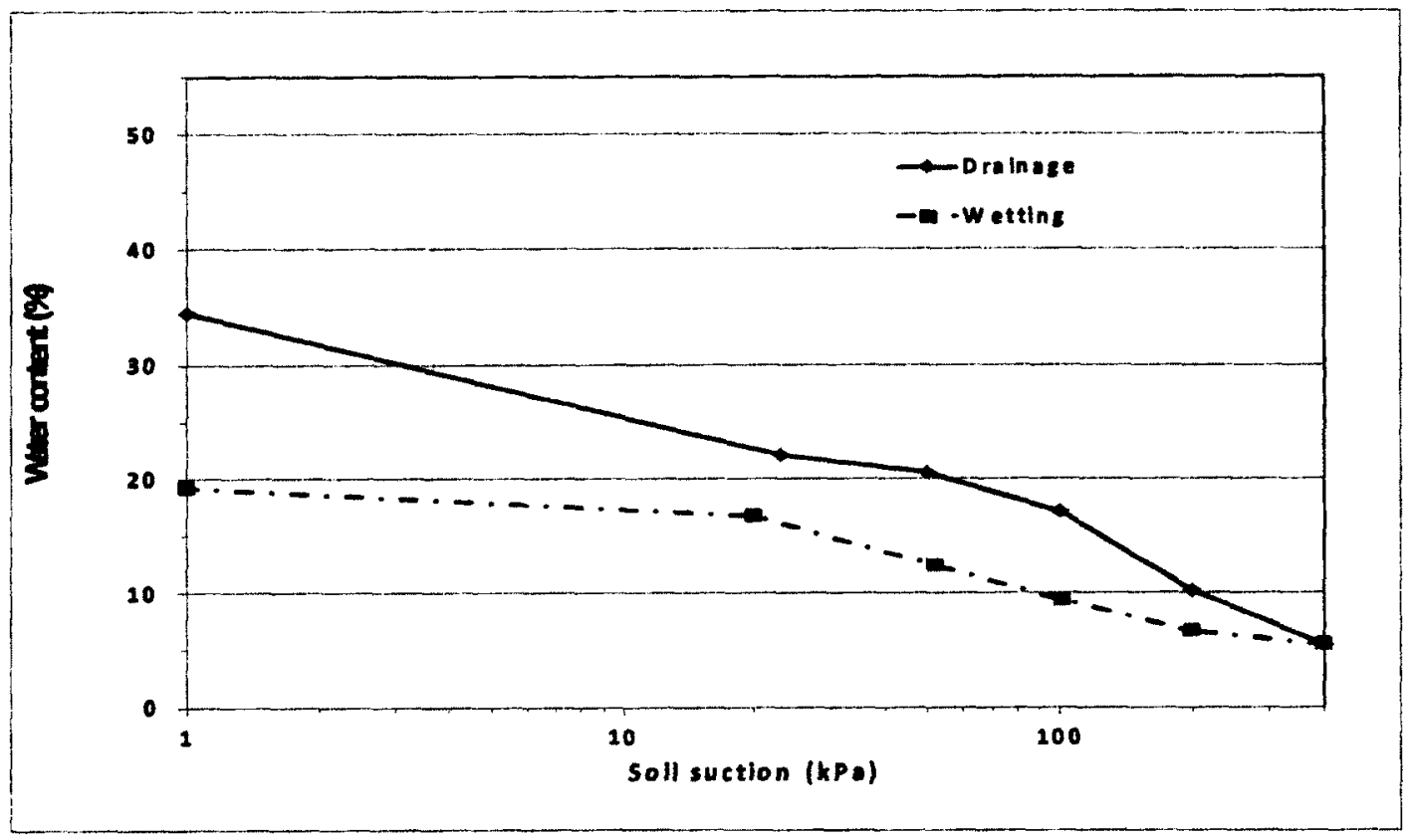

Figure 5-72: Water content -suction curve for gold mine tailings, $w_{i}=40.7 \%$, $\log$ scale

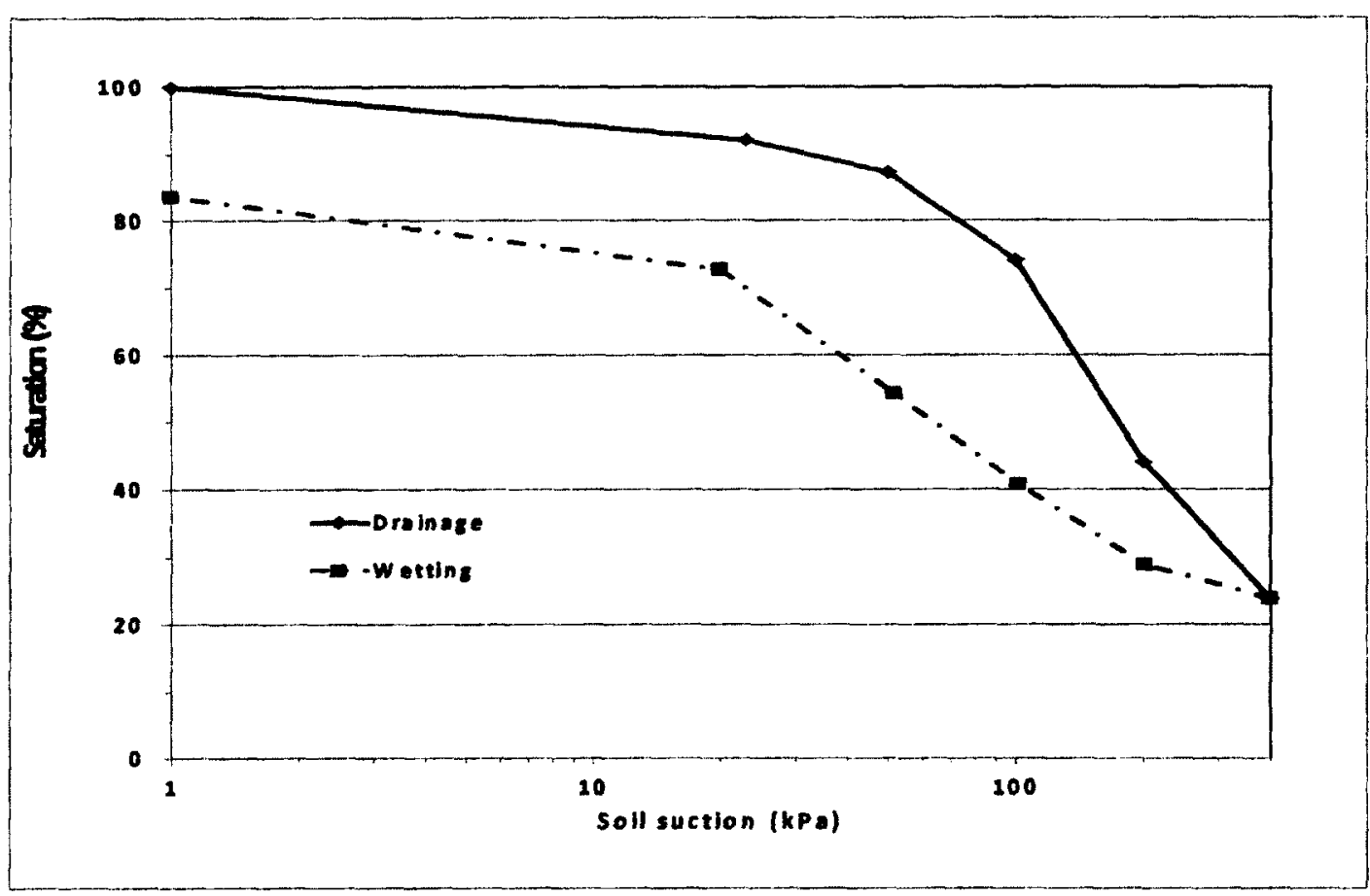

Figure 5-73: Saturation-suction curve for gold mine tailings, $\mathrm{w}_{\mathrm{i}}=40.7 \%$, log scale 


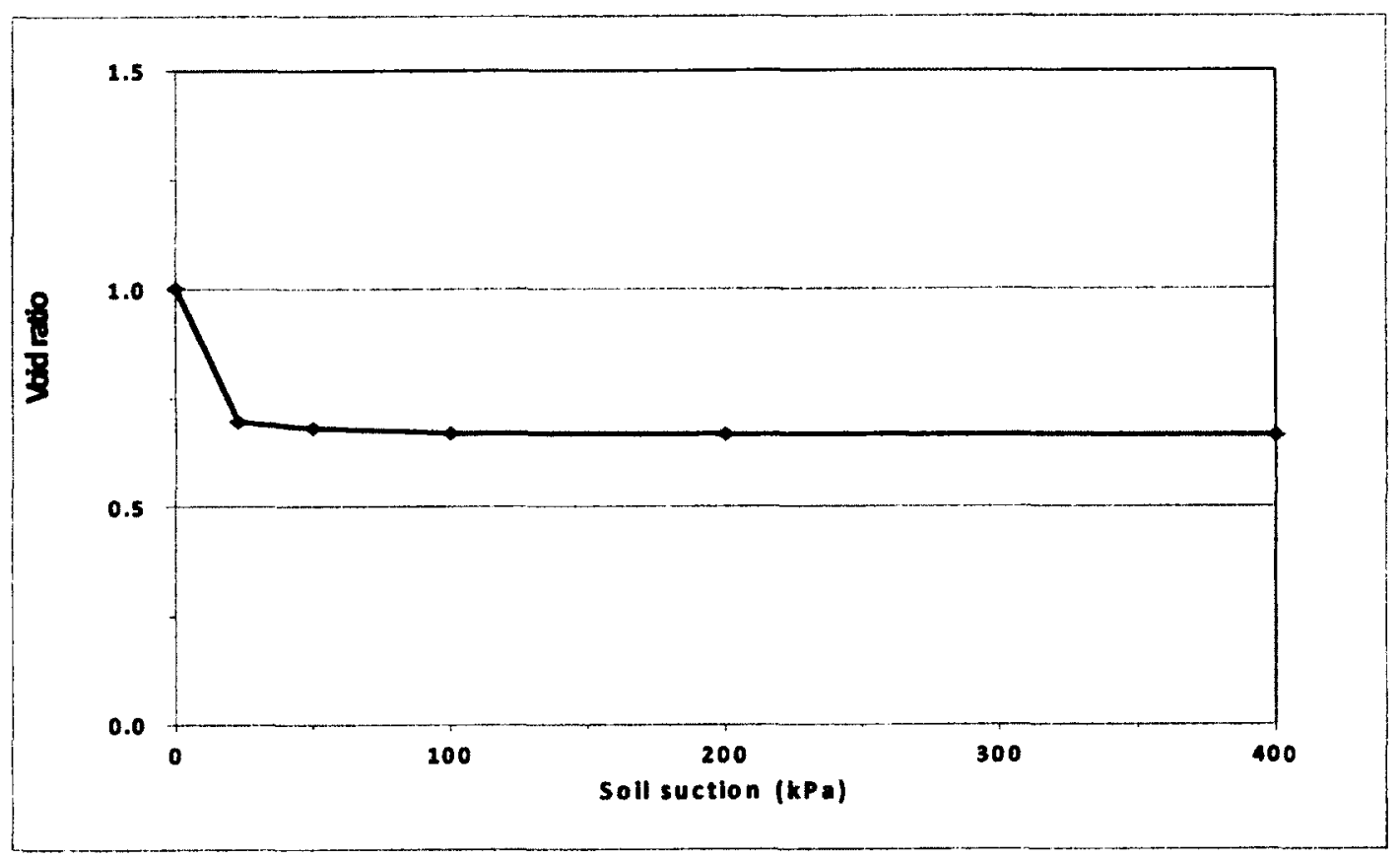

Figure 5-74: Void ratio -suction curve for gold mine tailings, $\mathrm{w}_{\mathrm{i}}=40.7 \%$

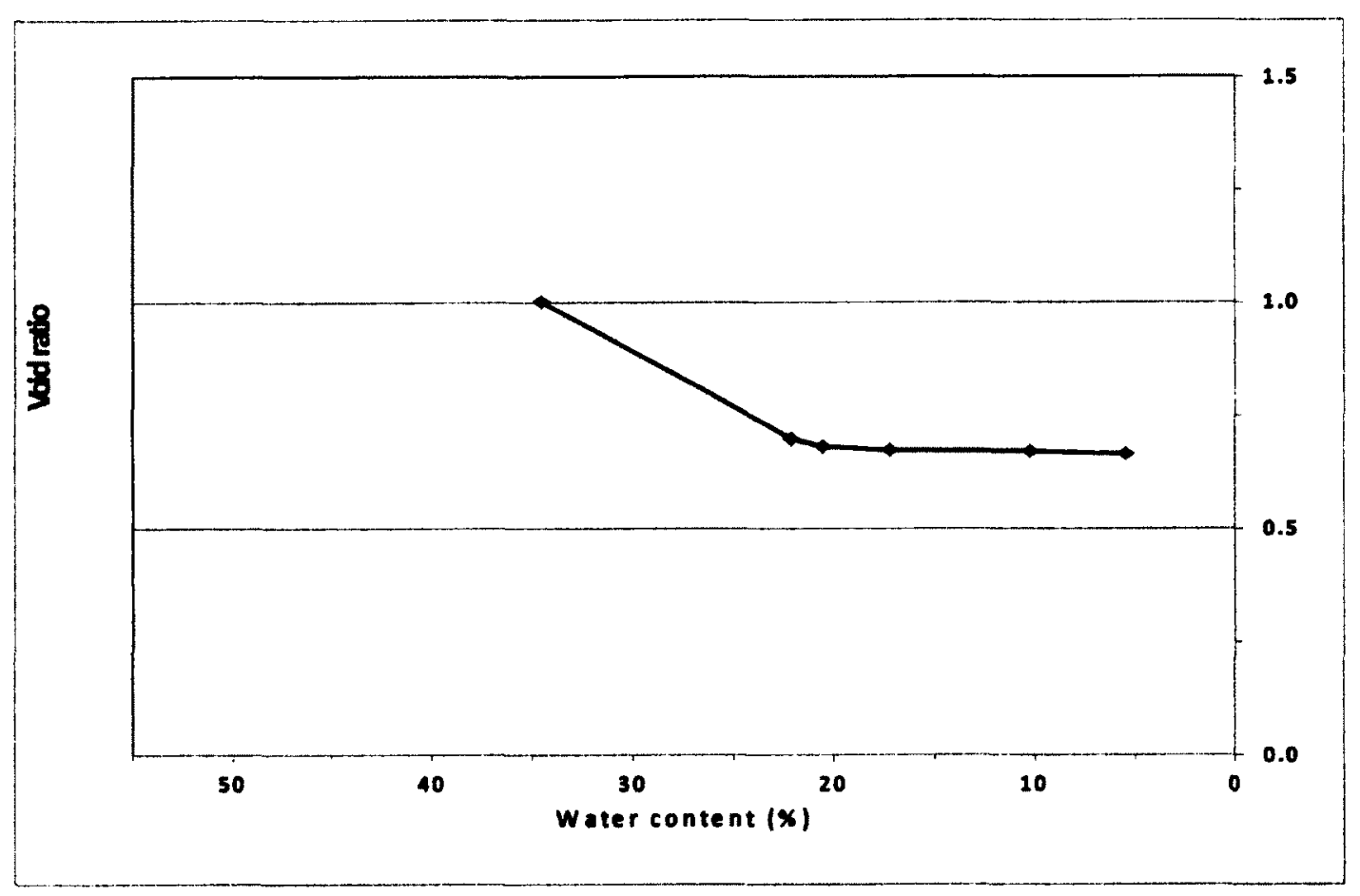

Figure 5-75: Shrinkage curve for gold mine tailings, $w_{i}=40.7 \%$ 


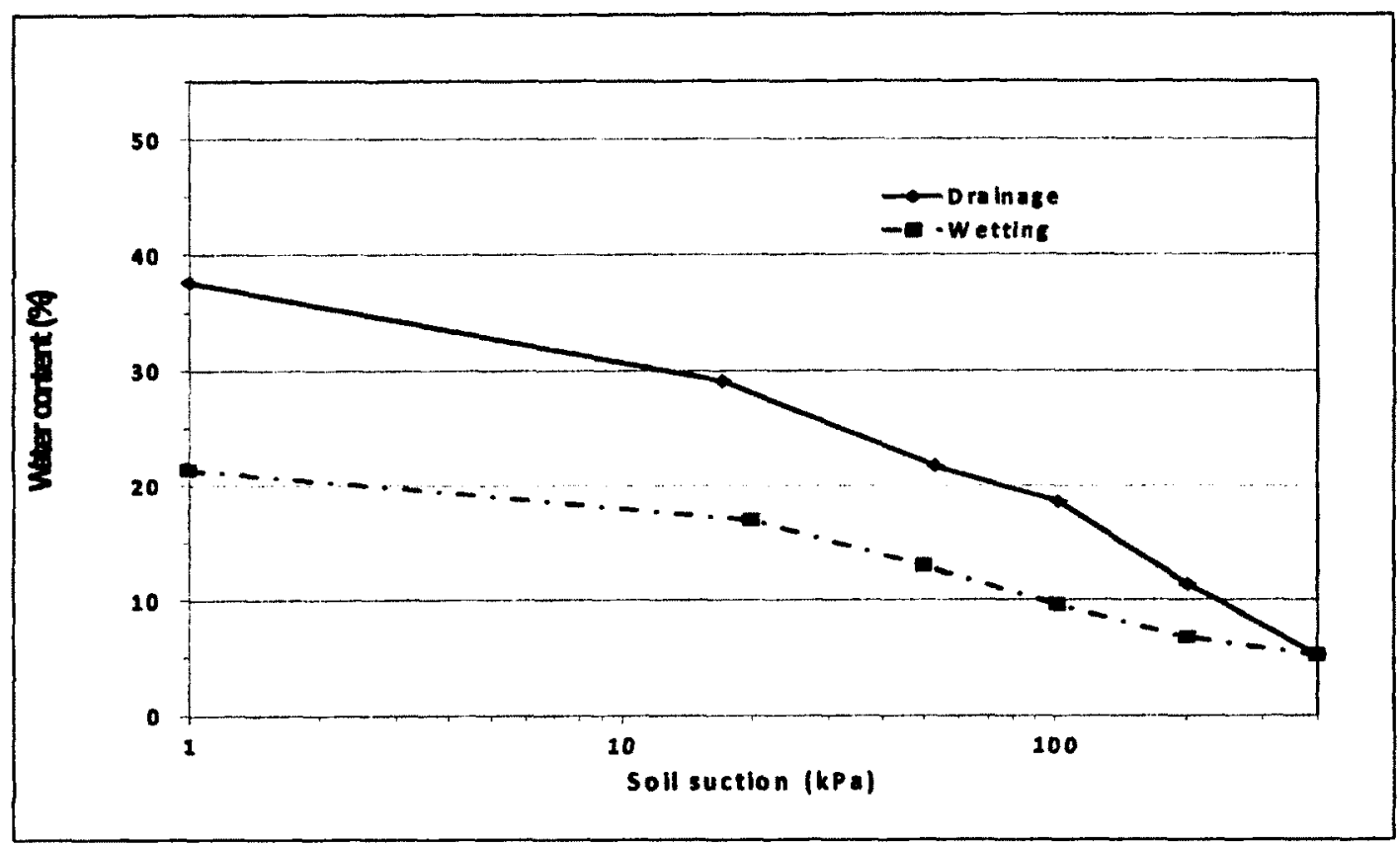

Figure 5-76: Water content -suction curve for gold mine tailings, $w_{i}=50.8 \%$, log scale

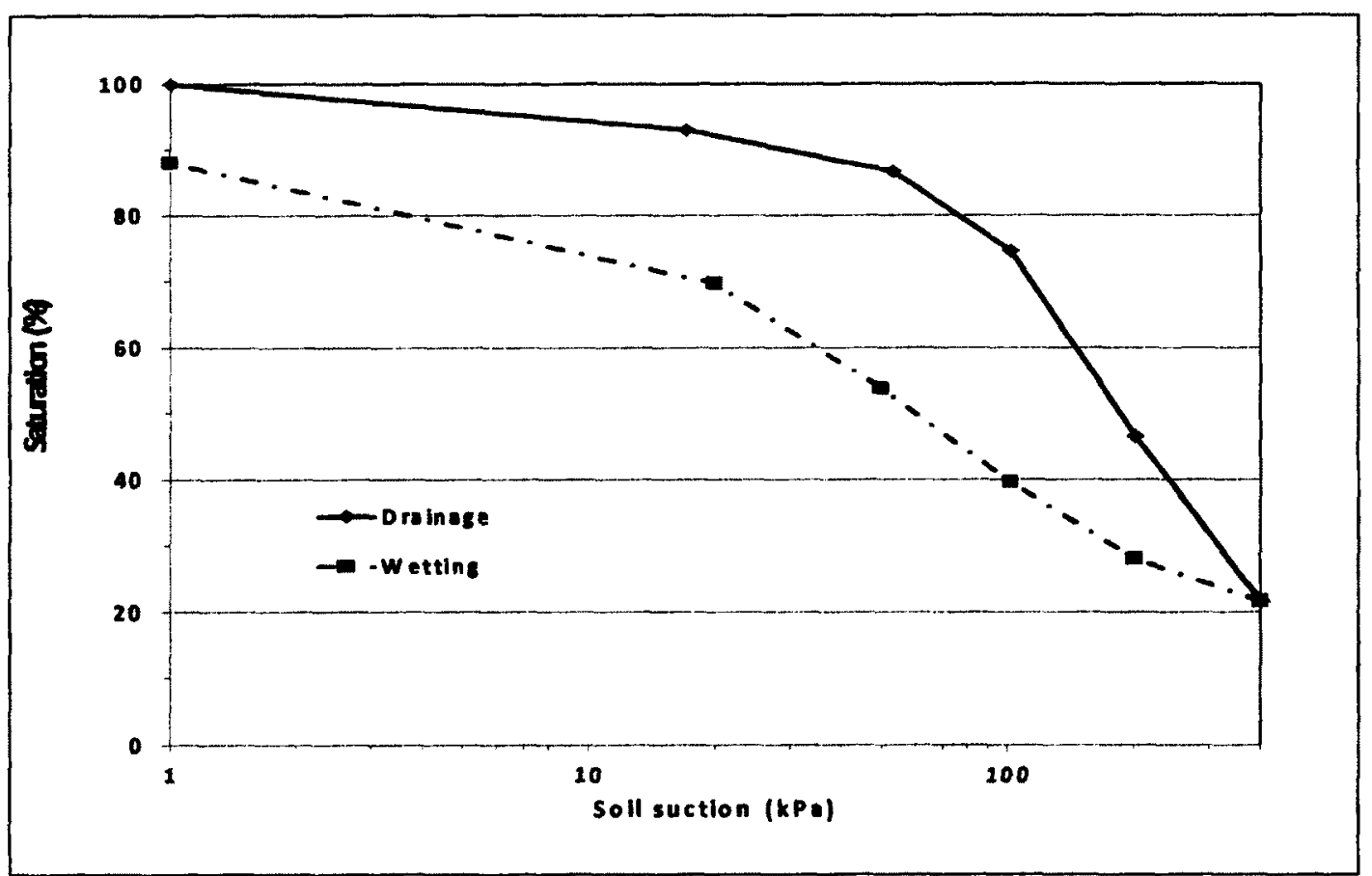

Figure 5-77: Saturation -suction curve for gold mine tailings, $w_{i}=50.8 \%$, $\log$ scale 


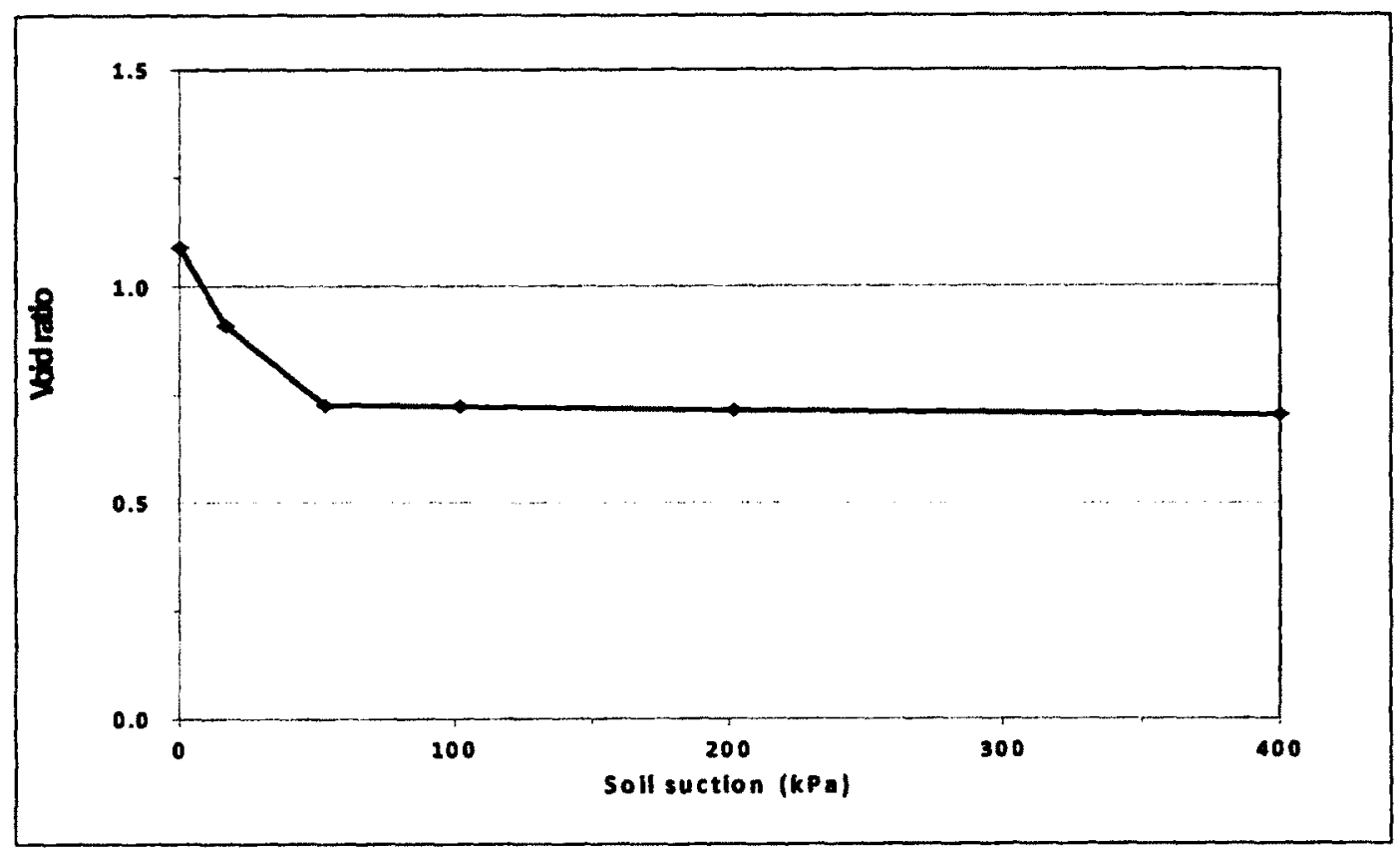

Figure 5-78: Void ratio-suction curve for gold mine tailings, $w_{i}=50.8 \%$

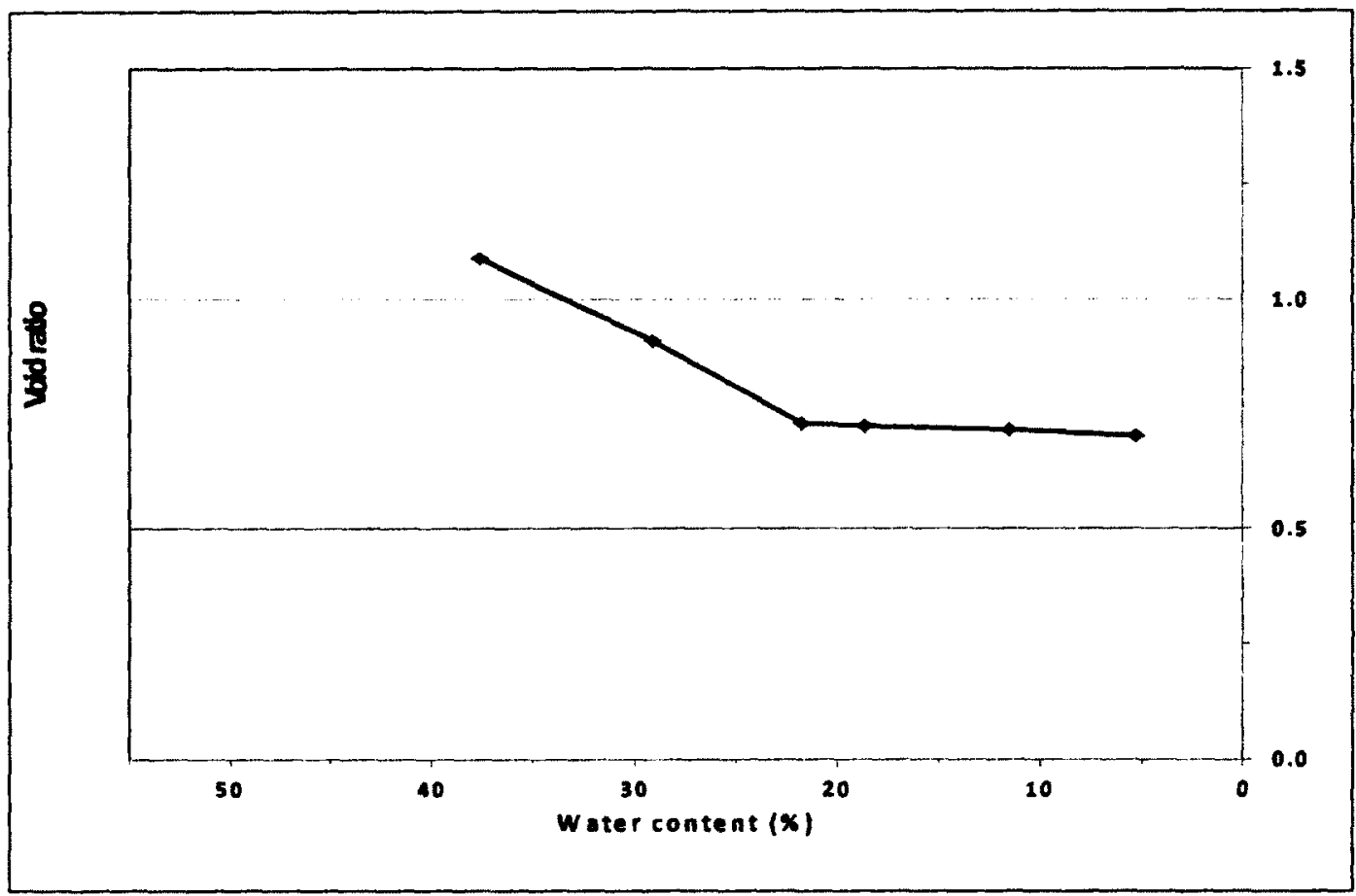

Figure 5-79: Shrinkage curve for gold mine tailings, $w_{i}=50.8 \%$ 


\section{5-3-2-6. Comparison of initial water content effect on TWCC for gold mine tailings}

Gold mine tailings behaviour was investigated under five different initial water contents (50\% to $22 \%$ ). Results of these tests are compared in Figures 5-80 to 5-82. According to these figures, the following conclusions can be drawn:

- Increase in initial water content has only a small effect on AEV.

- Tailings with higher initial water contents have lower water contents at $400 \mathrm{kPa}$ In other words, decreasing rate of water content in tailing with high IWC is bigger than tailings with low IWC. This is shown in Figure 5-83.

- Similar to water content, samples with high initial water content have lower degrees of saturation at $400 \mathrm{kPa}$

- The wetting curves of all five samples are similar: IWC is not an important factor.

- At low suction, high initial water content has higher void ratios but at high suction void ratio - suction curve tend to converge.

- Variation in initial water content seems to have small but consistent effect on the shrinkage curve. Though the shrinkage limits are all around $18 \%$ to $20 \%$ water content, higher initial water contents results in consistently higher final void ratios. 


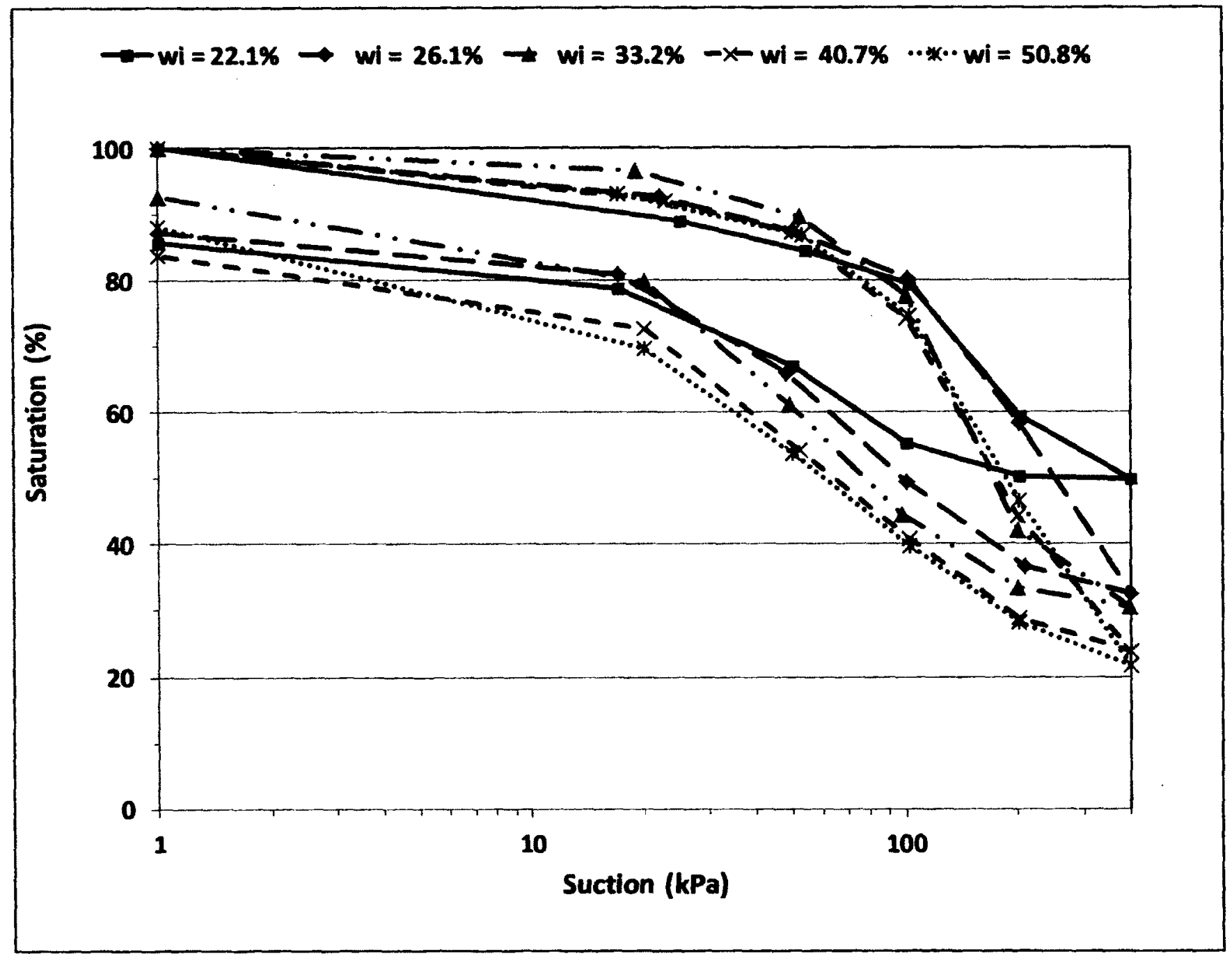

Figure 5-80: Effect of initial water content on saturation-suction curve for gold mine 


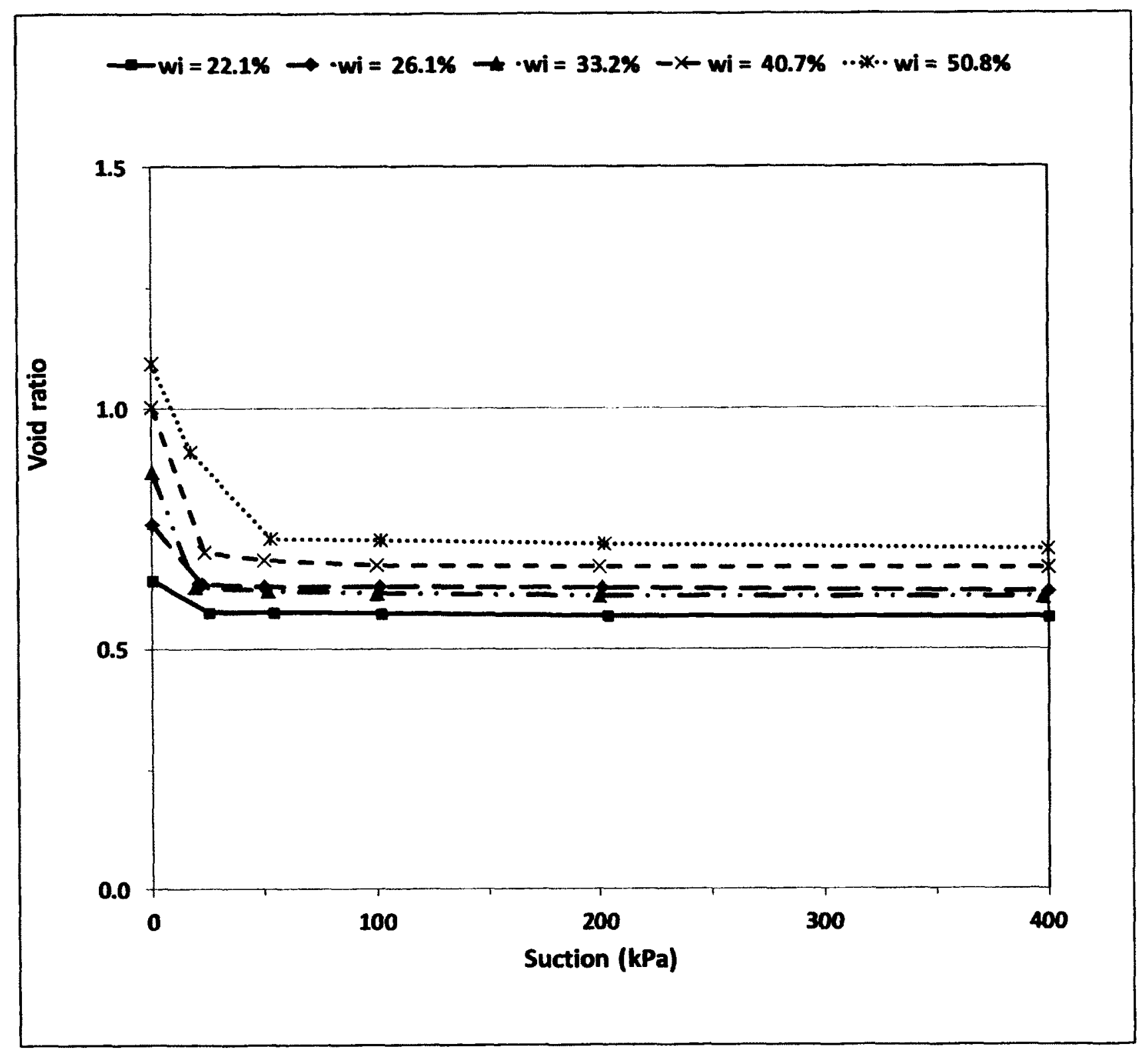

Figure 5-81: Effect of initial water content on void ratio-suction curve for gold mine 


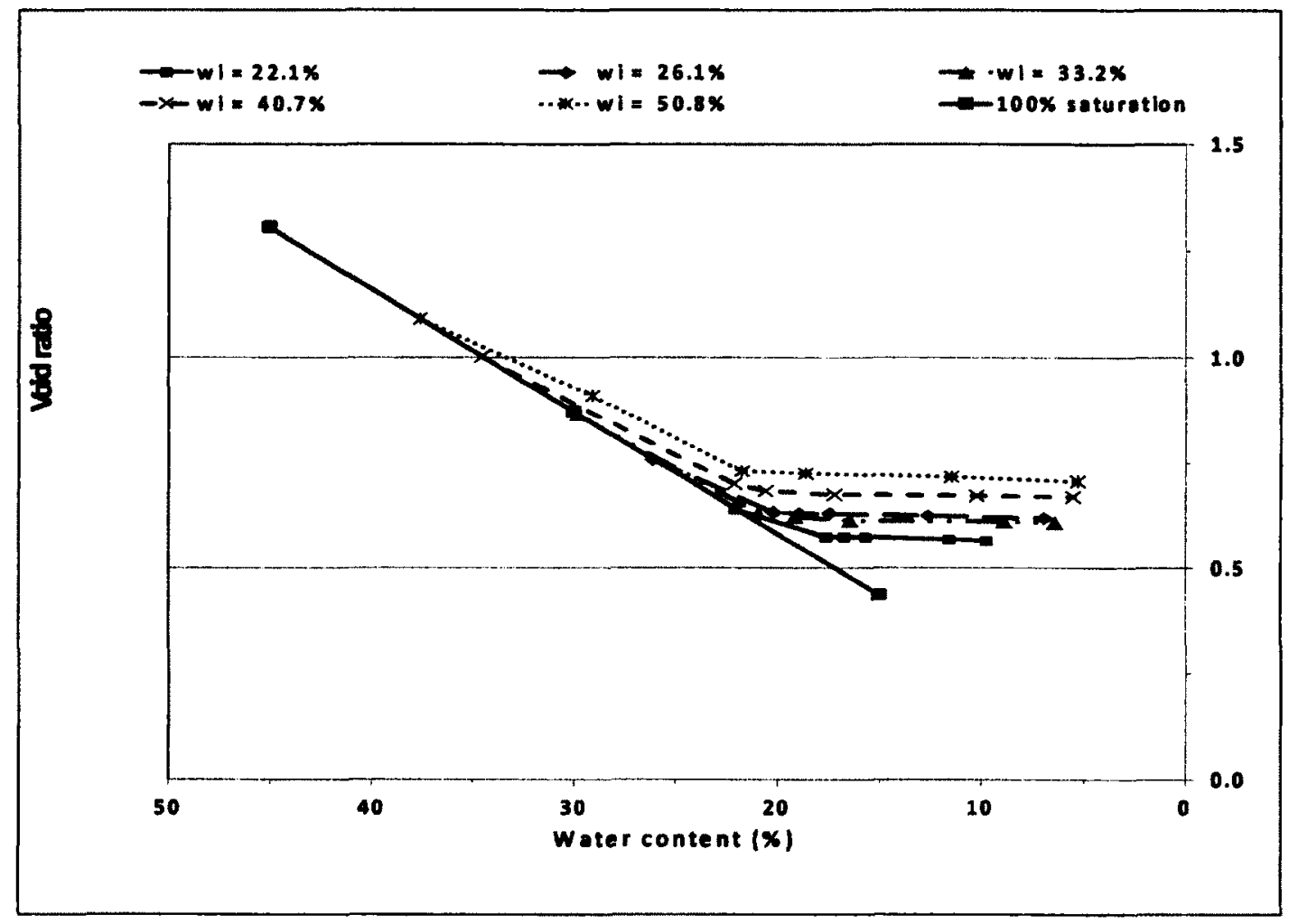

Figure 5-82: Effect of initial water content on shrinkage curve for gold

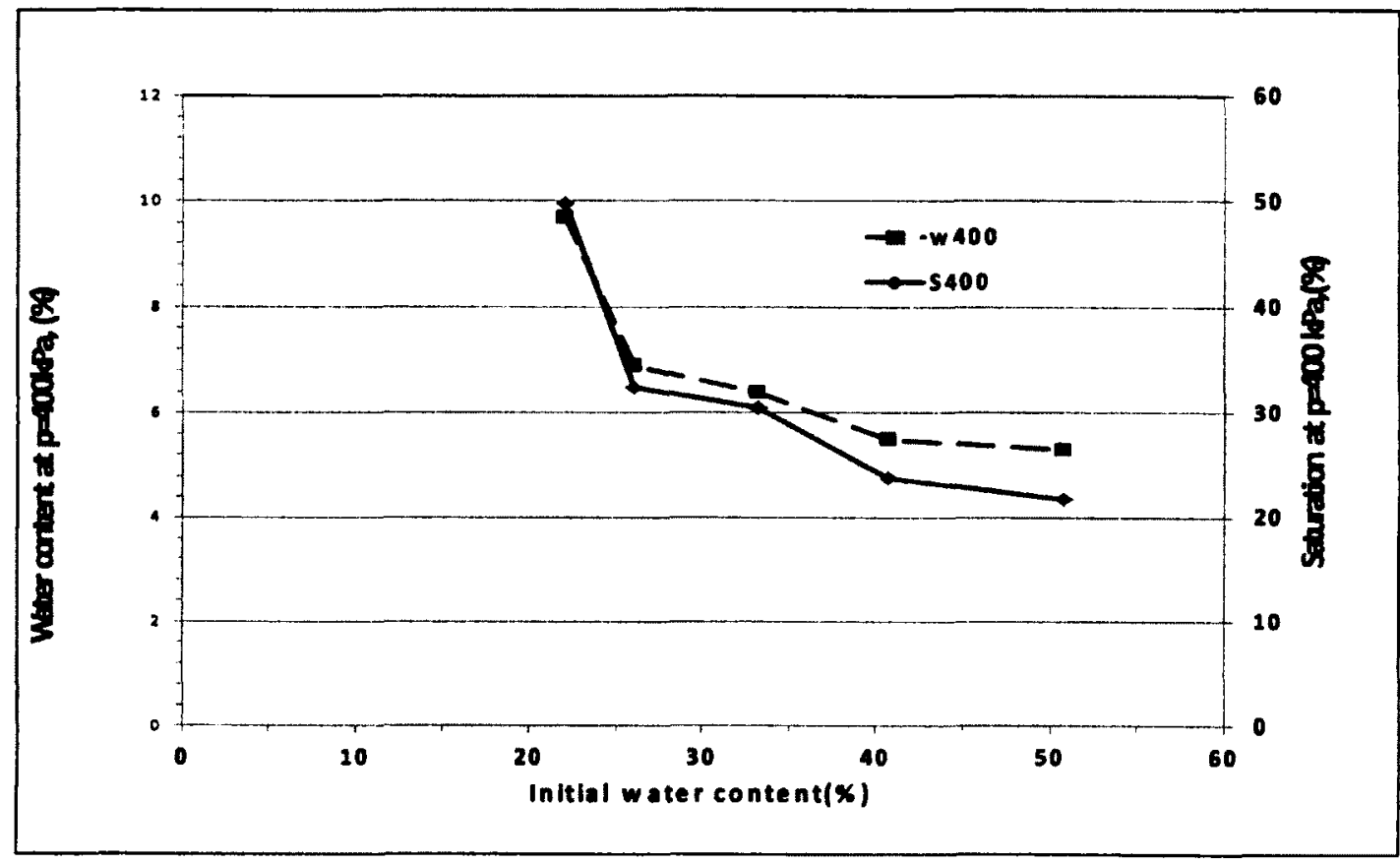

Figure 5-83: Effect of initial water content on final saturation and water content at suction of $400 \mathrm{kPa}$, for gold mine tailings 


\section{5-3-3. Compaction effect on TWCC for gold mine tailings}

To see the effect of compaction on TWCC, tailings were prepared at $40 \%$ water content, and then compacted using the standard proctor procedure (Section 4-1). For each of the three layers, 24 hours were allowed for settling before placement of the next layer, or the start of the axis-translation test.

Water content of compacted tailings was $32 \%$ with a void ratio equal to 0.93 . Water content and saturation of sample decreased to $11 \%$ and $47 \%$ at $400 \mathrm{kPa}$ suction respectively. Also void ratio went down to 0.65 . In Figures 5-84 to 5-87 behaviour parameters of compacted tailings is compared to tailings with initial water content of $33 \%$, which is close in terms of IWC:

- At high suction, $400 \mathrm{kPa}$, water content and saturation in compacted tailings is higher than non-compacted tailings (water content and saturation $11 \%$ and $47 \%$ ).

- For wetting, both samples have almost the same behaviour. Saturation and water content at $0 \mathrm{kPa}$ suction, end of wetting, for both samples are very close.

- The void ratio versus suction relationships are different, but the void ratio at the end of drying is the same. 


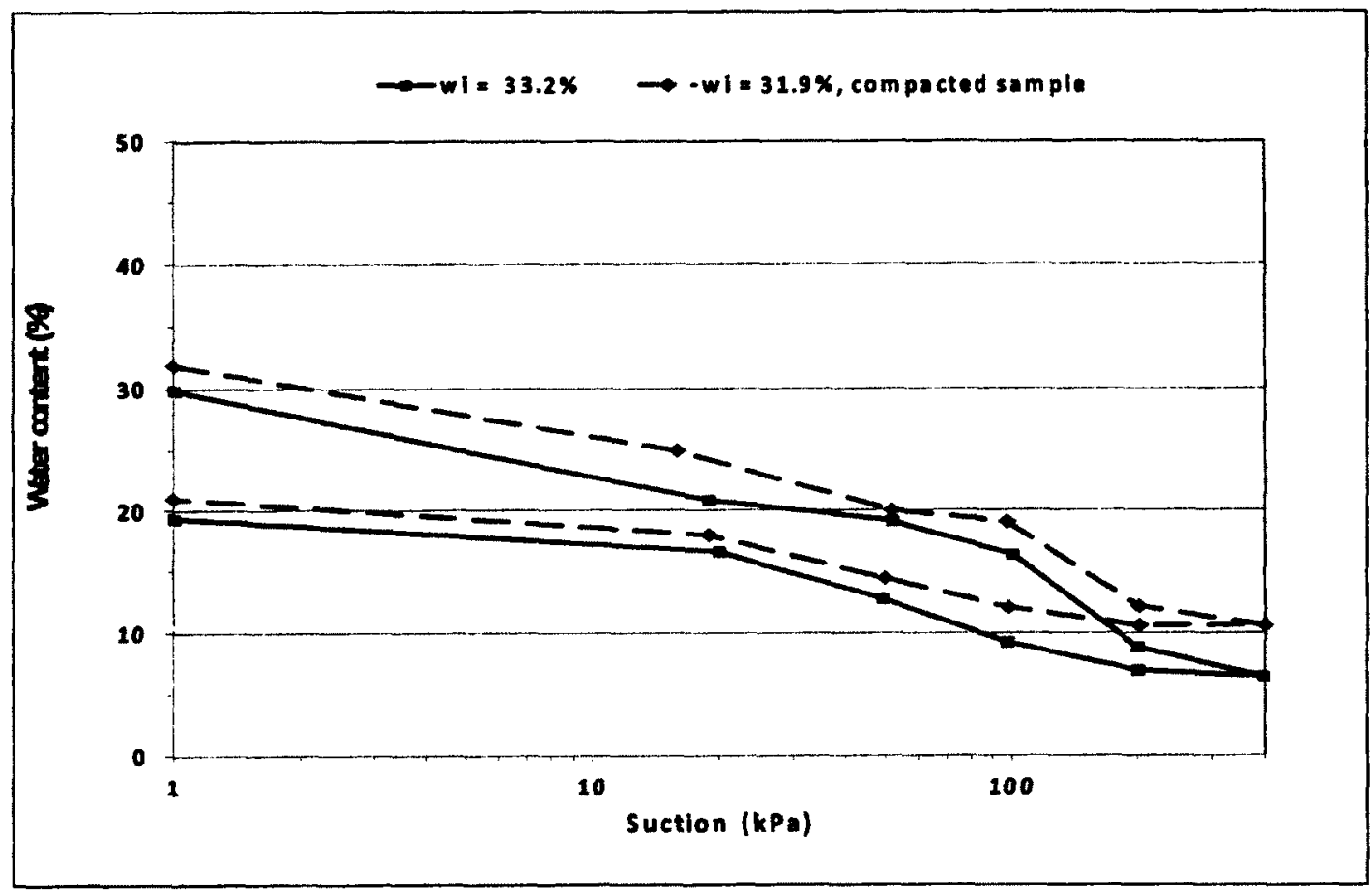

Figure 5-84: Effect of compaction on water content-suction curve for gold tailings, log scale

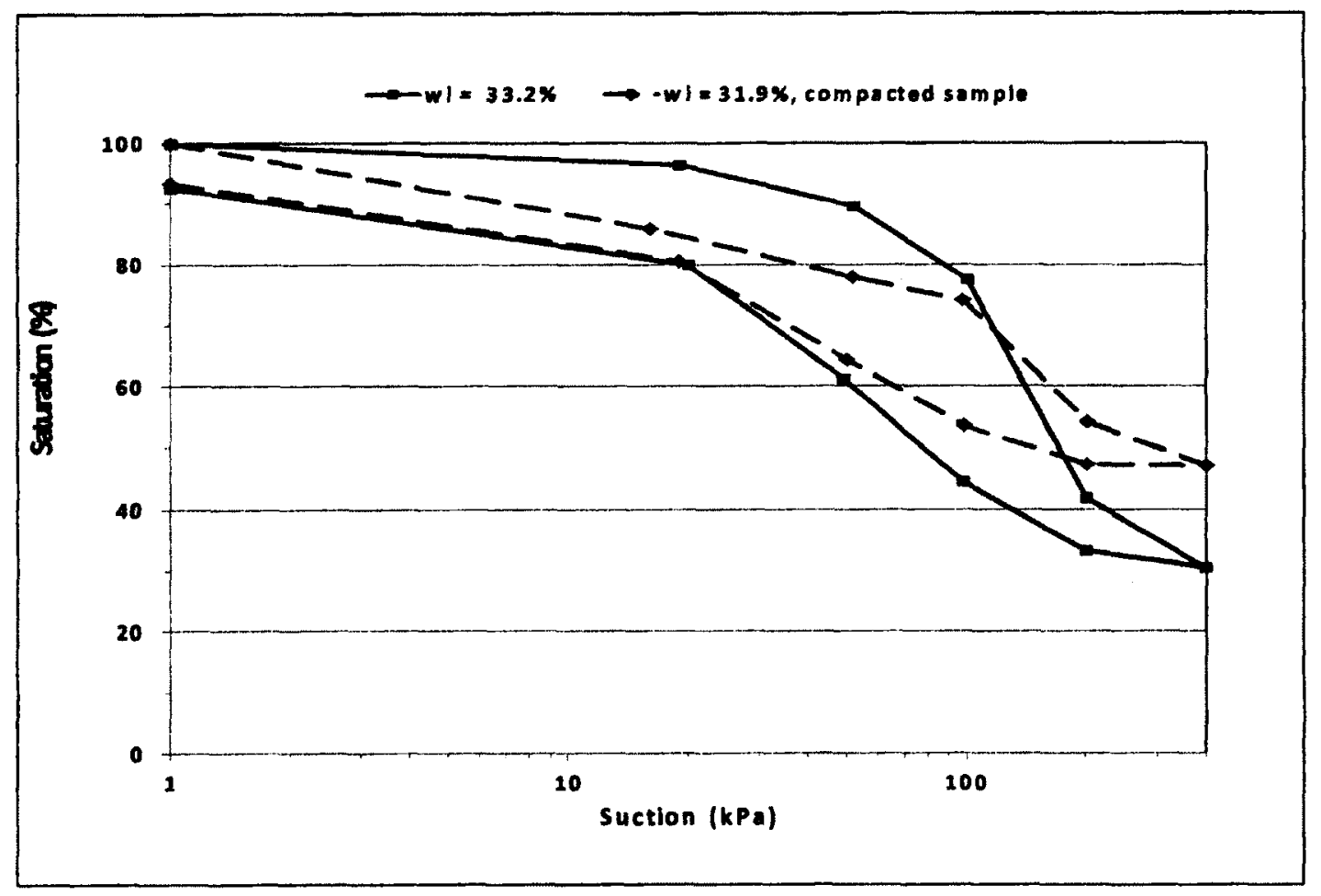

Figure 5-85: Effect of compaction on Saturation-suction curve for gold tailings, $\log$ scale 


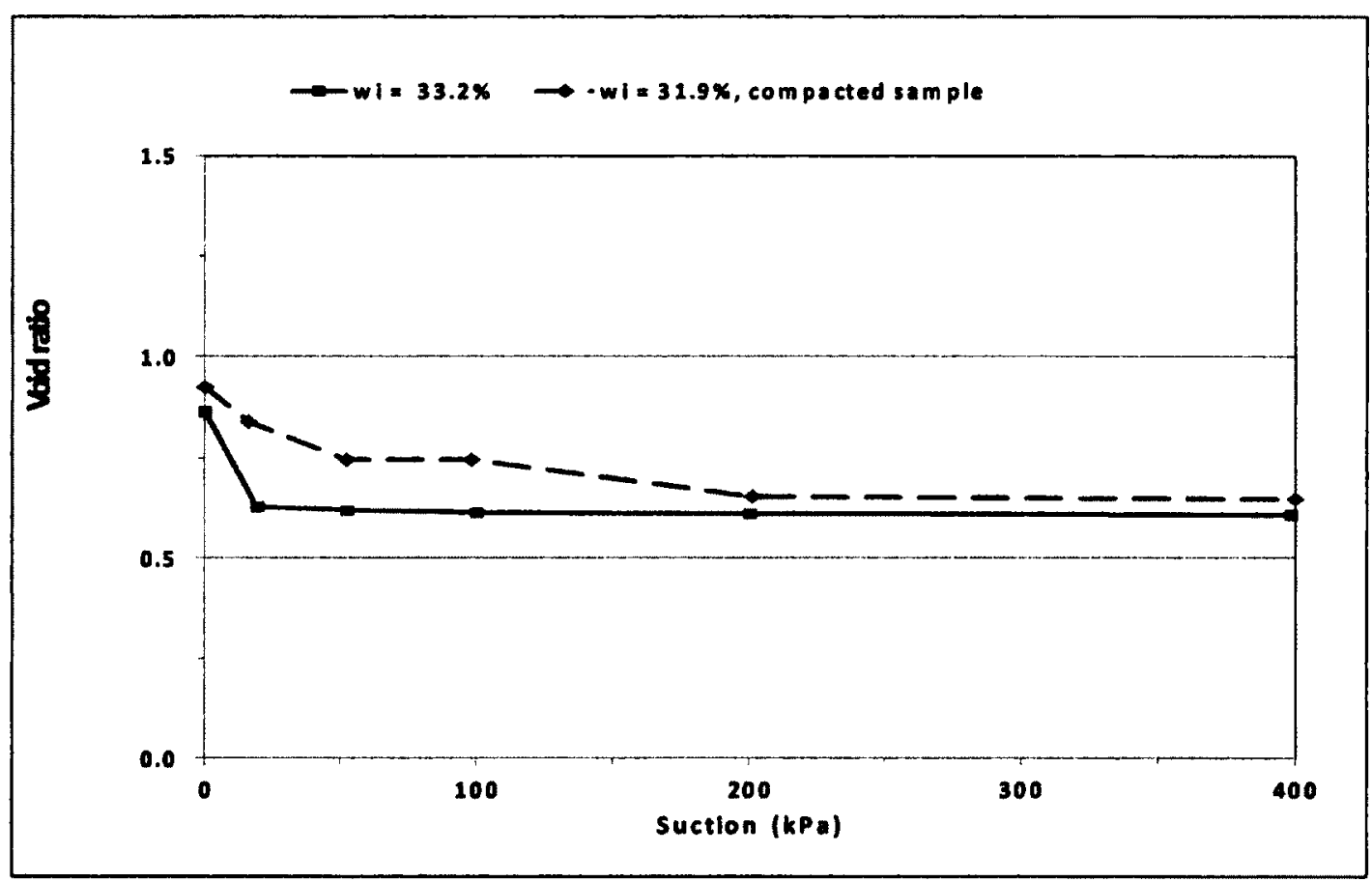

Figure 5-86: Effect of compaction on void ratio-suction curve for gold

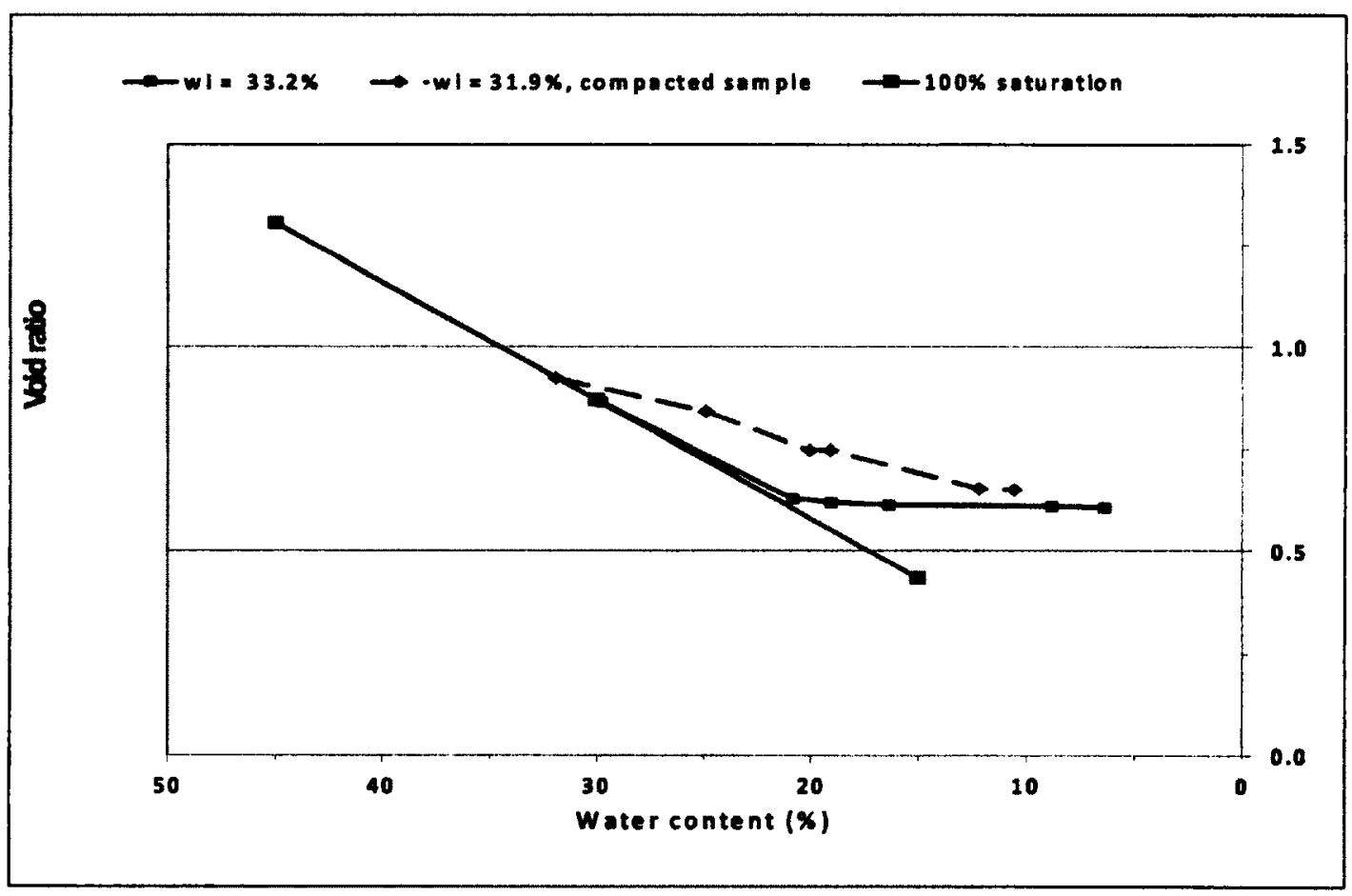

Figure 5-87: Effect of compaction on shrinkage curve for gold mine 


\section{5-3-4. Effect of loading on TWCC for gold mine tailings}

To study the effect of loading on the TWCC, three different groups of experimental tests were performed. The first group consisted of four TWCC tests under different levels of constant loading. Suction range was between 0 to $400 \mathrm{kPa}$. In the second group, the applied air pressure in the TWCC test was constant, but the applied 1D load was increased from 0 to $200 \mathrm{kPa}$ In the last group, no suction was applied and the 1-D consolidation curve was measured using the same apparatus and procedure as the other tests, up to a vertical load $200 \mathrm{kPa}$

\section{5-3-4-1. TWCC under constant loading condition}

There were four tests with the following characteristics:

- Initial water content of $24 \%$ and loading of $50 \mathrm{kPa}$

- Initial water content of $31 \%$ and loading of $50 \mathrm{kPa}$

- Initial water content of $28 \%$ and loading of $100 \mathrm{kPa}$

- Initial water content of $27 \%$ and loading of $150 \mathrm{kPa}$

\section{5-3-4-1-1. Initial water content of $24 \%$ and loading of $50 \mathrm{kPa}$}

These tailings were prepared from the "as-received" condition, without the addition of water. Initial water content of sample is $24 \%$ with saturation of $100 \%$. As expected, no bleed water was observed during the 24 hour settling period. The results of this test are shown in Figures 5-88 to 5-91. At $200 \mathrm{kPa}$ water content decreased to $10 \%$ and saturation at this point was $50 \%$. Air entry value, $\mathrm{AEV}$, is around $100 \mathrm{kPa}$ With decreasing suction to $0 \mathrm{kPa}$ water content and saturation increased to $18 \%$ and $88 \%$ respectively. In range of 
50 to $100 \mathrm{kPa}$ matric suction, just $0.4 \mathrm{~g}$ water went out and water content and saturation in this range did not significantly change. When suction increased to $200 \mathrm{kPa}$ around 3.3 $\mathrm{g}$ water drained and caused reduction of $34 \%$ in water content and saturation, (Figures 5100 and 5-101). Total volume change is around $6 \%$ and void ratio went decreased from 0.69 to 0.59 . According to shrinkage curve, Figure 5-91, water content at the minimum void ratio is around $15 \%$. 


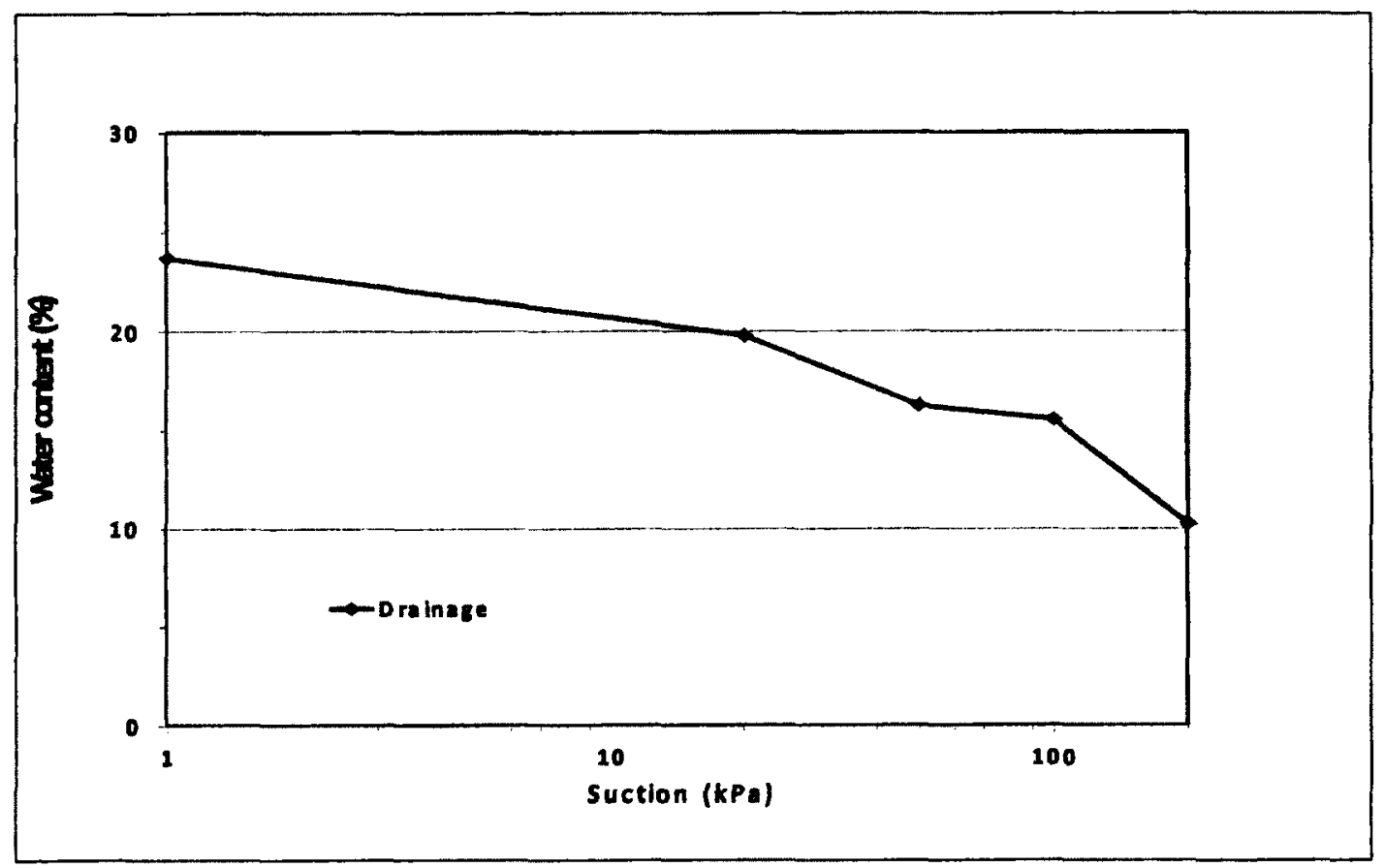

Figure 5-88: Water content -suction curve for gold mine tailings, loading=50 $\mathrm{kPa}, \mathrm{w}_{\mathrm{i}}=23.8 \%$, log scale

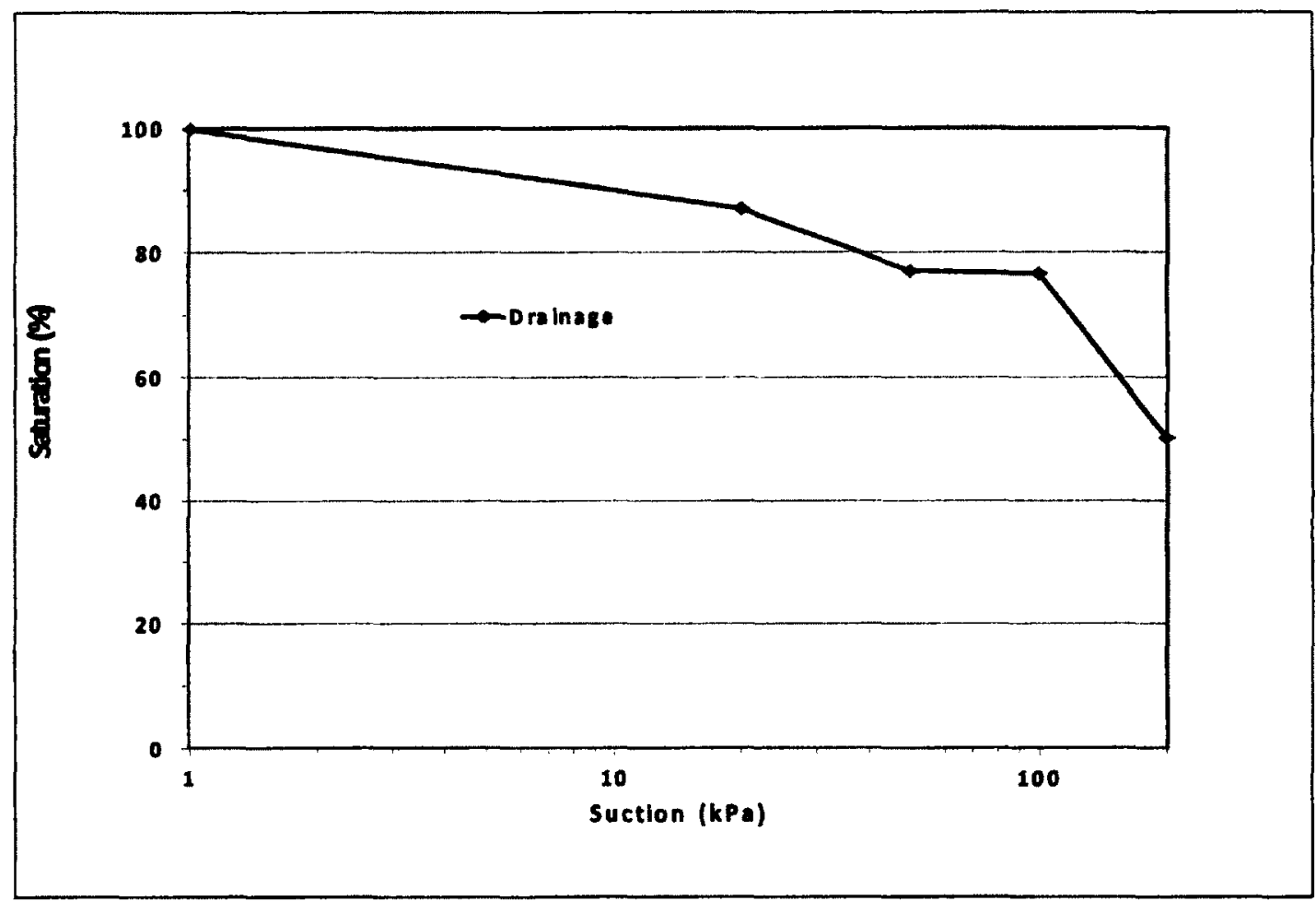

Figure 5-89: Saturation-suction curve for gold mine tailings, loading $=50 \mathrm{kPa}$, $\mathrm{w}_{\mathrm{i}}=23.8 \%$, log scale 


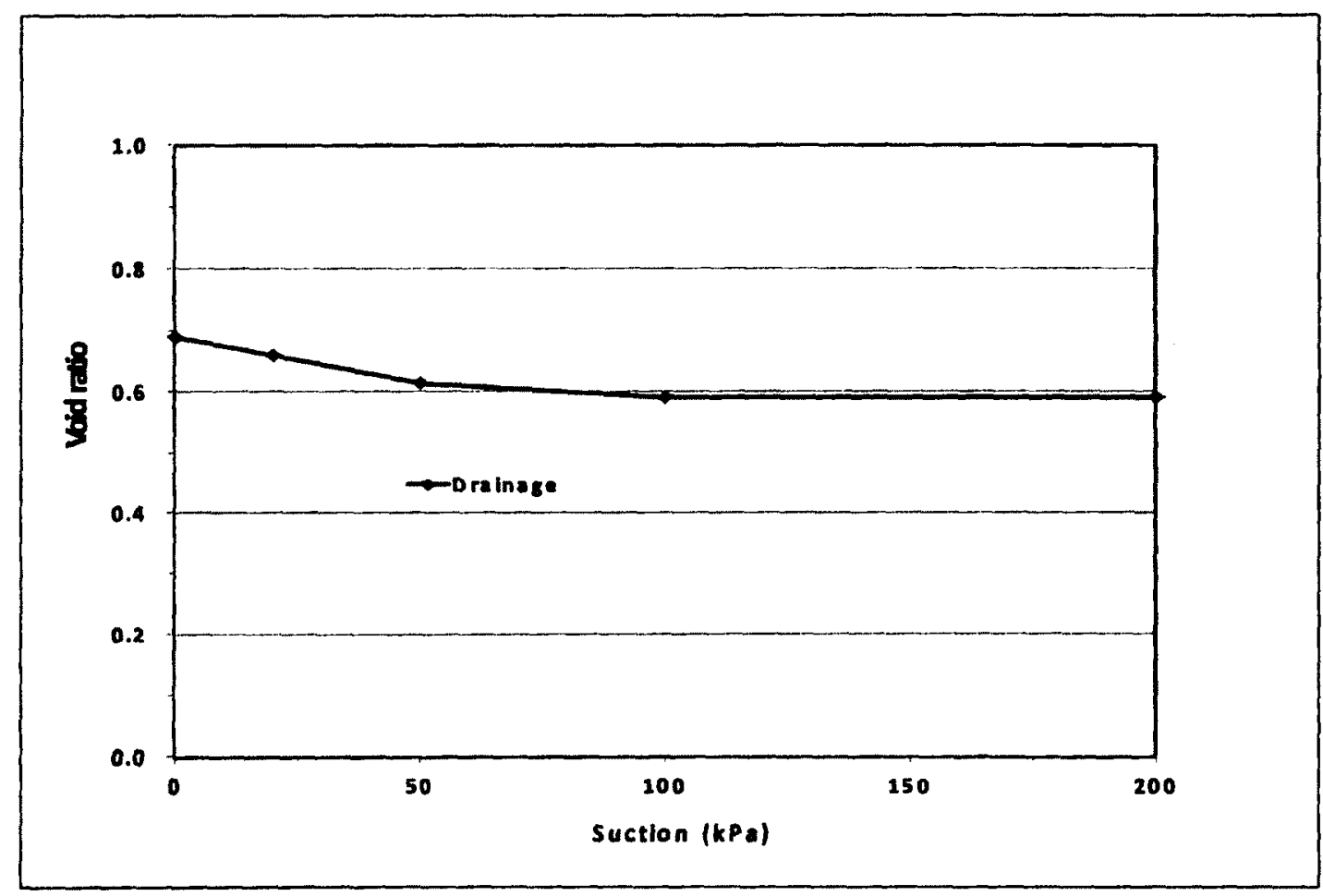

Figure 5-90: Void ratio--suction curve for gold mine tailings, loading $=50 \mathrm{kPa}$, $\mathrm{w}_{\mathrm{i}}=23.8 \%$, log scale

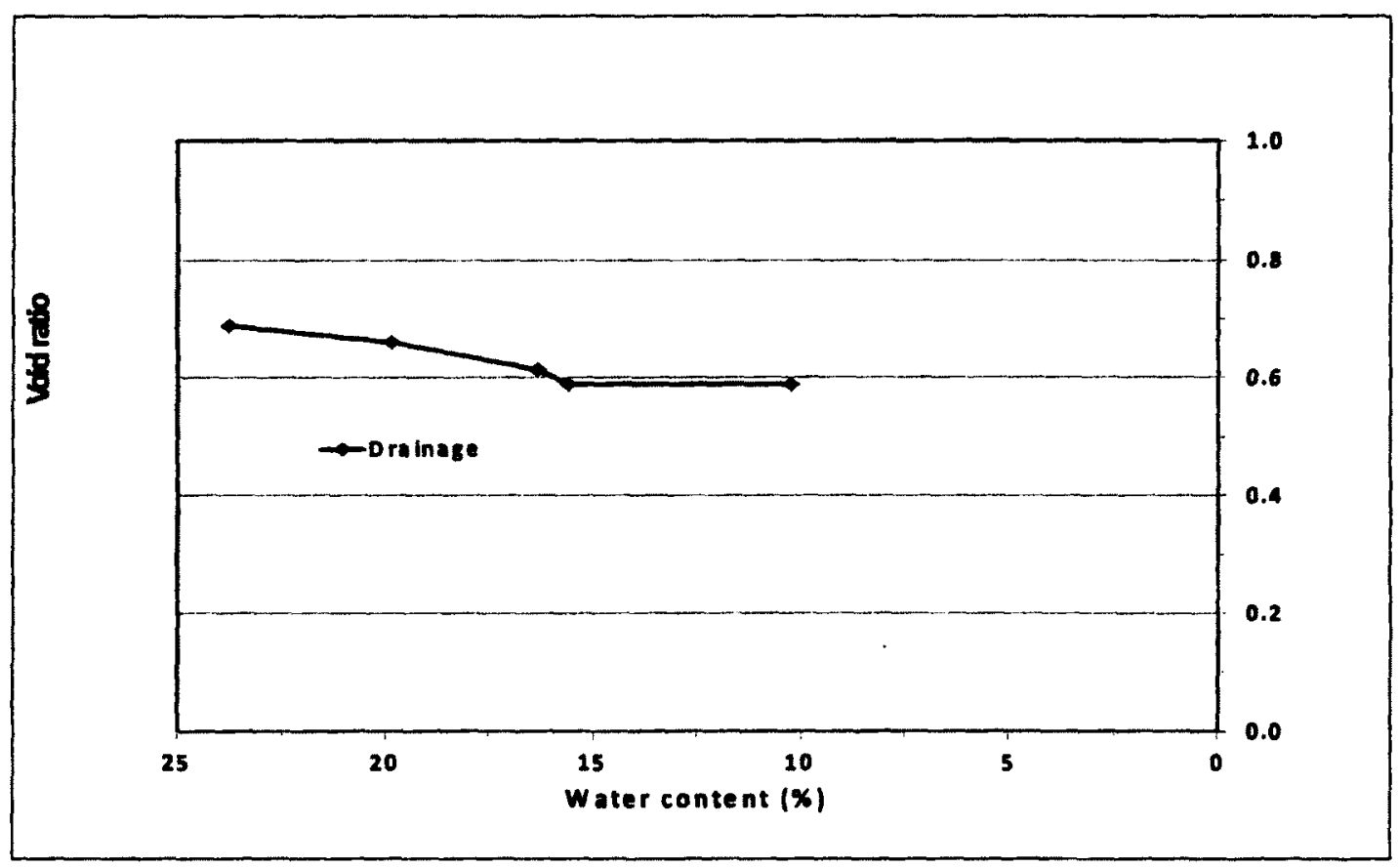

Figure 5-91: Shrinkage curve for gold mine tailings, loading $=50 \mathrm{kPa}$, $\mathrm{w}_{\mathrm{i}}=23.8 \%$ 


\section{5-3-4-1-2. Initial water content of $31 \%$ and loading of $50 \mathrm{kPa}$}

For this experimental test, the tailings water content was increased to $31 \%$, before allowing 24 hours for settling before application of load. In order to prevent destruction of the sample, it was necessary to increase the applied vertical load in stages of $1 \mathrm{kPa}, 24$, $\mathrm{kPa}$, and then $50 \mathrm{kPa}$, each stage for 2 to 3 days.

Water content and saturation of sample decreased from $31 \%$ and $100 \%$ at $0 \mathrm{kPa}$ suction to $10 \%$ and $49 \%$ at $200 \mathrm{kPa}$ suction and $50 \mathrm{kPa}$ loading. Also void ratio went down from 0.91 to 0.59 . Behaviour of tailings in range of 50 to $200 \mathrm{kPa}$ is the same as previous test, (tailings with $\mathrm{w}_{\mathrm{i}}=24 \%, \mathrm{l}=50 \mathrm{kPa}$ ), since between 50 to $100 \mathrm{kPa}$ applied suction, there is only small change in moisture and saturation, but in range of 100 to 200 $\mathrm{kPa}$ both parameters reduced substantially. Figures 5-92 and 5-93 show variations of water content and saturation in terms of suction plus $50 \mathrm{kPa}$ loading. Tables A5-26, A527 and Figures A5-41 to A5-42 in the appendix show more details.

\section{5-3-4-1-3. Initial water content of $28 \%$ and loading of $100 \mathrm{kPa}$}

The load had to apply incrementally, similarly to the last test. Water content and saturation of sample at maximum suction were $10 \%$ and $48 \%$ with void ratio of 0.59 . AEV for this tailings sample was around $100 \mathrm{kPa}$ Figures 5-94 and 5-95 show variations of water content and saturation of tailings sample versus suction and loading in log scale. More information is brought in Figures A5-43 and A5-44. 


\section{5-3-4-1-4. Initial water content of $27 \%$ and loading of $150 \mathrm{kPa}$}

Behaviour of tailings under this condition is shown in Figures 5-96 and 5-97. At 200 $\mathrm{kPa}$ pressure and $150 \mathrm{kPa}$ loading, water content decreased to $10 \%$ and saturation at this point was $47 \%$. Air entry value is around $100 \mathrm{kPa}$ With decreasing suction to $0 \mathrm{kPa}$ water content and saturation slowly increased to $18 \%$ and $88 \%$ respectively. Void ratio of sample decreased to 0.60 at maximum suction. Water content at shrinkage limit is $17 \%$. More information can be seen in Figures A5-45 and A5-46. 


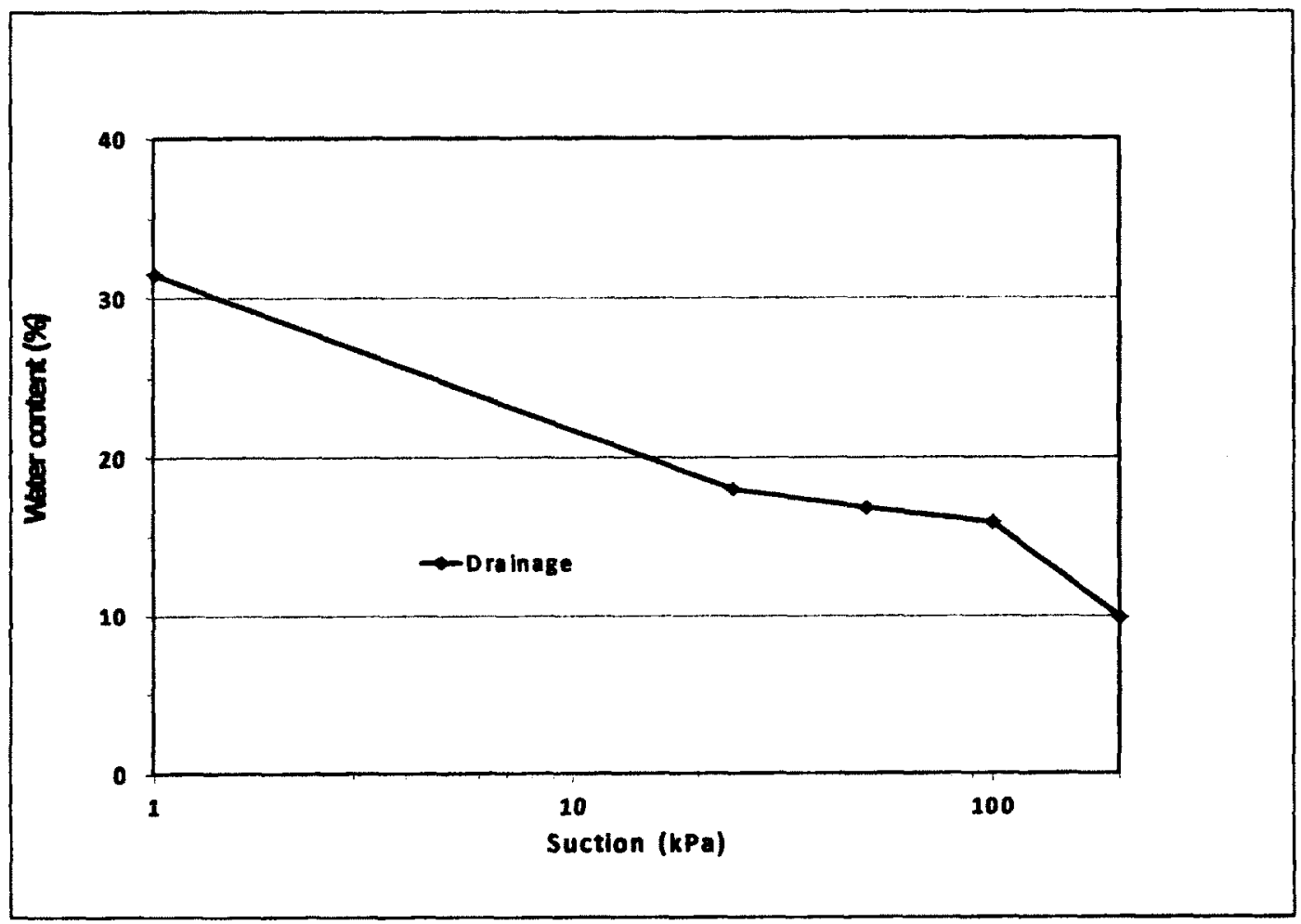

Figure 5-92: Water content-suction curve for gold mine tailings, loading $=50$ $\mathrm{kPa}, \mathrm{w}_{\mathrm{i}}=31.5 \%, \log$ scale

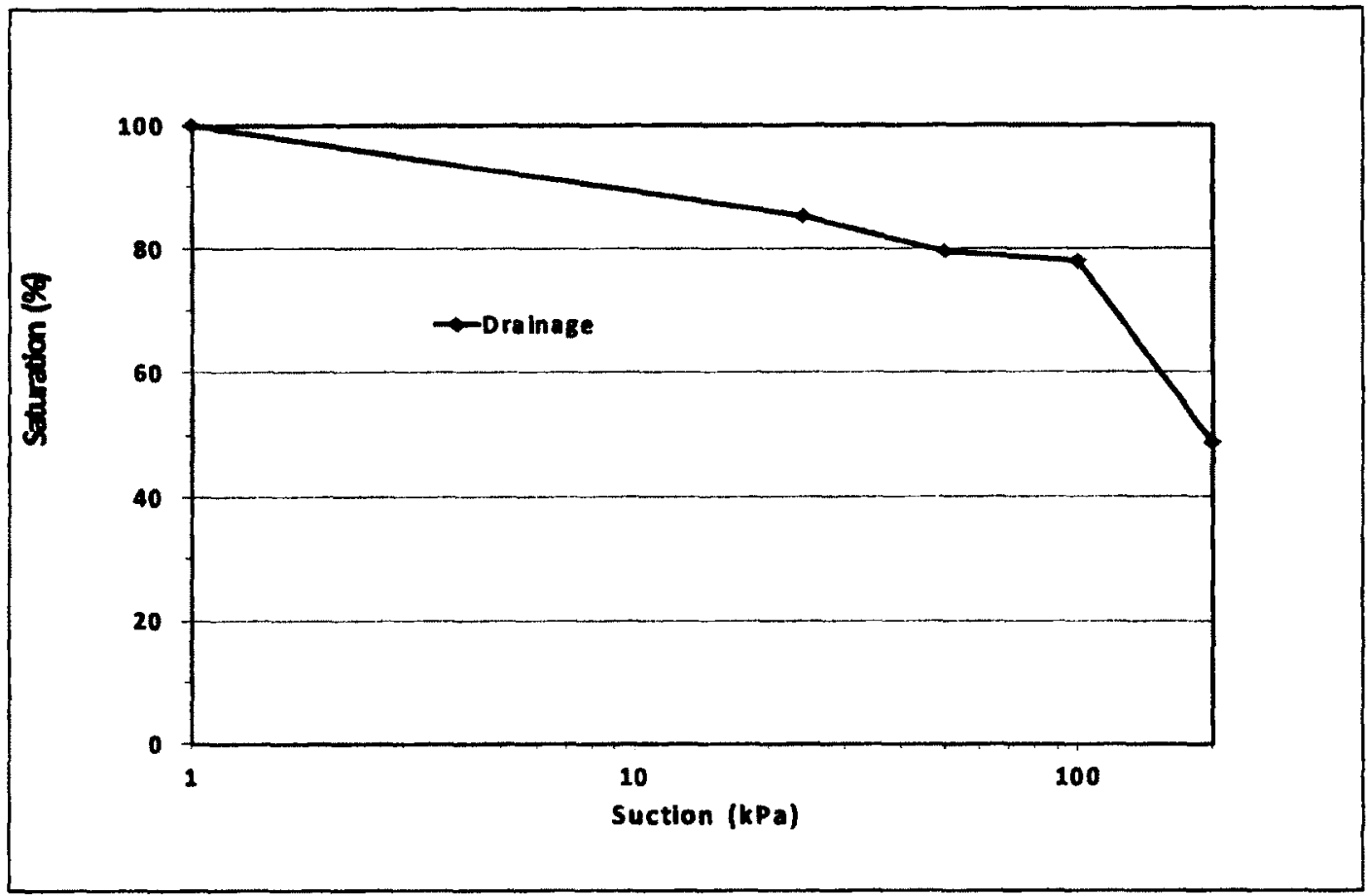

Figure 5-93: Saturation-suction curve for gold mine tailings, loading $=50 \mathrm{kPa}$, $\mathrm{w}_{\mathrm{i}}=31.5 \%$, log scale 


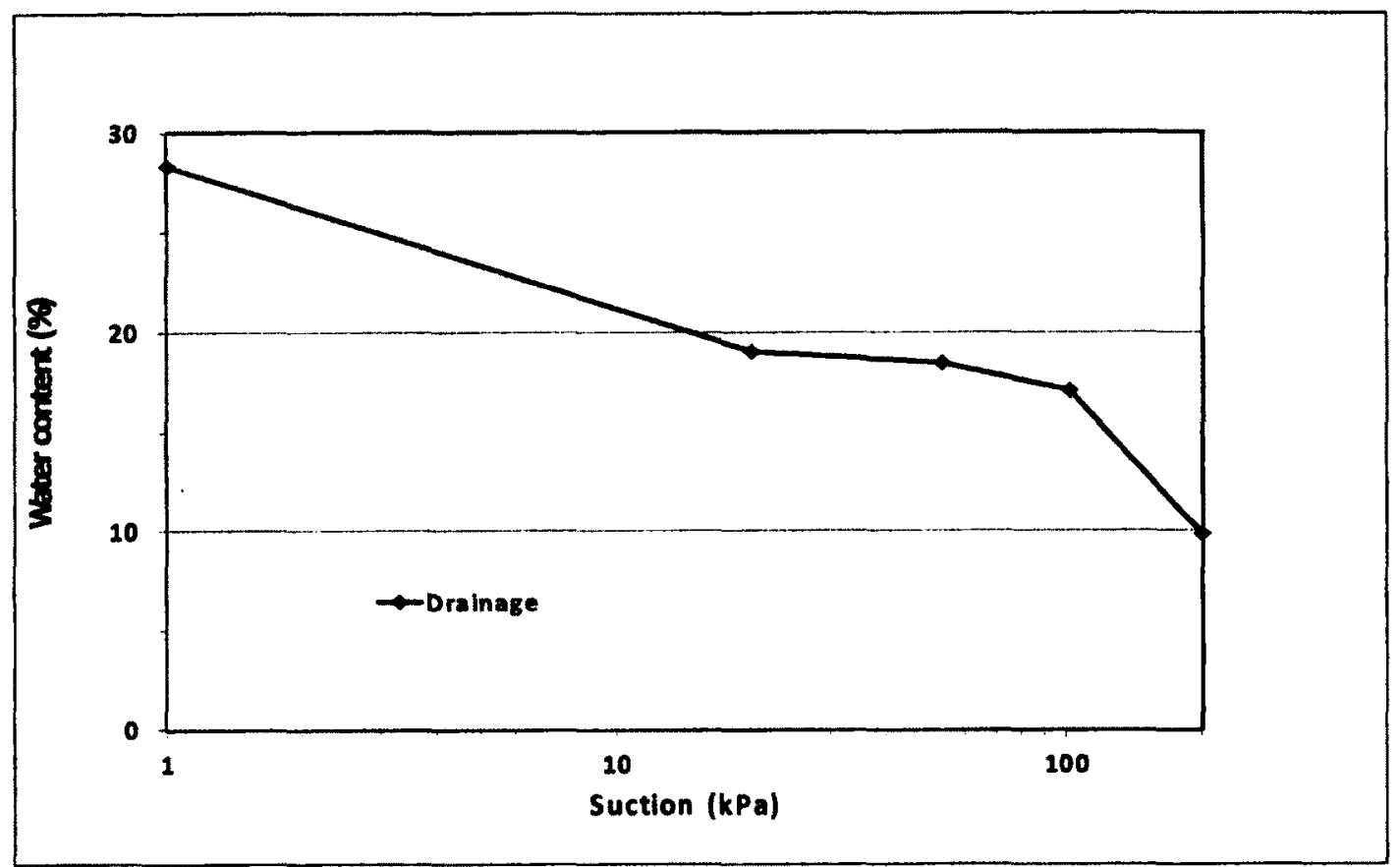

Figure 5-94: Water content-suction curve for gold mine tailings, loading $=100$ $\mathrm{kPa}, \mathrm{w}_{\mathrm{i}}=28.3 \%$, log scale

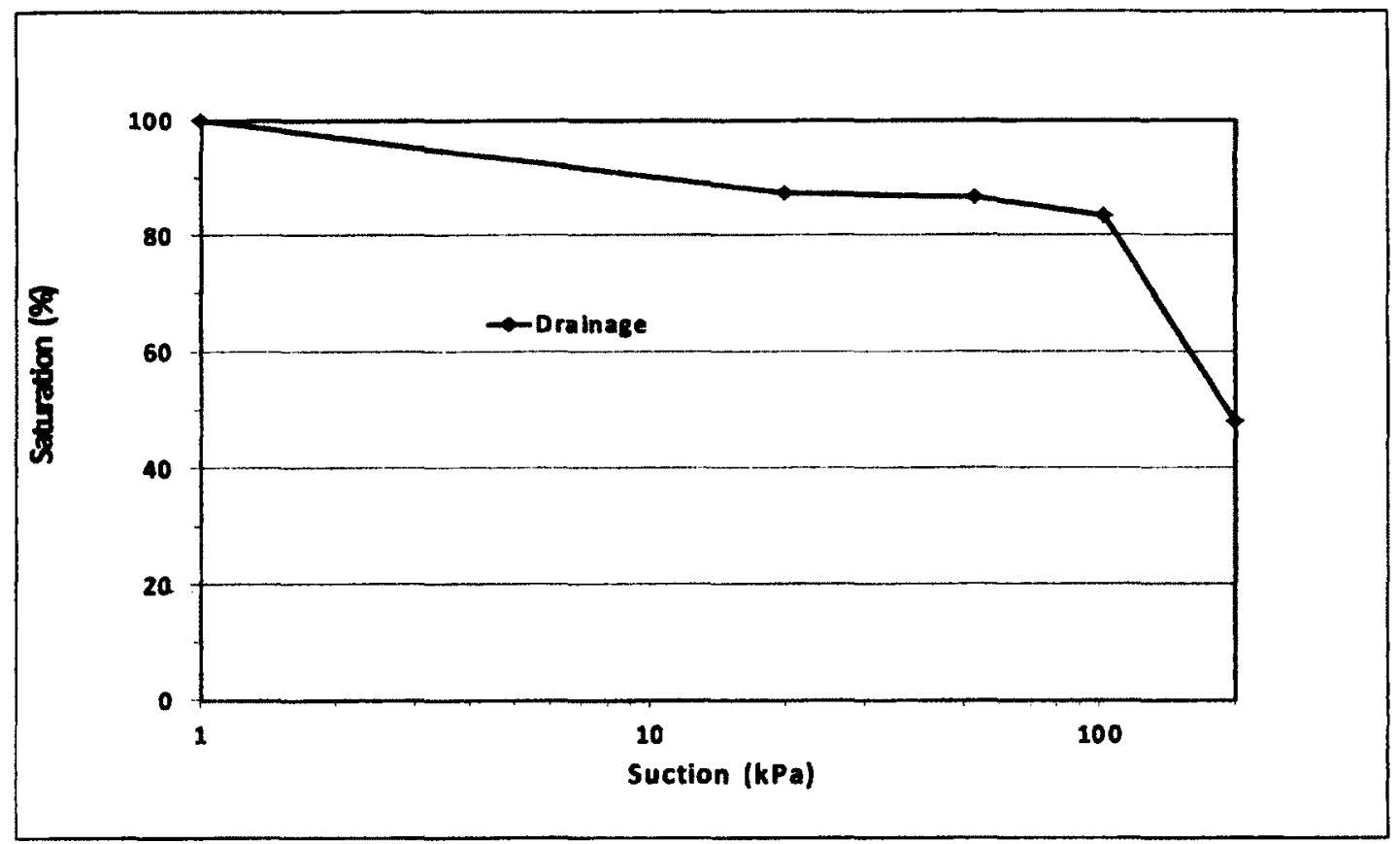

Figure 5-95: Saturation-suction curve for gold mine tailings, loading $=100 \mathrm{kPa}$, $\mathrm{w}_{\mathrm{i}}=28.3 \%$, log scale 


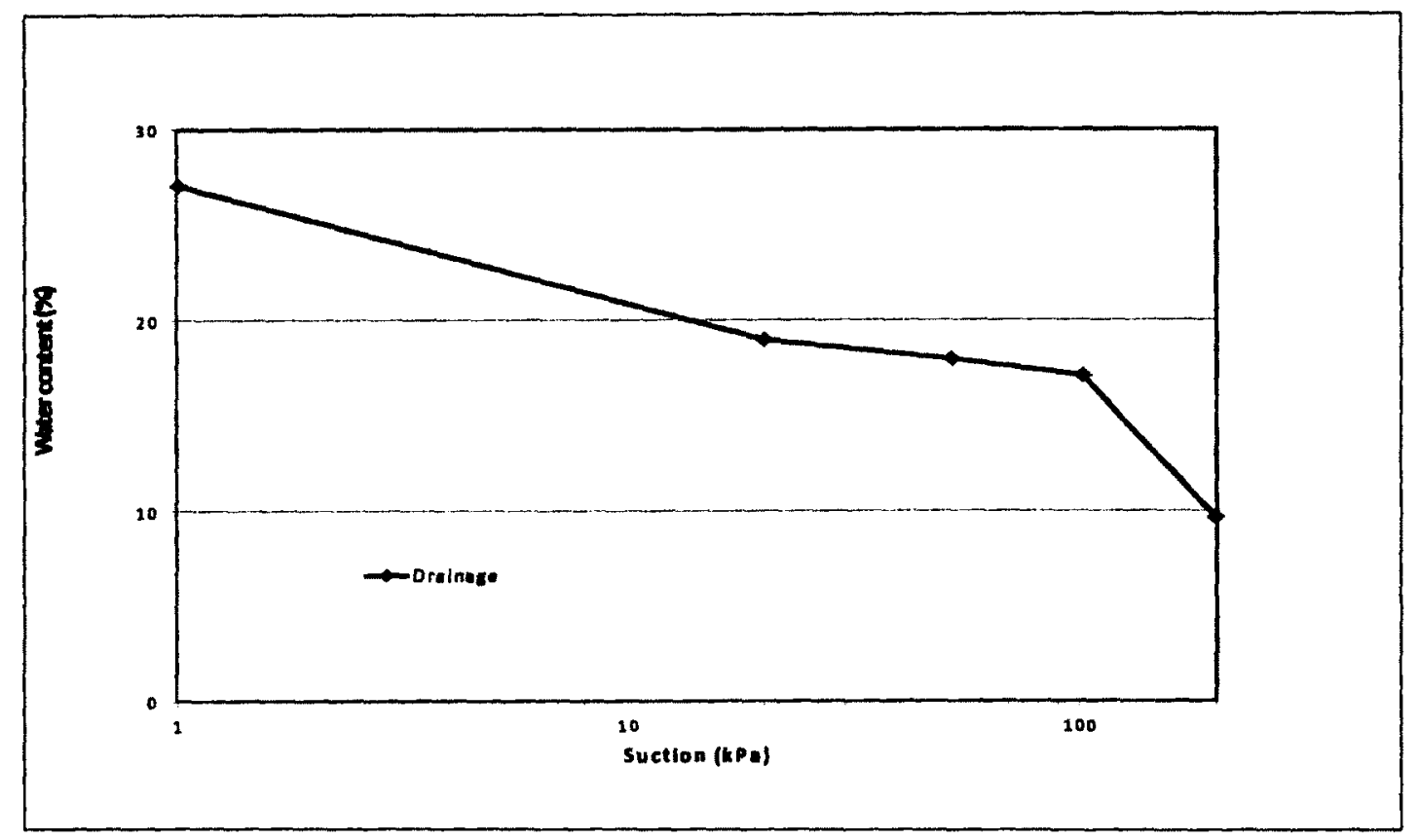

Figure 5-96: Water content-suction curve for gold mine tailings, loading $=150$ $\mathrm{kPa}, \mathrm{w}_{\mathrm{i}}=27.1 \%$, log scale

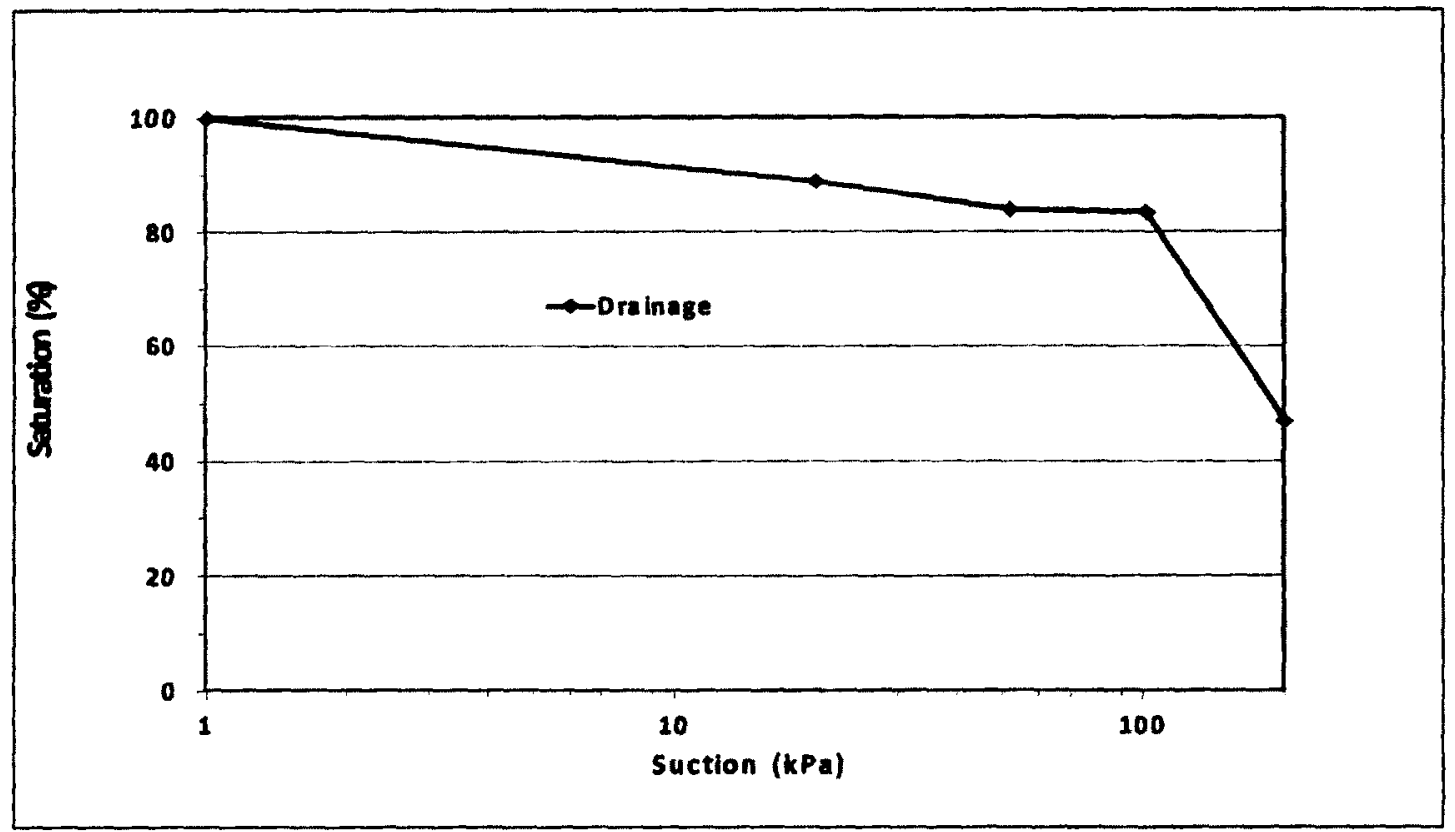

Figure 5-97: Saturation-suction curve for gold mine tailings, loading $=150 \mathrm{kPa}$, $\mathrm{w}_{\mathrm{i}}=27.1 \%$, log scale 


\section{5-3-4-1-5. Comparison of TWCC under different constant loading condition}

The TWCCs for the four different tests under constant loading were compared in Figures 5-98 to 5-101. More details is brought in Table A5-28 in the appendix. Following results can be taken from them:

- Water content at $200 \mathrm{kPa}$ suction for all of the samples are around $10 \%$.

- At $0 \mathrm{kPa}$ pressure, end of the test, water contents tend to converge, to about $18 \%$.

- Loading up to $150 \mathrm{kPa}$ does not significantly affect the water content-suction curve.

- Behaviour of saturation curve in range of 50 to $100 \mathrm{kPa}$ is the same as water content. In other word, there is small change in this range for saturation and water content.

- AEV does not change in terms of different loading.

- At $0 \mathrm{kPa}$ pressure, end of the test, saturation amount for different loading are almost the same and equal to $88 \%$.

- The application of 1-D loading up to $150 \mathrm{kPa}$ resulted in a convergence of the final void ratio in all tests to be 0.60 . This is somewhat different than in the tests without loading, wherein the final void ratio varied from 0.57 up to 0.7 .

- Overall, the application of a constant load, aside from the initial density at the start of the TWCC test, did not change the shape, or substantially change either water contents or degree of saturations $(<5 \%$ and $<10 \%)$ respectively , compared to the same TWCC without content 1-D loading.

In Figures 5-102 to 5-105 variations of water contents, saturation and void ratio for loaded and unloaded conditions have been compared. 
- Effect of suction and suction + constant loading on water content curve for samples with almost the same IWC, are close together.

- In saturation curve, at high suction, effect of suction and suction + constant loading are close together.

- Effect of suction and suction + constant loading on void ratio-suction curve for samples with IWC close together is almost the same.

- In shrinkage curve, at low suction, samples with higher IWC have sharper curve, but at high suction all curves tend to converge. 


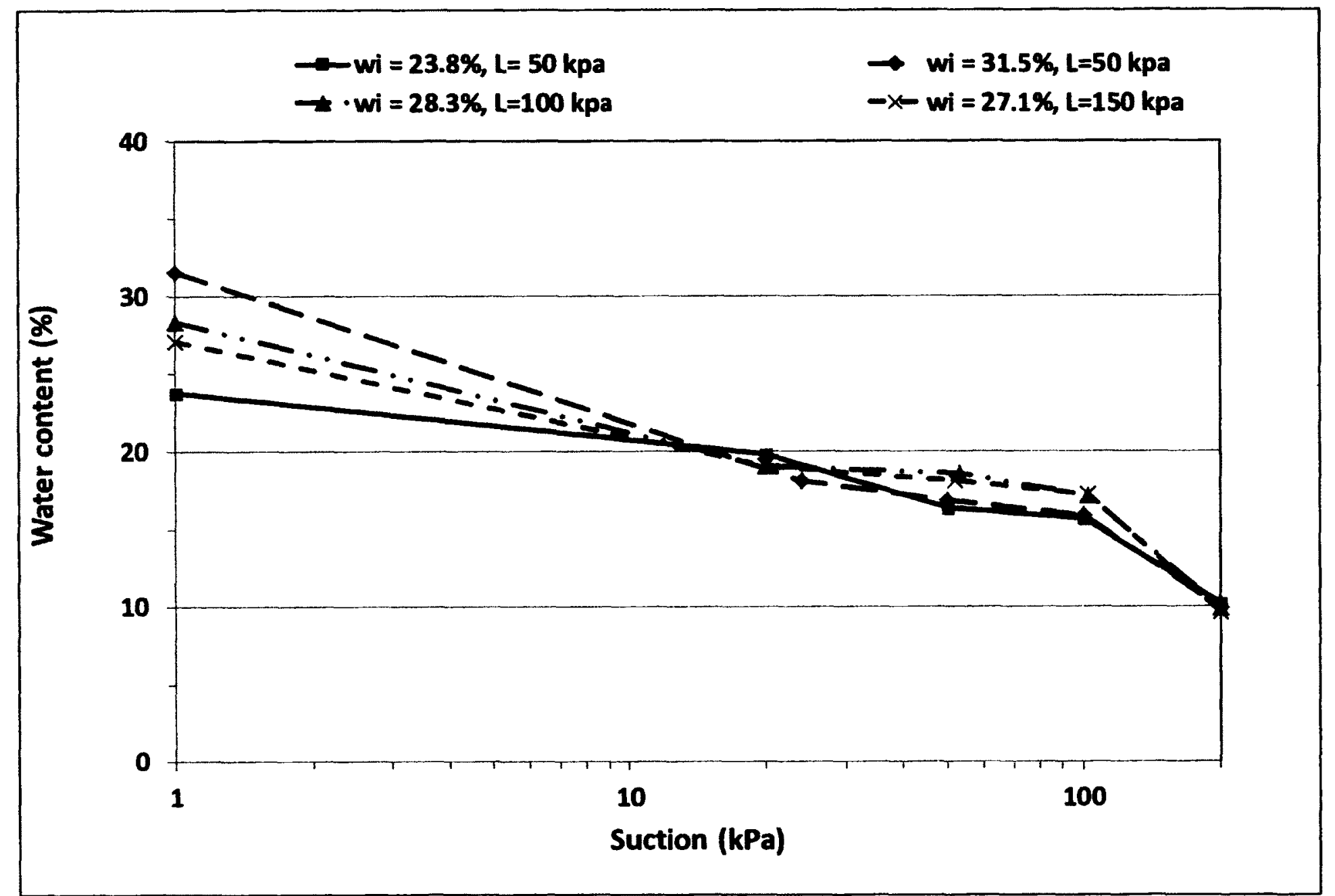

Figure 5-98: Effect of IWC and loading on water content-suction curve for gold mine tailings, log scale 


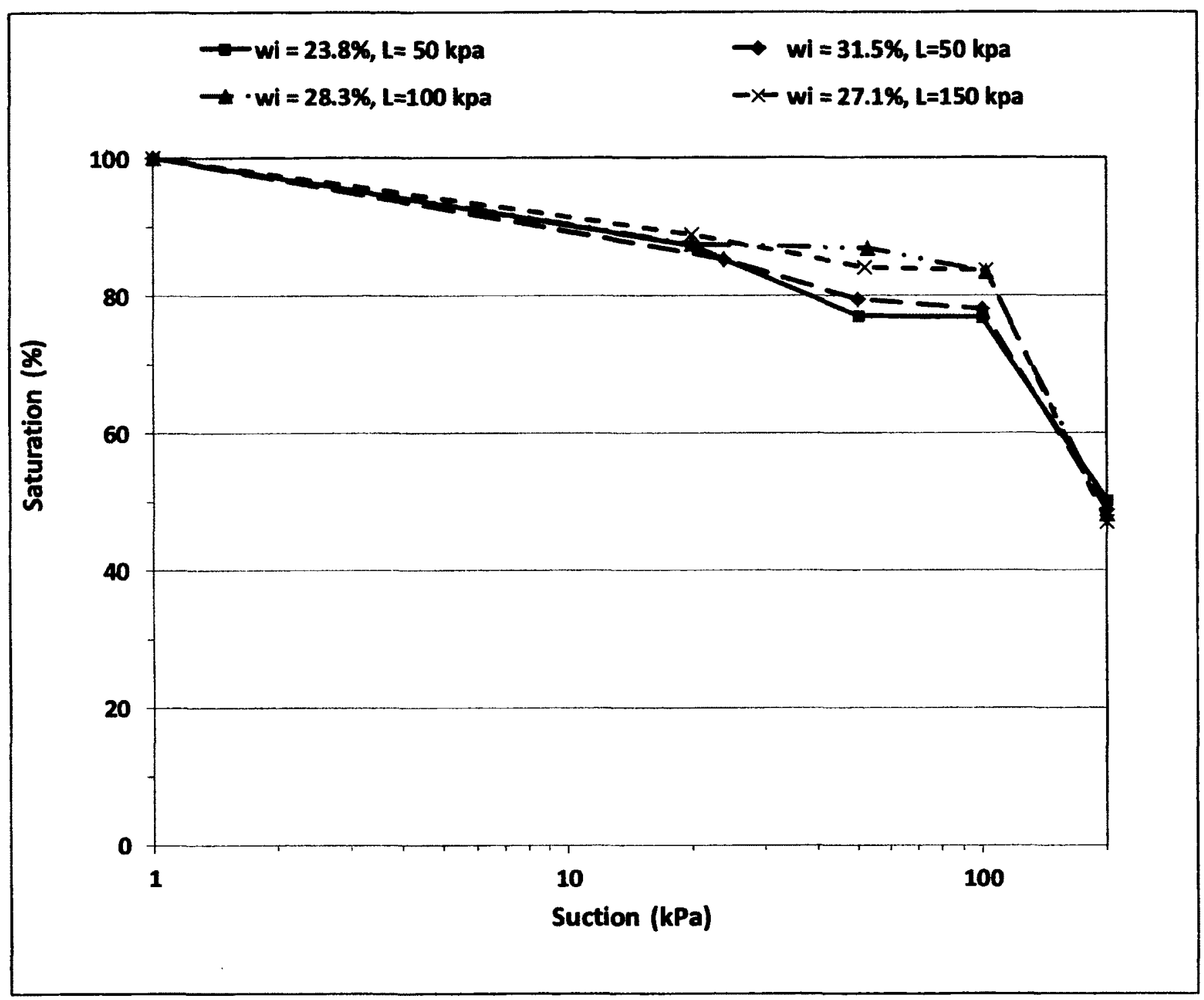

Figure 5-99: Effect of IWC and loading on saturation-suction curve for gold mine tailings, log scale 


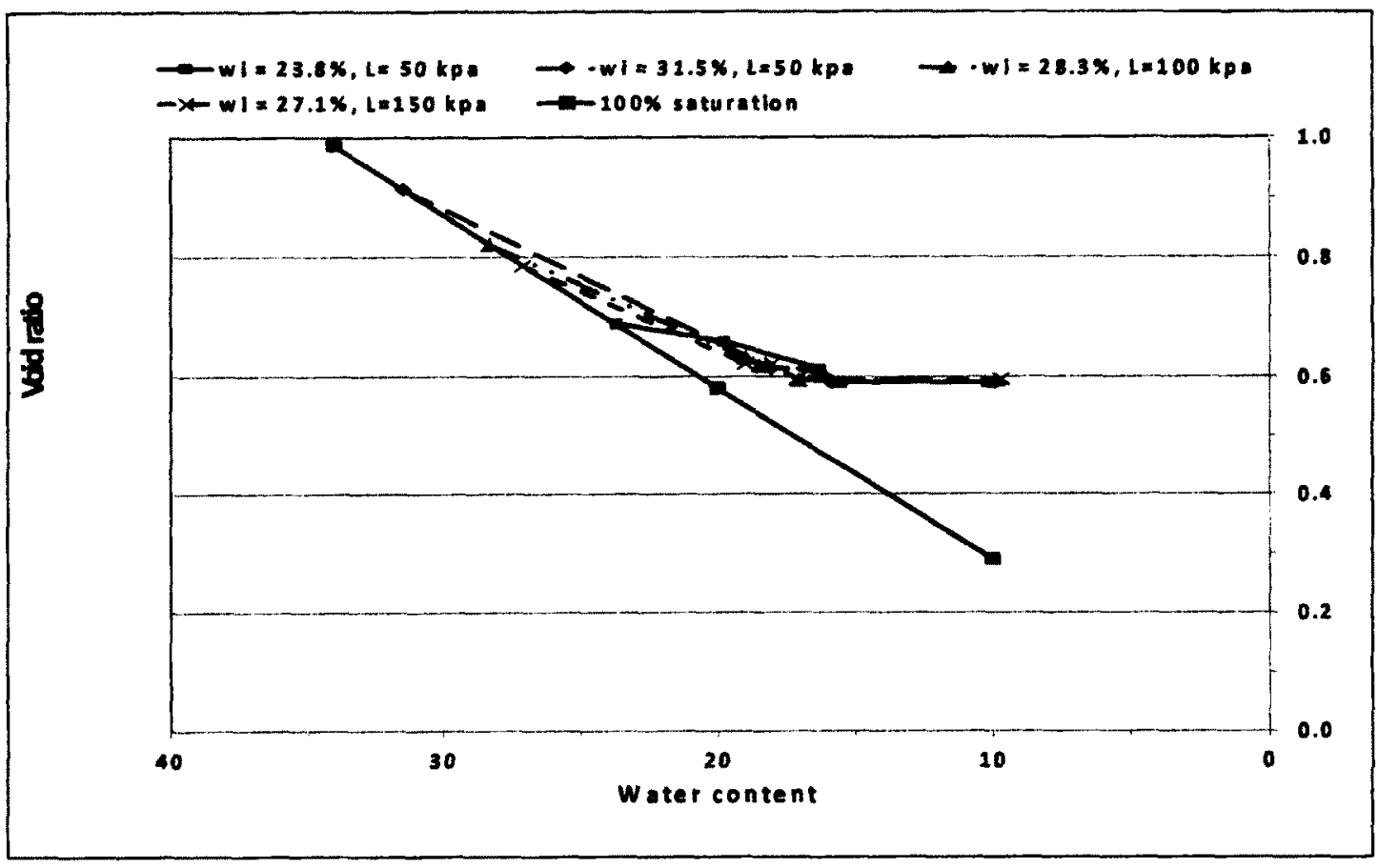

Figure 5-100: Effect of IWC and loading on shrinkage curve for gold mine tailings

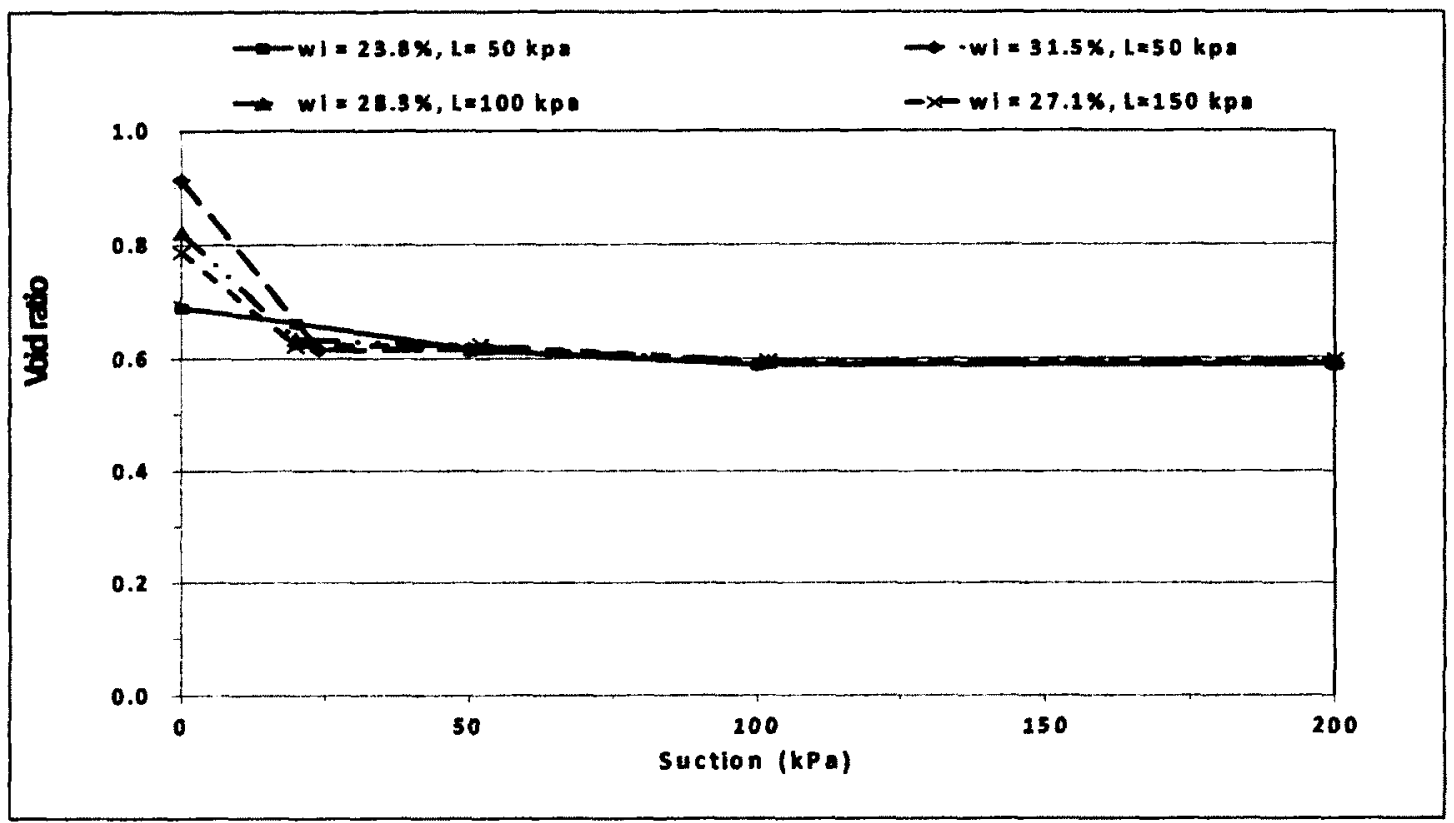

Figure 5-101: Effect of IWC and loading on void ratio-suction curve for gold mine tailings 


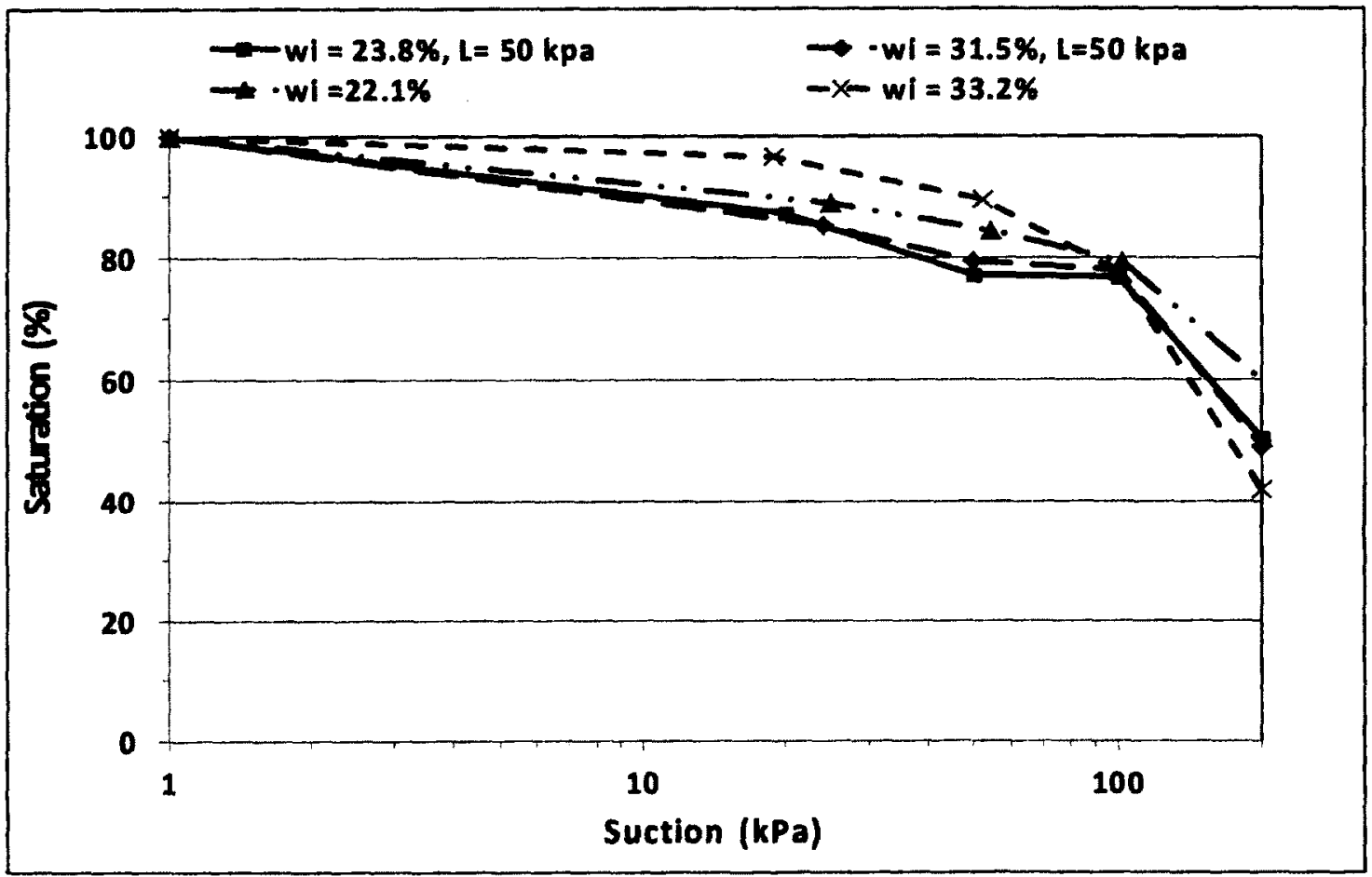

Figure 5-102: Comparison of saturation variations in loading and unloading conditions for gold mine tailings, log scale

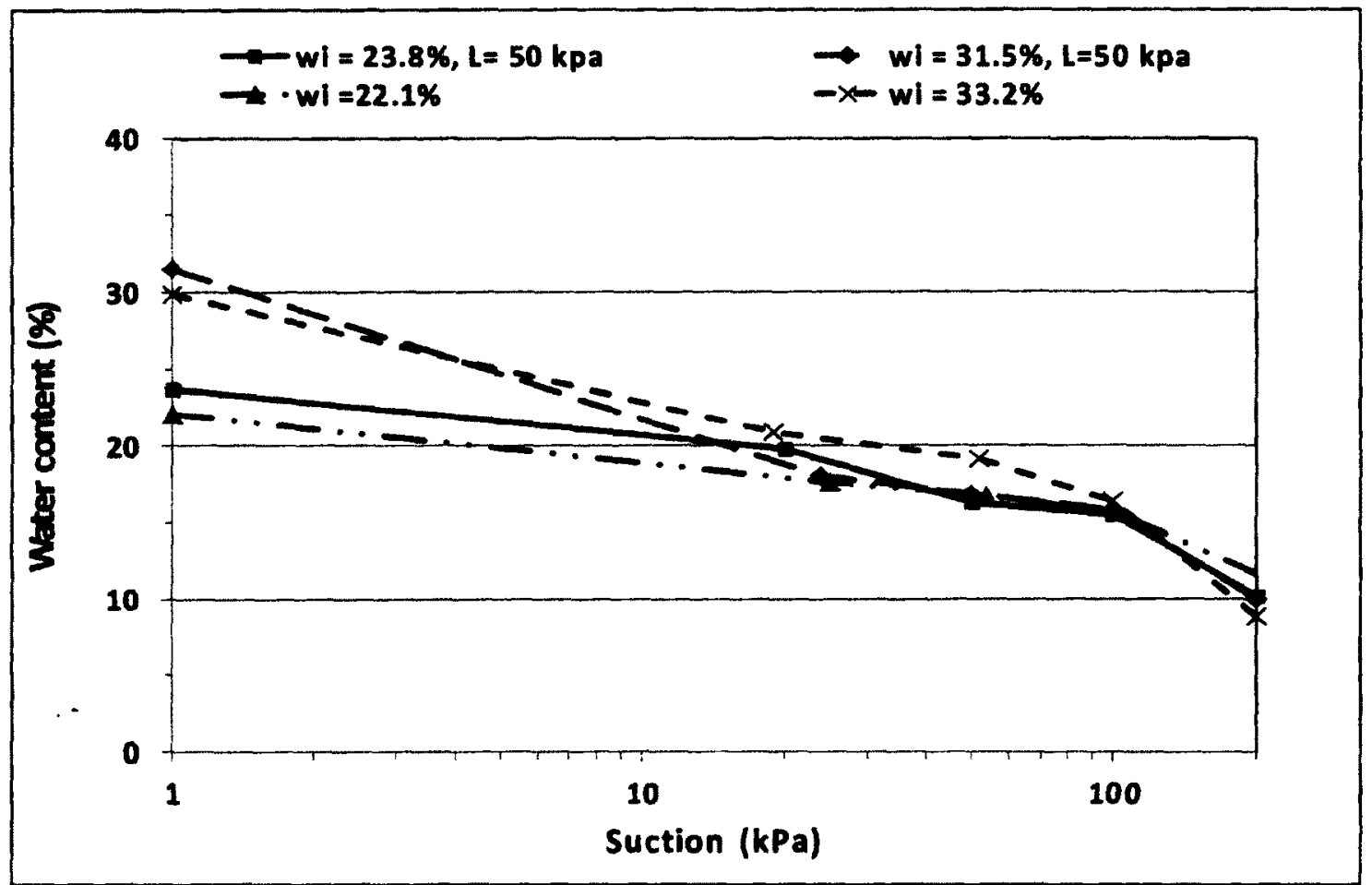

Figure 5-103: Comparison of water content variations in loading and unloading conditions for gold mine tailings, log scale 


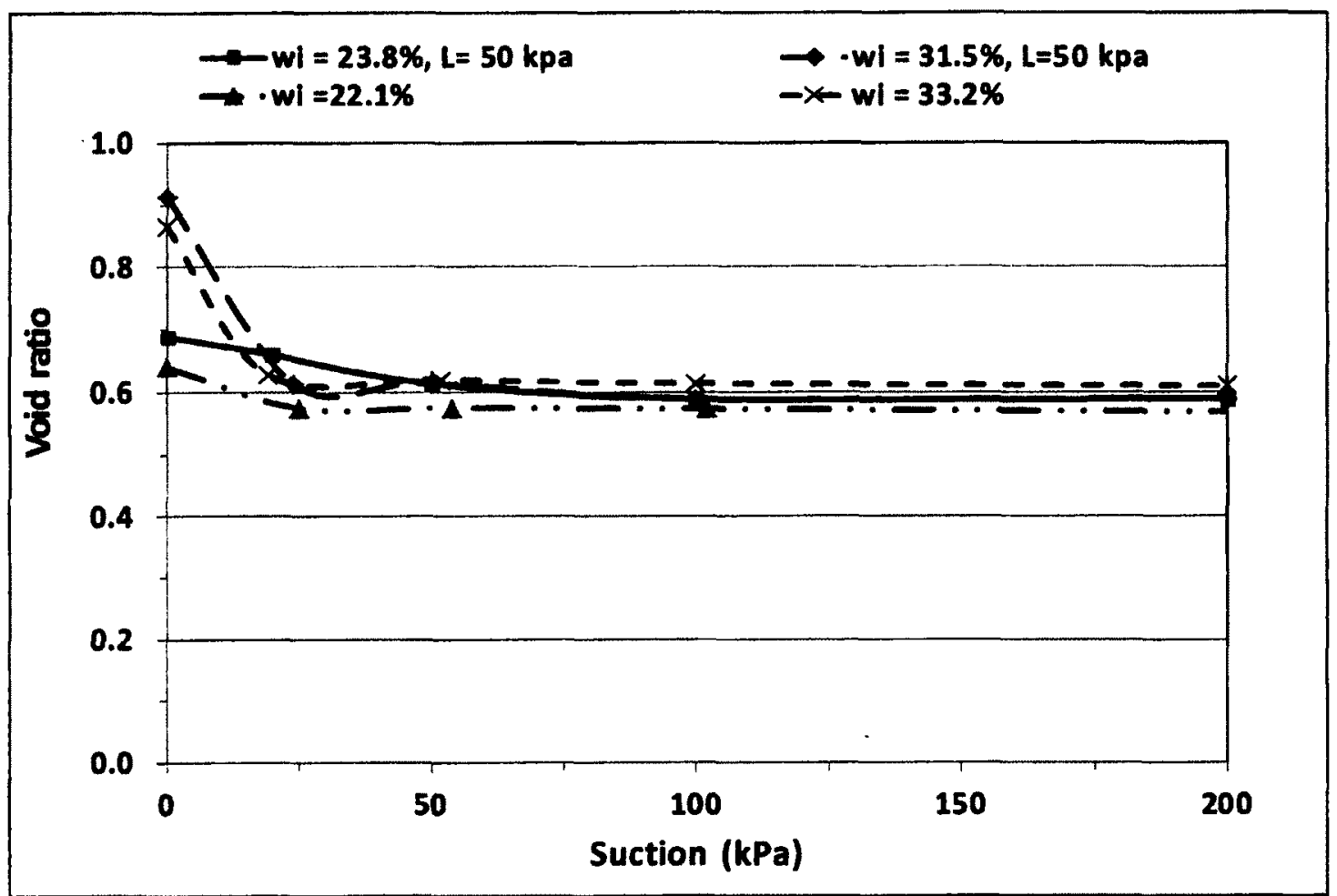

Figure 5-104: Comparison of void ratio variations in loading and unloading conditions for gold mine tailings

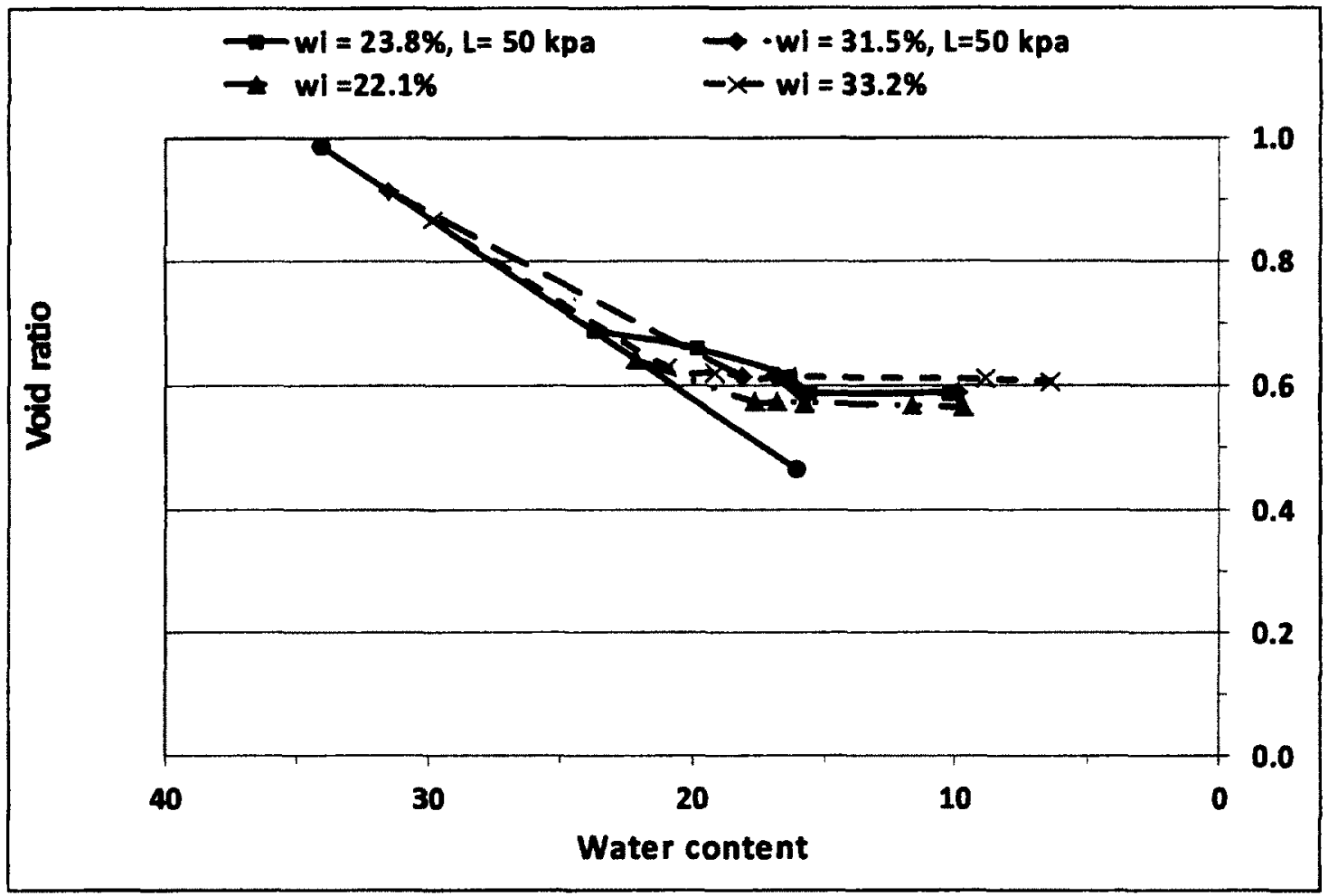

Figure 5-105: Comparison of shrinkage variations in loading and unloading conditions for gold mine tailings 


\section{5-3-4-2. TWCC under constant suction and variation of loading condition}

\section{(Consolidation under constant applied suction)}

In this section, the 1-D consolidation of Gold mine tailings under constant applied suctions was investigated. There were two tests:

- Constant applied suction of $50 \mathrm{kPa}$, Initial water content of $39 \%$, loading up to $200 \mathrm{kPa}$.

- Constant applied suction $150 \mathrm{kPa}$, Initial water content of $43 \%$, loading up to 200 $\mathrm{kPa}$

\section{5-3-4-2-1. Suction $50 \mathrm{kPa}$, Initial water content of 39\%, loading up to $200 \mathrm{kPa}$}

After 24 hours to allow for settling, $4.2 \mathrm{~g}$ water from the top of sample removed and water content was $33 \%$. Then a constant suction equal to $50 \mathrm{kPa}$ was applied, and 1-D loading was slowly increased over several days up to $50 \mathrm{kPa}$ After the sample reached equilibrium, the 1-D load was increased to $100 \mathrm{kPa}$ and then to $200 \mathrm{kPa}$

In all tests, a significant drop in the degree of saturation (from $100 \%$ to $80 \%$ ) occurred during the application of the first load. As it took between 6 to 8 days for this loading step to complete, it is possible that the sample somewhat dried out during this time. Therefore, the additional desaturation noticed at the application of the first load might not be part of the materials genera behaviour under these loading conditions.

Water content of sample dropped to $18 \%$ in loading of $200 \mathrm{kPa}$ And saturation from $100 \%$ decreased to $73 \%$. Initial void ratio of sample according to initial water content was 1.12 and reached to 0.72 at $200 \mathrm{kPa}$ loading. Total volume change was $19 \%$. At the end of the test suction was decreased to $0 \mathrm{kPa}$, no more suction and still sample was under $200 \mathrm{kPa}$ loading. In this situation, water content and saturation increased to $19 \%$ and $76 \%$ 
respectively. Variations of tailings water content, saturation, void ratio and shrinkage curve are shown in Figures 5-106 to 5-109. More details information can be seen in Tables A5-29, A5-30. 


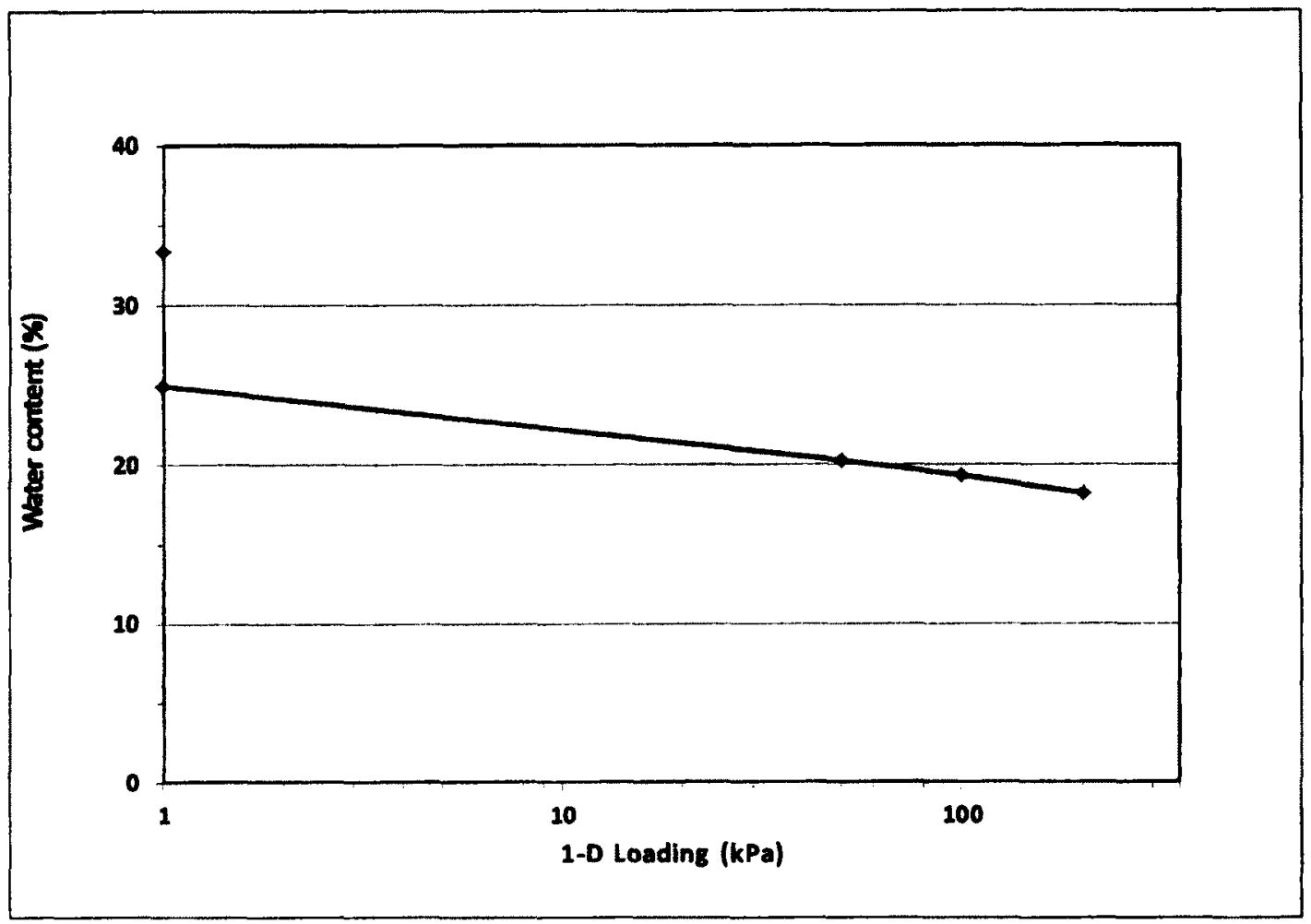

Figure 5-106: Water content-saturation curve for gold tailings, $w_{i}=38.8 \%$, applied matric suction $50 \mathrm{kPa}, \log$ scale

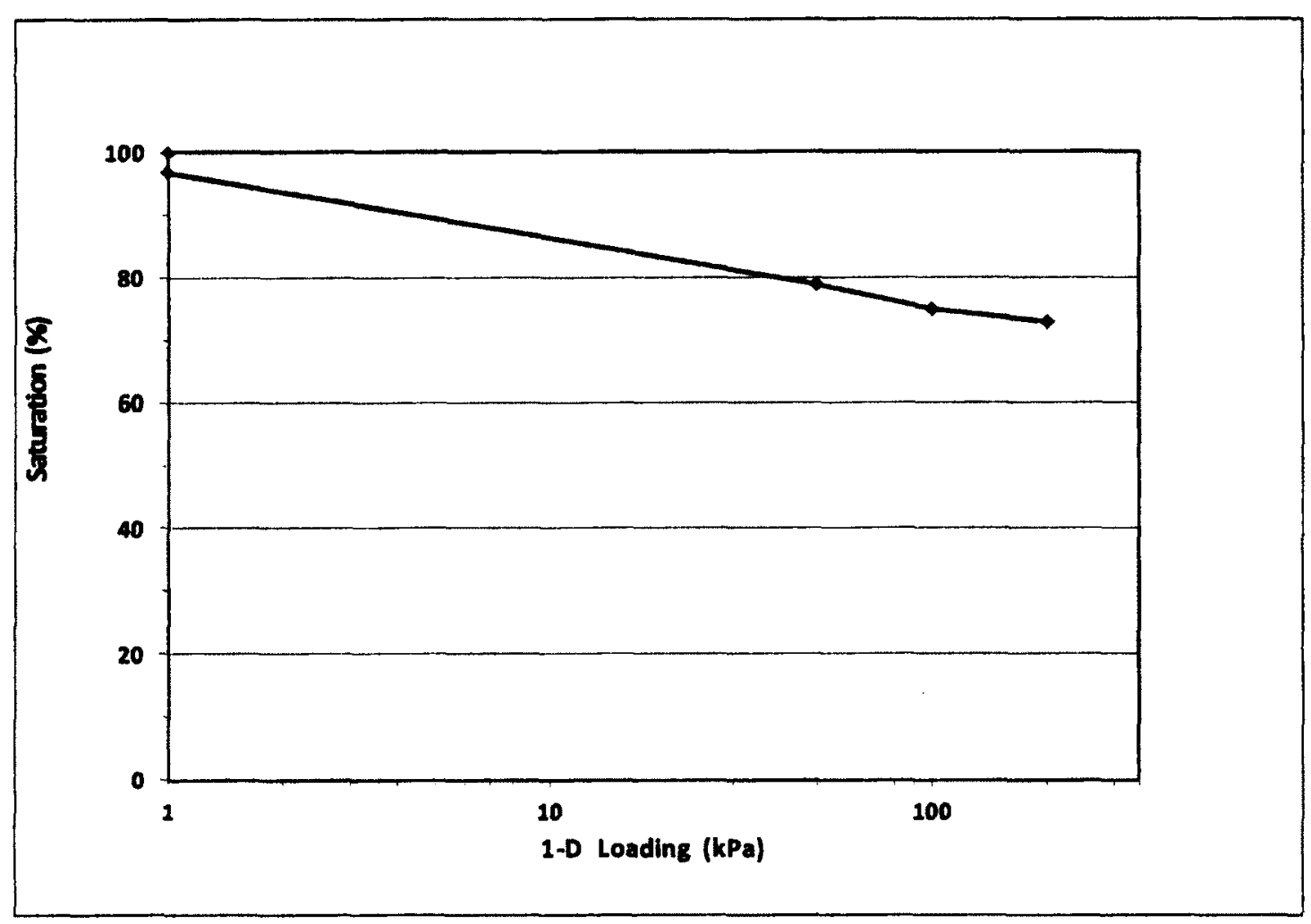

Figure 5-107: Saturation-suction curve for gold tailings, $w_{i}=38.8 \%$, applied matric suction $50 \mathrm{kPa}$, $\log$ scale 


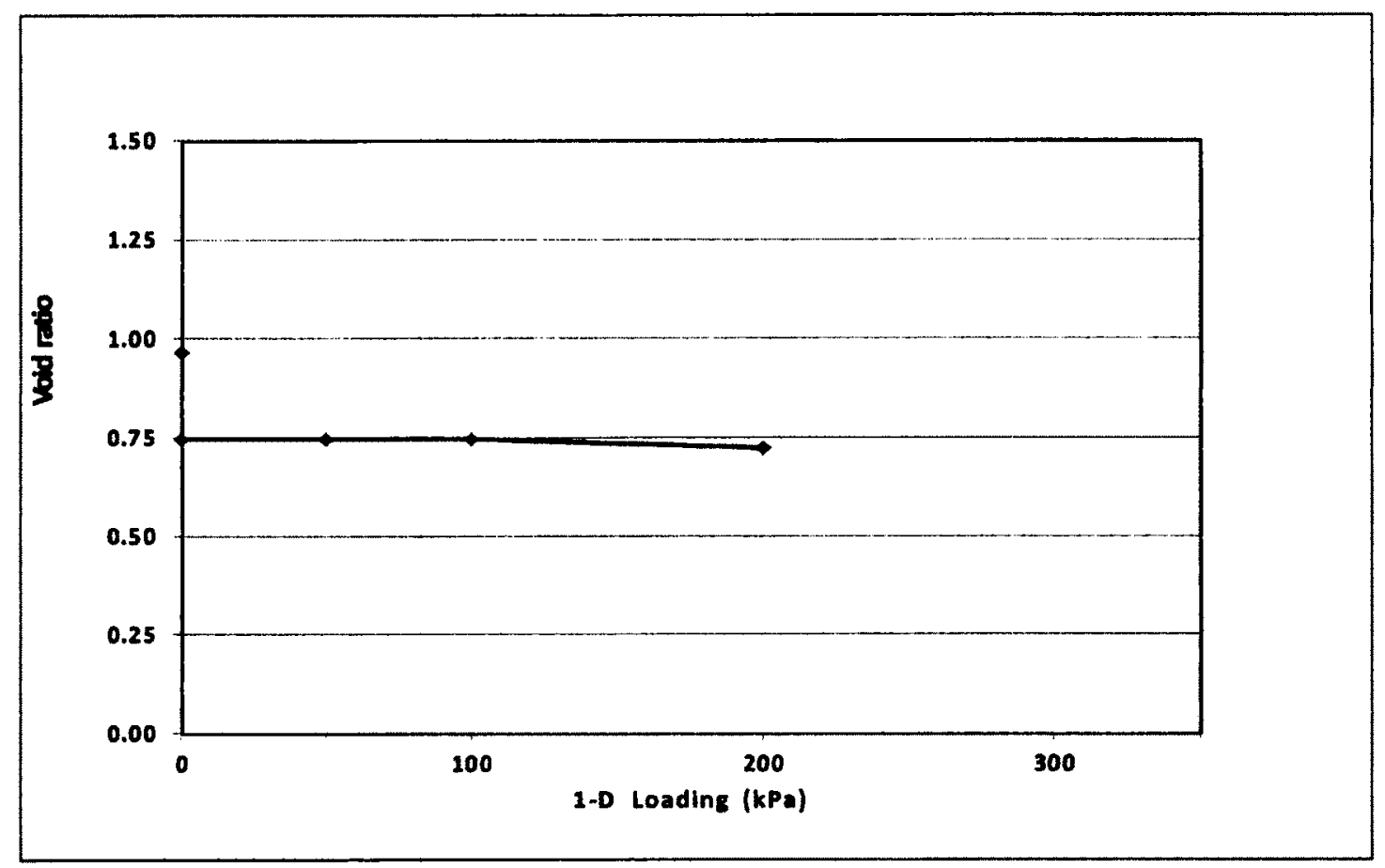

Figure 5-108: Consolidation curve for gold tailings, $\mathrm{w}_{\mathrm{i}}=38.8 \%$, applied matric suction $50 \mathrm{kPa}$

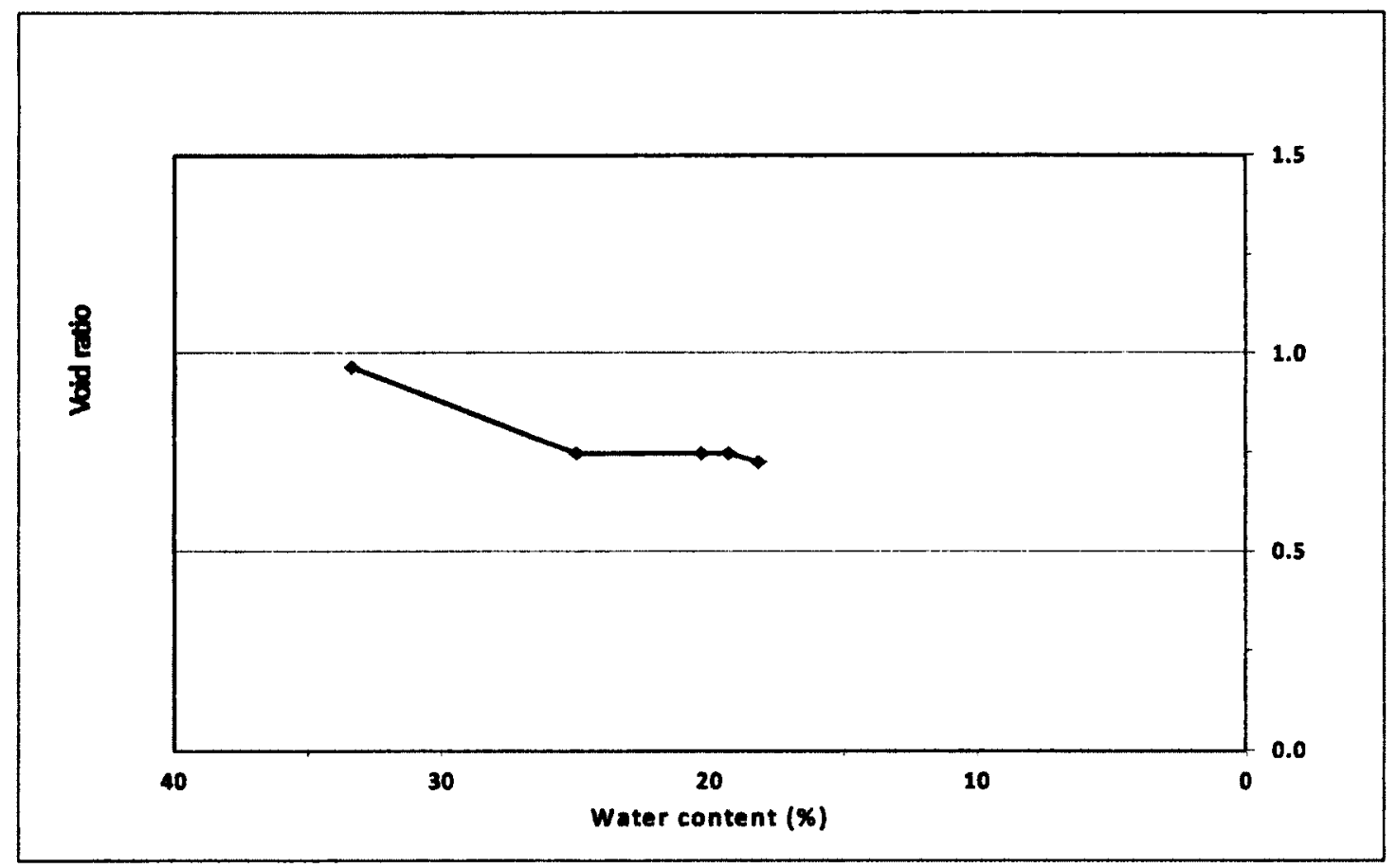

Figure 5-109: Shrinkage curve for gold tailings, $\mathrm{w}_{\mathrm{i}}=\mathbf{3 8 . 8} \%$, applied matric suction $50 \mathrm{kPa}$ 


\section{5-3-4-2-2.Suction $150 \mathrm{kPa}$, Initial water content equal $43 \%$, loading up to $200 \mathrm{kPa}$}

The procedure of this experimental test is the same as the previous test. After 24 hours, $4.8 \mathrm{~g}$ of water was removed from the top of sample and the water content was $36 \%$. Then a constant matric suction of $150 \mathrm{kPa}$ was applied, and the 1-D loading was increased in several days up to $50 \mathrm{kPa}$ After reaching equilibrium, 1-D loading was increased to $100 \mathrm{kPa}$ and then to $200 \mathrm{kPa}$

Initial void ratio of the sample was 1.23. Water content and saturation of sample at maximum loading of $200 \mathrm{kPa}$ and suction equal to $150 \mathrm{kPa}$ were $9 \%$ and $7 \%$ with void ratio of 0.67 . Total volume change was $25 \%$. At the end of the test suction was decreased to $0 \mathrm{kPa}$, but sample was still under $200 \mathrm{kPa}$ 1-D loading. In this situation, water content and saturation increased to $19 \%$ and $81 \%$ respectively. Variations of water content, saturation, void ratio and shrinkage curves are shown in Figures 5-110 to 5-113. 


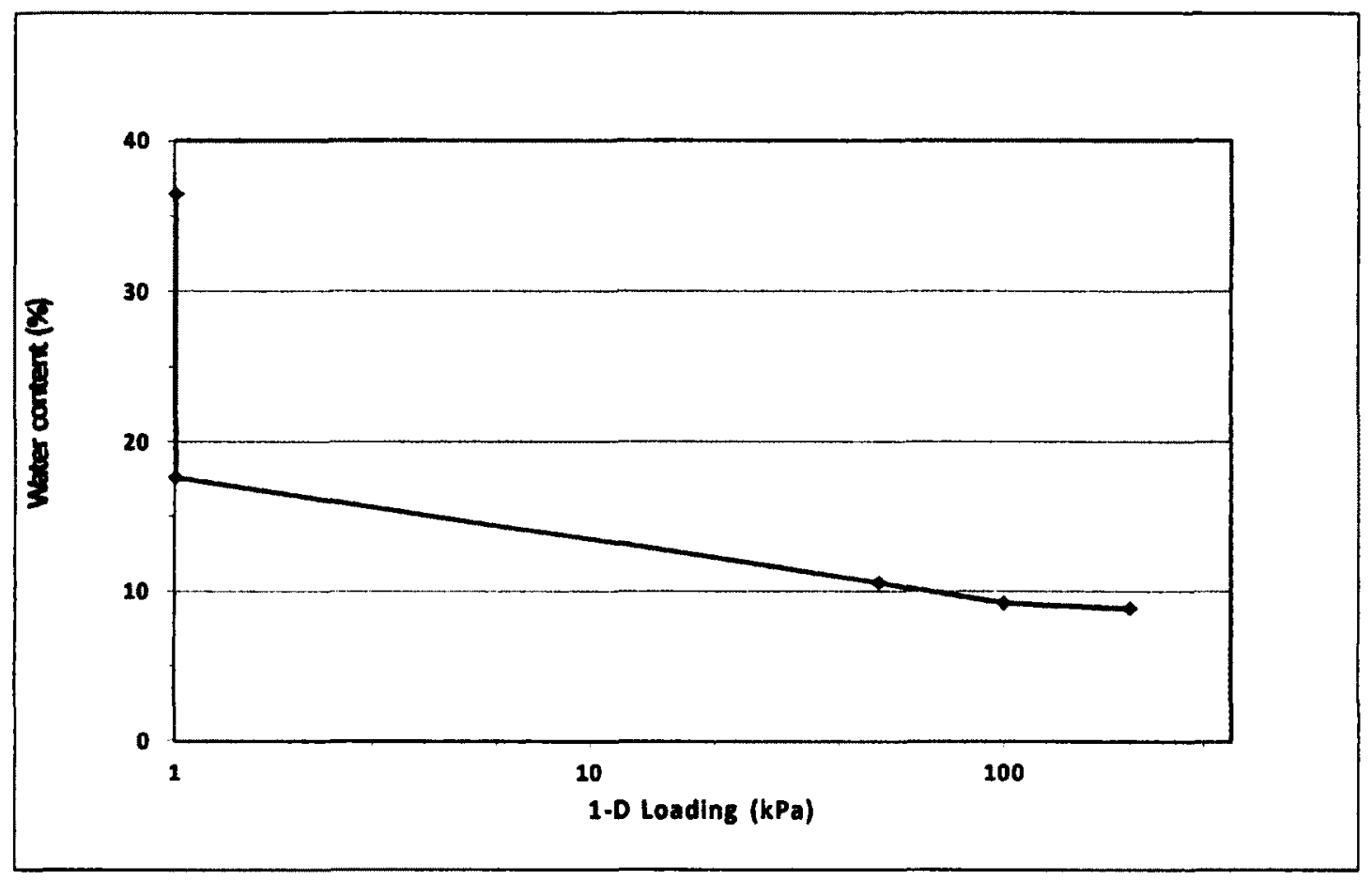

Figure 5-110: Water content-suction curve for gold tailings, $\mathrm{w}_{\mathrm{i}}=42.6 \%$, applied matric suction $150 \mathrm{kPa}$, log scale

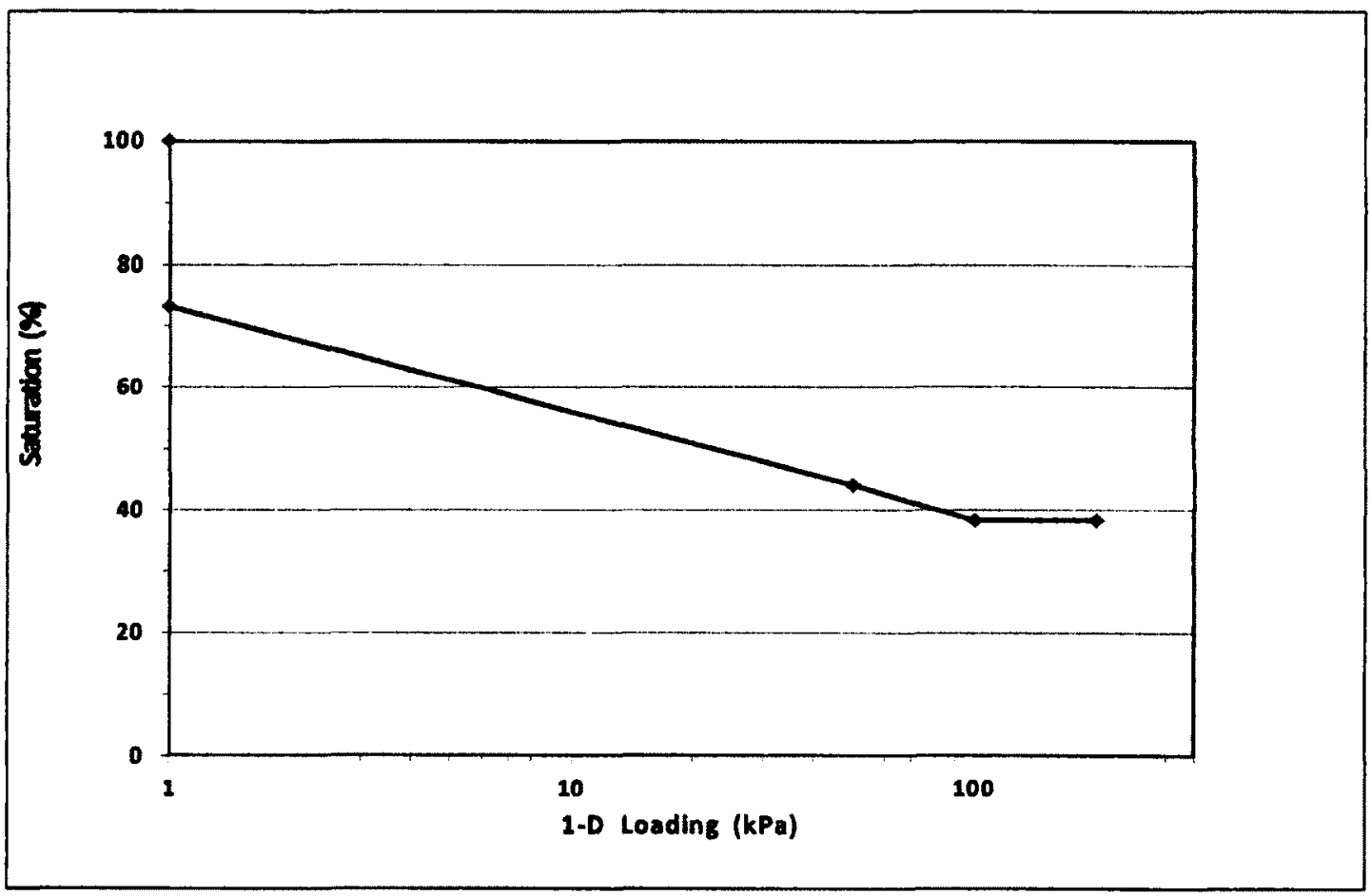

Figure 5-111: Saturation-suction curve for gold tailings, $\mathrm{w}_{\mathrm{i}}=42.6 \%$, applied matric suction $150 \mathrm{kPa}, \log$ scale 


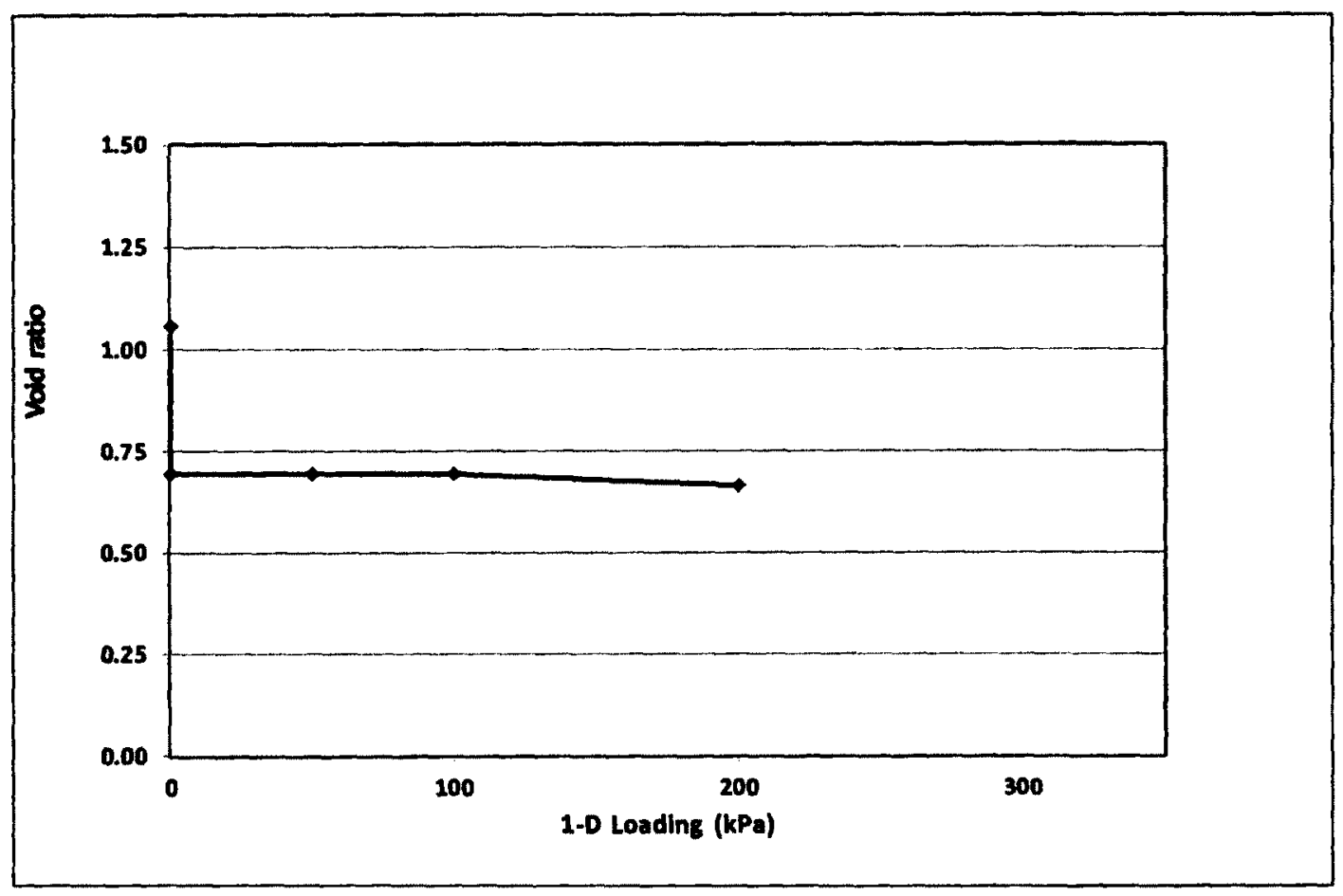

Figure 5-112: Consolidation curve for gold tailings, $\mathrm{w}_{\mathrm{i}}=42.6 \%$, applied matric suction $150 \mathrm{kPa}$

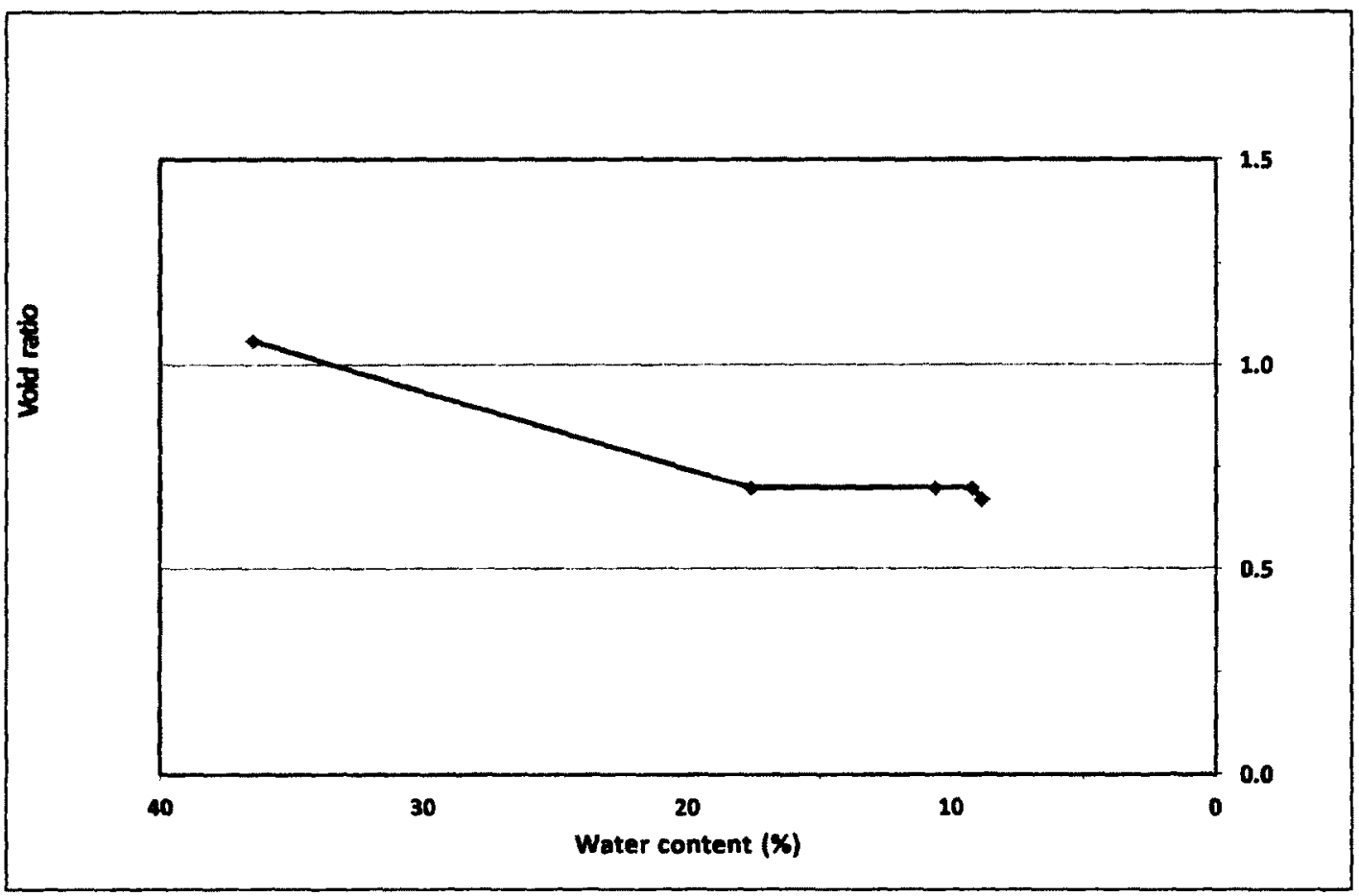

Figure 5-113: Shrinkage curve for gold tailings, $w_{i}=42.6 \%$, applied matric suction $150 \mathrm{kPa}$ 


\section{5-3-4-3. Behaviour of TWCC under no suction just loading condition}

So far behaviour of Gold mine tailings has been studied in different combination of suction and 1-D loading. For comparison, 1-D loading was applied with no matric suction, but using the same apparatus.

Figures 5-114 to 5-117 show the following results:

- Rate of decreasing water content and saturation was slow.

- Water content and saturation at a $200 \mathrm{kPa}$ applied load were around $20 \%$ and $81 \%$ respectively.

- Void ratio decreased from 1.05 to 0.73 .

More details are presented in Tables A5-31 and A5-32. 


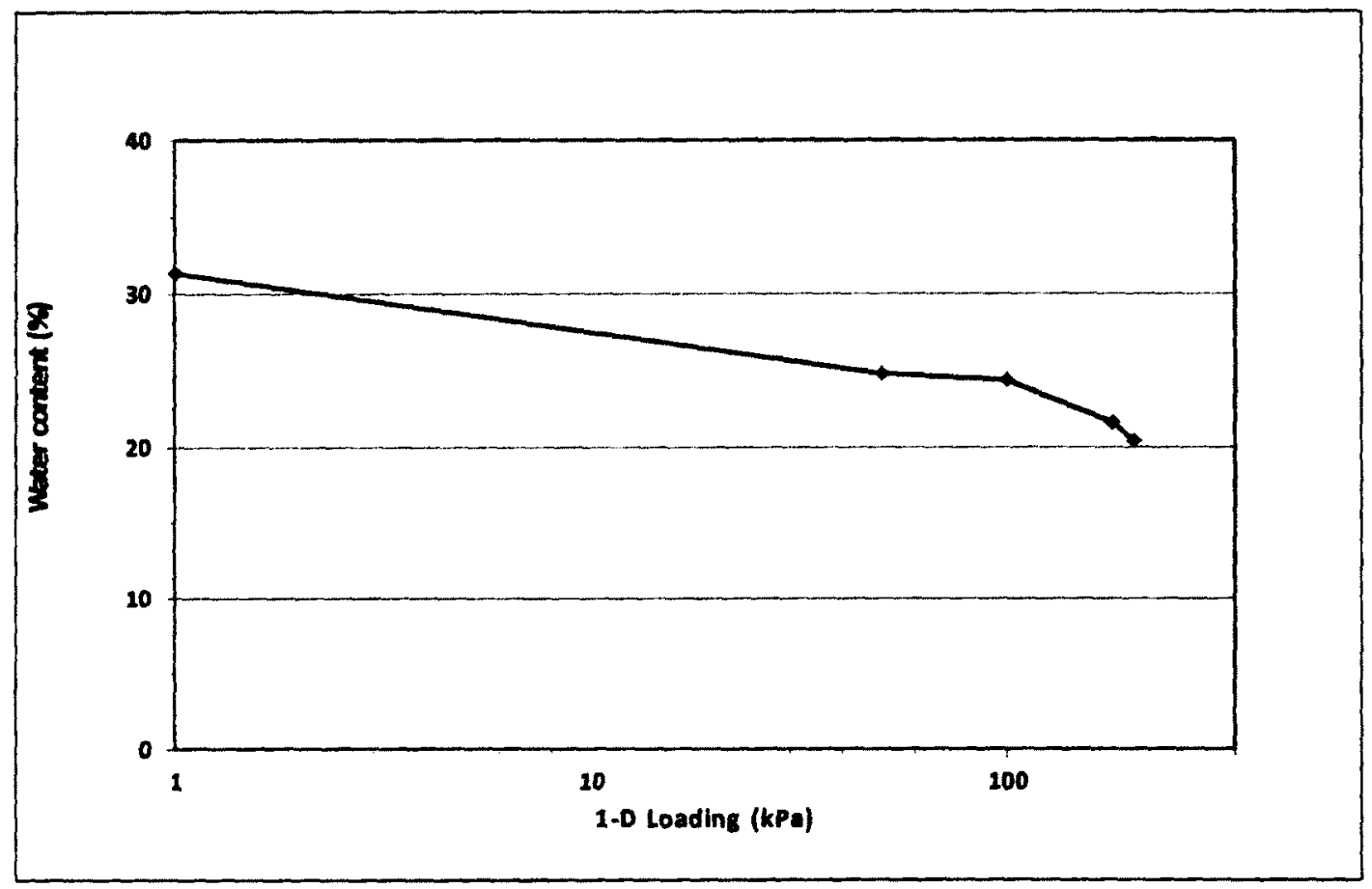

Figure 5-114: Effect of 1-D loading on water content curve for gold tailings, $\mathrm{w}_{\mathrm{i}}=36.3 \%$, applied matric suction $0 \mathrm{kPa}, \log$ scale

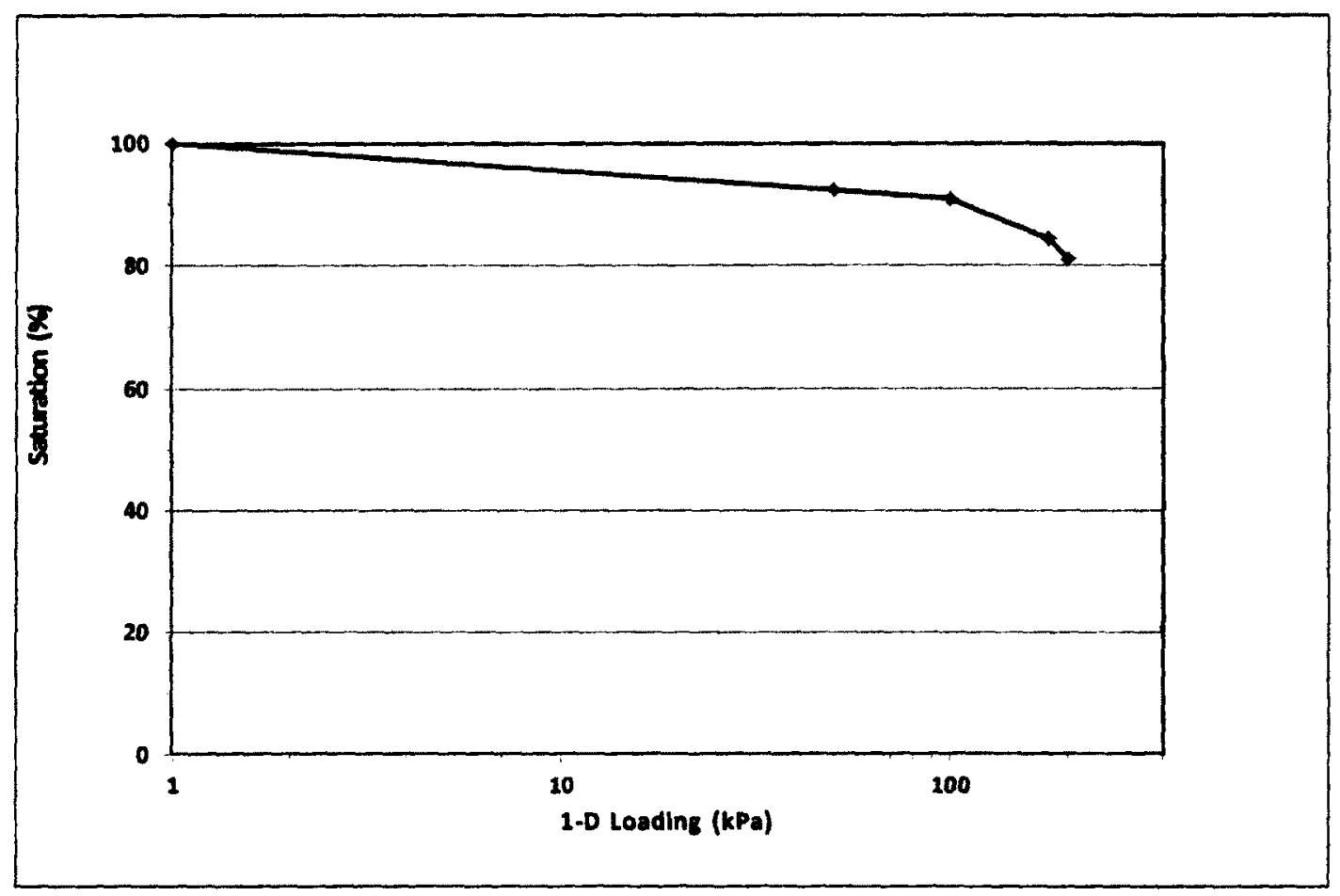

Figure 5-115: Effect of 1-D loading on saturation curve for gold tailings, $\mathrm{w}_{\mathrm{i}}=36.3 \%$, applied matric suction $0 \mathrm{kPa}$, log scale 


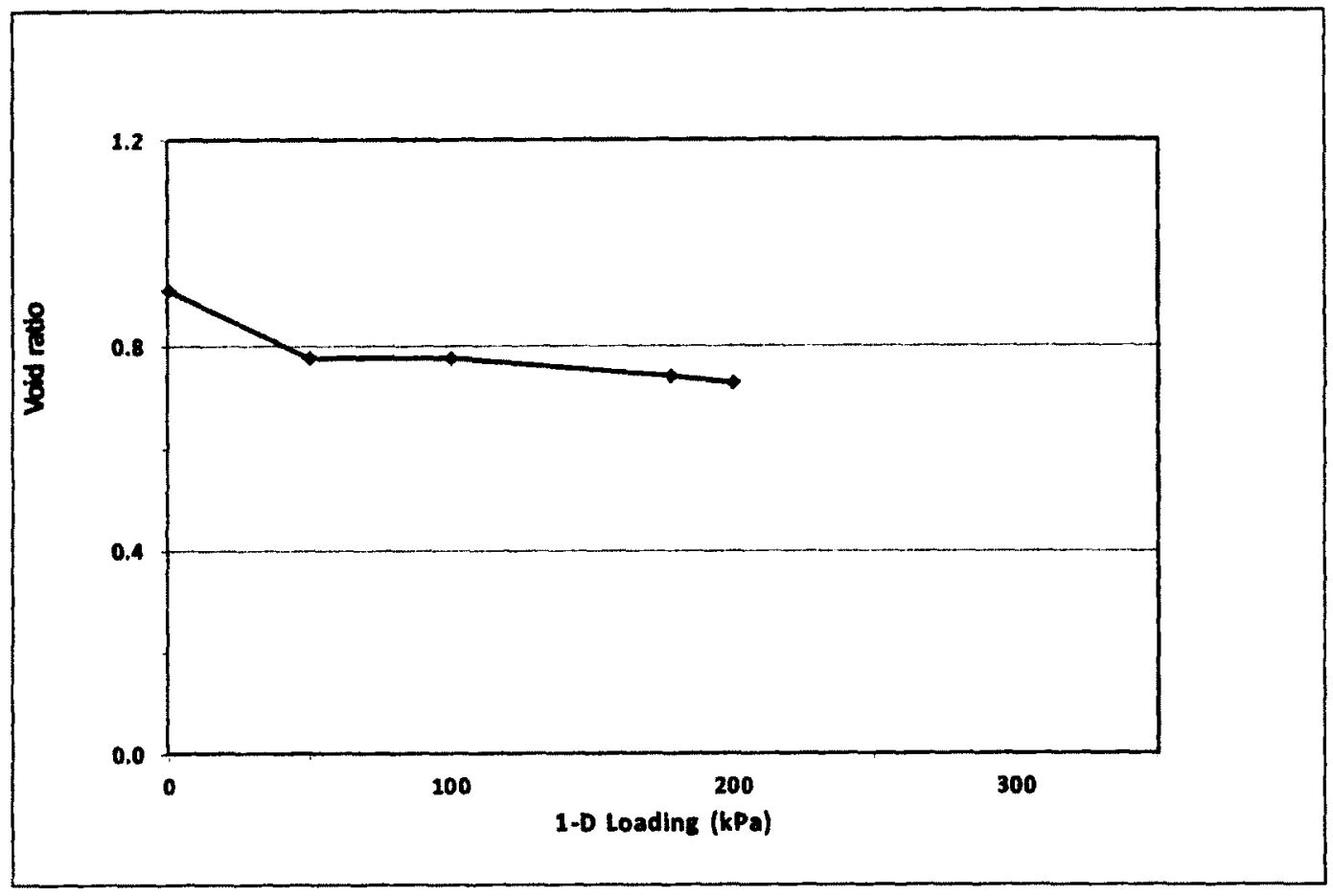

Figure 5-116: Effect of 1-D loading on void ratio curve for gold tailings, $\mathrm{w}_{\mathrm{i}}=36.3 \%$, applied matric suction $0 \mathrm{kPa}, \log$ scale

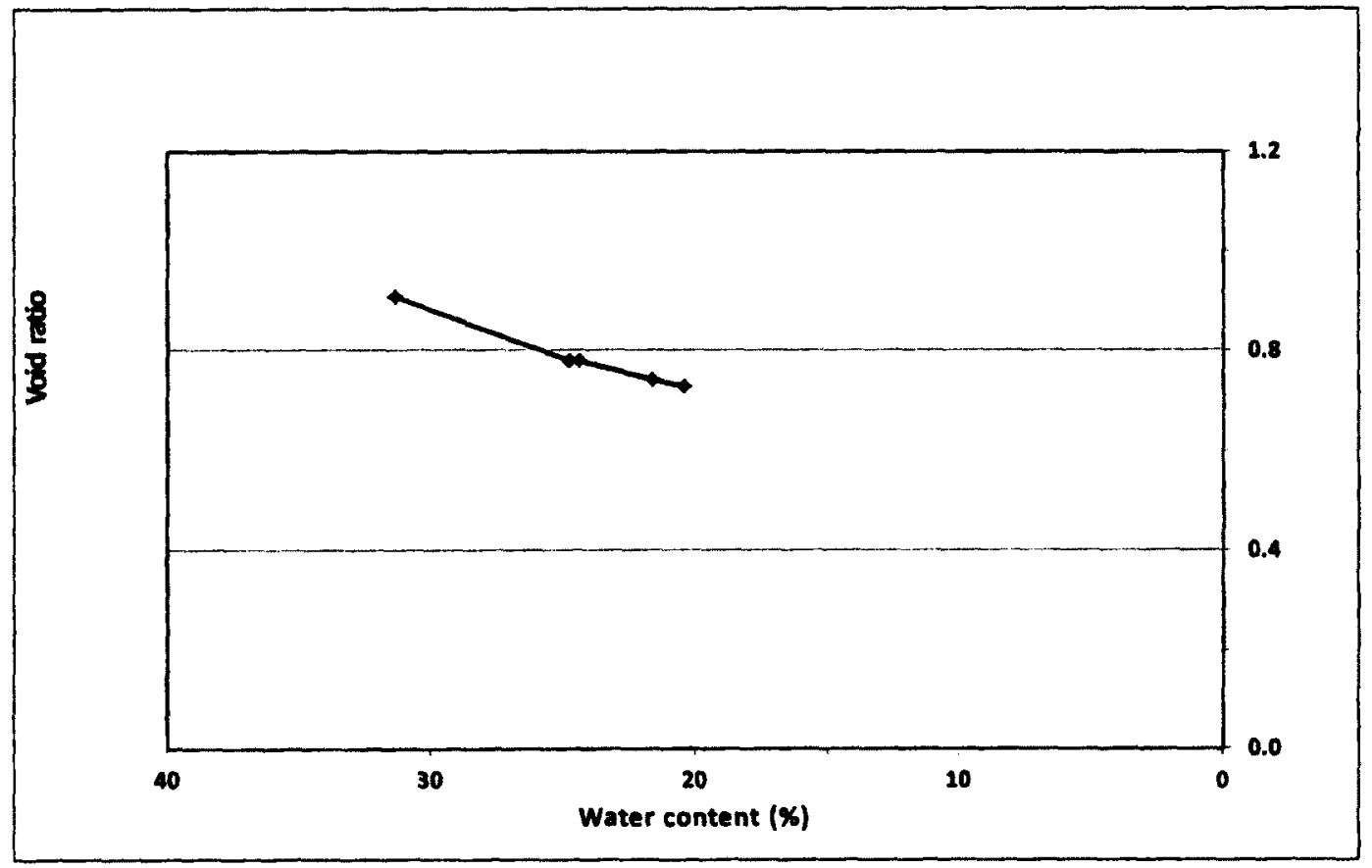

Figure 5-117: Effect of 1-D loading on shrinkage curve for gold tailings, $\mathrm{w}_{\mathrm{i}}=36.3 \%$, applied matric suction $0 \mathrm{kPa}, \log$ scale 


\section{5-3-5. Comparison of dewatering behaviour of gold tailings under different combinations of 1-D loading and matric suction.}

In the following Figures (5-130 to 5-133) four experimental tests have been compared:

- GMT sample with $\mathrm{w}_{\mathrm{i}}=33 \%$, suction up to $400 \mathrm{kPa}$, no loading.

- GMT sample with $w_{i}=31.5$, suction up to $200 \mathrm{kPa}$, 1-D loading $=50 \mathrm{kPa}$

- GMT sample with $\mathrm{w}_{\mathrm{i}}=39 \%$, suction $=50 \mathrm{kPa}, 1-\mathrm{D}$ loading up to $200 \mathrm{kPa}$

- GMT sample with $w_{i}=36 \%$, no suction, 1-D loading up to $200 \mathrm{kPa}$

Figures 5-118 to 5-1121 show the following results:

The influence of pre-loading of the TWCC, aside from the initial density of the tailings at the start of the TWCC, is fairly small. This is also seen in the previous Figures 5-98 to 5-101. The influence of a constant applied suction during consolidation is to decrease the void ratio for a given effective stress, though the void ratios of differently loaded samples tend to converge as stress increases.

Practically speaking, the results imply that pre-desiccation should be considered in determining the appropriate consolidation characteristics for assessing seepage from tailings impoundments, as well as their storage capacity.

Figures A5-47 and A5-48 in the appendix show more details. 


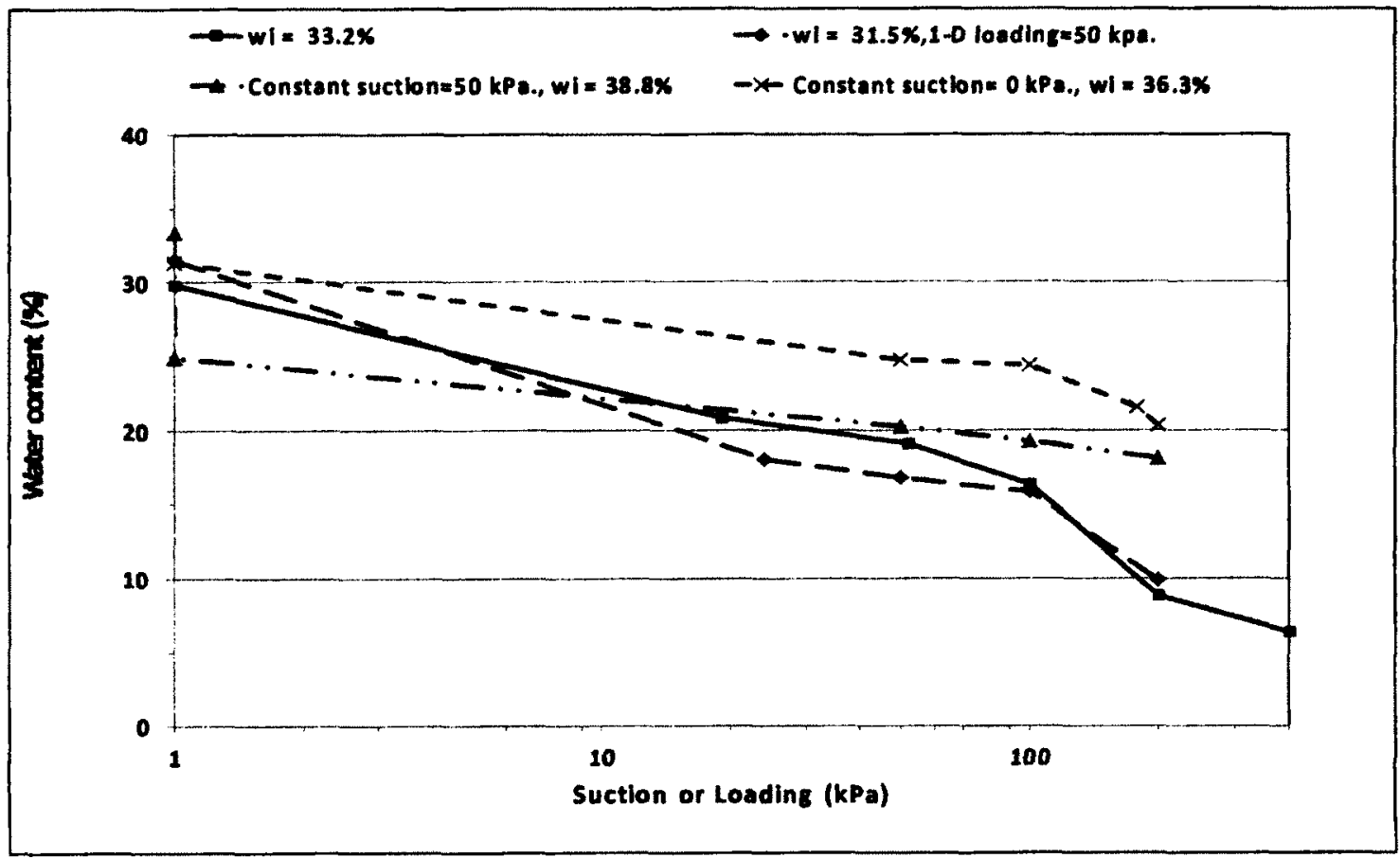

Figure 5-118: Effect of different parameters on water content curve for gold mine tailings, log scale

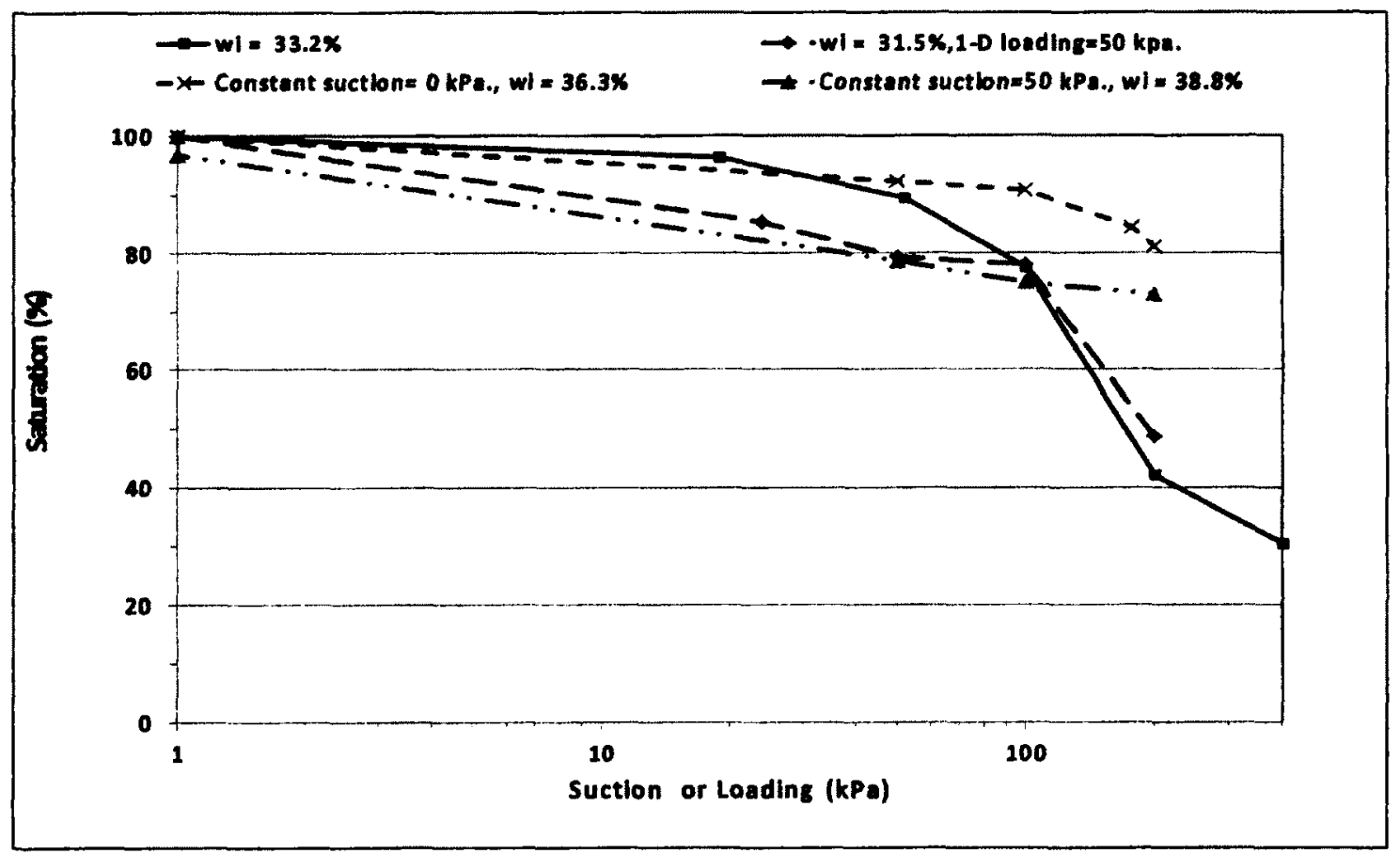

Figure 5-119: Effect of different parameters on saturation curve for gold mine tailings, log scale 


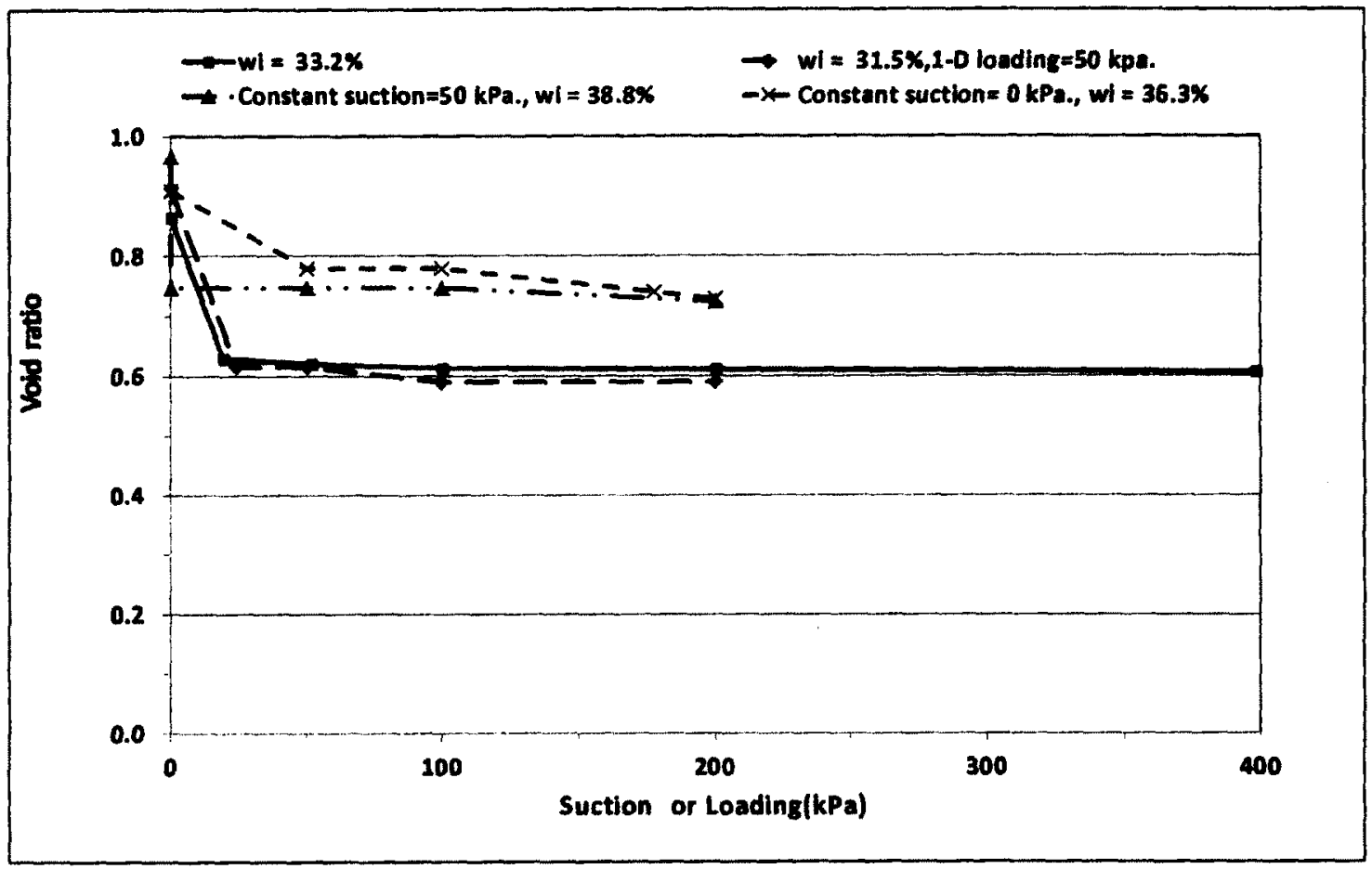

Figure 5-120: Effect of different parameters on consolidation curve for gold mine tailings

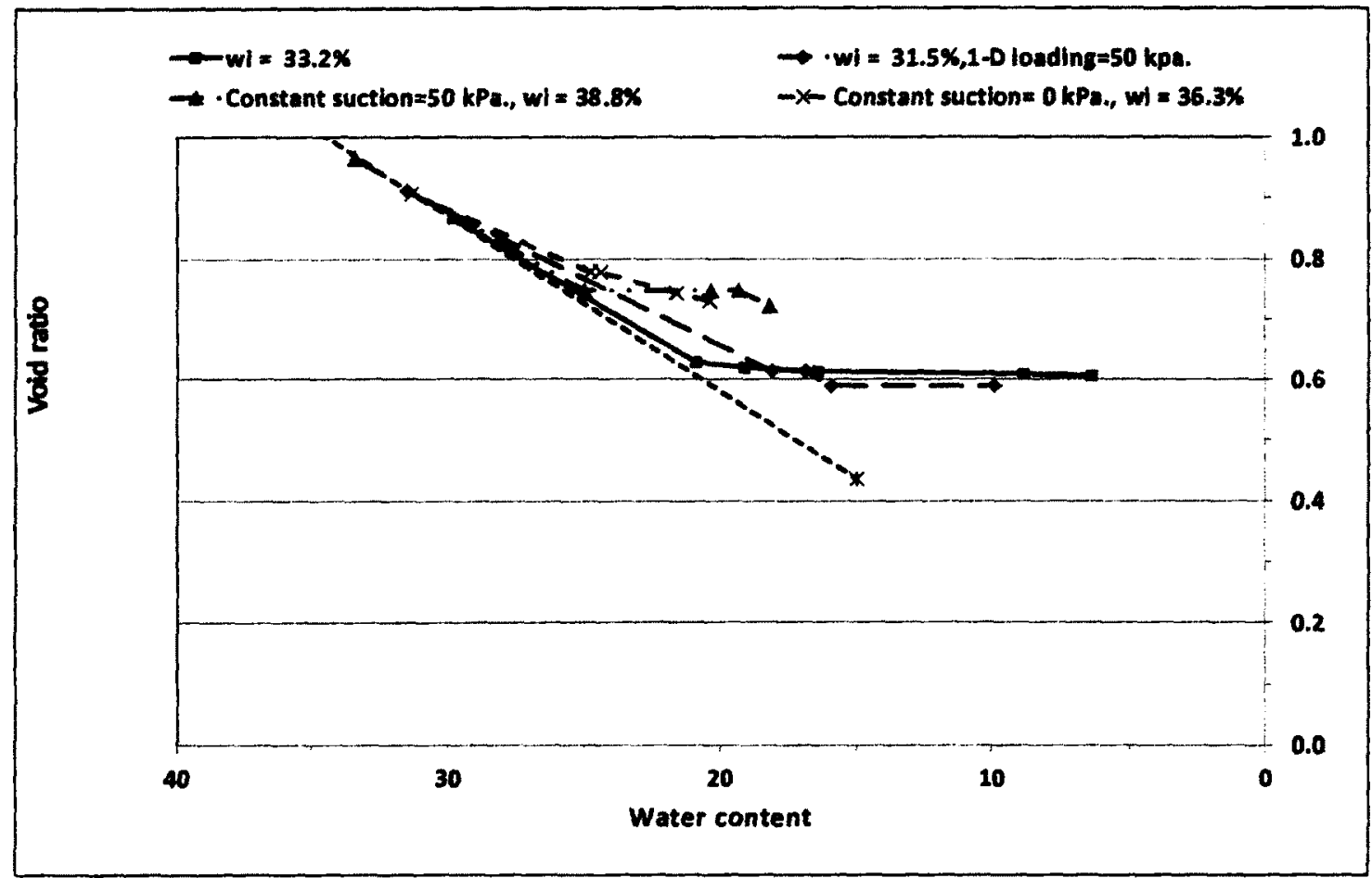

Figure 5-121: Effect of different parameters on shrinkage curve for gold mine tailings 
Chapter 6:

\section{Conclusions and Discussions}




\section{Conclusions and Discussions}

According to all of the experimental tests on artificial silt, oil sand mine tailings and gold mine tailings, following results can be taken:

- Varying sample thickness in the axis-translation tests between 10 to $30 \mathrm{~mm}$ did not affect the measured AEV or the WEV, but may have affected intermediate data on the SWCC.

In Oil sand mine tailings:

- As expected, adding polymer decreases the AEV by increases effective particle and pore-size

- The differences between TWCC for MFT with and without polymer are more prominent at lower suctions.

- Adding polymer results in lower water content for a given suction.

- Adding polymer did not affect the rewetting curve.

- At low suction, the rate of void ratio change with matric suction is greater when polymer is added.

- Adding polymer increases the shrinkage limit.

- In the limited number of tests conducted, increasing the degree of mixing in unamended MFT appears to decrease the AEV.

- At low applied suction, increased mixing energy during sample preparation decreases the degree of saturation. At high suctions, TWCC for samples with different degrees of mixing tend to converge.

- In un-amended MFT, the degree of mixing during sample preparation does not influence the shrinkage curve. 
- The degree of mixing does not affect the rewetting curve.

- Polymer reaction is sensitive to the degree of mixing during sample preparation. Over mixing can destroy the influence of polymer on the TWCC (Figure 5-80 and 5-81).

While the effect of the polymer on the AEV and the shrinkage limit are intuitively correspondent with increase in flocculation, the decrease in the AEV in un-amended MFT with increasing mixing energy is not as obvious. The latter results seems to imply that increasing mixing actually promotes flocculation in un-amended MFT. This observation warrants further investigation

In Gold mine tailings:

- Variation in initial water content does have small effect on the final void ratio in the TWCC. For samples ranging from initial water contents from $22 \%$ to $50 \%$, the final void ratio ranged from 0.57 to 0.70 .

- Initial water content had no significant effect on the AEV, given the resolution of the measurements. However, there is a trend of AEV increasing with decreasing IWC.

- Increasing the IWC of results in less water content and lower degree of saturation at high suction.

- IWC did not affect the wetting curve.

- Compaction of tailings increases water content and saturation at high suction.

- In gold mine tailings with the same initial water content, the TWCC under different values of constant loading, up to $150 \mathrm{kPa}$ were very similar, except for the starting water content at the beginning of axis-translation. 
- 1-D consolidation tests showed a small but significant change in void ratio with increasing constant levels of applied suction.

\section{Interpretation of the key results of dependency of final water content and void ratio on IWC}

As shown again in Figures 6-1 and 6-2, increasing IWC is correlated with increasing final void ratio and lower water content and degree of saturation at the highest measured value of matric suction. Departure from the $100 \%$ saturation line also occurs at higher water contents for samples with higher IWC. Additionally, the void ratio at different stages of dewatering (Figure 6-3) is also correlated with IWC. While the variation of the $\mathrm{AEV}$ with IWC, as determined by defining the AEV by degree of saturation $=0.85$, is not statistically significant, a trend is apparent.

All of these results can be potentially explained by the following hypothesis. The higher the IWC, the broader the initial pore-size distribution, and the greater the frequency of larger pores. The higher the IWC, the greater number of larger size pores that de-saturate before the SL This would both decrease the AEV, as well as increase the final void ratio, as these early de-saturating pores would not be susceptible to shrinkage during further drying. However, this hypothesis cannot be proven with resorting to observations of the microstructure of the tailings, which is beyond the scope of this thesis.

It is important to note that the inverse correlation between the initial water content and AEV (the higher the initial water, the lower the AEV), and between the initial water content and the residual water content (the higher the initial water content, the lower the 
residual water content) for the gold tailings is the same relationship found by Kawai et al, 2000, and Corey and Coleman 1954, as seen in Figures 2-18 and 2-21.

\section{Practical implications of the work}

I) The insensitivity of the TWCC to applied loads $<200 \mathrm{kPa}$ is practically important, as it allows for use of the same TWCC to model unsaturated flow in deep tailings impoundments.

II) The change in stiffness noted in the 1-D consolidation tests for previously desiccated tailings would be an important parameter for modelling consolidation of deep deposits of tailings, which has implications for rate of rise and volume capacity of an impoundment. The tailings increase in stiffness with increasing desiccation.

III) The tendency of tailings deposited at higher water contents to desaturate more at a given suction means that those tailings may be slightly more susceptible to ARD. If we consider equilibrium distribution of porewater pressure in say $30 \mathrm{~m}$ high deposit of tailings, assuming net outflow of zero at the surface, we have a linear distribution of matric suction, ranging from 0 at the bottom until $\sim 300 \mathrm{kPa}$ at the surface. Clearly, considering the two SWCC in Figure 6-1, the degree of saturation distribution will be different, which may impact the overall rate of acid generation and seepage water quality. 
All of the results are experimental tests using the axis-translation technique. To increase accuracy and better understand of tailings behaviour under initial states, in-situ measurement of water content and matric suction in the field is desirable. 


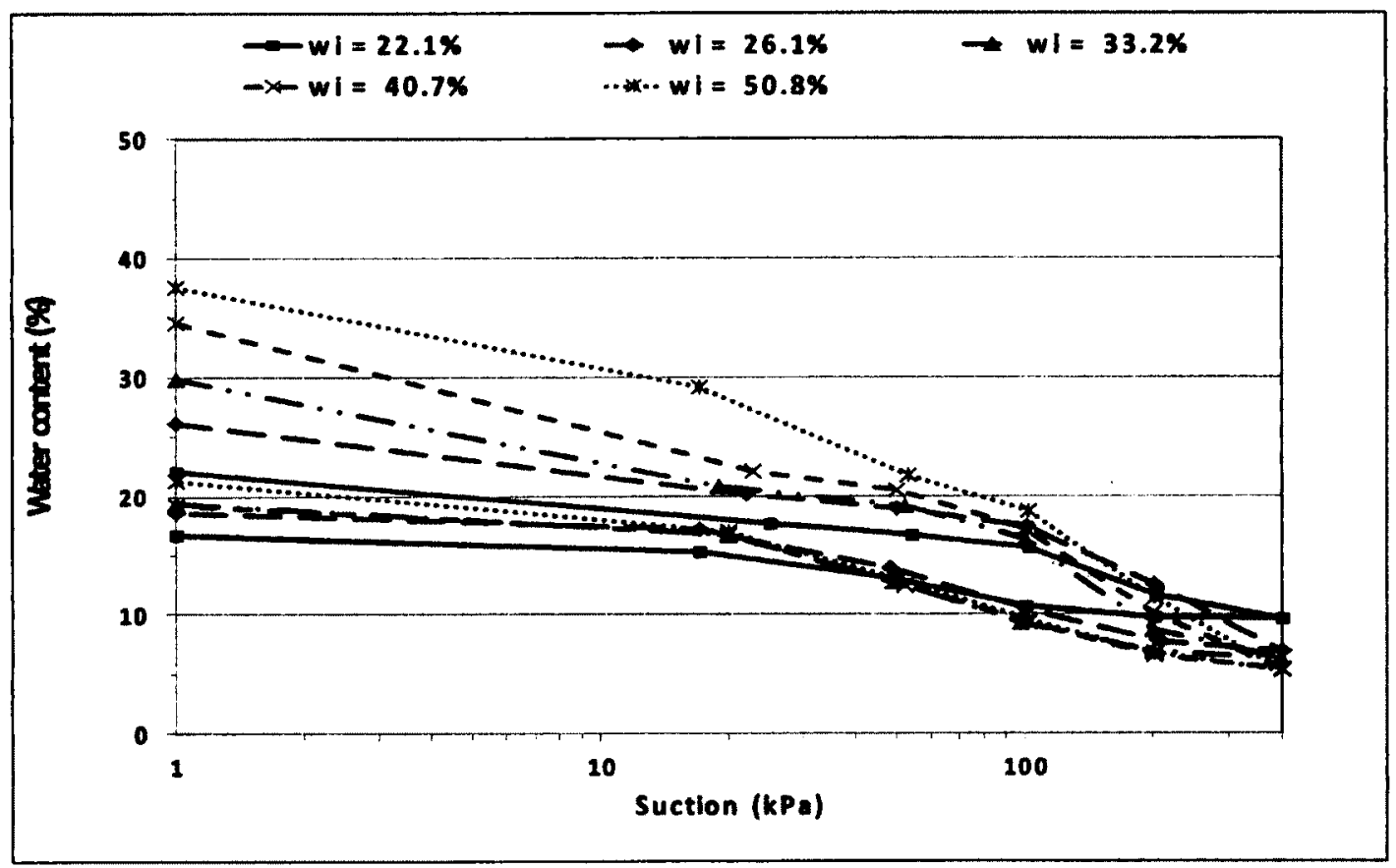

Figure 6-1: Effect of initial water content on water content-suction curve for gold mine tailings

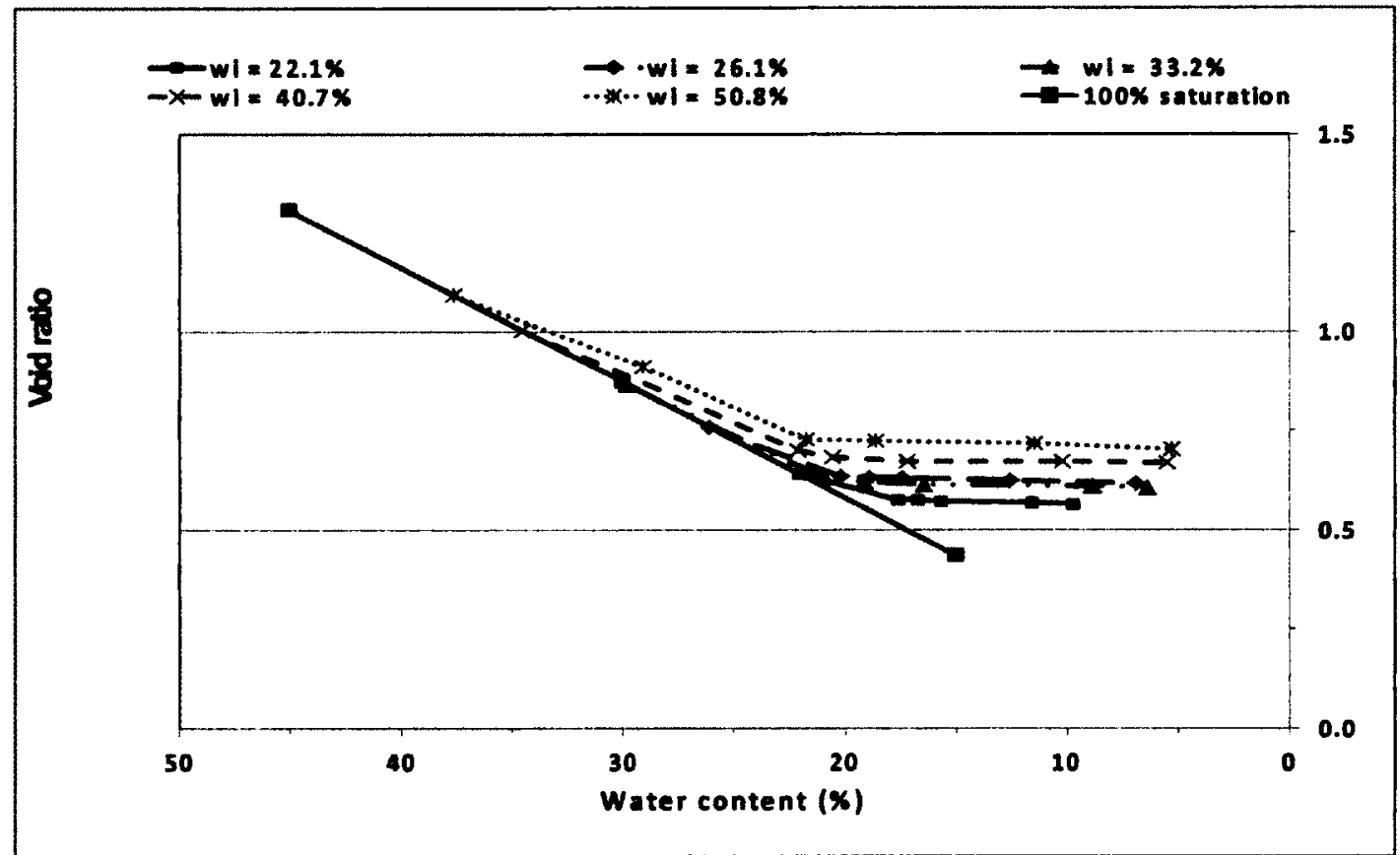

Figure 6-2: Effect of initial water content on shrinkage curve for gold mine tailings 


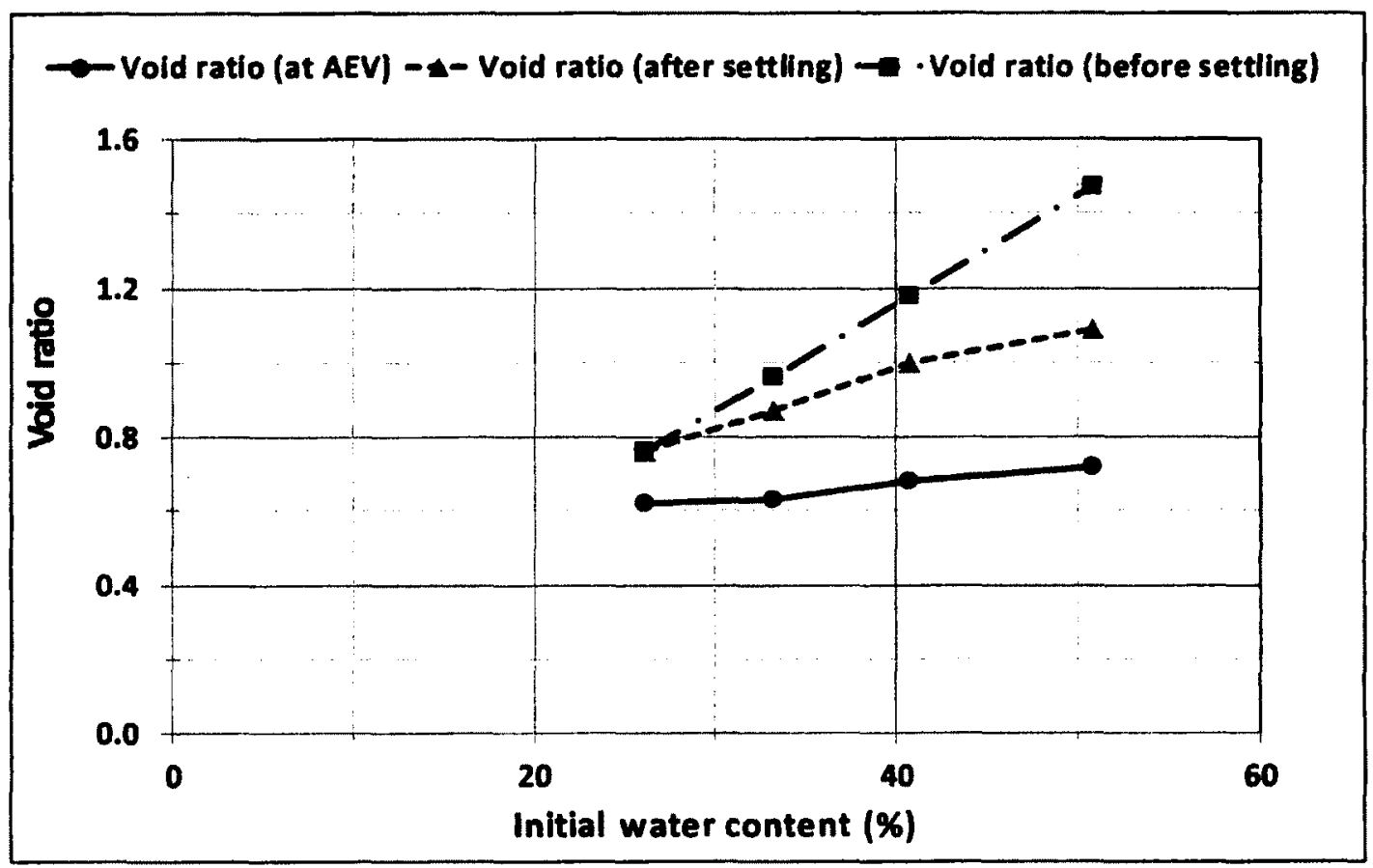

Figure 6-3: Relationship between initial water content and void ratio for gold mine tailings

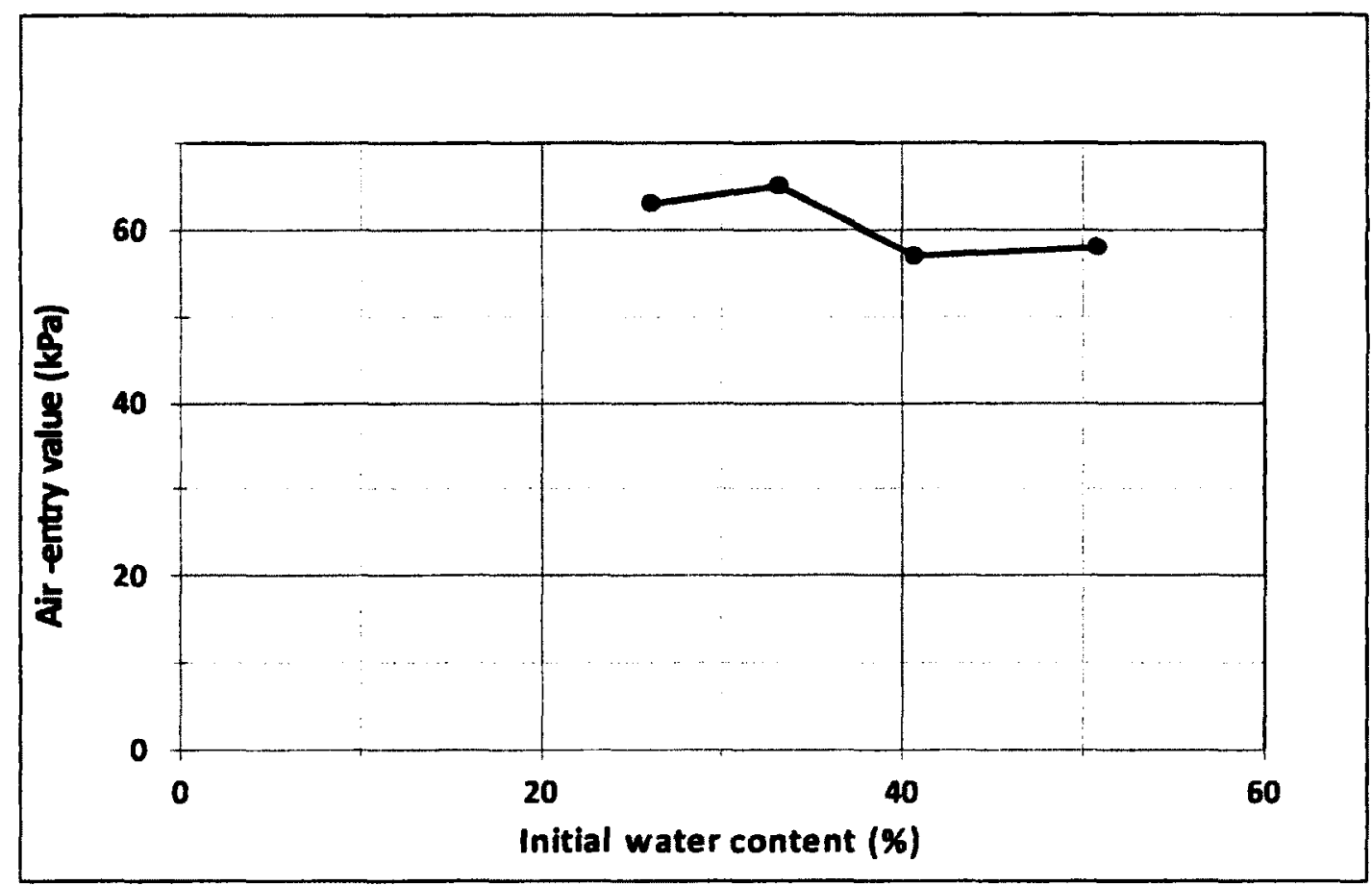

Figure 6-4: Relationship between initial water content and air-entry value for gold mine tailings 


\section{References}


African Barrick Gold. 2010. Bulyanhulu gold mine site visit [online]. Available from

http://www.africanbarrickgold.com/ /media/Files/A/African-Barrick-

Gold/Attachments/pdf/reports-and-presentations/2010/bulypressitevisit-sept2010-

Final.pdf

ASTM D698, 2007. Standard test method for Proctor Compaction test, Annual Book of ASTM.

ASTM D4943, 2007. Standard test method for Shrinkage curve test, wax method, Annual Book of ASTM.

Aubertin, M., Bussiere, B., and Chapuis, R.P. 199. Hydraulic conductivity of homogenized tailings from hard rock mines, Note, Canadian Geotechnical Journal. 33(3): 470-482.

Bajwa, T. 2012. Internal report submitted to Carleton University, Mine Waste research Group.

Belem,T., and Benzaazoua, M. 2004. An overview on the use of paste backfill technology as a ground support method in cut-and-fill mines. In Proceedings of the 5th International Symposium on Ground support in Mining and Underground Construction, Perth, Australia, pp. $637-650$.

Benckert, A., and Eurenius, J., 2001. Tailings dam constructions, Seminar on safe tailings dam constructions, 20-21 September 2001. Swedish Mining association, Gaellivare, pp. 30-36

Blight, G.E., et al. 1983. The behaviour of mine tailings during hydraulic deposition. 
The South African Institute of Mining and metallurgy Journal, pp. 73-86. [online]. Available from http://www.saimm.co.za/publications/downloads/v083n04p073 .pdf.

Budhu, M. 2000. Soil mechanics \& Foundations, United State of America. Chandler, R.J., and Tosatti, 1995. The Stava tailings dms failure, Italy, July 1985. In proceeding of the Institution of Civil Engineers Geotechnical Engineering. 113: $67-69$

Bryan, R., 2008. Drying and oxidation of surface-disposed paste tailings, M.A.Sc. thesis, Department of Civil and Environmental Engineering, Carleton University, Ottawa, Ontario, Canada.

Chandler, R.J., and Tosatti, G. 1995. The Stava tailings dams failure, Italy, July 1985. In proceedings of the Institution of Civil Engineers Geotechnical Engineering. 113: $67-79$

Croney, D., and Coleman, J.D. 1954. Soil structure in relation to soil to soil suction, Soil Science Journal, 5: 75-84.

Daliri, F., Simms, P., Sivathayalan, S., 2011. A comparison of different laboratory techniques to simulate stress and moisture history of hard rock mine tailings. In proceeding of tailings and Mine waste 2011, Vancouver, BC, 6-9 November, [online]. Available from https://circle.ubc.ca/bitstream/handle/2429/38673/Dalirie tal_TMW_2011.pdf?sequence $=1$

Davies, M.P. and Rice, S. 2001. An alternative to conventional tailings management dry stack filtered tailings. Proceeding of Tailings and Mine Waste 01, Balkema, pp. 411-420. 
Davies, M.P. 2002. Tailings impoundment failures: Are geotechnical engineers listening?, Geotechnical news. 20: 31-36

Environment Protection Agency, EPA, W.C. 1994. Design and evaluation of tailings dams. EPA530-R-94-038.

Fredlund, D.G., and Rahardjo, H. 1987. Soil mechanics principles for highway engineering in arid regions, Transportation Res. Record 1137, pp. 1-11

Fredlund, D.G., and Rahardjo, H. 1993. Soil mechanics for unsaturated soils. John Wiley \& Sons, New York.

Fredlund, D.G., and Xing, A. 1994. Equation for the soil-water characteristic curve. Canadian Geotechnical Journal. 31: 521-532

Hudson-Edwards, K.A. et al. 2003. The impact of tailings dam spills and clean-up operations on sediment and water quality in river system: the Rios ArioGuadiamas, Aznalcollar, Spain. Appl. Geochem. 18: 221-239

International Commission on Large Dams (ICOLD) 1995. Tailings Dams, Transport, Placement and Decantation - Review and Recommendations. Bulletin 101

Fisseha, B. 2008. Evaporation and unsaturated flow in multilayer deposits of gold paste tailings. Master of Applied Science. M. Sc. thesis, Department of Civil and Environmental Engineering, Carleton University, Ottawa. ON.

Fisseha, B., Bryan, R., Simms, P. 2010. Evaporation, unsaturated flow, and salt accumulation in multilayer deposits of paste gold tailings. Journal of Geotechnical, Geoenvironmental Eng. 136(12), 1703-1702.

Fourie, A.B. 2003. High density thickened tailings storage, [online]. Available from http://www.tailings.info/disposal/thickened.htm 
Frostiak, John. Et al. 2003. Surface disposal of past tailings at the Bulyanhulu gold mine, Tanzania, [online]. Available from http://www.tanzaniagold.com/bulyanhulu.htm] Golder 2005. Report on Bulyanhulu gold mine tailings storage facility optimization of deposition. Report No. 5098/658/5/S. Golder Associates Africa, Johannesburg, South Africa.

Gibbs, J.W. 1873. Graphical methods in the thermodynamics of fluid, trans. Connecticut Acad. Arts and Sci. 2: 309-342.

Hudson-Edwards, K.A. et al. 2003. The impact of tailings dam spills and clean-up operations on sediment and water quality in river system: the Rios Ario-Guadiamas, Aznalcollar, Spain. Appl. Geochem. 18: 221-239

Jacobsz, S.W. 1998. Jones \& Wagener Consulting Engineers, South Africa. Geotechnical reports.

Jeremy L., Ning, L. and David W. 2006. Hysteresis of Matric Suction and Capillary Stress in Monodisperse Disk-Shaped Particles, Journal of Engineering Mechanics, May 2006: $565-577$.

John, F. 2003. Development of Barrick gold's Bulyanhulu mine. $35^{\text {th }}$ annual meeting of Canadian mineral processors, paper 23.

Kawai, K., Karube, D., Kato, S., 2000. The Model of Water Retention Curve Considering Effects of Void Ratio. In:Rahardjo, H., Toll, D.G., Leong, E.C.(Eds.), Unsaturated Soils for Asia. Balkema, Rotterdam, pp.329-334.

Klohn, E.J. 1980. The Development of current tailings dam design and construction methods, in design and construction of tailings dams, Seminar proceedings, D. Wilson ed., Colorado school of mines press, Golden, CO, Nov. 6-7. 
Leong, E.C., and Rahardjo, H. 1997. Permeability functions for unsaturated soils.

Geotechnical and Geoenvironmental Engineering Journal, ASCE, 123(12): 11181126.

Mata, C., Romero, E., and Ledesma, A. 2002. Hydro-chemical effects on water retention in bentonite-sand mixtures. In Proceedings of the 3rd International Conference on Unsaturated Soils. UNSAT 2002, Recife Brazil. 1: 283-288.

Matthews, J.G., Dhadli, N., House, P., Simms, P. 2011. Field trials of thin-lift deposition of amended mature fine tailings at the Muskeg River Mine in Northern Alberta, proceeding of the $13^{\text {th }}$ international seminar on paste and thickened tailings, Australian Center for Geomechanics, Perth, Australia. pp. 271-280

Michelle T. 2000. Soil suction in mine tailings. M.Sc. thesis, Department of engineering, University of Pretoria, Pretoria, South Africa.

Mittal, H.K., and Morgenstern, N.R. 1975. Parameters for the design of tailings dams, Canadian Geotechnical Journal, 13: 277-293

Mohamed, T.A., et al., 2006. Relationship between shear strength and soil water characteristic curve of an unsaturated granitic residual soil. American Journal of Environmental Sciences 2 (4): 142-145.

Ng, C.W.W., Pang, Y.W., 2000. Influence of stress state on soil-water characteristics and slope stability. Journal of Geotechnical and Geoenvironmental Engineering, 126(2):157-166.

Padilla, J.M., et al. 2005. A new soil - water characteristic curve device. Proceeding of advanced experimental unsaturated soil mechanic, An international symposium, Trento, Italy. pp. 15-22. June 27-29. [online]. Available from http://www.soil 
vision.com/subdomains/unsaturatedsoil.com/Docs/Research\%20Papers/2005/Con ference $\% 20$ Papers/A\%20new $\% 20$ soil $\% 20-\% 20$ water $\% 20$ characteristic $\% 20$ curve \%20device.pdf

Priscu, C. 1999. Behaviour of mine tailings dams under high tailings deposition rates. PHD thesis, McGill University, Montreal, Canada.

Qiu, Y., and Sego, D.C., 2001. Laboratory properties of mine tailings, Canadian Geotechnical Journal, 38: 183-190. doi: 10.1139/cgj-38-1-183

Rademeyer, B. 2007. Planning, Design and Analysis of Tailings Dams. PHD thesis, Department of Engineering, University of Pretoria, Pretoria, South Africa

Real, F. and Franco, A. 2006. Tailings disposal at Neves-Corvo mine, Portugal. Mine water and the environment, International mine water association. Portugal, pp. 209-221.

Robinsky, E.I., et al. 1991. Thickened sloped tailings disposal, in proceeding of the Second International Conference on the Abatement of acid drainage, invited lecture, 16-18 September. Montreal, Quebec, pp. 1-20.

Santos, A., Martinz, J.M., and \&t Santiago, J.L 1992. Determination of Geotechnical Properties of Uranium Tailings, in Stability and Performance of slope and embankments. II, ASCE Geotechnical special publication No. 31, Berkeley, June 29-July 1, pp. 175-191

Shell Canada. Muskeg river mine, 2007. [online]. Available from http://www.shell.ca/home/content/can-en/aboutshell/ourbusiness/businessin canada/upstream//oilsands/muskeg_river/

Shell Canada Energy, 2011. Muskeg river mine Annual tailings management plan 2011, 
D74-Appendix E. [online]. Available from http:/www.ercb.ca/oilsands/ tailingsplans/Shell Muskegriver 2011 Tailingsplan.pdf

Sillers, W.S., Fredlund, D.G., Zakerzadeh, N., 2001. Mathematical attributes of some soil-water characteristic curve models. Geotechnical and Geological Engineering, 19: 243-283.

Simms, P. 2007. Environmental geotechnique for near-surface soils, Department of Civil and Environmental Engineering, Carleton University, Ottawa, Canada

Simms, P., Grabinsky, M., and Zhan, G., 2007. Modelling evaporation of paste tailings from the Bulyanhulu mine, Journal of Canadian Geotechnical, 44: 1417 - 1432

Sudhakar M., and Shivananda, R.P. 2005. Role of osmotic suction in swelling of salt amended clays. Canadian Journal of Geotechnical, 42: $307-315$.

Tailings.info, [online]. Available from http://www.tailings.info/containment.htm. [accessed July 2009].

Terra S., Joe O., and Simon D. 2009. Tailings plan review, The Pembina Institute and Water matters, Alberta, Canada.

Thamer, A. et al. 2006. Relationship between shear strength and soil water characteristic curve of an unsaturated granitic residual soil. American Journal of Environmental Sciences 2 (4): 142-145.

Theriault, J.A., Frostiak, J., and Welch, D. 2003. Surface disposal of past tailings at the Bulyanhulu gold mine, Tanzania. In proceeding of Sudbery 2003. Mining and the environment, Sudbery, Ontario, 26-28 May. (G. Spiers, P. Beckett and H. Conroy, eds.) laturentian University centre for Continuing Education, Sudbery, On. Pp. $265-269$ 
Tindall, J.A., and Kunkel, J.R. 1999. Unsaturated zone hydrology, New Jersey, Prentice Hall.

United Nations Environment Program (UNEP) 2007. Avoiding tailings dam failures, Good practice in prevention. Workshop on the safety of tailings management facilities, Armenia

U.S. National research Council (USNRC), 1994. Drilling and excavation technologies for the future, National Academy Press, Washington, D.C.

Vanapalli, S.K., Pufahl, D.E., Fredlund, D.G., 1999. The influence of soil structure and stress history on the soil-water characteristic of a compacted till. Geotechnique, 49(2):143-159.

Vick, S.G. 1990. Planning, Design and Analysis of Tailings Dams. BiTech Publishers, Limited, Vancouver, British Columbia, Canada.

Volpe, R.L. 1979. Physical and Engineering Properties of Copper Tailings, in Current geotechniall practice in mine waste disposal, ASCE, NY, pp. 242-260

Welch, D.E. 2003. High density thickened tailings storage, [online]. Available from http://www.tailings.info/disposal/thickened.htm

Wilson, G.W., Fredlund, D.G., Barbour, S.L., 1997. The effect of soil suction on evaporative fluxes from soil surfaces [online]. Canadian Geotechnical Journal, 34: 145-155. Available from http://article.pubs.nrc-cnrc.gc.ca/ppv/RPViewDoc? iss $\mathrm{n}=1208-6010$ \&volume $=34 \&$ issue $=1$ \&startPage $=145$

Yanful, E.K. 2007. Erosion characteristics and resuspension of sub-aqueous mine tailings [online]. Canadian Environmental Engineering Science Journal, 6: 175-190. doi: $10.1139 / \mathrm{S} 06-040$ 
Yang, H., Rahardjo, H., Leong, E.C., and Fredlund, D.G. 2004. Factors affecting drying and wetting soil-water characteristic curves of sandy soils, [online], Canadian Geotechnical Journal, 41(5): 908-920, doi: 10.1139/t04-042.

Yasuda, Naoki. 2006. Hydraulic performance of the seepage collection ditches at the Albian sand Muskeg river mine. M.A.Sc. thesis, Waterloo University, Waterloo, Canada

Yilmaz, E., Kesimal, A., and Ercikdi, B. 2004. Evaluation of acid producing sulphidic mine tailings as a paste backfill. Istanbul University. Muh. Fak. Yerbilimleri Dergisi. 17: 11-19

Zhou, J. et al., 2005. Influences affecting the soil - water characteristic curve [online].

Zhejiang university Science journal, 6A(8): 797-804. Available from http://www. Zju.edu.cn/jzus/2005/A0508/A050804.pdf. 


\section{Appendix-A:}

\section{More information for experimental tests results}


Table A5-1: Standard proctor compaction test for artificial silt

\begin{tabular}{|c|c|c|c|c|c|c|}
\hline \multirow[t]{2}{*}{ Description } & \multicolumn{6}{|c|}{ Test number } \\
\hline & 1 & 2 & 3 & 4 & 5 & 6 \\
\hline $\begin{array}{l}\text { Weight of proctor mold and base+ Compact } \\
\text { soil(g) }\end{array}$ & 5579.5 & 5640.9 & 5682.5 & 5729.0 & 5776.2 & 5758.2 \\
\hline Weight of soil moisture container (g) & 2.0 & 2.0 & 2.1 & 2.0 & 2.1 & 2.0 \\
\hline Weight of container + moist soil (g) & 26.5 & 16.2 & 23.6 & 13.1 & 13.7 & 17.3 \\
\hline Weight of container + dry soil (B) & 25.5 & 15.4 & 22.1 & 12.1 & 12.4 & 15.4 \\
\hline Weight of dry soil (g) & 23.5 & 13.4 & 20.0 & 10.1 & 10.3 & 13.4 \\
\hline Weight of water (g) & 1.0 & 0.8 & 1.5 & 1.0 & 1.3 & 1.9 \\
\hline Bulk unit weight $(\mathrm{kN} / \mathrm{m} 3)$ & 14.5 & 15.1 & 15.6 & 16.1 & 16.5 & 16.4 \\
\hline Moisture content (\%) & 4.3 & 6.0 & 7.5 & 9.9 & 12.6 & 14.2 \\
\hline Dry unit weight of soil (kN/m3) & 13.9 & 14.3 & 14.5 & 14.6 & 14.7 & 14.3 \\
\hline Inside volume of the mold = & 943.9 & $\mathrm{~cm} 3$ & & & & \\
\hline Weight of proctor mold and base $=$ & 4183.1 & 8 & & & & \\
\hline Weight of Compact soil (g) & 1396.4 & 1457.8 & 1499.4 & 1545.9 & 1593.1 & 1575.1 \\
\hline Weight of dry Compact soil (g) & 1339.4 & 1375.7 & 1394.8 & 1406.6 & 1414.6 & 1379.5 \\
\hline Volume of dry compact soil $(\mathrm{Cm} 3)$ & 540.1 & 554.7 & 562.4 & 567.2 & 570.4 & 556.2 \\
\hline Volume of void $(\mathrm{Cm} 3)$ & 403.8 & 389.2 & 381.5 & 376.7 & 373.5 & 387.7 \\
\hline Void ratio & 0.75 & 0.70 & 0.68 & 0.66 & 0.65 & 0.70 \\
\hline
\end{tabular}


Table A5-2: Effect of suction on saturation for silt, $w_{i}=35.3 \%$, before settling

\begin{tabular}{|c|c|c|c|c|c|}
\hline Suction & $\begin{array}{c}\text { Total } \\
\text { volume } \\
(\mathrm{Cm} 3)\end{array}$ & $\begin{array}{c}\text { Volume of } \\
\text { void } \\
(\mathrm{Cm} \mathrm{3})\end{array}$ & $\begin{array}{c}\text { Vold } \\
\text { ratio }\end{array}$ & $\begin{array}{c}\text { Volume of } \\
\text { Water } \\
(\mathrm{Cm} \mathrm{3})\end{array}$ & Saturation \\
\hline 0 & 554.1 & 258.6 & 0.88 & 258.6 & 100.0 \\
\hline 20 & 514.0 & 218.5 & 0.74 & 162.2 & 74.2 \\
\hline 30 & 474.8 & 179.3 & 0.62 & 126.6 & 70.6 \\
\hline 40 & 461.7 & 166.2 & 0.56 & 69.8 & 42.0 \\
\hline 50 & 461.7 & 166.2 & 0.56 & 43.8 & 26.4 \\
\hline 60 & 461.7 & 166.2 & 0.56 & 34.3 & 20.6 \\
\hline 70 & 461.7 & 166.2 & 0.56 & 22.6 & 13.6 \\
\hline 100 & 461.7 & 166.2 & 0.56 & 5.5 & 3.3 \\
\hline
\end{tabular}

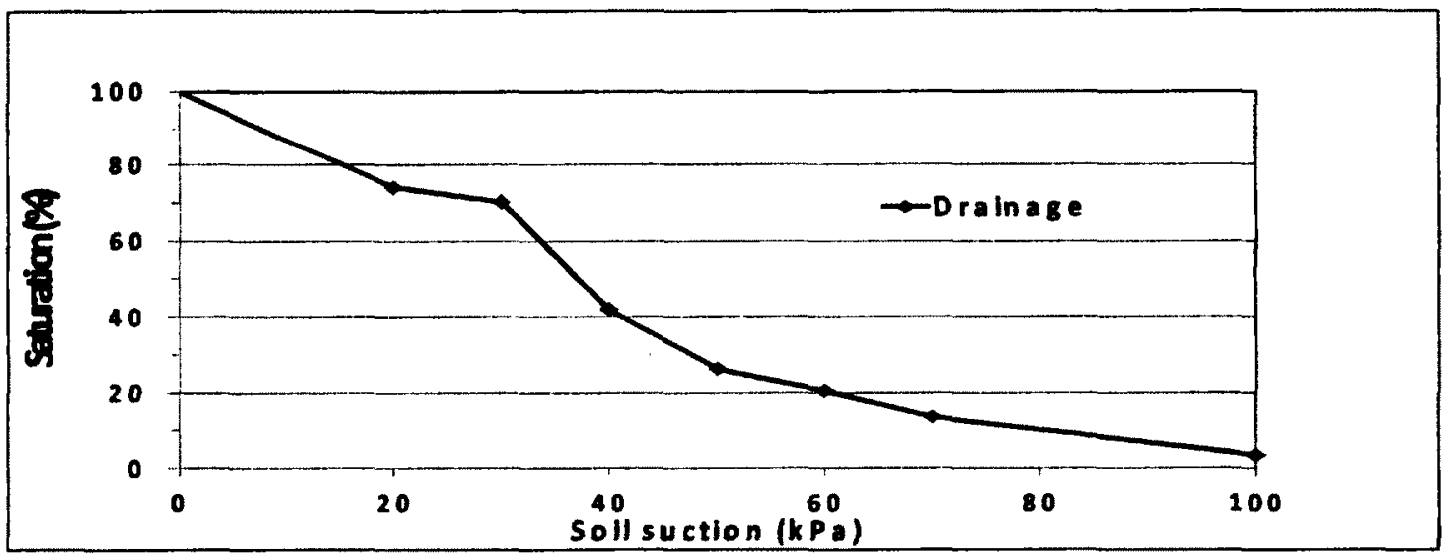

Figure 5-1: Saturation-suction curve for silt, $\mathrm{w}_{\mathrm{i}}=35.3 \%$, before settling

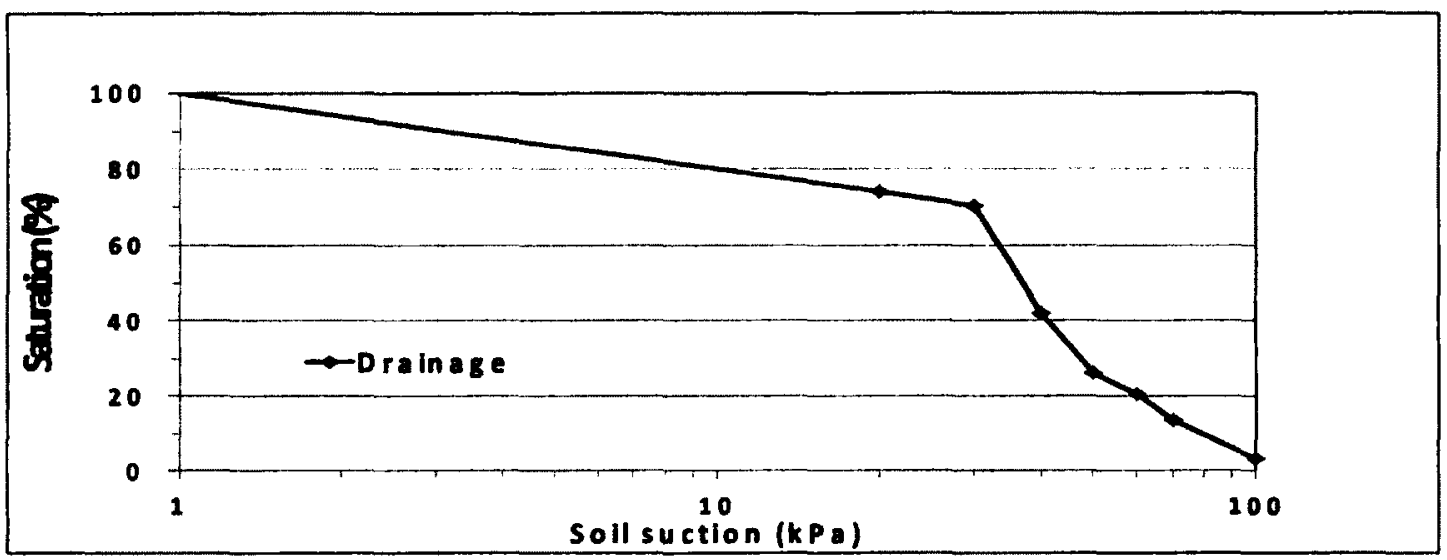

Figure 5-2: Saturation-suction curve for silt, $\mathrm{w}_{\mathrm{i}}=35.3 \%$, before settling, log scale 


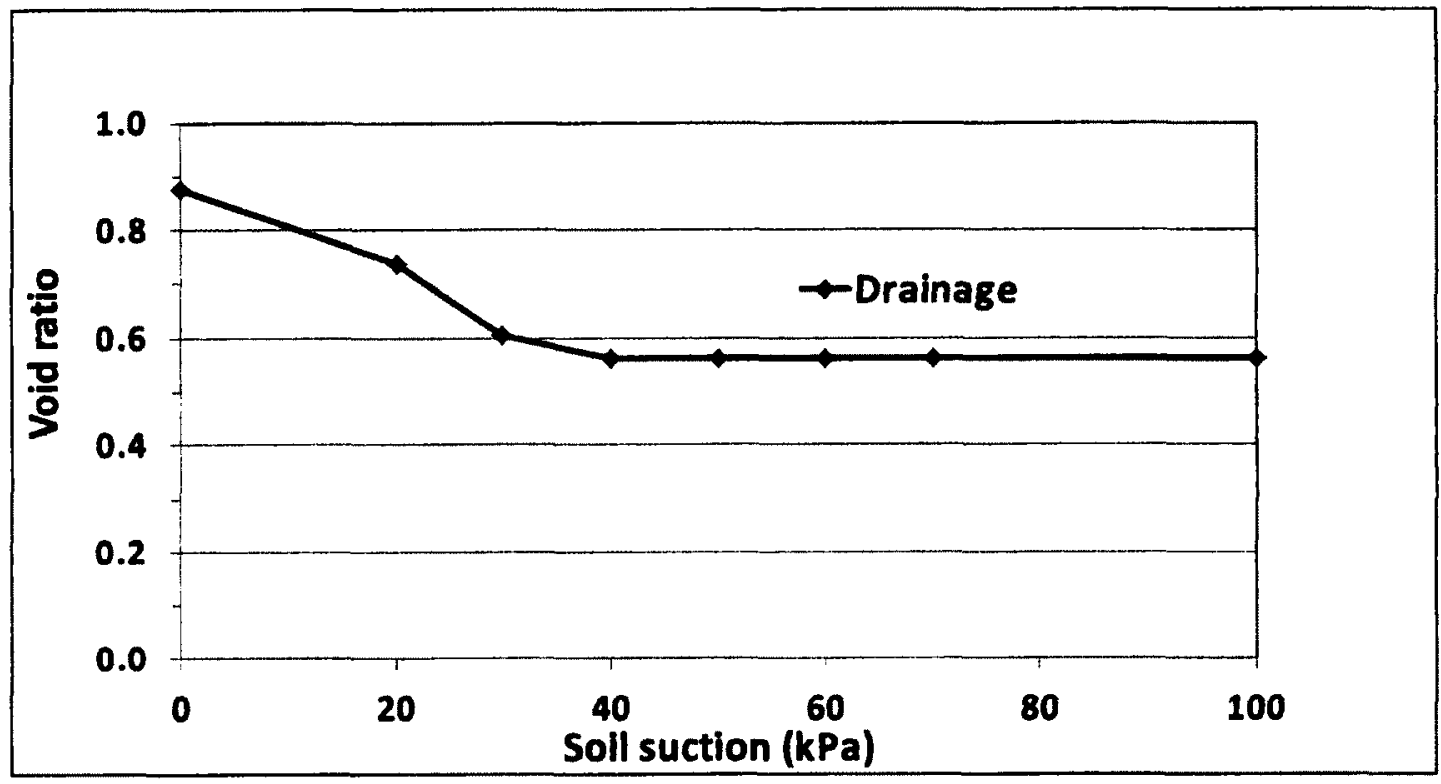

Figure A5-3: Void ratio-suction curve for silt, $w_{i}=35.3 \%$, before settling

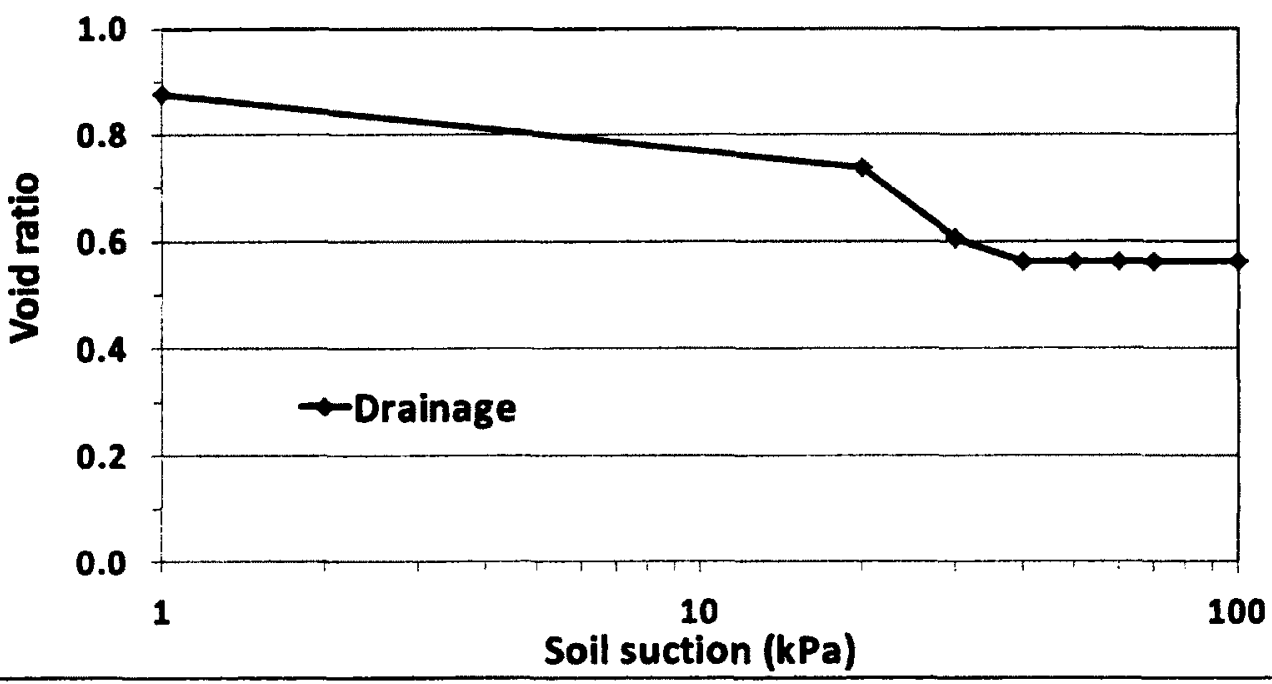

Figure A5-4: Void ratio-suction curve for silt, $\mathrm{w}_{\mathrm{i}}=35.3 \%$, before settling, log scale 


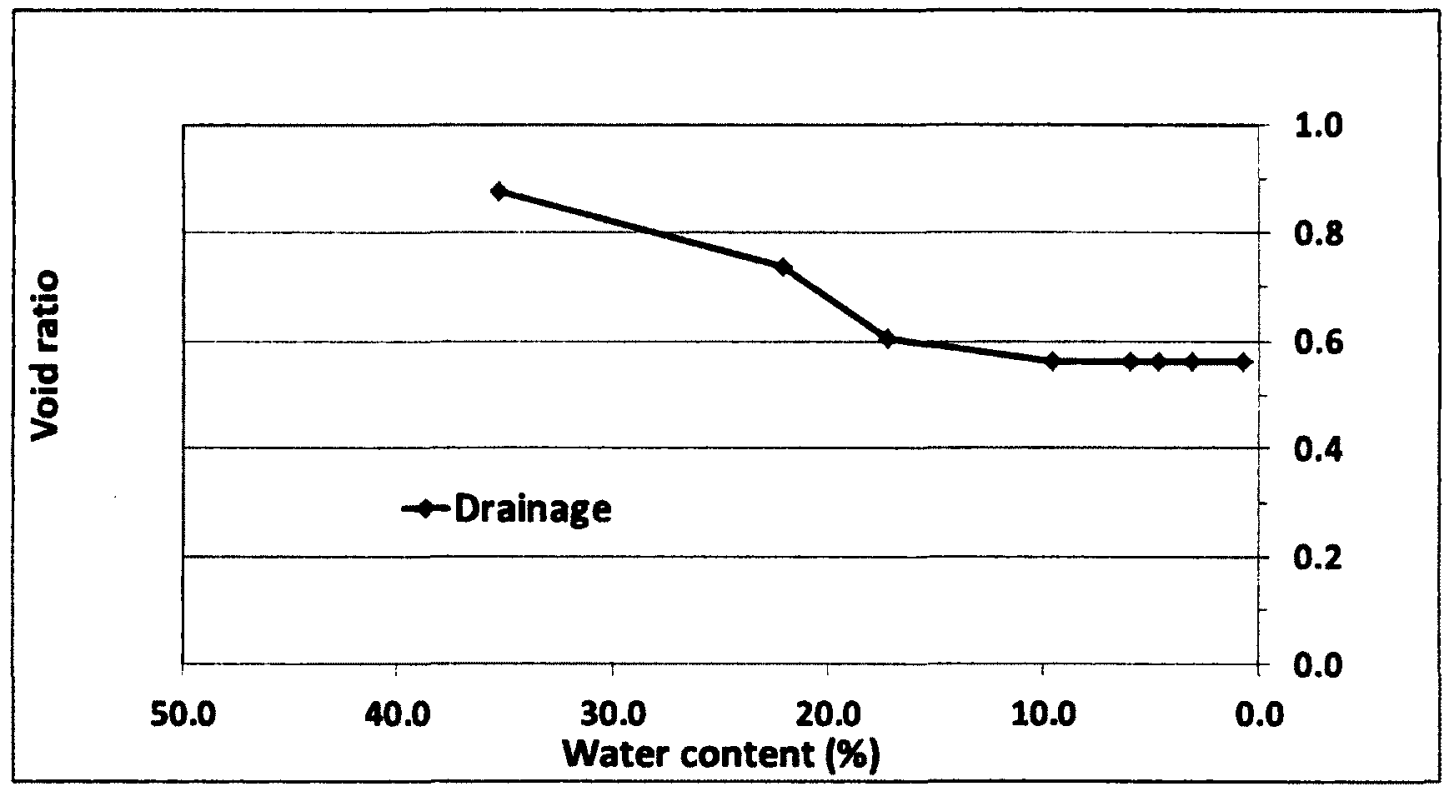

Figure A5-5: Shrinkage curve for silt, $\mathrm{w}_{\mathrm{i}}=35.3 \%$, before settling

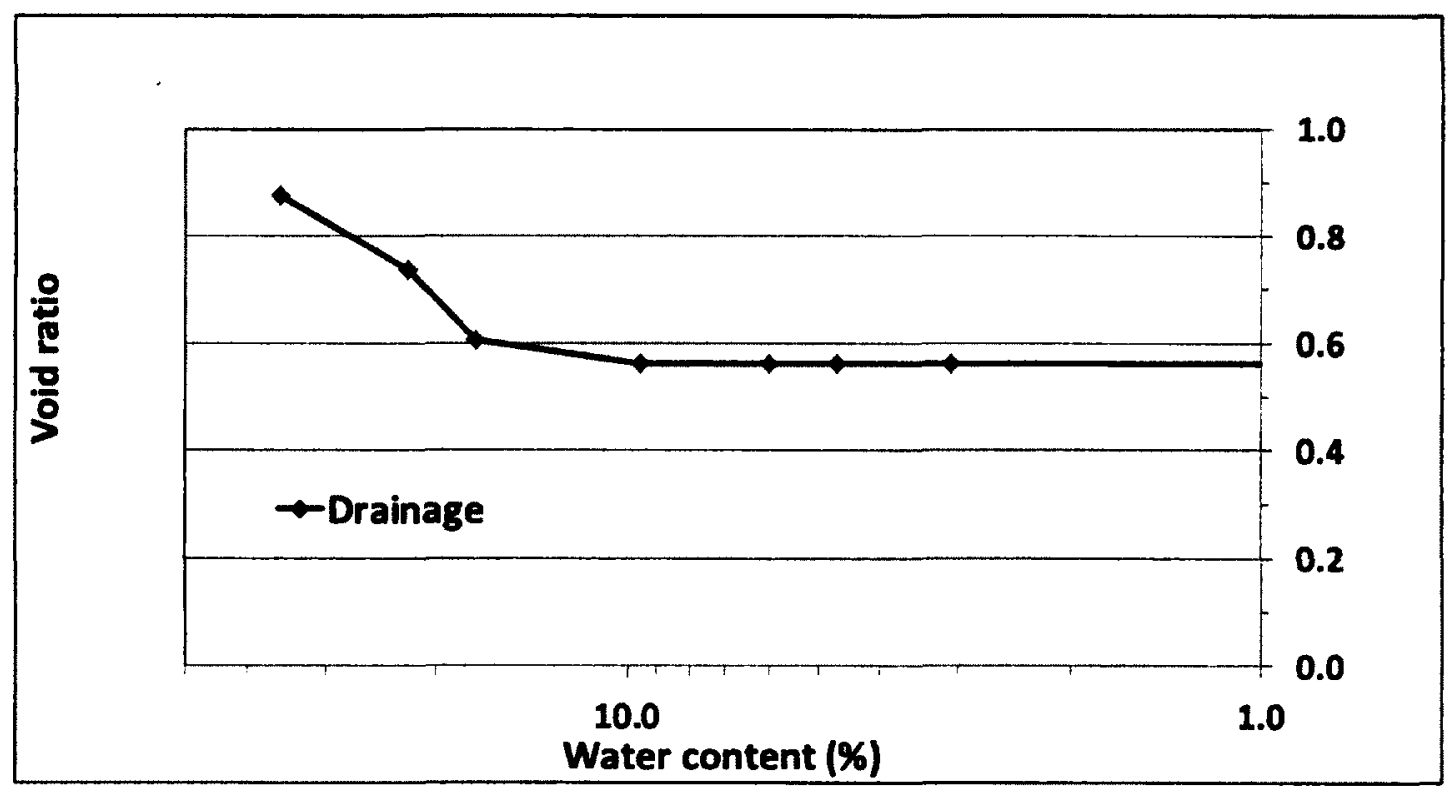

Figure A5-6: Shrinkage curve for silt, $w_{i}=35.3 \%$, before settling, log scale 


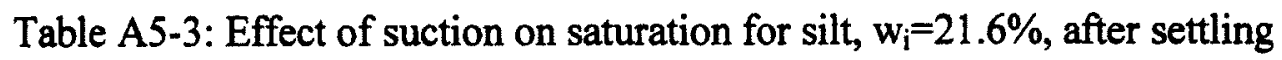

\begin{tabular}{|c|c|c|c|c|c|}
\hline Suction & $\begin{array}{c}\text { Total } \\
\text { volume } \\
(\mathrm{KPa})\end{array}$ & $\begin{array}{c}\text { Volume of } \\
\text { void } \\
(\mathrm{Cm})\end{array}$ & $\begin{array}{c}\text { Void } \\
\text { ratio }\end{array}$ & $\begin{array}{c}\text { Volume of } \\
\text { Water } \\
(\mathrm{Cm} 3)\end{array}$ & Saturation \\
\hline 0 & 312.7 & 109.1 & 0.54 & 109.1 & 100.0 \\
\hline 12 & 312.7 & 109.1 & 0.54 & 102.6 & 94.0 \\
\hline 20 & 312.7 & 109.1 & 0.54 & 84.8 & 77.7 \\
\hline 30 & 312.7 & 109.1 & 0.54 & 61.3 & 56.2 \\
\hline 38 & 312.7 & 109.1 & 0.54 & 53.0 & 48.6 \\
\hline 52 & 312.7 & 109.1 & 0.54 & 47.7 & 43.7 \\
\hline 60 & 312.7 & 109.1 & 0.54 & 43.7 & 40.0 \\
\hline 70 & 312.7 & 109.1 & 0.54 & 39.2 & 35.9 \\
\hline 80 & 312.7 & 109.1 & 0.54 & 28.4 & 26.0 \\
\hline 90 & 312.7 & 109.1 & 0.54 & 20.2 & 18.5 \\
\hline 100 & 312.7 & 109.1 & 0.54 & 9.7 & 8.9 \\
\hline
\end{tabular}

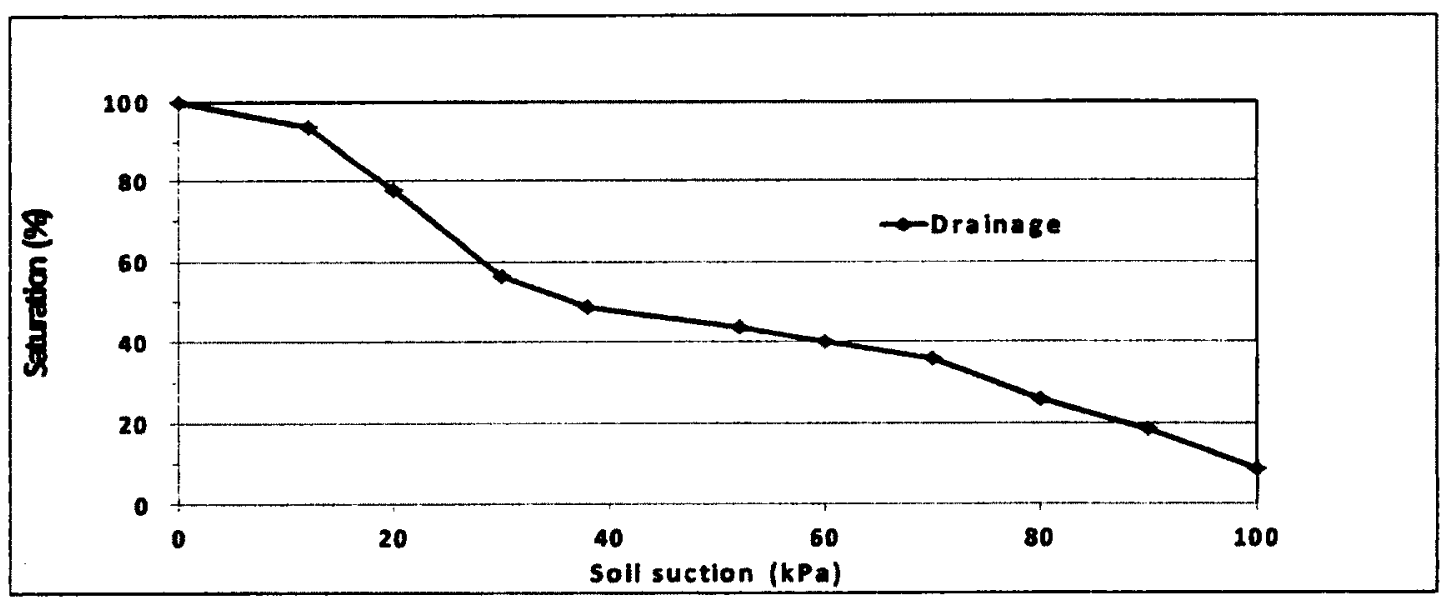

Figure A5-7: Saturation-suction curve for silt, $\mathrm{w}_{\mathrm{i}}=21.6 \%$, after settling

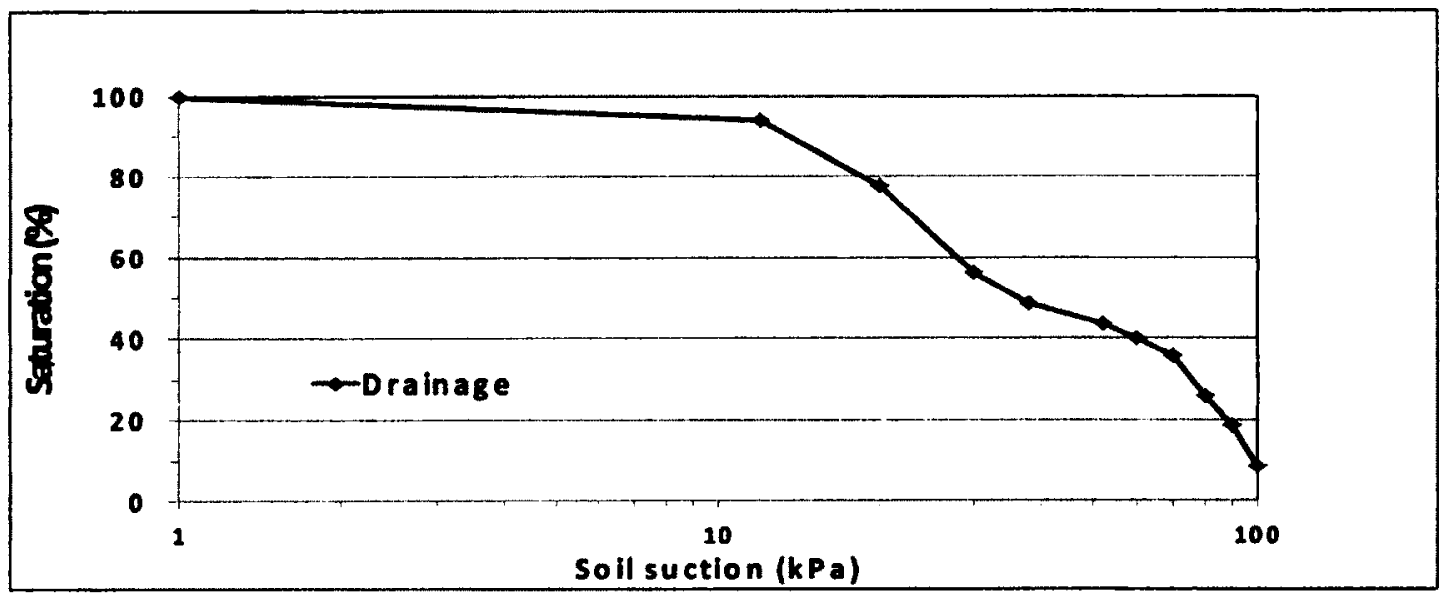

Figure A5-7: Saturation-suction curve for silt, $\mathrm{w}_{\mathrm{i}}=21.6 \%$, after settling, log scale 
Table A5-4: Effect of suction on saturation for silt, $\mathrm{w}_{\mathrm{i}}=26.1 \%$, after settling

\begin{tabular}{|c|c|c|c|c|c|}
\hline $\begin{array}{l}\text { Suction } \\
(k P \bullet)\end{array}$ & $\begin{array}{l}\text { Total } \\
\text { volume } \\
\text { (Cm 3) }\end{array}$ & $\begin{array}{c}\text { Volum of } \\
\text { vold } \\
(\mathrm{Cm} 3)\end{array}$ & $\begin{array}{l}\text { Vold } \\
\text { retio }\end{array}$ & $\begin{array}{c}\text { Volume of } \\
\text { Woter } \\
(\mathrm{Cm} 3)\end{array}$ & $\begin{array}{l}\text { Saturetion } \\
(x)\end{array}$ \\
\hline 0 & 391.6 & 153.7 & 0.65 & 153.7 & 200.0 \\
\hline 10 & 392.6 & 253.7 & 0.65 & 144.6 & 94.1 \\
\hline 17 & 391.6 & 153.7 & 0.65 & 137.8 & 89.7 \\
\hline 28 & 391.6 & 153.7 & 0.65 & 104.7 & 68.1 \\
\hline 38 & 392.6 & 153.7 & 0.65 & 45.9 & 29.9 \\
\hline 50 & 391.6 & 153.7 & 0.65 & 23.1 & 13.0 \\
\hline 40 & 391.6 & 153.7 & 0.65 & 23.2 & 15.0 \\
\hline 30 & 391.6 & 153.7 & 0.65 & 23.1 & 25.0 \\
\hline 12 & 391.6 & 253.7 & 0.65 & 31.0 & 20.2 \\
\hline 0 & 391.6 & 153.7 & 0.65 & 200.6 & 65.5 \\
\hline
\end{tabular}

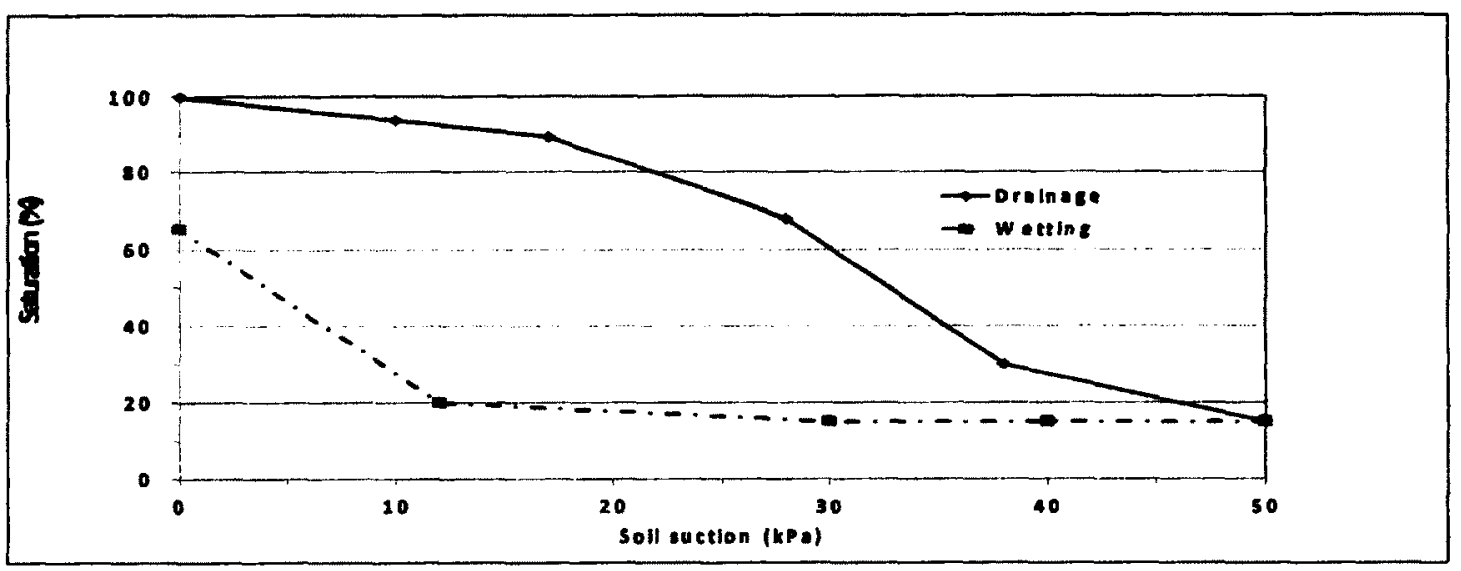

Figure A5-9: Saturation-suction curve for silt, $\mathrm{w}_{\mathrm{i}}=26.1 \%$, after settling

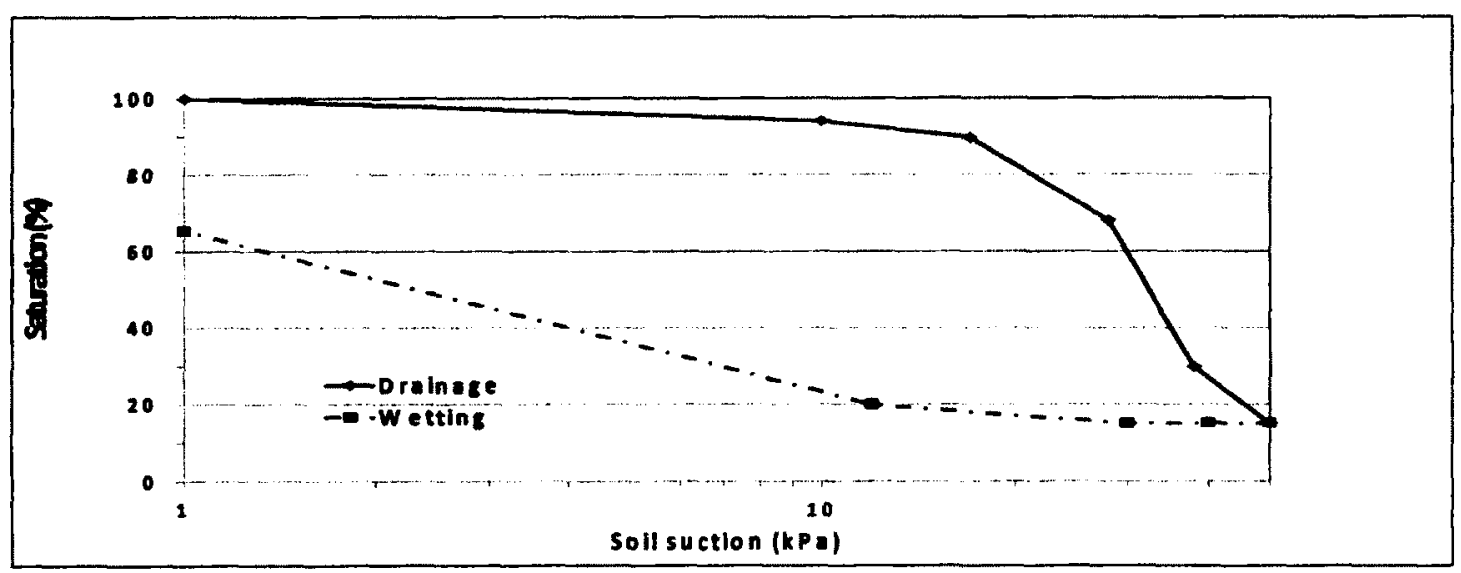

Figure A5-10: Saturation-suction curve for silt, $\mathrm{w}_{\mathrm{i}}=26.1 \%$, after settling, log scale 
Table A5-5: Effect of suction on saturation for silt, $w_{i}=24.7 \%$, after settling

\begin{tabular}{|c|c|c|c|c|c|}
\hline $\begin{array}{l}\text { Suction } \\
(K P=)\end{array}$ & $\begin{array}{l}\text { Total } \\
\text { volum } \\
\text { (Cm } 3)\end{array}$ & $\begin{array}{l}\text { Volum of } \\
\text { void } \\
\text { (cm } 3 \text { ) }\end{array}$ & $\begin{array}{l}\text { Vold } \\
\text { ratio }\end{array}$ & $\begin{array}{c}\text { volume of } \\
\text { weter } \\
(\mathrm{cm} 3)\end{array}$ & $\begin{array}{c}\text { soturation } \\
(*)\end{array}$ \\
\hline 0 & 130.0 & 49.4 & 0.61 & 49.4 & 100.0 \\
\hline 13 & 130.0 & 49.4 & 0.61 & 44.8 & 90.8 \\
\hline 20 & 130.0 & 49.4 & 0.61 & 36.7 & 74.4 \\
\hline 28 & 130.0 & 49.4 & 0.61 & 21.1 & 42.8 \\
\hline 36 & 130.0 & 49.4 & 0.61 & 5.9 & 12.0 \\
\hline 50 & 130.0 & 49.4 & 0.61 & 3.6 & 7.3 \\
\hline 38 & 130.0 & 49.4 & 0.61 & 3.6 & 7.3 \\
\hline 29 & 130.0 & 49.4 & 0.61 & 3.6 & 7.3 \\
\hline 20 & 130.0 & 49.4 & 0.61 & 6.0 & 12.2 \\
\hline 5 & 130.0 & 49.4 & 0.61 & 24.8 & 50.2 \\
\hline 0 & 130.0 & 49.4 & 0.61 & 41.7 & 84.5 \\
\hline
\end{tabular}

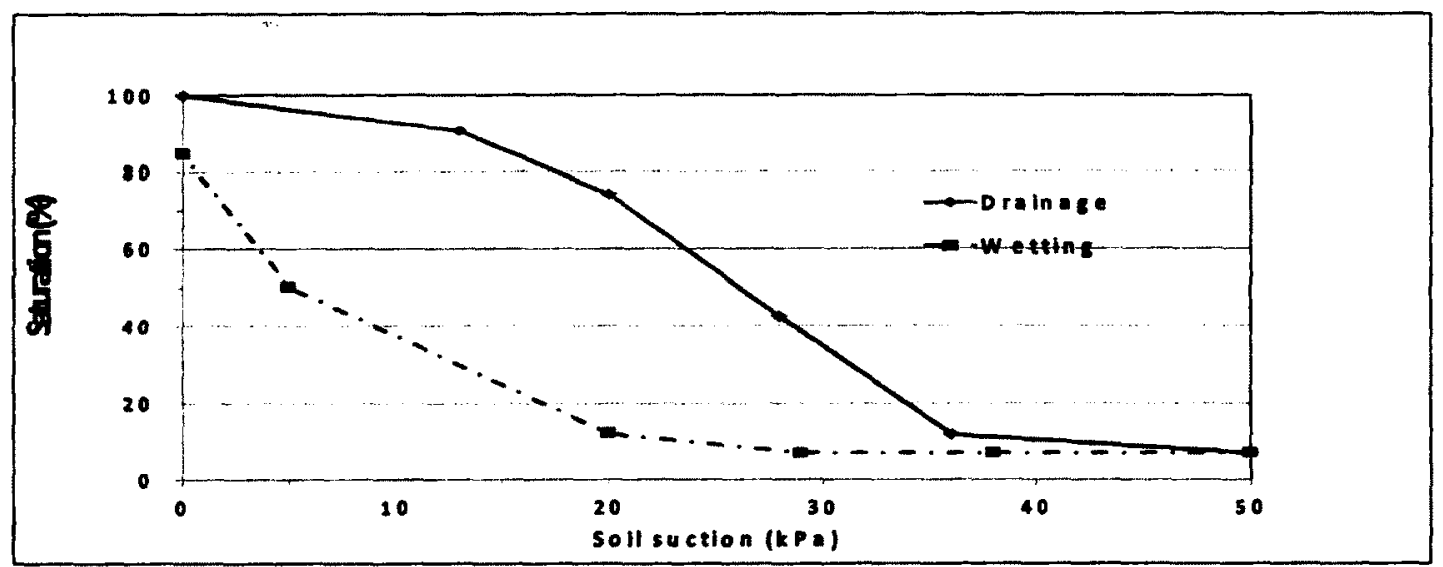

Figure A5-12: Saturation-suction curve for silt, $\mathrm{w}_{\mathrm{i}}=24.7 \%$, after settling

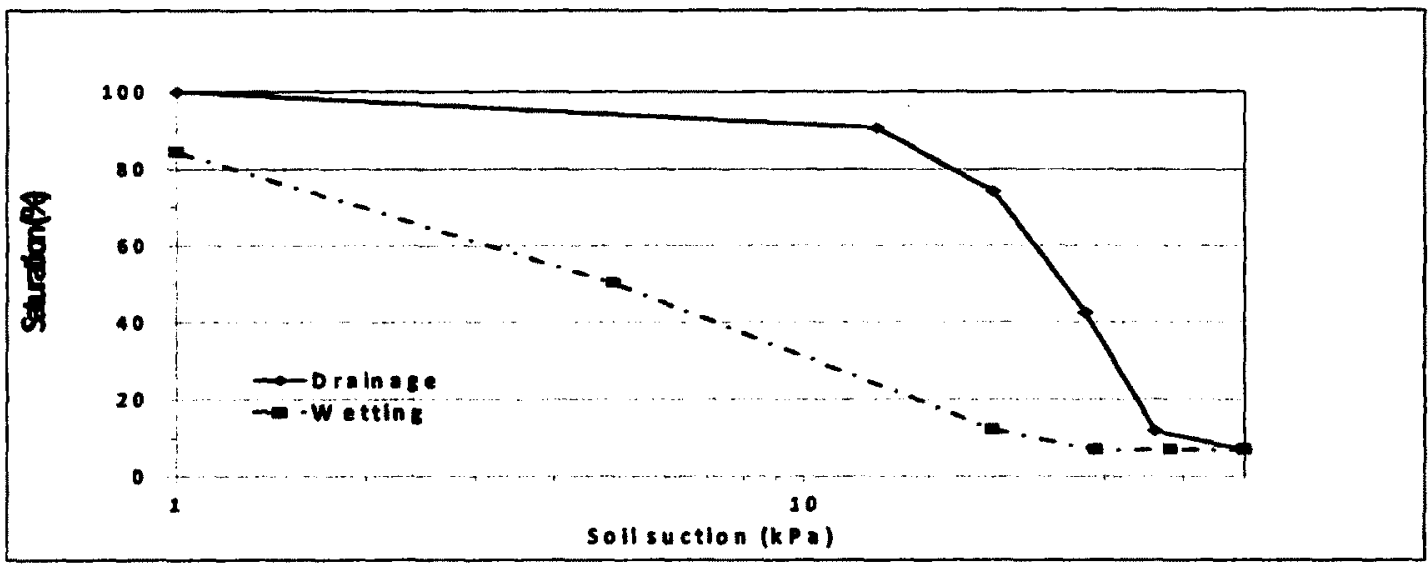

Figure A5-12: Saturation-suction curve for silt, $\mathrm{w}_{\mathrm{i}}=24.7 \%$, after settling, log scale 
Table A5-6: Effect of suction on water content for oil sand mine tailings, $w_{i}=127.1 \%$

\begin{tabular}{|c|c|c|c|c|c|c|c|c|c|c|c|c|c|}
\hline \multirow{2}{*}{$\begin{array}{l}\text { Sirtion } \\
\text { (PPa) }\end{array}$} & \multirow{2}{*}{$\begin{array}{c}\text { sol } \\
\text { uegitt } \\
\text { (d) }\end{array}$} & \multirow{2}{*}{$\begin{array}{l}\text { vets } \\
\text { uejt } \\
0\end{array}$} & \multirow{2}{*}{$\begin{array}{c}\text { mitial tota } \\
\text { uedt } \\
\text { (d) }\end{array}$} & \multirow{2}{*}{$\begin{array}{c}\text { firal totd } \\
\text { uegit } \\
\text { ge }\end{array}$} & \multirow{2}{*}{$\begin{array}{l}\text { wotes } \\
\text { at } \\
\text { g }\end{array}$} & \multirow{2}{*}{$\begin{array}{l}\text { veterin } \\
\text { theunit } \\
\text { (O) }\end{array}$} & \multirow{2}{*}{$\begin{array}{c}\text { Whter } \\
\text { cortert } \\
\text { (PA) }\end{array}$} & \multicolumn{2}{|c|}{ intid soils } & \multicolumn{2}{|c|}{ find sois } & \multicolumn{2}{|c|}{ dargeinsols } \\
\hline & & & & & & & & $\begin{array}{l}\text { heigt } \\
\text { (m) }\end{array}$ & $\begin{array}{l}\text { volume } \\
\text { (oris) }\end{array}$ & $\begin{array}{l}\text { hidt } \\
(\mathrm{m})\end{array}$ & $\begin{array}{l}\text { volume } \\
\text { (cmis) }\end{array}$ & $\begin{array}{l}\text { heidt } \\
\text { (m) }\end{array}$ & $\begin{array}{c}\text { volume } \\
\text { BA }\end{array}$ \\
\hline 0 & b & 21 & 73 & 923 & uv & 821 & $2 / .1$ & III & D/3 & 117 & 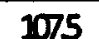 & 00 & 00 \\
\hline 0 & 646 & 821 & 10203 & 10093 & 00 & 821 & 10.1 & 117 & 1075 & 117 & 1075 & 00 & $\infty$ \\
\hline 20 & 646 & 821 & 10093 & 10639 & 54 & 768 & 1188 & 117 & 1075 & 115 & $10 \mathrm{~B} 4$ & 02 & 38 \\
\hline 50 & 646 & 768 & 10639 & 10033 & 106 & 661 & 1004 & 115 & 1084 & 110 & 942 & 05 & 89 \\
\hline 100 & 646 & 661 & 10083 & 10860 & 173 & 489 & 756 & 110 & 942 & 100 & 801 & 10 & 149 \\
\hline 200 & 646 & 489 & 10860 & 10129 & 231 & 258 & 399 & 100 & 801 & 87 & 662 & 13 & $17 A$ \\
\hline 400 & 646 & 258 & 10129 & 1006 & 23 & 235 & 363 & 87 & 662 & 85 & 641 & 02 & 31 \\
\hline 500 & 646 & 235 & 1006 & 10021 & 15 & 219 & 340 & 85 & 641 & 85 & 628 & 00 & 20 \\
\hline 800 & 646 & 219 & 1001 & 1007.7 & 14 & 206 & 318 & 85 & 28 & 85 & 28 & 00 & $\infty$ \\
\hline 500 & 646 & 206 & 1007.7 & 1007.7 & $\infty$ & 206 & 318 & 85 & 68 & 85 & 28 & 00 & $\infty$ \\
\hline 300 & 646 & 206 & 1007.7 & 1000.7 & $\infty$ & 206 & 318 & 85 & 28 & 85 & $\underline{28}$ & 00 & $\infty$ \\
\hline 200 & 646 & 206 & 1007.7 & 1000.7 & $\infty$ & 206 & 318 & 85 & 28 & 85 & 28 & 00 & $\infty$ \\
\hline 100 & 646 & 206 & 1007.7 & 10078 & $-a 1$ & 206 & 319 & 85 & 28 & 85 & 628 & 00 & 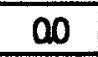 \\
\hline 50 & 646 & 206 & 10078 & 10080 & 02 & 208 & 322 & 85 & 628 & 85 & 28 & 00 & $\infty$ \\
\hline $\mathbf{2 1}$ & 646 & 208 & 10080 & 10083 & 03 & 211 & 327 & 85 & 628 & 85 & 628 & 00 & 00 \\
\hline 0 & 646 & 21 & 10083 & $1 \mathrm{~m}_{12}$ & -29 & 240 & 372 & 85 & 628 & 85 & 628 & $\infty$ & $\infty$ \\
\hline
\end{tabular}

Table A5-7: Effect of suction on saturation for oil sand mine tailings, $w_{i}=127.1 \%$

\begin{tabular}{|c|c|c|c|c|c|}
\hline Suction & $\begin{array}{c}\text { Total } \\
\text { volume } \\
(\mathrm{kPa})\end{array}$ & $\begin{array}{c}\text { Volume of } \\
\text { void } \\
(\mathrm{Cm} 3)\end{array}$ & $\begin{array}{c}\text { Void } \\
\text { ratio }\end{array}$ & $\begin{array}{c}\text { Volume of } \\
\text { Water } \\
(\mathrm{Cm} 3)\end{array}$ & Saturation \\
\hline 0 & 107.5 & 82.1 & 3.24 & 82.1 & 100.0 \\
\hline 0 & 107.5 & 82.1 & 3.24 & 82.1 & 100.0 \\
\hline 20 & 103.4 & 78.1 & 3.08 & 76.8 & 98.3 \\
\hline 50 & 94.2 & 68.8 & 2.72 & 66.1 & 96.1 \\
\hline 100 & 80.1 & 54.8 & 2.16 & 48.9 & 89.2 \\
\hline 200 & 66.2 & 40.8 & 1.61 & 25.8 & 63.1 \\
\hline 400 & 64.1 & 38.8 & 1.53 & 23.5 & 60.5 \\
\hline 500 & 62.8 & 37.5 & 1.48 & 21.9 & 58.5 \\
\hline 800 & 62.8 & 37.5 & 1.48 & 20.6 & 54.9 \\
\hline 500 & 62.8 & 37.5 & 1.48 & 20.6 & 54.9 \\
\hline 380 & 62.8 & 37.5 & 1.48 & 20.6 & 54.9 \\
\hline 200 & 62.8 & 37.5 & 1.48 & 20.6 & 54.9 \\
\hline 100 & 62.8 & 37.5 & 1.48 & 20.6 & 55.1 \\
\hline 50 & 62.8 & 37.5 & 1.48 & 20.8 & 55.5 \\
\hline 21 & 62.8 & 37.5 & 1.48 & 21.1 & 56.3 \\
\hline 0 & 62.8 & 37.5 & 1.48 & 24.0 & 64.0 \\
\hline & & & & & \\
\hline
\end{tabular}


Table A5-8: Effect of suction on water content for oil sand mine tailings, $\mathrm{w}_{\mathrm{i}}=131.2 \%$

\begin{tabular}{|c|c|c|c|c|c|c|c|c|c|c|c|c|c|}
\hline \multirow{2}{*}{$\begin{array}{c}\text { Suction } \\
(\mathrm{NPa})\end{array}$} & \multirow{2}{*}{$\begin{array}{c}\text { soil } \\
\text { neigtt } \\
\text { (g) }\end{array}$} & \multirow{2}{*}{$\begin{array}{c}\text { weter } \\
\text { weigtt } \\
\text { (g) }\end{array}$} & \multirow{2}{*}{$\begin{array}{l}\text { ritial total } \\
\text { ueigtt } \\
\text { (g) }\end{array}$} & \multirow{2}{*}{$\begin{array}{l}\text { final total } \\
\text { neigtt } \\
\text { (d) }\end{array}$} & \multirow{2}{*}{$\begin{array}{l}\text { ueter } \\
\text { at } \\
\text { (g) }\end{array}$} & \multirow{2}{*}{$\begin{array}{c}\text { vaterin } \\
\text { theunit } \\
(\mathrm{g})\end{array}$} & \multirow{2}{*}{$\begin{array}{c}\text { Whter } \\
\text { contert } \\
199\end{array}$} & \multicolumn{2}{|c|}{ initial soils } & \multicolumn{2}{|c|}{ find soils } & \multicolumn{2}{|c|}{ drengeinsails } \\
\hline & & & & & & & & $\begin{array}{l}\text { heigtt } \\
(\mathrm{mm})\end{array}$ & $\begin{array}{c}\text { vdiume } \\
(\mathrm{am} B)\end{array}$ & $\begin{array}{l}\text { hegitt } \\
(\mathrm{mm})\end{array}$ & $\begin{array}{c}\text { volume } \\
\text { (ams) }\end{array}$ & $\begin{array}{l}\text { hedt } \\
(\mathrm{mm})\end{array}$ & $\begin{array}{c}\text { volume } \\
(89)\end{array}$ \\
\hline 0 & 1260 & 165 & 36370 & 3587.0 & 00 & 163 & 1312 & 17.1 & 2147 & 17.1 & 2147 & 00 & 00 \\
\hline 0 & 1260 & $11 \mathbf{3} 3$ & 36870 & 36273 & 97 & 1556 & 1235 & 17.1 & 2247 & 164 & 2050 & a.7 & 45 \\
\hline 24 & 1260 & 1556 & 30273 & 3508.5 & 338 & 1218 & 967 & 164 & 2050 & 150 & 1765 & 14 & 139 \\
\hline 52 & 1260 & 1218 & 3985 & 3527.2 & 663 & 555 & 440 & 150 & 1765 & 134 & 1466 & 16 & 170 \\
\hline 105 & 1260 & 555 & 35272 & 3502 & 7.0 & 485 & 385 & 134 & 146.6 & 127 & 1385 & 0.7 & 55 \\
\hline 211 & 1260 & 485 & 35202 & 35158 & 44 & 441 & 350 & 127 & 1385 & 123 & 1324 & Q.4 & 44 \\
\hline 402 & 1260 & 441 & 35158 & 35114 & 44 & 397 & 315 & 123 & 1324 & 120 & 1282 & Q3 & 3.1 \\
\hline 510 & 1260 & 39.7 & 35114 & 35107 & 07 & 390 & 310 & 120 & 1282 & 120 & 127.7 & ao & 04 \\
\hline 415 & 1260 & 39.0 & 35107 & 3510.7 & 00 & 390 & 310 & 120 & 127.7 & 120 & 127.7 & 00 & 90 \\
\hline 200 & 1260 & 390 & 35107 & 35107 & 00 & 390 & 310 & 120 & 127.7 & 120 & 127.7 & 00 & 00 \\
\hline 105 & 1260 & 390 & 35107 & 35117 & -10 & 400 & 317 & 120 & 127.7 & 120 & 127.7 & 00 & $\infty$ \\
\hline 55 & 1260 & 400 & 35117 & 3513.2 & -15 & 415 & 329 & 120 & 127.7 & 120 & 127.7 & $a 0$ & 00 \\
\hline 24 & 1260 & 41.5 & 35132 & 3517.1 & -39 & 454 & 360 & 120 & 127.7 & 120 & 127.7 & Q0 & $\infty 0$ \\
\hline 0 & 1260 & 454 & 3517.1 & 3527.8 & -107 & 561 & 445 & 120 & 127.7 & 120 & 127.7 & 00 & 00 \\
\hline
\end{tabular}

Table A5-9: Effect of suction on saturation for oil sand mine tailings, $w_{i}=131.2 \%$

\begin{tabular}{|c|c|c|c|c|c|}
\hline Suction & $\begin{array}{c}\text { Total } \\
\text { volume } \\
(\mathrm{KPa})\end{array}$ & $\begin{array}{c}\text { Volume of } \\
\text { void } \\
(\mathrm{Cm} 3)\end{array}$ & $\begin{array}{c}\text { Void } \\
\text { ratio }\end{array}$ & $\begin{array}{c}\text { Volume of } \\
\text { Water } \\
(\mathrm{Cm} 3)\end{array}$ & Saturation \\
\hline & & $\%)$ & \\
\hline 0 & 214.7 & 165.3 & 3.34 & 165.3 & 100.0 \\
\hline 0 & 205.0 & 155.6 & 3.15 & 155.6 & 100.0 \\
\hline 24 & 176.5 & 127.1 & 2.57 & 121.8 & 95.8 \\
\hline 52 & 146.6 & 97.1 & 1.97 & 55.5 & 57.1 \\
\hline 105 & 138.5 & 89.1 & 1.80 & 48.5 & 54.4 \\
\hline 211 & 132.4 & 83.0 & 1.68 & 44.1 & 53.2 \\
\hline 402 & 128.2 & 78.8 & 1.60 & 39.7 & 50.4 \\
\hline 510 & 127.7 & 78.3 & 1.59 & 39.0 & 49.8 \\
\hline 415 & 127.7 & 78.3 & 1.59 & 39.0 & 49.8 \\
\hline 220 & 127.7 & 78.3 & 1.59 & 39.0 & 49.8 \\
\hline 105 & 127.7 & 78.3 & 1.59 & 40.0 & 51.1 \\
\hline 55 & 127.7 & 78.3 & 1.59 & 41.5 & 53.0 \\
\hline 24 & 127.7 & 78.3 & 1.59 & 45.4 & 58.0 \\
\hline 0 & 127.7 & 78.3 & 1.59 & 56.1 & 71.6 \\
\hline
\end{tabular}




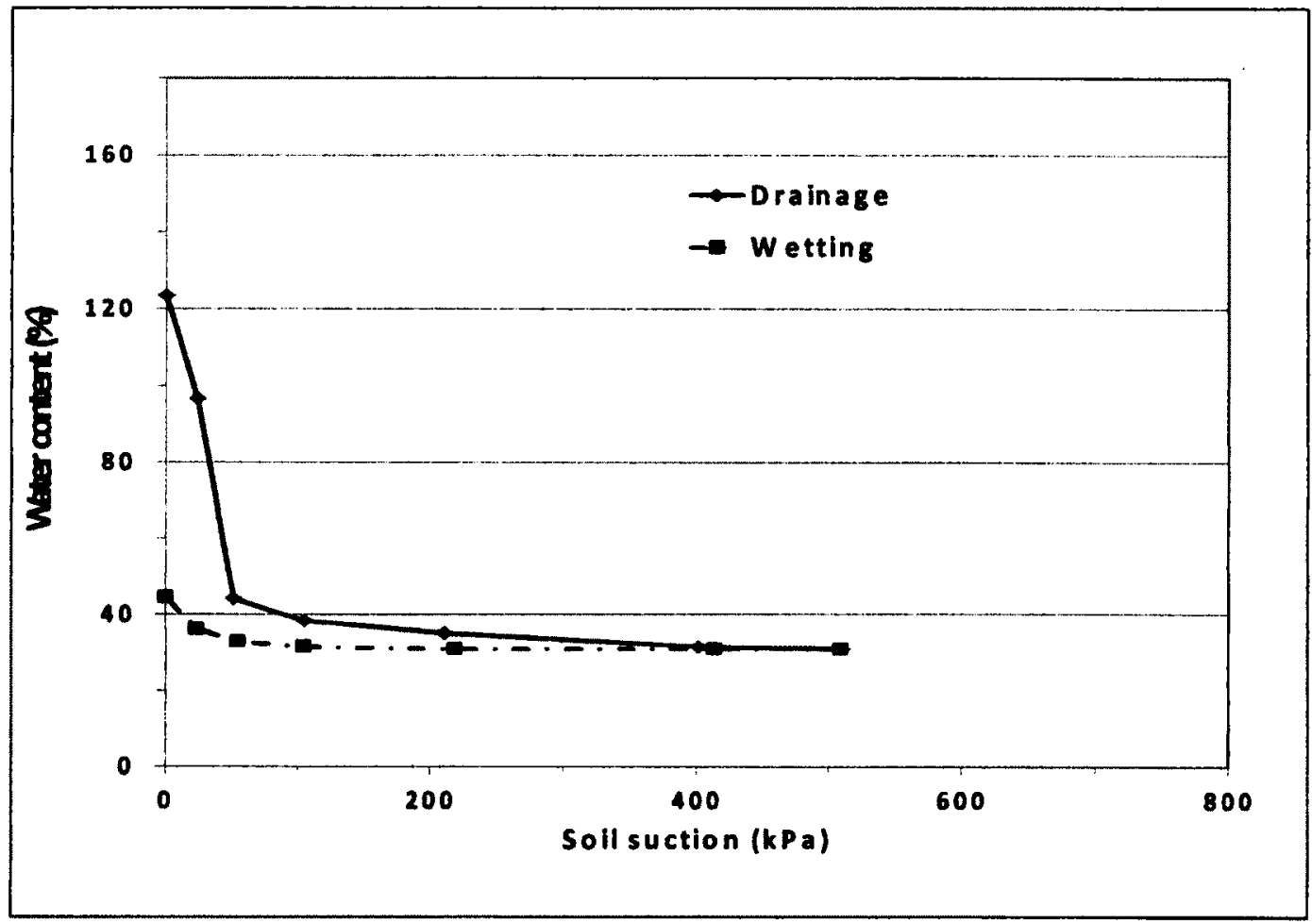

Figure A5-13: Water content-suction curve for oil sand tailings, $w_{i}=131.2 \%$

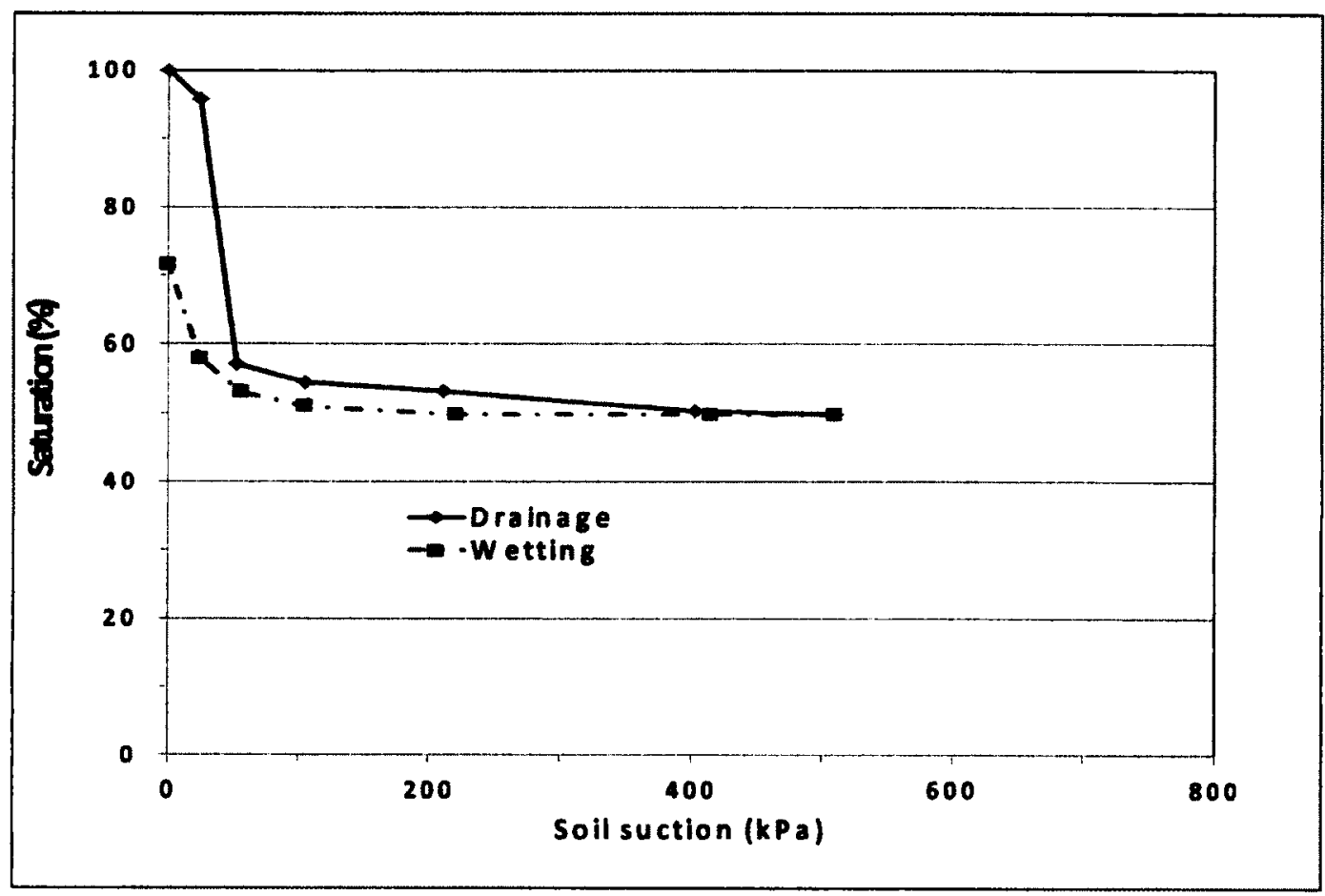

Figure A5-14: Saturation-suction curve for oil sand tailings, $w_{\mathrm{i}}=131.2 \%$ 


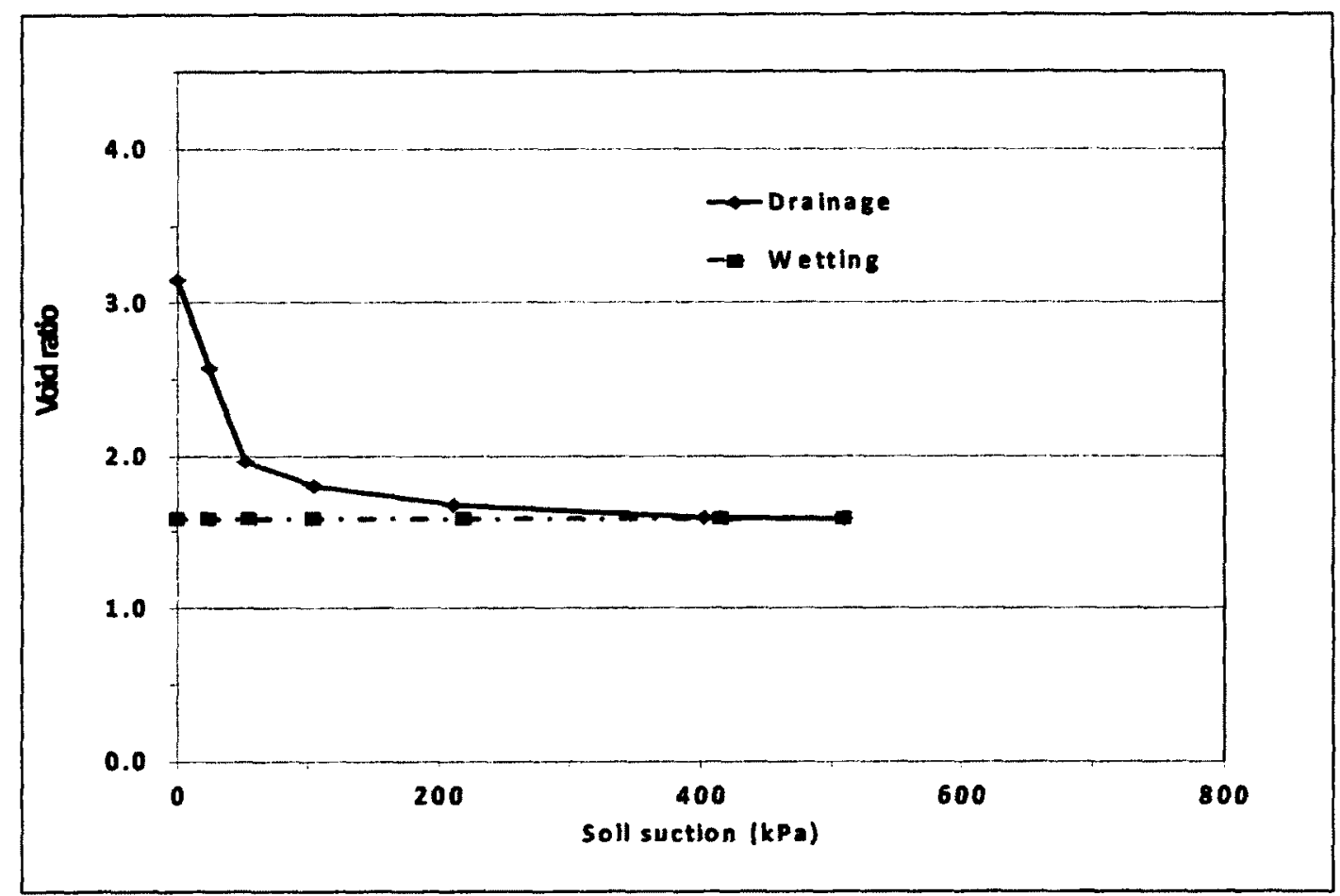

Figure A5-15: Void ratio-suction curve for oil sand tailings, $w_{i}=131.2 \%$

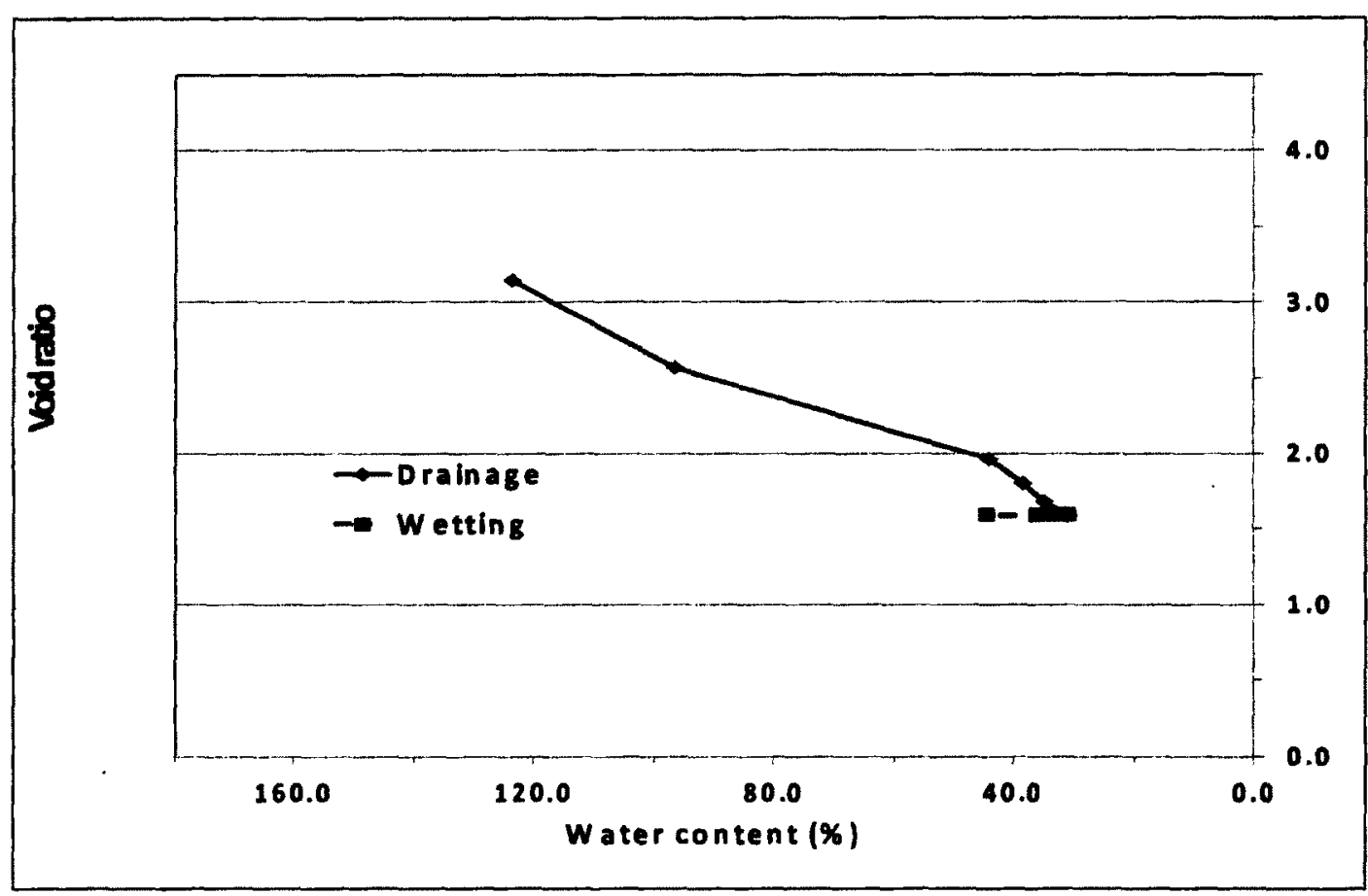

Figure A5-16: Shrinkage curve for oil sand tailings, $\mathrm{w}_{\mathrm{i}}=131.2 \%$ 
Table A5-10: Effect of suction on water content for oil sand mine tailings, $w_{i}=156.6 \%$

\begin{tabular}{|c|c|c|c|c|c|c|c|c|c|c|c|c|c|}
\hline \multirow{2}{*}{$\begin{array}{l}\text { Suction } \\
(\mathrm{kPa})\end{array}$} & \multirow{2}{*}{$\begin{array}{c}\text { soil } \\
\text { weight } \\
\text { (g) }\end{array}$} & \multirow{2}{*}{$\begin{array}{l}\text { water } \\
\text { weight } \\
\text { (g) }\end{array}$} & \multirow{2}{*}{$\begin{array}{c}\text { Initial total } \\
\text { weight } \\
\text { (g) }\end{array}$} & \multirow{2}{*}{$\begin{array}{c}\text { final total } \\
\text { weight } \\
(\mathrm{g})\end{array}$} & \multirow{2}{*}{$\begin{array}{l}\text { water } \\
\text { out } \\
\text { (g) }\end{array}$} & \multirow{2}{*}{$\begin{array}{c}\text { water in } \\
\text { the unit } \\
\text { (g) }\end{array}$} & \multirow{2}{*}{$\begin{array}{c}\text { Water } \\
\text { content } \\
(\%)\end{array}$} & \multicolumn{2}{|c|}{ initial soils' } & \multicolumn{2}{|c|}{ final soils' } & \multicolumn{2}{|c|}{ change in soils' } \\
\hline & & & & & & & & $\begin{array}{l}\text { height } \\
\text { (mm) }\end{array}$ & $\begin{array}{l}\text { volume } \\
(\mathrm{cm} 3)\end{array}$ & $\begin{array}{l}\text { height } \\
(\mathrm{mm})\end{array}$ & $\begin{array}{c}\text { volume } \\
(\mathrm{cm} 3)\end{array}$ & $\begin{array}{l}\text { height } \\
(\mathrm{mm})\end{array}$ & $\begin{array}{l}\text { volume } \\
(\%)\end{array}$ \\
\hline 0 & 79.3 & 124.3 & & & 0.0 & 124.3 & 156.6 & 17.0 & 155.4 & 17.0 & 155.4 & 0.0 & 0.0 \\
\hline 0 & 9.3 & 124.3 & 5 & 1 & 5.4 & 118.9 & 149.8 & 17.0 & 155.4 & 16.4 & 150.0 & 0.6 & 1.5 \\
\hline 19 & 79.3 & 118.9 & 78 & 11180.4 & 7.4 & 111.5 & 140.5 & 16.4 & 150.0 & 15.7 & 143.7 & 0.7 & 4.2 \\
\hline 52 & 79.3 & 111.5 & 81.3 & 11169.5 & 11.8 & 99.7 & 125.6 & 15.7 & 143.7 & 14.6 & 133.7 & 1.1 & 5.9 \\
\hline 96 & 79.3 & .7 & 167.9 & 11131.3 & 36.6 & 63.1 & & 14.6 & 133.7 & 12.0 & 109.9 & 2.6 & 17.8 \\
\hline 197 & 7 & .1 & 2 & 5 & 30.7 & 2.4 & 8 & 12.0 & 109.9 & 10.0 & 7 & 2.0 & 25.7 \\
\hline 390 & 79.3 & .4 & 9 & .9 & 5.0 & 4 & 5 & 10.0 & 81.7 & 10.0 & 8 & 0.0 & 8.4 \\
\hline 590 & 79.3 & & 34.0 & 11092.5 & 1.5 & 25.9 & 32.6 & 10.0 & 74.8 & 10.0 & 73.0 & 0.0 & 2.4 \\
\hline 800 & & & & & 0 & & & 10.0 & 73.0 & 10.0 & 1 & 0.0 & 3.9 \\
\hline 400 & 5 & & 11091.5 & 11091.5 & 0. & 24. & 30.3 & 10.0 & 70.1 & 10.0 & 70.1 & 0.0 & 0.0 \\
\hline 200 & 79. & 1 & 915 & 11092.1 & -0. & & 31.1 & 10.0 & 70.1 & 10.0 & 1 & 0.0 & 0.0 \\
\hline 100 & 79.3 & & & 33.4 & -1.3 & 26.0 & 32.7 & 10.0 & 70.1 & 10.0 & 70.1 & 0.0 & 0.0 \\
\hline 47 & 79.3 & 26.0 & & & -1.3 & 27.3 & 34.4 & 10.0 & 70.1 & 10.0 & 70.1 & 0.0 & 0.0 \\
\hline 20 & 79.3 & 27.3 & 11094.7 & 11097.2 & -2.5 & 29.8 & 37.5 & 10.0 & 70.1 & 10.0 & 70.1 & 0.0 & 0.0 \\
\hline$\underline{0}$ & 79.3 & 29.8 & 11097.2 & 11099.1 & -1.9 & 31.7 & 39.9 & 10.0 & 70.1 & 10.0 & 70.14 & 0.0 & 0.0 \\
\hline
\end{tabular}

Table A5-11: Effect of suction on saturation for oil sand mine tailings, $w_{i}=156.6 \%$

\begin{tabular}{|c|c|c|c|c|c|}
\hline Suction & $\begin{array}{c}\text { Total } \\
\text { volume } \\
(\mathrm{kPa})\end{array}$ & $\begin{array}{c}\text { Volume of } \\
\text { void } \\
(\mathrm{Cm} 3)\end{array}$ & $\begin{array}{c}\text { Void } \\
\text { ratio }\end{array}$ & $\begin{array}{c}\text { Volume of } \\
\text { Water } \\
(\mathrm{Cm} 3)\end{array}$ & Saturation \\
\hline 0 & 155.4 & 124.3 & 3.99 & 124.3 & 100.0 \\
\hline 0 & 150.0 & 118.9 & 3.82 & 118.9 & 100.0 \\
\hline 19 & 143.7 & 112.6 & 3.62 & 111.5 & 99.0 \\
\hline 52 & 133.7 & 102.6 & 3.30 & 99.7 & 97.1 \\
\hline 96 & 109.9 & 78.8 & 2.53 & 63.1 & 80.0 \\
\hline 197 & 81.7 & 50.6 & 1.63 & 32.4 & 64.0 \\
\hline 390 & 74.8 & 43.7 & 1.40 & 27.4 & 62.6 \\
\hline 590 & 73.0 & 41.9 & 1.35 & 25.9 & 61.8 \\
\hline 800 & 70.1 & 39.0 & 1.25 & 24.1 & 61.7 \\
\hline 400 & 70.1 & 39.0 & 1.25 & 24.1 & 61.7 \\
\hline 200 & 70.1 & 39.0 & 1.25 & 24.7 & 63.2 \\
\hline 100 & 70.1 & 39.0 & 1.25 & 26.0 & 66.5 \\
\hline 47 & 70.1 & 39.0 & 1.25 & 27.3 & 69.9 \\
\hline 20 & 70.1 & 39.0 & 1.25 & 29.8 & 76.3 \\
\hline 0 & 70.1 & 39.0 & 1.25 & 31.7 & 81.1 \\
\hline
\end{tabular}




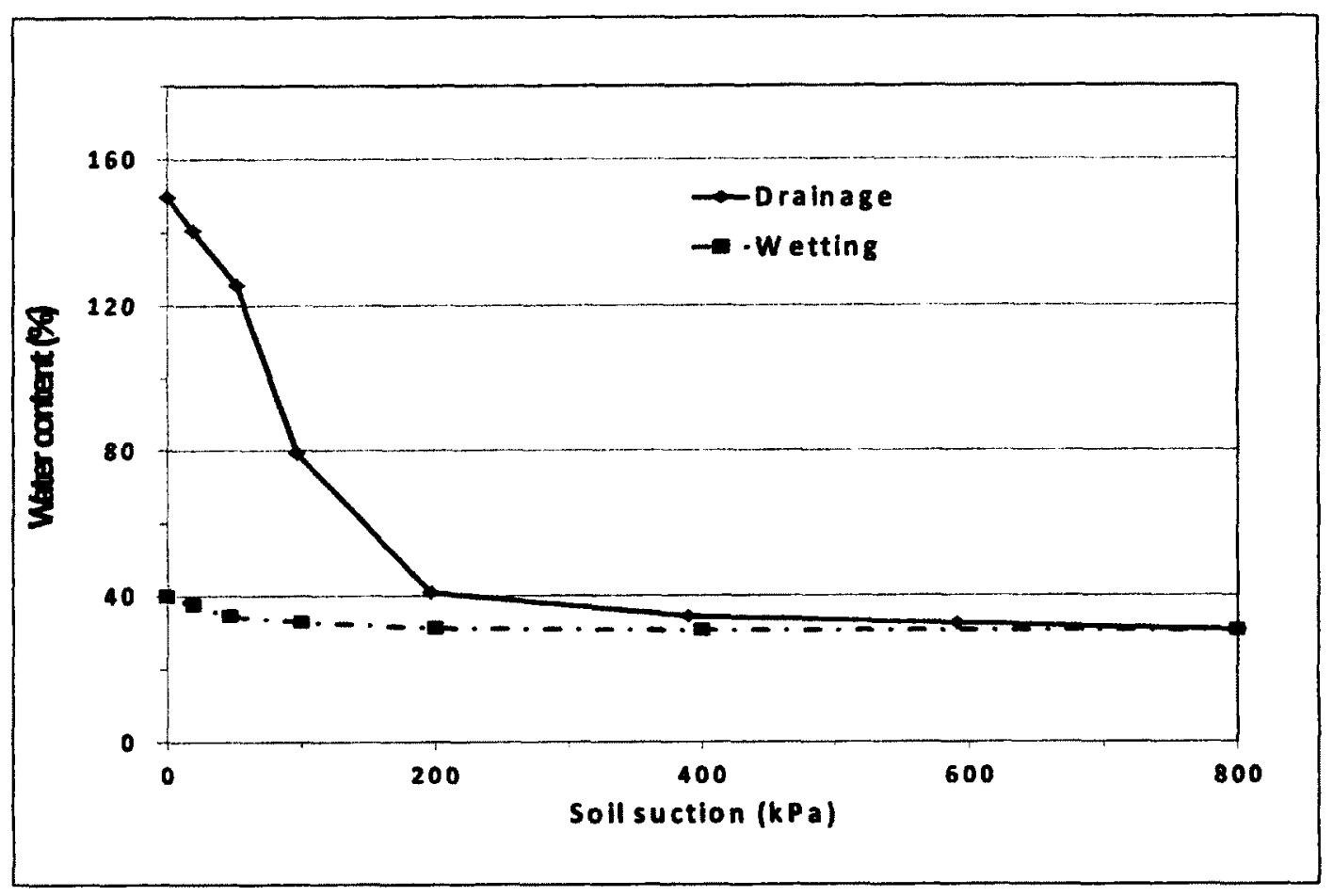

Figure A5-17: Water content-suction curve for oil sand tailings, $w_{i}=156.6 \%$

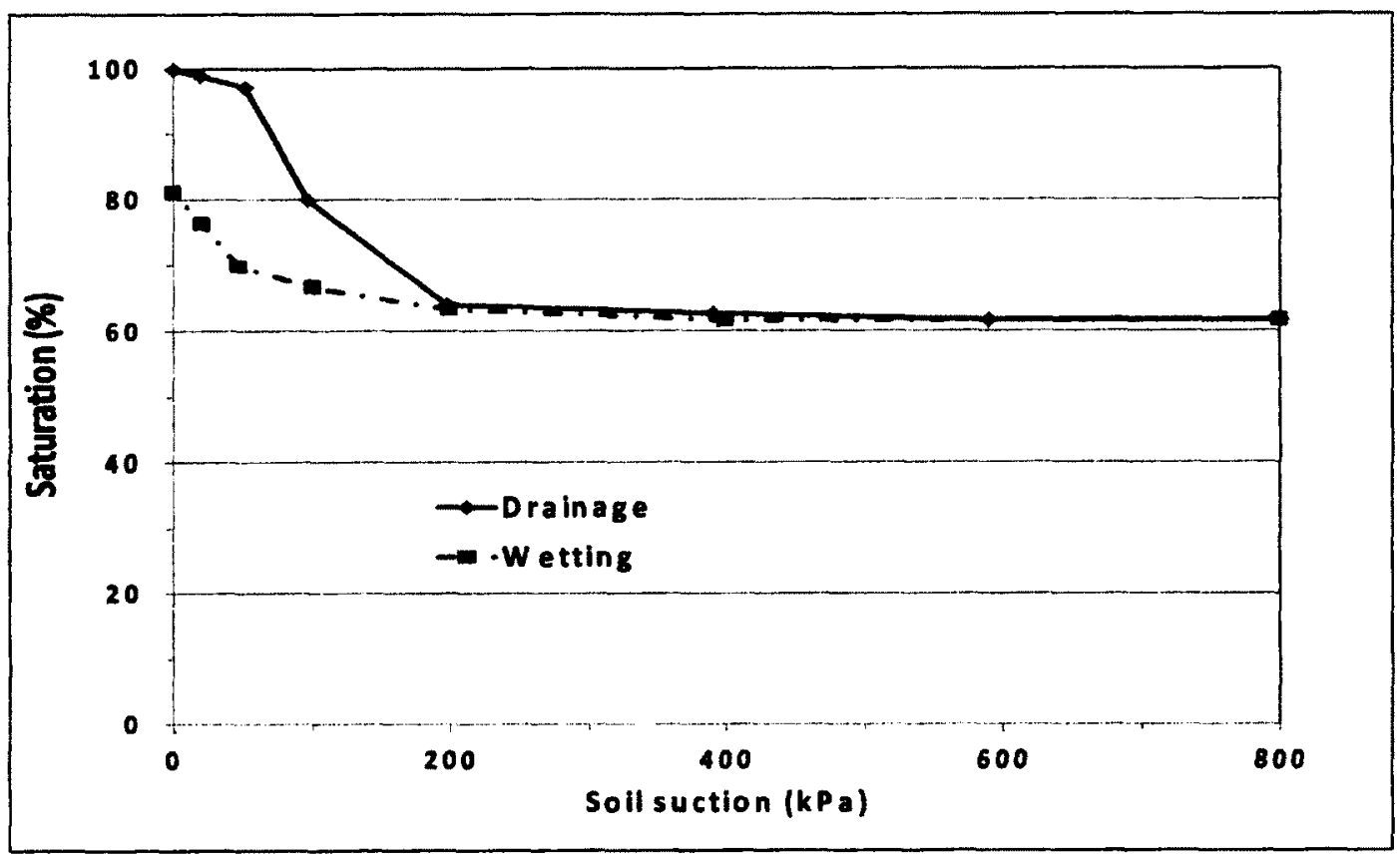

Figure A5-18: Saturation-suction curve for oil sand tailings, $w_{i}=156.62 \%$ 


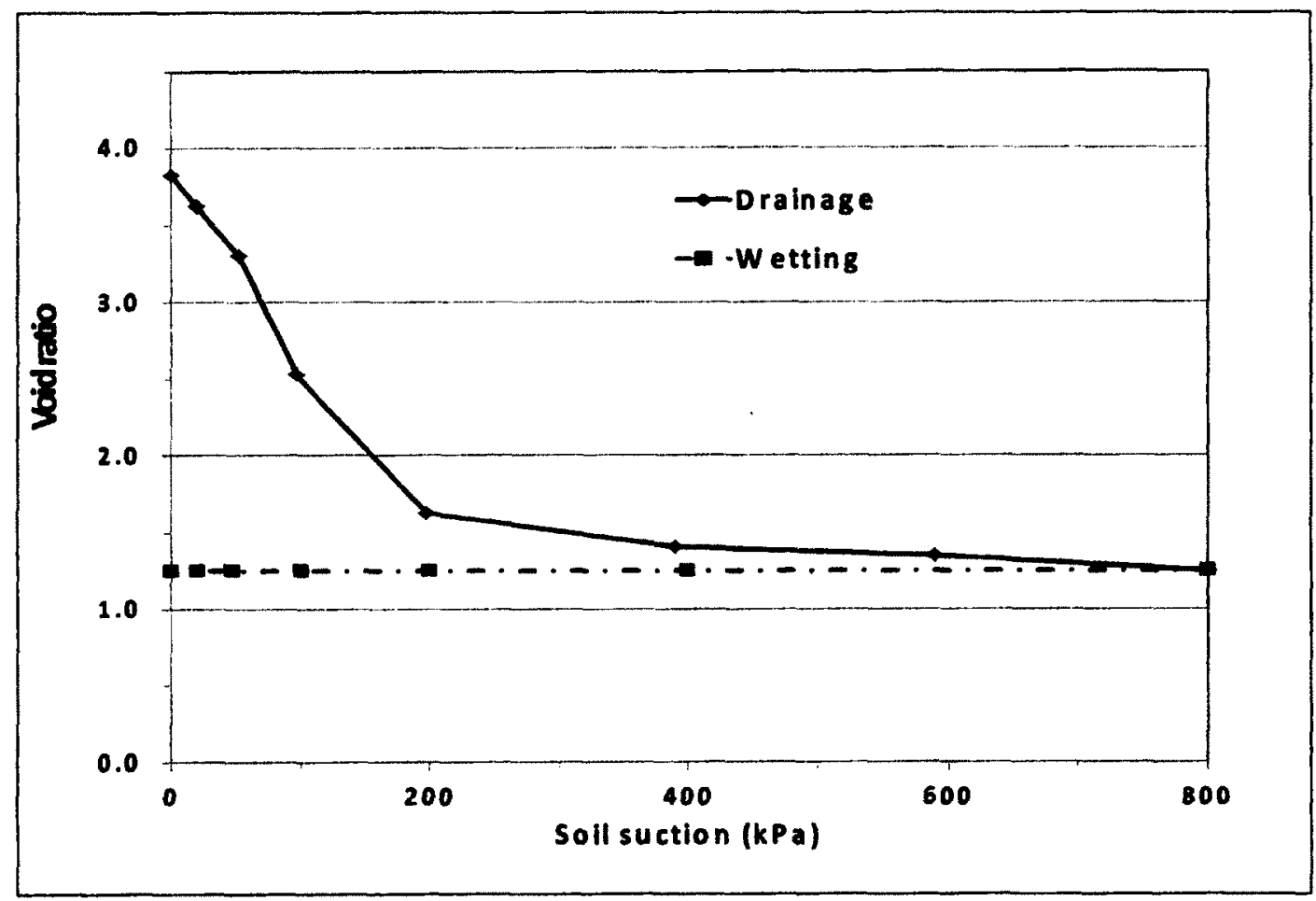

Figure A5-19: Void ratio-suction curve for oil sand tailings, $\mathrm{w}_{\mathrm{i}}=156.6 \%$

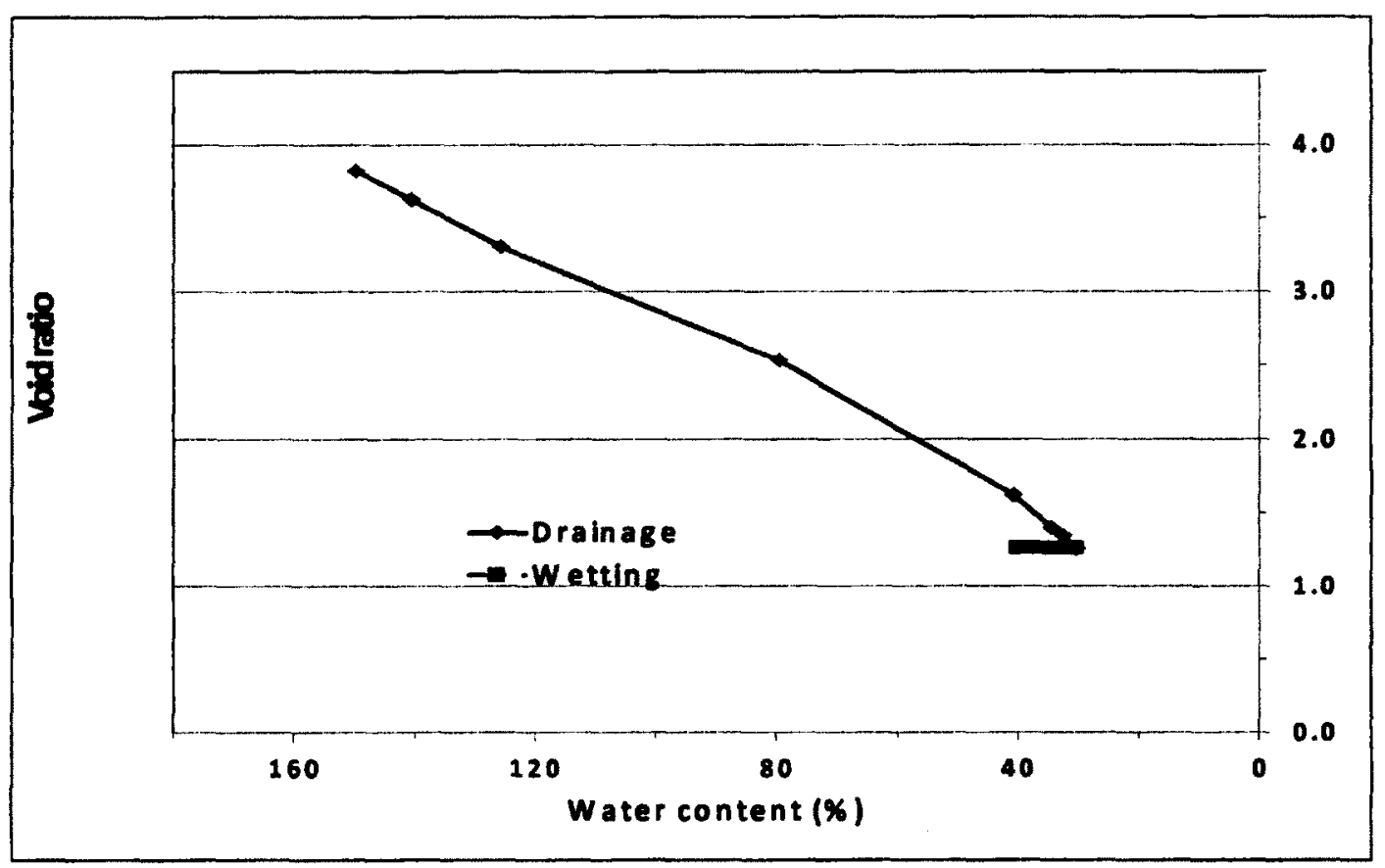

Figure A5-20: Shrinkage curve for oil sand tailings, $\mathrm{w}_{\mathrm{i}}=156.6 \%$ 
Table A5-12: Effect of mixing on tailing-water characteristic curve for oil sand mine

\begin{tabular}{|c|c|c|c|c|c|c|c|}
\hline \multicolumn{3}{|c|}{ wi $=154.7 \%$, mixed sample } & \multicolumn{4}{c|}{ wi =156.6\% } \\
\hline Suction & $\begin{array}{c}\text { Water } \\
\text { content } \\
(\%)\end{array}$ & $\begin{array}{c}\text { Saturati } \\
\text { on } \\
(\%)\end{array}$ & Void ratio & Suction & $\begin{array}{c}\text { Water } \\
\text { content } \\
(\mathrm{kPa})\end{array}$ & $\begin{array}{c}\text { Saturatio } \\
\mathrm{n} \\
(\%)\end{array}$ & Void ratio \\
\hline & & & & & & & \\
\hline 0 & 154.7 & 100.0 & 3.94 & 0 & 156.6 & 100.0 & 3.99 \\
\hline 0 & 153.0 & 100.0 & 3.90 & 0 & 149.8 & 100.0 & 3.82 \\
\hline 19 & 90.0 & 90.7 & 2.53 & 19 & 140.5 & 99.0 & 3.62 \\
\hline 45 & 49.9 & 66.7 & 1.90 & 52 & 125.6 & 97.1 & 3.30 \\
\hline 102 & 42.1 & 63.9 & 1.68 & 96 & 79.5 & 80.0 & 2.53 \\
\hline 196 & 38.6 & 63.7 & 1.55 & 197 & 40.8 & 64.0 & 1.63 \\
\hline 370 & 35.6 & 63.5 & 1.43 & 390 & 34.5 & 62.6 & 1.40 \\
\hline 500 & 32.0 & 62.9 & 1.30 & 590 & 32.6 & 61.8 & 1.35 \\
\hline 780 & 30.1 & 61.3 & 1.25 & 800 & 30.3 & 61.7 & 1.25 \\
\hline 400 & 30.1 & 61.3 & 1.25 & 400 & 30.3 & 61.7 & 1.25 \\
\hline 200 & 30.6 & 62.3 & 1.25 & 200 & 31.1 & 63.2 & 1.25 \\
\hline 100 & 31.5 & 64.0 & 1.25 & 100 & 32.7 & 66.5 & 1.25 \\
\hline 48 & 32.4 & 66.0 & 1.25 & 47 & 34.4 & 69.9 & 1.25 \\
\hline 20 & 33.7 & 68.6 & 1.25 & 20 & 37.5 & 76.3 & 1.25 \\
\hline 0 & 38.5 & 78.3 & 1.25 & 0 & 39.9 & 81.1 & 1.25 \\
\hline
\end{tabular}


Table A5-13: Effect of suction on water content in oil sand tailings, wi $=171.6 \%$, with polymer

\begin{tabular}{|c|c|c|c|c|c|c|c|c|c|c|c|c|c|}
\hline \multirow{2}{*}{$\begin{array}{l}\text { Suction } \\
(\mathrm{kPa}) .\end{array}$} & \multirow{2}{*}{$\begin{array}{c}\text { soil } \\
\text { weight } \\
\text { (g) } \\
\end{array}$} & \multirow{2}{*}{$\begin{array}{c}\text { water } \\
\text { weight } \\
\text { (g) }\end{array}$} & \multirow{2}{*}{\begin{tabular}{|c|} 
Initial total \\
weight \\
(g)
\end{tabular}} & \multirow{2}{*}{$\begin{array}{c}\text { final total } \\
\text { weight } \\
\text { (g) }\end{array}$} & \multirow{2}{*}{$\begin{array}{l}\text { water } \\
\text { out } \\
\text { (g) }\end{array}$} & \multirow{2}{*}{\begin{tabular}{|c|} 
water in \\
the unit \\
(g) \\
\end{tabular}} & \multirow{2}{*}{$\begin{array}{c}\text { Water } \\
\text { content } \\
(\%) \\
\end{array}$} & \multicolumn{2}{|c|}{ initial soils' } & \multicolumn{2}{|c|}{ final soils' } & \multicolumn{2}{|c|}{ change in soils' } \\
\hline & & & & & & & & $\begin{array}{l}\text { height } \\
(\mathrm{mm})\end{array}$ & $\begin{array}{c}\text { volume } \\
(\mathrm{cm} 3)\end{array}$ & $\begin{array}{l}\text { height } \\
(\mathrm{mm})\end{array}$ & $\begin{array}{c}\text { volume } \\
\text { (cm3) }\end{array}$ & $\begin{array}{l}\text { height } \\
(\mathrm{mm})\end{array}$ & $\begin{array}{c}\text { volume } \\
(\%)\end{array}$ \\
\hline 0 & 5 & & & & & & & & & & & & \\
\hline 0 & 125.5 & 215.3 & 3698.2 & 3677.3 & 20.9 & 194.4 & 154.9 & 20.9 & 264.5 & 19.3 & 243.6 & 1.6 & 7.9 \\
\hline 23 & 125.5 & 194.4 & 3677.3 & 3636.4 & 40.9 & 153.5 & 122.3 & 19.3 & 243.6 & 16.5 & 204.5 & 2.8 & 16.0 \\
\hline 51 & 125.5 & 153.5 & 3636.4 & 3555.2 & 81.2 & 72.3 & 57.6 & 16.5 & 204.5 & 14.5 & 164.0 & 2.0 & 19.8 \\
\hline 103 & 125.5 & 72.3 & 3555.2 & 3542.0 & 13.2 & 59.1 & 47.1 & 14.5 & 164.0 & 13.2 & 147.7 & 1.3 & 9.9 \\
\hline 201 & 125.5 & 59.1 & 3542.0 & 3535.1 & 6.9 & 52.2 & 41.6 & 13.2 & 147.7 & 12.8 & 141.8 & 0.4 & 4.0 \\
\hline 400 & 125.5 & 52.2 & 3535.1 & 3524.1 & 11.0 & 41.2 & 32.8 & 12.8 & 141.8 & 12.0 & 131.8 & 0.8 & 7.1 \\
\hline 605 & 125.5 & 41.2 & 3524.1 & 3520.6 & 3.5 & 37.7 & 30.0 & 12.0 & 131.8 & 12.0 & 130.5 & 0.0 & 1.0 \\
\hline 800 & 125.5 & 37.7 & 3520.6 & 3517.5 & 3.1 & 34.6 & 27.6 & 12.0 & 130.5 & 12.0 & 130.5 & 0.0 & 0.0 \\
\hline 600 & 125.5 & 34.6 & 3517.5 & 3517.5 & 0.0 & 34.6 & 27.6 & 12.0 & 130.5 & 12.0 & 130.5 & 0.0 & 0.0 \\
\hline 400 & 125.5 & 34.6 & 3517.5 & 3517.5 & 0.0 & 34.6 & 27.6 & 12.0 & 130.5 & 12.0 & 130.5 & 0.0 & 0.0 \\
\hline 200 & 125.5 & 34.6 & 3517.5 & 3517.8 & -0.3 & 34.9 & 27.8 & 12.0 & 130.5 & 12.0 & 130.5 & 0.0 & 0.0 \\
\hline 105 & 125.5 & 34.9 & 3517.8 & 3519.5 & -1.7 & 36.6 & 29.2 & 12.0 & 130.5 & 12.0 & 130.5 & 0.0 & 0.0 \\
\hline 53 & 125.5 & 36.6 & 3519.5 & 3521.7 & -2.2 & 38.8 & 30.9 & 12.0 & 130.5 & 12.0 & 130.5 & 0.0 & 0.0 \\
\hline 20 & 125.5 & 38.8 & 3521.7 & 3528.9 & -7.2 & 46.0 & 36.7 & 12.0 & 130.5 & 12.0 & 130.5 & 0.0 & 0.0 \\
\hline 0 & 125.5 & 46.0 & 3528.9 & 3540.1 & -11.2 & 57.2 & 45.6 & 12.0 & 130.5 & 12.0 & 130.5 & 0.0 & 0.0 \\
\hline 20 & 125.5 & 57.2 & 3540.1 & 3539.1 & 1.0 & 56.2 & 44.8 & 12.0 & 130.5 & 12.0 & 130.5 & 0.0 & 0.0 \\
\hline 53 & 125.5 & 56.2 & 3539.1 & 3536.2 & 2.9 & 53.3 & 42.5 & 12.0 & 130.5 & 12.0 & 130.5 & 0.0 & 0.0 \\
\hline 101 & 125.5 & 53.3 & 3536.2 & 3532.3 & 3.9 & 49.4 & 39.4 & 12.0 & 130.5 & 12.0 & 130.5 & 0.0 & 0.0 \\
\hline 208 & 125.5 & 49.4 & 3532.3 & 3524.2 & 8.1 & 41.3 & 32.9 & 12.0 & 130.5 & 12.0 & 130.5 & 0.0 & 0.0 \\
\hline 405 & 125.5 & 41.3 & 3524.2 & 3521.8 & 2.4 & 38.9 & 31.0 & 12.0 & 130.5 & 12.0 & 130.5 & 0.0 & 0.0 \\
\hline 800 & 125.5 & 38.9 & 3521.8 & 3516.7 & 5.1 & 33.8 & 26.9 & 12.0 & 130.5 & 12.0 & 130.5 & 0.0 & 0.0 \\
\hline 400 & 125.5 & 33.8 & 3516.7 & 3516.7 & 0.0 & 33.8 & 26.9 & 12.0 & 130.5 & 12.0 & 130.5 & 0.0 & 0.0 \\
\hline 103 & 125.5 & 33.8 & 3516.7 & 3518.3 & -1.6 & 35.4 & 28.2 & 12.0 & 130.5 & 12.0 & 130.5 & 0.0 & 0.0 \\
\hline 60 & 125.5 & 35.4 & 3518.3 & 3523.2 & -4.9 & 40.3 & 32.1 & 12.0 & 130.5 & 12.0 & 130.5 & 0.0 & 0.0 \\
\hline 0 & 125.5 & 40.3 & 3523.2 & 3539.4 & -16.2 & 56.5 & 45.0 & 12.0 & 130.5 & 12.0 & 130.5 & 0.0 & 0.0 \\
\hline
\end{tabular}


Table A5-14: Effect of suction on saturation in oil sand tailings, wi=171.6\%, with polymer

\begin{tabular}{|c|c|c|c|c|c|}
\hline $\begin{array}{l}\text { Suction } \\
\text { (kPa) }\end{array}$ & $\begin{array}{c}\text { Total } \\
\text { volume } \\
(\mathrm{Cm} 3)\end{array}$ & $\begin{array}{c}\text { Volume of } \\
\text { void } \\
(\mathrm{Cm} 3)\end{array}$ & $\begin{array}{l}\text { Void } \\
\text { ratio }\end{array}$ & $\begin{array}{c}\text { Volume of } \\
\text { Water } \\
\text { (Cm } 3)\end{array}$ & $\begin{array}{c}\text { Saturation } \\
(\%)\end{array}$ \\
\hline 0 & 264.5 & 215.3 & 4.37 & 215.3 & 100.0 \\
\hline 0 & 243.6 & 194.4 & 3.95 & 194.4 & 100.0 \\
\hline 23 & 204.5 & 155.3 & 3.16 & 153.5 & 98.8 \\
\hline 51 & 164.0 & 114.8 & 2.33 & 72.3 & 63.0 \\
\hline 103 & 147.7 & 98.5 & 2.00 & 59.1 & 60.0 \\
\hline 201 & 141.8 & 92.6 & 1.88 & 52.2 & 56.4 \\
\hline 400 & 131.8 & 82.6 & 1.68 & 41.2 & 49.9 \\
\hline 605 & 130.5 & 81.3 & 1.65 & 37.7 & 46.4 \\
\hline 800 & 130.5 & 81.3 & 1.65 & 34.6 & 42.6 \\
\hline 600 & 130.5 & 81.3 & 1.65 & 34.6 & 42.6 \\
\hline 400 & 130.5 & 81.3 & 1.65 & 34.6 & 42.6 \\
\hline 200 & 130.5 & 81.3 & 1.65 & 34.9 & 42.9 \\
\hline 105 & 130.5 & 81.3 & 1.65 & 36.6 & 45.0 \\
\hline 53 & 130.5 & 81.3 & 1.65 & 38.8 & 47.7 \\
\hline 20 & 130.5 & 81.3 & 1.65 & 46.0 & 56.6 \\
\hline 0 & 130.5 & 81.3 & 1.65 & 57.2 & 70.3 \\
\hline 20 & 130.5 & 81.3 & 1.65 & 56.2 & 69.1 \\
\hline 53 & 130.5 & 81.3 & 1.65 & 53.3 & 65.6 \\
\hline 101 & 130.5 & 81.3 & 1.65 & 49.4 & 60.8 \\
\hline 208 & 130.5 & 81.3 & 1.65 & 41.3 & 50.8 \\
\hline 405 & 130.5 & 81.3 & 1.65 & 38.9 & 47.8 \\
\hline 800 & 130.5 & 81.3 & 1.65 & 33.8 & 41.6 \\
\hline 400 & 130.5 & 81.3 & 1.65 & 33.8 & 41.6 \\
\hline 103 & 130.5 & 81.3 & 1.65 & 35.4 & 43.5 \\
\hline 60 & 130.5 & 81.3 & 1.65 & 40.3 & 49.6 \\
\hline 0 & 130.5 & 81.3 & 1.65 & 56.5 & 69.5 \\
\hline
\end{tabular}




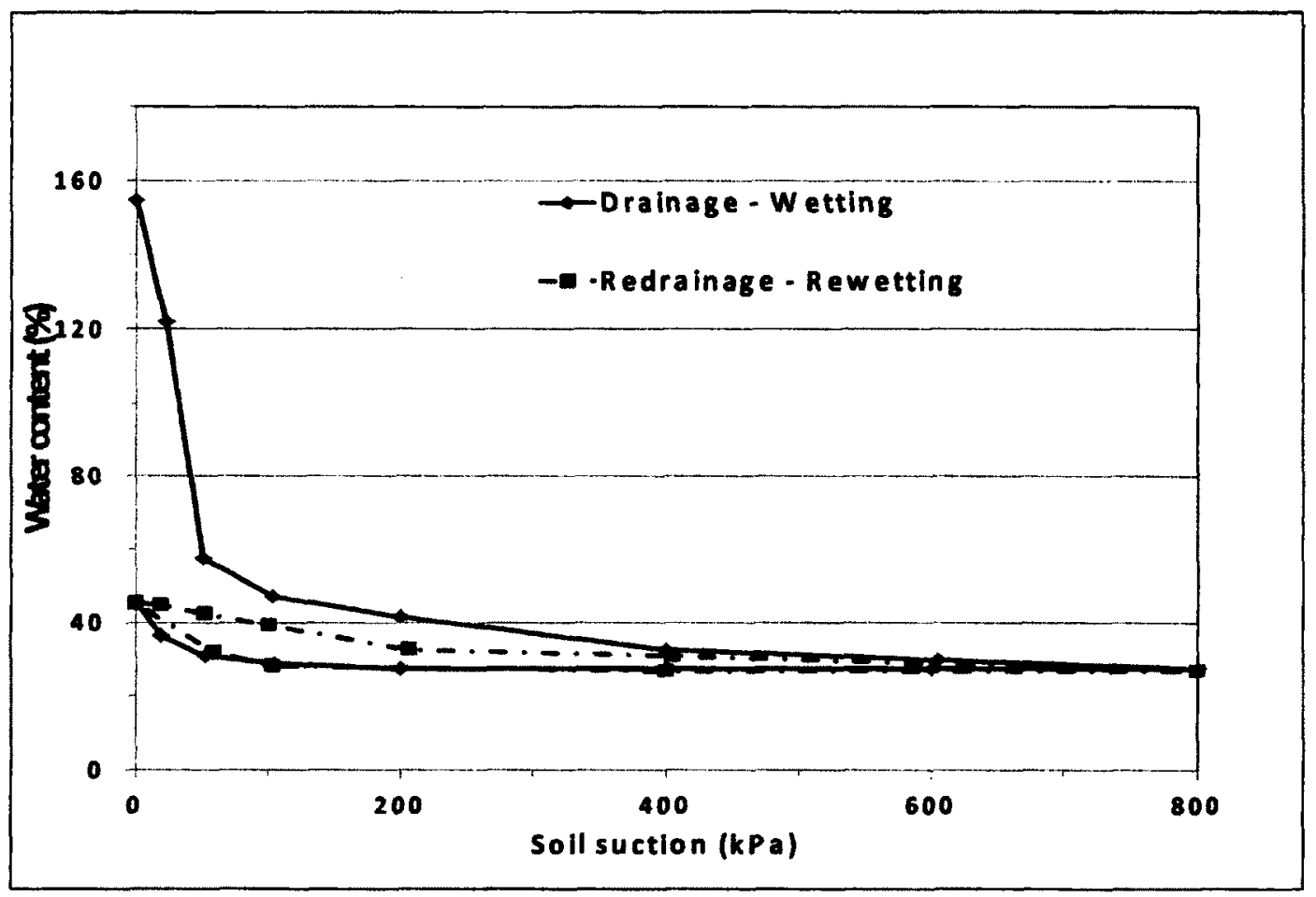

Figure A5-21: Water content-suction curve for oil sand tailings, $w_{i}=171.6 \%$, with polymer

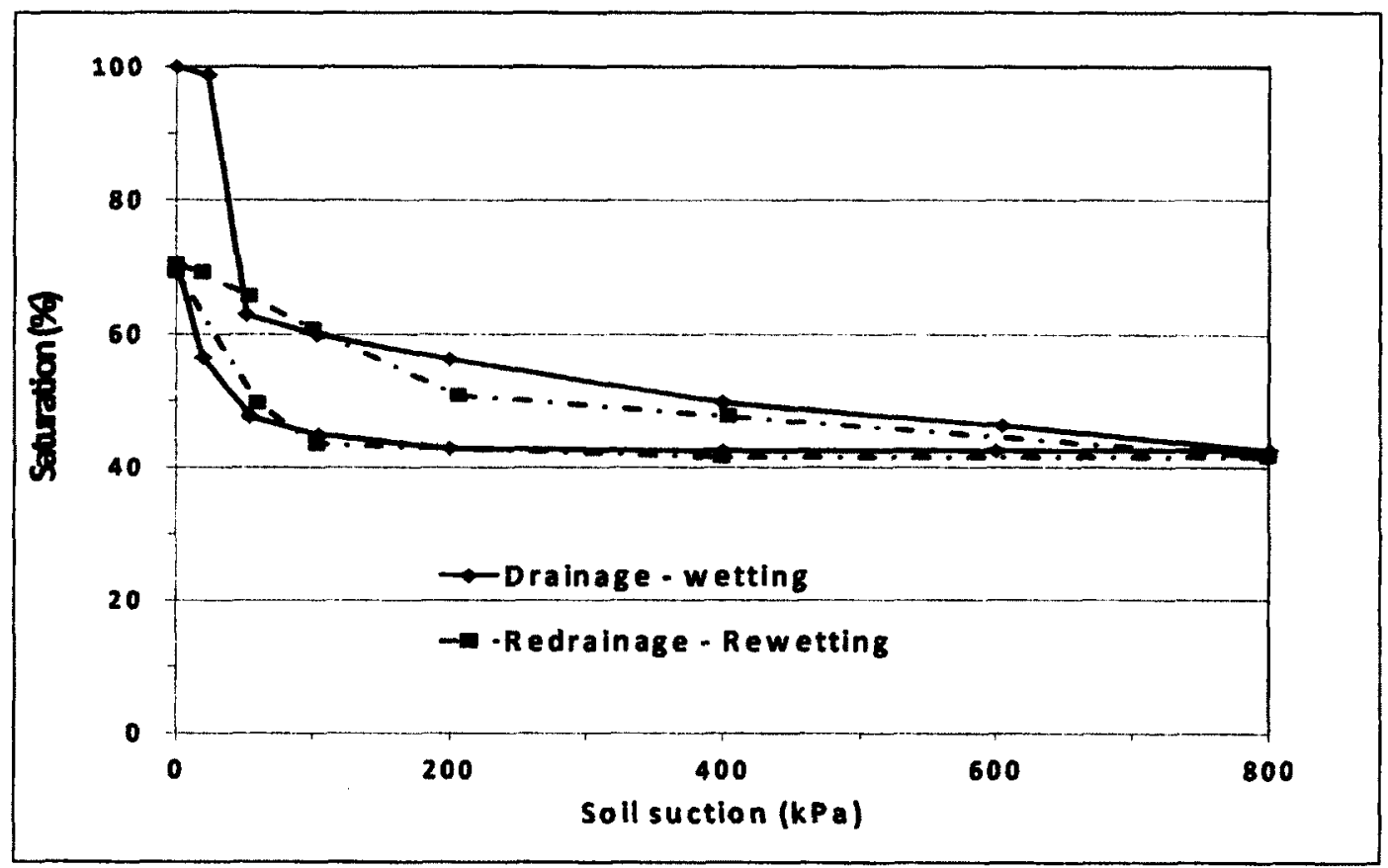

Figure A5-22: Saturation-suction curve for oil sand tailings, $w_{i}=171.6 \%$, with polymer 


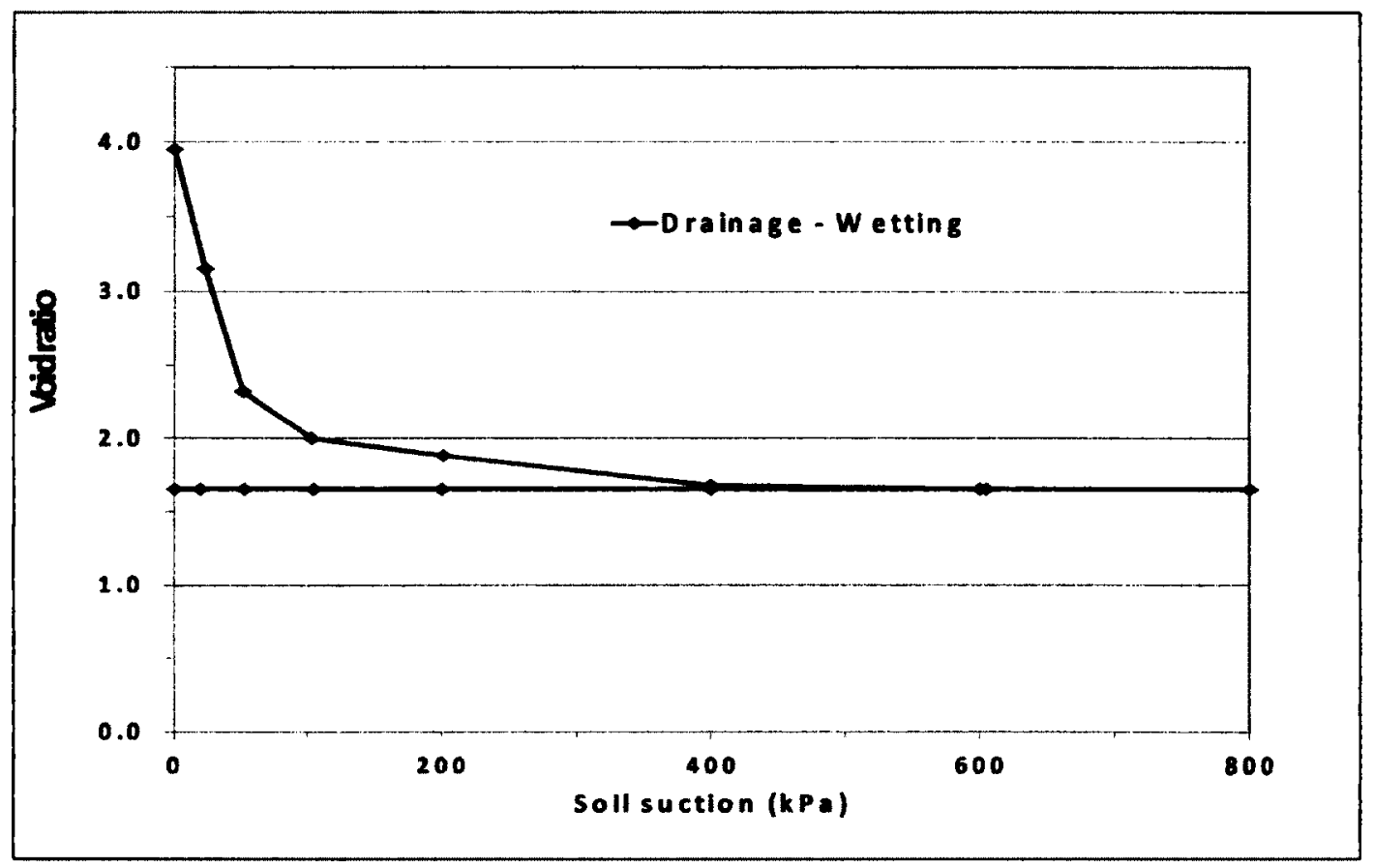

Figure A5-23: Void ratio-suction curve for oil sand tailings, $w_{i}=171.6 \%$, with polymer

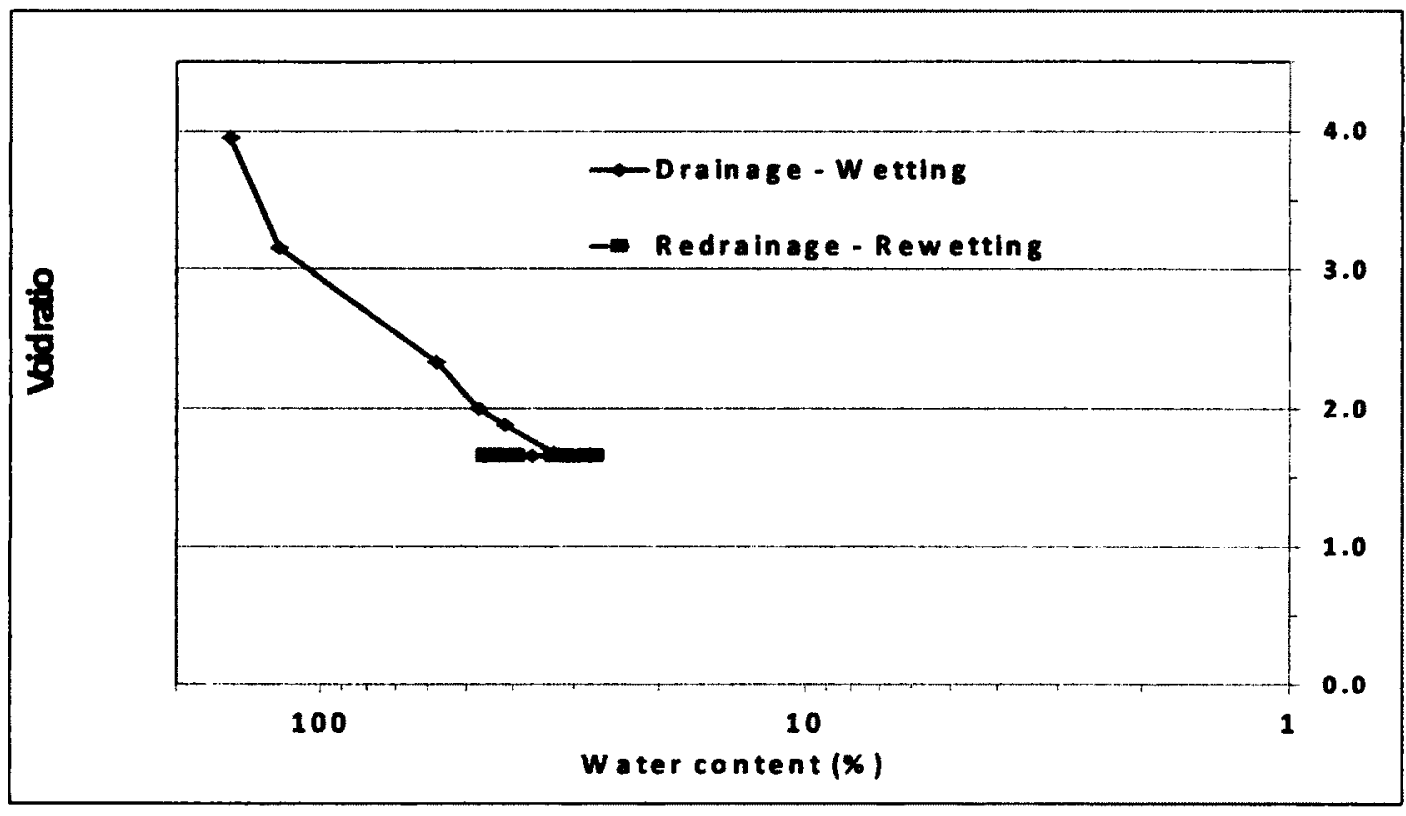

Figure A5-24: Shrinkage curve for oil sand tailings, $w_{i}=171.6 \%$, with polymer 
Table A5-15: Comparison of polymer effect on TWCC to no added polymer in oil sand tailings

\begin{tabular}{|c|c|c|c|c|c|c|c|c|c|c|c|}
\hline \multicolumn{4}{|c|}{$\mathrm{wi}=\% 171.6$ with polymer } & \multicolumn{4}{|c|}{$w i=\% 1312$} & \multicolumn{4}{|c|}{$w i=\% 1566$} \\
\hline $\begin{array}{l}\text { Suction } \\
\text { (Na) }\end{array}$ & $\begin{array}{l}\text { Water } \\
\text { contert } \\
199\end{array}$ & $\begin{array}{c}\text { Sturtion } \\
199\end{array}$ & Vidratio & $\begin{array}{l}\text { sution } \\
\text { (Na) }\end{array}$ & $\begin{array}{c}\text { Watter critert } \\
194\end{array}$ & $\begin{array}{l}\text { Saturation } \\
19\end{array}$ & Vaidratio & $\begin{array}{l}\text { Suction } \\
\text { (NPo) }\end{array}$ & $\begin{array}{c}\text { Weter cortent } \\
19\end{array}$ & $\begin{array}{l}\text { Situration } \\
\text { (94) }\end{array}$ & Vaidratio \\
\hline 0 & 1716 & 1000 & 435 & 0 & 1312 & 1000 & 334 & 0 & 1566 & 1000 & 399 \\
\hline 0 & 1549 & 1000 & 398 & 0 & 1235 & 1000 & 315 & 0 & 1998 & 1000 & 3.82 \\
\hline 23 & 123 & 98 & 316 & 24 & 967 & 958 & 257 & 19 & 1405 & 990 & 32 \\
\hline s1 & 57.6 & జ0 & 233 & 52 & 440 & 57.1 & 197 & 52 & 1256 & 97.1 & 330 \\
\hline 100 & 47.1 & 600 & 200 & 105 & 385 & 544 & 180 & 96 & 795 & 800 & 253 \\
\hline$\underline{m}$ & 416 & 564 & 188 & 21 & 350 & 532 & 168 & 197 & 408 & 640 & 168 \\
\hline 400 & 328 & 49 & 168 & 40 & 315 & 504 & 160 & 300 & 345 & $\mathbf{2 . 6}$ & 140 \\
\hline 605 & 300 & 464 & $1 \Phi$ & 510 & 310 & 498 & 150 & 500 & 326 & ณ8 & 135 \\
\hline 800 & 27.6 & 426 & $1 \Phi$ & 415 & 310 & 498 & 109 & 800 & 303 & 617 & 125 \\
\hline$\infty 0$ & 27.6 & $\$ 26$ & 165 & 20 & 310 & 49.8 & 159 & 400 & 303 & 617 & 125 \\
\hline 400 & 20.6 & 426 & 165 & 106 & 317 & 511 & 159 & 200 & 311 & $\lcm{2} 2$ & 125 \\
\hline 200 & 27.8 & 429 & 16 & 5 & 329 & 530 & 15 & 100 & 327 & 665 & 125 \\
\hline 105 & 29.2 & 450 & $1 \oplus$ & 24 & 360 & 580 & 150 & 47 & 344 & 29 & 125 \\
\hline 53 & 309 & 47.7 & 165 & $\underline{0}$ & 445 & 726 & 159 & 20 & 37.5 & 723 & 125 \\
\hline 20 & 36.7 & 566 & 165 & & & & & 0 & 329 & 811 & 125 \\
\hline 0 & 456 & 703 & 165 & & & & & & & & \\
\hline
\end{tabular}


Table A5-16: Effect of suction on water content in oil sand tailings, wi $=126.9 \%$, with polymer, mixed sample

\begin{tabular}{|c|c|c|c|c|c|c|c|c|c|c|c|c|c|}
\hline \multirow{2}{*}{$\begin{array}{l}\text { Suction } \\
(\mathrm{kPa})\end{array}$} & \multirow{2}{*}{$\begin{array}{c}\text { soll } \\
\text { weight } \\
\text { (g) }\end{array}$} & \multirow{2}{*}{$\begin{array}{c}\text { water } \\
\text { weight } \\
(\mathrm{g})\end{array}$} & \multirow{2}{*}{$\begin{array}{c}\text { Initial total } \\
\text { weight } \\
(\mathrm{l})\end{array}$} & \multirow{2}{*}{$\begin{array}{c}\text { final total } \\
\text { weight } \\
(\mathrm{g})\end{array}$} & \multirow{2}{*}{$\begin{array}{l}\text { water } \\
\text { out } \\
(\mathrm{g})\end{array}$} & \multirow{2}{*}{$\begin{array}{c}\text { water in } \\
\text { theunit } \\
\text { (b) }\end{array}$} & \multirow{2}{*}{$\begin{array}{l}\text { Water } \\
\text { content } \\
(x) \\
\end{array}$} & \multicolumn{2}{|c|}{ initial soils' } & \multicolumn{2}{|c|}{ final soilis' } & \multicolumn{2}{|c|}{ changeinsoill' } \\
\hline & & & & & & & & $\begin{array}{l}\text { height } \\
\text { (mm) }\end{array}$ & $\begin{array}{l}\text { volume } \\
(\mathrm{cm} 3)\end{array}$ & $\begin{array}{l}\text { height } \\
(\mathrm{mm})\end{array}$ & $\begin{array}{c}\text { volume } \\
(\mathrm{cm} 3)\end{array}$ & $\begin{array}{l}\text { height } \\
\text { (mm) }\end{array}$ & $\begin{array}{l}\text { volume } \\
(\%)\end{array}$ \\
\hline$\overline{0}$ & 80.8 & $\overline{02.5}$ & 111711 & 1171.1 & 0.0 & 102.5 & 126.9 & 11.7 & $\overline{1075}$ & 147 & 1342 & .29 & 4.9 \\
\hline 0 & 80.8 & 102.5 & 11171.1 & 11167.8 & 3.3 & 99.2 & 122.8 & 14.7 & 134.2 & 14.3 & 130.9 & 0.4 & 2.5 \\
\hline$\overline{30}$ & 80.8 & 99.2 & 11167.8 & 11161.7 & 6.1 & 93.1 & 115.2 & 14.3 & 130.9 & 14.0 & 128.3 & 0.3 & $\frac{2.0}{2.0}$ \\
\hline 48 & 80.8 & 93.1 & 11161.7 & 11151.7 & 10.0 & 83.1 & 102.8 & 14.0 & 128.3 & 13.0 & 119.1 & 1.0 & 7.1 \\
\hline 100 & 80.8 & 83.1 & 11151.7 & 11129.9 & 21.8 & 61.3 & 75.9 & 13.0 & 119.1 & 12.0 & 109.9 & 1.0 & 7.7 \\
\hline 188 & 80.8 & 61.3 & 11129.9 & 11103.2 & 26.7 & 34.6 & 42.8 & 12.0 & 109.9 & 9.5 & 77.6 & 2.5 & 29.4 \\
\hline 380 & 80.8 & 34.6 & 11103.2 & 11099.6 & 3.6 & 31.0 & 38.4 & 9.5 & 77.6 & 9.0 & 73.0 & 0.5 & 6.0 \\
\hline 800 & 80.8 & 31.0 & 11099.6 & 11097.2 & 2.4 & 28.6 & 35.4 & 9.0 & 73.0 & 9.0 & 72.1 & 0.0 & 1.2 \\
\hline 400 & 80.8 & 28.6 & 11097.2 & 11097.2 & 0.0 & 28.6 & 35.4 & 9.0 & 72.1 & 9.0 & 72.1 & 0.0 & 0.0 \\
\hline 199 & 80.8 & 28.6 & 11097.2 & 11097.2 & 0.0 & 28.6 & 35.4 & 9.0 & 72.1 & 9.0 & 72.1 & 0.0 & 0.0 \\
\hline 100 & 80.8 & 28.6 & 11097.2 & 11097.2 & 0.0 & 28.6 & 35.4 & 9.0 & 72.1 & 9.0 & 72.1 & 0.0 & 0.0 \\
\hline 50 & 80.8 & 28.6 & 11097.2 & 11097.2 & 0.0 & 28.6 & 35.4 & 9.0 & 72.1 & 9.0 & 72.1 & 0.0 & 0.0 \\
\hline 20 & 80.8 & 28.6 & 11097.2 & 11099.8 & -2.6 & 31.2 & 38.6 & 9.0 & 72.1 & 9.0 & 72.1 & 0.0 & 0.0 \\
\hline 0 & 0.8 & 31.2 & & IIII & $\ldots$ & 33.3 & 41.2 & 9.0 & 12.1 & 9.0 & 2 & 0.0 & 0 \\
\hline
\end{tabular}

Table A5-17: Effect of suction on saturation in oil sand tailings, wi $=126.9 \%$, with polymer, mixed sample

\begin{tabular}{|c|c|c|c|c|c|}
\hline $\begin{array}{c}\text { Suction } \\
(\mathrm{kPa})\end{array}$ & $\begin{array}{c}\text { Total } \\
\text { volume } \\
(\mathrm{Cm} 3)\end{array}$ & $\begin{array}{c}\text { Volume of } \\
\text { void } \\
(\mathrm{Cm} 3)\end{array}$ & $\begin{array}{c}\text { Void } \\
\text { ratio }\end{array}$ & $\begin{array}{c}\text { Volume of } \\
\text { Water } \\
(\mathrm{Cm} 3)\end{array}$ & $\begin{array}{c}\text { Saturation } \\
(\%)\end{array}$ \\
\hline 0 & 134.2 & 102.5 & 3.24 & 102.5 & 100.0 \\
\hline 0 & 130.9 & 99.2 & 3.13 & 99.2 & 100.0 \\
\hline 30 & 128.3 & 96.6 & 3.05 & 93.1 & 96.4 \\
\hline 48 & 119.1 & 87.4 & 2.76 & 83.1 & 95.0 \\
\hline 100 & 109.9 & 78.2 & 2.47 & 61.3 & 78.3 \\
\hline 188 & 77.6 & 45.9 & 1.45 & 34.6 & 75.3 \\
\hline 380 & 73.0 & 41.3 & 1.30 & 31.0 & 75.1 \\
\hline 800 & 72.1 & 40.4 & 1.28 & 28.6 & 70.8 \\
\hline 400 & 72.1 & 40.4 & 1.28 & 28.6 & 70.8 \\
\hline 199 & 72.1 & 40.4 & 1.28 & 28.6 & 70.8 \\
\hline 100 & 72.1 & 40.4 & 1.28 & 28.6 & 70.8 \\
\hline 50 & 72.1 & 40.4 & 1.28 & 28.6 & 70.8 \\
\hline 20 & 72.1 & 40.4 & 1.28 & 31.2 & 77.2 \\
\hline 0 & 72.1 & 40.4 & 1.28 & 33.3 & 82.4 \\
\hline
\end{tabular}




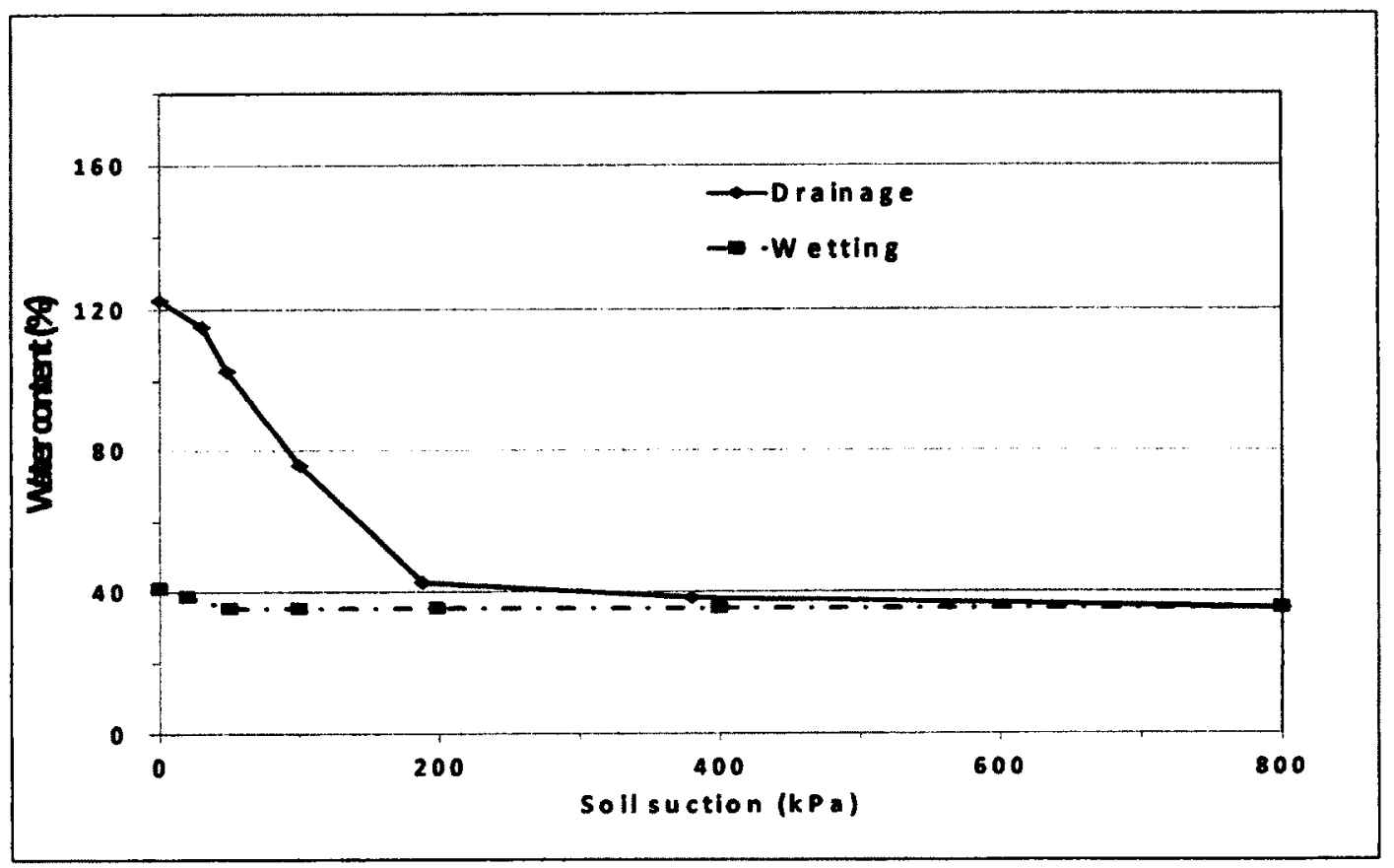

Figure A5-25: Water content-suction curve for oil sand tailings, $w_{i}=126.9 \%$, with polymer, mixed sample

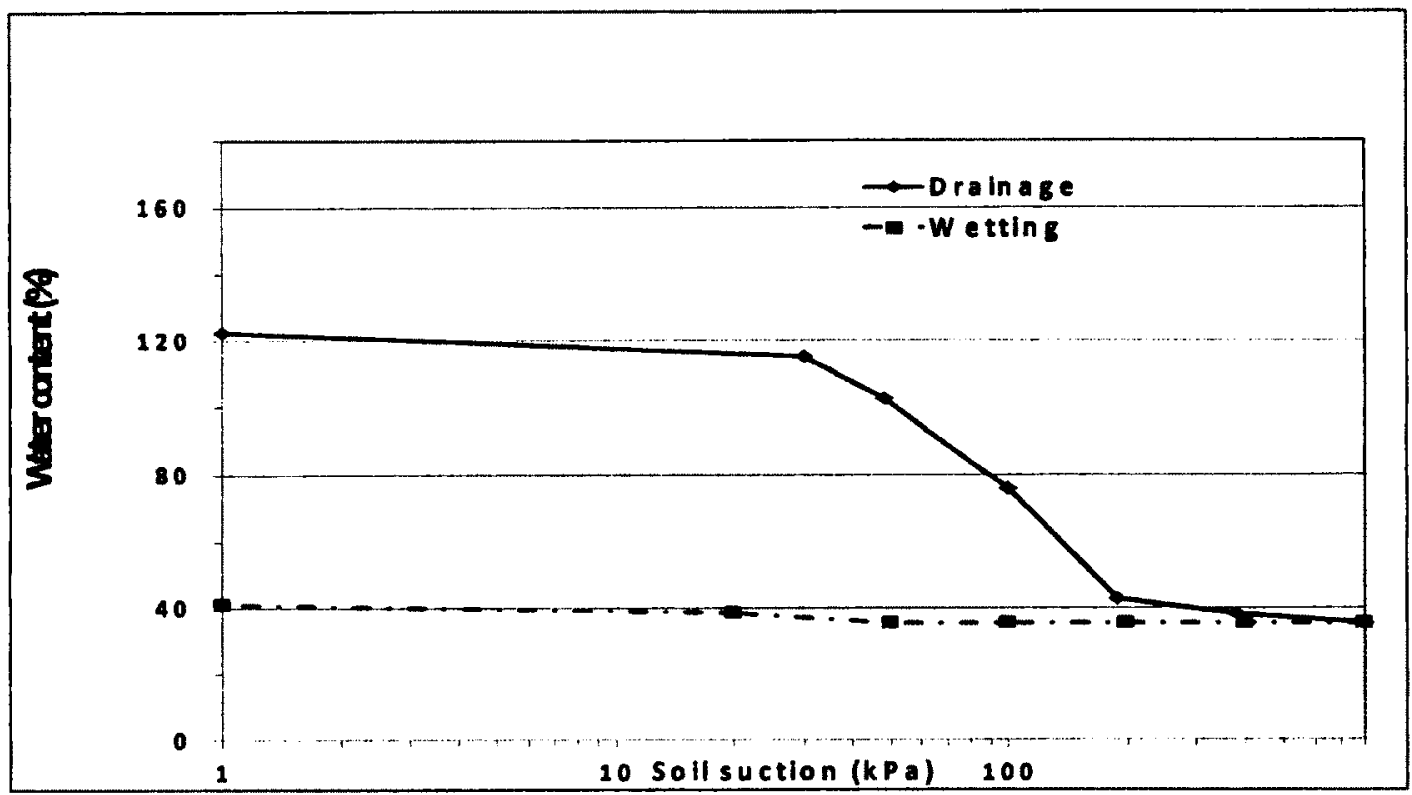

Figure A5-26: Water content-suction curve for oil sand tailings, $w_{i}=126.9 \%$, with polymer, mixed sample, log scale 


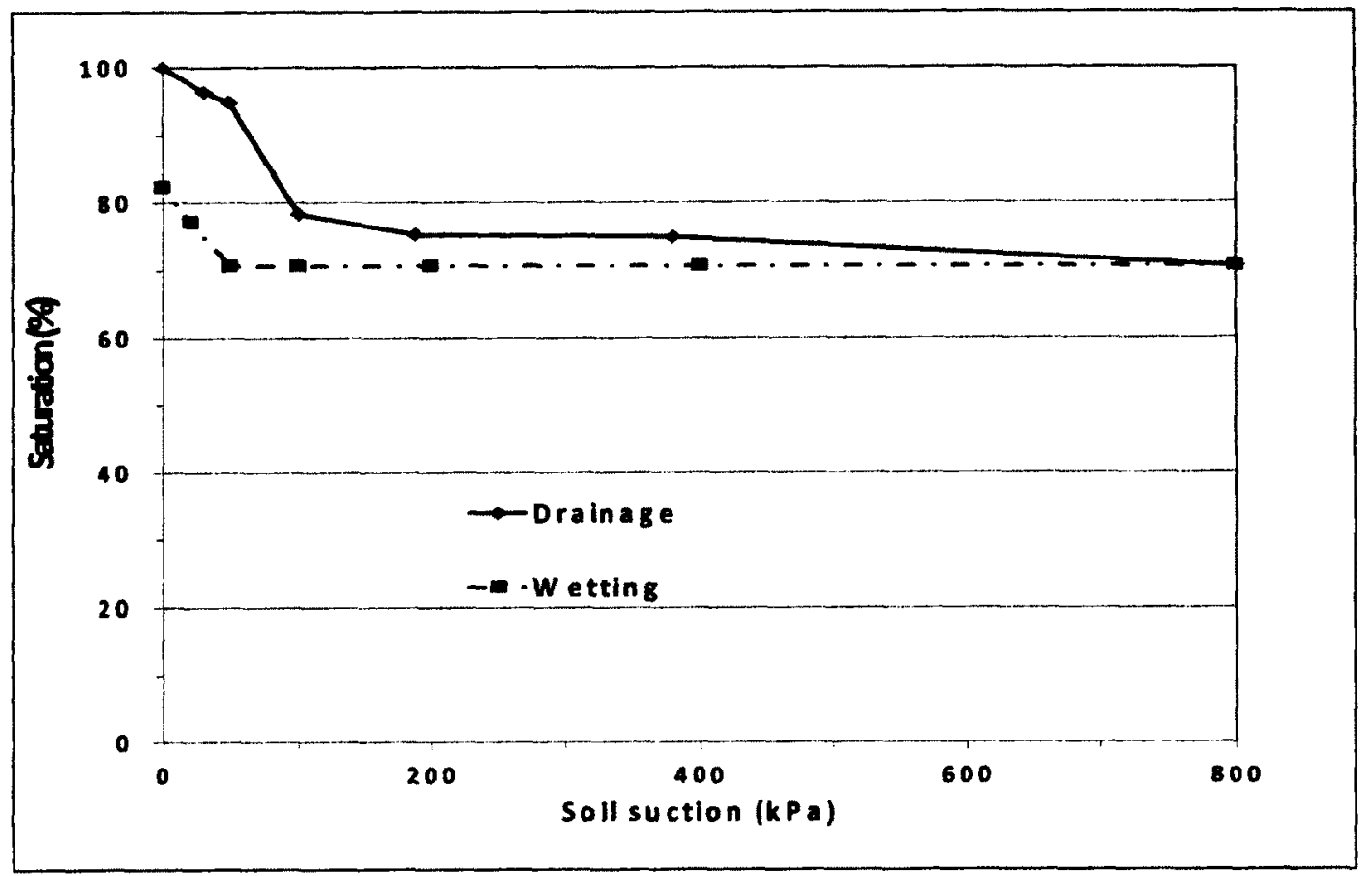

Figure A5-27: Saturation-suction curve for oil sand tailings, $w_{i}=126.9 \%$, with polymer, mixed sample

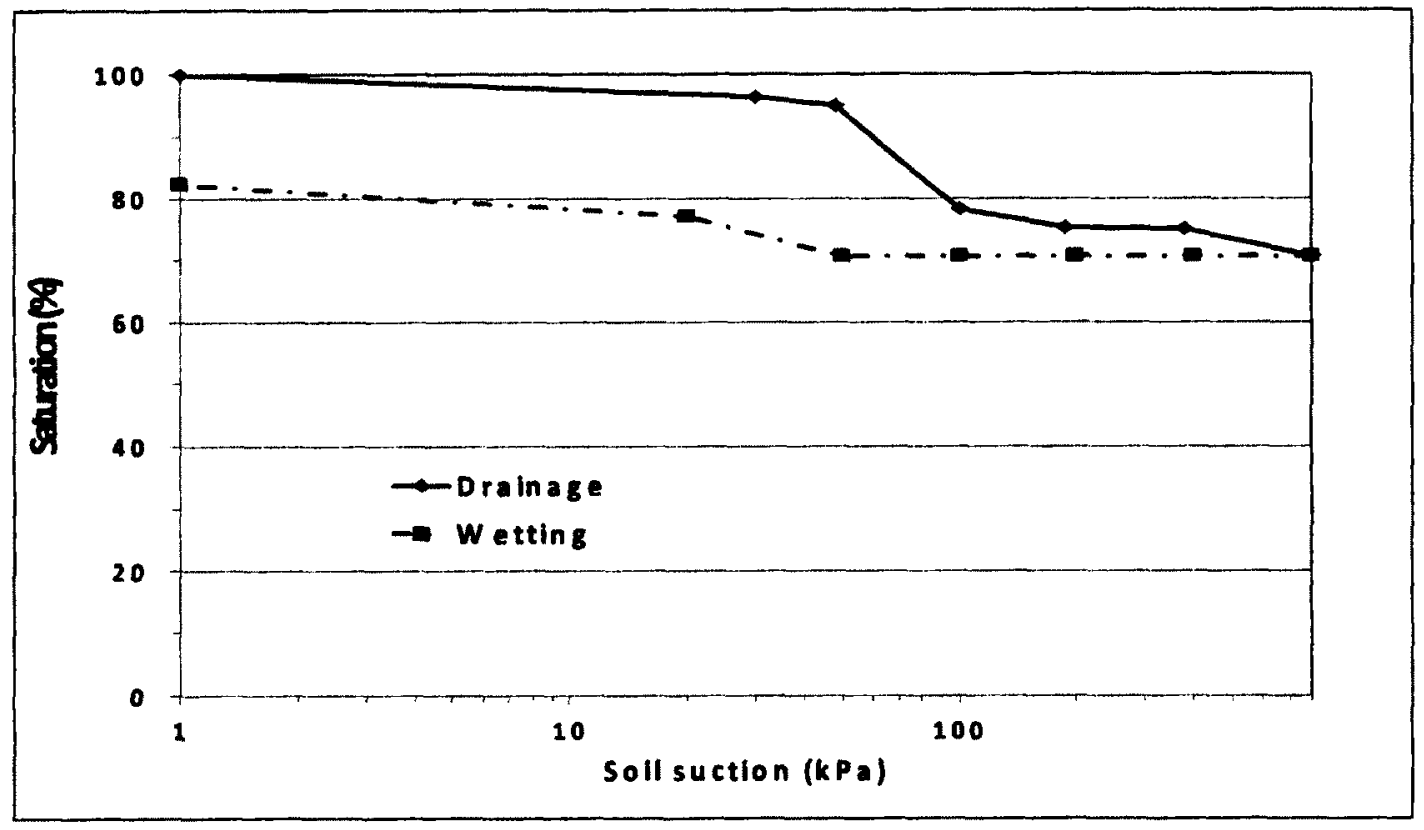

Figure A5-28: Saturation-suction curve for oil sand tailings, $w_{i}=126.9 \%$, with polymer, mixed sample, log scale 


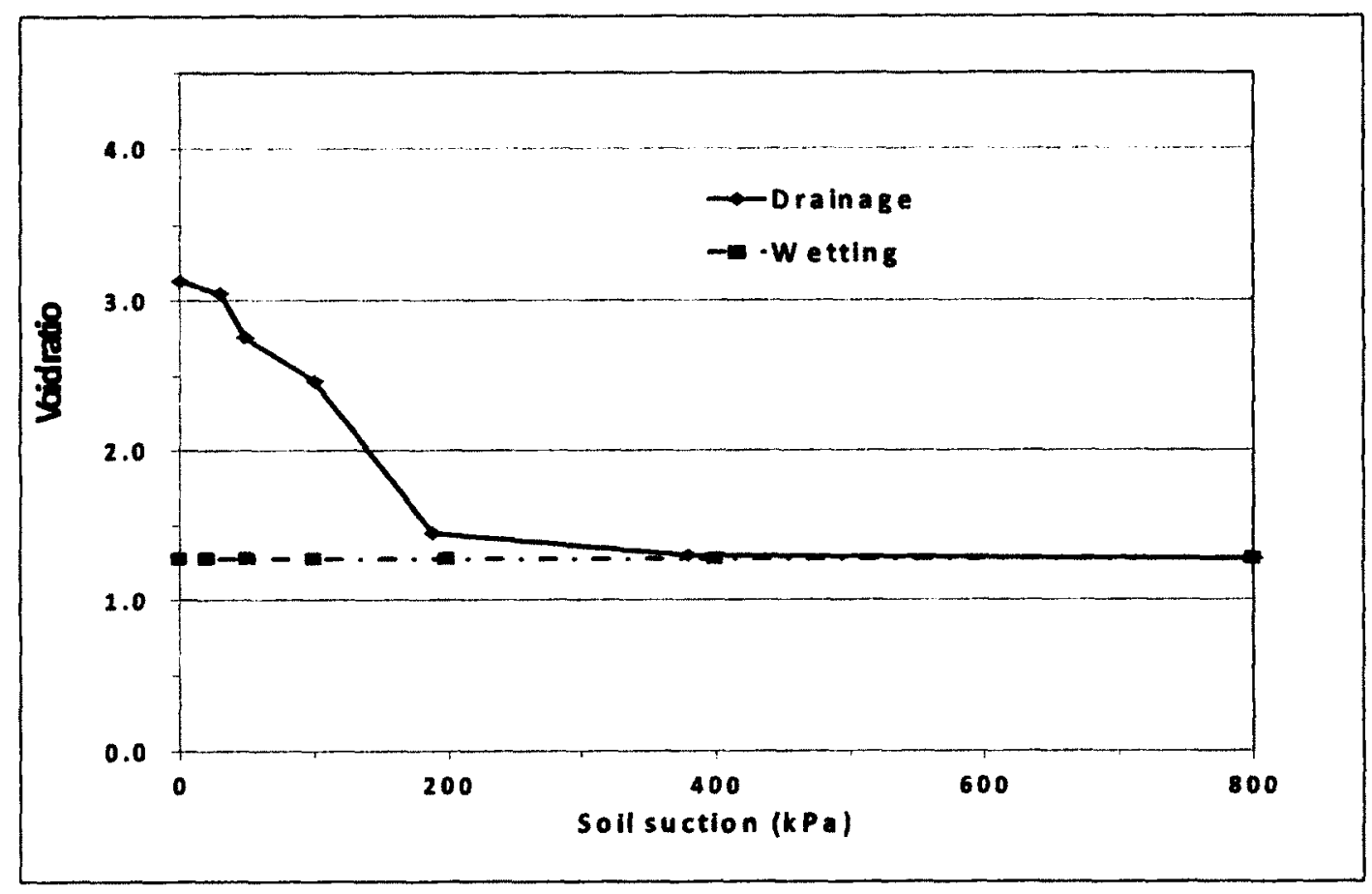

Figure A5-29: Void ratio-suction curve for oil sand tailings, $w_{i}=126.9 \%$, with polymer, mixed sample

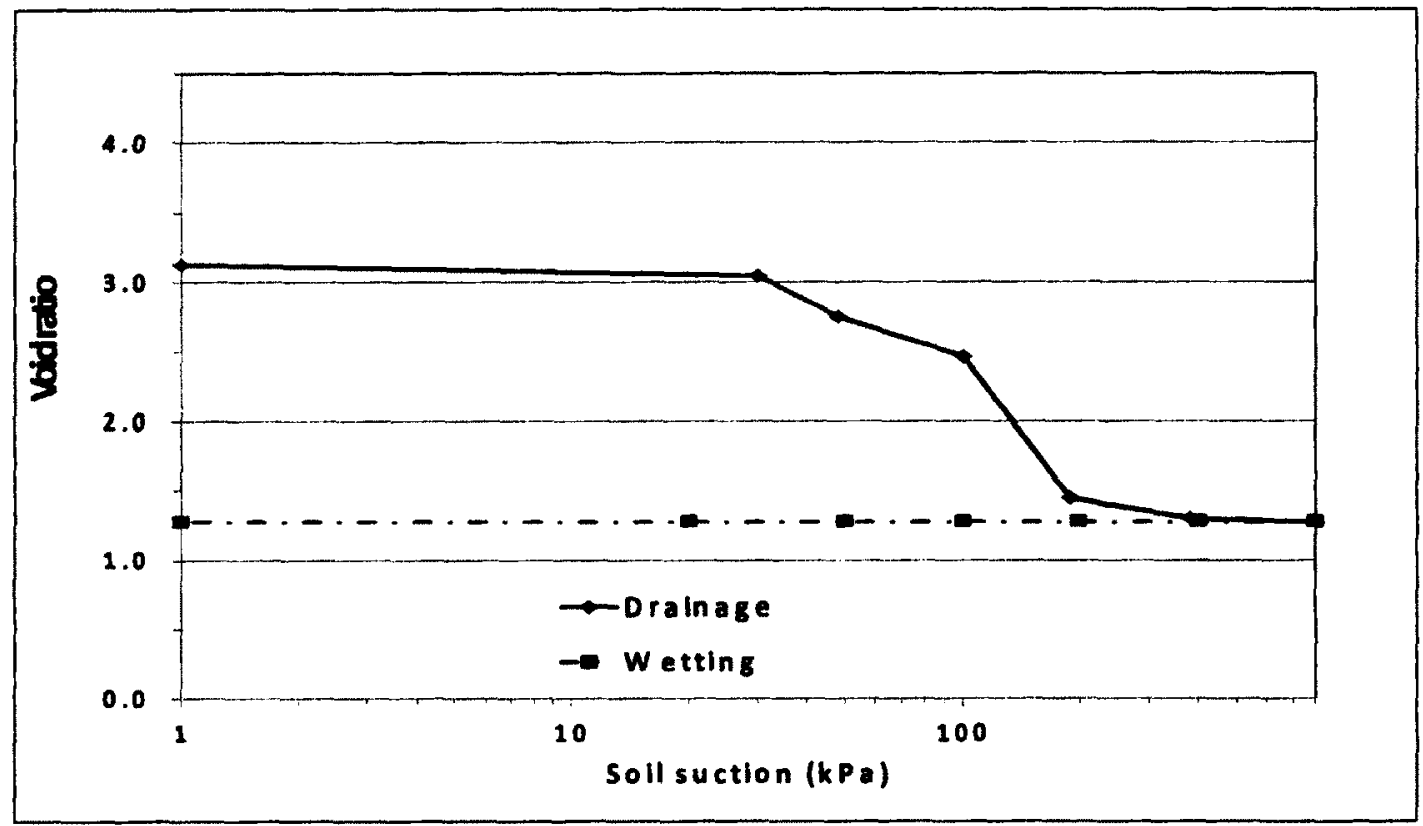

Figure A5-30: Void ratio-suction curve for oil sand tailings, $\mathrm{w}_{\mathrm{i}}=126.9 \%$, with polymer, mixed sample, log scale 


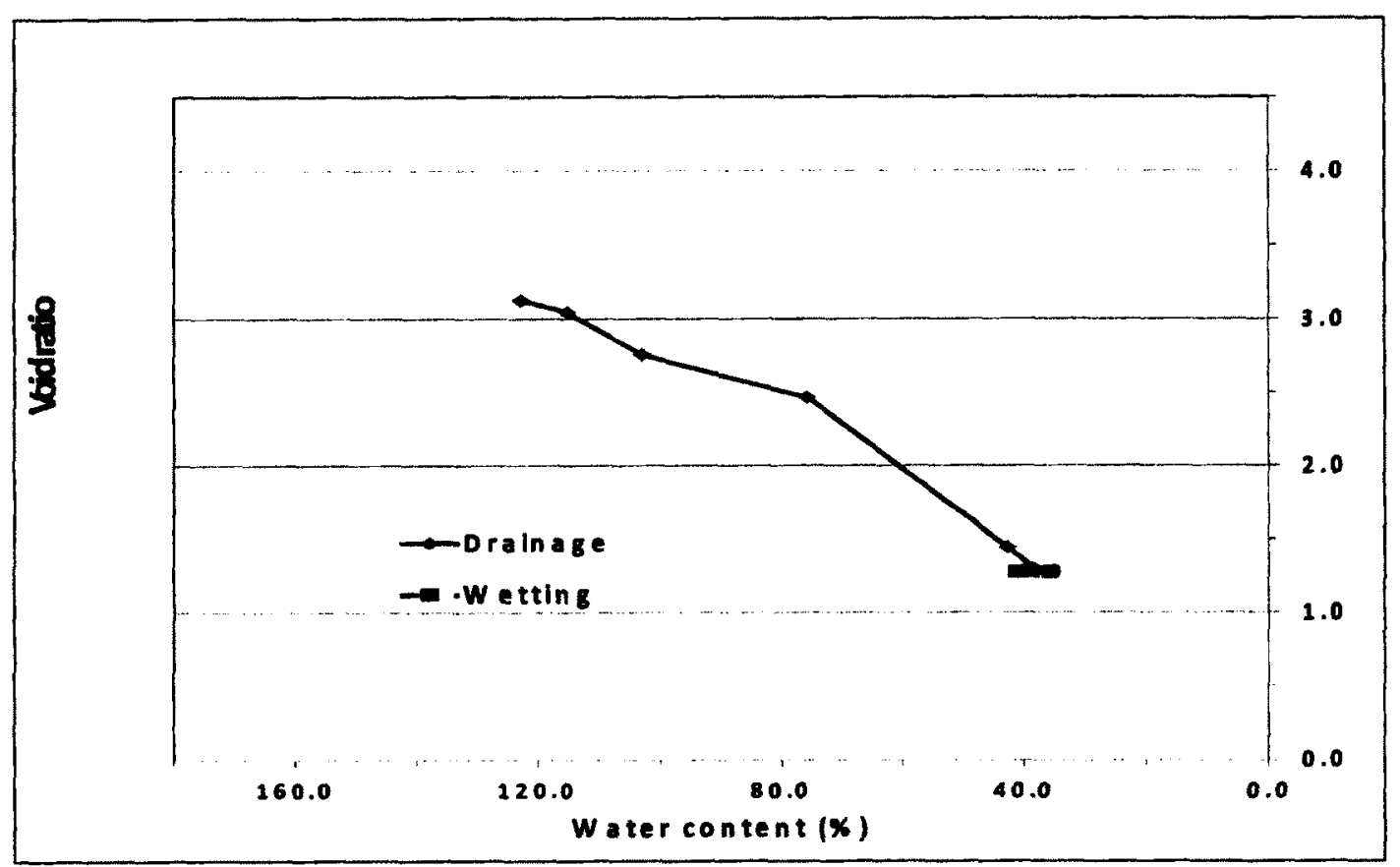

Figure A5-31: Shrinkage curve for oil sand tailings, $w_{i}=126.9 \%$, with polymer, mixed sample

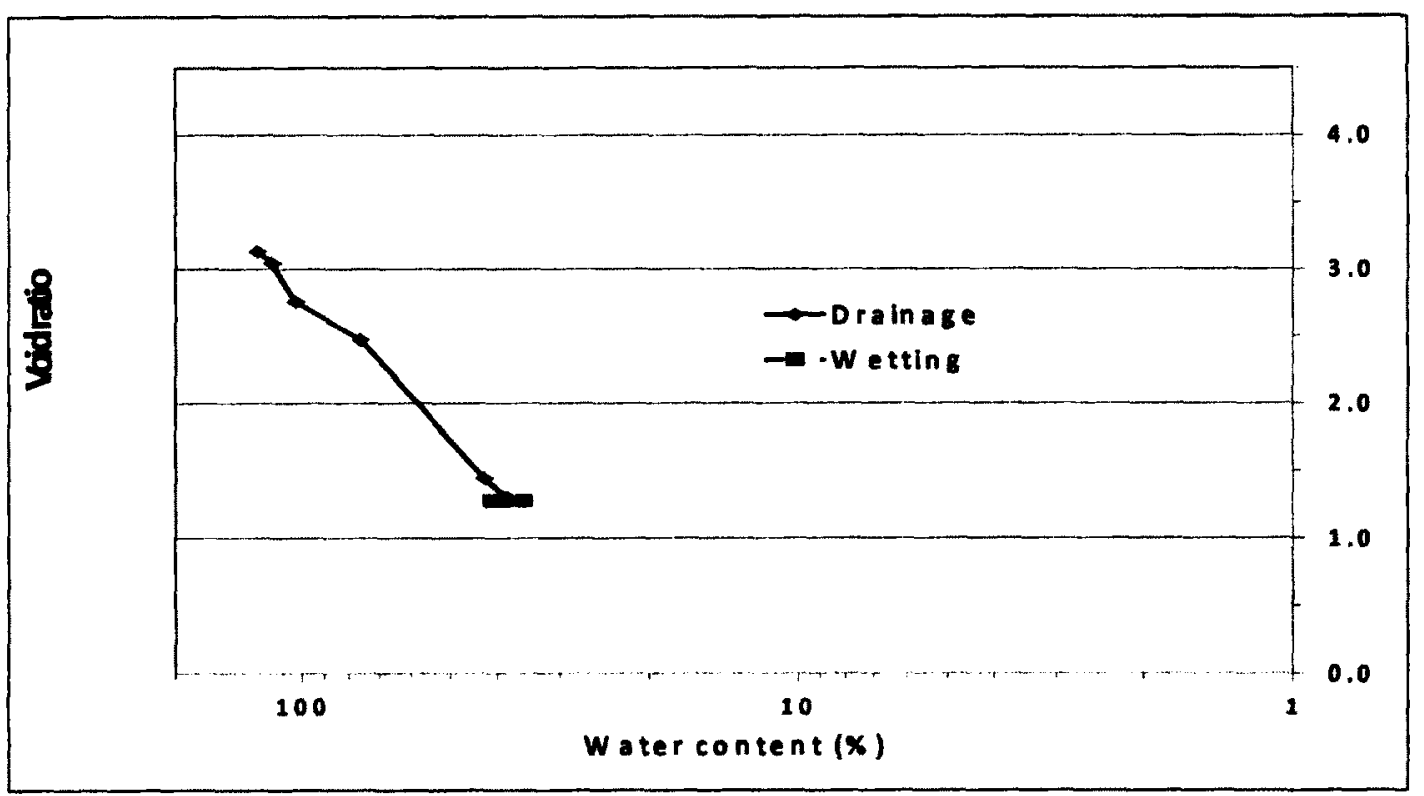

Figure A5-32: Shrinkage curve for oil sand tailings, $\mathrm{w}_{\mathrm{i}}=126.9 \%$, with polymer, mixed sample, log scale 
Table A5-18: Effect of suction on water content for gold mine tailings, wi $=126.9 \%$

\begin{tabular}{|c|c|c|c|c|c|c|c|c|c|c|c|c|c|}
\hline \multirow{2}{*}{$\begin{array}{c}\text { Suction } \\
\text { (kPa) }\end{array}$} & \multirow{2}{*}{$\begin{array}{c}\text { soll } \\
\text { welght } \\
\text { (g) }\end{array}$} & \multirow{2}{*}{$\begin{array}{l}\text { water } \\
\text { weight } \\
\text { (B) }\end{array}$} & \multirow{2}{*}{$\begin{array}{c}\text { Initial total } \\
\text { weight } \\
\text { (g) }\end{array}$} & \multirow{2}{*}{$\begin{array}{l}\text { final total } \\
\text { weight } \\
\text { (g) }\end{array}$} & \multirow{2}{*}{$\begin{array}{l}\text { water } \\
\text { out } \\
\text { (g) }\end{array}$} & \multirow{2}{*}{$\begin{array}{l}\text { water in } \\
\text { the unit } \\
\text { (g) }\end{array}$} & \multirow{2}{*}{$\begin{array}{c}\text { Water } \\
\text { content } \\
\text { (\%) }\end{array}$} & \multicolumn{2}{|c|}{ initial soils } & \multicolumn{2}{|c|}{ finalsoils } & \multicolumn{2}{|c|}{ change in solls ${ }^{\prime}$} \\
\hline & & & & & & & & $\begin{array}{l}\text { height } \\
\text { (mm) }\end{array}$ & $\begin{array}{l}\text { volume } \\
\text { (cm3) }\end{array}$ & $\begin{array}{l}\text { height } \\
\text { (mm) }\end{array}$ & $\begin{array}{l}\text { volume } \\
\text { (cm3) }\end{array}$ & $\begin{array}{l}\text { height } \\
(\mathrm{mm})\end{array}$ & $\begin{array}{c}\text { volume } \\
(\%)\end{array}$ \\
\hline 0 & 367.9 & 96.2 & 3807.8 & 3807.8 & 0.0 & 96.2 & 26.1 & 17.7 & 223.1 & 17.7 & 223.1 & 0.0 & 0.0 \\
\hline 0 & 367.9 & 96.2 & 3807.8 & 3807.8 & 0.0 & 96.2 & 26.1 & 17.7 & 223.1 & 17.7 & 223.1 & 0.0 & 0.0 \\
\hline 22 & 367.9 & 96.2 & 3807.8 & 3786.0 & 21.8 & 74.4 & 20.2 & 17.7 & 223.1 & 17.0 & 207.1 & 0.7 & 7.1 \\
\hline 50 & 367.9 & 74.4 & 3786.0 & 3781.3 & 4.7 & 69.7 & 18.9 & 17.0 & 207.1 & 17.0 & 206.7 & 0.0 & 0.2 \\
\hline 101 & 367.9 & 69.7 & 3781.3 & 3775.7 & 5.6 & 64.1 & 17.4 & 17.0 & 206.7 & 17.0 & 206.7 & 0.0 & 0.0 \\
\hline 201 & 367.9 & 64.1 & 3775.7 & 3757.9 & 17.8 & 46.3 & 12.6 & 17.0 & 206.7 & 17.0 & 206.2 & 0.0 & 0.2 \\
\hline 400 & 367.9 & 46.3 & 3757.9 & 3737.0 & 20.9 & 25.4 & 6.9 & 17.0 & 206.2 & 17.0 & 205.2 & 0.0 & 0.5 \\
\hline 208 & 367.9 & 25.4 & 3737.0 & 3740.3 & -3.3 & 28.7 & 7.8 & 17.0 & 205.2 & 17.0 & 205.2 & 0.0 & 0.0 \\
\hline 100 & 367.9 & 28.7 & 3740.3 & 3750.4 & -10.1 & 38.8 & 10.5 & 17.0 & 205.2 & 17.0 & 205.2 & 0.0 & 0.0 \\
\hline 48 & 367.9 & 38.8 & 3750.4 & 3763.2 & -12.8 & 51.6 & 14.0 & 17.0 & 205.2 & 17.0 & 205.2 & 0.0 & 0.0 \\
\hline 17 & 367.9 & 51.6 & 3763.2 & 3775.0 & -11.8 & 63.4 & 17.2 & 17.0 & 205.2 & 17.0 & 205.2 & 0.0 & 0.0 \\
\hline 0 & 367.9 & 63.4 & 3775.0 & 3779.9 & -4.9 & 68.3 & 18.6 & 17.0 & 205.2 & 17.0 & 205.2 & 0.0 & 0.0 \\
\hline 19 & 367.9 & 68.3 & 3779.9 & 3777.9 & 2.0 & 66.3 & 18.0 & 17.0 & 205.2 & 17.0 & 205.2 & 0.0 & 0.0 \\
\hline 50 & 367.9 & 66.3 & 3777.9 & 3776.7 & 1.2 & 65.1 & 17.7 & 17.0 & 205.2 & 17.0 & 205.2 & 0.0 & 0.0 \\
\hline 100 & 367.9 & 65.1 & 3776.7 & 3772.5 & 4.2 & 60.9 & 16.6 & 17.0 & 205.2 & 17.0 & 205.2 & 0.0 & 0.0 \\
\hline 204 & 367.9 & 60.9 & 3772.5 & 3750.1 & 22.4 & 38.5 & 10.5 & 17.0 & 205.2 & 17.0 & 205.2 & 0.0 & 0.0 \\
\hline 100 & 367.9 & 38.5 & 3750.1 & 3755.4 & -5.3 & 43.8 & 11.9 & 17.0 & 205.2 & 17.0 & 205.2 & 0.0 & 0.0 \\
\hline 52 & 367.9 & 43.8 & 3755.4 & 3762.2 & -6.8 & 50.6 & 13.8 & 17.0 & 205.2 & 17.0 & 205.2 & 0.0 & 0.0 \\
\hline 19 & 367.9 & 50.6 & 3762.2 & 3772.9 & -10.7 & 61.3 & 16.7 & 17.0 & 205.2 & 17.0 & 205.2 & 0.0 & 0.0 \\
\hline 0 & 367.9 & 61.3 & 3772.9 & 3779.4 & -6.5 & 67.8 & 18.4 & 17.0 & 205.2 & 17.0 & 205.2 & 0.0 & 0.0 \\
\hline
\end{tabular}

Table A5-19: Effect of suction on saturation for gold mine tailings, wi $=126.9 \%$

\begin{tabular}{|c|c|c|c|c|c|}
\hline $\begin{array}{c}\text { Suction } \\
(k P a)\end{array}$ & $\begin{array}{c}\text { Total } \\
\text { volum e } \\
(C \mathrm{Cm} 3)\end{array}$ & $\begin{array}{c}\text { Volume of } \\
\text { void } \\
\left(\begin{array}{ccc}c & 3\end{array}\right)\end{array}$ & $\begin{array}{l}\text { Void } \\
\text { ratio }\end{array}$ & $\begin{array}{c}\text { Volume of } \\
w \text { ater } \\
\left(\begin{array}{ccc}\text { ( } 3)\end{array}\right)\end{array}$ & $\begin{array}{c}\text { Saturation } \\
(\%)\end{array}$ \\
\hline 0 & 223.1 & 96.2 & 0.76 & 96.2 & 100.0 \\
\hline 0 & 223.1 & 96.2 & 0.76 & 96.2 & 100.0 \\
\hline 22 & 207.1 & 80.3 & 0.63 & 74.4 & 92.7 \\
\hline 50 & 206.7 & 79.8 & 0.63 & 69.7 & 87.4 \\
\hline 101 & 206.7 & 79.8 & 0.63 & 64.1 & 80.3 \\
\hline 201 & 206.2 & 79.3 & 0.63 & 46.3 & 58.4 \\
\hline 400 & 205.2 & 78.4 & 0.62 & 25.4 & 32.4 \\
\hline 208 & 205.2 & 78.4 & 0.62 & 28.7 & 36.6 \\
\hline 100 & 205.2 & 78.4 & 0.62 & 38.8 & 49.5 \\
\hline 48 & 205.2 & 78.4 & 0.62 & 51.6 & 65.8 \\
\hline 17 & 205.2 & 78.4 & 0.62 & 63.4 & 80.9 \\
\hline 0 & 205.2 & 78.4 & 0.62 & 68.3 & 87.2 \\
\hline 19 & 205.2 & 78.4 & 0.62 & 66.3 & 84.6 \\
\hline 50 & 205.2 & 78.4 & 0.62 & 65.1 & 83.1 \\
\hline 100 & 205.2 & 78.4 & 0.62 & 60.9 & 77.7 \\
\hline 204 & 205.2 & 78.4 & 0.62 & 38.5 & 49.1 \\
\hline 100 & 205.2 & 78.4 & 0.62 & 43.8 & 55.9 \\
\hline 52 & 205.2 & 78.4 & 0.62 & 50.6 & 64.6 \\
\hline 19 & 205.2 & 78.4 & 0.62 & 61.3 & 78.2 \\
\hline 0 & 205.2 & 78.4 & 0.62 & 67.8 & 86.5 \\
\hline
\end{tabular}




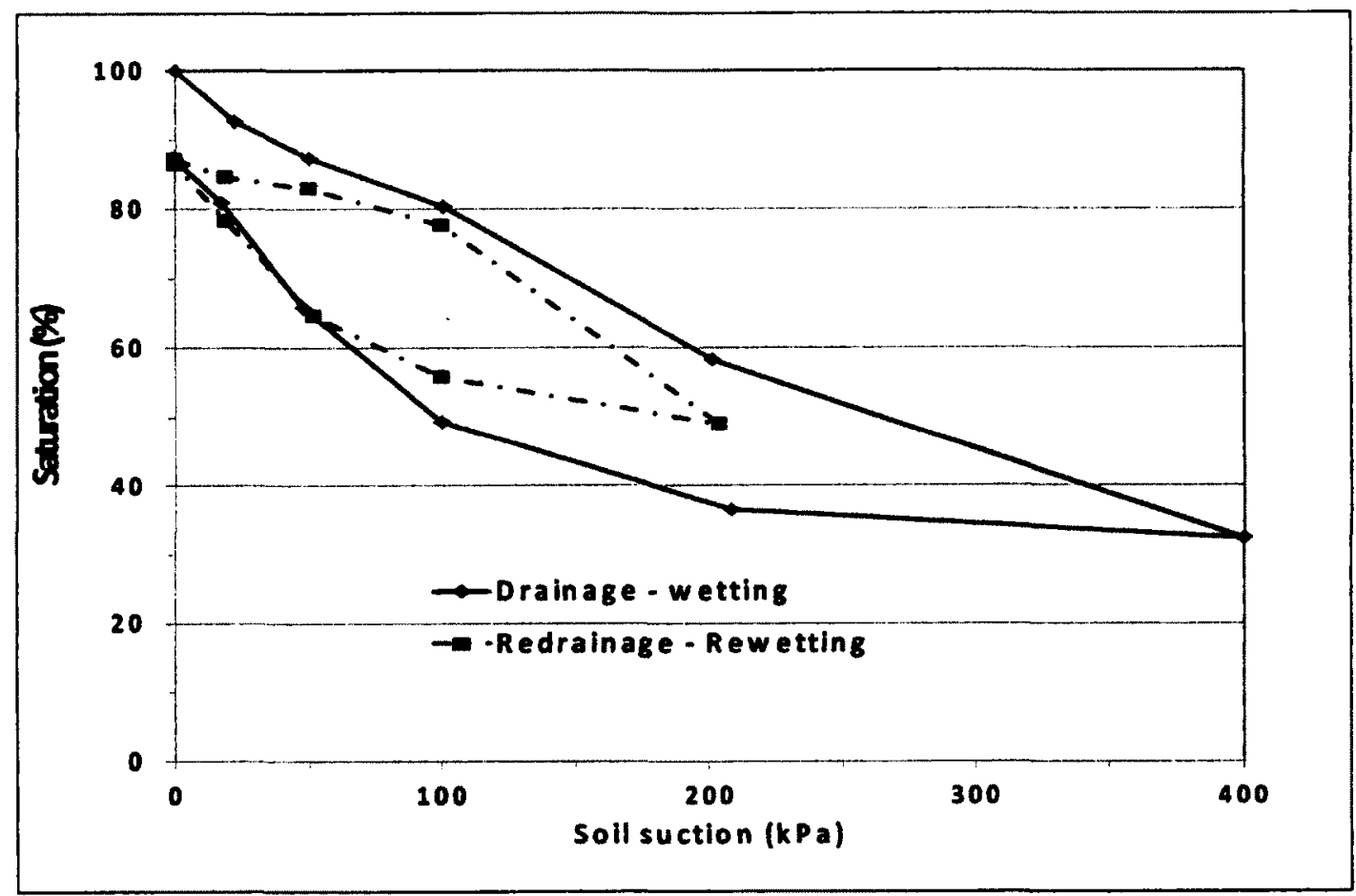

Figure A5-33: Saturation-suction curve for gold mine tailings, $w_{\mathrm{i}}=26.1 \%$

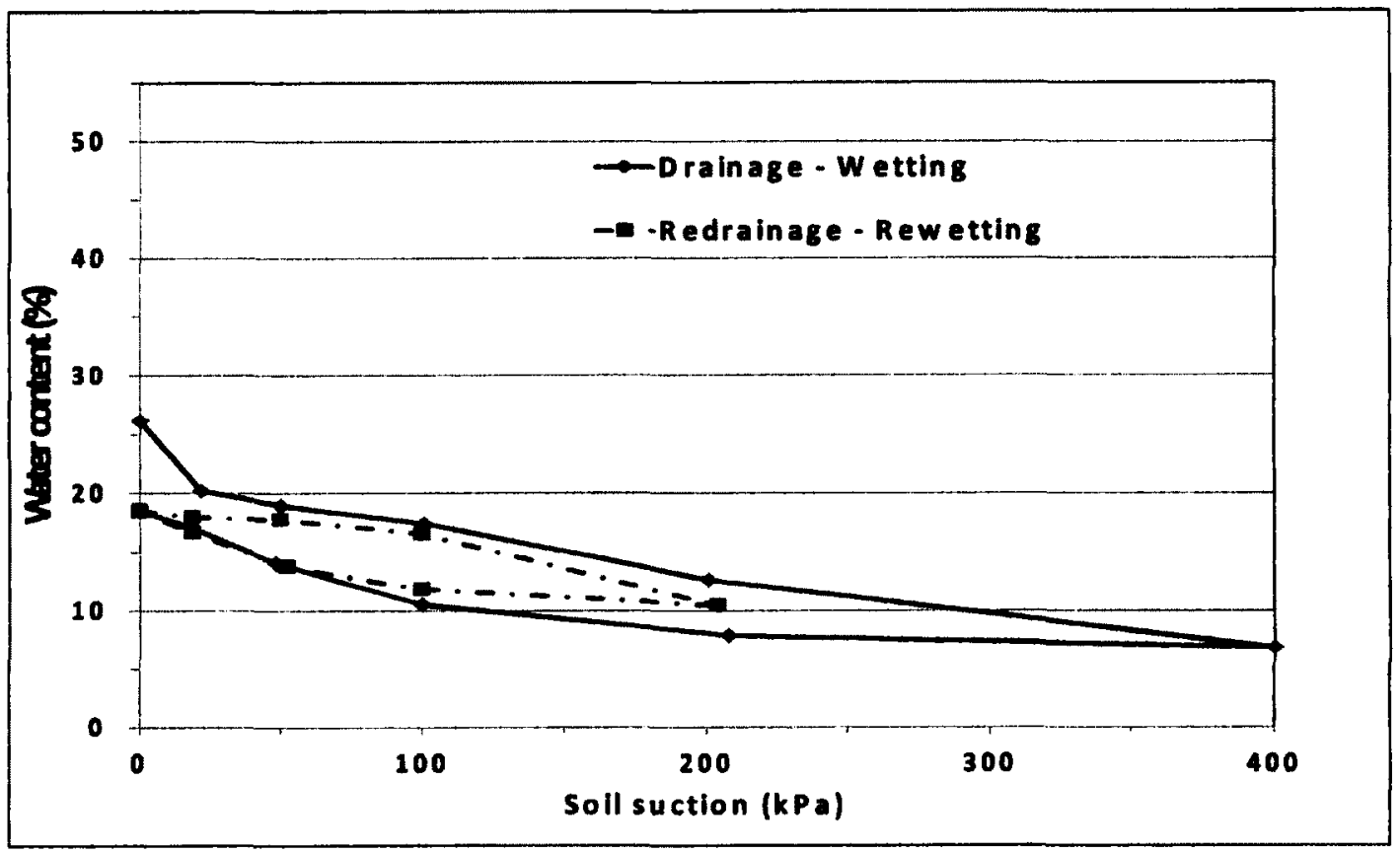

Figure A5-34: Water content-suction curve for gold mine tailings, $\mathrm{w}_{\mathrm{i}}=26.1 \%$ 
Table A5-20: Effect of suction on water content for gold mine tailings, wi $=33.2 \%$

\begin{tabular}{|c|c|c|c|c|c|c|c|c|c|c|c|c|c|}
\hline \multirow{2}{*}{$\begin{array}{l}\text { Suction } \\
\text { (kPa) }\end{array}$} & \multirow{2}{*}{$\begin{array}{c}\text { soil } \\
\text { weight } \\
\text { (g) }\end{array}$} & \multirow{2}{*}{$\begin{array}{l}\text { water } \\
\text { weight } \\
\text { (g) }\end{array}$} & \multirow{2}{*}{$\begin{array}{l}\text { Initial total } \\
\text { weight } \\
\text { (B) }\end{array}$} & \multirow{2}{*}{$\begin{array}{c}\text { final total } \\
\text { weight } \\
\text { (g) }\end{array}$} & \multirow{2}{*}{$\begin{array}{c}\text { water } \\
\text { out } \\
\text { (g) }\end{array}$} & \multirow{2}{*}{$\begin{array}{c}\text { water in } \\
\text { the unit } \\
\text { (g) }\end{array}$} & \multirow{2}{*}{$\begin{array}{c}\text { Water } \\
\text { content } \\
(\%)\end{array}$} & \multicolumn{2}{|c|}{ initial soils' } & \multicolumn{2}{|c|}{ final soils' } & \multicolumn{2}{|c|}{ change in solls' } \\
\hline & & & & & & & & $\begin{array}{l}\text { height } \\
\text { (mm) }\end{array}$ & $\begin{array}{c}\text { volume } \\
\text { (cm3) }\end{array}$ & $\begin{array}{l}\text { height } \\
\text { (mm) }\end{array}$ & $\begin{array}{c}\text { volume } \\
(\mathrm{cm} 3)\end{array}$ & $\begin{array}{l}\text { height } \\
\text { (mm) }\end{array}$ & $\begin{array}{c}\text { volume } \\
\text { (\%) }\end{array}$ \\
\hline 0 & 273.9 & 90.9 & 3709.0 & 3709.0 & 0.0 & 90.9 & 33.2 & 14.9 & 185.4 & 14.9 & 185.4 & 0.0 & 0.0 \\
\hline 0 & 273.9 & 90.9 & 3709.0 & 3699.9 & 9.1 & 81.8 & 29.9 & 14.9 & 185.4 & 14.2 & 176.3 & 0.7 & 4.9 \\
\hline 19 & 273.9 & 81.8 & 3699.9 & 3675.4 & 24.5 & 57.3 & 20.9 & 14.2 & 176.3 & 12.5 & 153.9 & 1.7 & 12.7 \\
\hline 52 & 273.9 & 57.3 & 3675.4 & 3670.6 & 4.8 & 52.5 & 19.2 & 12.5 & 153.9 & 12.5 & 153.1 & 0.0 & 0.5 \\
\hline 100 & 273.9 & 52.5 & 3670.6 & 3663.1 & 7.5 & 45.0 & 16.4 & 12.5 & 153.1 & 12.5 & 152.5 & 0.0 & 0.4 \\
\hline 200 & 273.9 & 45.0 & 3663.1 & 3642.3 & 20.8 & 24.2 & 8.8 & 12.5 & 152.5 & 12.5 & 152.1 & 0.0 & 0.3 \\
\hline 398 & 273.9 & 24.2 & 3642.3 & 3635.6 & 6.7 & 17.5 & 6.4 & 12.5 & 152.1 & 12.5 & 151.8 & 0.0 & 0.2 \\
\hline 200 & 273.9 & 17.5 & 3635.6 & 3637.2 & -1.6 & 19.1 & 7.0 & 12.5 & 151.8 & 12.5 & 151.8 & 0.0 & 0.0 \\
\hline 98 & 273.9 & 19.1 & 3637.2 & 3643.6 & -6.4 & 25.5 & 9.3 & 12.5 & 151.8 & 12.5 & 151.8 & 0.0 & 0.0 \\
\hline 49 & 273.9 & 25.5 & 3643.6 & 3653.2 & -9.6 & 35.1 & 12.8 & 12.5 & 151.8 & 12.5 & 151.8 & 0.0 & 0.0 \\
\hline 20 & 273.9 & 35.1 & 3653.2 & 3663.9 & -10.7 & 45.8 & 16.7 & 12.5 & 151.8 & 12.5 & 151.8 & 0.0 & 0.0 \\
\hline 0 & 273.9 & 45.8 & 3663.9 & 3671.2 & -7.3 & 53.1 & 19.4 & 12.5 & 151.8 & 12.5 & 151.8 & 0.0 & 0.0 \\
\hline 45 & 273.9 & 53.1 & 3671.2 & 3667.8 & 3.4 & 49.7 & 18.1 & 12.5 & 151.8 & 12.5 & 151.8 & 0.0 & 0.0 \\
\hline 102 & 273.9 & 49.7 & 3667.8 & 3657.9 & 9.9 & 39.8 & 14.5 & 12.5 & 151.8 & 12.5 & 151.8 & 0.0 & 0.0 \\
\hline 200 & 273.9 & 39.8 & 3657.9 & 3640.8 & 17.1 & 22.7 & 8.3 & 12.5 & 151.8 & 12.5 & 151.8 & 0.0 & 0.0 \\
\hline 99 & 273.9 & 22.7 & 3640.8 & 3645.0 & -4.2 & 26.9 & 9.8 & 12.5 & 151.8 & 12.5 & 151.8 & 0.0 & 0.0 \\
\hline 49 & 273.9 & 26.9 & 3645.0 & 3652.9 & -7.9 & 34.8 & 12.7 & 12.5 & 151.8 & 12.5 & 151.8 & 0.0 & 0.0 \\
\hline 0 & 273.9 & 34.8 & 3652.9 & 3669.1 & -16.2 & 51.0 & 18.6 & 12.5 & 151.8 & 12.5 & 151.8 & 0.0 & 0.0 \\
\hline
\end{tabular}

Table A5-21: Effect of suction on saturation for gold mine tailings, wi $=33.2 \%$

\begin{tabular}{|c|c|c|c|c|c|}
\hline Suction & $\begin{array}{c}\text { Total } \\
\text { volume } \\
(\mathrm{kPa})\end{array}$ & $\begin{array}{c}\text { Volume of } \\
\text { void } \\
(\mathrm{Cm} 3)\end{array}$ & $\begin{array}{c}\text { Void } \\
\text { ratio }\end{array}$ & $\begin{array}{c}\text { Volume of } \\
\text { Water } \\
(\mathrm{Cm} 3)\end{array}$ & Saturation \\
\hline 0 & 185.4 & 90.9 & 0.96 & 90.9 & 100.0 \\
\hline 0 & 176.3 & 81.8 & 0.87 & 81.8 & 100.0 \\
\hline 19 & 153.9 & 59.4 & 0.63 & 57.3 & 96.4 \\
\hline 52 & 153.1 & 58.6 & 0.62 & 52.5 & 89.6 \\
\hline 100 & 152.5 & 58.0 & 0.61 & 45.0 & 77.6 \\
\hline 200 & 152.1 & 57.6 & 0.61 & 24.2 & 42.0 \\
\hline 398 & 151.8 & 57.3 & 0.61 & 17.5 & 30.5 \\
\hline 200 & 151.8 & 57.3 & 0.61 & 19.1 & 33.3 \\
\hline 98 & 151.8 & 57.3 & 0.61 & 25.5 & 44.5 \\
\hline 49 & 151.8 & 57.3 & 0.61 & 35.1 & 61.2 \\
\hline 20 & 151.8 & 57.3 & 0.61 & 45.8 & 79.9 \\
\hline 0 & 151.8 & 57.3 & 0.61 & 53.1 & 92.6 \\
\hline 45 & 151.8 & 57.3 & 0.61 & 49.7 & 86.7 \\
\hline 102 & 151.8 & 57.3 & 0.61 & 39.8 & 69.4 \\
\hline 200 & 151.8 & 57.3 & 0.61 & 22.7 & 39.6 \\
\hline 99 & 151.8 & 57.3 & 0.61 & 26.9 & 46.9 \\
\hline 49 & 151.8 & 57.3 & 0.61 & 34.8 & 60.7 \\
\hline 0 & 151.8 & 57.3 & 0.61 & 51.0 & 89.0 \\
\hline & & & & & \\
\hline
\end{tabular}




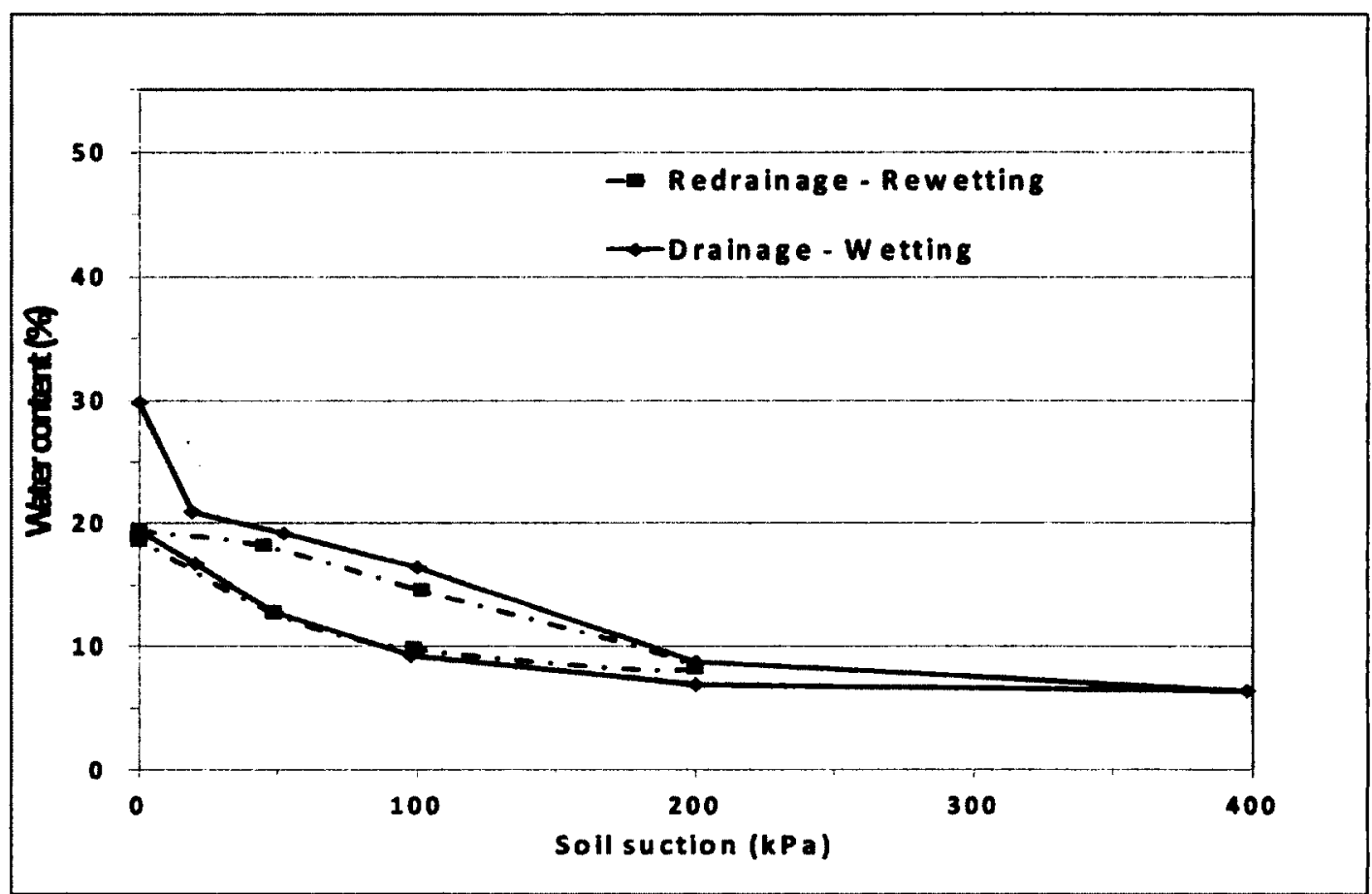

Figure A5-35: Water content-suction curve for gold mine tailings, $w_{i}=33.2 \%$

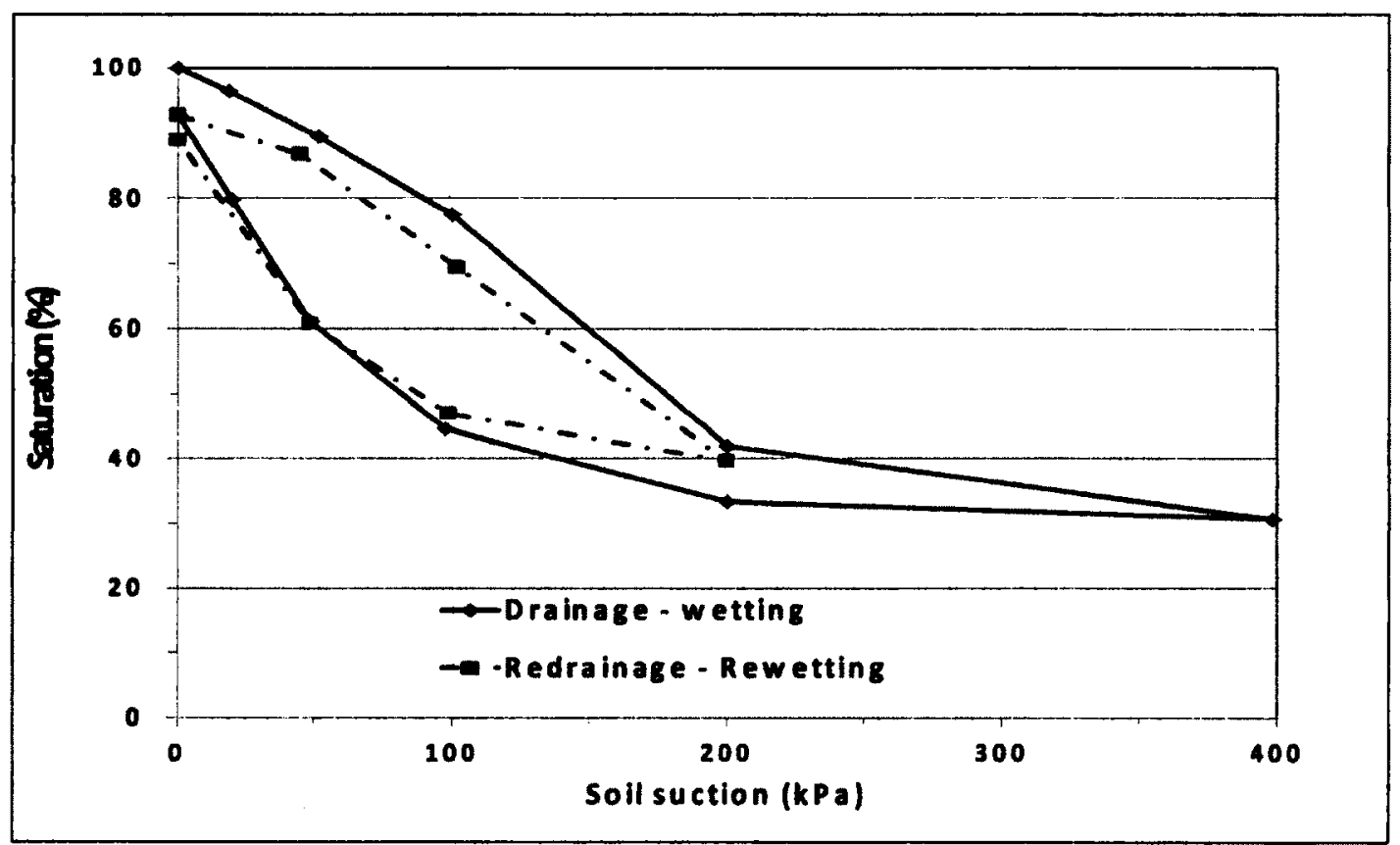

Figure A5-35: Saturation-suction curve for gold mine tailings, $w_{i}=33.2 \%$ 
Table A5-22: Effect of suction on water content for gold mine tailings, wi $=40.7 \%$

\begin{tabular}{|c|c|c|c|c|c|c|c|c|c|c|c|c|c|}
\hline \multirow{2}{*}{$\begin{array}{l}\text { Surtia } \\
\text { (198) }\end{array}$} & \multirow{2}{*}{$\begin{array}{c}\text { sd } \\
\text { weid } \\
\text { led }\end{array}$} & \multirow{2}{*}{$\begin{array}{l}\text { ude } \\
\text { vedf } \\
\text { lid }\end{array}$} & \multirow{2}{*}{$\begin{array}{l}\text { Inid tod } \\
\text { veigt } \\
\text { ld }\end{array}$} & \multirow{2}{*}{$\begin{array}{c}\text { firdtod } \\
\text { vedit } \\
\text { de }\end{array}$} & \multirow{2}{*}{$\begin{array}{c}\text { uate } \\
\text { al } \\
\text { (a) }\end{array}$} & \multirow{2}{*}{$\begin{array}{c}\text { utain } \\
\text { teuril } \\
\text { (d) }\end{array}$} & \multirow{2}{*}{ 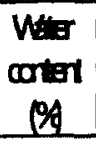 } & \multicolumn{2}{|c|}{ inidats sals } & \multicolumn{2}{|c|}{ fritsols } & \multicolumn{2}{|c|}{ derginsots } \\
\hline & & & & & & & & $\begin{array}{l}\text { redt } \\
\text { (mil) }\end{array}$ & $\begin{array}{l}\text { volue } \\
\text { (and }\end{array}$ & $\begin{array}{l}\text { hidit } \\
\text { (nd) }\end{array}$ & $\begin{array}{l}\text { vodm } \\
\text { (ord }\end{array}$ & $\begin{array}{l}\text { reit) } \\
\text { (m) }\end{array}$ & vam \\
\hline & & & & & & & & & & & & & \\
\hline C & $288 E$ & 10.6 & $350^{2}$ & $3 \times 3 n ?$ & $\alpha$ & $177 . \epsilon$ & $40 ;$ & 172 & 20.2 & 12 & 210.2 & $\alpha$ & $a C$ \\
\hline$C$ & 288 & $10 . \epsilon$ & $3750^{2}$ & 37325 & $\overline{17 \mathcal{E}}$ & $\overline{9 \varepsilon}$ & $34 \epsilon$ & 172 & 202 & $15 \mathrm{c}$ & 194 & 14 & 82 \\
\hline$\underline{z}$ & $28 B$ & 98 & $3 / 325$ & 3067 & 35 & $64 C$ & 22 & $15 \mathrm{C}$ & 1924 & $14 C$ & 1091 & $1 c$ & 152 \\
\hline 5 & $288 E$ & GAC & $396 i$ & $3 \operatorname{coc}$ & 47 & $59^{2}$ & $2 \mathbf{2 x}^{x}$ & $14 C$ & 1921 & $14 C$ & $1 \sigma .6$ & $\alpha$ & $\alpha c$ \\
\hline $\bar{x}$ & ZRE & 592 & 3 & $302 A$ & 96 & 497 & 1.2 & $14 C$ & 15.6 & $14 C$ & $106 t$ & $\alpha$ & aE \\
\hline$\underline{x}$ & 28BE & 497 & 3024 & 3022 & 202 & $29^{5}$ & 12 & $1 \mathrm{AC}$ & $166 E$ & $14 C$ & 1654 & $\alpha$ & 02 \\
\hline 40 & 283E & 29 & 322 & $368^{c}$ & 137 & 158 & 5 & $14 C$ & 1664 & $14 C$ & $166 \mathrm{C}$ & $\alpha$ & $a_{2}$ \\
\hline 20 & 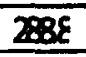 & $15 \varepsilon$ & 3645 & $361 c$ & -34 & 292 & $6 E$ & $14 C$ & $1 \cos$ & $14 C$ & 166 & $a c$ & $\alpha C$ \\
\hline $\boldsymbol{w}$ & 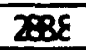 & 192 & $337 \mathrm{C}$ & $30 \mathrm{Ai}$ & $-7 \mathcal{E}$ & $2 x$ & 93 & $14 C$ & $106 \mathrm{C}$ & AC & $166 C$ & $\alpha$ & $\alpha$ \\
\hline 5 & 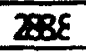 & $Z I C$ & 3ani & $30 \mathrm{~s}$ & $\underline{x}$ & $36 c$ & 25 & $14 C$ & 165 & $14 \mathrm{C}$ & $18 \mathrm{EC}$ & $\alpha$ & $\alpha$ \\
\hline$x$ & $\mathbf{Z B E}$ & $36 C$ & 308 & $3 \cos 1$ & -122 & 482 & 15i & $14 C$ & $166 C$ & $14 C$ & 186 & $\alpha$ & $\alpha$ \\
\hline$C$ & $28 E$ & $48^{2}$ & $3 \sin$ & 30084 & -7.4 & $\overline{5 i}$ & 192 & $1 \mathrm{AC}$ & $106 \mathrm{C}$ & $14 C$ & [6] & $\alpha$ & $Q C$ \\
\hline
\end{tabular}

Table A5-23: Effect of suction on saturation for gold mine tailings, wi=40.7\%

\begin{tabular}{|c|c|c|c|c|c|}
\hline Suction & $\begin{array}{c}\text { Total } \\
\text { volume } \\
(\mathrm{kPa})\end{array}$ & $\begin{array}{c}\text { Volume of } \\
\text { void } \\
(\mathrm{Cm} 3)\end{array}$ & $\begin{array}{c}\text { Void } \\
\text { ratio }\end{array}$ & $\begin{array}{c}\text { Volume of } \\
\text { Water } \\
(\mathrm{Cm} 3)\end{array}$ & $\begin{array}{c}\text { Saturation } \\
(\%)\end{array}$ \\
\hline 0 & 217.2 & 117.6 & 1.18 & 117.6 & 100.0 \\
\hline 0 & 199.4 & 99.8 & 1.00 & 99.8 & 100.0 \\
\hline 23 & 169.1 & 69.5 & 0.70 & 64.0 & 92.0 \\
\hline 50 & 167.6 & 68.0 & 0.68 & 59.3 & 87.2 \\
\hline 100 & 166.6 & 67.1 & 0.67 & 49.7 & 74.1 \\
\hline 200 & 166.4 & 66.8 & 0.67 & 29.5 & 44.2 \\
\hline 400 & 166.0 & 66.4 & 0.67 & 15.8 & 23.8 \\
\hline 201 & 166.0 & 66.4 & 0.67 & 19.2 & 28.9 \\
\hline 102 & 166.0 & 66.4 & 0.67 & 27.0 & 40.6 \\
\hline 52 & 166.0 & 66.4 & 0.67 & 36.0 & 54.2 \\
\hline 20 & 166.0 & 66.4 & 0.67 & 48.3 & 72.7 \\
\hline 0 & 166.1 & 66.5 & 0.67 & 55.7 & 83.7 \\
\hline
\end{tabular}




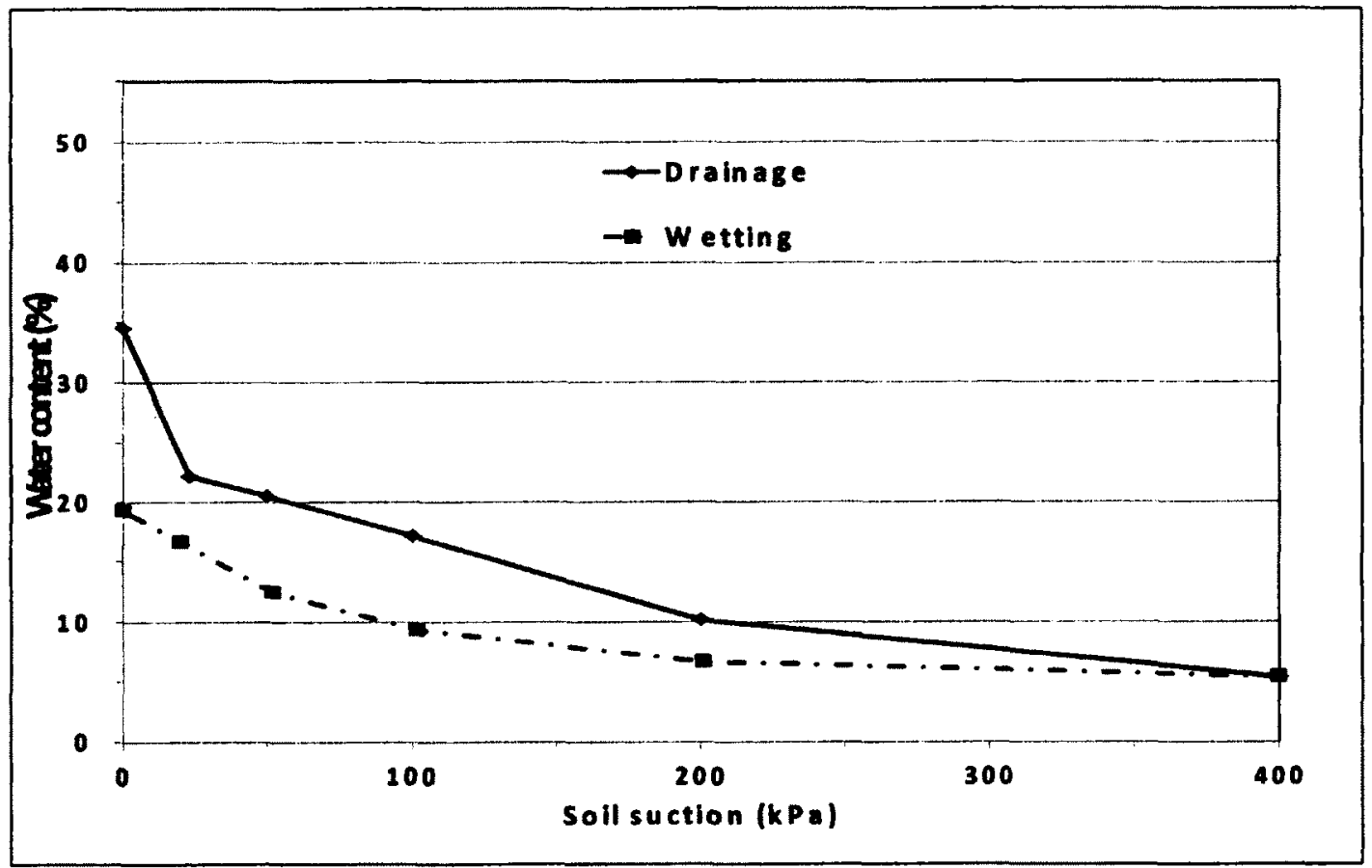

Figure A5-37: Water content-suction curve for gold mine tailings, $\mathrm{w}_{\mathrm{i}}=40.7 \%$

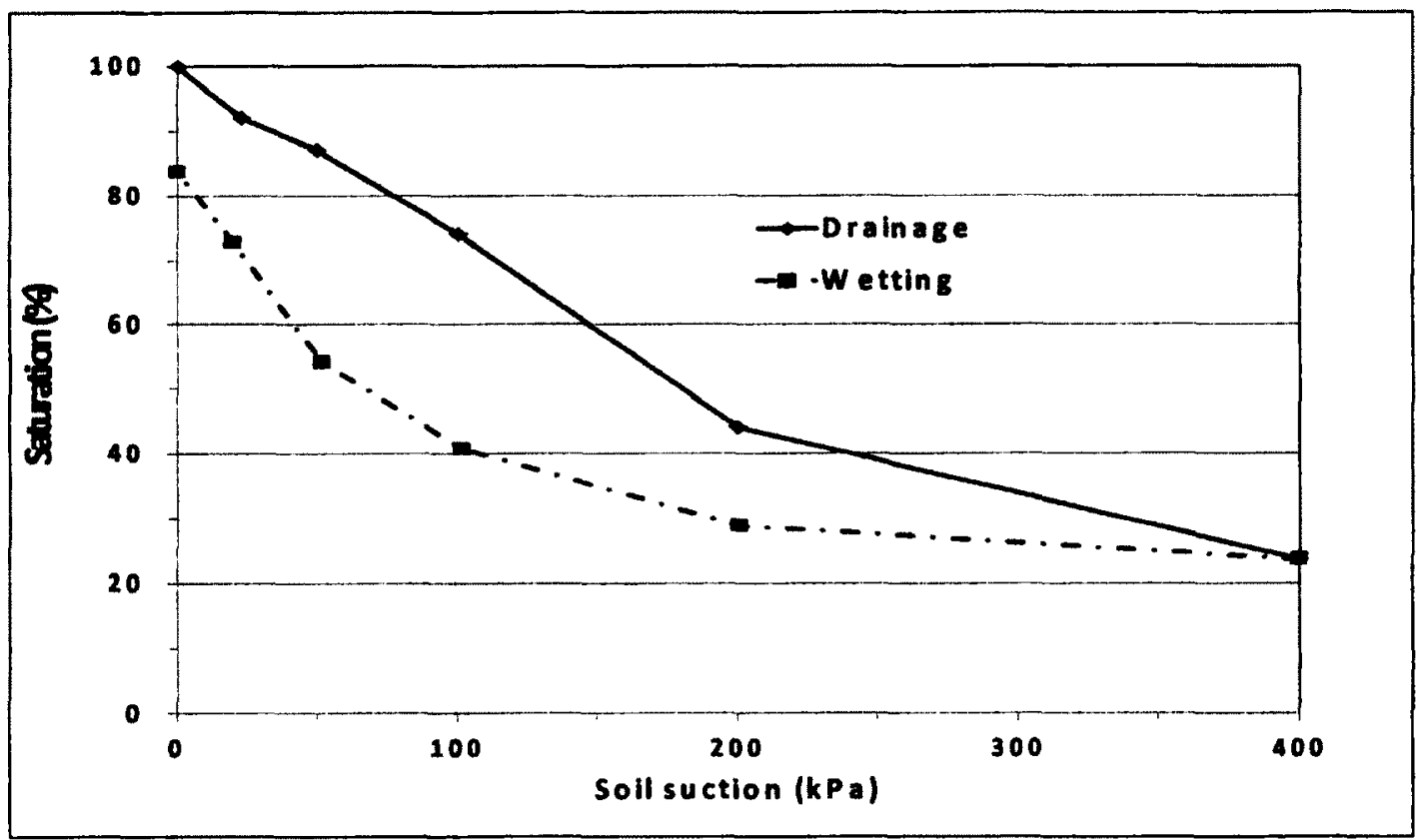

Figure A5-38: Saturation-suction curve for gold mine tailings, $\mathrm{w}_{\mathrm{i}}=40.7 \%$ 
Table A5-24: Effect of suction on water content for gold mine tailings, wi $=50.8 \%$

\begin{tabular}{|c|c|c|c|c|c|c|c|c|c|c|c|c|c|}
\hline \multirow{2}{*}{$\begin{array}{l}\text { Suction } \\
(1 P a)\end{array}$} & \multirow{2}{*}{$\begin{array}{c}\text { sol } \\
\text { weidt } \\
\text { (d) }\end{array}$} & \multirow{2}{*}{$\begin{array}{l}\text { noter } \\
\text { ueidt } \\
\text { (d) }\end{array}$} & \multirow{2}{*}{$\begin{array}{l}\text { Irital totd } \\
\text { wedt } \\
\text { (d) }\end{array}$} & \multirow{2}{*}{$\begin{array}{l}\text { firel totd } \\
\text { weigt } \\
\text { (d) }\end{array}$} & \multirow{2}{*}{$\begin{array}{l}\text { were } \\
\text { at } \\
\text { (g) }\end{array}$} & \multirow{2}{*}{$\begin{array}{c}\text { netes in } \\
\text { theurit } \\
\text { (d) }\end{array}$} & \multirow{2}{*}{$\begin{array}{c}\text { Water } \\
\text { contert } \\
1 \% 9\end{array}$} & \multicolumn{2}{|c|}{ intital sols' } & \multicolumn{2}{|c|}{ find sols' } & \multicolumn{2}{|c|}{ dageinsa's' } \\
\hline & & & & & & & & $\begin{array}{l}\text { heigt } \\
\text { (m) }\end{array}$ & $\begin{array}{l}\text { volume } \\
\text { (cmil) }\end{array}$ & $\begin{array}{l}\text { (m) } \\
\text { (m) }\end{array}$ & $\begin{array}{l}\text { vodure } \\
\left.(\mathrm{cm})^{2}\right)\end{array}$ & $\begin{array}{l}\text { hedt } \\
\text { (mm) }\end{array}$ & $\begin{array}{l}\text { vodure } \\
194\end{array}$ \\
\hline 0 & 3005 & 1832 & 38886 & 38886 & 0.0 & 183.2 & 508 & 242 & 3007.5 & 24.2 & 307.5 & Q0 & 00 \\
\hline 0 & 3005 & 1832 & 30886 & 38411 & 47.5 & 1357 & 37.6 & 24.2 & 307.5 & 206 & 2000 & 36 & 154 \\
\hline 17 & 3005 & 135.7 & 38411 & 38105 & 306 & 1051 & 29.2 & 206 & 2000 & 195 & 237.3 & 11 & 87 \\
\hline 53 & 3005 & 1051 & 38125 & 37839 & 26.6 & 785 & 248 & 195 & 237.3 & 179 & 2449 & 16 & 95 \\
\hline 100 & 3005 & 785 & 37839 & $3 \pi / 26$ & 113 & 6.2 & 186 & 17.9 & 2149 & 17.9 & 2143 & 00 & 02 \\
\hline 202 & 3005 & 6.2 & 3726 & 37468 & 258 & 414 & 115 & 17.9 & 2143 & 179 & 2133 & 00 & 0.5 \\
\hline 400 & 3005 & 414 & 37468 & 37244 & 224 & 190 & 53 & 17.9 & 2133 & 179 & 2118 & 00 & 07 \\
\hline 202 & 3005 & 190 & 37244 & 37300 & -56 & 246 & 68 & 17.9 & 2118 & 17.9 & 2218 & Qo & 00 \\
\hline 102 & 3005 & 246 & 37300 & 37901 & -101 & 347 & 96 & 17.9 & 2018 & 109 & 2118 & 00 & 00 \\
\hline 50 & 3005 & 347 & 37401 & 3725 & -124 & 47.1 & 131 & 17.9 & 2118 & 17.9 & 2118 & 00 & 00 \\
\hline$\underline{20}$ & 3605 & 47.1 & 37525 & 37664 & -139 & 610 & 169 & 17.9 & 2118 & 17.9 & 2118 & 00 & 00 \\
\hline 0 & 3005 & 6. & 37664 & 37824 & -160 & 77.0 & 214 & 17.9 & 2118 & 179 & 2118 & 00 & 00 \\
\hline
\end{tabular}

Table A5-25: Effect of suction on saturation for gold mine tailings, wi $=50.8 \%$

\begin{tabular}{|c|c|c|c|c|c|}
\hline Suction & $\begin{array}{c}\text { Total } \\
\text { volume } \\
(\mathrm{kPa})\end{array}$ & $\begin{array}{c}\text { Volume of } \\
\text { void } \\
(\mathrm{Cm} 3)\end{array}$ & $\begin{array}{c}\text { Void } \\
\text { ratio }\end{array}$ & $\begin{array}{c}\text { Volume of } \\
\text { Water } \\
(\mathrm{Cm} 3)\end{array}$ & Saturation \\
\hline 0 & 307.5 & 183.2 & 1.47 & 183.2 & 100.0 \\
\hline 0 & 260.0 & 135.7 & 1.09 & 135.7 & 100.0 \\
\hline 17 & 237.3 & 113.0 & 0.91 & 105.1 & 93.0 \\
\hline 53 & 214.9 & 90.5 & 0.73 & 78.5 & 86.7 \\
\hline 102 & 214.3 & 90.0 & 0.72 & 67.2 & 74.6 \\
\hline 202 & 213.3 & 89.0 & 0.72 & 41.4 & 46.5 \\
\hline 400 & 211.8 & 87.5 & 0.70 & 19.0 & 21.7 \\
\hline 202 & 211.8 & 87.5 & 0.70 & 24.6 & 28.1 \\
\hline 102 & 211.8 & 87.5 & 0.70 & 34.7 & 39.6 \\
\hline 50 & 211.8 & 87.5 & 0.70 & 47.1 & 53.8 \\
\hline 20 & 211.8 & 87.5 & 0.70 & 61.0 & 69.7 \\
\hline 0 & 211.8 & 87.5 & 0.70 & 77.0 & 88.0 \\
\hline
\end{tabular}




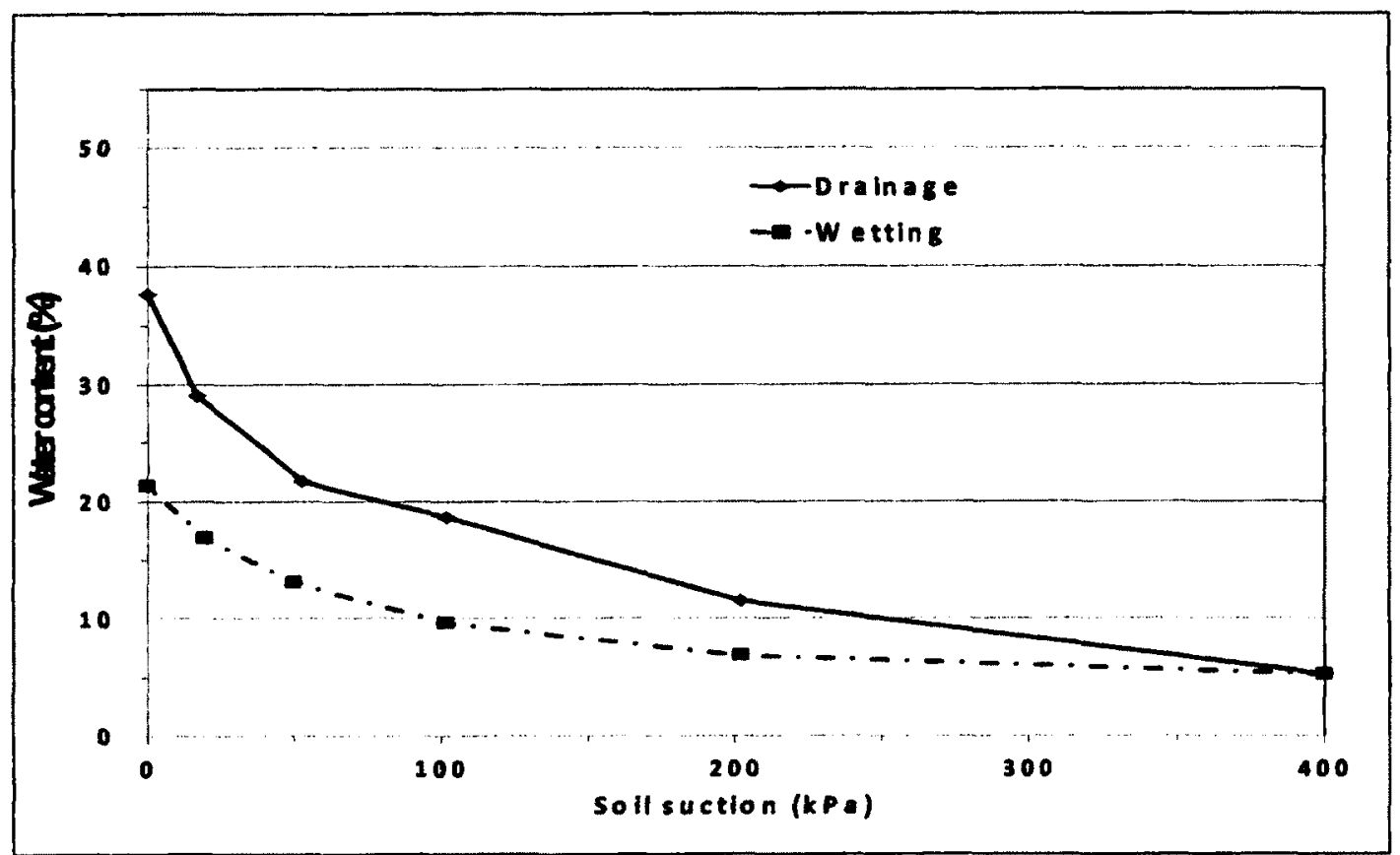

Figure A5-39: Water content-suction curve for gold mine tailings, $w_{i}=50.8 \%$

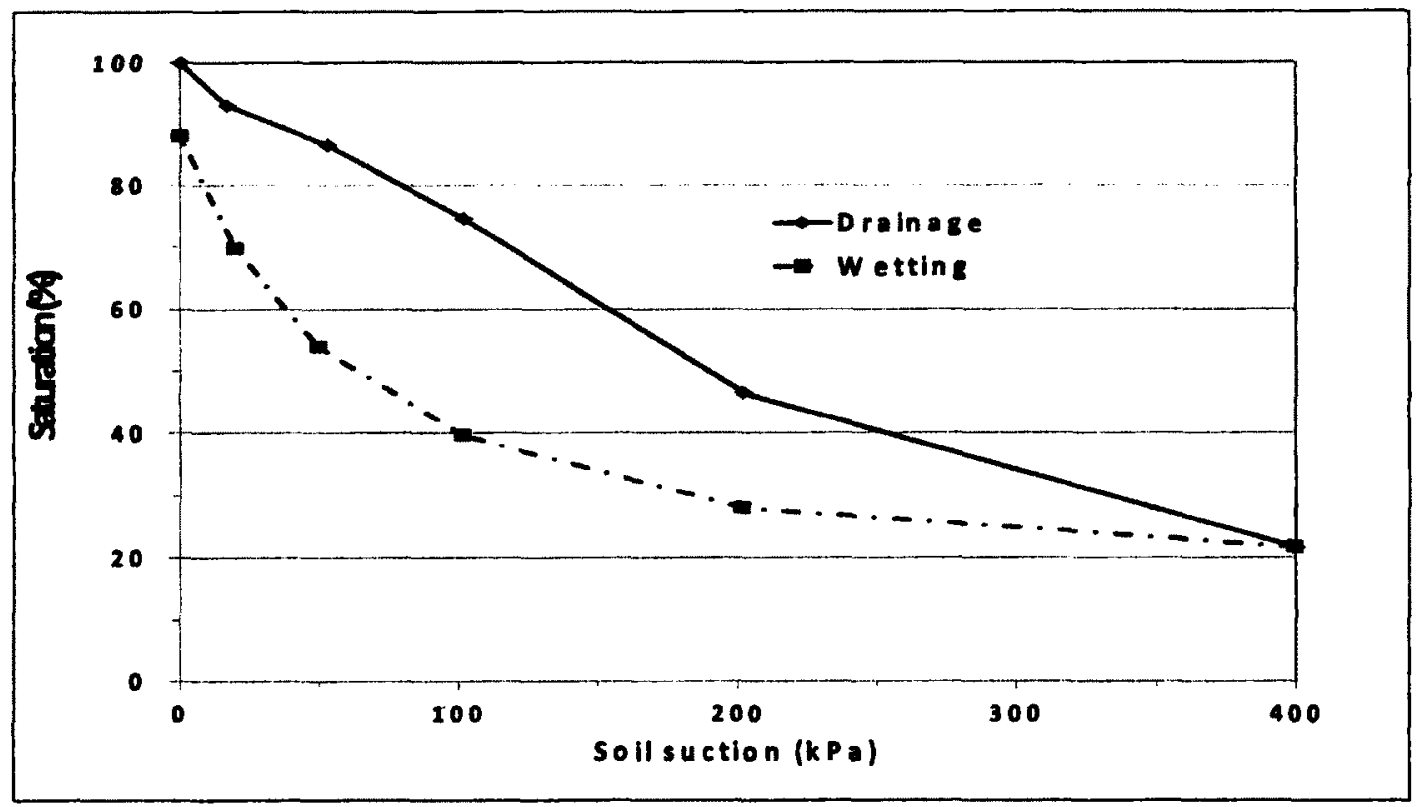

Figure A5-40: Saturation-suction curve for gold mine tailings, $\mathrm{w}_{\mathrm{i}}=50.8 \%$ 
Table A5-26: Effect of suction on water content for gold mine tailings, wi $=31.5 \%, 1-\mathrm{D}$ loading $=50 \mathrm{kPa}$

\begin{tabular}{|c|c|c|c|c|c|c|c|c|c|c|c|c|c|c|}
\hline \multirow{2}{*}{$\begin{array}{l}\text { Sution } \\
\text { (16) }\end{array}$} & \multirow{2}{*}{$\begin{array}{c}\text { sol } \\
\text { veigh } \\
\text { (8) }\end{array}$} & \multirow{2}{*}{$\begin{array}{c}\text { veter } \\
\text { vidh } \\
\text { (d) }\end{array}$} & \multirow{2}{*}{$\begin{array}{l}\text { Lod } \\
\text { (Ka) }\end{array}$} & \multirow{2}{*}{$\begin{array}{c}\text { ritid tad } \\
\text { vigth } \\
(\mathrm{g}\end{array}$} & \multirow{2}{*}{$\begin{array}{c}\text { find tot } \\
\text { veight } \\
(d\end{array}$} & \multirow{2}{*}{$\begin{array}{l}\text { vat } \\
\text { at } \\
6\end{array}$} & \multirow{2}{*}{$\begin{array}{l}\text { uterin } \\
\text { theurit } \\
\text { (d) }\end{array}$} & \multirow{2}{*}{ 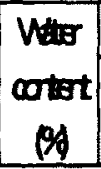 } & \multicolumn{2}{|c|}{ intid so's } & \multicolumn{2}{|c|}{ ind sols } & \multicolumn{2}{|c|}{ drgeinsats } \\
\hline & & & & & & & & & $\begin{array}{l}\text { reigh } \\
(m+r)\end{array}$ & $\begin{array}{l}\text { volue } \\
\text { (onti) }\end{array}$ & $\begin{array}{l}\text { regoth } \\
\text { (min) }\end{array}$ & $\begin{array}{l}\text { Ictume } \\
\text { for }\end{array}$ & $\begin{array}{l}\text { heigh } \\
(\mathrm{m})\end{array}$ & volume \\
\hline 0 & 60 & 21 & $\infty$ & 15599 & 11599 & $\infty$ & 21 & 315 & 137 & 422 & 137 & 422 & $\infty$ & $\boldsymbol{\infty}$ \\
\hline 0 & 60 & 21 & $\infty$ & 1599 & 115499 & $\infty$ & 21 & 315 & 137 & 442 & 137 & 422 & $\infty$ & $\infty$ \\
\hline 24 & 600 & 21 & 500 & $11 \times 32$ & 115442 & 90 & D1 & 181 & 137 & 442 & 116 & 3732 & 21 & 56 \\
\hline 50 & 60 & 21 & 500 & $158 B 1$ & 11523 & 08 & 113 & 168 & 116 & 3732 & 116 & 3732 & $\infty$ & $\infty$ \\
\hline $\mathbf{m}$ & 670 & 113 & 900 & 1542 & 15446 & 0.6 & 106 & 59 & 116 & 3732 & 116 & 3674 & $\infty$ & 16 \\
\hline 20 & 60 & 106 & 500 & 15415 & 115875 & 40 & 66 & 99 & 116 & 3674 & 116 & 367 & $\infty$ & $\infty$ \\
\hline 0 & 6.0 & 66 & 500 & 15572 & 115425 & -53 & 120 & 79 & 116 & 3674 & 116 & 3674 & $\infty$ & $\infty$ \\
\hline
\end{tabular}

Table A5-27: Effect of suction on saturation for gold mine tailings, wi $=31.5 \%, 1-\mathrm{D}$ loading $=50 \mathrm{kPa}$

\begin{tabular}{|c|c|c|c|c|c|}
\hline $\begin{array}{l}\text { Stion } \\
\text { (PA) }\end{array}$ & $\begin{array}{l}\text { Tadd } \\
\text { vdune } \\
\text { (cmit) }\end{array}$ & $\begin{array}{c}\text { Votuned } \\
\text { vod } \\
\text { (and }\end{array}$ & $\begin{array}{l}\text { Vad } \\
\text { ratio }\end{array}$ & $\begin{array}{l}\text { Vameof } \\
\text { Who } \\
\text { (cind }\end{array}$ & $\begin{array}{c}\text { Sturion } \\
(4)\end{array}$ \\
\hline 0 & 442 & 21 & $\infty 91$ & 21 & 1000 \\
\hline 0 & 442 & 211 & 091 & 211 & 100 \\
\hline 24 & $3 / 3$ & 142 & 061 & 21 & $\mathbf{8 3}$ \\
\hline 50 & 373 & 142 & 061 & 113 & 794 \\
\hline $\mathbf{m}$ & 367 & 136 & $\infty$ & 106 & 780 \\
\hline 200 & 367 & 136 & 09 & 66 & 488 \\
\hline 0 & 367 & 136 & $\infty \Phi$ & 20 & 879 \\
\hline
\end{tabular}




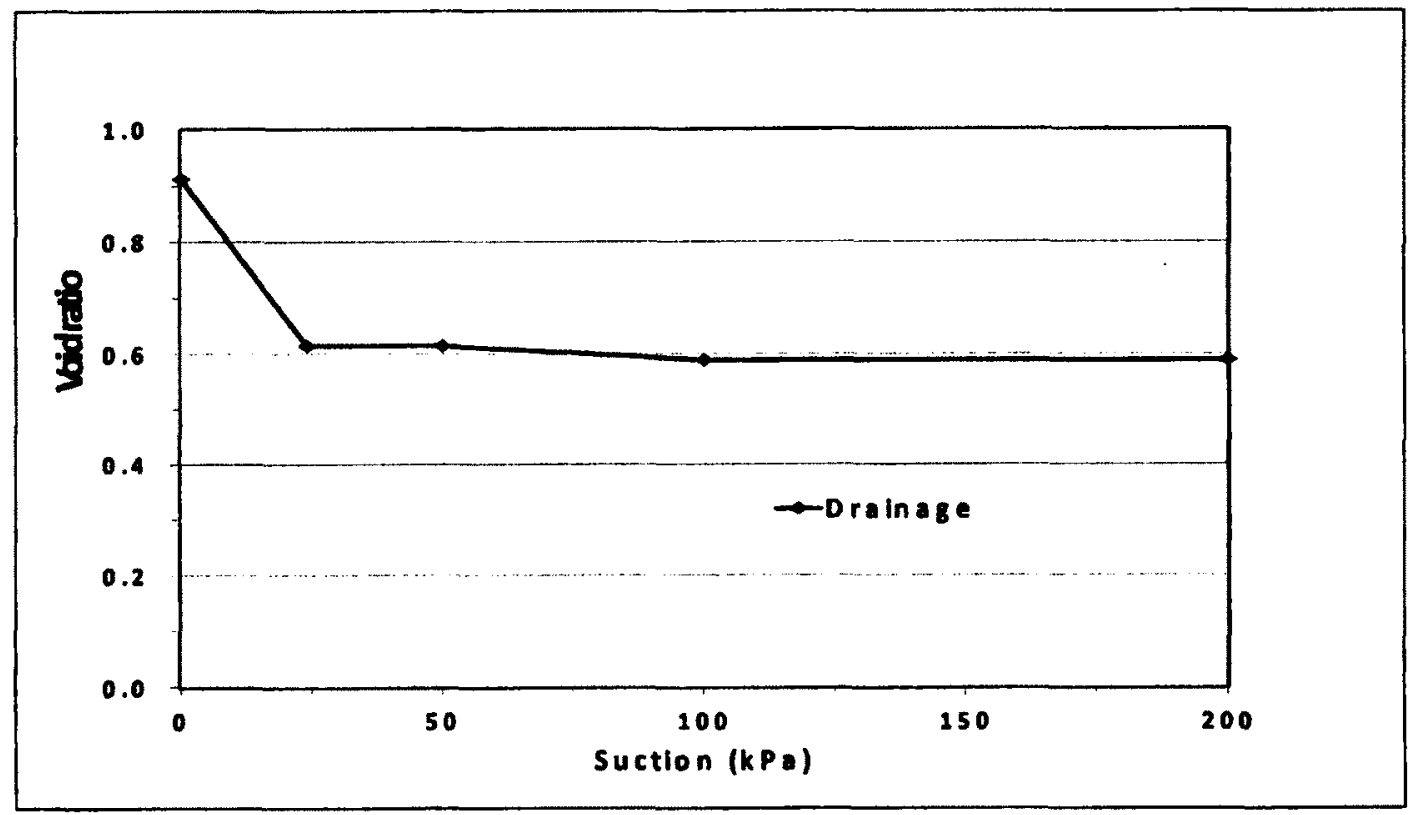

Figure A5-41: Void ratio-suction curve for gold mine tailings, $w_{i}=31.5 \%$, 1 -D loading $50 \mathrm{kPa}$

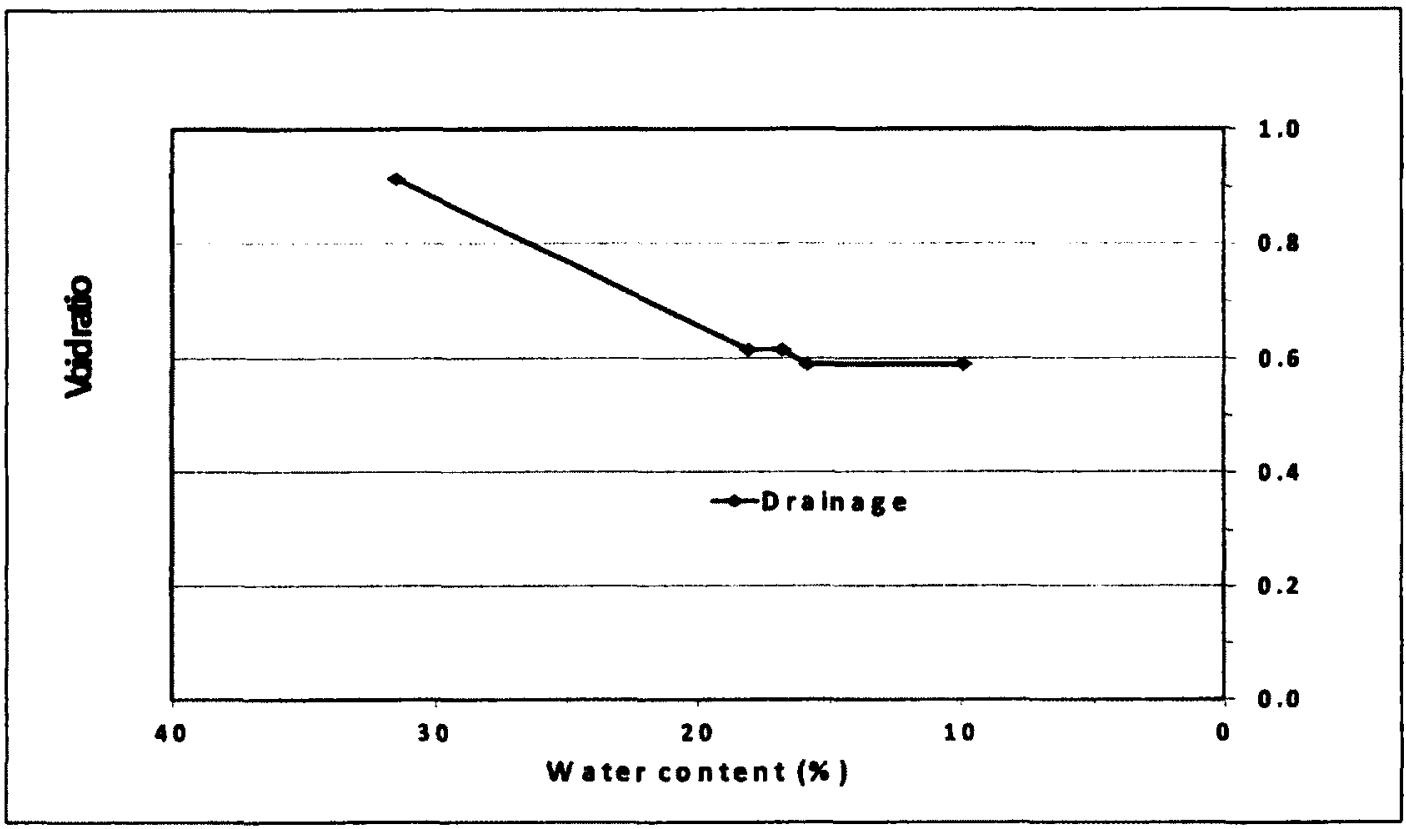

Figure A5-42: Shrinkage curve for gold mine tailings, $\mathrm{w}_{\mathrm{i}}=31.5 \%, 1-\mathrm{D}$ loading $50 \mathrm{kPa}$ 


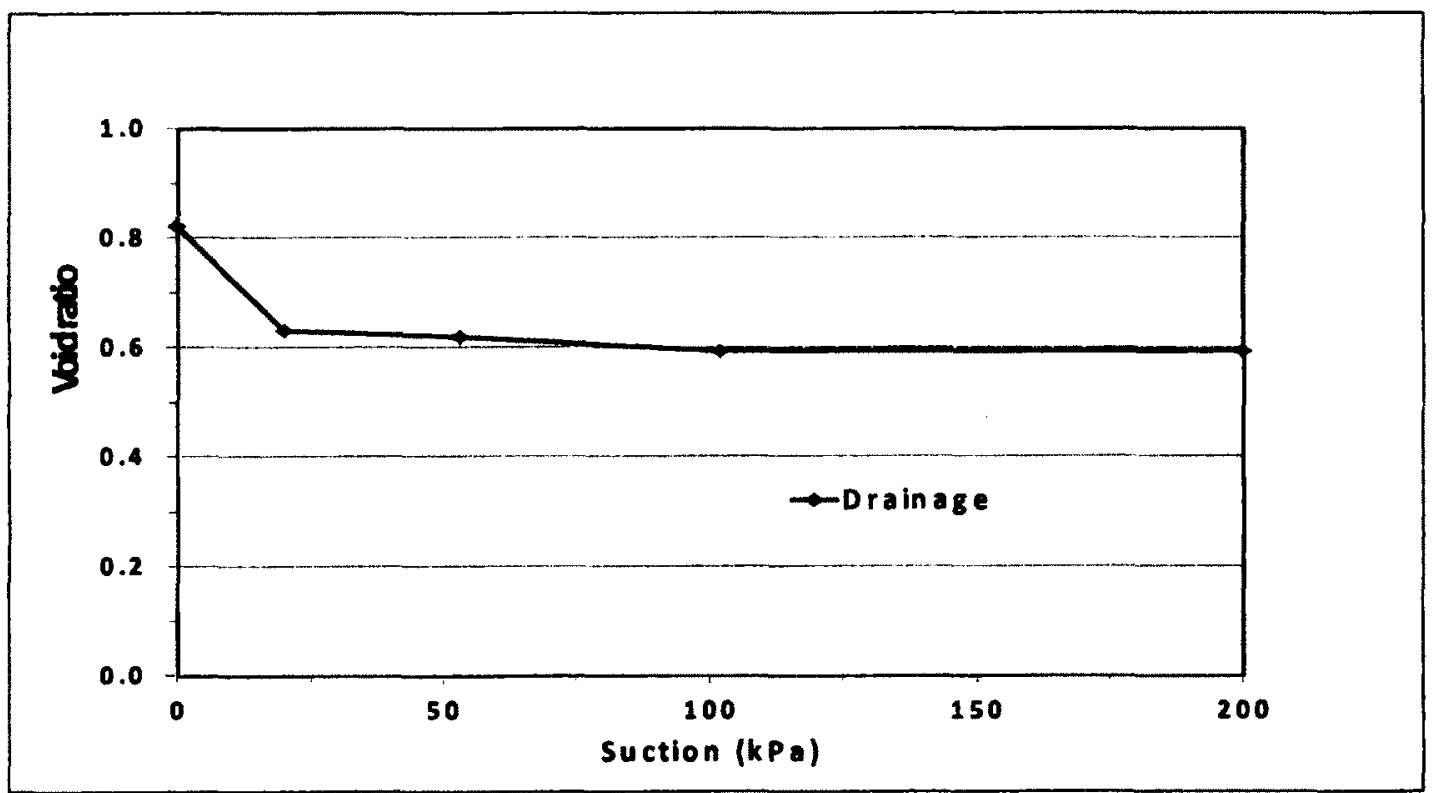

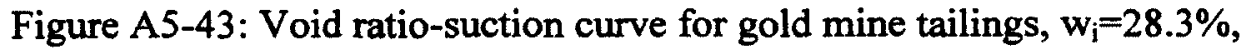
$1-\mathrm{D}$ loading $100 \mathrm{kPa}$

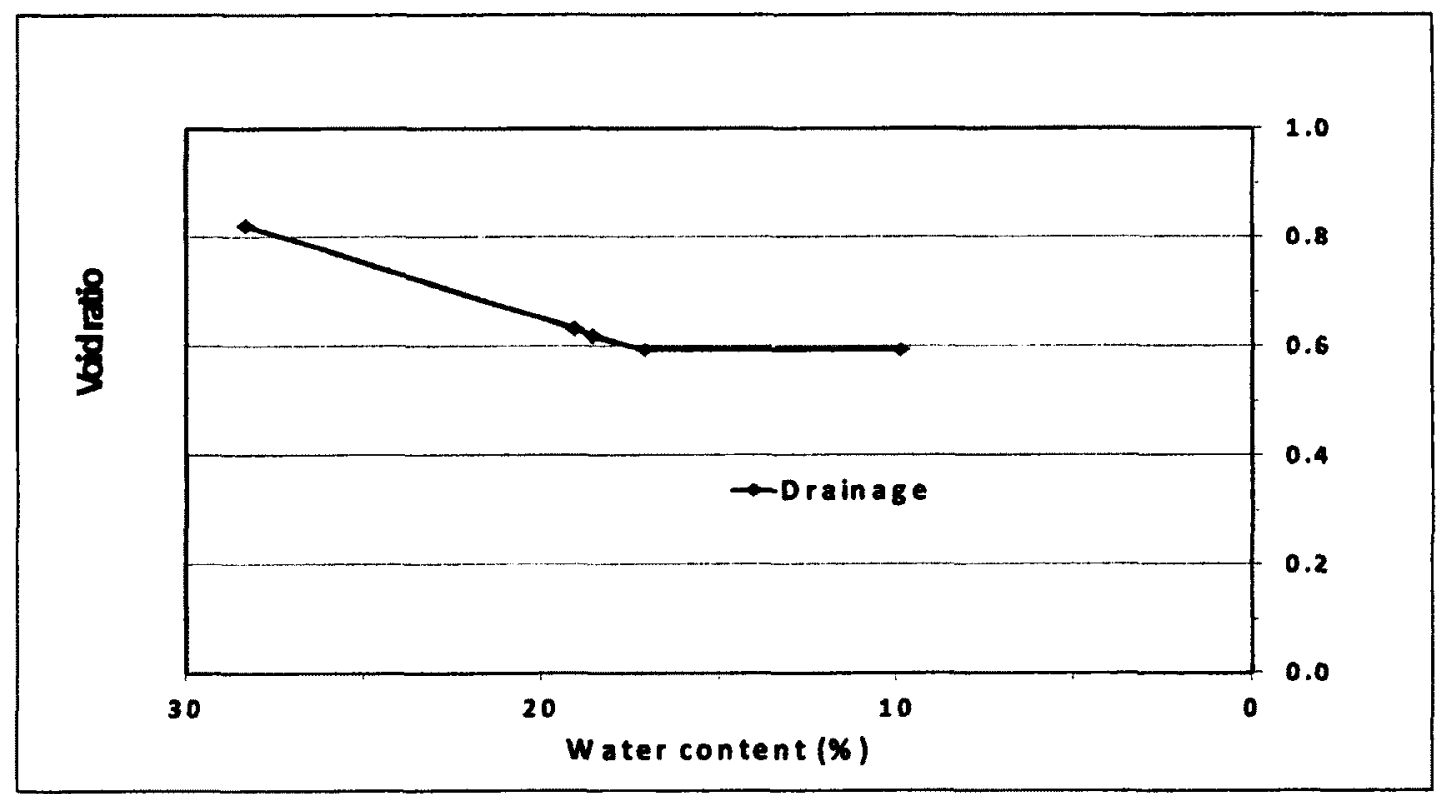

Figure A5-44: Shrinkage curve for gold mine tailings, $\mathrm{w}_{\mathrm{i}}=28.3 \%$, 1-D loading $100 \mathrm{kPa}$ 


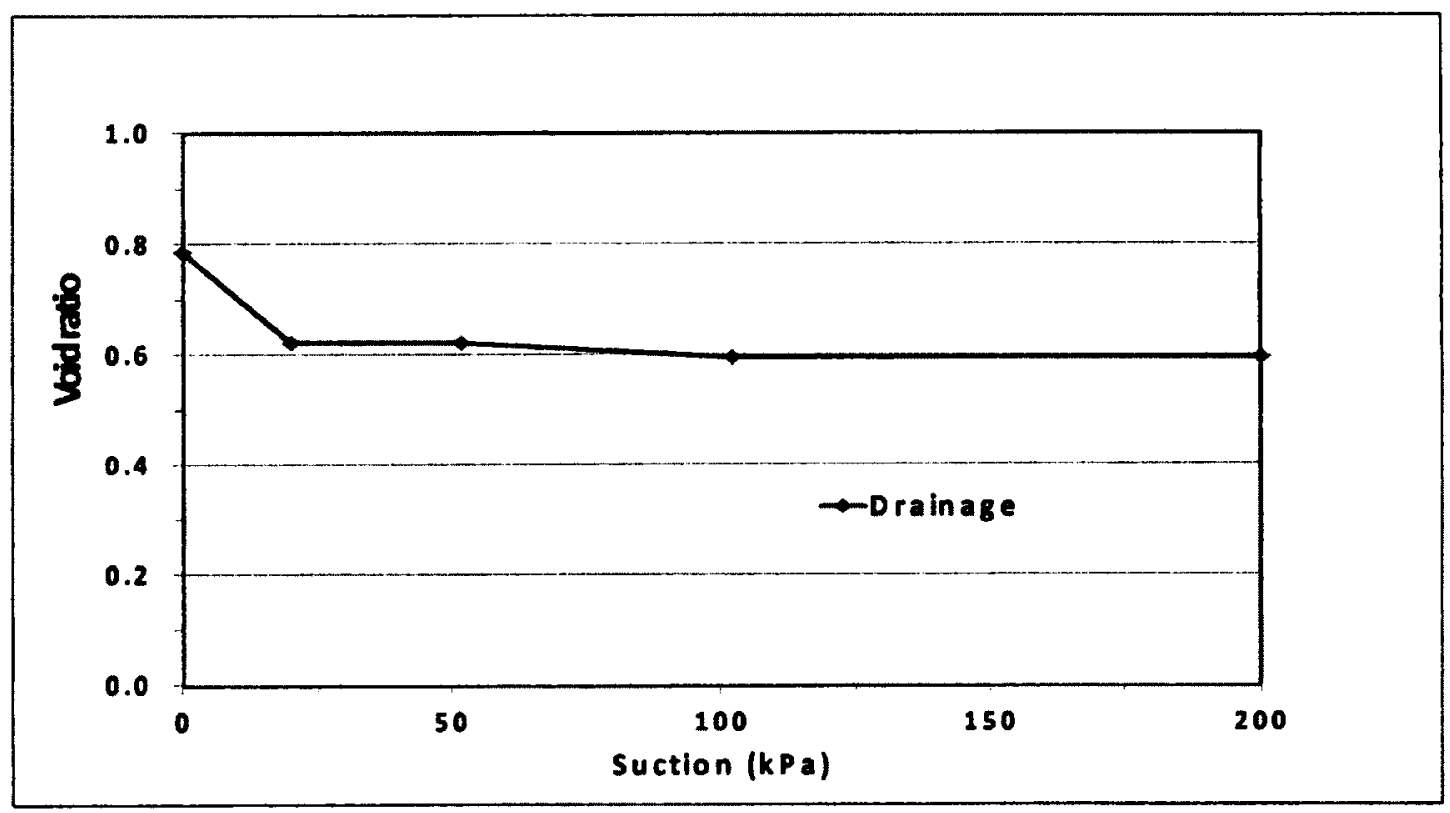

Figure A5-45: Void ratio-suction curve for gold mine tailings, $w_{\mathrm{i}}=27.1 \%$, $1-\mathrm{D}$ loading $150 \mathrm{kPa}$

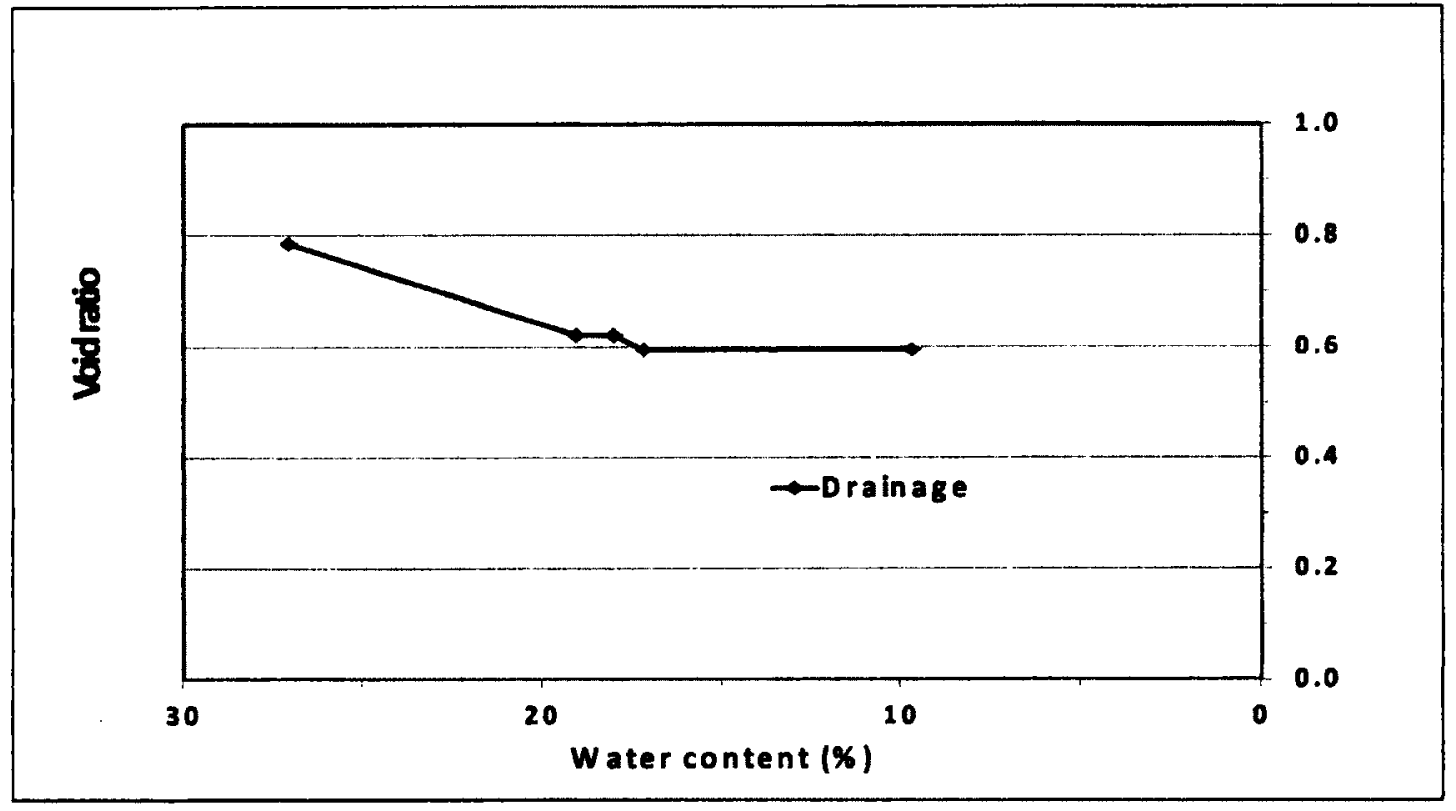

Figure A5-46: Shrinkage curve for gold mine tailings, $w_{i}=27.1 \%$, 1-D loading $150 \mathrm{kPa}$ 
Table A5-28: Comparison of initial water content and 1-D loading effect on gold mine tailings

\begin{tabular}{|c|c|c|c|c|c|c|c|c|c|c|c|c|c|c|c|}
\hline \multicolumn{4}{|c|}{$w=\$ 23.8, b a d i n g=50 \mathrm{kpa}$} & \multicolumn{4}{|c|}{$w i=k 31.5$, bading $=50 \mathrm{kpa}$} & \multicolumn{4}{|c|}{$w_{i}=y_{28.3,3}$ loading $=100 \mathrm{lpa}$} & \multicolumn{4}{|c|}{$w=X 27.1,100 \mathrm{ding}=150 \mathrm{kpa}$} \\
\hline $\begin{array}{l}\text { Suction } \\
(k P a) \mid\end{array}$ & $\begin{array}{c}\text { Water } \\
\text { content } \\
(x)\end{array}$ & $\begin{array}{c}\text { Ssturation } \\
\mid(x)\end{array}$ & Vod & $\begin{array}{l}\text { Suction } \\
(k \mathrm{R}) \mid\end{array}$ & $\begin{array}{c}\text { Whater } \\
\text { content } \\
|x|\end{array}$ & $\begin{array}{c}\text { Soturition } \\
\mid(8 \mid)\end{array}$ & ratio & $\begin{array}{l}\text { Suction } \\
\mid\left(\left|P_{2}\right|\right)\end{array}$ & $\begin{array}{c}\text { Water } \\
\text { content } \\
(y)\end{array}$ & $\begin{array}{c}\text { Satrition } \\
|y|\end{array}$ & $\begin{array}{l}\text { Void } \\
\text { ratio }\end{array}$ & $\begin{array}{l}\text { Suction } \\
(\mathrm{KP} P \mathrm{~A})\end{array}$ & $\begin{array}{l}\text { Water } \\
\text { content } \\
|y|\end{array}$ & $\begin{array}{c}\text { Sturation } \\
\mid(x)\end{array}$ & Void \\
\hline 0 & 23.8 & 1000 & 0.69 & 0 & 31.5 & 100.0 & 0.9 & 0 & 28.3 & 1000 & 0.82 & 0 & 27.1 & 1000.0 & 0.79 \\
\hline 0 & 23.8 & 100.0 & 0.69 & 0 & 31.5 & 100.0 & 0.91 & 0 & 28.3 & 100.0 & 0.82 & 0 & 27.1 & 1000.0 & 0.79 \\
\hline 20 & 19.8 & 87.1 & 0.66 & 24 & 18.1 & 85.3 & 0.0 & 20 & 19.0 & 87.4 & 0.63 & 20 & 19.0 & 88.9 & 0.62 \\
\hline 50 & 16.3 & 77.1 & 0.61 & 50 & 16.8 & 79.4 & . & 53 & 18.5 & 86.7 & 0.62 & 52 & 18.0 & 84.1 & 0.62 \\
\hline 100 & 15.6 & 76.7 & 0.59 & 100 & 15.9 & 78.0 & 0.59 & 102 & 17.1 & 83.4 & 0.59 & 102 & 17.2 & 83.6 & 0.60 \\
\hline 200 & 10.2 & 50.2 & 0.59 & 200 & 9.9 & 48.8 & 0.55 & 200 & 9.9 & 48.2 & 0.59 & 200 & 9.7 & 47.0 & 0.60 \\
\hline 0 & 17.9 & 88.0 & 0.59 & 0 & 17.9 & 87.9 & 0.59 & 0 & 18.0 & 87.9 & 0.59 & 0 & 18.1 & 88.0 & 0.60 \\
\hline
\end{tabular}


Table A5-29: Effect of constant suction and 1-D loading on water content for gold mine tailings, wi $=38.8 \%$, constant suction $=50 \mathrm{kPa}$

\begin{tabular}{|c|c|c|c|c|c|c|c|c|c|c|c|c|c|c|}
\hline \multirow{2}{*}{$\begin{array}{l}\text { Sution } \\
\text { (Ka) }\end{array}$} & \multirow{2}{*}{$\begin{array}{c}\text { sal } \\
\text { weith } \\
0\end{array}$} & \multirow{2}{*}{$\begin{array}{l}\text { veter } \\
\text { veigh } \\
\text { (d) }\end{array}$} & \multirow{2}{*}{$\begin{array}{l}\text { Loadng } \\
\text { (Kp) }\end{array}$} & \multirow{2}{*}{$\begin{array}{c}\text { Intiditata } \\
\text { neidh } \\
\text { (d) }\end{array}$} & \multirow{2}{*}{$\begin{array}{l}\text { firt tota } \\
\text { weigh } \\
\text { (d) }\end{array}$} & \multirow{2}{*}{$\begin{array}{l}\text { ueter } \\
\text { at } \\
\text { (d) }\end{array}$} & \multirow{2}{*}{$\begin{array}{l}\text { uaterin } \\
\text { theunt } \\
\text { (8) }\end{array}$} & \multirow{2}{*}{$\begin{array}{l}\text { Water } \\
\text { contert } \\
P Q\end{array}$} & \multicolumn{2}{|c|}{ initid so's' } & \multicolumn{2}{|c|}{ findsots } & \multicolumn{2}{|c|}{ dtrgeinsats } \\
\hline & & & & & & & & & $\begin{array}{l}h=\mathrm{h} \\
(\mathrm{mm})\end{array}$ & 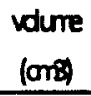 & $\begin{array}{l}\text { hith } \\
\text { (m) }\end{array}$ & $\begin{array}{l}\text { volume } \\
\text { (ori) }\end{array}$ & $\begin{array}{l}\text { heith } \\
(\mathrm{m})\end{array}$ & $\begin{array}{c}\text { vdume } \\
19\end{array}$ \\
\hline 0 & 785 & 324 & 0 & 4513 & 4513 & 00 & 304 & 388 & 17.9 & 5750 & 17.9 & 57.50 & 00 & 00 \\
\hline 0 & 785 & 304 & 0 & 4513 & 4247.1 & 42 & 262 & 33.4 & 179 & 5750 & 166 & 5324 & 13 & 7.4 \\
\hline 50 & 785 & 262 & 0 & 112414 & 19347 & 66 & 196 & 250 & 166 & 5324 & 147 & 47.29 & 19 & 112 \\
\hline 50 & 785 & 19.6 & 50 & 115588 & 1155.1 & 3.7 & 159 & 203 & 14.7 & 429 & 147 & 47.29 & 00 & $\infty$ \\
\hline 50 & 785 & 159 & 100 & 115550 & 11542 & 08 & 152 & 193 & 147 & 47.2 & 147 & 47.2 & 00 & 00 \\
\hline 50 & 785 & 152 & 200 & 115542 & 11583 & 09 & 143 & 182 & 147 & 47.29 & $\mathbf{1 4 5}$ & 4665 & 0.2 & 14 \\
\hline 0 & 785 & 143 & 200 & 115833 & 11540 & -07 & 150 & 191 & 145 & 4665 & 145 & 4665 & 00 & 00 \\
\hline
\end{tabular}

Table A5-30: Effect of constant suction and 1-D loading on saturation for gold mine tailings, wi $=38.8 \%$, constant suction $=50 \mathrm{kPa}$

\begin{tabular}{|c|c|c|c|c|c|c|}
\hline Surtion & $\begin{array}{l}\text { Looding } \\
\text { RPA }\end{array}$ & $\begin{array}{l}\text { Tatd } \\
\text { voure } \\
\text { (onst) }\end{array}$ & $\begin{array}{l}\text { valued } \\
\text { void } \\
\text { (ond }\end{array}$ & $\begin{array}{l}\text { Vid } \\
\text { ratio }\end{array}$ & 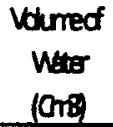 & $\begin{array}{l}\text { Sturation } \\
\text { (9) }\end{array}$ \\
\hline 0 & 0 & 575 & 304 & 112 & 304 & 1000 \\
\hline 0 & 0 & 532 & 262 & 097 & 262 & 1000 \\
\hline 50 & 0 & 47.3 & 202 & $a 75$ & 19.6 & 969 \\
\hline 50 & 50 & 473 & 202 & $a \bar{J}$ & 159 & 788 \\
\hline 50 & 100 & 473 & 202 & 0.5 & 152 & 750 \\
\hline 50 & 200 & 466 & 196 & $a 72$ & 143 & 70 \\
\hline$\overline{0}$ & 200 & 466 & 196 & $a 72$ & 150 & $\overline{754}$ \\
\hline
\end{tabular}


Table A5-31: Effect of 1-D loading on water content for gold mine tailings, wi $=36.3 \%$, no suction

\begin{tabular}{|c|c|c|c|c|c|c|c|c|c|c|c|c|c|c|}
\hline \multirow{2}{*}{$\begin{array}{l}\text { Sution } \\
\text { (1) }\end{array}$} & \multirow{2}{*}{$\begin{array}{c}\text { sd } \\
\text { udidh } \\
\text { gd }\end{array}$} & \multirow{2}{*}{$\begin{array}{l}\text { vats } \\
\text { veigh } \\
\text { (d) }\end{array}$} & \multirow{2}{*}{$\begin{array}{l}\text { Losing } \\
\text { (14a) }\end{array}$} & \multirow{2}{*}{ 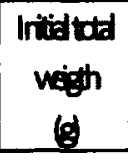 } & \multirow{2}{*}{$\begin{array}{l}\text { findtetd } \\
\text { vigh } \\
0\end{array}$} & \multirow{2}{*}{$\begin{array}{l}\text { uttor } \\
\text { at } \\
0\end{array}$} & \multirow{2}{*}{$\begin{array}{c}\text { notsin } \\
\text { teuit } \\
\theta\end{array}$} & \multirow{2}{*}{$\begin{array}{c}\text { Wher } \\
\text { cotot } \\
084\end{array}$} & \multicolumn{2}{|c|}{ intidsats } & \multicolumn{2}{|c|}{ indsods } & \multicolumn{2}{|c|}{ darginsols } \\
\hline & & & & & & & & & $\begin{array}{l}\text { rith } \\
\text { (min) }\end{array}$ & $\begin{array}{l}\text { vome } \\
\text { (on }\end{array}$ & $\begin{array}{l}\text { righ } \\
\text { (mii) }\end{array}$ & $\begin{array}{l}\text { vame } \\
\text { (on) }\end{array}$ & $\begin{array}{l}\text { ridh } \\
\text { (min) }\end{array}$ & $\begin{array}{l}\text { deme } \\
\text { (di) }\end{array}$ \\
\hline 0 & 50 & 22 & 0 & 42515 & 4515 & $\infty$ & 272 & 363 & 188 & 6046 & 165 & 505 & 23 & 123 \\
\hline 0 & 50 & 272 & 0 & 8515 & $\$ 2778$ & 37 & 235 & 313 & 165 & 요 & 153 & 485 & 12 & 70 \\
\hline 0 & 50 & 235 & 50 & 11587.7 & 11528 & 49 & 186 & 248 & 153 & 403 & 143 & 460 & 10 & 68 \\
\hline 0 & 750 & 186 & 100 & 115004 & 112001 & 03 & 183 & 244 & 143 & 4600 & 143 & 4600 & $\infty$ & $\infty$ \\
\hline 0 & 750 & 183 & 18 & 115001 & 11580 & 21 & 162 & 216 & 143 & 4600 & 140 & 4504 & 03 & 21 \\
\hline 0 & 50 & 162 & 20 & $11 \mathrm{ERO}$ & 1158.1 & $\infty 9$ & 153 & 204 & 140 & 4504 & 139 & 4472 & 01 & 07 \\
\hline
\end{tabular}

Table A5-32: Effect of 1-D loading on saturation for gold mine tailings, wi $=36.3 \%$, no suction

\begin{tabular}{|c|c|c|c|c|c|c|}
\hline $\begin{array}{l}\text { Sution } \\
\text { (PA) }\end{array}$ & $\begin{array}{l}\text { Loodrg } \\
\text { (PA) }\end{array}$ & $\begin{array}{l}\text { Tdt } \\
\text { volue } \\
\text { (Ond }\end{array}$ & $\begin{array}{c}\text { Vetuned } \\
\text { void } \\
\text { (and }\end{array}$ & $\begin{array}{l}\text { Vid } \\
\text { ritio }\end{array}$ & 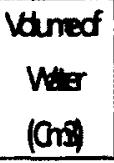 & $\begin{array}{c}\text { Sturtion } \\
P A\end{array}$ \\
\hline 0 & 0 & 830 & $\mathrm{Z2}$ & 105 & 772 & 1000 \\
\hline 0 & 0 & 493 & 255 & $\infty$ & 235 & 100 \\
\hline 0 & 50 & 460 & 201 & 078 & 186 & 923 \\
\hline 0 & 100 & 460 & 201 & $\mathrm{a} 78$ & 183 & 908 \\
\hline 0 & 178 & 450 & 192 & 074 & 162 & 844 \\
\hline 0 & 200 & 447 & 189 & $\mathrm{OB}$ & 153 & 810 \\
\hline
\end{tabular}




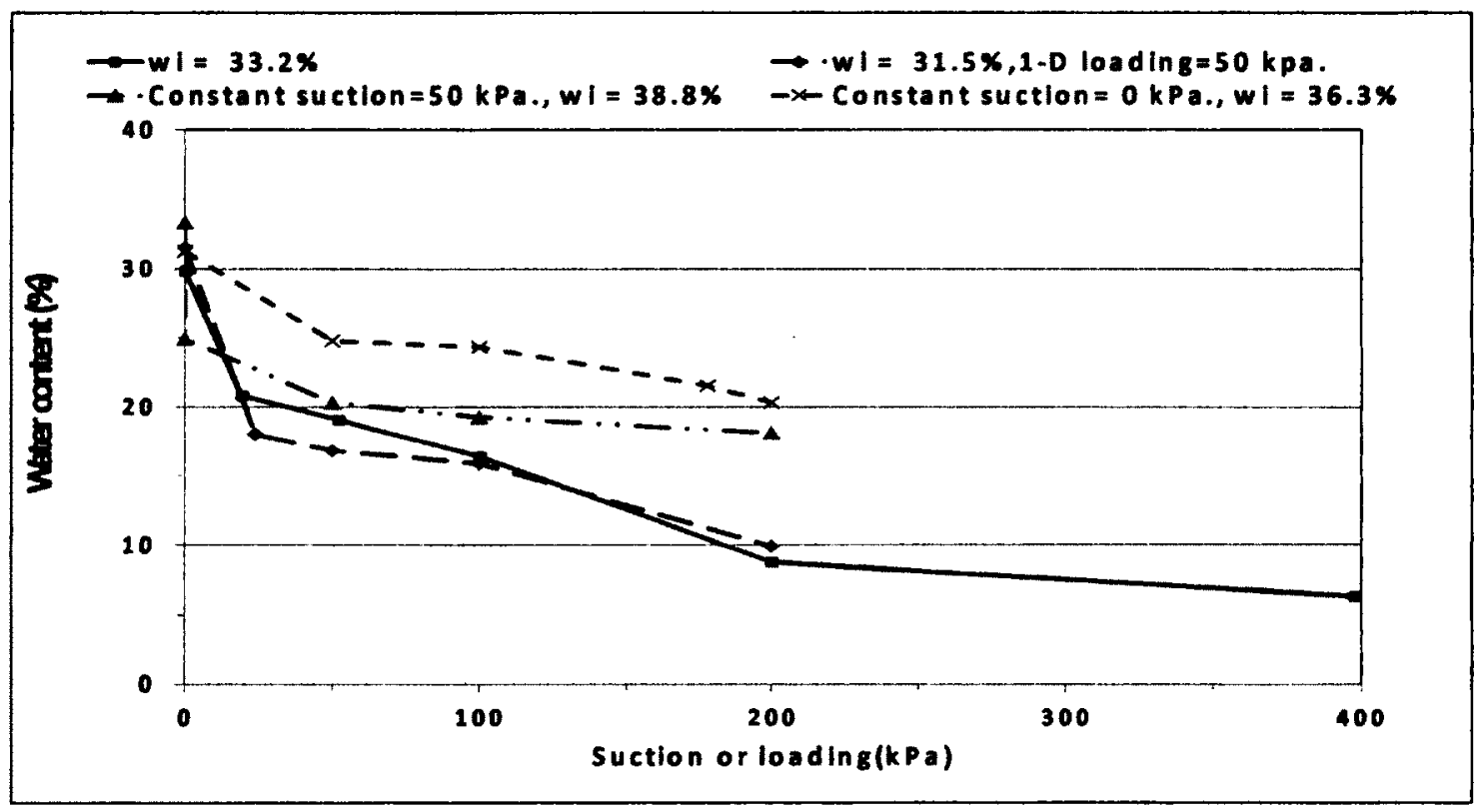

Figure A5-47: Effect of suction and 1-D loading on water content-suction curve for gold mine tailings

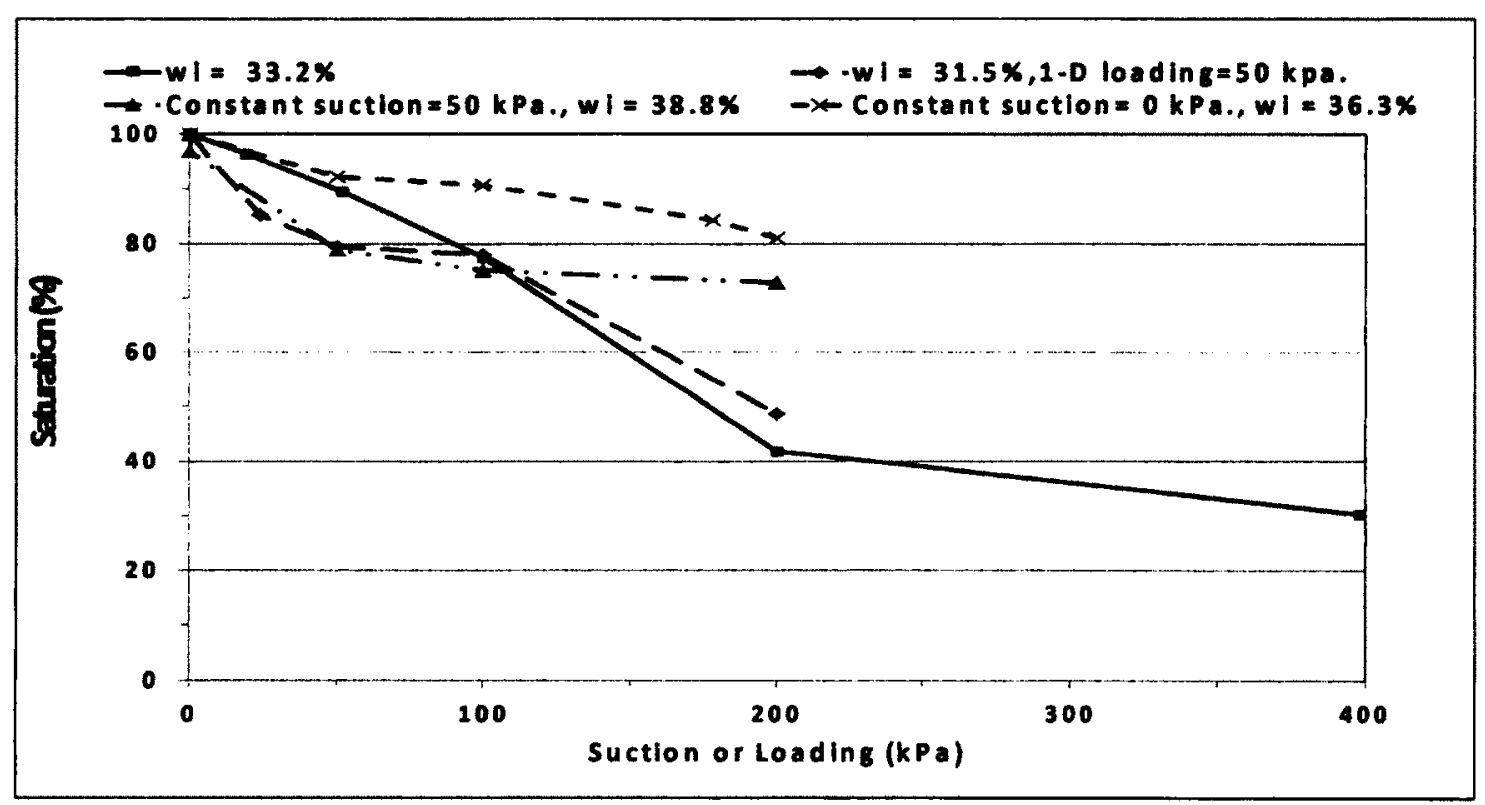

Figure A5-48: Effect of suction and 1-D loading on saturation-suction curve for gold mine tailings 


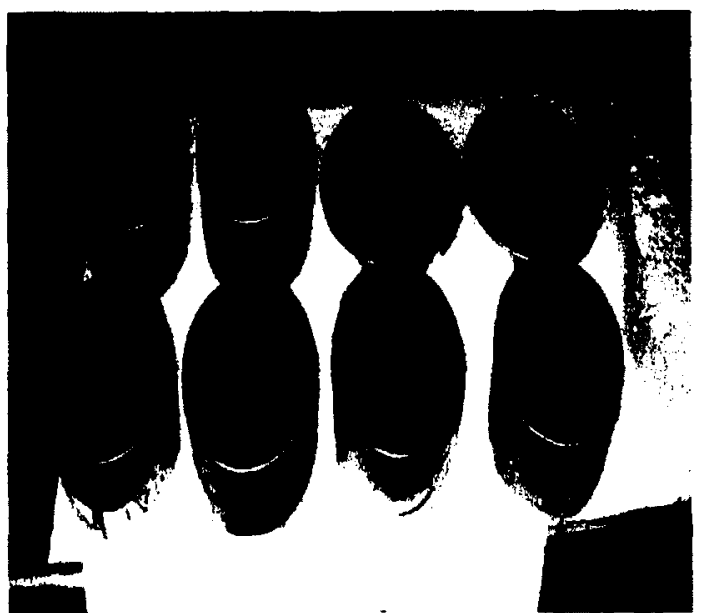

(1a) After two days

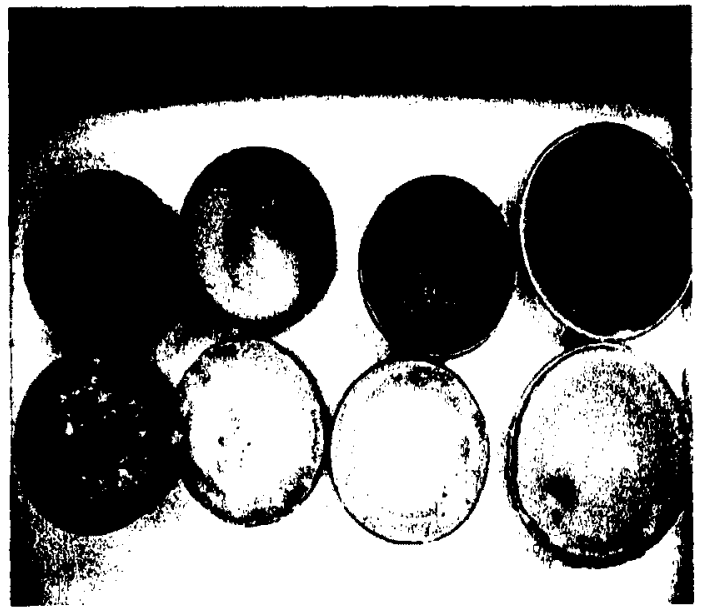

(1b) After nine days, some filled by

Picture A-1: Shrinkage test, samples with dinterent water

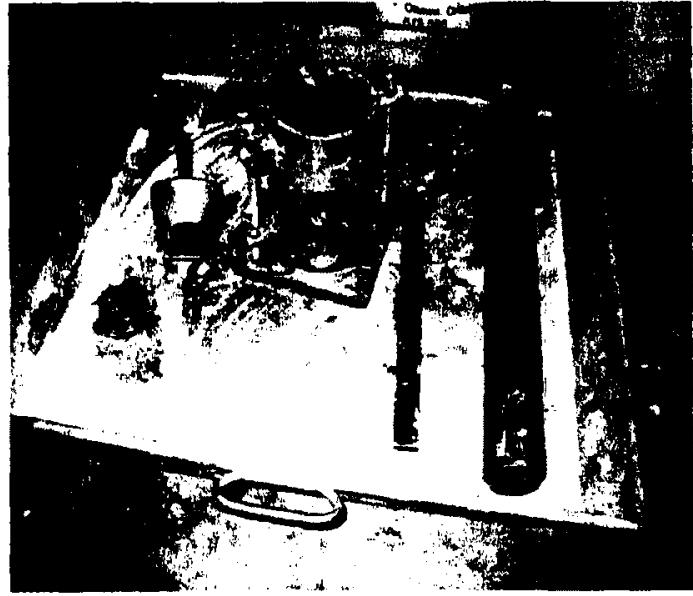

(2a) Standard compaction apparatus.
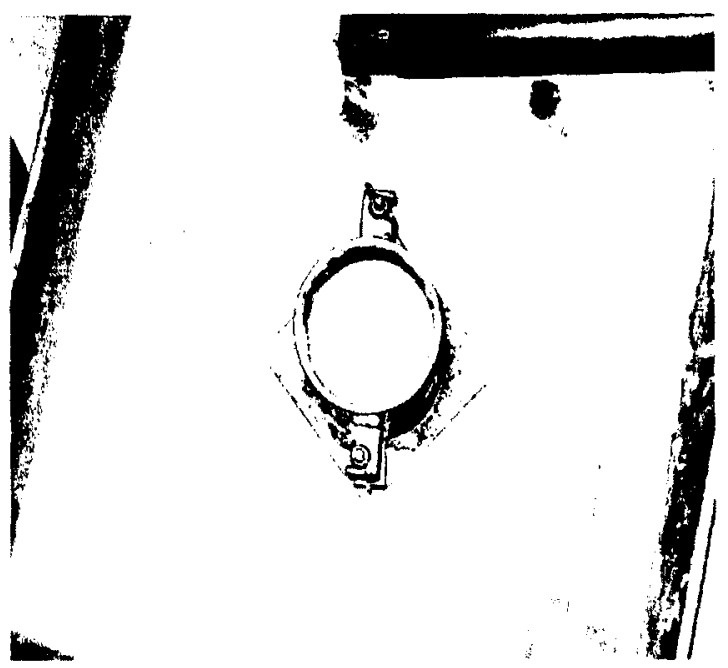

(2c) Compacted third layer

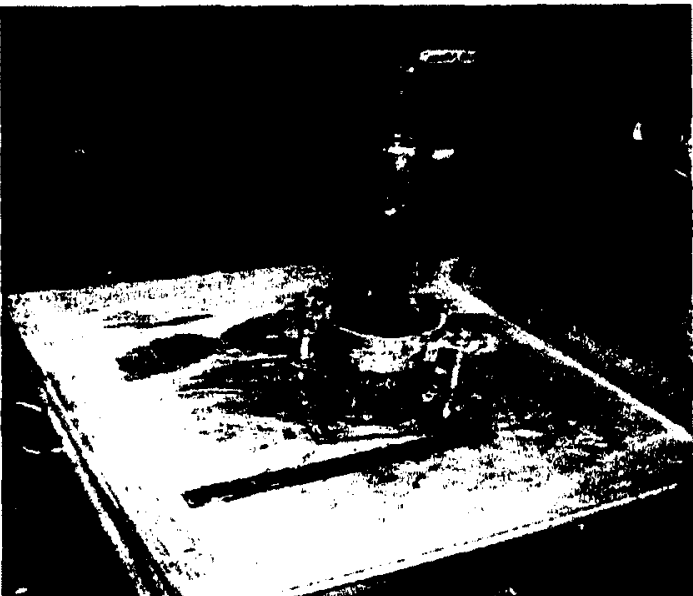

(2b) Compacting first layer

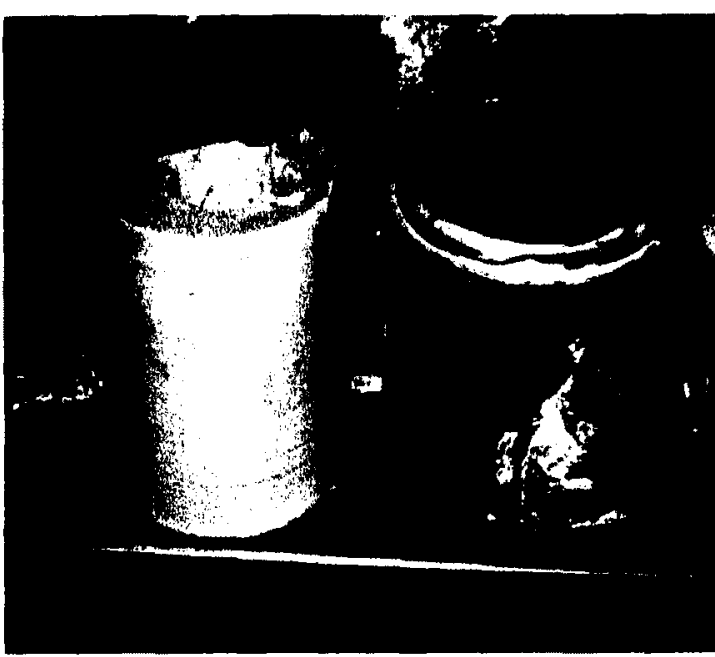

(2d) End of compaction test, take a sample for water content determination 


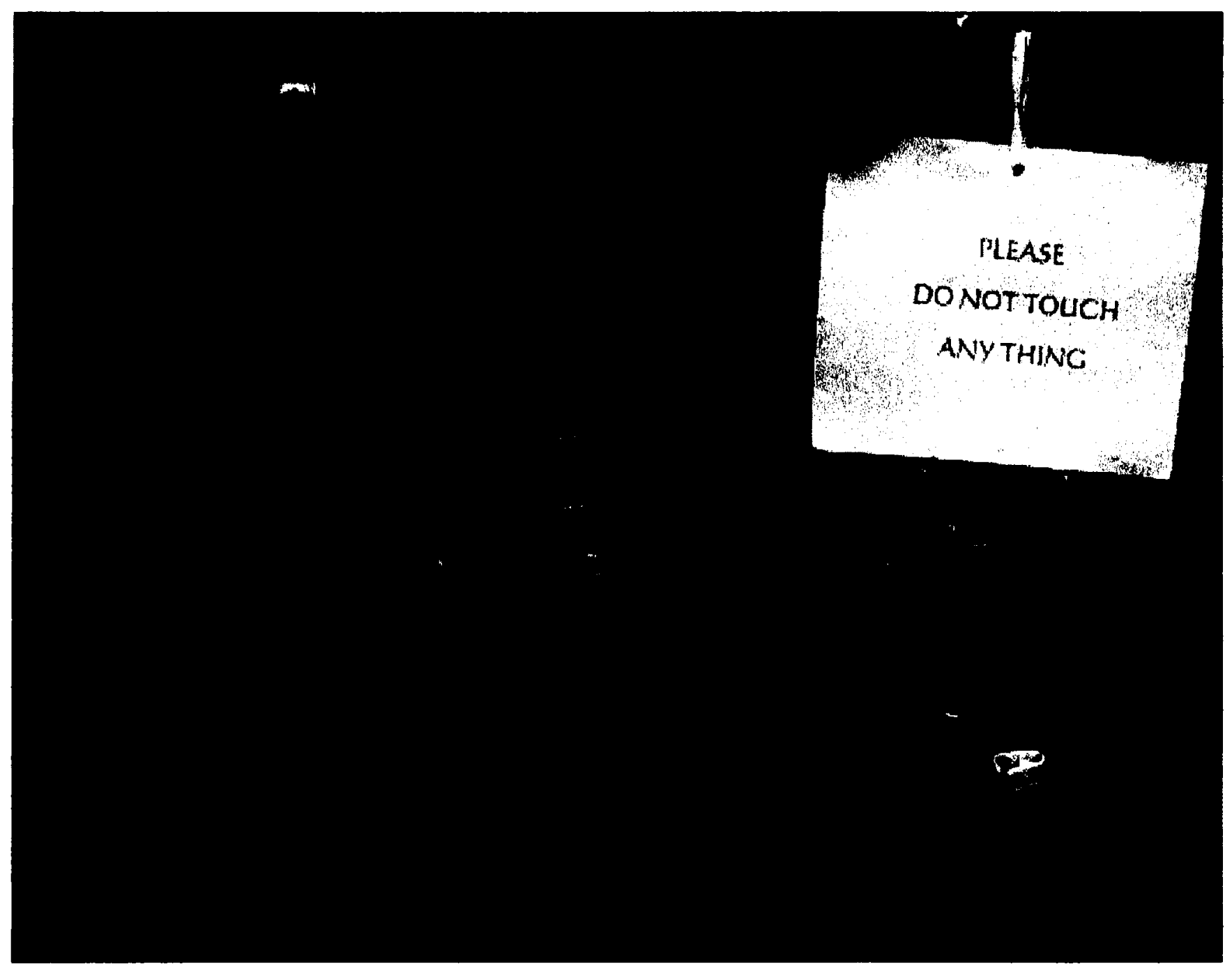

Picture A-3: Set up Tailings water Characteristive Curve device in the lab.

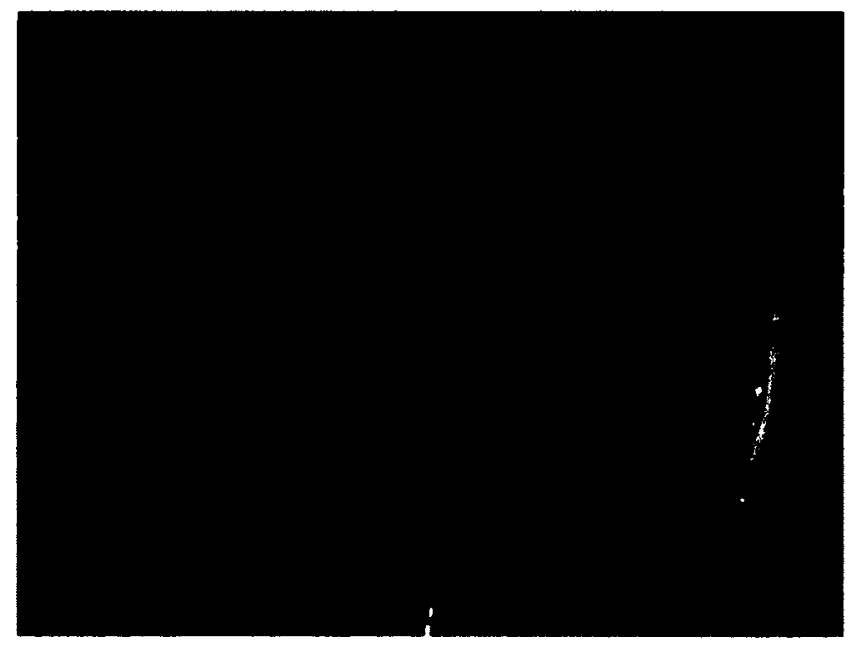

(4a) Artificial silt, after settling

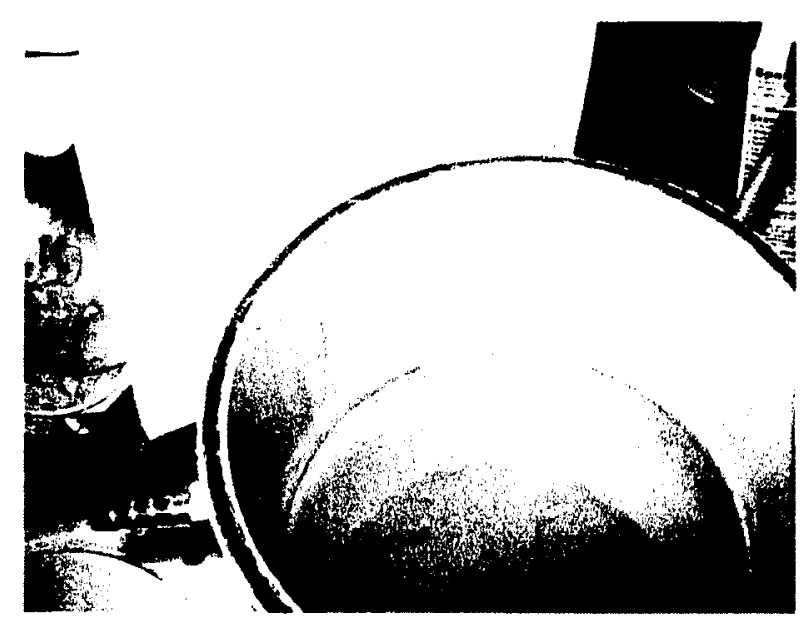

(4b) Artificial silt, after removing top water 


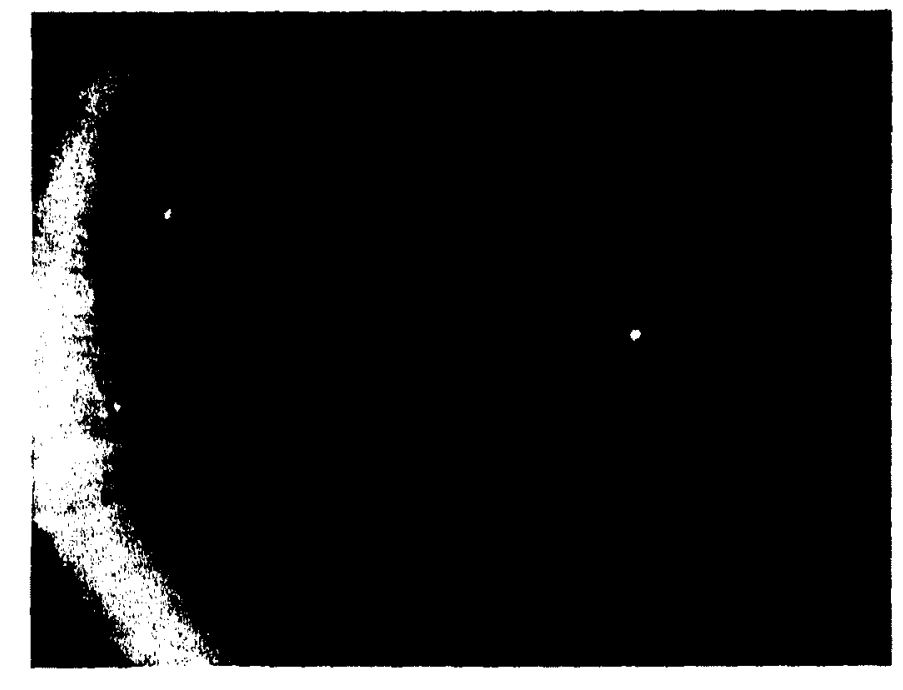

(4c) Artificial silt, end of the test

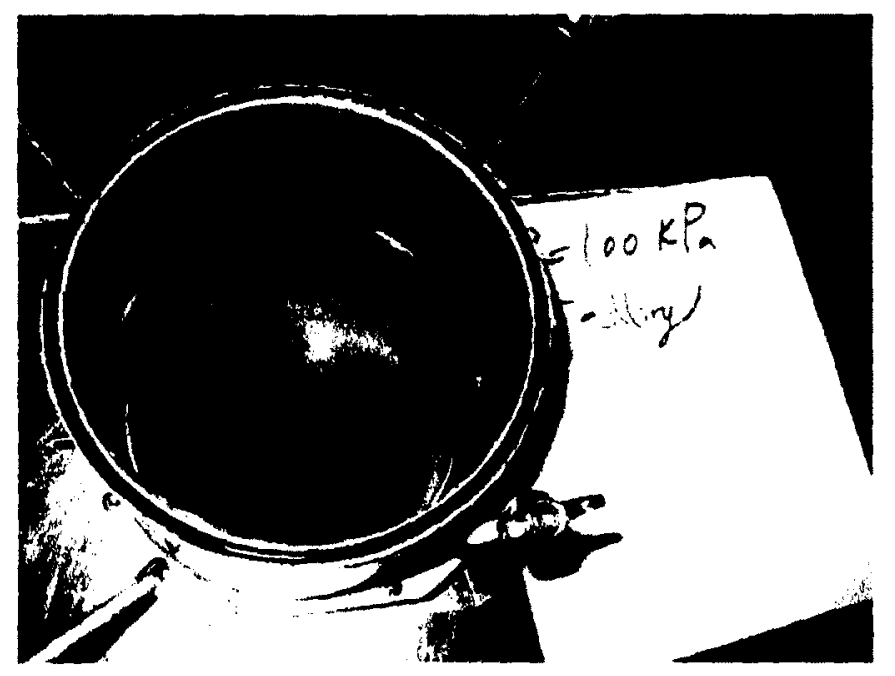

(4e) GMT, after $100 \mathrm{kpa}$. pressure

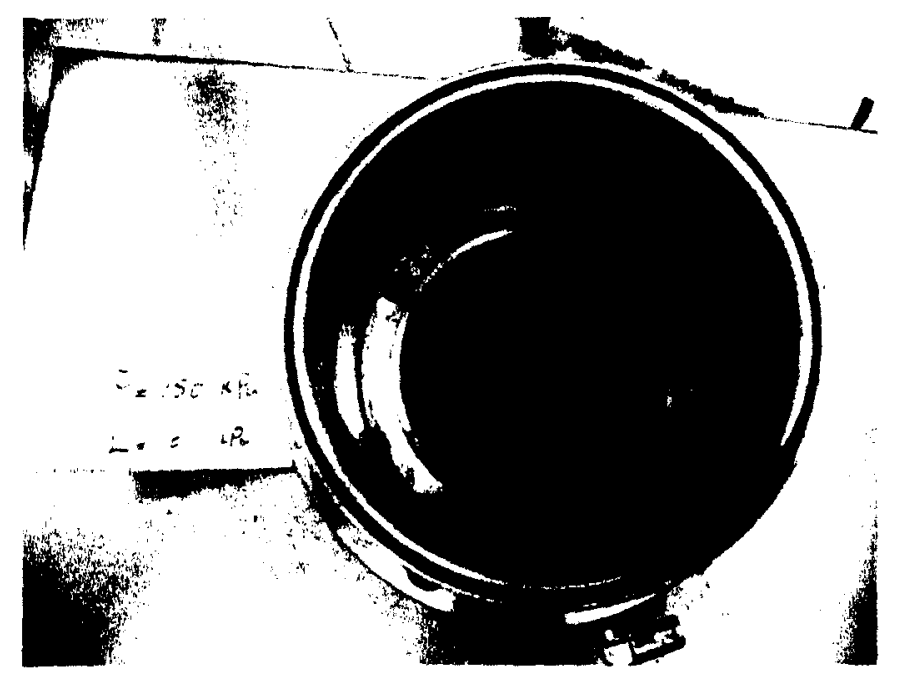

(4g) GMT, after $150 \mathrm{kpa}$. pressure, in loading unit

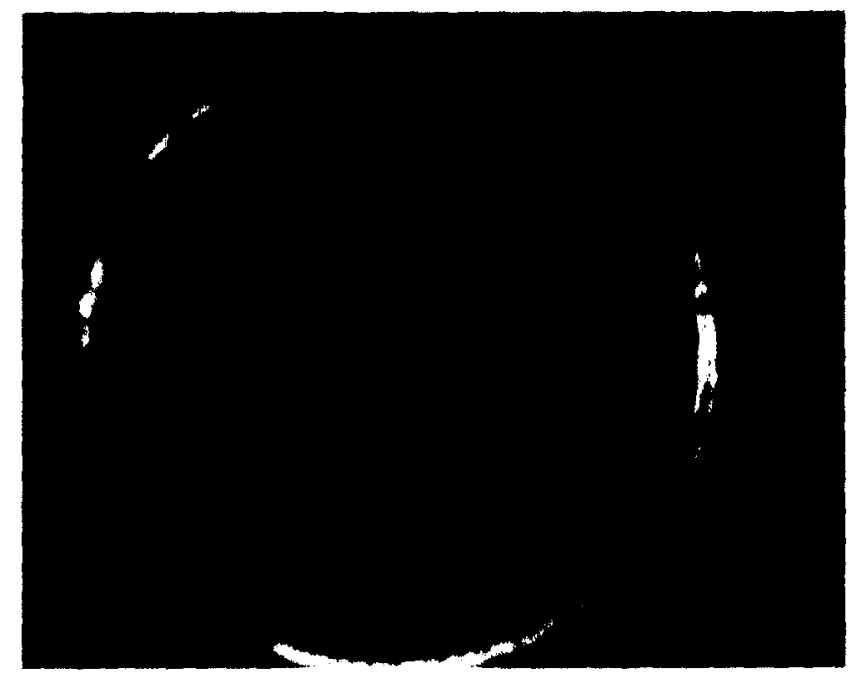

(4d) MFT, end of the test

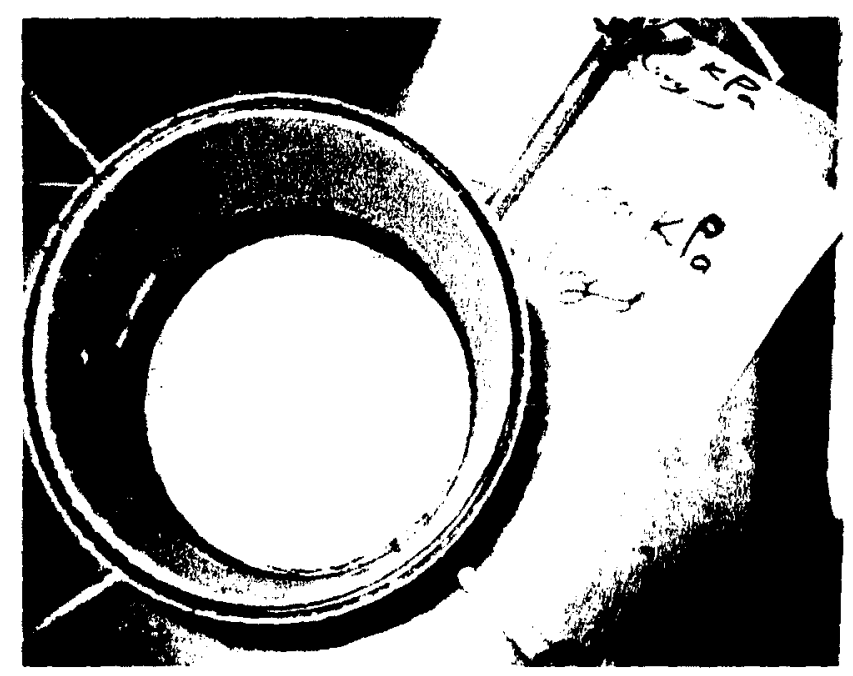

(4f) GMT, after $200 \mathrm{kpa}$. pressure

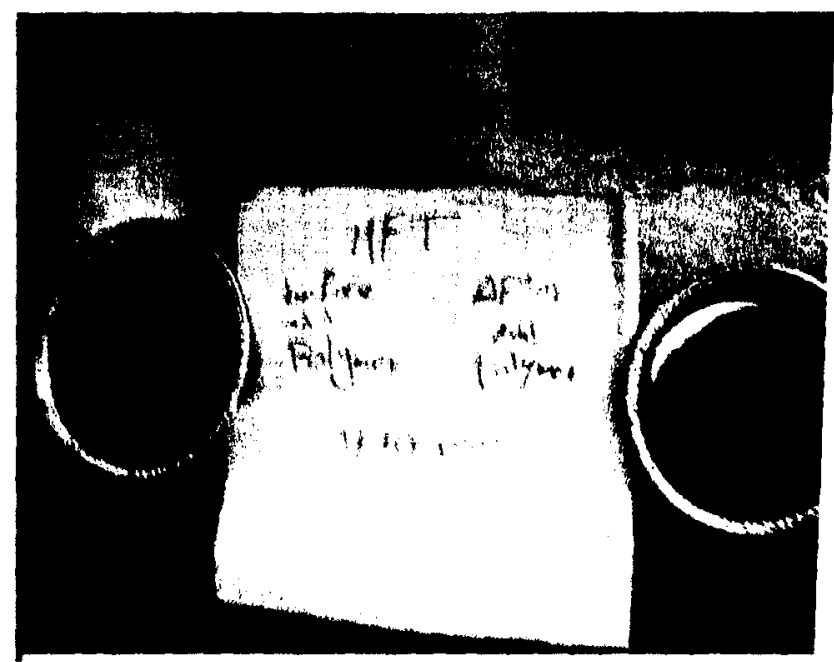

(4h) MFT, after oven dry, left: without polym right: with polymer 


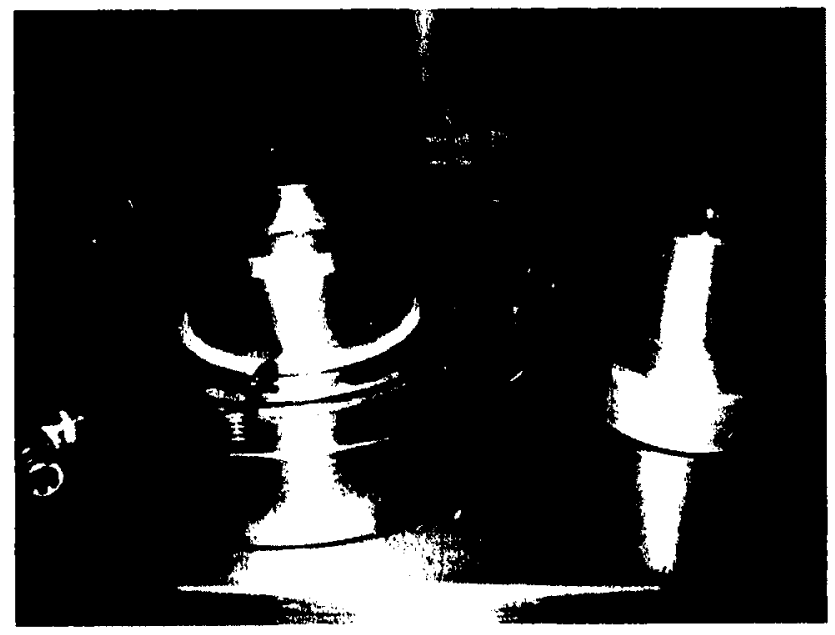

(5a) Sample in small ring

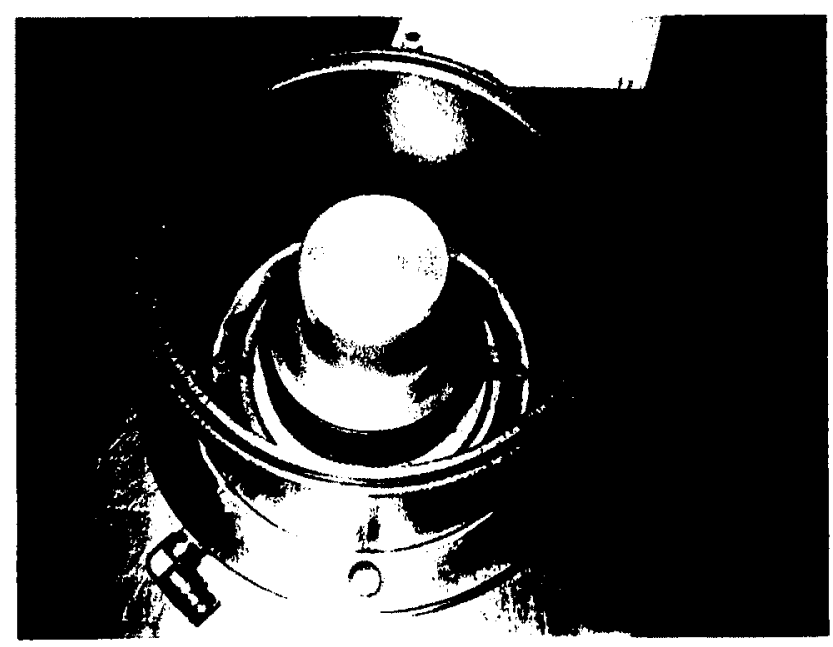

(5b) Ready for loading

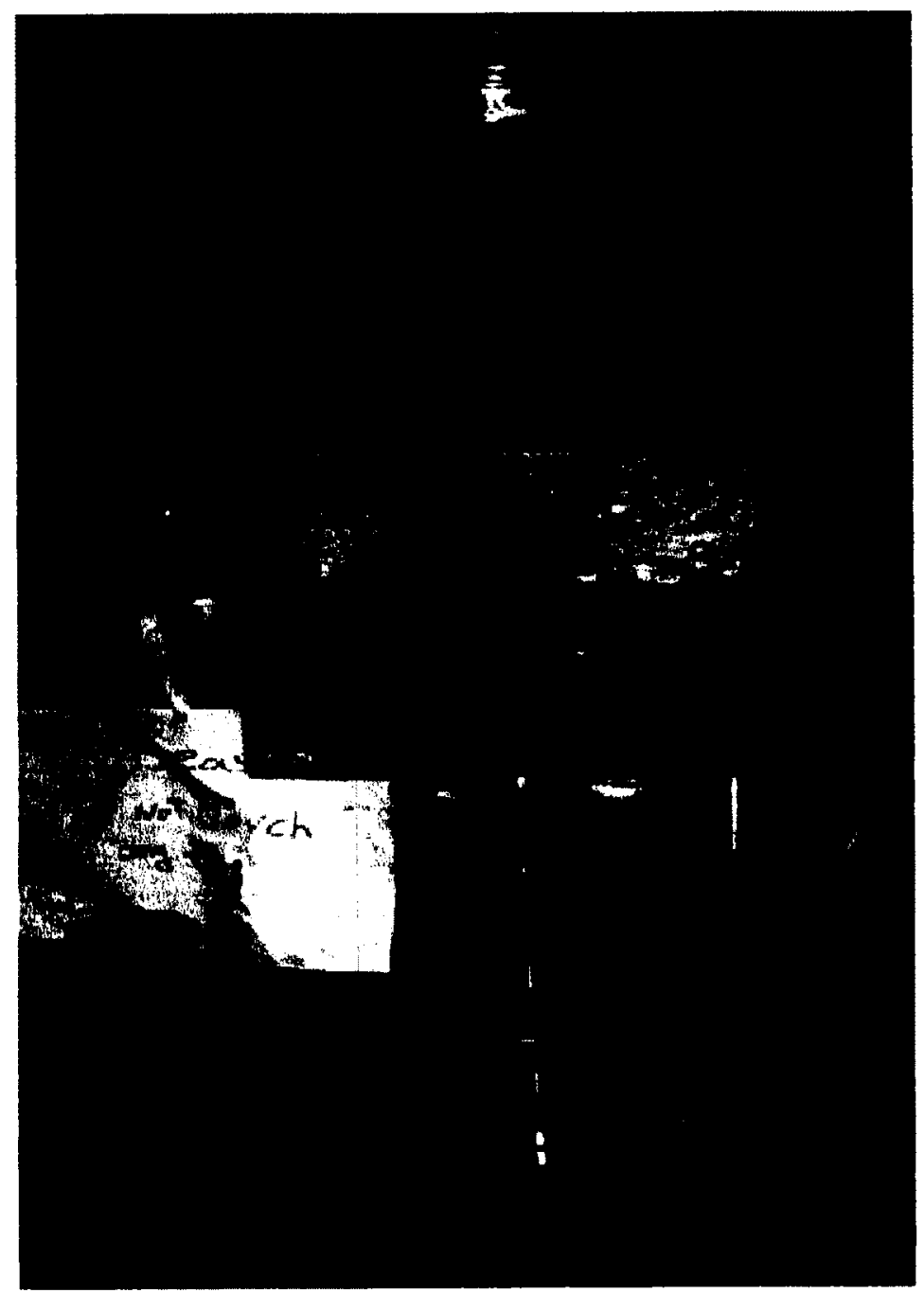

Picture A-5: Suction + 1-D Loading test set up for TWCC, load= $150 \mathrm{kPa}$. 
Appendix-B:

Estimation of the Soil water characteristic curve 


\section{Estimation of the Soil water characteristic curve}

There are several methods for estimation of the SWCC which can consider under three categories:

a) Statistical estimation of water content versus soil suction (Gupa \& Larson, 1979).

b) Describe SWCC with soil parameters estimation for an algebraic function (Rawls \& Brakensiek, 1985, 1989).

c) Grain - size distribution curve to estimate SWCC which called physico-empirical method (Arya \& Paris, 1981, Fredlund et al, 1997, Tyler \& Wheatcraft, 1989).

\section{1- 1. Physico - empirical model}

In this part physico-empirical method will be presented and results compared to other models.

For this model that recently was studied by Fredlund et al, a total of 15 soil types were classified ranging from sand to silty clay loam and SWCC shape is controlled by grainsize distribution and soil density / porosity. This model uses basic soils data function such as grain-size distribution, porosity and yield function that calls pedo-transfer function ( PTF ).

Unimodel and biomodel equations of the Fredlund et al $(1997,2000)$ is used for grainsize distribution representation. For SWCC representation, the Fredlund and Xing (1994) equation is used. This equation is flexible as even can cover water content of zero under $1,000,000 \mathrm{kPa}$. 


$$
w_{w}=w_{s} \times\left[1-\frac{\operatorname{Ln}\left(1+\frac{\psi}{h_{r}}\right)}{\operatorname{Ln}\left(1+\frac{10^{6}}{h_{r}}\right)}\right]\left[\frac{1}{\left\{\operatorname{Ln}\left[\exp (1)+\left(\frac{\psi}{a_{f}}\right)^{n_{f}}\right]\right\}^{m_{f}}}\right]
$$

Where: $w_{s}=$ saturated water content

$a_{\mathrm{f}}, \mathrm{n}_{\mathrm{f}}, \mathrm{m}_{\mathrm{f}}=$ fitting parameters, related to AEV, rate of desaturation and curvature of suction respectively

$h_{r}=$ soil suction at residual water content, $(3000 \mathrm{kPa})$.

In the physic - empirical method, it is assumed that the grain-size distribution and poresize distribution are strongly related, volumetric water content can be calculated from pore-size and volumetric water content is used to get soil suction. According to Fredlund and Xing (1994) equation figure B-1 shows effect of fitting parameters $\left(m_{f}\right.$ and $\left.n_{f}\right)$ on gravimetric water content.

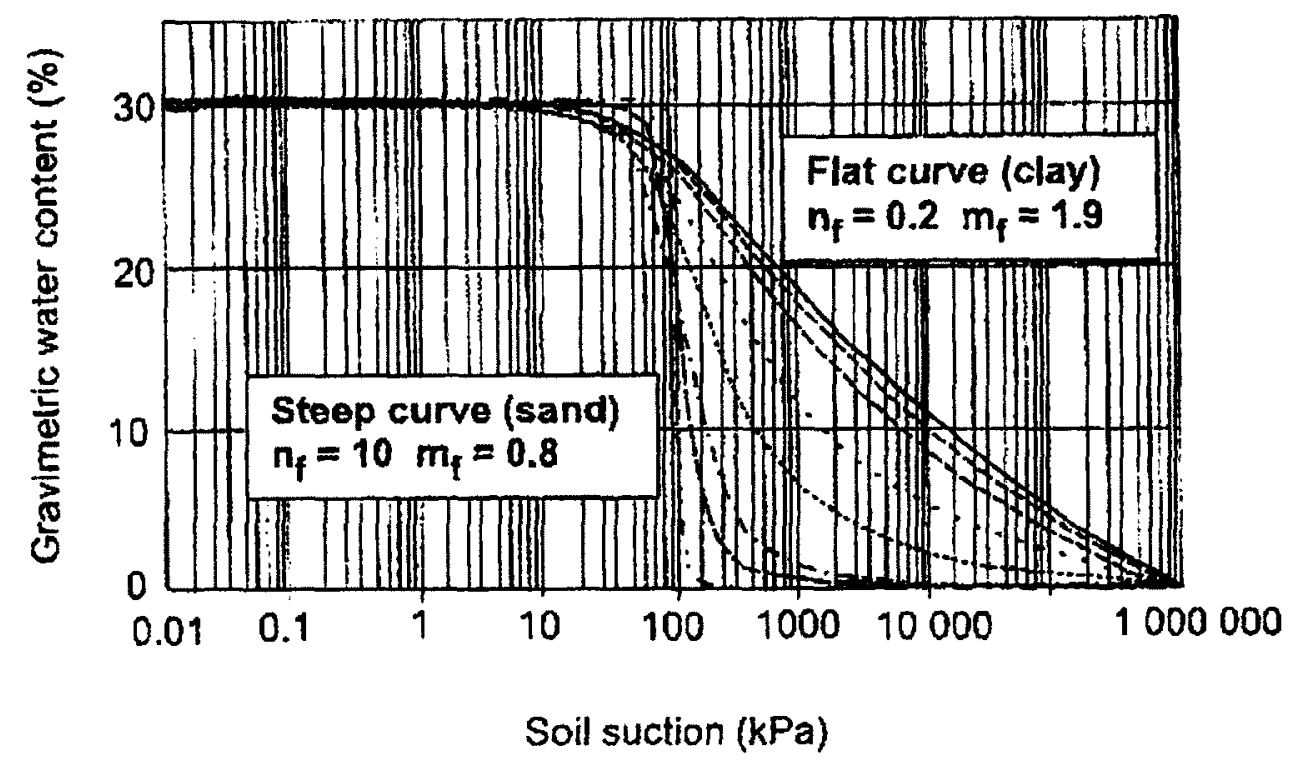

Figure B-1: Effect of fitting parameters $\left(m_{f}, n_{f}\right)$ to particle size, at $a_{f}=100 \mathrm{kPa}$

(Fredlund et al, 2002) 
Effective grain-size diameter is calculated by following equation:

$$
\frac{1}{d_{e}}=\frac{3}{2} \times \frac{\Delta g_{l}}{d_{l}}+\sum_{i=2}^{i=n} \frac{\Delta g_{i}}{d_{i}}
$$

Where:

$\mathrm{d}_{\mathrm{c}}=$ effective grain-size diameter

$d_{1}=$ largest diameter of the most coarse fraction

$\Delta g_{1}=$ weight of last fraction (Vukovic \& Soro, 1992)

Figures B-2 and B-3 show variation of fitting parameters $\left(n_{f}, m_{f}\right)$ with effective grainsize diameter respectively. In figures B-4 to B-7 comparison between experimental and predicted SWCC for different soil type can be seen. As it shows there is very good relation between experimental and predicted SWCC.

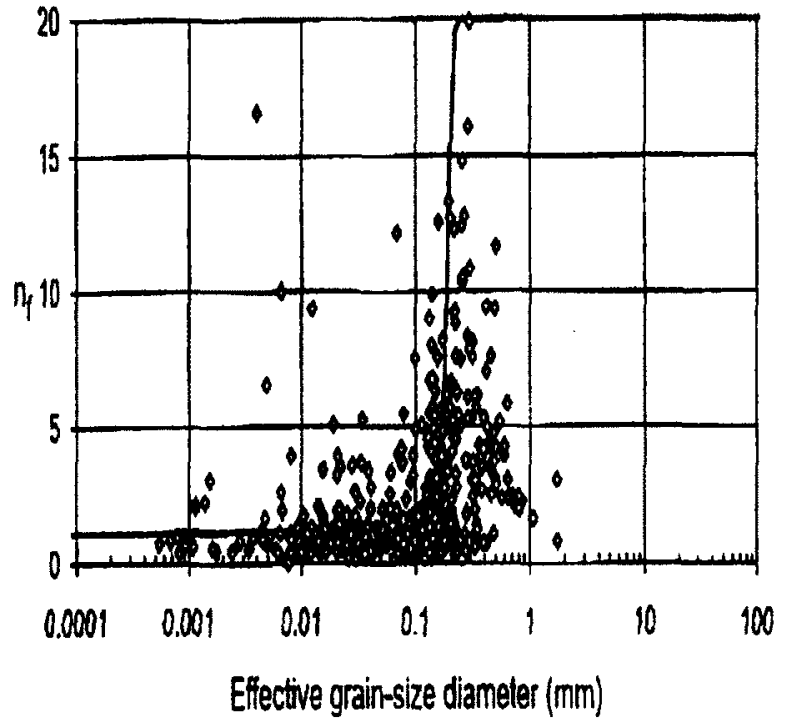

Figure B-2: relationship between effective Grain-size and $n_{f}$ (Fredlund, 2002)

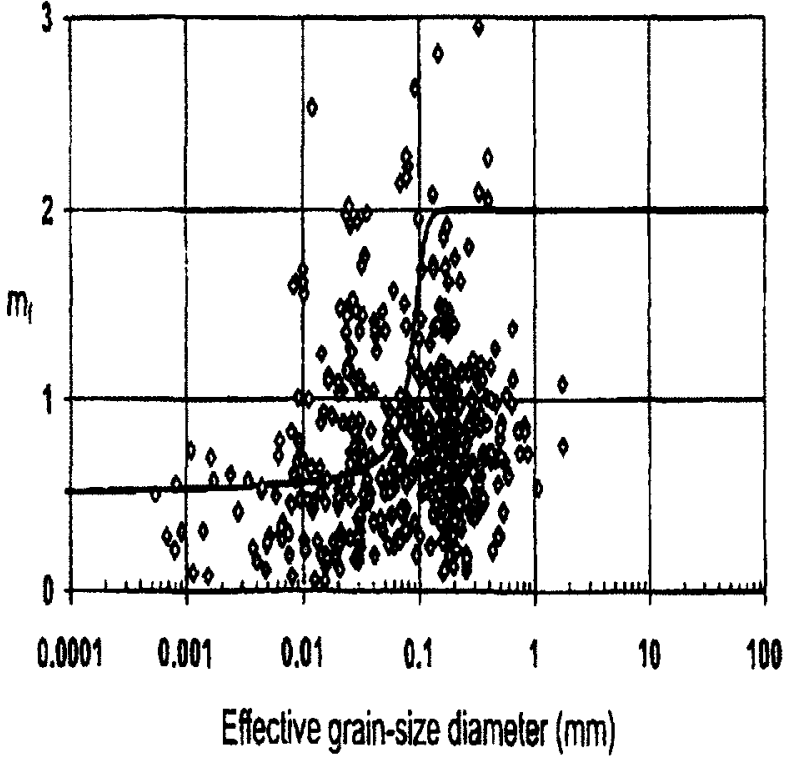

Figure B-3: relationship between effective Grain-size and $\mathrm{m}_{\mathrm{f}}$ (Fredlund, 2002) 


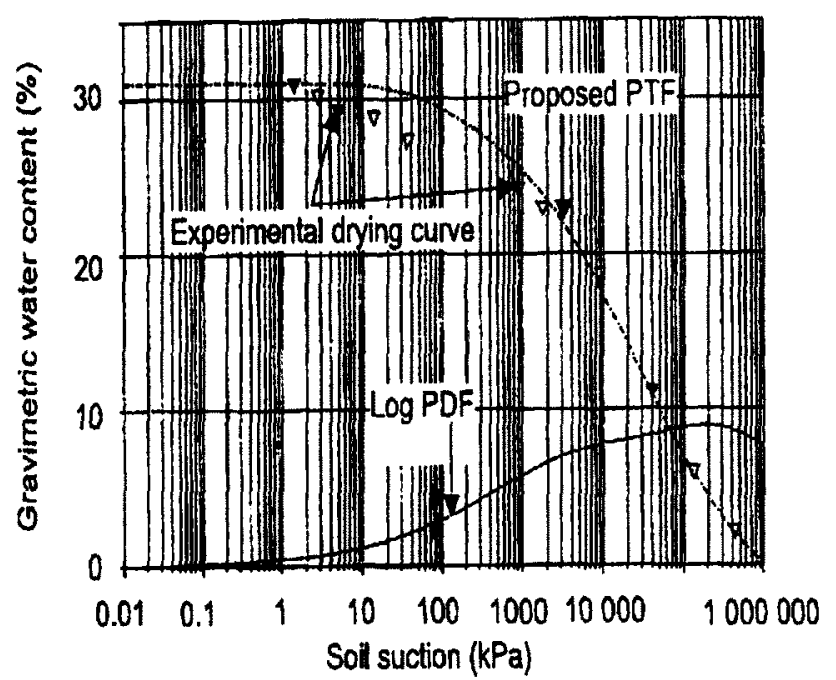

Figure B-4: comparison of experimental and predicted SWCC for a clay,(Russam, 1958)

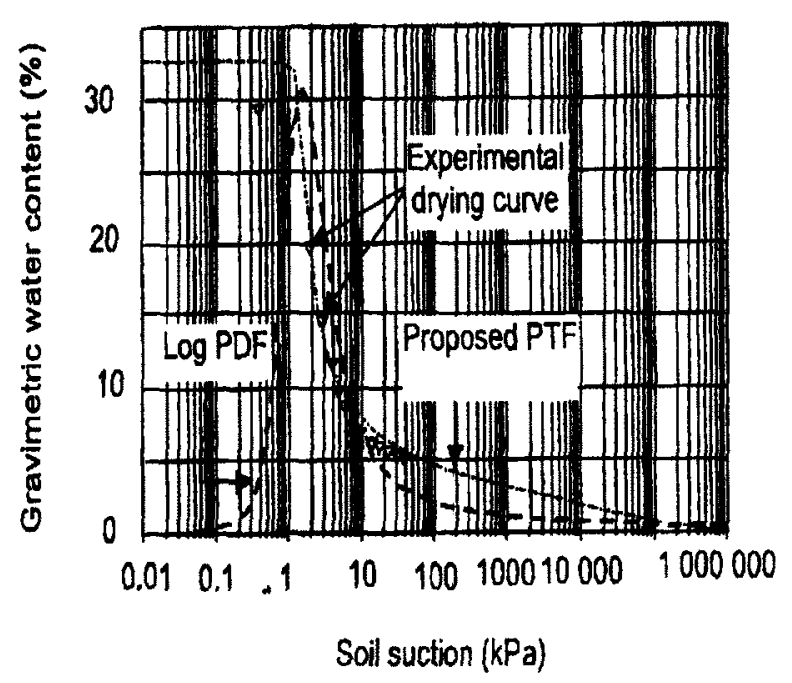

Figure B-6: comparison of experimental and predicted SWCC for a sand,(Dane \& Hruska, 1983) loam,(Schuh, 1991)
SWCC estimation is difficult for fallowing four groups (Fredlund et al, 2002):

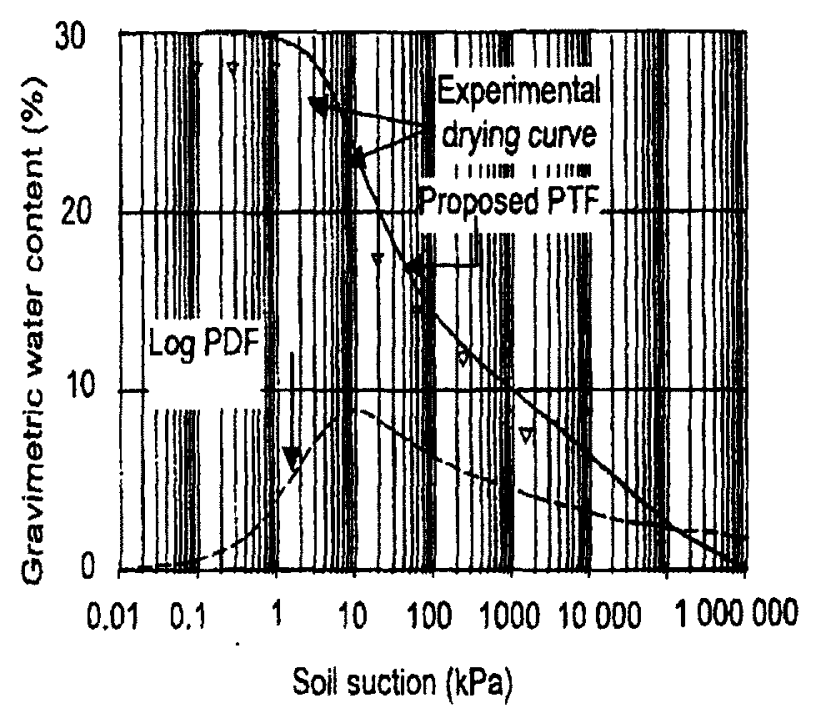

Figure B-5: comparison of experimental and predicted SWCC for a silt loam,(Vereecken ea al, 1989)

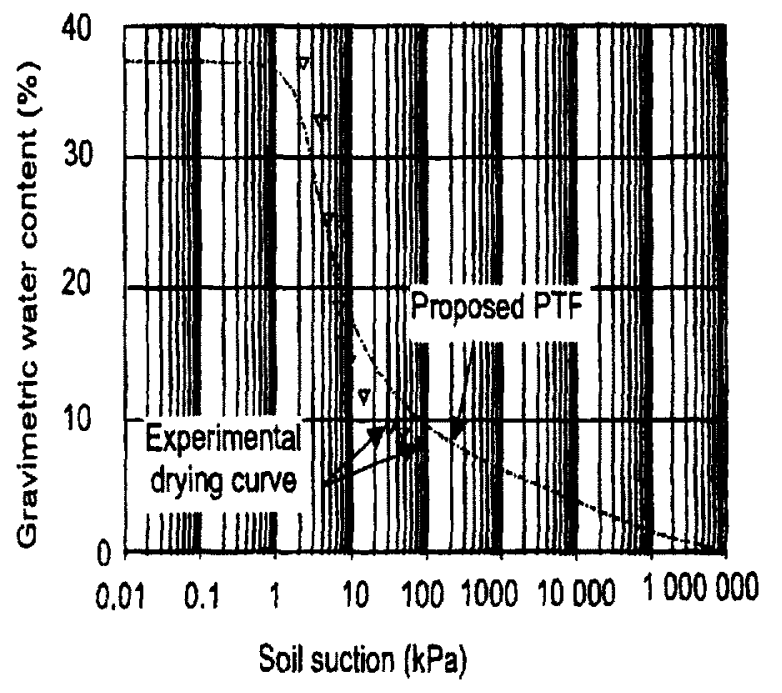

Figure B-7: comparison of experimental and predicted SWCC for a sandy 
a) Soils with high amount of clay sized particles.

b) Soils mix of large amount of coarse-sized particles and few fines.

c) Soils with biomodel behavior (e.g. sand-bentonite).

d) Mine waste, tailings and waste rock because of angular particles shapes.

In SWCC estimation, the packing factor that is function of particle size assumed to be constant. But effect of packing factor on SWCC is illustrated in figure B-8. As it shows packing factor has more effect on SWCC in desaturation zone which is between AEV and residual saturation zone.

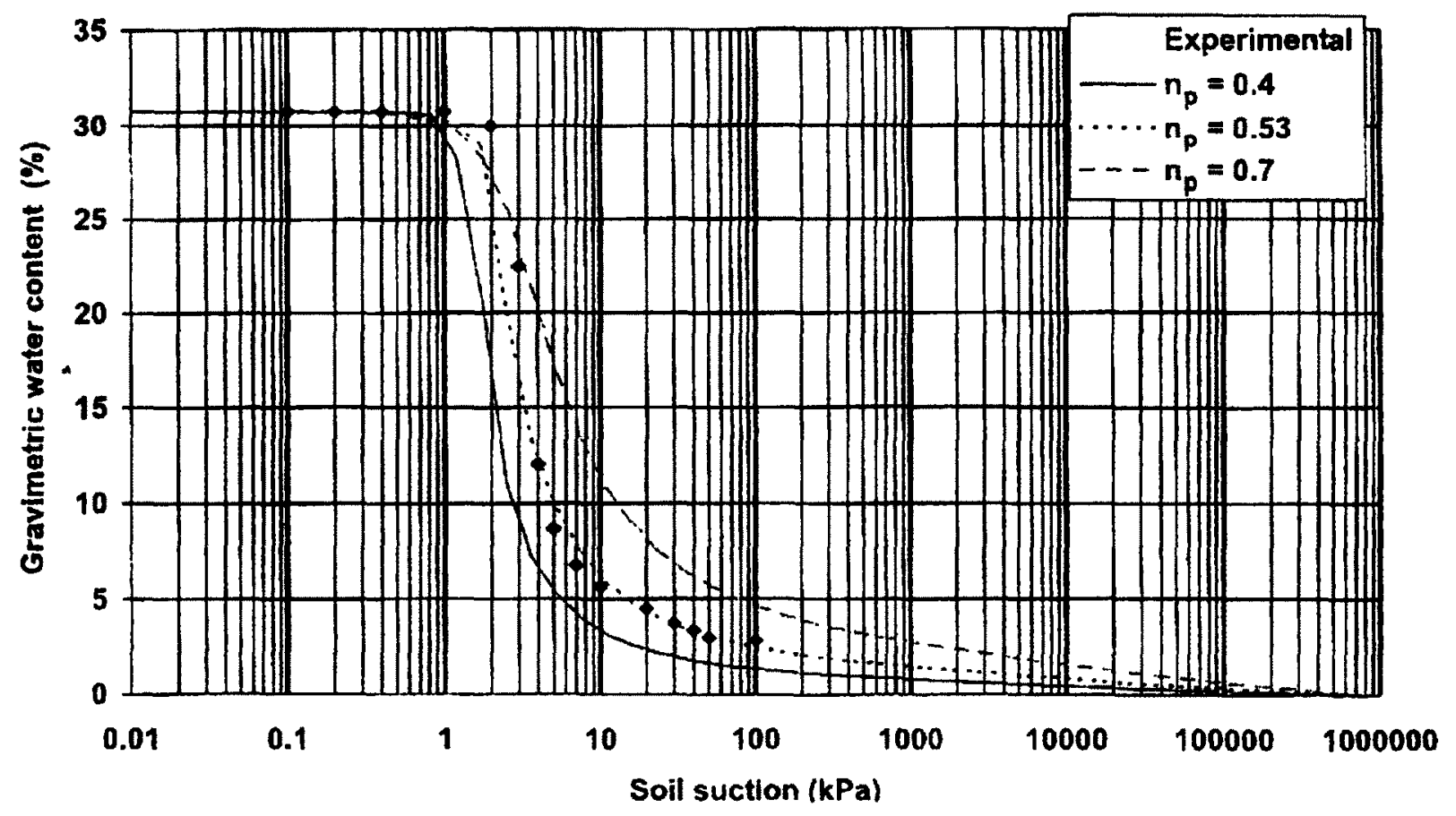

Figure B-8: Effect of packing factor, $\mathrm{n}_{\mathrm{f}}$ on $\mathrm{SWCC}$ for a sand (Mualem, 1984) 


\section{1 - 2. Comparison of models results}

The other models which used pedo-transfer function ( PTF ) to estimate SWCC are presented by:

- Arya and Paris (1981)

- Scheinost et al (1997)

- Rawls and Brakensiek (1985)

- Vereecken et al (1989)

- Tyler and Wheatcraft (1989)

Air entry value (AEV) and rate of soil desaturation (maximum slope) are very important in SWCC. All of the models estimated those parameters and accuracy of estimations is calculated by square difference (SD) that is square difference between experimental and estimated results (Table B-1).

According to this table, the Fredlund et al (1997) and Rawls \& Brakensiek (1985)

methods have the highest accuracy in estimation of AEV (SD $=0.585 \& 0.7870$ respectively) but Tyler and Wheatcraft (1989) technic is not good in AEV estimation (SD $=3.4380$ ). for rate of desaturation (maximum slope) estimation Fredlund et al (1997), Scheinost et al (1997) and Vereecken et al (1989) methods have reasonable accuracy but Rawls and Brakensiek (1985) methods is not acceptable ( $\mathrm{SD}=7.850)$. 
Table B-1: Comparison of AEV and maximum slopes of SWCC for models according to square difference.

\begin{tabular}{|l|c|c|}
\hline \multicolumn{1}{|c|}{ Method } & $\begin{array}{c}\text { PTF AEV } \\
\text { Squared difference }\end{array}$ & $\begin{array}{c}\text { PTF maximum slope } \\
\text { Squared difference }\end{array}$ \\
\hline Fredlund et al (1997) & 0.5850 & 0.487 \\
\hline Arya and Paris (1981) & 0.8620 & 0.586 \\
\hline Scheinost et al (1997) & 1.1911 & 0.476 \\
\hline Rawls and Brakensiek & 0.7870 & 7.850 \\
\hline (1985) & 1.3281 & 0.462 \\
\hline $\begin{array}{l}\text { Vereecken et al (1989) } \\
\text { (1989), Fredlund et al. (2002) }\end{array}$ & 3.4380 & 0.988 \\
\hline
\end{tabular}




\section{Appendix-C:}

Variations of water content and density in tailings layers 


\section{1- Variations of water content and density in tailings layers}

To investigate variations of water content and density from layer to layer, a proctor compaction test was performed with the following modifications:

1. Prepare a sample of artificial silt with $\% 38$ to $\% 40$ of water content, ( approximately pumping water content).

2. Add the first layer of sample in the mold.

3. Let the layer settle down for 24 hours then remove excess water on the top of the layer.

4. Measure weight and height of layer before compaction.

5. First layer is compacted by dropping proctor hammer 25 times from specific distance.

6. Measure weight and height of layer after compaction.

7. Take a sample from compacted silt in the mold and determine water content, (moisture) of sample

8. Add second layer and repeat number 3 to 7 .

9. Add third layer and repeat number 3 to 7 .

Result of this test listed in table C-1 and illustrated in figures C-1 to C-4. As these figures show first layer has maximum dry unit weight, $15.3 \mathrm{kN} / \mathrm{m}^{3}$ and minimum void ratio, 0.59 as well. The total unit weight for layers 1,2 and 3 is $14.7 \mathrm{kN} / \mathrm{m}^{3}$ at water content of 26 percent with void ratio of 0.65 . 
A test was also performed where the silt layers were left to settle, but were not compacted. Results for this test can be seen in table C-2 and figures C-5 to C-8. The dry unit weight for all three layers is $15.3 \mathrm{kN} / \mathrm{m}^{3}$ at water content of 23.1 percent with void ratio of 0.59 .

Comparing these two tests shows increasing dry unit weight in test with 24 hours' time with decreasing in water content and void ratio and this is because some voids which created by removing some water from silt is filled by silt particles, (TableC-3, Figure C-9 to C-12).

Table C-1: Variation of void ratio and volume of artificial silt in S.P.C.T. in each layer

\begin{tabular}{|l|c|c|c|}
\hline \multicolumn{1}{|c|}{ Description } & \multicolumn{3}{c|}{ Layer's number } \\
\hline & Layer 1 & Layer 1\&2 & Layer 1,283 \\
\hline Weight of proctor mold and base+ Compact soil(g) & 5051.7 & 5556.6 & 6058.2 \\
\hline Weight of soil moisture container (g) & 2.1 & 2.1 & 2.1 \\
\hline Weight of container + moist soil (g) & 34.7 & 28.9 & 24.9 \\
\hline Weight of container + dry soil (g) & 27.6 & 23.2 & 20.2 \\
\hline Weight of dry soil $(\mathrm{g})$ & 25.5 & 21.1 & 18.1 \\
\hline Weight of water $(\mathrm{g})$ & 7.1 & 5.7 & 4.7 \\
\hline Bulk unit weight $(\mathrm{kN} / \mathrm{m3})$ & 19.6 & 18.6 & 18.6 \\
\hline Moisture content $(\%)$ & 27.8 & 27.0 & 26.0 \\
\hline Dry unit weight of soil $(\mathrm{kN} / \mathrm{m} 3)$ & 15.3 & 14.6 & 14.7 \\
\hline Inside volume of the mold $(\mathrm{cm} 3)=$ & 392.2 & 678.2 & 943.9 \\
\hline
\end{tabular}




\begin{tabular}{|l|c|c|c|}
\hline Weight of proctor mold and base $(\mathrm{g})$ & 4268.9 & 4268.9 & 4268.9 \\
\hline Weight of Compact soil $(\mathrm{g})$ & 782.80 & 1287.70 & 1789.30 \\
\hline Weight of dry Compact soil $(\mathrm{g})$ & 612.31 & 1013.82 & 1420.45 \\
\hline Volume of dry compact soil (Cm3) & 246.90 & 408.80 & 572.76 \\
\hline Volume of void (Cm3) & 145.32 & 269.42 & 371.14 \\
\hline Void ratio & 0.59 & 0.66 & 0.65 \\
\hline Initial height (cm) & 5.2 & 8.9 & 12.7 \\
\hline Final height (cm) & 4.8 & 8.3 & 12.0 \\
\hline Initial volume (Cm3) & 424.9 & 727.2 & 1037.8 \\
\hline Final volume (Cm3) & 392.2 & 678.2 & 980.6 \\
\hline Volume change (\%) & -7.7 & -6.7 & -5.5 \\
\hline Specific gravity $=2.48$ & & & \\
\hline
\end{tabular}




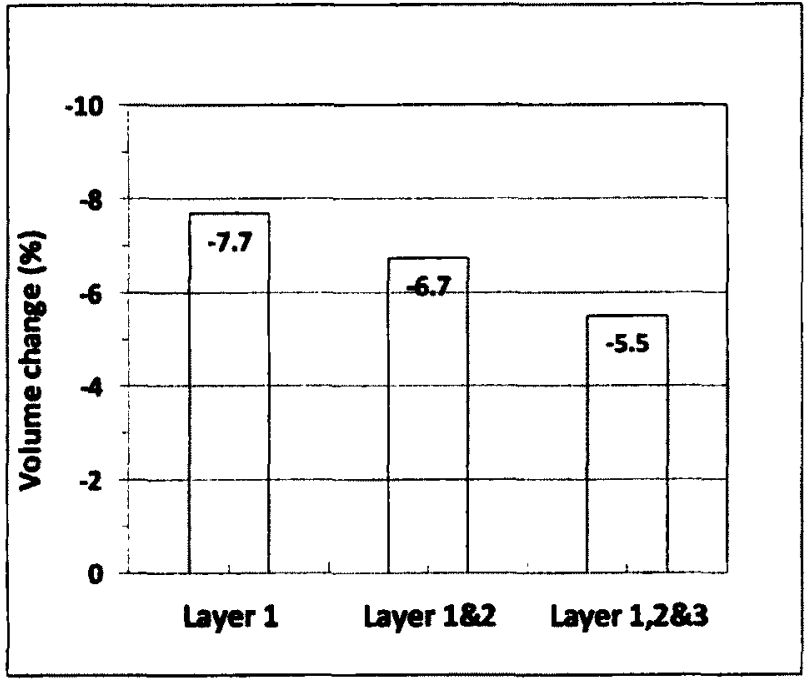

Figure C-1: Volume variations for silt in S.P.C.T

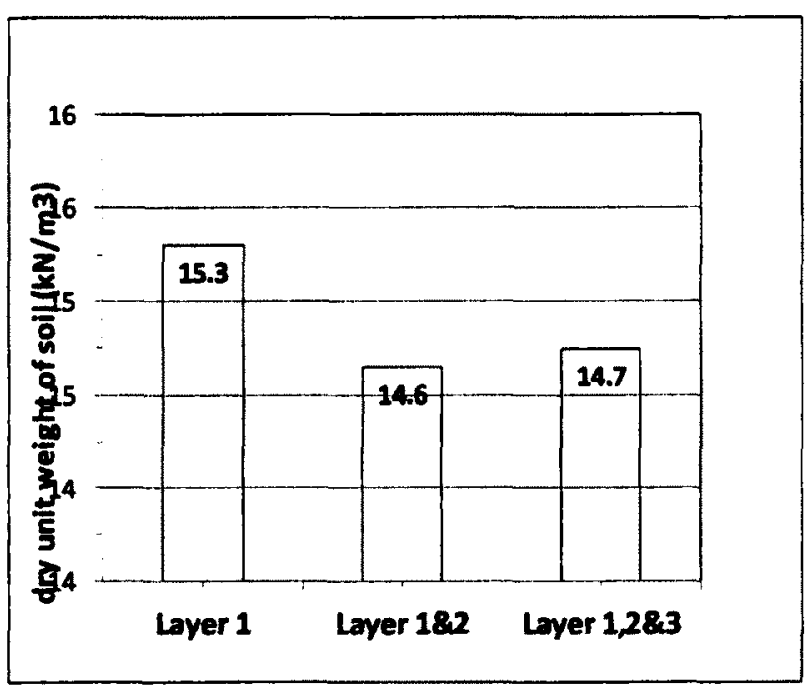

Figure C-3: Dry unit weight variations for silt in S.P.C.T

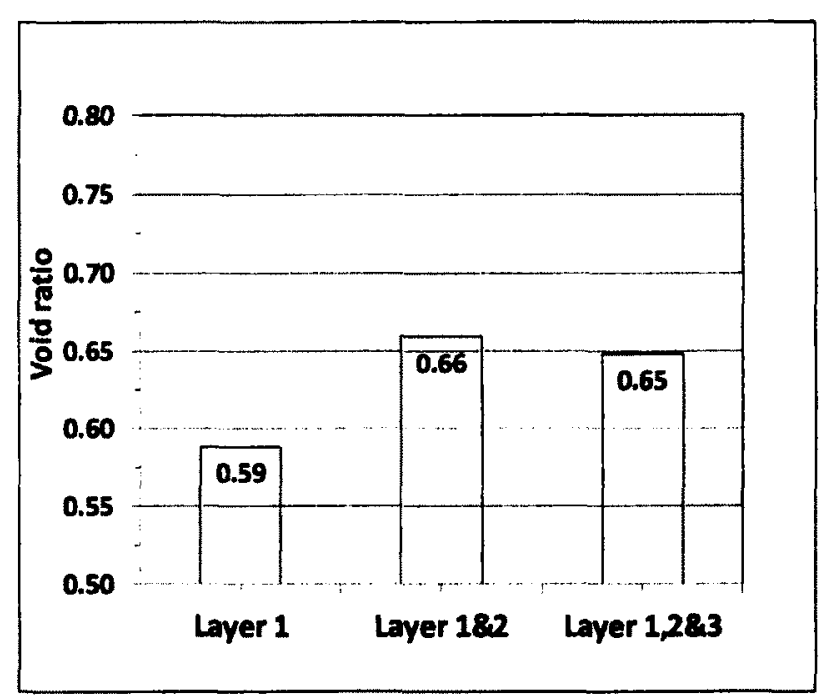

Figure C-2: Void ratio variations for silt in S.P.C.T

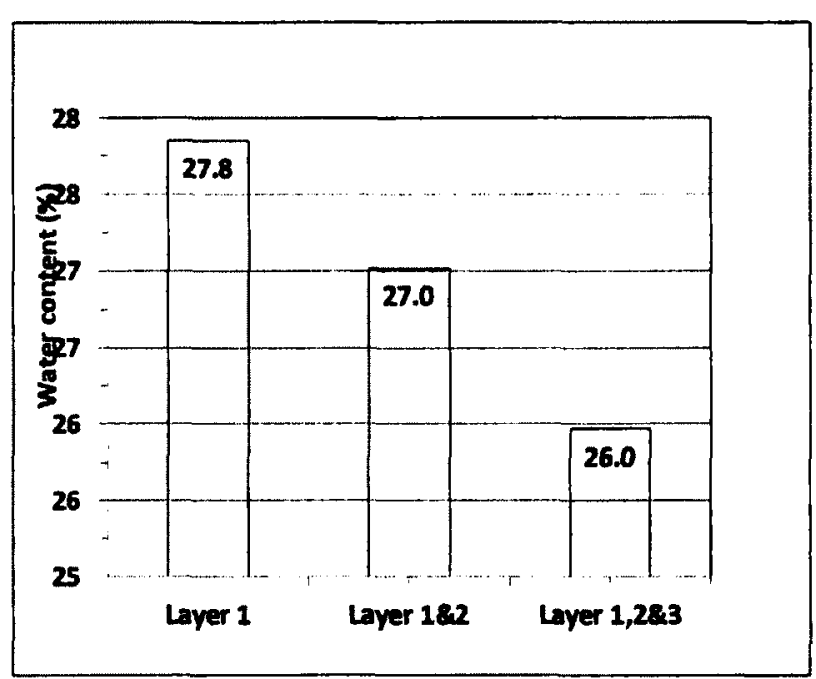

Figure C-4: Water content variations for silt in S.P.C.T 
Table C-2: S.P.C.T. for Artificial silt - compacted and non-compacted silt

\begin{tabular}{|c|c|c|c|c|c|}
\hline \multirow[t]{2}{*}{ Description } & \multicolumn{3}{|c|}{ Layer's number } & \multirow{2}{*}{$\begin{array}{c}\text { Non } \\
\text { compacted } \\
\text { dry soil }\end{array}$} & \multirow{2}{*}{$\begin{array}{l}\text { Compacted } \\
\text { dry soil }\end{array}$} \\
\hline & Layer 1 & $\begin{array}{l}\text { Layer } \\
1 \& 2\end{array}$ & $\begin{array}{l}\text { Layer } \\
1,2 \& 3\end{array}$ & & \\
\hline $\begin{array}{l}\text { Weight of proctor mold and baset } \\
\text { Compact soill(g) }\end{array}$ & 4884.4 & 5511.3 & 6076.8 & 5555.4 & 5703.3 \\
\hline Weight of soil moisture container (g) & 2.1 & 2.1 & 2.0 & 2.1 & 2.1 \\
\hline Weight of container + moist soil (g) & 21.9 & 24.9 & 39.9 & 12.1 & 12.1 \\
\hline Weight of container + dry soil $(\mathrm{g})$ & 17.7 & 20.5 & 32.8 & 12.1 & 12.1 \\
\hline Weight of dry soil (g) & 15.6 & 18.4 & 30.8 & 10.0 & 10.0 \\
\hline Weight of water (g) & 4.2 & 4.4 & 7.1 & 0.0 & 0.0 \\
\hline Bulk unit weight $(\mathrm{kN} / \mathrm{m} 3)$ & 18.9 & 19.1 & 18.8 & 13.4 & 14.9 \\
\hline Moisture content (\%) & 26.9 & 23.9 & 23.1 & 0.0 & 0.0 \\
\hline Dry unit weight of soil $(\mathrm{kN} / \mathrm{m} 3)$ & 14.9 & 15.4 & 15.3 & 13.4 & 14.9 \\
\hline Inside volume of the mold $(\mathrm{cm} 3)=$ & 318.7 & 637.4 & 943.9 & 943.9 & 943.9 \\
\hline Weight of proctor mold and base $(\mathrm{g})=$ & 4268.4 & 4268.4 & 4268.4 & 4268.6 & 4268.9 \\
\hline Weight of Compact soil (g) & 616.00 & 1242.90 & 1808.40 & 1286.80 & 1434.40 \\
\hline
\end{tabular}




\begin{tabular}{|l|c|c|c|c|c|}
\hline Weight of dry Compact soil (g) & 485.33 & 1003.04 & 1469.18 & 1286.80 & 1434.40 \\
\hline Volume of dry compact soil (Cm3) & 195.70 & 404.45 & 592.41 & 518.87 & 578.39 \\
\hline Volume of void (Cm3) & 122.98 & 232.91 & 351.49 & 425.03 & 365.51 \\
\hline Void ratio & 0.63 & 0.58 & 0.59 & 0.82 & 0.63 \\
\hline Initial height (cm) & 4.2 & 8.4 & 12.2 & & \\
\hline Final height (cm) & 3.9 & 7.8 & 11.5 & & \\
\hline Initial volume (Cm3) & 343.2 & 682.3 & 1197.0 & & \\
\hline Final volume $(\mathrm{Cm} 3)$ & 318.7 & 637.4 & 1133.0 & & \\
\hline Volume change (\%) & -7.1 & -6.6 & -5.3 & & \\
\hline
\end{tabular}




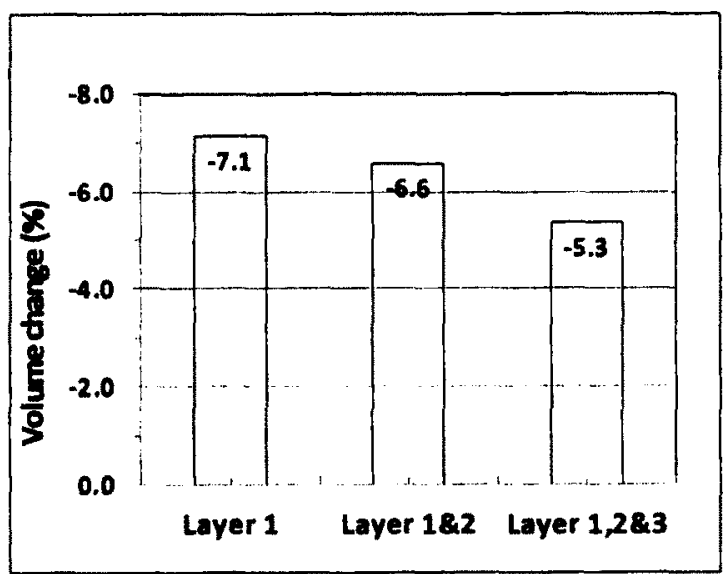

Figure C-5: Volume variations for silt in S.P.C.T, $24 \mathrm{~h}$ settling time for each layer

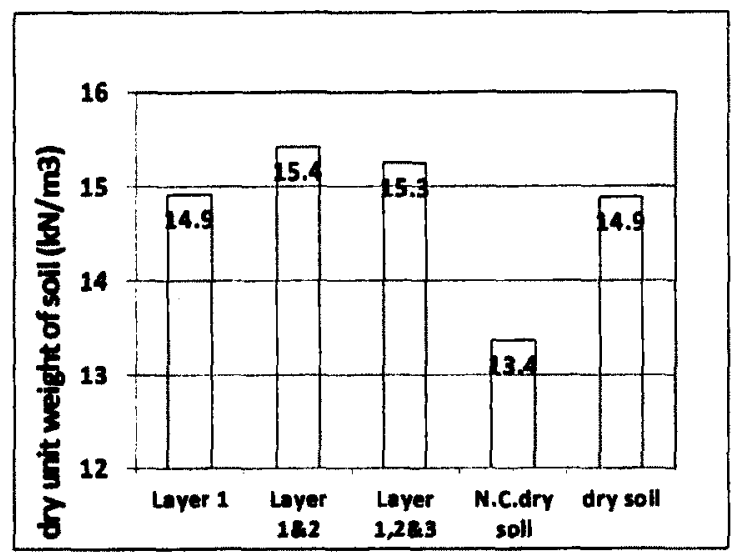

Figure C-7: Dry unit weight variations for silt in S.P.C.T, $24 \mathrm{~h}$ settling time for each layer

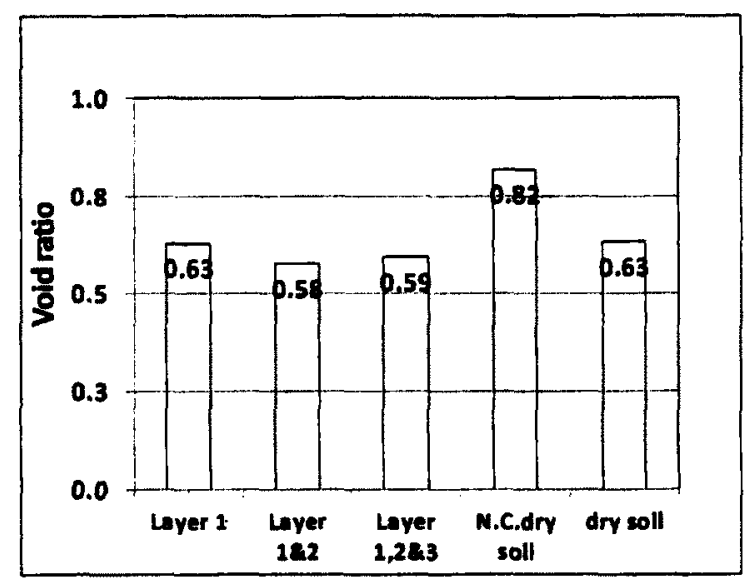

Figure C-6: Void ratio variations for silt in S.P.C.T, $24 \mathrm{~h}$ settling time for each layer

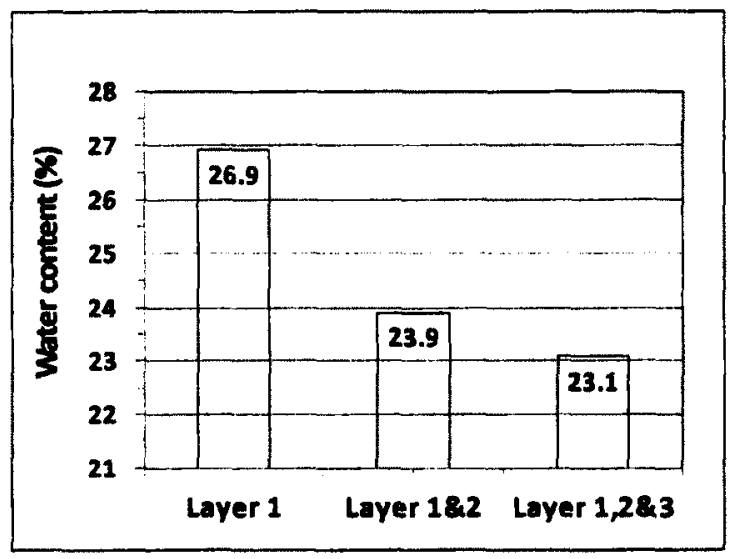

Figure C-8: Water content variations for silt in S.P.C.T, 24 h settling time for each layer 
Table C-3: S.P.C.T. result for silt, after $24 \mathrm{~h}$ settling time for each layer

\begin{tabular}{|l|c|c|c|c|c|c|}
\hline \multirow{2}{*}{ Description } & \multicolumn{3}{|c|}{ S.P.C.T } & \multicolumn{3}{c|}{ S.P.C.T. - 24 h time } \\
\cline { 2 - 7 } & Layer 1 & Layer 1\&2 & Layer 1,2\&3 & Layer 1 & Layer 1\&2 & Layer 1,2\&3 \\
\hline Moisture content (\%) & 27.8 & 27.0 & 26.0 & 26.9 & 23.9 & 23.1 \\
\hline Dry unit weight of soll (kN/m3) & 15.3 & 14.6 & 14.7 & 14.9 & 15.4 & 15.3 \\
\hline Void ratio & 0.59 & 0.66 & 0.65 & 0.63 & 0.58 & 0.59 \\
\hline Volume change (\%) & -7.7 & -6.7 & -5.5 & -7.1 & -6.6 & -5.3 \\
\hline
\end{tabular}

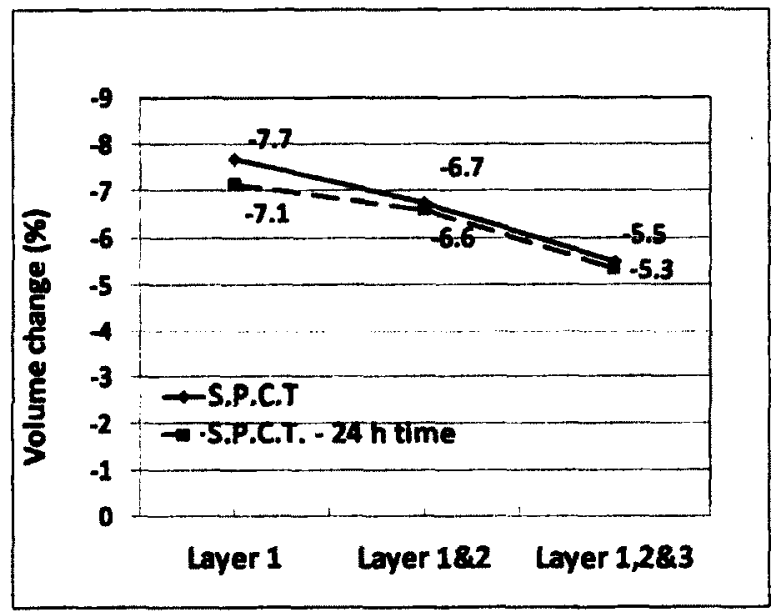

Figure C-9: Comparison of Volume variations for silt

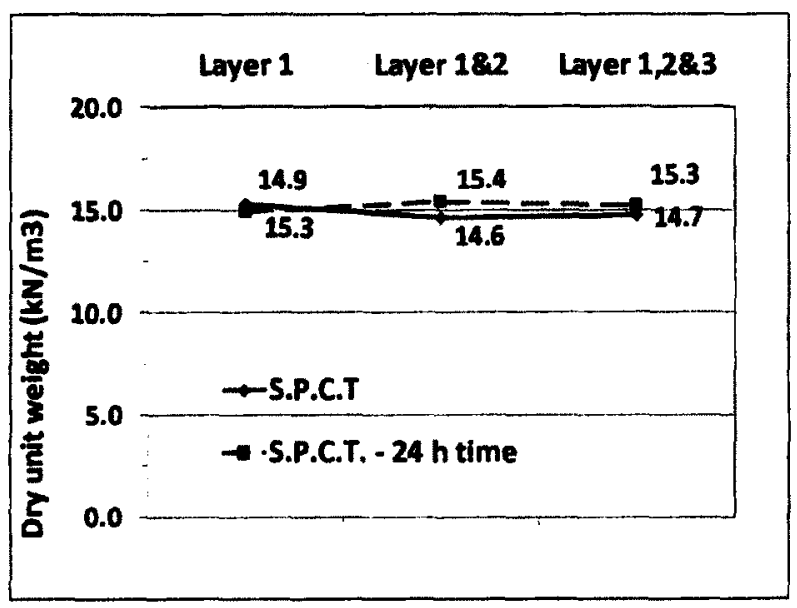

Figure C-11: Comparison of dry unit weight variations for silt

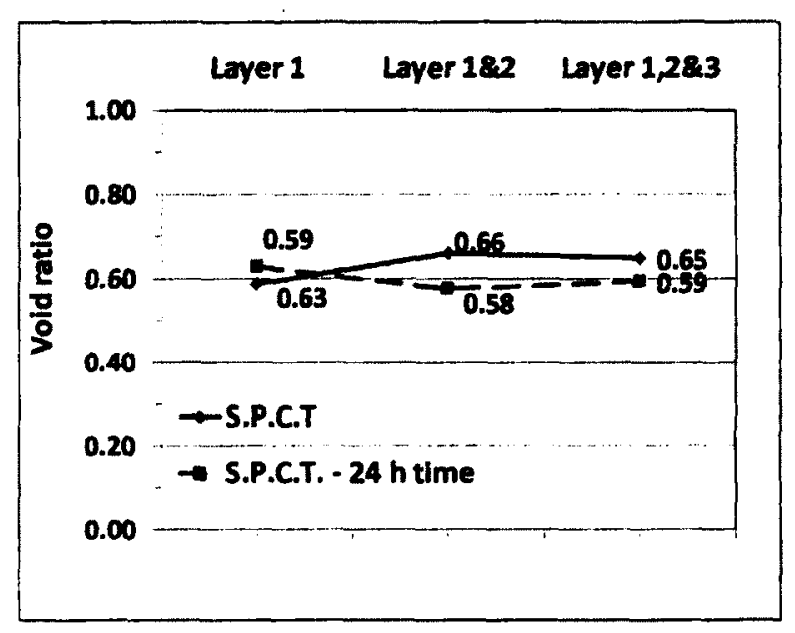

Figure C-10: Comparison of void ratio variations for silt

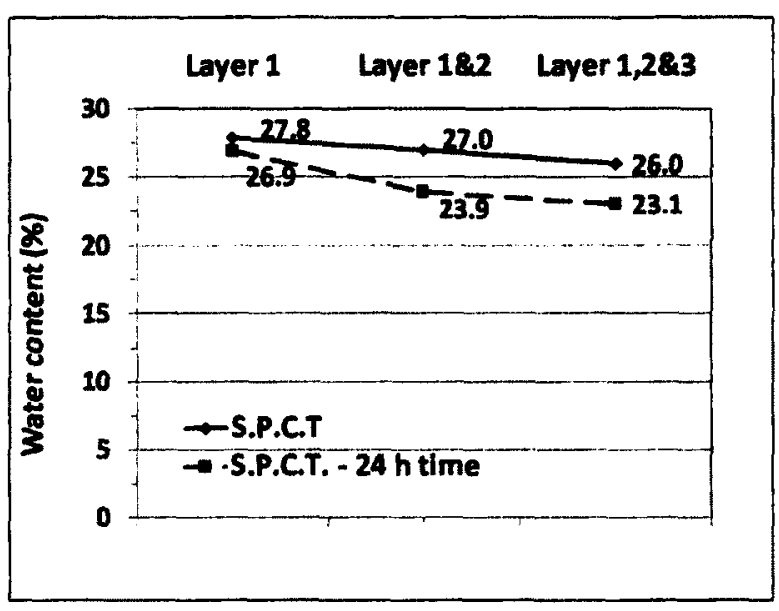

Figure C-12: Comparison of water content variations for silt 


\section{Appendix-D:}

\section{Experimental methods procedure}




\section{Proctor Compaction test (ASTM D698)}

Figure D-1 shows required equipment for proctor compaction test. There are two types of Proctor compaction test:

1. Standard Proctor compaction test: simulate field compaction in the lab.

2. Modified Proctor compaction test: Simulate larger compaction for more serious loads and bigger equipment.

Two different type of Proctor compaction test were compared in Table D-1.

Table D-1: Comparison of standard and modified proctor compaction test

\begin{tabular}{|l|l|}
\hline Standard proctor compaction test & Modified proctor compaction test \\
\hline $1 / 30 \mathrm{ft}^{3}$ mold, $\left(943.9 \mathrm{~cm}^{3}\right)$ & $1 / 30 \mathrm{ft}^{3}$ mold, $\left(943.9 \mathrm{~cm}^{3}\right)$ \\
\hline $5.5 \mathrm{lb}$ hammer, $(2.495 \mathrm{~kg})$ & $10 \mathrm{lb}$ hammer, $(4.536 \mathrm{~kg})$ \\
\hline 12 drop, $(30.48 \mathrm{~cm})$ & 18 drop, $(45.72 \mathrm{~cm})$ \\
\hline 3 layers of soil & 5 layers of soil \\
\hline 25 blows / layer & 25 blows / layer \\
\hline
\end{tabular}

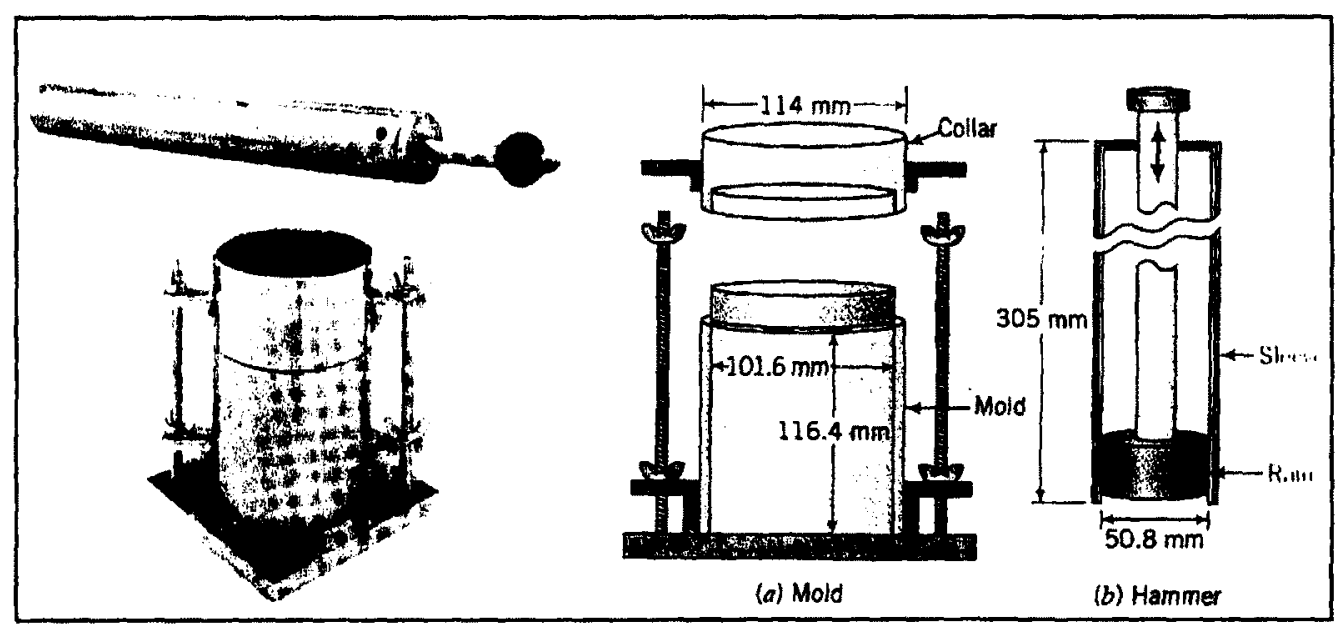

Figure D-1: Compaction apparatus ( Budhu, 2000). 


\section{1-1. Proctor compaction test procedure}

1. Take approximately $10 \mathrm{lbs}$ of soil passing No.4sieve.

2. Add enough water to bring water content to about $5 \%$.

3. Record the weight of the Proctor mold, which volume is $943.9 \mathrm{~cm}^{3}$.

4. Assemble the compaction apparatus.

5. Add the soil in the mold in 3 equal layers and each layer is compacted by dropping proctor hammer 25 times from specific distance, (Figure D-2).

6. Remove top extension and excess soil.

7. Determine the weight of the mold and compacted soil.

8. Take a sample from compacted soil in the mold and determine water content, (moisture) of sample.

9. Remove all of the soil from mold, break it down, add some water to raise moisture by $2 \%-3 \%$ and repeat number 4 to 8 .

By increasing water content, weight of mold with the soil in the mold will increase so soil density increases until moisture reaches to optimum point, after this point weight of mold plus soil will decrease and it means soil passed its maximum dry unit weight. Then graph dry unit weight versus the soil water content, the peak point of curve shows optimum point,(maximum dry unit weight at optimum water content). 

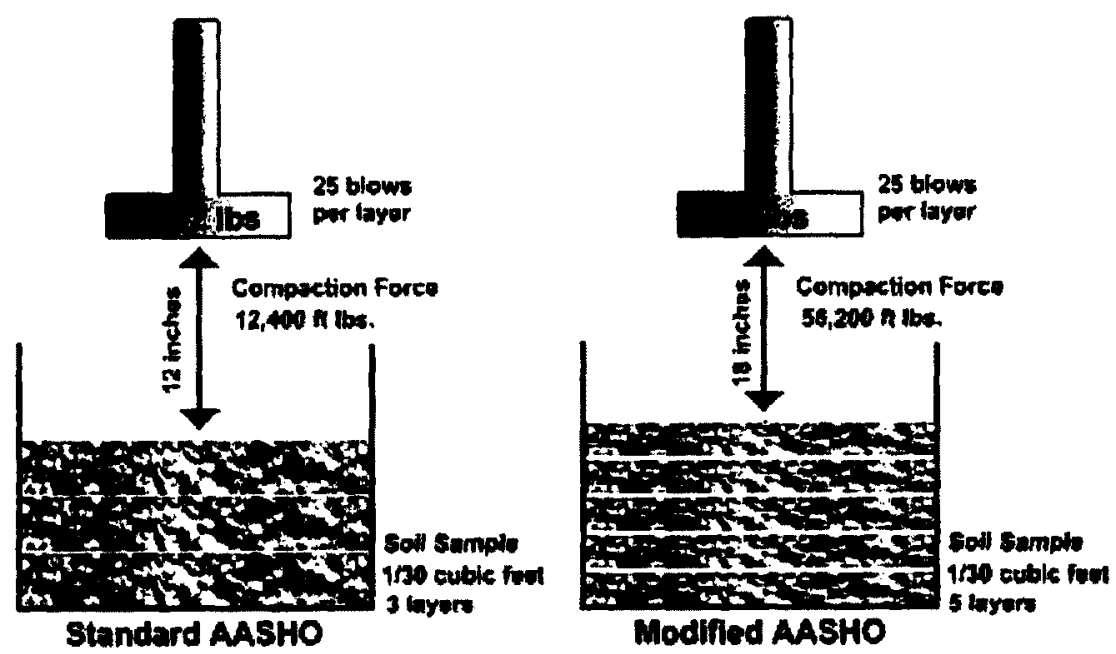

Figure D-2: Compare of Standard and modified proctor compaction test

\section{Shrinkage curve test (ASTM D4943)}

There are four states of physical and mechanical behaviour of fine grain soil:

Liquid, plastic, semisolid and solid which are related to water content. Figure D-3 shows volume of soil versus water content. With decreasing water content, drying, soil behaviour is tending from liquid to solid.

Shrinkage limit is directly related to the water content and is just enough water to fill all the pores in soil and soil is just saturated, i.e. shrinkage limit is the maximum water content, that a reduction in water content does not cause a reduction in volume of the soil mass. (Point D in Figure D-3). 


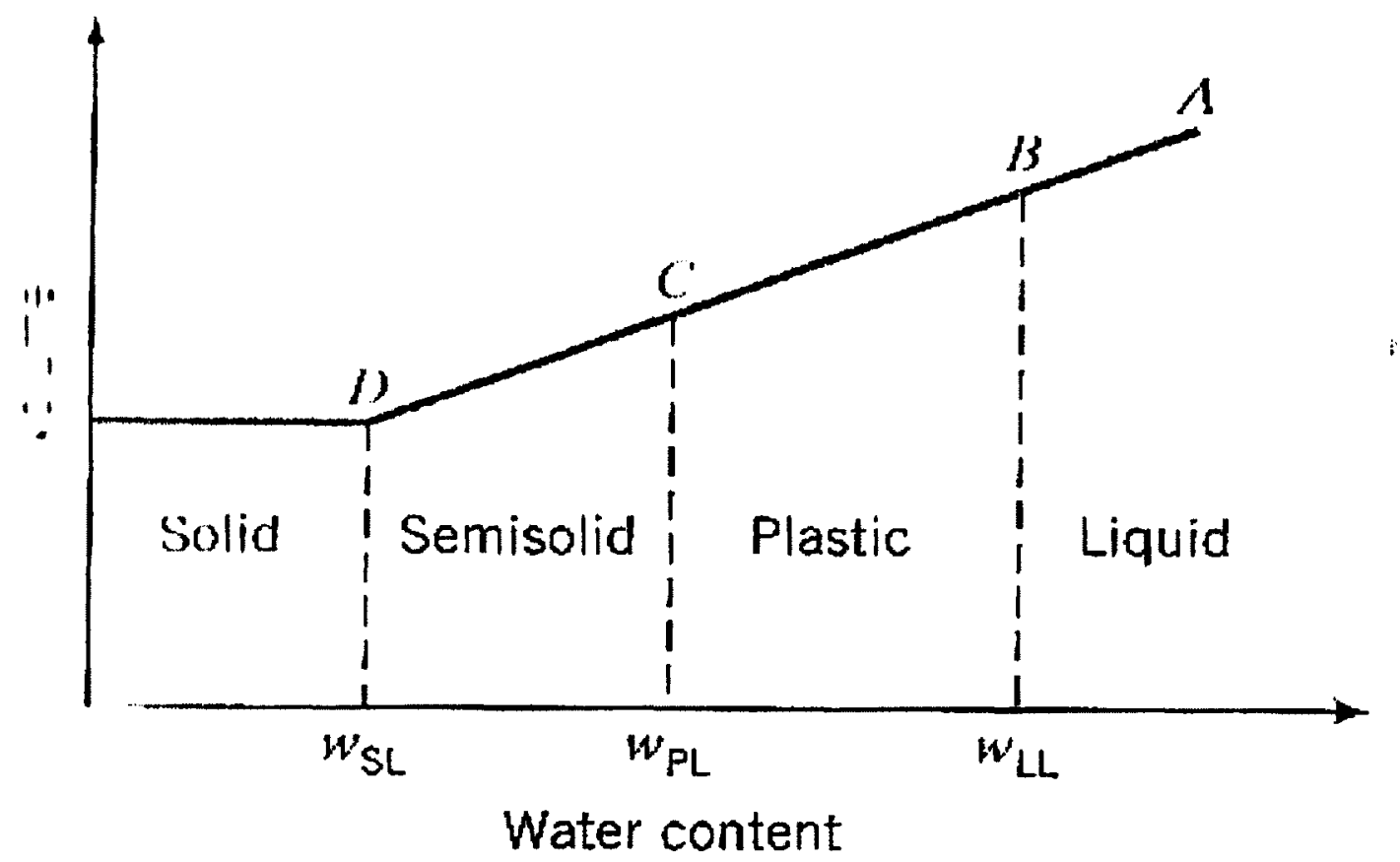

Figure D-3: Soil states as a function of volume and water content

\section{2-1. Shrinkage limit test procedure}

1. Weight a clean and dry tare container.

2. Pour water into the tare container and fill it up to the rim.

3. Record the volume of container.

4. Prepare a sample of soil with known water content and density.

5. Fill the tare container of known volume to the top with the sample.

6. Mass container + sample and leave it for several days for air dry.

7. At the end of the drying period, weight the container and sample. 
8. Heat up wax with known density, once heated, pour wax into container containing dried sample and Fill up to the rim.

9. Once the wax has cooled and container is filled to the top with wax, take the weight of the sample, container, and wax.

Since the density of the wax is known, and the mass of sample before the wax was added is known, the change in mass can be related to the total volume of wax added. The volume of soil is equal to the total volume of the container minus the volume of wax added.

10. Calculate the shrinkage limit using the following formula:

$$
S L(\%)=\left(\frac{M w e t-M d r y}{M d r y}-\frac{V w e t-V d r y}{M d r y} * \rho w\right) * 100
$$

Where:

$$
\begin{gathered}
\text { Mwet }=\text { wet weight of soil } \\
\text { Mdry }=\text { dry weight of soil } \\
V w e t=\text { wet volume of soil sample } \\
V d r y=\text { dry volume of soil sample } \\
\rho_{\mathrm{w}}=\text { water density }
\end{gathered}
$$

\section{Soil Water Characteristive Curve by axis-translation}

The SWCC has been measured for different initial conditions and under different applied loads. For the silt-four different SWCC tests have done:

e) SWCC test started before full settling allowed (within 1 hour of sample preparation). 
f) SWCC test after settling (24 hours after specimen preparation).

g) Drying and wetting SWCC test after settling

h) SWCC test with variable thickness.

The axis-translation device can be used to obtain the complete TWCC for tailings. Matric suctions from near zero value up to $1500 \mathrm{kPa}$ (15 bar) can be applied, and it is also possible to apply one dimensional loading to a specimen.

Two different samples preparation methods were used: i) Hand mixing and ii) mechanical mixing. In hand mixing, the sample was mixed with a large spoon by hand for about a minute, until a homogeneous mixture was observed. In mechanical mixing the sample was mixed with a paint mixer for 20 minutes. Mechanical mixing was only used for the oil sand tailings. For the oil sand tailings, polymer amended samples were prepared in two separate ways: i) the required polymer was mixed with the required additional water to bring the tailings to a given water content, before mixing the polymerwater solution with the as-received tailings by hand mixing. ii) or added polymer directly to the as-received tailings sample employing the mechanical mixing method.

\section{3-1. TWCC / SWCC test procedure}

1. Prepare tailings sample with required initial water content $\left(w_{i}\right)$.

2. Prepare axis-translation cell, surfaces be free of any grits of sand or any other impurities and ceramic stone in the bottom plate should be saturated.

3. Weigh the cell.

4. Add tailings specimen in the cell and weight again (W1) to determine mass of specimen.

5. Connect the two tube ends to the cell 
6. Place the top plate.

7. Open the water valves to enter water from water tubs to the bottom plate which ceramic stone is placed.

8. Connect the pressure source to the device.

9. Expel any trapped air in the bottom plate by using flashing device.

10. Apply the first pressure, $\sim 20 \mathrm{kPa}$, to the cell.

11. Leave the system for equilibration, defined by no more change in volume of water in the tubes.

12. Close water valves, disconnect pressure and take the top plate out.

13. Weight the cell (W2),

14. Calculate amount of water out by W2-W1.

15. Calculate any change in specimen volume with measuring several points of sample surface and several points of distance between specimen and cylinder wall.

16. Replace top plate and connect water tubes and go to number 8 for applying next pressure.

17. Graph water content - suction or saturation - suction.

18. At the end of the test, obtained samples to measure gravimetric water content by oven-drying, to confirm accuracy of steps 13 and 14 .

\section{3-2. TWCC / SWCC under 1-D loading}

The same apparatus allows for application of a vertical loading (1-D loading), during the SWCC test. A number of different tests were performed on the gold 
tailings, exposing the samples to different combinations of suction and load paths. Thesis include:

d) SWCC under a constant 1-D loading

e) SWCC under a constant suction, but variable 1-D loading

f) No suction, but variable load to produce a consolidation curve.

The procedure was as follows:

1- Follow TWCC procedure up to number 5.

2- Place the load plate centered on the sample.

3- Place the top plate

4- Put the weight plate on top of the load shaft.

5- Measure distance between weight plate and top plate of the cell $\left(h_{1}\right)$.

6-1- To apply constant loading, put the weight on weight plate and increase slowly the weight up to desired load amount over several days to prevent any damage to the specimen. After equilibration, measure distance between weight plate and top plate again $\left(h_{2}\right)$. Then calculate volume change.

6-2- Follow TWCC procedure from 7 to 16.

6-3- Graph consolidation curve, void ratio - suction.

7-1- For variable loading test, put the weight on weight plate and increase slowly the weight up to desired load amount during several days to prevent any damage to the specimen. After equilibrium time, measure distance between weight plate and top plate again $\left(h_{2}\right)$. Then calculate volume change.

7-2- Follow TWCC procedure from 7 to 15.

7-3- increase weight up to next level of loading. 
7-4- After equilibrium, measure distance between weight plate and top plate.

7-5- Calculate volume change. Go to number 7-3 to apply next loading.

7-6- Graph consolidation curve according to variations of loading. 